Latvijas Lauksaimniecības universitāte Ekonomikas un sabiedrības attīstības fakultāte Ekonomikas un reǵionālās attīstības institūts

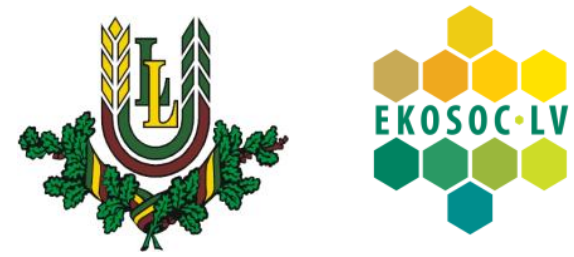

$M g$. Līva Griņeviča

promocijas darbs

\title{
JAUNIEŠU BEZDARBA IETEKMĒJOŠO FAKTORU ANALİZE LATVIJĀ \\ ANALYSIS OF FACTORS INFLUENCING YOUTH UNEMPLOYMENT IN LATVIA
}

ekonomikas doktora (Dr.oec.) zinātniskā grāda iegūšanai

Promocijas darbs ir izstrādāts Ekonomikas nozares

Reǵionālās ekonomikas apakšnozarēe

Promocijas darba zinātniskā vadītāja,

Dr.habil.oec. profesore Baiba Rivža

Promocijas darba autore Līva Griņeviča

Jelgava 2016 


\begin{abstract}
ANOTĀCIJA
Promocijas darba autors $M g$. Līva Griṇeviča Latvijā".

Promocijas darba tēma ,Jauniešu bezdarba ietekmējošo faktoru analīze
\end{abstract}

Hipotēze: Izvērtējot faktorus, kas ietekmē jauniešu bezdarba veidošanos Latvijā, var efektīvāk veidot pasākumus un scenārijus, kas sekmē jauniešu iekḷaušanos darba tirgū.

Promocijas darba mērksis ir izvērtēt galvenos jauniešu bezdarbu ietekmējošos faktorus Latvijā un izstrādāt ieteikumus produktīvai jauniešu nodarbinātības veicināšanai.

Mērķa sasniegšanai izstrādātie un risinātie darba uzdevumi:

1. Analizēt zinātnisko literatūru par bezdarba teorētiskajām pamatnostādnēm, jauniešu bezdarbu, jauniešu sociālo iekḷaušanos darba tirgū, kā arī izpētīt bezdarbu reǵionālā kontekstā.

2. Izvērtēt Latvijas un ES tiesiskos un politikas plānošanas dokumentus par bezdarbā esošo personu tiesisko aizsardzību un jauniešu nodarbinātības veicināšanu.

3. Izvērtēt ekonomiskos rādītājus saistībā ar jauniešu bezdarbu, noskaidrot citu Eiropas valstu pieredzi bedzarba samazināšanā, kā arī aprēḳināt zaudējumus no jauniešiem esošiem bezdarbā.

4. Analizēt jauniešu bezdarba tendences un instrumentus jauniešu bezdarba samazināšanai Latvijā, balstoties uz darba devēju un jauniešu aptaujās iegūto informāciju.

5. Noskaidrot nozares ekspertu viedokli par jauniešu iespēju iekḷauties darba tirgū un, pamatojoties uz to, izstrādāt scenārijus un priekšlikumus jauniešu bezdarbnieku nodarbinātības veicināšanai Latvijā.

Pêtîjuma izklāsts ir strukturēts piecās nodaḷās ar apakšnodalāām.

Darba pirmajā nodaḷā ir apkopotas teorētiskās atziṇas par bezdarbu un jauniešu bezdarbu, izklāstīiti bezdarba analīzes modeḷi vēsturiskā kontekstā, noteikti jauniešu bezdarbu ietekmējošie faktori, analizēta jauniešu sociālā iekḷaušanās darba tirgū, kā arī analizētas bezdarba tendences reǵionālā kontekstā.

Otrajā nodaḷā ir analizēti bezdarba situācijā esošu personu aizsardzības tiesiskie, stratēgiskie un politikas dokumenti, balstoties uz Latvijas un starptautisko dokumentu ietvaru.

Trešajā nodaḷā analizēts jauniešu darba tirgus un bezdarba tendences Latvijā. Nodaḷā izpētîta Eiropas valstu pieredze jauniešu nodarbinātības veicināšanā, kā arī aprēķināti Latvijas ekonomiskie zaudējumi jauniešu bezdarba dēḷ.

Ceturtajā nodaḷā izvērtēti jauniešu bezdarbu ietekmējošie faktori Latvijā, balstoties uz jauniešu aptaujās iegūto informāciju. Apkopots darba devēju viedoklis par jauniešu konkurētspēju darba tirgū un jauniešu uzņēmējdarbības veicināšanu.

Darba piektajā nodaḷā analizēta jauniešu iekḷaušanās Latvijas darba tirgū, balstoties uz ekspertu vērtējumiem. Pēc pētîjumos iegūtajiem rezultātiem izstrādāti scenāriji jauniešu iekḷaušanai darba tirgū Latvijā.

Darba nobeigumā formulēti galvenie secinājumi, galvenie pētījuma rezultāti, kā arī atsegtas problēmas un izvirzīti priekšlikumi to risināšanai.

Promocijas darba apjoms ekonomikas doktora (Dr.oec.) grāda iegūšanai ir 204 lapas. Darbā ir 19 tabulas, 52 attēli, 7 pielikumi, izmantoti 246 informācijas avoti, t.sk. 127 avoti angḷ valodā. 


\begin{abstract}
ANNOTATION
The author of the doctoral thesis: $M g$. Līva Griņeviča

The theme of the doctoral thesis: "Analysis of Factors Influencing Youth Unemployment in Latvia".

Hypothesis: After assessing the factors influencing the emergence of youth unemployment in Latvia, one can more effectively develop measures and scenarios that promote the youth's inclusion in the labour market.

The aim of the doctoral thesis is to evaluate the main factors influencing youth unemployment in Latvia and to develop proposals for efficient youth employment.

There are set the following tasks to achieve the aim:

1. To analyse the scientific literature on the theoretical framework of unemployment, youth unemployment and the youth's social inclusion in the labour market, as well as to explore the unemployment in regional context.

2. To examine the legal and policy documents of Latvia and the EU with regard to the legal protection of unemployed persons and the employability of young people.

3. To analyse the economic indicators of youth unemployment, to identify the experience of other European countries in decreasing unemployment, as well as to calculate the economic loss from youth unemployment in Latvia.

4. To analyse the trends in youth unemployment and the instruments for reducing it in Latvia based on the information obtained in the surveys of employers and youth's.

5. To establish the opinions of industry experts on the opportunity for the youth to integrate into the labour market and, based on their opinions, to develop scenarios and proposals for increasing youth employment in Latvia.

The research outline is structured into five chapters with subdivisions.

The first chapter discusses theoretical findings on unemployment and youth unemployment, sets out models for unemployment analyses in historical context, identifies the factors influencing youth unemployment, examines the youth's social inclusion in the labour market as well as analyses unemployment in regional context.

The second chapter is devoted to the national and international frameworks of legal, strategic and policy documents aimed at protecting unemployed persons.

The third chapter deals with an analysis of the trends in the youth labour market and in youth unemployment in Latvia. The chapter examines the experience of European countries in promoting youth employment as well as calculates the economic loss from youth unemployment in Latvia.

The fourth chapter examines the factors influencing youth unemployment in Latvia based on the information obtained in the questionnaire surveys of youth. It summarises the opinions of employers on the youth's competitiveness in the labour market and on promoting youth entrepreneurship.

The fifth chapter of the thesis is devoted to an analysis of young people entering into the labour market of Latvia, based on an expert evaluation. Based on the study results, there are obtained scenarios for youth integration into the labour market.

The summary formulates the main conclusions, the main findings, as well as reveals the problems and gives proposals to solve them.

The volume of the doctoral thesis to acquire the degree of doctor of economics (Dr.oec.) is 204 pages. The paper has 19 tables, 52 pictures, 7 attachments, used 246 sources of information, including 127 sources in English.
\end{abstract}




\begin{abstract}
АННОТАЦИЯ
Автор: Мг. Лива Гриневича

Тема диссертации: „Анализ факторов влияющих на уровень безработицы молодежи Латвии"

Гипотеза: Оценка факторов, влияющих на формирование безработицы латвийской молодежи, даст возможность разработать более эффективные меры и сценарии, способствующие успешному продвижению молодых людей на рынке труда.

Цель работы: оценить основные факторы, определяющие уровень безработицы среди молодежи в Латвии и разработать предложения по увеличению продуктивной занятости молодежи.

\section{Для достижения поставленной цели необходимо было разработать и решить следущие задачи:}

1. Проанализировать научную литературу, посвященную теоретическим основам исследования безработицы молодежи, социальной интеграции молодых людей на рынке труда и изучить безработицу в региональном контексте.

2. Провести анализ и оценку законодательства и документов политического планирования и регулирования Латвии и ЕС, связанных с занятостью молодежи и охраной прав безработных.

3. Оценить экономические показатели связанные с безработицей среди молодежи, изучить опыт других европейских стран по сокращению безработицы и расчитать потери Латвии от существующей безработицы среди молодежи.

4. Проанализировать тенденций безработицы среди молодежи и определить необходимые инструменты для снижения ее уровня в Латвии, на основе информации, полученной в ходе интервьюирования работодателей и молодежи.
\end{abstract}

5. Выяснить мнения отраслевых экспертов и молодых людей о возможностях выйти на рынок труда, на основании чего, разработать сценарии и предложения по обеспечению занятости молодежи в Латвии.

Поставленные задачи структурированы и решены в работе в пяти главах с подразделами.

Первая глава включает в себя обсуждение теоретических основ безработицы среди молодежи. Проведен исторический анализ закономерностей возникновения безработицы и факторов влияющих на уровень безработицы среди молодежи. Обсуждена социальная интеграция молодых людей на рынке труда с учетом региональных особенностей.

Во второй главе анализируются Латвийские и международные правовые и политические документы, связанные с защитой лиц, находящихся без работы и оказанием им государственной помощи.

Третья глава посвящена анализу экономической ситуации и тенденциям по безработице молодежи в Латвии. В главе изучен опыт европейских стран по вовлечению молодежи в рынок труда и проведены расчеты, связанные с экономическими потерями Латвии из-за безработицы молодежи.

В четвертой главе на основании анкетирования, установлены основные, по мнению молодежи, факторы влияющие на уровень молодежной безработицы. 
На основании опроса обобщены и проанализированы предложения работодателей по увеличению конкурентоспособности молодежи на рынке труда.

Пятая глава работы на основе экспертных оценок посвящена анализу возможностей молодых людей достойно войти на рынок труда Латвии. На основании результатов исследования, разработаны сценарии интеграции молодежи на рынке труда.

В конце работы сформулированы основные выводы и главные результаты работы и даны предложения направленные на снижение уровня безработицы среди молодежи Латвии.

Объем работы претендующей на получение степени доктора экономических наук (Dr.oec.) составляет 204 страницу. В работе имеется 19 таблиц, 52 рисунка и 7 приложений. Использовано 246 источника информации, в том числе 127 на английском языке. 


\section{SATURA RĀDĪTĀJS/ \\ TABLE OF CONTENTS}

INFORMĀCIJA PAR PUBLIKĀCIJĀM UN ZINĀTNISKI PĒTNIECISKO

DARBU/ INFORMATION ON PUBLICATIONS AND SCIENTIFIC WORK... 8

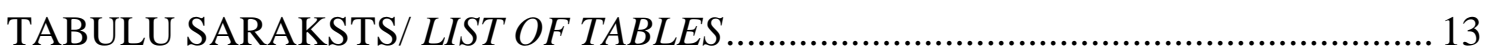

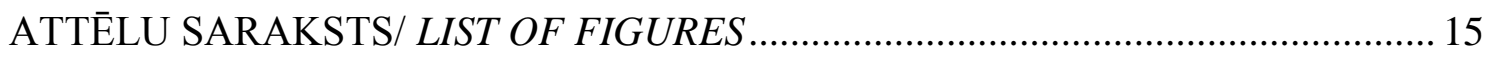

AKRONĪMI UN ABREVIATŪRAS/ ACRONYMS AND ABBREVIATIONS ................ 20

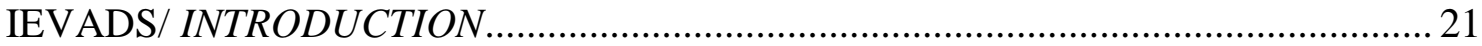

1. BEZDARBS UN TĀ EKONOMISKĀ NOZĪME/ UNEMPLOYMENT

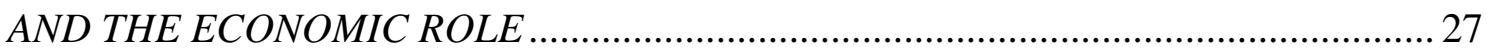

1.1. Bezdarba jēdziens un tā veidi/ Concept of unemployment and types.....................27

1.2. Jauniešu bezdarbs kā ekonomiska problēma/ Youth unemployment

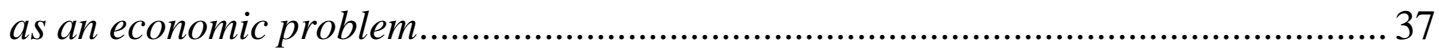

1.3. Bezdarbs reǵionālā kontekstā/ Unemployment in the regional context ................ 43

1.4. Jauniešu sociālā iekḷaušanās darba tirgū/ Youth's social inclusion

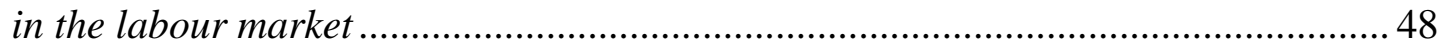

1. nodalas secinājumi/ Conclusions for Chapter 1.....................................................56

2. NORMATĪVAIS IETVARS UN VALSTS POLITIKA JAUNIEŠU BEZDARBA KONTEKSTĀ/ REGULATORY FRAMEWORK AND PUBLIC POLICY IN THE CONTEXT OF YOUTH UNEMPLOYMENT .

2.1. Starptautisko dokumentu ietvars, kas nosaka un regulē bezdarbnieku tiesības/ Framework of international documents specifying and regulating the rights of the unemployed ......

2.2. Latvijas normatīvo dokumentu ietvars, kas nosaka un regulē bezdarbnieka tiesības/ Framework of Latvian regulatory documents specifying and regulating the rights of the unemployed.

2.3. Stratēǵiskie plānošanas dokumenti Latvijā, kas nosaka pasākumus jauniešu bezdarba likvidēšanai/ Strategic policy documents in Latvia that define measures for reducing youth unemployment

2.4. Programmas un to pasākumi jauniešu bezdarba samazināšanai/ Programmes and their measures aimed at reducing youth unemployment...

2. nodaląas secinājumi/ Conclusions for Chapter 2.

3. DARBA TIRGUS UN BEZDARBA TENDENCES LATVIJĀ UN CITĀS EIROPAS VALSTĪS/ LABOUR MARKET AND UNEMPLOYMENT TRENDS IN LATVIA AND OTHER EUROPEAN COUNTRIES

3.1. Ekonomisko rādītāju analīze Latvijā/ Analysis of economic indicators for 
3.2. Bezdarba analīze Latvijā/ Analysis of unemployment in Latvia.....

3.3. Jauniešu bezdarba ekonomiskās izmaksas Latvijā/ Economic costs of youth unemployment in Latvia .98

3.4. Eiropas valstu pieredze/ Experience of European countries............................... 101

3. nodaļas secinājumi/ Conclusions for Chapter 3

4. JAUNIEŠU IESPĒJU DARBA TIRGŪ APZINĀŠANA UN TO IETEKMĒJOŠO FAKTORU NOTEIKŠANA LATVIJĀ / IDENTIFICATION OF OPPORTUNITIES FOR THE YOUTH IN THE LABOUR MARKET AND THE DETERMINATION OF FACTORS INFLUENCING THE OPPORTUNITIES IN LATVIA ....

4.1. Jauniešu bezdarba virzītājspēki un tendences darba tirgū/ Driving forces of youth unemployment and tendencies into the labour market.....

4.2. Jauniešu bezdarbu ietekmējošo faktoru analīze/ Analysis of the factors affecting youth unemployment.

4.3. Jauniešu uzṇēmējspēju veicināšanas aktualitāte/ Urgency of a youth entrepreneurial incentive.

4.4. Jauniešu nodarbinātības iespējas un to konkurētspēja darba devēju skatījumā/

Youth employability and competitiveness from employers' point of view

4.5. Jauniešu konkurētspēju darba tirgū ietekmējošie faktori/ Factors influencing youth's competitiveness in the labour market.

4. nodaļas secinājumi/ Conclusions for Chapter 4

5. JAUNIEŠU IEKL̦AUŠANĀS LATVIJAS DARBA TIRGŪ/ YOUTH

INCLUSION INTO THE LATVIAN LABOUR MARKET

5.1. Jauniešu bezdarbnieku nodarbinātības veicināšanas scenāriju izvērtējums pēc hierarhiju analīzes metodes/ Assessment of employment promotion scenarios for unemployed youth by the Analytic Hierarhy Process

5.2. Jauniešu iekḷaušanās darba tirgū ekspertu skatījumā/ Young people entering

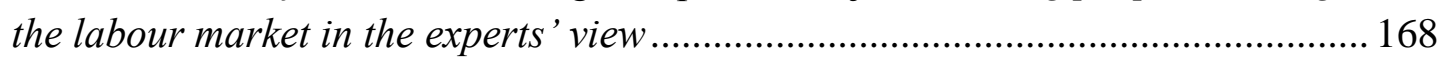

5. nodaḷas secinājumi/ Conclusions for Chapter 5................................................. 181

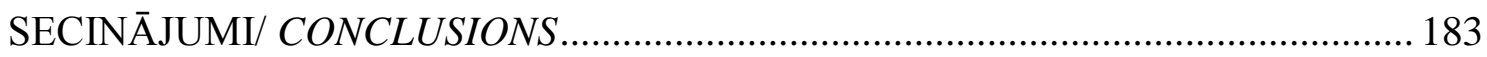

IDENTIFICĒTĀS PROBLĒMAS UN PRIEKŠLIKUMI/ IDENTIFIED

PROBLEMS AND THEIR POSSIBLE SOLUTIONS ............................................... 183

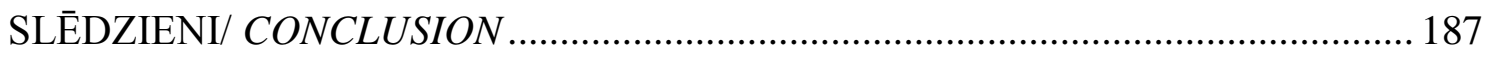

IZMANTOTĀS LITERATŪRAS AVOTI/ LIST OF THE BIBLIOGRAPHIC

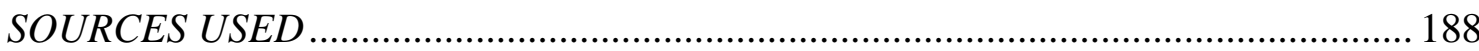

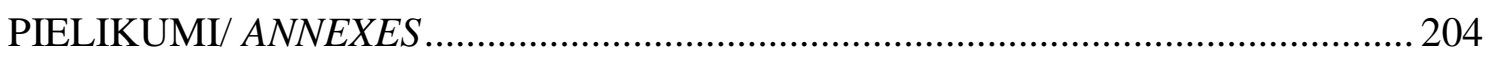




\section{INFORMĀCIJA PAR PUBLIKĀCIJĀM UN ZINĀTNISKI PËTNIECISKO DARBU/ INFORMATION ON PUBLICATIONS AND SCIENTIFIC WORK}

Uzṇēmējdarbības vadības profesionālo studiju un uzṇēmumu un iestāžu vadītāja kvalifikācijas studiju maǵistre Līva Grineviča promocijas darbu „Jauniešu bezdarba ietekmējošo faktoru analīze Latvijā" ir izstrādājusi laika periodā no 2012. gada septembra līdz 2016. gada martam LLU Ekonomikas un sabiedrības attīstības fakultātes Ekonomikas un reǵionālās attīstības institūta Dr.habil.oec. profesores Baibas Rivžas zinātniskajā vadībā.

\section{Publicētie zinātniskie raksti}

Par pētījuma rezultātiem un promocijas darba saturu autorei ir 20 publikācijas starptautiskos recenzētos zinātniskos izdevumos.

1. Griṇeviča L., Rivža B., Rivža P. (2016) Jauniešu iekḷaušanās darba tirgū Latvijas regionos/ Youth Inclusion into the Labour Market in the Regions of Latvia. Atrodas: Latvijas Universitātes 74. konference, „Ekonomika. Vadība. Demogrāifia", sekcija Latvijas uzṇēmumu konkurētspēja ārējos tirgos (EKOSOC - VPP 5.2.1)/ Latvian Companies Competitiveness in External Markets.

2. Grinevica L., Rivza B., Rivza P. (2016) Scenarios for Reducing Youth Unemployment and Promoting Sustainability in the Regions of Latvia. In: Journal of Security and Sustainability Issues. International Entrepreneurial Perspectives and Innovative Outcomes, Vol. 5, No. 3, Lithuania, Vilnius: The General Jonas Žemaitis Military Academy of Lithuania, pp. 437-449, ISSN 2029-7017 (online), ISSN 2029-7025.

3. Grineviča L., Rivža B., Koval̦evs R. (2015) Youth Social Inclusion Trends in the Latvian Labour Market. In: Social Research, No. 1 (37), Lithuania, Vilnius: Šiauliai University, Faculty of Social Sciences, pp.57-66. ISSN 1392-3110.

4. Grinevica L., Rivza B. (2015) Youth Long-term Unemployment Reduction Opportunities. In: Economic Science for Rural Development, Rural Development and Entrepreneurship: Proceedings of the International Scientific Conference, No. 39, Latvia, Jelgava: Latvia University of Agriculture, pp. 5767. ISSN 1691-3078. EBSCO, AGRIS, Web of Science.

5. Griņeviča L., Rivža B. (2015) Legal Framework of Youth Unemployment and Entrepreneurship Regulation in Latvia. In: Regional Formation and Development Studies, Vol. 15, No. 1, Lithuania, Klaipeda: University of Klaipeda, pp. 56-64. ISSN: 2351-6542. EBSCO.

6. Grinevica L., Rivza B. (2015) Youth Long-term Unemployment Problems and Integration into the Labour Market. In: Nordic View to Sustainable Rural Development: Proceedings of the 25th NJF Congress, Latvia, Riga, pp.462-467. ISBN 978-9934-14-548-3. EBSCO, CAB Abstracts, Web of Science.

7. Grinevica L., Rivza B. (2015) Biznesa atbalsta programmas jauniešiem/ Business Support Programmes for Young People. Atrodas: Latvijas Universitātes 73. Konference, „Ekonomika. Vadība. Demogrāfija”, sekcija Latvijas uzñēmumu konkurētspēja ārējos tirgos (EKOSOC - VPP 5.2.1).

8. Grinevica L., Rivza B. (2015) Youth Unemployment Problem in the European Union. In: 10th International Scientific Conference „Students on Their Way to Science", Collection of Abstracts, Latvia, Jelgava: Latvia University of Agriculture, p. 130. ISSN 2255-9566. 
9. Grinevica L., Rivza B. (2015) Youth Unemployment Problem in Latvia Compared with Belarus. In: International Multidisciplinary Scientific Conference on Social Sciences and Arts SGEM 2015: Conference Proceedings of Political Sciences, Law, Finance, Economics and Tourism, Vol. II, Finance, Economics and Tourism, Bulgaria, Albena: Honored Organizer - Bulgarian Academy of Sciences, p. 1007-1014. ISBN 978-619-7105-47-6, ISSN 23675659. Web of Science, Thomson Reuters.

10. Grinevica L., Rivza B., Peteris R. (2015) The Analytic Hierarchy process as a Tool to Promote Youth Employment and Sustainability in Latvia. In: $56^{\text {th }}$ International Riga Technical University Conference "Scientific Conference on Economics and Entrepreneurship SCEE' 2015" Proceedings, Latvia, Riga: Riga Technical University, p.132. ISBN 978-9934-8275-3-2, ISSN: 2256-0866.

11. Grinevica L., Kovalevs R. (2015) Integration of Young People into the Latvian Labour Market. In: Economics and Business, Latvia, Riga: Riga Technical University, pp. 64-68. DOI: 10.1515/eb-2015-0010. EBSCO.

12. Griņeviča L. (2015) Jauniešu bezdarbs un to iekḷaušanās darba tirgū Latvijas reǵionos. No: Ražas svētki „Vecauce - 2015”: Lauksaimniecības zinātne reorganizācijas laikā: zinātniskā semināra rakstu krājums/ Latvijas Lauksaimniecības universitāte, Lauksaimniecības fakultāte. SIA LLU mācību un pētījumu saimniecība „Vecauce”. Jelgava: LLU, 29. - 32. lpp.

13. Grinevica L., Rivza B. (2015) Analysis of Youth Integration into the Labour Market by the Quintuple Helix Model. In: Research for Rural Development 2015: 21th Annual International Scientific Conference, Latvia, Jelgava: Latvia University of Agriculture, p. 197-203, ISSN 1691-4031. EBSCO, Scopus.

14. Grinevica L., Rivza B. (2015) The Cost of Youth Unemployment. In: 11th International Scientific Conference „Students on Their Way to Science”, Collection of Abstracts, Latvia, Jelgava: Latvia University of Agriculture, p. 132. ISSN 2255-9566.

15. Grinevica L., Rivza B. (2014) Integration of Young People into the Labour Market Through Participation in Business Support Programmes. In: Economic Science for Rural Development, Integrated and Sustainable Regional Development: Proceedings of the International Scientific Conference, No. 36. Latvia, Jelgava: Latvia University of Agriculture, pp. 86-94. ISSN 1691-3078. EBSCO, Web of Science, CAB Abstracts, AGRIS.

16. Grinevica L. (2014) Analysis of Theoretical and Practical Aspects of Youth Long-term Unemployment in Latvia. In: Research for Rural Development 2014: 20th Annual International Scientific Conference, Latvia, Jelgava: Latvia University of Agriculture, pp. 258-264. ISSN 1691-4031. EBSCO, Scopus, AGRIS.

17. Grinevica L., Kovalevs R. (2014) The Youth's Social Cohesion and Labour Market Trends. In: Proceedings of Riga Technical University 55th International Scientific Conference "Scientific Conference on Economics and Entrepreneurship (SCEE'2014)". Section: Building Entrepreneurship, Real Estate, Region and Territory Engineering Economy Problems, Latvia, Riga: Riga Technical University, ISBN 978-9934-8275-2-5.

18. Grinevica L., Rivza B. (2013) Long-Term Unemploymet Problems in Latvia Between Forty and Preretirement Age. In: Economic Science for Rural Development, Rural Development and Entrepreneurship, marketing and Sustainable Consumption: Proceedings of the International Scientific 
Conference, No. 32. Latvia, Jelgava: Latvia University of Agriculture, pp. 196202. ISSN 1691-3078. EBSCO, Web of Science, AGRIS.

19. Grinevica L. (2013) Business Support Programs as a Possibility to be Selfemployed. In: International Conference: Entrepreneurship and Innovation as Key Drivers of Regional Development: Conference Materials, Abstract Book, Latvia, Ventspils: Ventspils University College, p. 24.

20. Griņeviča L., Koval̦evs R., Rivža B. (2013) Long-Term Unemployment of Women as a Possibility to be Self-employed. In: Regional Review: Research Papers, No. 9, Latvia, Daugavpils: Daugavpils University, Faculty of Social Sciences, Institute of Social Research, pp. 39-48. ISSN 1691-6115. EBSCO, ProQuest.

\section{Dalība starptautiskās un nacionālās zinātniskās konferencēs}

Par pētījuma rezultātiem ziņots 19 starptautiskās un nacionālās zinātniskās konferencēs.

1. "The Cost of Youth Unemployment in Latvia". 2nd International Conference "Trends in Regional Development in the EU Countries 2016". Warsaw (Poland)/ Jelgava (Latvia). 4 November, 2016.

2. "The Cost of Youth Unemployment". 11th International Scientific Conference "Students on their Way to Science". Latvia University of Agriculture, Jelgava, Latvia, 22 April, 2016.

3. „Jauniešu iekļaušanās darba tirgū Latvijas regionos”. Latvijas Universitātes 74. konference „Ekonomika. Vadība. Demogrāfija”, sekcija Latvijas uzn̦ēmumu konkurētspēja ārējos tirgos (EKOSOC-VPP 5.2.1.)/ Latvian Companies Competitiveness in External Markets. Latvijas Universitāte, Rīga, Latvija, 2016. gada 19. februārī.

4. “Jauniešu bezdarbs un to iekļaušanās darba tirgū Latvijas reǵionos”. Ražas svētki „Vecauce - 2015”: Lauksaimniecības zinātne reorganizācijas laikā. Vecauce, Latvija, 2015. gada 4. novembrī.

5. "The Analytic Hierarchy Process as a Tool for Promotion of Youth Employment and Sustainability in Latvia". RTU $56^{\text {th }}$ International Scientific Conference "Scientific Conference on Economics and Entrepreneurship (SCEE' 2015)". Riga Technical University, Riga, Latvia, 15 October, 2015.

6. "Youth Employment in the Regions of Latvia". $1^{\text {st }}$ International Conference " Trends in Regional Development in the EU Countries 2015". Warsaw (Poland)/ Jelgava (Latvia). 24 September, 2015.

7. "Youth Long-term Unemployment Problems and Integration into the Labour Market”. 25th NJF Congress „Nordic View to Sustainable Rural Development”. Jelgava, Latvia, 16 - 18 June, 2015.

8. "Youth Unemployment Problem in the European Union". 10th International Scientific Conference "Students on their Way to Science". Latvia University of Agriculture, Jelgava, Latvia, 24 April, 2015.

9. "Youth Long-term Unemployment Reduction Opportunities". 16th International Scientific Conference: "Economic Science for Rural Development". Latvia University of Agriculture, Jelgava, Latvia, 23 - 24 April, 2015.

10. "Biznesa atbalsta programmas jauniešiem". Latvijas Universitātes 73. konference, „Ekonomika. Vad̄̄ba. Demogrāfija”, sekcija Latvijas uzṇēmumu konkurētspēja ārējos tirgos (EKOSOC-VPP 5.2.1.), 2015. gada 20. februāris. 
11. "Youth Social Inclusion into the Labour Market". Annual $21^{\text {th }}$ International Scientific Conference: "Research for Rural Development". Latvia University of Agriculture, Jelgava, Latvia, 13 - 15 May, 2015.

12. "Integration of Young People into the Labour Market through Participation in Business Support Programmes". 15th International Scientific Conference: "Economic Science for Rural Development". Latvia University of Agriculture, Jelgava, Latvia, 24 - 25 April, 2014.

13. "Youth Long-term Unemployment as a Possibility to be Self-Employed". Annual 20th International Scientific Conference: "Research for Rural Development". Latvia University of Agriculture, Jelgava, Latvia, 21 - 23 May, 2014.

14. "Business Support Programs as a Possibility to be Self-Employed". 9th International Scientific Conference: "Students on Their Way to Science". Latvia University of Agriculture, Jelgava, Latvia, 25 April, 2014.

15. "Business Support Programs for Young People as a Possibility to be SelfEmployed".10th International Scientific Conference "Social Sciences for Regional Development: Influence and Perspectives". Klaipeda University, Faculty of Social Sciences, Klaipeda, Lithuania, 25 September, 2014.

16. "Integration of Young People into the Labour Market". 55th International Scientific Conference "Scientific Conference on Economics and Entrepreneurship (SCEE' 2014)". Riga Technical University, Riga, Latvia, 17 October, 2014.

17. "Youth Long-term Unemployment Trends and Social Inclusion". 14th Ernestas Galvanauskas' International Scientific Conference "Rethinking Regional Competitiveness", 27 - 28 November, 2014, University of Siauliai, Siauliai, Lithuania.

18. "Decreasing of Youth Long-term unemployment by Business Support Programmes". Siauliai, Lithuania, Jonas Pranas Aleksa International Scientific Conference „Contemporary Rural Vision”, 27 - 28 September, 2013.

19. "Business Support Programs for Young People as a Possibility to be Selfemployed". International Conference: "Entrepreneurship and Innovation as Key Drivers of Regional Development", Ventspils University, Ventspils, Latvia, 15 16 July, 2013.

\section{Informācija par promocijas darba autores akadēmisko un sabiedrisko darbību saistībā ar promocijas darba tēmu}

1. Ziņojums par promocijas darbu Latvijas Lauksaimniecības un meža zinātņu akadēmijas prezidija un Latvijas Zinātņu akadēmijas Lauksaimniecības un meža zinātnuu nodaļas kopsēēe. Latvijas Zinātṇu akadēmija, Rīga, Latvija, 21. septembris, 2015.

2. Saņemts Atzinības raksts par mūsdienās aktuālas tematikas nozīmīgu un uzskatāmu ziņojumu 25. starptautiskā kongresa „Nordic View to Sustainable Rural Development” sekcijā „Sustainable Rural and Territorial Development II”, 2015.

3. Zinātniskās sekretāres p. i. Latvijas Zinātnuu akadēmijas Humanitāro un sociālo zinātnu nodaḷā (2014. gada novembris līdz šim brīdim).

4. Darbība kā pētniekam un doktorantam programmas VPP EKOSOC-LV projektā 5.2.3. „Latvijas lauku un reǵionālās attīstības procesi un iespējas zināšanu ekonomikas kontekstā" sadarbībā ar Latvijas Lauksaimniecības universitāti (2014. gada oktobris līdz šim brīdim). 
5. Iesaiste valsts pētījumu programmas projektā „Tautsaimniecības transformācija, gudra izaugsme, pārvaldība un tiesiskais ietvars valsts un sabiedrības ilgtspējīgai attīstībai - jaunas pieejas ilgtspējīgas zināšanu sabiedrības veidošanai (EKOSOC-LV)". Sadarbībā ar Latvijas Zinātņu akadēmiju projektā darbība kā programmas vadītājas asistentei (2014. gada novembris līdz šim brīdim).

6. Darbs koordinējošā eksperta amatā NVA Ogres filiālē ESF projektos „Pasākumi noteiktām personu grupām” un „Mūžizglītība” (2010. gads - 2012. gads).

Informācija par promocijas darba autores akadēmisko un sabiedrisko darbību papildus promocijas darba tēmai

1. Dalība VPP EKOSOC-LV „telpas bloka” projekta 5.2.3. izbraukuma seminārā. Daugavpils, Latvija, 27.-28. jūlijs, 2016.

2. Dalība VPP EKOSOC-LV izbraukuma semināra sekcijā kā moderatoram. Strautmaļi, Latvija, 20.-22. jūlijs, 2016.

3. Ziņojums VIII Sēlijas kongresā „Kultūras mantojums kā gudru attīstību veicinošs faktors". Jaunjelgava, Latvija, 27. maijs, 2016. 


\section{TABULU SARAKSTS/ LIST OF TABLES}

Tabulas

numurs

1.1. Darba tirgu regulējošo ekonomisko teoriju vēsturiskā attīstība/ Historical development of economic theories regulating the labour market

1.2. Uz zināšanām balstītas sistēmas izveides mijiedarbību ietekmējošie faktori jauniešu iekḷaušanai darba tirgū/ Factors influencing interaction in the creation of a knowledge-based system for youth's integration into the labour market

2.1. Starptautisko dokumentu ietvars, kas nosaka un regulē bezdarbnieka tiesības/ Framework of international documents specifying and regulating the rights of the unemployed

2.2. Latvijas likumi, kas nosaka un regulē bezdarbnieka tiesības/ Latvian laws that apply to the unemployed

2.3. Latvijas stratēgiskie plānošanas dokumenti, kas attiecināmi uz jauniešiem bezdarbniekiem/ National strategic policy documents pertaining to youth being unemployed

3.1. Starptautisko ilgtermiņa emigrantu dinamika dažādās vecuma grupās no 15 - 29 gadiem Latvijā no 2006. 2015. gadam (\%)/ Changes in the number of international long-term emigrants aged 15-29 in Latvia in the period $2006-2015(\%)$.

3.2. Jauniešu ilgstošā bezdarba un jauniešu bezdarba dinamika dažādās vecuma grupās no 15 - 29 gadiem Latvijā 2015. gadā (\%)/ Changes in the number of youth long-term unemployment (12 months and more) and youth uemployment aged 15-29 in Latvia in the period $2006-2015(\%)$

3.3. Jauniešu bezdarba ietekmē nesaražotā IKP aprēķina dati no 2008. -2015. gadam/ Lost GDP due to youth unemployment from 2008 to 2015

4.1. Darba devēju pārstāvētās nozares, darbinieku skaits un Latvijas reǵions, kurā uzņēmums/institūcija reǵistrēts $(\mathrm{n}=14) /$ Industries represented by employers, the number of employees and the region of Latvia where the company/institution is registered $(n=14)$

4.2. Atbalsta instrumentu izvērtējums par jauniešu iespējām iekḷauties darba tirgū darba devēju vērtējumā/ Evaluation of support instruments for youth to enter the labour market by employers

5.1. Hierarhiju analīzes ekspertu pārstāvētās darbības jomas/ Industries represented by experts for hierarchy analysis

5.2. Relatīiā svarīguma skala/ Relative importance scale
Lappuse 
5.3. Eksperta A kritēriju grupu vērtēšanas matrica/

Comparison matrix of criteria groups by expert $A$

5.4. Kritēriju grupu prioritātes vektoru izvērtējums ekspertu skatījumā/ Evaluation of the criteria group priority vector by experts

5.5. Ekspertu scenāriju ticamības izvērtēšana/ Evaluation of the reliability of scenarios by experts

5.6. Ekspertu darbības joma un ienemamais amats $(\mathrm{n}=8) /$

Field of activity and profession of experts $(n=8)$

5.7. Izglìtības līmeņa ietekme uz jaunieša iespējām iekḷauties darba tirgū ekspertu vērtējumā/ Influence of the education level on youth's entering the labour market in the experts' view

5.8. Atbalsta instrumentu izvērtējums par jauniešu iespējām iekļauties darba tirgū/ Evaluation of support instruments for youth to enter the labour market

5.9. Izglīīîas institūcijas pārstāvja ieņemamais amats un pārstāvētais reǵions $(\mathrm{n}=6) /$ Position and represented region of a representative from an educational institution $(n=6)$ 


\section{ATTĒLU SARAKSTS/ \\ LIST OF FIGURES}

Attēla

numurs

1.1. Beveridža līkne/ Beveridge curve

1.2. Bezdarbu ietekmējošie faktori un to mijiedarbība/ Factors influencing unemployment and their interaction

1.3. Indivīda attīstības un vides mijiedarbība/ Interaction between the development of an individual and the environment

1.4. Zināšanu pārnese un faktoru mijiedarb̄̄iba pieckāršajā Helix modelī/ Knowledge transfer and factor interaction in the Quintuple Helix model

2.1. Jauniešu bezdarbnieku tiesiskā regulējuma hierarhija Latvijas Republikā/ Hierarchy of the legal framework for unemployed youth in the Republic of Latvia

3.1. Pastāvīgo iedzīvotāju īpatsvars Latvijas plānošanas regionos no 2006.- 2015. gadam (\%)/ Proportion of permanent residents in the planning regions of Latvia from 2006 to 2015 (\%)

3.2. Pastāvīgo iedz̄ivotāju īpatsvars vecumā no 15- 29 gadiem iedzīvotāju kopskaitā Latvijā no 2006.- 2015. gadam (\%)/ Proportion of the population aged 15-29 in the total population in Latvia from 2006 to 2015 (\%)

3.3. Nodarbinātības līmenis Latvijā kopumā un jauniešiem dažādās vecuma grupās no 2006. - 2015. gadam (\%)/ Employment rates overall and for youth in different age groups in Latvia from 2006 - 2015 (\%)

3.4. Iedzīvotāju ekonomiskās aktivitātes līmenis atsevišķās jauniešu vecuma grupās un kopumā Latvijā no 2006.- 2015. gadam (\%)/ Level of economic activity of inhabitants for youths in certain age groups and overall in Latvia from 2006 to $2015(\%)$

3.5. Augstskolās un koledžās pamatstudijās uzṇemto studentu sadalījums pēc dzīvesvietas Latvijas statistisko reǵionu teritorijās un ārpus Latvijas 2010. gada - 2014. gada mācību periodam (\%)/ Distribution of matriculated students in undergraduate studies at universities and colleges by residence in the statistical regions of Latvia and outside Latvia in the study period 2010-2014 (\%)

3.6. Grādu vai kvalifikāciju ieguvušo studentu īpatsvars pa izglītības tematiskajām grupām augstskolās un koledžās Latvijā no 2006.- 2015.gadam (\%)/ Proportion of students who acquired a qualification or degree by thematic groups at universities and colleges in Latvia from 2006 to 2015 (\%)

3.7. Strādājošo mēneša vidējā bruto darba samaksa Latvijas statistiskajos reǵionos no 2006. - 2015. gadam, EUR/ Gross average monthly wage and salary of employees in the statistical regions of Latvia from 2006 - 2015 in EUR.
Lappuse

31

36

52

53

58

85

85

88

90

91 
3.8. Bezdarba līmenis jauniešiem dažādās vecuma grupās un kopumā Latvijā no 2006. gada līdz 2015. gadam (\%)/ Unemployment rate for youth in various age groups (aged 15 to 29 years) and the overall unemployment rate in Latvia from 2006 to 2015 (\%)

3.9. Bezdarba līmenis un vidējais bezdarba līmenis jauniešiem vecumā līdz 29 gadiem kopumā ES dalībvalstīs 2015. gadā $(\%) /$ Average unemployment rate and the unemployment rate for youth aged up to 25 years in the EU Member States in August 2015 (seasonally adjusted data) (\%).

3.10. Jauniešu bezdarbnieku īpatsvars no reǵionā registrēto bezdarbnieku kopskaita Latvijas plānošanas reǵionos 2015. gada beigās (\%)/ Youth unemployment proportion from total unemployed in the planning regions of Latvia in the end of $2015(\%)$

3.11. Baltkrievijas jauniešu aptaujas $(n=96)$ rezultāti jautājumam „Lūdzu, novērtējiet, cik lielā mērā dažādi ārēji, no Jums paša zināmā mērā neatkarīgi, faktori ir Jums iepriekš traucējuši atrast darbu?" (\%)/ Results of a youth survey $(n=96)$ in Belarus to the question "Please rate, how significant are the following exogenous factors that hindered you from finding a job before" (\%)

4.1. Respondenta statuss sadalījumā pēc dzimuma (n=764) $(\%) /$ Status of respondents by gender $(n=764)(\%)$

4.2. Respondentu, kas piedalījās aptaujā, sadalījums pa Latvijas pilsētām (n=764) (\%)/ Distribution of respondents who participated in the survey by city of Latvia $(n=764)(\%)$

4.3. Jauniešu, kuri šobrīd ir bez darba, darba meklējumu ilgums mēnešos Latvijā $(\mathrm{n}=292)(\%) /$ Job search duration for youth who are currently unemployed in Latvia, months, $(n=292)$ (\%)

4.4. Aptaujas dalībnieku izglītības līmenis un iegūtā darba meklējumu pieredze Latvijā $(\mathrm{n}=764)(\%) /$ Level of education and acquired job search experience of respondents in Latvia $(n=764)(\%)$

4.5. Aptaujas dalībnieku sadalījums par pieredzi darba meklējumos pēc dzīves vietas Latvijā (n=764) (\%)/ Distribution of survey participants by place of residence regarding their experience in search of a job in Latvia $(n=$ 764) $(\%)$

4.6. Jauniešu Latvijāa aptaujas rezultāti $(n=764)$ jautājumam „Lūdzu, novērtējiet, cik lielā mērā dažādi ārēji, no Jums paša zināmā mērā neatkarīgi, faktori Jums ir iepriekš traucējuši atrast darbu?" (\%)/ Distribution of the answers of youth $(n=$ 764) to the question "Please rate, how significant are the following exogenous factors that hindered you from finding a job before?" (\%) 
4.7. Jauniešu nodarbinātību Latvijā ietekmējošā faktora „,maz brīvu darba vietu" izvērtējums jauniešu skatījumā $(\mathrm{n}=764)$ pēc respondentu dzīves vietas Latvijā (\%)/Assessment of the factor influencing youth employment "there are few vacancies" by youth $(n=764)$ by residence of the respondents in Latvia (\%)

4.8. Jauniešu nodarbinātību Latvijā ietekmējošā faktora „nav informācijas par darba piedāvājumiem" izvērtējums jauniešu skatījumā $(\mathrm{n}=764)$ pēc respondentu dzīves vietas Latvijā $(\%) /$ Assessment of the factor influencing youth employment "I do not have information about job vacancies" by youth $(n=$ 764) by residence of the respondents in Latvia (\%)

4.9. Jauniešu nodarbinātību Latvijā ietekmējošā faktora ,slikti attīstīta infrastruktūra" izvērtējums jauniešu skatījumā $(\mathrm{n}=764)$ pēc respondentu dzīves vietas Latvijā (\%)/ Assessment of the factor influencing youth employment "poorly developed infrastructure" by youth $(n=764)$ by residence of the respondents in Latvia (\%)

4.10. Jauniešu nodarbinātību Latvijā ietekmējošā faktora „zināšanu, prasmju trūkums attiecīgajā jomā” izvērtējums jauniešu skatîjumā pēc iegūtā izglìtības līmeṇa $(n=764)(\%) /$ Assessment of the factor influencing youth employment "the lack of skills and knowledge in the relevant field" by youth (n $=764$ ) by residence of the respondents in Latvia (\%)

4.11. Jauniešu nodarbinātību Latvijā ietekmējošā faktora „nav nepieciešamā darba pieredze" izvērtējums jauniešu skatījumā pēc iegūtā izglītības līmeña $(\mathrm{n}=764)(\%) /$ Assessment of the factor influencing youth employment "I do not have the necessary work experience" by youth $(n=764)$ by residence of the respondents in Latvia (\%)

4.12. Jauniešu nodarbinātību Latvijā ietekmējošā faktora „iegūtā/ iegūstamā izglītība neatbilst piedāvātajām darba vietām" izvērtējums jauniešu skatījumā pēc iegūtā izglītības līmeña $(\mathrm{n}=764)(\%) /$ Assessment of the factor influencing youth employment "another education field" by youth $(n=764)$ by residence of the respondents in Latvia (\%)

4.13. Jauniešu nodarbinātību Latvijā ietekmējošā faktora „,neapmierina darba apstākḷi, izvērtējums jauniešu skatîjumā, balstoties uz iegūto izglītības līmeni $(\mathrm{n}=764)(\%) /$ Assessment of the factor influencing youth employment "unsatisfactory working conditions" by youth $(n=764)$ by residence of the respondents in Latvia (\%)

4.14. Jauniešu nodarbinātību Latvijā ietekmējošā faktora „nodarbinātības statuss - bezdarbnieks" izvērtējums jauniešu skatījumā balstoties uz iegūto izglītības līmeni $(\mathrm{n}=764)(\%) /$ Assessment of the factor influencing youth employment "status- unemployed" by youth $(n=764)$ by residence of the respondents in Latvia (\%) 
4.15. Jauniešu nodarbinātību Latvijā ietekmējošā faktora ,gimenes apstākḷi" izvērtējums jauniešu skatījumā, balstoties uz iegūto izglìtības līmeni $(\mathrm{n}=764)(\%) /$ Assessment of the factor influencing youth employment "family circumstances" by youth $(n=764)$ by residence of the respondents in Latvia (\%)

4.16. Jauniešu nodarbinātību Latvijā ietekmējošā faktora „neapmierina piedāvātā darba samaksa” izvērtējums jauniešu skatījumā $(\mathrm{n}=764)$ pēc respondentu dzīves vietas Latvijā (\%)/Assessment of the factor influencing youth employment "not satisfied with the salary" by youth $(n=764)$ by residence of the respondents in Latvia (\%)

4.17. Jauniešu Latvijā aptaujas rezultāti (n=764), izvērtējot apgalvojumu svarīgumu attiecībā uz jauniešu uzṇēmējdarbības attīstības iespēju veicināšanu (\%)/ Results of a survey of youth $(n=764)$ on the importance of promotion of opportunities for youth entrepreneurship development (\%)

4.18. Jauniešu interese par uznēmējdarbības uzsākšanu Latvijā atkarībā no iegūtā izglīî̄bas līmeņa $(\mathrm{n}=764)(\%) /$ Youth's interest in starting up their own business in Latvia $(n=764)$ (\%)

4.19. Jauniešu Latvijā aptaujas rezultāti $(n=764)$ sniedzot informāciju par nozari, kurā vēlētos darboties, ja uzsāktu uzñēmējdarbību (\%)/ Results of a survey of youth $(n=764)$ on industries in which the youth would like to start up a business in Latvia (\%)

4.20. Jauniešu Latvijā aptaujas rezultāti $(\mathrm{n}=764)$ sniedzot atbildi uz jautājumu „Par kuru/ kurām no uzṇēmējdarbības atbalsta programmām esat informēts un zināt?" (\%)/ Results of a survey of youth $(n=764)$ giving an answer to the question "Which business support programs you are informed and know more information?" in Latvia (\%)

4.21. Jauniešu apgalvojumu par to konkurētspēju darba tirgū stipro pušu izvērtējuma rezultāti pēc pāru salīdzināšanas metodes/ Results of the comparison of youth assertions about their competitiveness strengths in the labour market employing the pairwise method

4.22. Jauniešu apgalvojumu par to konkurētspēju darba tirgū vājo pušu izvērtējuma rezultāti pēc pāru salīdzināšanas metodes/ Results of the comparison of youth assertions about their competitiveness weaknesses in the labour market employing the pairwise method

4.23. Jauniešu apgalvojumu par to konkurētspēju darba tirgū iespēju izvērtējuma rezultāti pēc pāru salīdzināšanas metodes/ Results of the comparison of youth assertions about their competitiveness opportunities in the labour market employing the pairwise method 
4.24. Jauniešu apgalvojumu par to konkurētspēju darba tirgū draudu izvērtējuma rezultāti pēc pāru salīdzināšanas metodes/ Results of the comparison of youth assertions about their competitiveness threats in the labour market employing the pairwise method

4.25. Eilera - Venna diagramma jauniešu konkurētspējai darba tirgū Latvijā/ Euler - Venn diagram for youth's competitiveness in the labour market of Latvia

5.1. Prioritāšu vektoru noteikšanas shēma/ Scheme for the determination of priority vectors.

5.2. Vērtēšanas kritēriju hierarhija jauniešu bezdarbnieku nodarbinātības veicināšanai Latvijā/ Hierachy of evaluation criteria for promoting the employment of unemployed youth in Latvia

5.3. Interešu grupu nozīmīguma vērtējums ekspertu skatījumā/ Evaluation of the significance of interest groups by experts

5.4. Ekspertu viedoklis par indivīda interesēm jauniešu nodarbinātības veicināšanā/ Expert opinions on individual interests in promoting youth employment

5.5. Ekspertu viedoklis par izglītības iestāžu interesēm jauniešu nodarbinātības veicināšanā/ Expert opinions on education institution interests in promoting youth employment

5.6. Ekspertu viedoklis par uzṇēmēju interesēm jauniešu nodarbinātības veicināšanā/ Expert opinions on business interests in promoting youth employment

5.7. Ekspertu viedoklis par pašvaldību interesēm jauniešu nodarbinātības veicināšanā/ Expert opinions on local government interests in promoting youth employment

5.8. Ekspertu viedoklis par valsts interesēm jauniešu nodarbinātības veicināšanā/ Expert opinions on national interests in promoting youth employment

5.9. Ekspertu viedoklis par ES interesēm jauniešu nodarbinātības veicināšanā/ Expert opinions on the EU's interests in promoting youth employment

5.10. Piemērotākā scenārija izvēle jauniešu nodarbinātības veicināšanai ekspertu skatījumā/ Selection of the most appropriate scenario for promoting youth employment in Latvia by eksperts

5.11. Piemērotākais scenārijs jauniešu nodarbinātības veicināšanai ekspertu vērtējumā/ Selection of the most appropriate scenario for promoting youth employment in Latvia by eksperts 


\section{AKRONĪMI UN ABREVIATŪRAS/ \\ ACRONYMS AND ABBREVIATIONS}

ANO

AHP

ASV

CSP

CV

EK

EM

EP

ES

ESF

ERAF

Eurostat

Eurofound

EUR

IKP

IZM

JSPA

LAD

LB

LBAS

LDDK

LIAA

LM

LR

LU

MVU

NEET

NVA

OECD

OT

PB

PSRS

RTU

SDO

UNESCO

VIAA

VID

VSAA
Apvienoto Nāciju Organizācija

Hierarhiju analīzes metode (The Analytic Hierarhy

Process)

Amerikas Savienotās Valstis

Centrālā statistikas pārvalde

Dzīves gājums (Curriculum Vitae)

Eiropas Komisija

Ekonomikas ministrija

Eiropas Padome

Eiropas Savienība

Eiropas Sociālais Fonds

Eiropas Reǵionālās attīstības fonds

Eiropas Savienības Statistikas birojs (The Statistical Office of the European Union)

Eiropas Dzīves un darba apstākḷu uzlabošanas

fonds (The European Foundation for the Improvement of Living and Working Conditions)

Eiro valūtas starptautiskais apzīmējums

Iekšzemes kopprodukts

Izglītības un zinātnes ministrija

Jaunatnes starptautisko programmu aǵentūra

Lauku atbalsta dienests

Latvijas Banka

Latvijas Brīvo arodbiedrību savienība

Latvijas Darba devēju konfederācija

Latvijas Investīciju un attīstības aǵentūra

Labklājības ministrija

Latvijas Republika

Latvijas Universitāte

Mazie un vidējie uzņēmumi

Nav izglìtībā, nodarbinātībā vai apmācībā (Not in Education, Employment, or Training)

Nodarbinātības valsts aǵentūra

Ekonomiskās sadarbības un attīstības organizācija

(Organisation for Economic Co-operation and

Development)

Ogres tehnikums

Pasaules Banka

Padomju Sociālistisko Republiku Savienība

Rīgas Tehniskā universitāte

Starptautiskā Darba organizācija (International Labour Organization, ILO)

Apvienoto Nāciju Izglītības, zinātnes un kultūras organizācija

Valsts izglītības attīstības aǵentūra

Valsts ieñēmumu dienests

Valsts sociālās apdrošināšanas aǵentūra 


\section{IEVADS/ \\ INTRODUCTION}

Pētījuma aktualitāte. Viena no ES attīstības prioritātēm ir jauniešu bezdarba samazināšana. Nacionālie darbaspēka apsekojumi (Hoffman, 2011) liecina, ka kopš 2008. gada jauniešu bezdarbs ir palielinājies visās ES valstīs (Hjūza, Borbējs-Pece, 2012).

Jauniešu bezdarbs ir viens no būtiskākajiem problēmjautājumiem, kas jārisina Eiropas valstīs kopumā un arī Latvijā. Ārvalstu pētījumos Latvija tiek pozicionēta kā „depresīvais" regions, kurā 2030. gadā būs nepietiekams jauniešu skaits (Territorial Observation..., 2008). Līdz ar to Latvija, kā valsts ar uzṇēmējdarbības attīstîbai nedraudzīgu vidi, nespēs konkurēt ar citām Eiropas valstīm un investîciju plūsma tiks apdraudēta, kā arī novirzīta uz citiem, konkurētspējīgākiem un demogrāfiskā ziņā attīstītākiem reğioniem.

Nenoliedzami gan bezdarbs kopumā, gan jauniešu bezdarbs atstāj nopietnas sekas tautas ekonomikā un attīstībā, graujot balstus cilvēku labklājībai un labākas dzīves apstākḷiem. Tādēl iespējai strādāt algotu darbu visos laikos bijusi svarīga loma - gan no valsts, gan no cilvēka personīgās izaugsmes viedokḷa. Darbs un darba samaksa paver cilvēkam neskaitāmas iespējas un kāa „materiālās labklājīibas avots ieņem nozīmīgu vietu cilvēka dzīvē'. Materiālā labklājība, ko cilvēks var gūt, strādājot algotu darbu, spēj sniegt daudzveidīgas iespējas labākai un piesātinātākai dz̄ivei (Anča u.c., 2002).

Pašreizējās ekonomiskās nestabilitātes kontekstā jauniešu izredzes un iespējas darba tirgū ir nenoteiktas (Balan, 2014a). Pāreja no mācībām uz naudas pelnīšanu kḷūst aizvien problemātiskāka (Keep, 2012). Aizvien „dažādāki” jaunieši (arī tādi, kam ir bijušas labas sekmes) neiegūst izglîtību vai apmācību un nav nodarbināti, darba piedāvājums ir mazāks, t.sk. pienācīga, prasmēm adekvāta darba piedāvājums (pretstatā nekvalificētam pagaidu darbam), un jauniešu prasmes darba devēju vidū nav pārāk pieprasītas (Global Trends for..., 2010).

No 1980. gada jauniešu bezdarbs pirmoreiz kḷuva par nopietnu problēmu rūpnieciski attīstītajās valstīs, kad strauji pilnveidojās darba tirgi. Autori Klarks (Clark) un Sammers (Summers) 1982. gadā norādīja, ka jauniešu bezdarba problēma rodas no darbavietu trūkuma.

Jauniešu bezdarbs rada īpašas bažas, jo indivīdi, kas kḷuvuši par bezdarbniekiem, var kḷūt nelabvēlīgi sabiedrībai. Jaunieši, kuri nespēj atrast darbu pēc izglītības iegūšanas, var tikt uztverti kā neefektīvs cilvēkkapitāls ar nodarbinātības iespēju pasliktināšanos, kas varētu veicināt indivīda sociālo atstumtību. Vienlaikus jauniešu bezdarbs ir problemātisks ne tikai bezdarbā esošajai personai, bet arī ekonomikai kopumā (Salvador, Leiner-Killinger, 2008).

Krīze, kas Eiropu skāra 2008. gadā, būtiski un aizvien vairāk ietekmē jauniešus: 2015. gada augustā jauniešu (vecumā līdz 25 gadiem) bezdarbs ES 28 bija 20.1\%, bet kopējais bezdarbs 9.4\%. Jauniešu bezdarbs ir vairāk nekā divas reizes lielāks par ES 28 bezdarba līmeni pieaugušo vidū. Līdztekus tūlītējai krīzes ietekmei izglītības sistēmas un darba tirgus strukturālo problēmu dēl pāreja no skolas uz darbu ir kḷuvusi ilgstoša un sarežgìita. Bezdarbs jaunībā var atstāt paliekošu negatīvu ietekmi. Papildu lielākam bezdarba riskam nākotnē jaunieši ir arī pakḷauti augstākam nabadzības un atstumtības riskam un biežāk saskaras ar veselības problēmām. EK ziņojumā „Komisijas paziņojums Eiropas Parlamentam, Eiropas Padomei, Eiropas Ekonomikas un sociālo lietu komitejai un Reǵionu komitejai” (2012) uzsvērts, ka steidzami ir vajadzīgi efektīvi risinājumi jauniešu pārejai uz nodarbinātību (Komisijas paziņojums Eiropas..., 2012). 
Kopš 2013. gada bezdarbs (arī jauniešu bezdarbs) atsevišķos Latvijas reǵionos ir samazinājies, tomēr vēl aizvien ir novērojams augsts bezdarba līmenis Latgales regionā, kā arī citos Latvijas reǵionos. Tas veicina iedzīvotāju izbraukšanu no valsts darba meklējumos ārvalstīs. Reālā nodarbinātības situācija Latvijā neatbilst statistikas datiem, jo ne visi iedzīvotāji, kam nav darba, ir registrējušies Nodarbinātības valsts aǵentūrā (NVA). Līdz ar to statistikas dati nav precīzi. Bezdarbnieku nereǵistrēšanās NVA negatīvi ietekmē Latvijas tautsaimniecību kopumā, jo NVA atbalsts palielina ekonomiski aktīvo iedzīvotāju skaitu, kas maksā nodokḷus un papildina valsts budžeta ieņēmumus.

Bezdarbnieka iespējas atrast darbu ietekmē indivīda izglītības līmenis un iegūtās zināšanas, darba pieredze un apgūtās praktiskās iemaņas, kā arī no indivīda neatkarīgi apstākḷi, tādi kā infrastruktūras attīstība, politiskā un ekonomiskā situācija valstī utt. Darba tirgū vēsturiski nozīmīgas ir zināšanas un indivīda spēja savas zināšanas pielietot, pierādot sevi darbā.

Arvien notiekošās kvalitatīvās pārmaiņas tehnoloǵijās mūsdienās ir izsaukušas būtiskas izmainas sabiedrībā. Notiek pāreja no industriālās sabiedrības uz zināšanu sabiedrību, kurā cilvēku darbu - gan fizisko, gan intelektuālo - arvien biežāk sāk veikt pašu cilvēku radītās "gudrās" mašīnas (Bikse, 2005). Aktuālas 21. gs. ir indivīda zināšanas informācijas tehnologiju jomā, kas nodrošina konkurētspējīgo priekšrocību attiecībā pret citiem darba meklētājiem. Zināšanu sabiedrībā galvenais ir izglītots cilvēks, viņa spēja efektīvi radīt un izmantot zināšanas pastāvīgi mainīgos apstākḷlos. Cilvēks kḷūst par informācijas un zināšanu nesēju un glabātāju, galveno ekonomikas izaugsmes faktoru un nacionālās bagātības radītāju. Viṇam ir jābūt gatavam dzīvei uz zināšanām balstītā sabiedrībā. Izglīitība ir pārmainuu nesēja, tās loma jaunajos apstākḷos arvien pieaug (Bikse, 2005). Eurostat apkopotie statistikas dati norāda, ka jaunieši ar zemu izglītības līmeni biežāk kḷūst par bezdarbniekiem nekā jaunieši ar iegūtu izglītību (Sustainable Development in..., 2015).

Bezdarba vēsturiskās attīstības analīzē autore izmantojusi Filipsa (Philipss), Frīdmana (Friedman), Keinsa (Keynes), Māršala (Marshall), Marksa (Marx), Oukena (Okun), Pigu (Pigou), Rikardo (Ricardo), Smita (Smith), Seja (Say), Šumpētera (Schumpeter) un citu autoru atzinas.

Jauniešu bezdarba aktualitātes izpētei izmantoti Arulampalama (Arulampalam), Bella (Bell) (2009), Bertelota (Berthelot) (1995), Blančflovera (Blanchflower) (2000, 2009), Dītriha (Dietrich) (2012), Fadingera (Fadinger) (2014), Komineti (Cominetti) (2012), Lī (Lee) (2012), Sissona (Sissons) (2012) un citu autoru pētījumos gūtās atziñas.

Sociālās iekḷaušanās un bezdarba kopsakarības analizējuši tādi autori kā Berghmans (Berghman), Bubanijs (Bubany), Hansens (Hansen), Paugams (Paugam) (1995, 1996), Sonnets (Sonnet) (2010), Kalve (2005), Golubina (2007), Omarova (2009) u.c.

Reǵionālo atšksirību iezīmju analīzei pievērsušies tādi autori kā Buligina (2014), Buttons (Button) (1999), Fatejevs (1994), Pentekosts (Pentecost) (1999), Putāns (2014), Rasnača (2011), Sloka (2014), Teilors (Taylor), Vaidere (2006), Vilka (2006), Vanags (2006), Vanags (2006) u.c.

LR Jaunatnes likums nosaka, ka jaunietis ir persona vecumā no 13 līdz 25 gadiem. Savukārt ES statistikas un plānošanas dokumentos par jaunieti tiek uzskatīta persona vecumā no 15 līdz 30 gadiem (Youth in Europe..., 2009).

Darba analītiskās nodaļas pētījuma veikšanai autore izmanto ES plānošanas dokumentos minēto jauniešu vecuma posmu, lai statistiskos rādītājus būtu iespējams salīdzināt ar citām ES dalībvalstīm. Jauniešu aptaujas ietvaros ir apzināti jaunieši vecumā no 17 līdz 29 gadiem. 
Autores darbs NVA no 2010. gada līdz 2012. gadam, ikdienā saskaroties ar bezdarbniekiem un novērtējot reālo darba tirgus situāciju, kā arī analizētie citu autoru pētījumi radīja interesi par bezdarbā esošo jauniešu iekḷaušanos darba tirgū, lai izanalizētu un apzinātu faktorus, kas veicina jauniešu bezdarbu. Autore uzskata, ka šīs problēmas risināšanai vajadzētu pievērst lielāku uzmanību valdības līmenī, n,emot par paraugu citu Eiropas valstu pieredzi.

Promocijas darba hipotēze - izvērtējot faktorus, kas ietekmē jauniešu bezdarba veidošanos Latvijā, var efektīvāk veidot pasākumus un scenārijus, kas sekmē jauniešu iekḷaušanos darba tirgū.

Promocijas darba mērksis - izvērtēt jauniešu bezdarbu ietekmējošos faktorus Latvijā un izstrādāt ieteikumus jauniešu nodarbinātības veicināšanai.

Pētījuma objekts - jauniešu bezdarbs.

Pētijuma subjekts - jauniešu bezdarbu ietekmējošie faktori Latvijā.

Risinātie darba uzdevumi pētījuma mērķa sasniegšanai

1. Analizēt zinātnisko literatūru par bezdarba teorētiskajām pamatnostādnēm, jauniešu bezdarbu, jauniešu sociālo iekḷaušanos darba tirgū, kā arī izpētīt bezdarbu reǵionālā kontekstā.

2. Izvērtēt Latvijas un ES tiesiskos un politikas plānošanas dokumentus par bezdarbā esošo personu tiesisko aizsardzību un jauniešu nodarbinātības veicināšanu.

3. Izvērtēt ekonomiskos rādītājus saistībā ar jauniešu bezdarbu, noskaidrot citu Eiropas valstu pieredzi bezdarba samazināšanā, kā arī aprēķināt zaudējumus no bezdarbā esošiem jauniešiem.

4. Analizēt jauniešu bezdarba tendences un instrumentus jauniešu bezdarba samazināšanai Latvijā, balstoties uz darba devēju un jauniešu intervijās iegūto informāciju.

5. Noskaidrot nozares ekspertu viedokli par jauniešu iespēju iekļauties darba tirgū un, pamatojoties uz to, izstrādāt scenārijus un priekšlikumus jauniešu bezdarbnieku nodarbinātības veicināšanai Latvijā.

Mērķa sasniegšanai un darba uzdevumu risināšanai pētījuma izklāsts ir strukturēts piecās nodaḷās ar apakšnodaļām.

Pirmajā nodaḷā ir apkopotas teorētiskās atziņas par bezdarbu un jauniešu bezdarbu, izklāstīti bezdarba analīzes modeļi vēsturiskā kontekstā, noteikti jauniešu bezdarbu ietekmējošie faktori, analizēta jauniešu sociālā iekl̦aušanās darba tirgū, kā arī analizētas bezdarba tendences reǵionālā kontekstā.

Darba otrā nodaļa ir veltīta bezdarba situācijā esošu personu tiesiskās aizsardzības stratēǵgisko un politikas dokumentu analīzei, balstoties uz Latvijas un starptautisko dokumentu ietvaru.

Trešā nodaļa veltīta jauniešu darba tirgus un bezdarba tendenču analīzei Latvijā. Nodaļā izpētīta Eiropas valstu pieredze jauniešu nodarbinātības veicināšanā, kā arī aprēķināti Latvijas ekonomiskie zaudējumi jauniešu bezdarba dēḷ.

Ceturtā nodaļa veltīta jauniešu bezdarbu ietekmējošo faktoru izvērtēšanai Latvijā, balstoties uz jauniešu aptaujās iegūto informāciju. Apkopots darba devēju viedoklis par jauniešu konkurētspēju darba tirgū un jauniešu uzṇēmējdarbības veicināšanu.

Piektajā nodaļā analizēta jauniešu iekļaušanās darba tirgū Latvijā, balstoties uz ekspertu vērtējumiem. Pēc pētījumos iegūtajiem rezultātiem izstrādāti scenāriji jauniešu iekl̦aušanai darba tirgū.

Darba nobeigumā formulēti galvenie secinājumi, galvenie pētījuma rezultāti, kā arī atsegtas problēmas un izvirzīti priekšlikumi to risināšanai. 
Promocijas darba apjoms ekonomikas doktora (Dr.oec.) grāda iegūšanai ir 204 lapas. Darbā ir 19 tabulas, 52 attēli, 7 pielikumi, izmantoti 246 informācijas avoti, t.sk. 127 avoti anglu valodā.

\section{Aizstāvamās tēzes}

1. Bezdarbu veicina ne tikai darbaspēka pārpalikums, bet arī indivīda neatbilstība darba tirgus prasībām.

2. Jauniešu bezdarba normatīvajā un politiskajā ietvarā netiek uzsvērta problēmas aktualitāte un pie problēmas risinājumiem nav definētas atbildīgās institūcijas, kam jāuzṇemas atbildība.

3. Jauniešu negatīvā pieredze darba tirgū atstāj ietekmi uz individuālajiem rezultātiem nākotnē, tajā skaitā gan personīgajiem ienākumiem un dzīves līmeni, gan uz valsts attīstību.

4. Jauniešu bezdarbnieku iespējas iekḷauties darba tirgū ietekmē no indivīda atkarīgi faktori, tādi kā izglîtības līmenis, praktiskā pieredze, un neatkarīgi faktori, tādi kā infrastruktūras attīstība, nepietiekams brīvo darbavietu skaits, neapmierinoši darba apstākḷi.

5. Jauniešu bezdarbnieku nodarbinātību veicinātu ciešāka komunikācija starp izglītības iestādēm un uzņēmējiem, kā arī ESF atbalsta piesaiste jauniešu uzṇēmējdarbības veicināšanai.

\section{Pētījumu metodes}

- Vispārzinātniskās pētījumu metodes:

- monogrāfiskā jeb aprakstošā metode, kuras pielietošana palīdzēja rast detalizētu priekšstatu par pētāmo problēmu teorētiskajā skatījumā, balstoties uz plašu zinātniskās literatūras apskatu;

- grafiskā metode - grafiskās metodes lietošana palīdzēja uzskatāmi un efektīvi atklāt objekta sakarības un dinamiku;

- sintēzes un analīzes metode - atsevišķi pētāmā objekta elementi tika savienoti vienotā sistēmā, pētot to kopsakarības.

- Sociologisko pētījumu metodes:

- ekspertaptaujas metode tika izmantota, lai noskaidrotu ekspertu un darba devēju viedokli par pētāmo problemātiku un iezīmētu galvenās tendences darba tirgū;

- aptauja (anketēšana) izmantota, lai noskaidrotu jauniešu viedokli un redzējumu par jauniešu iespējām iekļauties darba tirgū;

- Statistisko pētījumu metodes, tādas kā aprakstošā statistika, salīdzināšana, grupēšana, laika rindu analīze, vidējo lielumu aprēķināšana, krostabulācijas (crosstabs) tika izmantotas, lai analizētu jauniešu bezdarbu ietekmējošos faktorus un jauniešu iekḷaušanās veicināšanu darba tirgū Latvijā. Nesaražotā IKP aprēķins tika pielietots, lai aprēķinātu no 2008. līdz 2015. gadam Latvijā nesaražotā IKP apjomu jauniešu bezdarba ietekmē.

- Prognozēšanas metodes:

- scenāriju metode pielietota, lai balstoties uz pētījumā iegūto informāciju, tiktu izveidoti jauniešu bezdarbnieku iekḷaušanos darba tirgū veicinošie scenāriji;

- hierarhiju analīzes metode (Analytical Hierarchy Process - AHP), izmantota lēmuma pieņemšanai par īstenojamajiem efektīvākajiem jauniešu bezdarbnieku iekļaušanos darba tirgū veicinošajiem scenārijiem Latvijā, aprēķinot prioritātes vektoru koordinātes, saskaņotības attiecību un vidèjās vêrtības;

- SVID un PEST analīze, pāru metode un Eilera-Venna diagrammas pielietotas, lai uzskatāmi sagrupētu jauniešu bezdarbnieku iekļaušanos darba tirgū ietekmējošos faktorus. 
Izmantotie dati un materiāli. Promocijas darbā izmantoti NVA apkopotie statistiskie dati un pētījumi, Latvijas CSP, ES Statistikas biroja - Eurostat, Eurofound, Baltkrievijas statistiskie dati un ziņojumi, Zviedrijas, Austrijas u.c. valdību statistikas dati un zinojumi, ES un Latvijas interneta resursi un periodiskie izdevumi, kuros tiek publicēti tiesību akti, vadošo nozares ekspertu publicētie zinātniskie raksti, monogrāfijas un grāmatas, nozares ekspertu pētījumi, mērḳa grupas anketēšana un intervijas ar ekspertiem. Autore ir izmantojusi ScienceDirect, EBSCO, Scopus, Web of Science, AGRIS datu bāzēs pieejamos žurnālus.

Pēdējo gadu laikā Latvijā veiktie nozīmīgākie pētījumi saistībā ar jauniešu bezdarba tematiku - 2014. gadā Latvijas Republikas Centrālā statistikas pārvalde ir izdevusi datu krājumu „Jaunieši Latvijā”, kas ir analītiska publikācija, kurā apkopoti statistikas dati par jauniešiem vecumā no 15 līdz 24 gadiem, un 2015. gadā AS „,DNB Banka” ir izdevusi izglītības un jaunieša bezdarba jautājumiem veltītu „DNB Latvijas barometru” Nr. 82 tēmā „Izglītība un jauniešu iesaistǐšanās darba tirgū”.

ESF nacionālās programmas „Darba tirgus pētījumi” projekta „Nodarbinātības valsts aǵentūras pētījumi” ietvaros 2006. gadā NVA ir veikusi pētījumu „Jauniešu bezdarbnieku kvalitatīvā sastāva atbilstības darba tirgus pieprasījumam izvērtēšana", kura ietvaros tika analizēta šis kategorijas bezdarbnieku izglītība, zināšanas un pamata prasmes. Tika analizēta jauniešu bezdarbnieku iepriekšèjā darba pieredze, bezdarba iemesli, kā arī noskaidrots, ko jaunieši sagaida, sadarbojoties ar NVA. Pētījuma ietvaros tika noskaidrots, kas kavē jauniešu iesaistīšanos darba tirgū un NVA aktīvajos nodarbinātības pasākumos.

\section{Zinātniskais nozīmīgums un pētījuma novitātes}

1. Izstrādāti, sagrupēti un uzskatāmi parādīti jauniešu bezdarbu ietekmējošie faktori Latvijā, t.sk. republikas pilsētās, balstoties uz teorētisko un praktisko pētījumu bāzes.

2. Aprēķināti zaudējumi no nesaražotā iekšzemes kopprodukta Latvijā 2008.2015. gadā jauniešu bezdarba ietekmē.

3. Apzināta jauniešu interese un informētība par uzņēmējdarbības atbalsta programmām un jauniešu iespējām uzsākt uzņēmējdarbību.

4. Izstrādāti un novērtēti jauniešu bezdarbnieku nodarbinātības veicināšanas scenāriji Latvijā.

Promocijas darba tautsaimnieciskais nozīmīgums. Šis pētījums ir aktuāls NVA, IZM, Latvijas augstskolām un darba devējiem efektīvāku nodarbinātības veicināšanas pasākumu plānu izstrādē un sadarbības veidošanā ilgtermiṇā, kā arī VIAA jauniešu nodarbinātības projektu izstrādei un mērķfinansējuma piesaistei no ES, LM, EM u.c. valsts institūcijām.

Promocijas darba rezultāti atspoguḷo jauniešu bezdarba aktualitāti un tendences darba tirgū, līdz ar to šie pētījuma rezultāti ir noderīgi arī darba devējiem, lai izprastu potenciālo darbinieku ietekmējošos sociālos, ekonomiskos un politiskos faktorus un noskaidrotu citu darba devēju un ekspertu viedokli par darba tirgus situāciju. Darba devējiem attīstībai nozīmīgi ir izprast potenciālā darbinieka viedokli par situāciju darba tirgū un individuālajām vajadzībām, kas mēdz ietekmēt indivīda (šî darba kontekstā jaunieša) iekḷaušanos darba tirgū.

Promocijas darba tēmas norobežojums. Apjoma ierobežojuma dēl darba ietvaros tika detalizētāk skatīts jauniešu bezdarba aktualitātes nozīmīgums un to ietekmējošie faktori, jauniešu sociālā iekḷaušanās darba tirgū, kā arī analizēta jauniešu uzn̦ēmējdarbības aktualitāte jauniešu un darba devēju skatījumā. Situācijas izpēte ir balstīta uz jauniešu, darba devēju, kā arī ekspertu aptaujām. Pētîjumā pielietota hierarhiju analīzes metode, detalizēti neskatot kopējos valsts ieguvumus no konkrēto 
scenāriju realizēšanas. Darba tematikas plašākai analīzei darba autore plāno pievērsties savos turpmākajos pētījumos.

Pētījuma izstrādi apgrūtināja tas, ka Latvijā bezdarbā esošām personām nav obligāti jāregíistrējas NVA, tāpēc nav iespējams pilnvērtīgi pētīt jauniešu bezdarbu.

Pētījums veikts laika posmā no 2012. gada septembra līdz 2016. gada martam. Statistikas datu analīzei izmantoti dati no 2003. gada līdz 2015. gadam, atkarībā no datu pieejamības.

Pētījumu atbalsta Valsts pētījumu programma 5.2. „Tautsaimniecības transformācija, gudra izaugsme, pārvaldība un tiesiskais ietvars valsts un sabiedrības ilgtspējīgai attīstībai - jaunas pieejas ilgtspējīgas zināšanu sabiedrības veidošanai (EKOSOC - LV)”. Autores pētniecības darbs tapa programmas projekta 5.2.3. „Latvijas lauku un reǵionālās attīstības procesi un iespējas zināšanu ekonomikas kontekstā" ietvaros. 


\section{BEZDARBS UN TĀ EKONOMISKĀ NOZĪME/ UNEMPLOYMENT AND THE ECONOMIC ROLE}

Globalizācijas procesu ietekmē notiek ne tikai kapitāla, preču un pakalpojumu brīva pārvietošanās starp valstīm, bet arvien straujāk sāk veidoties globālais darba tirgus. Globalizācija, nojaucot robežas starp darba tirgiem, pastiprina cilvēku mobilitātes problēmu plašā nozīmē. Viṇiem jābūt gataviem nemitīgām pārmaiṇām ne tikai ražošanā vispār, bet galvenais - dzīves vietas maiņai, spējai iesaistīties starptautiskā darba tirgus konkurencē, pārejai uz citu profesiju vai amatu, pastāvīgai sevis pilnveidošanai. Par konkurētspējas galveno nosacījumu globālajā darbaspēka tirgū kḷūst cilvēka izglītības līmenis, viṇa iegūtās kompetences: zināšanas, iemaņas, attieksmes un prasme tās pielietot (Bikse, 2009).

Pasaules globālās ekonomiskās nestabilitātes ietekmē Latvijā, kā arī citās pasaules valstīs, ir palielinājies jauniešu bezdarbs. Aktuāla ir jauniešu bezdarba problēma gan Latvijā, gan ES, ko ietekmē dažādi ekonomiskie, politiskie un sociālie aspekti. Līdz ar to būtiski ir izpētīt un izanalizēt jauniešu - bezdarbnieku ekonomisko aktivitāti ietekmējošos faktorus, to tendences un dinamiku, gūstot padziļinātu priekšstatu par bezdarba līmeņa samazināšanas iespējām.

Labvēlīgu apstākḷu radīšana jauniešiem, lai attīstītu savas prasmes, varētu strādāt un aktīvi iesaistīties sabiedrībā, ir būtiska ilgtspējīgas ekonomiskās un sociālās attīstības nodrošināšanā (Policies to Support..., 2010).

„Pašreizējā ekonomiskā situācija ir izvirzījusi jautājumus par sabiedriskās rīcībpolitikas pielāgošanu, kā arī par iedzīvotāju pielāgošanos, īpaši jauniešu, kas ir viena no vismazāk aizsargātajām grupām. Haotiskā ekonomika un strauji mainīgās politiskās un sociālās struktūras ietekmē jauniešus, valstis, kopienas un darba devējus. Pieaug dažādu valsts, privātā un brīvprātīgā sektora apvienību skaits, un būtisks jautājums ir, kā jaunos sociālās partnerības veidus vislabāk izmantot, lai apturētu jauniešu bezdarba paplašināšanos. Gan esošie, gan jaunie politikas pasākumi dažādos veidos cenšas novērst jauniešu bezdarba (un nepietiekamās nodarbinātības) ekonomisko, sociālo un psihologiisko ietekmi” (Hjūza, Borbējs- Pece, 2012).

Darba autore turpmāk šîs nodaļas ietvaros detalizētāk analizēs bezdarba jēdzienu un tā veidus, bezdarba vēsturisko attīstību, jauniešu bezdarba aktualitāti, sociālās iekḷaušanās un bezdarba mijiedarbības aspektus, kā arī bezdarba reǵionālās atšķirības teorētiķu skatījumā.

\subsection{Bezdarba jēdziens un tā veidi/ Concept of unemployment and types}

Darba autore analizē bezdarba jēdzienu un tā vēsturisko attīstību, jo gan bezdarbs kopumā, gan jauniešu bezdarbs atstāj nopietnas sekas uz valsts ekonomiku nākotnē.

Darba tirgus analīze bez bezdarba problēmu izpētes būtu nepilnīga. Pēc Akadēmisko terminu datu bāzē pieejamās informācijas, bezdarbs ir tirgus ekonomikas parādība, kad daḷa iedzīvotāju darbspējas vecumā nevar atrast darbu savā profesijā. Bezdarbs svārstās atkarībā no valsts ekonomikas rosības (Akadēmisko terminu..., b.g.).

SDO metodika nosaka, ka bezdarbnieki jeb darba meklētāji ir visas tās personas, kas vai nu ir vai nav reg̣istrētas NVA, un attiecībā uz kurām vienlaicīgi attiecas sekojoši trīs nosacījumi:

- darba atrašanas gadījumā ir gatavs nekavējoties (tuvāko 2 nedēḷu laikā) sākt strādāt. Ieskaita arī personas, kas darbu jau ir atradušas un uzsāks to 3 mēnešu laikā; 
- pārskata nedēḷā nekur nestrādāja un nebija pagaidu prombūtnē no darba;

- pēdējo 4 nedēļu laikā aktīvi meklēja darbu (Termini, b.g.).

CSP metodika nosaka, ka bezdarbnieki ir personas (vecumā no 15 līdz 74 gadiem), kuras vai nu ir, vai nav registrētas NVA un kuras atbilst šādiem nosacījumiem:

- pārskata nedēḷā nekur nestrādāja un nebija pagaidu prombūtnē no darba;

- pēdējo 4 nedēlı laikā aktīvi meklēja darbu;

- darba atrašanas gadījumā ir gatavas nekavējoties (tuvāko 2 nedēḷu laikā) sākt strādāt. Šajā kategorijā ieskaita arī personas, kuras darbu jau ir atradušas un uzsāks to 3 mēnešu laikā (Nodarbinātība un bezdarbs, 2015).

Profesore Bikse bezdarbu ir definējusi sekojoši - bezdarbs ir tāds stāvoklis ekonomikā, kad kvalificēts un darbspējīgs iedzìvotājs var un vēlas strādāt saskaņā ar piedāvāto darba algas likmi, bet viņam nav darba (Bikse, 2003, 78).

Atšķirīgu bezdarba skaidrojumu piedāvā autors Gaga. Bezdarbs ir neaizstājams tirgus ekonomikas raksturlielums. Izpaužoties darba tirgū, bezdarbs tomēr nav tikai darba tirgus funkcionēšanas rezultāts. Bezdarbs, no vienas puses, ir kā nodarbinātības „odere” (tās iekšpuse), no otras puses, - sajūt tādu faktoru ietekmi, kas ir atšksirīgi no faktoriem, kas rada nodarbinātību. Autors Gaga uzsvēris, ka, neraugoties uz to, bezdarbs vienmēr tiek skatīts kontekstā ar nodarbinātību: nodarbinātības pieaugums, kā likums, mazina bezdarbu, tajā pašā laikā darbinieku skaita samazināšana to palielina. Pēc definīcijas: bezdarbs - tas ir nenodarbināto darbspējīgo iedzīvotāju skaits, kuri vēlas strādāt. Makroekonomikā bezdarbs - tas vienmēr ir sabiedrības darba potenciāla, darbaspēka kopuma kā ražošanas faktora neizmantošana. Šajā ziṇā bezdarbs ir līdzīgs liekai ražošanas jaudai vai neizmantotām zemes platībām (Gaga, 2009).

Pētnieks Ulnicāns uzsvēris, ka bezdarbs ir dabiska un neizbēgama parādība tirgus ekonomikas apstākḷos. Laicīgi nerisināta, atsevišksam indivīdam tā var pārvērsties par nopietnu sociālu un psihologisku problēmu. Ekonomiskās lejupslīdes laikā bezdarbs var kḷūt par nopietnu valstisku problēmu (Ulnicāns, 2013).

Bezdarbs ir ekonomiska problēma, jo tā esamība atspoguḷo resursu zaudējumus ekonomikā kopumā. Ja bezdarbnieki būtu nodarbināti, valsts ekonomika iegūtu vairāk preču un pakalpojumu, līdz ar to arī ražošanas apjoms valstī būtu lielāks. Savukārt, valsts budžeta izdevumi bezdarbnieku pabalstiem un nodokļu likmes valdības izdevumu finansēšanai būtu mazākas (Stiglics, Drifils, 1994).

Apkopojot bezdarba jēdziena teorētiskos skaidrojumus, tajos uzsvērta indivīda nespēja atrast piemērotu darbu, neatbilstot darba tirgus prasībām. Bezdarba problēma netiek attiecināta uz indivīdu kā tādu, bet tiek uztverta kā dažādu ietekmējošo faktoru mijiedarbības rezultātā radusies parādība, kas saistīta ar valsts ekonomisko stāvokli, nosakot pieprasījumu un piedāvājumu darba tirgū.

Savukārt, bezdarba līmenis ir bezdarbnieku īpatsvars atbilstošās vecuma grupas ekonomiski aktīvo iedzīvotāju kopskaitā (izteikts procentos) (Nodarbinātība un bezdarbs, 2015).

Jāpiebilst, ka bezdarba līmenis ir relatīvs jēdziens, jo ne visi bezdarba situācijā esošie indivīdi (tajā skaitā arī jaunieši) ir reǵistrējušies NVA, līdz ar to šis statistiskais rādītājs nav absolūti precīzs un nesniedz skaidru redzējumu par bezdarbā esošo personu skaitu, atrašanās vietu utt.

Arī Bikse uzsver, ka bezdarba līmenis nav precīzs rādītājs, jo:

- personas, kas zaudējušas cerības atrast darbu, netiek uzskatītas par bezdarbniekiem;

- pastāv slēptais bezdarbs. Ja ir piespiedu dīkstāves, bezalgas atvalinājumi, bezdarbs netiek konstatēts, tādēḷ reālais bezdarba līmenis ir daudz augstāks; 
- iespējama nepareizi sniegta informācija apsekojuma laikā. Vieni var norādīt, ka meklē darbu, bet to patiesībā nedarīt, citi var nodarboties ar ēnu ekonomiku u. tml. (Bikse, 2003, 78).

Bezdarba līmen̦a tendenču noskaidrošanai lieto tādu rādītāju kā bezdarba norma. Bezdarba normu nosaka kā attiecību starp bezdarbnieku skaitu un kopējo darbaspēka daudzumu (Anča u.c., 2002).

Bezdarba normu aprēķina pēc sekojošas formulas:

Bezdarba norma = bezdarbnieku skaits/ kopējais darbaspēka daudzums (Anča u.c., 2002). šădi:

Pēc Valsts regionālās attīstības agentūras informācijas bezdarba līmeni aprēķina

Bezdarba līmenis = regiistrēto bezdarbnieku skaits/ iedzīvotāju skaits darbspējas vecumā gada sākumā $\times 100 \%$ (Reǵionālās attīstības indikatoru..., b.g.).

\section{Makroekonomikas literatūrā aprakstītas vairākas bezdarba formas.}

Aktuāla problēma ir ilgtermiņa bezdarbs. Zinātniskajā literatūrā ilgtermiņa bezdarba definīcija un tās periods atšķiras dažādās valstīs un dažādās starptautiskās statistikas aǵentūrās, sākot no 6 mēnešu perioda līdz vairāk nekā 12 mēnešiem. Biežāk sastopamais vidējais minimālais ilgums ir līdz 9 mēnešiem. Tas tiek izmantots zinātniskajā literatūrā, lai noteiktu brīdi, sākot ar kuru bezdarbs tiek uzskatīts par ilgtermiņa bezdarbu. 9 mēneši ir bezdarba periods, pēc kura varbūtība atrast darbu samazinās, jo darba devēji vairāk cenšas nolīgt bezdarbnieku, kurš ir bijis bez darba mazāk nekā 9 mēnešus (Garrouste et al., 2010).

LR LM noteikusi, ka ilgstošie darba meklètāji (bezdarbnieki) ir personas, kuras ir bez darba 12 mēnešus un ilgāk, aktīvi meklē darbu un tā atrašanas gadījumā ir gatavas sākt strādāt tuvāko 2 nedēlu laikā (Informatīvais ziṇojums par..., 2013).

Pētnieks Junankars (Junankar) ilgtermiņa bezdarbu definē kā 12 mēnešu periodu vai ilgāku laiku, kad persona ir bezdarbnieks. Bezdarbnieki ne tikai zaudē savas prasmes, viņi zaudē motivāciju un tiek pakl̦auti saslimšanas riskam. Jo no ekonomiskā viedokḷa cilvēkkapitāls tiek amortizēts. Šie cilvēki bieži vien dzīvo nabadz̄̄bā, vini ir zaudējuši savu pašcieņu un cieņu, viņi pieņem nespēju integrēties darba tirgū ar aizvainojumu un atkāpjas no iespējām (Junankar, 2011).

LR LM noteikusi, ka sezonālais bezdarbs (seasonal unemployment) rodas tad, kad darbam ir sezonāls raksturs, piemēram, daudziem lauksaimniecības un būvniecības darbiem ir sezonāls raksturs un tas nozīmē, ka piemēram, ziemas mēnešos var pieaugt sezonālā bezdarba līmenis un bezdarbnieku skaits noteiktās profesijās/nozarēs (Darba tirgus sakarības, b.g.). Darbaspēka pieprasījumu lielā mērā ietekmē laika apstākḷi, kas ir neparedzami un nekontrolējami, un gadalaiku maiņas, kas ir neizbēgamas. Tieši tādēl sezonālais jeb sezonas bezdarbs ir neizbēgama un normāla parādība noteiktās tautsaimniecības nozarēs un darbiniekiem, iesaistoties tajās, ir jārēķinās ar nozares sezonālo raksturu (Sloka, b.g.).

Mērenais bezdarbs (3-5\%) tiek uzskatīts par tirgus ekonomikas attīstībai nepieciešamo nosacījumu. Bezdarba procents tiek definēts kā attiecība starp bezdarbnieku skaitu un ekonomiski aktīvajiem iedzīvotājiem konkrētajā laika posmā (Gaga, 2009).

Ciklisk $\overline{\boldsymbol{a}}$ bezdarba (cyclical unemployment) gadījumā pieprasījums pēc darbaspēka ievērojami mainās. Cikliskais bezdarbs saistîts ar cikliskajām tendencēm izaugsmē un ražošanā. Ekonomiskās krīzes laikā ražošana samazinās un bezdarba 
līmenis palielinās, savukārt, uzlabojoties ekonomiskajai situācijai, iespējas sameklēt darbu palielinās (Vilne, Birzniece, 2001; Cyclical Unemployment, b.g.).

Brīvprātīgais bezdarbs - katrā sabiedrībā ir iedzīvotāju slānis, kuri savas psihologiiskās dabas vai arī citu iemeslu dēl nevēlas strādāt, piemēram, nav ar mieru strādāt par piedāvāto atalgojumu, bet labprāt strādātu par lielāku atalgojumu (Bikse, 2003, 81; Gaga, 2009).

Piespiedu bezdarbs rodas tad, ja pastāv fiksēta darba alga, un tādējādi cena, ko maksā par darba spēku ir neelastīga (Bikse, 2003, 81).

Institucionālais bezdarbs rodas, kad darba tirgus organizācija nav pietiekami efektīva, piemēram, nepilnīga informācija par brīvajām darba vietām (Gaga, 2009).

Dabiskais bezdarbs ir tad, kad ekonomikā ir „,pilnīga nodarbinātība” - brīvo darbavietu skaits ir vienāds ar bezdarbnieku skaitu īslaicīgajā un strukturālajā bezdarbā (Bikse, 2003, 81).

Pilnībā novērst bezdarbu nav iespējams, jo vienmēr pastāvēs dabiskais bezdarbs, kuru veido frikcionālais, sezonālais un strukturālais (Darba tirgus sakarības, b.g.).

Frikcionālais (īslaicīgais) bezdarbs (frictional unemployment) rodas, jo tirgus nepārtraukti mainās, informācija par darba iespējām ir nepiln̄̄ga un nepieciešams laiks, lai darba devēji un nenodarbinātie strādnieki atrastu cits citu. Pat tad, ja kopējais darba resursu daudzums ir nemain̄̄gs, tā iekšienē notiek nepārtrauktas izmaiņas, vienmēr ir cilvēki, kas no jauna iesaistās darba tirgū, un citi dažādu iemeslu dēl to pamet (Birzniece, Vilne, 2001). Par īslaicīgi nenodarbinātām personām var kḷūt jaunieši, kas nesen absolvējuši mācību iestādi vai personas, kas nolēmušas mainīt darba vietu.

Profesore Sloka uzsvērusi, ka tā kā atrašanās frikcionālajā bezdarbā ir brīvprātīga un rašanās galvenie iemesli ir piemērotākas darba vietas meklējumi vai cilvēku mērķtiecīga tiekšanās pēc labāka darba atalgojuma, tad tas ir uzskatāms par normālu, īslaicīgu un pat vēlamu parādību (Sloka, b.g.).

Strukturālais bezdarbs (structural unemployment) ir tāds bezdarbs, ko izraisa izmaiņas ekonomikas struktūrā, kas noved pie neatbilstības starp strādātāja kvalifikāciju, dzīves vietu un esošajām darba vietām. Atšķirībā no frikcionālā bezdarba, kad darbu atrast ir iespējams samērā īsā laika periodā, strukturālā bezdarba gadījumā ir nepieciešams pārkvalificēties, lai pielāgotos main̄̄gajai tautsaimniecības struktūrai, tāpēc šis bezdarba veids ir ilgstošāks (Sloka, b.g.). Prasmju neatbilstību darba tirgus prasībām var radīt ne tikai darbinieku nespēja apgūt jaunas prasmes un pāriet no vienas nozares uz citu (piem., no būvniecības uz apstrādes rūpniecību), bet arī reǵionālās mobilitātes trūkums (piem., no perifērijas uz regionāliem centriem) (Augsts bezdarbs Latvijā..., 2010).

Strukturālais bezdarbs mazāk attiecas uz jauniešiem bezdarbniekiem, jo jaunieši pārsvarā apgūst darba tirgum atbilstošu izglītību. Tas varētu skart jauniešus, kas izvēlējušies apgūt profesiju, kura nav pieprasīta darba tirgū un kurā ir izveidojusies pārprodukcija. Tādā gadījumā jaunietim vajadzētu apgūt citu profesiju.

Izplatītākie model̦i, ar kuru palīdzību tiek skaidrots strukturālais bezdarbs, ir efektīvās algas koncepcija un „,iesaistīto un neiesaistīto” koncepcija.

Blančarda - Sammera modelis ir viens no vecākajiem t.s. bezdarba histerēzes modeliiem. Par bezdarba histerēzi sauc tādu situāciju, kas raksturīga daudziem darba tirgiem, kad dabiskais bezdarba līmenis jeb NAIRU ir atkarīgs no faktiskā bezdarba līmeņa. Blančarda un Sammera modelis atklāj, ka esošais bezdarbs ir ļoti būtiski atkarīgs no bezdarba iepriekšējā periodā (Blanchard, Summers, 1986). Šajā modelī histerēzes izskaidrošanai izmantota "iesaistīto un neiesaistîto" (insider and outsider) koncepcija. Kā būtiskākais punkts minēts tas, ka algas noteikšanas procesā starp "iesaistītajiem", kas ir nodarbināti un "neiesaistītajiem", kas meklē darbu, pastāv 
fundamentāla asimetrija. "Neiesaistītie" tiek ignorēti un algas tiek noteiktas tā, lai nodrošinātu darbu "iesaistītajiem". Līdzīgi šīs sakarības pētīja Linbeks (Lindbeck) un Snovers (Snower), vēlākos pētījumos nosakot, ka nominālā alga ir vienošanās starp darba devēju un ,iesaistîtajiem” rezultāts (Lindbeck, Snower, 1990). Makroekonomiskie šoki, kas samazina nodarbinātību, izmaina "iesaistīto" skaitu un tādējādi izmaina arī līdzsvara algu likmi, radot histerēzi. Šie apsvērumi tad arī izskaidro š̀ modẹ̦a pamatpieņēmumu, ka līdzsvara bezdarba līmenis jeb NAIRU seko faktiskajam bezdarba līmenim. Ja makroekonomiskais šoks ir iepriekš paredzams, nekādas izmaiņas nodarbinātîbā netiek novērotas. "Iesaistītie" algas nosaka tā, lai saglabātu savu darba vietu, līdz ar to samazinās reālā darba alga, turpretī nodarbinātība saglabājas iepriekšējā līmen̄̄ (Purmalis, 2011).

Efektīvās algas koncepcija parāda negribēto bezdarbu kā līdzsvara nosacījumu gadījumā, kad darba devējs nespēj bez maksas noteikt strādājošo darba atdevi. Ja nav perfekta pārraudzība un ir pilna nodarbinātība, nepastāvot draudiem tikt atlaistam, strādājošie izvēlēsies slinkot (George, Borjas, 2005). Darbaspēks ir īpaša prece, kurai cena var mainīt preces kvalitāti. Alga var ietekmēt darba efektivitāti (Purmalis, 2011).

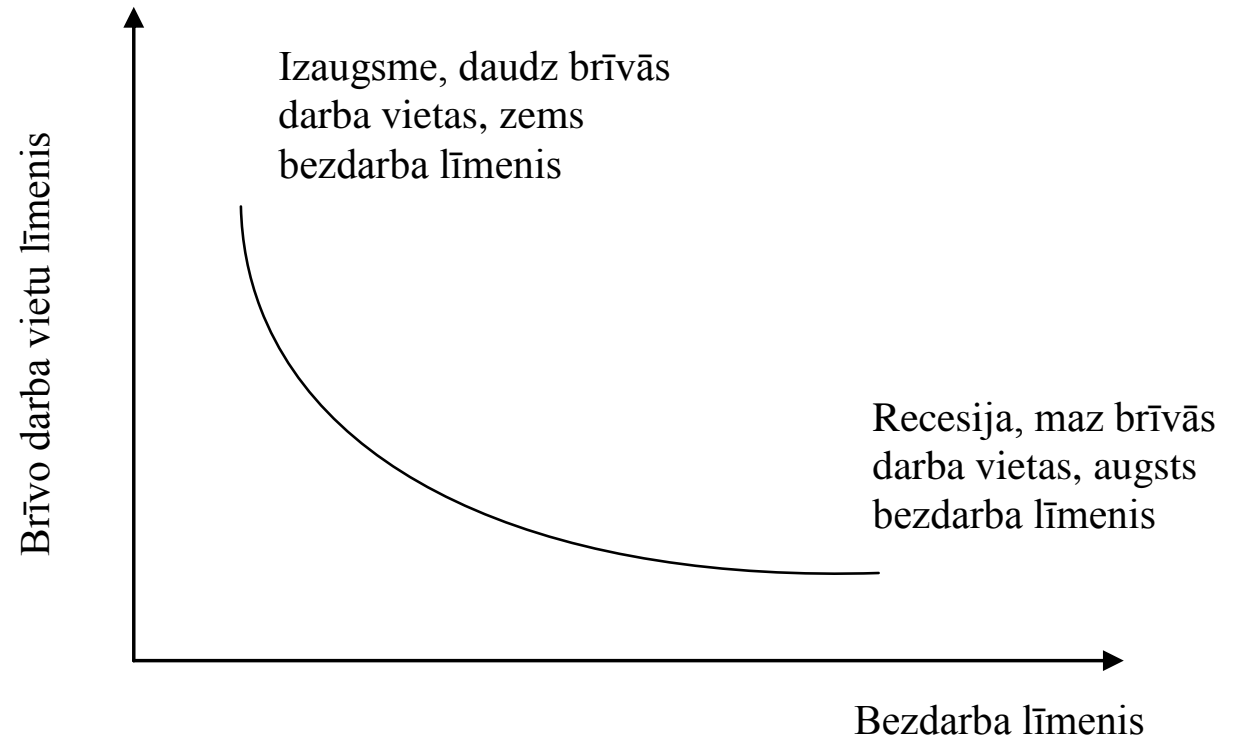

Avots: Nickell, b.g.

\section{1. att./ Fig. 1.1. Beveridža līkne/ Beveridge curve.}

Beveridža līkne. Bezdarba un brīvo darba vietu sakarības grafisku attēlojumu atspoguļo Beveridža līkne. Parasti brīvās darba vietas attēlo uz vertikālās ass un bezdarbu uz horizontālās ass. Beveridža līknei ir negatīvs kāpums, augstākam bezdarbam atbilst mazāk brīvās darba vietas. Ja laika gaitā Beveridža līkne pārvietojas tālāk no koordinātu sistēmas sākumpunkta, tad tas liecina, ka pie noteikta brīvo darba vietu līmeņa bezdarba līmenis ir augstāks kas, savukārt, norāda uz darba tirgus efektivitātes samazināšanos. Neefektīva darba tirgus iemesli var būt darbaspēka piedāvājuma un pieprasījuma kvalitatīva neatbilstība, kā arī geogrāfiska neatbilstība, kas saistīta ar darbaspēka mobilitāti (skatīt 1.1. att.) (Purmalis, 2011).

Noteikts punkts uz Beveridža līknes raksturo tautsaimniecības stāvokli ekonomiskā cikla fāzē. Piemēram, recesijas laikā ir vērojams augsts bezdarba līmenis un zems brīvo darba vietu līmenis, kas atbilst Beveridža līknes lejasdaļai, savukārt, 
izaugsmes periodos brīvo darba vietu līmenis būs augsts, bet bezdarba līmenis zems, kas atbilst līknes augšējai daļai (Purmalis, 2011).

Autori Anča, Barisa un Cimdiņš definējuši sekojošus bezdarba cēloņus:

- pārmaiņas ekonomikas struktūrā un ekonomikas kritums;

- situācija, kad darba devējs ir spiests samazināt resursus, tai skaitā arī darbaspēku;

- valdības politika darba jomā (piemēram, kad minimālās darba algas palielināšana paaugstina ražošanas izmaksas un tādējādi pazemina pieprasījumu pēc darbaspēka;

- sezonas izmaiņas dažās tautsaimniecības nozarēs;

- demogrāfiskas izmaiṇas (piemēram, kad darbspējīga vecuma iedzīvotāju skaita pieaugums palielina darbaspēka piedāvājumu un bezdarba līmeni (Anča u.c., 2002).

Nodarbinātības un bezdarba jautājumi jau agrīni piesaistījuši daudzu ievērojamu ekonomikas un zinātnisko skolu pārstāvju uzmanību.

Autors Gaga iezīmē paralēles starp bezdarbu un anglu ekonomista, ekonomikas teorijas klasiskās skolas radītāja Ādama Smita (Adam Smith, 1723-1790) attīstītajām teorijām par relatīvajām cenām.

Smita pieņēmumi balstījās uz divām atšķirīgām valstu ekonomikām: agrīnās un primitīvās valsts, kuras ir definētas kā ekonomikas, kurās kapitāls nav uzkrāts un zeme nav īpašumā; un progresīvā ekonomika, kur kapitālu un zemi vairāk nav iespējas iegūt (History of Economic...., 1989, 65).

Dāvids Rikardo (David Ricardo, 1772-1823) 1817. gadā pabeidza darbu pie savas ievērojamākās grāmatas "Politiskās ekonomikas un nodokḷu pamati" (On the Principles of Political Economy and Taxation). Grāmatā autors uzsvēris vērtības darba teorijas nozīmi, kas nosaka preču relatīvo cenu, balstoties uz darbaspēka daudzumu, kas nepieciešams, lai saražotu šìs preces (Ricardo, 2015).

Nozīmīgu ieguldījumu tirgus un nodarbinātības teorijā ieguldīja franču zinātnieks Žans Batists Sejs (Jean-Baptiste Say, 1767-1832). Daudzos jautājumos Ž. B. Sejs bija vienisprātis ar ekonomikas klasiķiem, kuri tirgum piešķīra noteicošo lomu ekonomikas attīstībā, un uzskatīja, ka tirgus ekonomikā nevar būt pārprodukcijas (piedāvājums atbilst pieprasījumam), deficīta, bezdarba un darbaspēka trūkuma. Ž. B. Sejs bija Ā. Smita uzskatu izskaidrotājs Eiropā un Amerikā. Viṇa grāmata "Politiskās ekonomikas līgums" (Traité d'économie politique) tika tulkots no franču uz angl̦u valodu un izmantota kā mācību grāmata Anglijā un ASV (The Concisce Encyclopedia..., 2008).

Ekonomikas klasiķi savus secinājumus par to, ka pilnīga nodarbinātība tirgus saimniecībai ir norma, pamatoja ar vēl vienu argumentu - cenu un darba algas attiecību elastīgumu. Ekonomikas klasiķi secināja, ka piespiedu bezdarbs nav iespējams. Tādas tirgus regulěšanas sviras kā procentu likmes, cenu un darba algas attiecību elastīgums spēj nodrošināt pilnīgu nodarbinātību. Ekonomisti uzskatīja, ka valsts iejaukšanās ir lieka un pat kaitīga (Gaga, 2009).

19.gs. beigās klasiķu sekotāji radīja neoklasicisma virzienu ekonomikas teorijā. Tā pamatlicējs bija Kembridžas universitātes profesors Alfrēds Māršals (Alfred Marshall, 1842-1924). A. Maršals uzskatīja, ka nodarbinātības nodrošināšanā svarīga loma ir pieprasījuma un piedāvājuma regulēšanai, ko aprakstījis savā darbā "Ekonomikas principi”. Viņš uzskatīja, ka augsta darba alga samazina nodarbinātību un palielina bezdarbu un to pamatoja ar "maksimālā darba ražīguma teoriju" (The Concisce Encyclopedia..., 2008). 
Vācu zinātnieks Kārlis Markss (Karl Marx, 1818-1883) 1867. gadā izdeva pirmo darba "Kapitāls" sējumu, kur nodarbinātības teorija ieņēma nozīmīgu vietu viņa ekonomiskajā mācībā un balstījās uz 3 koncepcijām:

- virsvērtības teorija - pamatota ar darbaspēka būtības un īpatnību analīzi, uzsverot, ka kapitālistiskā tirgus saimniecības apstākḷıs darbaspēks kḷūst par preci;

- kapitāla dabiskā pieauguma teorija - samaksājot darbiniekiem algu par paveikto darbu, darba devējs sañem produkta/ pakalpojuma pievienoto vērtību, kurā ietverta gan darbaspēka vērtībā, gan virsvērtība;

- apdzīvotîbas likums - "strādājošie iedzīvotāji, radot kapitāla uzkrājumus, rada milzīgus līdzekḷus, kas tos padara par salīdzinoši liekiem iedzīvotājiem" t.i., bezdarbniekiem. "Liekie iedzīvotāji” ir neizbēgami kapitālistiskā tirgus ražošanā (Gaga, 2009).

Bezdarba būtības izpētei pievērsās Artūrs Pigu (Arthur Pigou, 1877-1959). 1933. gadā iznāca viṇa nozīmīgākais darbs par nodarbinātîbas tēmu „Bezdarba teorija” (Theory of Unemployment). Autors uzskatīja, ka bezdarba iemesls ir augstais darba algu līmenis un tā samazināšana palielinās nodarbinātību, samazināsies ražošanas izdevumi un būs iespējams papildus pieņemt darbā jaunus strādniekus. Samazinoties ražošanas izmaksām, samazināsies arī vispārējās preču cenas un pieaugs pirktspēja tām iedzīvotāju grupām, kuru iztikas avots nav darba alga. Tā rezultātā radīsies papildu pieprasījums, kas veicinās ražošanas paplašināšanos un nodarbinātību. A. Pigu atbalstīja strādājošos, kas nepiekrita strādāt par darba algu, kas veidojās tirgū, pieprasījuma un piedāvājuma rezultātā (Takami, 2011).

20. gs. ekonomists Džons Meinards Keinss (John Maynard Keynes, 1883-1946) uzsvēra, ka galvenais ir ražīguma līmenis, piemēram, tas, ko rada ieñēmumi no investīcijām, lai gan tie ir stabili, ne vienmēr ir pilnīga nodarbinātība (Ekelund, Hebert, 1997, 471). 1936. gadā Dž. M. Keinss pabeidza darbu pie grāmatas "Vispārējā nodarbinātības teorija, procenti un nauda" (The General Theory of Employment, Interest and Money), kuras pamatmērķis bija noskaidrot, kas nosaka nodarbinātības līmeni (The Concisce Encyclopedia..., 2008). Dž. M. Keinss uzskatīja, ka bezdarba un inflācijas iemesli slēpjas nevis iekšējos iemeslos, bet ekonomiskajā sistēmā, kas nav un nevar būt pašregulējoša. Noraidot apgalvojumu, ko prezentēja klasiķi, ka piedāvājums rada pieprasījumu, un, balstoties uz to nesakritību, viņš uzsvēra nepieciešamību palielināt pieprasījuma kopējo apjomu, uzskatot, ka tikai tas veicinās ražošanas apjoma palielināšanos un tautas labklājību. Savukārt, efektīva pieprasījuma trūkums noved pie ražošanas jaudu nepilnīgas slodzes, zema ražošanas tempa pieauguma, krīzes parādībām un bezdarba. Valstij ir jābūt atbildīgai par kopējo pieprasījumu. Paplašinot vai palielinot pieprasījumu, mazināsies bezdarbs (Gaga, 2009).

Savukārt Jozefs Šumpēters (Joseph Schumpeter, 1883-1950) norādīja, ka $\bar{A}$. Smita darba dalīšana ir praktiski vienīgais ekonomikas progresa faktors, kā atslēgas elementus norādot dabu, uzkrāšanu un nodarbinātību (History of Economic...., 1989, 117).

J. Šumpēters uzsvēra, ka brīvais tirgus veicina zaudētu darba vietu skaita pieaugumu, izpostītus uzñēmumus un nozaru saplūšanu, kas ir raksturīgi izaugsmes sistēmai. J. Šumpēters definējis frāzi "tehnolog̣iskais bezdarbs", kas nozīmē darba vietu skaita samazinājumu, piemēram, ar tehnologiijām strādājošajiem, bet palielina darba vietu skaitu programmētājiem (Cox, Alm, 2008).

Sakarības starp inflācijas līmeni un bezdarbu pētījis Viliams Filipss (William Phillipss, 1914-1975). Viņš empīriski atklāja apgrieztu proporcionālu sakarību starp inflācijas tempu un bezdarba līmeni - augstam inflācijas līmenim atbilst zemāks 
bezdarba līmenis, un otrādi, - augsta nodarbinātība iespējama tikai pie augstas inflācijas. (Gaga, 2009). Par godu izgudrotājam sakarību starp inflāciju un bezdarba līmeni dēvē par Filipsa likkni.

1.1. tabula/ Table 1.1.

\section{Darba tirgu regulējošo ekonomisko teoriju vēsturiskā attīstība/ Historical development of economic theories regulating the labour market}

\begin{tabular}{|c|c|c|}
\hline Zinātnieks & $\begin{array}{c}\text { Pārstāvētā } \\
\text { zinātniskā skola, } \\
\text { koncepcija }\end{array}$ & Galvenie pētījumu atzinumi un virzieni \\
\hline $\begin{array}{l}\bar{A} . \text { Smits (Adam Smith) } \\
1723-1790\end{array}$ & $\begin{array}{l}\text { Ekonomiskās } \\
\text { teorijas klasiskās } \\
\text { skolas radītājs }\end{array}$ & $\begin{array}{l}\text {-Preču ražošanas un darba tirgus sakarības; } \\
\text {-tirgus pašregulācija - minimāla valsts iejaukšanās; } \\
\text {-alga mainās atkarībā no darba viegluma vai } \\
\text { smaguma pakāpes un nodarbošanās cienīguma. }\end{array}$ \\
\hline $\begin{array}{l}\text { D. Rikardo (David } \\
\text { Ricardo) } 1772-1823\end{array}$ & $\begin{array}{l}\text { Ekonomiskās } \\
\text { teorijas klasiskās } \\
\text { skolas pārstāvis }\end{array}$ & $\begin{array}{l}\text {-Iestājās pret pilnīgu valsts iejaukšanos ekonomikā; } \\
\text {-atbalstīja brīvu tirdzniecību; } \\
\text {-kapitālisma sistēmas atž̄̌šana; } \\
\text {-piln̄̄ga nodarbinātība tika uzskatīta kā tirgus } \\
\text { ekonomikas norma. }\end{array}$ \\
\hline $\begin{array}{l}\text { Ž. B. Sejs (Jean-Baptiste } \\
\text { Say) 1767-1832 }\end{array}$ & $\begin{array}{l}\text { Ekonomiskās } \\
\text { teorijas klasiskās } \\
\text { skolas pārstāvis }\end{array}$ & $\begin{array}{l}\text {-Pievērsās tirgus un nodarbinātības teorijai; } \\
\text {-Uzskatīja, ka ekonomikā nevar būt pārprodukcija, } \\
\text { bezdarbs un darba spēka trūkums; } \\
\text {-Tirgus pašregulācija nodrošina pilnu nodarbinātību. }\end{array}$ \\
\hline $\begin{array}{l}\text { A. Maršals } \quad \text { (Alfred } \\
\text { Marshall) } 1842-1924\end{array}$ & $\begin{array}{l}\text { Ekonomikas } \\
\text { teorijas } \\
\text { neoklasicisma } \\
\text { virziena } \\
\text { pamatlicējs }\end{array}$ & $\begin{array}{l}\text {-Pieprasījuma un piedāvājuma regulēšanas ietekme } \\
\text { uz nodarbinātību; } \\
\text {-augsta darba alga samazina nodarbinātību un } \\
\text { palielina bezdarbu; } \\
\text {-izstrādāja maksimālo darba ražīguma teoriju. }\end{array}$ \\
\hline $\begin{array}{l}\text { K. Markss (Karl Marx) } \\
1818-1883\end{array}$ & $\begin{array}{l}\text { Kapitālistiskās } \\
\text { ideologijas } \\
\text { pārstāvis }\end{array}$ & $\begin{array}{l}\text {-Nodarbinātības teorija, kas balstās uz trim } \\
\text { svarīgākajām sastāvdal̦ām - virsvērtības teorija, } \\
\text { kapitāla dabiskā pieauguma teorija, apdzīvotības } \\
\text { likums. }\end{array}$ \\
\hline $\begin{array}{l}\text { A. Pigu (Arthur Pigou) } \\
\text { 1877-1959 }\end{array}$ & $\begin{array}{l}\text { Ekonomikas } \\
\text { teorijas } \\
\text { neoklasicisma } \\
\text { virziena pārstāvis }\end{array}$ & $\begin{array}{l}\text {-Bezdarba iemesls ir augstais darba algas līmenis, tā } \\
\text { samazināšana palielinās nodarbinātību; } \\
\text {-nodarbinātības apjomu nosaka reālais darba } \\
\text { pieprasījums. }\end{array}$ \\
\hline $\begin{array}{l}\text { Ď̆. M. Keinss (John } \\
\text { Maynard Keynes) } 1883- \\
1946\end{array}$ & $\begin{array}{l}\text { Kapitālisma un } \\
\text { nodarbinātības } \\
\text { ekonomiskās } \\
\text { teorijas } \\
\text { izveidotājs }\end{array}$ & $\begin{array}{l}\text {-Bezdarba un inflācijas iemesli slēpjas pašā } \\
\text { ekonomiskajā sistēmā, kas nav un nevar būt } \\
\text { pašregulējoša; } \\
\text {-investīciju apjomi nerada līdzsvaru, tādēl var rasties } \\
\text { lielas kopējās ražošanas un nodarbinātības svārstības; } \\
\text {-valstij ir jānodrošina pienācīgs efektīva pieprasījuma } \\
\text { apjoms, jo paplašinot pieprasījuma apjomu } \\
\text { mazināsies bezdarbs. }\end{array}$ \\
\hline $\begin{array}{l}\text { J. Šumpēters } \quad \text { (Joseph } \\
\text { Schumpeter) 1883-1950 }\end{array}$ & $\begin{array}{l}\text { Kapitālisma un } \\
\text { nodarbinātības } \\
\text { ekonomiskās } \\
\text { teorijas pārstāvis }\end{array}$ & $\begin{array}{l}\text {-Frāzes "tehnologiskais bezdarbs" radītājs; } \\
\text {-brīvais tirgus veicina zaudētu darba vietu skaita } \\
\text { pieaugumu, izpostītus uzṇēmumus un nozaru } \\
\text { saplūšanu. }\end{array}$ \\
\hline $\begin{array}{l}\text { M. Frīdmans (Milton } \\
\text { Friedman) 1912-2006 }\end{array}$ & $\begin{array}{l}\text { Monetārisma } \\
\text { virziena radītājs }\end{array}$ & $\begin{array}{l}\text {-Tirgus ekonomikai ir augsts noturības un } \\
\text { konkurences līmenis; } \\
\text {-valsts iejaukšanās ekonomikā ir galvenais cēlonis } \\
\text { inflācijai, bezdarbam, ekonomikas pieauguma } \\
\text { nestabilitātei. }\end{array}$ \\
\hline
\end{tabular}

Avots: autores veidots pēc Gaga, 2009; History of Economic..., 1989; Cox, Alm, 2008 
1.1. tabulas turpinājums/ Continuation of Table 1.1.

Darba tirgu regulējošo ekonomisko teoriju vēsturiskā attīstība/ Historical development of economic theories regulating the labour market

\begin{tabular}{|l|l|l|}
\hline \multicolumn{1}{|c|}{ Zinātnieks } & \multicolumn{1}{|c|}{$\begin{array}{c}\text { Pārstāvētā } \\
\text { zinātniskā skola, } \\
\text { koncepcija }\end{array}$} & \multicolumn{1}{|c|}{ Galvenie pētījumu atzinumi un virzieni } \\
\hline $\begin{array}{l}\text { V. Filipss (William } \\
\text { Phillipss) 1914-1975 }\end{array}$ & $\begin{array}{l}\text { Kapitālisma un } \\
\text { nodarbinātības } \\
\text { ekonomiskās } \\
\text { teorijas pārstāvis }\end{array}$ & $\begin{array}{l}\text {-Inflācijas un bezdarba kopsakarības; } \\
\text {-Filipsa līkne - augstam inflācijas līmenim atbilst } \\
\text { zemāks bezdarba līmenis, un otrādi. }\end{array}$ \\
\hline $\begin{array}{l}\text { P. E. Samuelsons (Paul } \\
\text { Anthony Samuelson) } \\
\text { 1915-2009 }\end{array}$ & $\begin{array}{l}\text { Neoklasiskās } \\
\text { sintēzes skolas } \\
\text { radītājs }\end{array}$ & $\begin{array}{l}\text {-Centās risināt jautājumus saistībā ar ražošanas un } \\
\text { nodarbinātības stagnāciju, un vienlaicīgu cenu } \\
\text { inflāciju. }\end{array}$ \\
\hline $\begin{array}{l}\text { A. M. Oukens (Arthur } \\
\text { Melvin Okun) } \\
\text { 1928-1980 }\end{array}$ & $\begin{array}{l}\text { Oukena likuma } \\
\text { radītājs }\end{array}$ & $\begin{array}{l}\text {-Izstrādāja metodiku bezdarba dēḷ nesaražotā reālāan } \\
\text { iekšzemes kopprodukta aprēksināšanai. }\end{array}$ \\
\hline
\end{tabular}

Avots: autores veidots pēc Gaga, 2009; History of Economic..., 1989; Cox, Alm, 2008

60. gados daudzās attīstītajās valstīs veidojās stagflācija. Filipsa līkne pārstāja attēlot inflācijas un bezdarba savstarpējās sakarības patieso situāciju. Izrādījās, ka cīṇa ar inflāciju un bezdarbu ir daudz sarežg̀îtāka problēma (Gaga, 2009).

Pols Entonijs Samuelsons (Paul Anthony Samuelson, 1915-2009) ir neoklasiskās sintēzes skolas radītājs, kas centās risināt jautājumus saistībā ar ražošanas un nodarbinātības stagnāciju un vienlaicīgu cenu inflāciju. Šajā nolūkā valdība varētu, palielinot pieprasījumu pēc precēm un pakalpojumiem, pastāvīgi samazināt bezdarbu un veicinot augstāku inflāciju (The Concisce Encyclopedia..., 2008).

1960. gadā Miltons Frīdmans (Milton Friedman, 1912-2009) un amerikāṇu ekonomists Edmunds Strothers Phelps (Edmund Strother Phelps, 1933) apstrīdēja E. Samuelsona viedokli. M. Friedmans apgalvoja, ka lai saglabātu bezdarbu pastāvīgi zemāku būtu nepieciešama ne tikai lielāka, bet pastāvīgi paātrināta inflācija (The Concisce Encyclopedia..., 2008).

M. Frīdmans bija viens to tiem zinātniekiem, kas bija pret valsts iejaukšanos ekonomikā un uzskatīja, ka tā ir galvenais cēlonis inflācijai, bezdarba un ekonomikas pieauguma nestabilitātei (Gaga, 2009).

E. S. Phelps pētot nodarbinātības, cenu un algu dinamikas kopsakarības, nonāca pie dabiskā bezdarba formulējuma pastāvēšanas un mehānisma, kas to regulē (Phelps, b.g.).

E. S. Phelps 1990. gadā pievērsās ekonomiskās iekḷaušanās (integrācijas pētījumiem). 1997. gadā viņš publicēja grāmatu "Darba atalgojums: kā uzņēmumos atjaunot līdzdalību un iekl̦auties", kurā aprakstīti bezdarba cēloṇi un kopsakarības un zemo algu līmenis darbiniekiem, kas uzñēmējiem nav izdevīgs (Phelps, b.g.).

Neoklasicisma ekonomikas pārstāvji uzskatīja, ka darba tirgus, tāpat kā citi tirgi, darbojas uz cenu līdzsvara pamata. Arī autors Junankars (Junankar) uzskata, ka tīrā neoklasicisma ekonomikā darbaspēka pieprasījums ir atkarīgs no kopējā pieprasījuma līmeña (Junankar, 2011).

Ievērojamais ASV ekonomists Arturs Melvins Oukens (Arthur Melvin Okun, 1928-1980) ir izstrādājis metodiku, kā aprēķināt bezdarba dēḷ nesaražoto reālo iekšzemes kopproduktu. Ja faktiskais bezdarba līmenis ir par 1.0\% lielāks nekā dabiskais bezdarba līmenis, tad nesaražotais IKP līdzinās 2.0\%. Šo sakarību dēvē par Oukena likumu (Okun's law). 
Iepriekš minētie ievērojamākie zinātnieki, to pārstāvētās ekonomiskās teorijas zinātniskās skolas un galvenie pētījumu atzinumi un virzieni apkopoti 1.1. tabulā.

Balstoties uz teorētisko aspektu analīzi dažādu teorētiķu skatījumā, promocijas darba autore ir apkopojusi būtiskākos bezdarbu ietekmējošos ekonomiskos, politiskos, sociālos un kultūras faktorus, kas var nozīmīgi ietekmēt darbavietu skaitu, valsts ekonomiku, indivīda dz̄ives līmeni, kā arī bezdarbnieku iekļaušanos darba tirgū. 1.2. attēlā redzama faktoru savstarpējā mijiedarbība.

Ekonomiskie faktori, kas ietekmē bezdarbu, ir eksporta un importa apjoms, uzṇēmumu skaits, atalgojuma līmenis, pieprasījums un piedāvājums pēc precēm un pakalpojumiem.

Nozīmīgākie politiskie faktori, kas ietekmē bezdarbu, ir politiskā stabilitāte, attiecības starp valsts institūcijām un uzņēmējiem, attiecības starp izglītības iestādēm un uzņēmējiem, kā arī attiecības ar citu valstu reǵioniem.

Kā nozīmīgākie sociālie un kultūras faktori minami izglītības līmenis, iepriekšējā darba pieredze, veselība, sociālā adaptācija, personiskās īpašības, kā arī darba tirgus pieprasījums pēc indivīda profesijas.

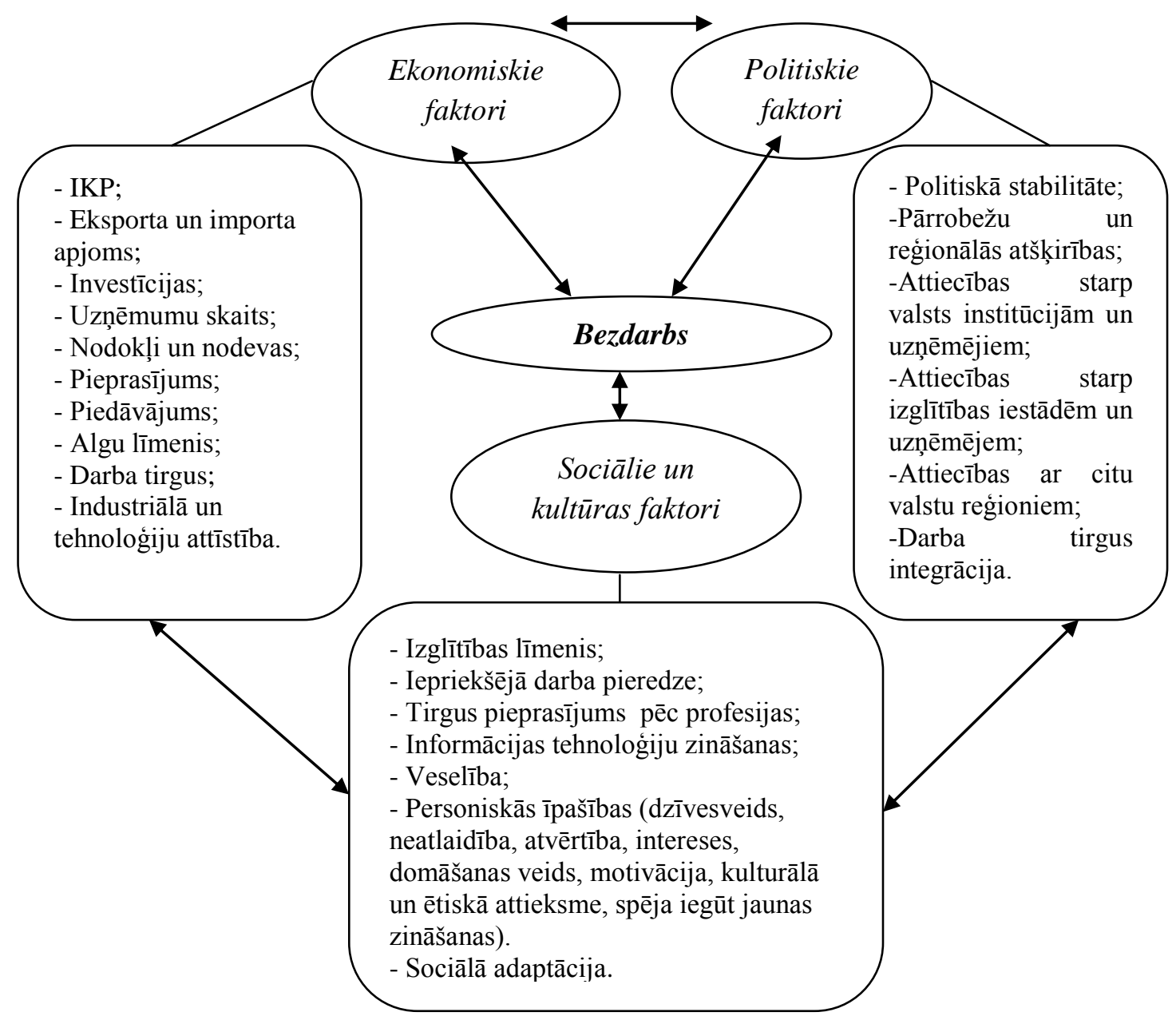

Avots: autores konstrukcija, balstoties uz teorētisko studiju bāzi, pēc Arulampalam, 2001; Balan, Vasile, 2013; Bell, Blanchflower, 2009; Clark, Summers, 1982; Fadinger et.al., 2014; Martin, 2009; Pigozne, 2014; Špona, 2004; Villeruša, Gobina, 2007

\section{2. att./ Fig. 1.2. Bezdarbu ietekmējošie faktori un to mijiedarbība/ Factors influencing unemployment and their interaction}


Jauniešu bezdarba problēma ir būtisks nākotnes attīstības „stūrakmens”, kas ietekmēs gan valsts, gan pasaules ekonomisko izaugsmi, tādēl darba nākamajā nodal̦ā autore pēta tieši jauniešu bezdarba teorētiskos aspektus, tendences, kā arī ekonomisko nozīmīgumu un problemātiku.

\subsection{Jauniešu bezdarbs kā ekonomiska problēma/ Youth unemployment as an economic problem}

Tādi pētnieki kā Audas (Audas), Berde (Berde), Bells (Bell), Bertelots (Berthelot), Blančflovers (Blanchflower), Dītrihs (Dietrich), Dolitons (Doliton), Frīmans (Freeman), Klarks (Clark), Sammers (Summers) un citi jau kopš 1970. gada pēta teorētiskās un empīiskās jauniešu bezdarba definīciju atšķirības. Ievērojams skaits pētījumu koncentrējas uz starpvalstu atšķirībām bezdarba līmen̄i, kā arī to ietekmei uz aktīvu darba tirgus politiku, kas paredzēta, lai veicinātu nodarbinātības pieejamību jauniešiem (Blanchflower, Freeman, 2000).

Gan bezdarbs kopumā, gan tiešu jauniešu bezdarbs tiek uzskatīts par sociālu un ekonomisku problēmu (Striglics, Drifils, 1994).

Tā kā darbā vērsta uzman̄iba uz jauniešu bezdarbu kā ekonomisku problēmu, jānoskaidro, kādā vecuma posmā varam indivīdu uzskatīt par jaunieti.

LR Jaunatnes likumā, „Jaunatnes politikas pamatnostādnēs 2009.- 2018. gadam” jaunietis tiek uzskatīts par personu vecumā no 13 līdz 25 gadiem (Jaunatnes likums, 2008; Jaunatnes politikas pamatnostādnes..., 2009).

ES programmā „Jaunatne darbībā” 2007.- 2013. gadam par jauniešiem tiek uzskatītas personas vecumā no 13 līdz 30 gadiem (Eiropas Savienības programma..., b.g.).

ES statistikas un plānošanas dokumentos par jaunieti tiek uzskatīta persona vecumā no 15 līdz 30 gadiem (Youth in Europe..., 2009).

Savukārt NVA ,Jauniešu garantijas” pasākumos noteikts, ka tajos var pieteikties jaunieši vecumā no 15 līdz 29 gadiem, iesaistoties nodarbinātībā, apmācībā vai izglītības ieguvē (skatīt 1. pielikumu).

Tā kā darba uzstādījums ir apzināt faktorus, kas traucē jauniešiem bezdarbniekiem iekļauties darba tirgū, darba autore uzskata, ka ir jāņem vērā NVA programmās iekḷauto jauniešu vecuma posmu, darba ietvaros aptaujājot jauniešus vecumā no 17 līdz 29 gadiem. Darba analītiskās nodaļas pētījuma veikšanai autore izmantos ES plānošanas dokumentos minēto jauniešu vecuma posmu (15-30 gadi), lai statistiskos rādītājus būtu iespējams salīdzināt ar citām valstīm.

Darba autore atzīmēe, ka ārvalstīs jaunietis, kā redzams arī pēc ES programmām, ir uzskatāms arī vecuma posmā no 25 līdz 30 gadiem. Daļa šo jauniešu studē augstākajās mācību iestādēs, kā arī akadēmiski un profesionāli pilnveido savas zināšanas. Pretēja situācija ir Latvijā un arī citās Austrumeiropas valstīs, kad jaunieši studē un paralēli strādā, lai spētu segt studiju maksu, nodrošināt iztiku utt.

Darba autore secina, ka iepriekšminētajā literatūrā nav vienota jauniešu vecuma posma definējuma.

„Jaunatnes politikas pamatnostādnēs 2009.- 2018. gadam” par jaunieti tiek uzskatīts indivīds, kas atrodas pārejas posmā no bērna uz pieaugušā statusu (atbildības pastiprināšanās un patstāvīgas dzīves uzsākšana, gimenes veidošana utt.) (Jaunatnes politikas pamatnostādnes..., 2009), konkrēti nedefinējot vecuma posmu.

Arī autors Kīps (Keep) uzsver, ka jauniešu pāreja no mācībām uz naudas peln̄̄̌sanu kḷūst arvien problemātiskāka (Keep, 2012). Aizvien dažādāki jaunieši (arī tādi, kam ir bijušas labas sekmes) neiegūst izglītību vai apmācību un nav nodarbināti, 
darba piedāvājums ir mazāks, t. sk. „kārtīga” darba piedāvājums (pretstatā nekvalificētam pagaidu darbam), un jauniešu prasmes starp darba devējiem nav pārāk pieprasītas. Jauniešu īpatsvars no visiem iedzīvotājiem samazinās, un karjeras maina kḷūst aizvien sadrumstalotāka un ilgāka (Global Trends for..., 2010). Šì problēma ir saistīta ne tikai ar ekonomisko lejupslīdi, vāju ekonomiku un demogrāfiskā stāvokḷa izmain̄ām, bet arī ar strukturālajām problēmām (Hjūza, Borbējs- Pece, 2012).

Augsts jauniešu bezdarba līmenis rada arī lielākas sociālās un ekonomiskās izmaksas valstij (Lee et. al., 2012) .

Autori, Klarks (Clark) un Sammers (Summers) savā klasiskajā pētījumā par jauniešu bezdarba dinamiku 1982. gadā norāda, ka jauniešu bezdarba problēma rodas no darbavietu trūkuma. Kopējais pieprasījums rada spēcīgu ietekmi uz darba iespējām un darba tirgus pieredzi (Clark, Summers, 1982).

Jauniešu bezdarbs ir viena no aktuālākajām problēmām valstīs, kur kopš 2008. gada darba tirgus ievērojami novājinājās. Šîs attīstības tendences tiek dēvētās par „deja vu” elementu: jo, kā jau minēts iepriekš, jauniešu bezdarbs pirmoreiz kḷuva par nopietnu problēmu rūpnieciski attīstītajās valstīs laikā no 1980. gada. Darba tirgi strauji attīstìjās agrīnajā šì gadsimta dạ̦ā, bet jauniešu bezdarbs jau tad bija aktuāla problēma. Jauniešu bezdarba pašreizējā aktualizācija ir atkal veicinājusi valstu politiku koncentrāciju uz šo jautājumu (Bell, Blanchflower, 2009).

Arulampalams (Arulampalam) uzsvēris bezdarba nozīmīgo negatīvo ietekmi uz darba dz̄ives sākumposmu un turpmākām indivīda darba iespējām.

tirgū:

Autors noteicis negatīvos aspektus, kas var ietekmēt iespējas ieklauties darba

- netiek dota iespēja uzkrāt darba pieredzi;

- tiek veicināta vispārējo prasmju pasliktināšanās;

- iespējama negatīva ietekme uz pel̦nas iespējām nākotnē;

- traucēta pāreja no bezdarba uz nodarbinātību;

- sociālie zaudējumi no bezdarba (Arulampalam, 2001).

Jauniešu bezdarba cēloņi visbiežāk iedalīti šādās grupās:

- ekonomiskie un politiskie apstākḷi (valsts, sabiedrības radīti, darba tirgus un nodarbinātības politika u.c.);

- sociālie apstākḷi (zemas sociālās prasmes, jaunie vecāki u.c.);

- izglīīibas problēmas (zema kvalifikācija, nav izglītības);

- kultūru atšksirības (nacionālās vai etniskās minoritātes);

- veselības problēmas (hroniskas vai garīga rakstura veselības problēmas, invaliditāte);

- ekonomiskie šksēršşi, ǵeogrāfiskie apstākḷi (jaunieši lauku teritorijās, transporta nepieejamība u.c.) (Pīgozne, 2014, Dietrich, 2012).

Darba turpinājumā analizēts pētnieku viedoklis par bezdarba cēloņiem un pētījumos iegūtajiem rezultātiem un to kopsakarībām.

Valsts, sabiedrības un kultūras ietekme uz bezdarbu. 1936. gadā Latvijas Universitātes profesors Pauls Jurevičs rakstīja, ka kulturāla tauta nozīmē - labi audzināta tauta, kas izkopusi gan sevi, gan savu dzīvi. Audzināšanas viena no nozīmīgākajām funkcijām vienmēr bijusi - audzināt kulturālu cilvēku, kurš, apguvis kultūras pieredzi, var to saglabāt, attīstìt un nodot nākamajām paaudzēm. Ar kultūras cilvēka audzināšanu vienmēr mijsakarībā ir cilvēka tapšana par personību, kurš apzinās savu "Es" un kuram ir pašcieņas un pašvērtības attieksme pret sevi un citiem cilvēkiem (Špona, 2004, 6). 
Atzīstot cilvēku par augstāko vērtîbu, viņa pienākumus un tiesības uz darbu un izglītību, uz brīvību un laimi, viņa spēju un individualitātes attīstību, vienlaikus nepieciešama humāna izglītības un audzināšanas sistēma valstī (Špona, 2004).

Dinamiskā, nepārtrauktā sabiedrības attīstība izvirza uzdevumus jau arī pirmsskolas izglīîibas institūcijām adekvāti reaǵêt uz sociālajām un kultūras novitātēm, patstāvīgi pilnveidojoties un cenšoties mācību procesu pielāgot jauninājumiem, lai indivīds veiksmīgi spētu iekḷauties sabiedrībā (Špona, 2004).

Demogrāfiskās situācijas kopsakarība ar darba tirgu. Demogrāfiskā situācija, kurai raksturīga nepietiekama paaudžu nomaiņa, ir būtisks drauds ilgtspējīgai tautsaimniecības attīstībai valstī. Jauniešu veselības stāvoklis un negatīvie veselības paradumi var kavēt demogrāfiskās situācijas uzlabošanos nepieciešamajā līmen̄i, kā arī negatīvi ietekmēt mirstības rādītājus. Tas var būt nozīmīgs šķēerslis valsts tautsaimniecības izaugsmē, tostarp kopējā izglītības līmeņa paaugstināšanā un ar to saistītās materiālās labklājīibas pieaugumā un nodarbinātības jautājumu risināšanā. Jauniešu veselību raksturojošie subjektīvie un objektīvie veselības rādītāji apliecina, ka nopietni jāpievēršas jauniešu veselības uzlabošanas pasākumiem. Nelabvēlīgo demogrāfisko situāciju varētu uzlabot aktīvāka valsts politika jauniešu veselības saglabāšanā, veselīga dzīvesveida popularizēšanā un dz̄ives kvalitātes izaugsmē (Villeruša, Gobina, 2007).

Pieredzes un prasmju ietekme uz rezultātiem darba tirgū. Jauniešu pieredzes analizēšanai darba tirgū un tās ietekmei uz bezdarbu pievērsušies tādi autori kā Martins (Martin), Balans (Balan), Lī (Lee), Sisons (Sissons), Bertelots (Berthelot) u.c. Jaunieši, kas meklē savu pirmo darbu, tostarp studenti, saskaras ar daudz vairāk problēmām, nekā bezdarbnieki (Berthelot, 1995).

Autors Martins (Martin) uzsver, ka lielākajai daļai jauniešu nav uzkrāta darba pieredze darba un nav definēts skaidrs priekšstats par to, kāda veida darbu veikt un uz kādu ienākumu līmeni vajadzētu tiekties. Jauniešiem ir mazāk iztikas līdzekḷu nekā gados vecākiem darba ñēmējiem. Daudzās valstīs ir tendence, ka finanšu drošību pilnībā sniedz gimene, kas nozīmē to, ka šie jaunieši ir mazāk mobili darba tirgū (Martin, 2009).

Autori, Fadingers (Fadinger) un Mairs (Mayr), izveidojuši simulācijas model̦us algu, nodarbinātības līmeņa un emigrācijas rādītāju aprēķiniem, lai pierādītu, ka prasmju pieaugumam ir potenciāli liela ietekme uz rezultātiem darba tirgū (piemēram, darba produktivitāti, algu utt.) (Fadinger et al., 2014).

Autori, Lī (Lee), Sisons (Sissons), Balarms (Balarm), Džons (Jones) un Komineti (Cominetti) uzsver, ka, neatkarīgi no ekonomiskajiem apstākḷiem, jauniešu bezdarba līmenis parasti ir augstāks nekā pieaugušo bezdarba līmenis, jo jaunieši saskaras ar augstākiem bezdarba rādītājiem periodā, kad norisinās jauniešu pāreja no vienas darba vietas uz otru, pirms ir atrasts stabils karjeras ceḷš. Tiek uzskatīts, ka jaunieši biežāk zaudē darbu, un, otrkārt, jauniešiem nākas saskarties ar sīvāku konkurenci (Lee, et al., 2012).

Saskaņā ar OECD, jauniešiem ir jānodrošina piekl̦uve prasmēm un instrumentiem, kas veicinātu darba atrašanu. Šāda iespēja ne tikai uzlabo jaunieša izredzes un iespējas, bet arī veicina valsts ekonomisko izaugsmi, sociālo kohēziju un labklājību. Tieši tāpēc ieguldījumiem jaunatnē ir jābūt politikas prioritātei visā pasaulē (OECD Work on..., 2012).

Saskaņā ar OECD (2010) 2008. un 2009. gados plaši diskutēja, ka mazkvalificēti jaunieši saskaras ar ievērojamām problēmām darba tirgū. Mazkvalificēti jauniešu (vecumā no 15/16 līdz 24 gadiem) bija trīs reizes vairāk bez darba nekā augsti kvalificēti jaunieši. Aptuveni katrs desmitais jaunietis tika uzskatīts par tādu, kas 
nemācās un veic mazkvalificētu darbu ar iegūtu zemu kvalifikāciju vai bez kvalifikācijas (OECD, 2010).

Jaunieši vecumā no 15 līdz 24 gadiem ir viena no sociālā ziṇā neaizsargātākajām grupām. Beidzot vidusskolu, jaunietim nav nedz profesionālās izglīiības, nedz darba pieredzes, kā rezultātā viņa izredzes veiksmīgi konkurēt darba tirgū ir samērā niecīgas. Tādēl bezdarbs ir viena no nopietnākajām problēmām, ar kuru jaunietim jāsastopas, ienākot pieaugušo dzīvēe (Koroḷeva u.c., 1999).

Izglītības līmena ietekme uz rezultātiem darba tirgū. Izglītības līmeņa ietekmes un nodarbinātības kopsakarības pētījuši tādi autori kā Biavaši (Biavaschi), Eihorsts (Eichhorst), Džiuleti (Giulietti), Kendzia (Kendzia) u.c. Pārejā no izglītības iestādes uz nodarbinātību jāņem vērā, pirmkārt, demogrāfiskās tendences un ekonomikas izaugsme, un, otrkārt, mijiedarbība starp šo dinamiku un ilgtermiņa institucionālajiem model̦iem, jo īpaši normatīvajiem aktiem, kas ietekmē elastīgu vai pastāvīgu darba vietu radīšanu. Nozīmīga ir arī izglītības un apmācības politika. Gan vispārējās izglītības skolās, gan arī dažāda veida profesionālās izglītības iestādēs, ir nepieciešami priekšnoteikumi, lai veicinātu jauniešu nodarbinātību un produktivitāti (Biavaschi et al., 2013).

İpaši zemi izglītoti jaunieši saskaras ar problēmu atrast pirmo darbu, kas var radīt negatīvas ilgtermiņa sekas attiecībā uz viņu karjeras iespējām (Markso et al., 2011).

Darba devēji labprātāk izvēlas pieņemt darbā indivīdus ar lielāku pieredzi, jo ir jāpatērē mazāki līdzekḷi šāda darbinieka apmācībai.

Analizējot un salīdzinot maksas un budžeta studiju augstskolu absolventus, Latvijas Universaitātes pētījumā „Augstāko un profesionālo mācību iestāžu absolventu profesionālā darbība pēc mācību beigšanas" konstatēts, ka studenti, kas maksā par studijām, jau studiju laikā iekḷaujas darba tirgū būtiski biežāk nekā studenti, kuru izglìtību finansē valsts. Nozīmīgas atšķirības starp maksas un budžeta studentu nodarbinātību ir pierādītas tādās studiju tematiskajās grupās, kā pedagogu izglìtība un izglīî̄bas zinātnes, pakalpojumi, komerczinības un administrēšana, tiesību zinātnes, ražošana un pārstrāde. Savukārt, salīdzinot studiju laikā nestrādājošo absolventu darba gaitas, konstatēts, ka tie augstskolu absolventi, kas zināšanas apguvuši par valsts budžeta līdzekḷiem, pēc studiju beigšanas ātrāk atrod darbu nekā tie, kas studējuši par maksu. Tā kā maksas studenti lielākoties iesaistās darba tirgū jau studiju laikā, iespējams, ka tiem maksas studentiem, kas nopietnus darba meklējumus nav uzsākuši līdz studiju beigšanai, ir zemāka motivācija vispār meklēt darbu. Turklāt studijas par budžeta līdzekḷiem (neatkarīgi no studiju jomas), iespējams, liecina par labākām spējām un sekmēm mācībās, kas veicina konkurētspēju darba tirgū. Profesionālās izglītības iestāžu absolventi, kas studijas apguvuši par maksu, pelna vairāk nekā tie, kas mācījušies par budžeta līdzekḷiem. Iespējams, tas izskaidrojams ar to, ka maksas programmas tiek piedāvātas darba tirgū augstāk novērtētās profesijās (Augstāko un profesionālo..., 2007).

Būtiska ir arī cilvēkkapitāla dimensija - vecāku izglītības līmenis ir faktors, kas ietekmē darbā iekārtošanās iespējas un ātrumu. Profesionālo mācību iestāžu absolventi, kuru vecākiem ir pamata vai zemākā izglītība, darbu meklē un darbā iekārtojas vēlāk nekā absolventi, kuru vecākiem ir augstāks izglītības līmenis. Savukārt, veiksmīgāk un visātrāk darbu atrod absolventi, kuru vecākiem ir augstākā profesionālā izglīīiba. (Augstāko un profesionālo..., 2007).

Konstatēts, ka arī Latvijā studiju valoda ietekmē augstskolu absolventu profesionālo darbību. Tie absolventi, kas mācījušies krievu valodā, biežāk izvēlas strādāt izglītībai neatbilstoši un pelna mazāk nekā tie, kas studējuši latviešu valodā. Visaugstākās algas caurmērā ir tiem absolventiem, kas studējuši anglu valodā, jo angḷu valodā pārsvarā tiek īstenotas prestižas studiju programmas (piemēram, Rīgas 
Ekonomikas augstskolas programmas, Latvijas Universitātes Ekonomikas un vadības fakultātes studiju programmas u.c.), un to absolventiem ir augstāka konkurētspēja arī Latvijas darba tirgū (Augstāko un profesionālo..., 2007).

Izglīīibas ietekmes nozīmība uz nodarbinātību uzsvērta arī ES pētījumos. Pēc ES struktūrfondu nacionālās programmas „Darba tirgus pētījumi” projekta „Labklājības ministrijas pētījumi” tika izstrādāts pētîjums „Augstāko un profesionālo mācību iestāžu absolventu profesionālā darbība pēc mācību beigšanas", kurā noskaidrots, ka izglītības līmenis statistiski nozīmīgi ietekmē ieklaušanos darba tirgū jau studiju laikā - jo augstākā izglītîbas līmen̄̄ notiek studijas, jo biežāk studenti patstāvīgi strādā jau studiju laikā. Š $\overline{1}$ tendence vērojama gan augstskolu, gan profesionālo mācību iestāžu studentu vidū. Jo augstāku izglītības līmeni indivīds sasniedzis, jo lielāka iespēja, ka viņš strādās atbilstoši iegūtajai izglītībai (Augstāko un profesionālo..., 2007).

„No skolas uz darbu” pārejas ilgums pieaug - uzliekot lielākus finansiālos atbalsta slogus valsts institūcijām un gimenes locekļiem. Veidojas arī lielāks parādsaistību slogs jauniešiem, uzņemoties studiju kredītu saistības.

Motivācija strādāt profesijā atbilstoši iegūtajai izglītībai. Izvēle strādāt vai nestrādāt atbilstoši mācību iestādē iegūtajai izglītībai lielā mērā ir atkarīga no paša absolventa motivācijas to darīt, kas savukārt saistîta gan ar studiju programmas izvēli atbilstoši interesēm, gan studiju laikā gūtajām prasmēm un citiem subjektīvi vērtējamiem faktoriem. Svarīgs aspekts, kas nosaka, vai absolvents pēc izglītības iestādes beigšanas strādās atbilstoši iegūtajai izglītībai, ir iepriekšējā darba pieredze vai izglītība šajā jomā, kā arī iegūto praktisko un teorētisko zināšanu līmenis konkrētajā jomā. Absolventiem, kuriem šādu priekšrocību nav, darbu, kas atbilst iegūtajai izglītībai, atrast ir grūtāk. Tie, kas strādā atbilstoši iegūtajai izglīî̀bai, augstāk novērtē mācību iestādē gūto zināšanu un prasmju līmeni, kā arī to izmantošanas iespēju pašreizējā darbā. Tas norāda, ka gan profesionālajām izglīî̄bas iestādēm, gan augstskolām nepieciešams veidot ciešāku sadarbību ar darba devējiem, koriǵējot izglītības sistēmas piedāvājumu un organizējot prakses, lai tiem audzēkņiem un studentiem, kam nav darba pieredzes, veidotos atbilstošs priekšstats un zināšanas par profesiju vai specialitāti (Augstāko un profesionālo..., 2007).

Bezdarba ietekme uz atalgojuma līmeni. Elvuds (Ellwood) pētīja indivīda neatlaidību un ilgtermiņa ietekmi uz agrīno darbaspēka pieredzi. Ziņojumā autors secinājis, ka laika posmā, kad jaunietis ir bez darba, vēlāk atrodot darbu, sekas, kuras tiek radītas bezdarba periodā, vēl nebeidzas. Jaunietis, kurš pavada bez darba vienu gadu, iespējams, ka pavadīs mazāku laika periodu, veicot darba pienākumus, nekā tad, ja viņš būtu strādājis visu gadu. Turklāt, autors secināja, ka zaudētā darba pieredze veicina ievērojami zemāku algu līmeni (Ellwood, 1982).

Autors Balans (Balan) uzsvēris, ka bezdarbs jauniešu vidū rada ilgtermiņa ietekmi gan uz ienākumiem, gan uz stabilitāti darbā, jo jauniešiem, kurus skar bezdarbs, ir zemāks uzticamības līmenis un nav tik elastīgas nodarbinātības iespējas. Tādējādi rodas vairāk grūtību no profesionālās puses (Balan, 2014b).

Arī autori Mrozs (Mroz) un Savidžs (Savage), analizējuši ilgtermiņa ietekmi uz jauniešu bezdarbu, uz to vēlākiem darba tirgus rezultātiem. Piespiedu bezdarbs īstermiņā var veicināt neoptimālas investīcijas cilvēkkapitālā kā arī nākotnes finansiālo nestabilitāti (Mroz, Savage, 2006).

Bezdarba pabalstu ietekme uz bezdarbu. Autori Kalmfors (Calmfors) un Holmlunds (Holmlund) pētījuši bezdarba saistību ar bezdarba pabalstu apjomu. Autori uzsver, ka zemāks pabalsta līmenis un īsāks bezdarba apdrošināšanas periods samazina bezdarbu, bet lielāki bezdarbnieku pabalsti un bezdarba apdrošināšanas pabalsti palielina bezdarbu (Vodopivec, 2004). 
Apkopojot autoru apgalvojumus, autore secina, ka jauniešiem pārejas procesā no izglītības iestādes uz nodarbinātību, galvenokārt jārēksinās ar darba devēja vajadzībām, līdz ar to būtiska ir jaunieša iepriekšējā apmācības sistēmas politika un tās efektivitāte, kā arī jaunieša kompetences un prasmes, kas iegūtas studiju laikā. Nozīmīgu lomu jaunieša nākotnes attīstībā ieņem no indivīda neatkarīgi spēki, kā ekonomikas izaugsme, demogrāfijas tendences, politikas un tiesiskā regulējuma ietekme uz indivīda socializāciju darba tirgū. Nozīmīgi ir pietuvināt jauniešu apmācības procesu darba tirgus prasībām, kas nodrošinātu jaunietim iespēju nokḷūt ilgtspējīgākā darba vietā.

\section{Darba meklēšanas metodes dažădu autoru pētījumos, kas veicina jaunieša darba atrašanu:}

1) gimenes un paziņu atbalsts darba meklējumos. Tādu autoru, kā Holzera (Holzer), Bormana (Borman), Pavis (Pavis), Džona (Jones), pētījumi par darba meklēšanas metodēm liecina, ka neformālie tīkli, ko veido gimene un draugi, ir visefektīvākais darba meklēšanas palīglīdzeklis tieši jauniešu vidū, kas ir darba mērķa vecuma grupa. Autoru sociologiskie pêtījumi par iekļaušanos darba tirgū un jauniešu pāreju pieaugušas personas statusā ietekmē gimenes atbalsts, jo īpaši bezdarba situācijās. Jauniešu bezdarbs ietekmē jaunieša nākotni un palielina varbūtību, ka nākotnē būs lielāka iespēja kḷūt par bezdarbnieku, kā arī problemātiskāk integrēties darba tirgū un saņemt pietiekami augstu atalgojumu;

2) pašnodarbinātības vai uzņēmējdarbības uzsākšana. Tradicionālie karjeras cel̦i mainījušies, jaunatnes uzņēmējdarbība tiek uzskatīta par papildu veidu, kā integrēt jauniešus darba tirgū un pārvarēt nabadzību. Atbalstot šo tendenci politikā, pēdējo desmit gadu laikā visvairāk oficiāla nodarbinātība ir tikusi izveidota mazos uzñēmumos vai indivīds kḷuvis par pašnodarbinātu personu (Mayoux, 2001).

Autors Čigunta (Chigunta) uzsvēris vairākus iemeslus, kādēḷ ir svarīgi veicināt jaunatnes uzn̄ēmējdarbību:

- tiek radīta iespēja sevi pašnodarbināt, kā arī nodarbināt citus jauniešus;

- jaunieši nokḷūst ekonomiskajā apritē un veicina piederības sajūtu sabiedrībai;

- novērš dažādas sociāli psiholoǵiskas problēmas un likumpārkāpumus, kas izriet no bezdarba;

- iespēja jaunietim attīstīt jaunas prasmes un iegūt pieredzi;

- veicinot uzṇēmējdarbību, tiek veicināta vietējā reǵiona attīstība (Stimulating Youth Entrepreneurship..., 2006).

Uzņēmējdarbība un pašnodarbinātība ir kā jaunu darbavietu avots un ekonomiskās dinamikas virzītājspēks attīstītajās valstīs, kā arī uzlabo jauniešu dzīves apstākḷus un ekonomisko neatkarību jaunattīstības valstīs (Stimulating Youth Entrepreneurship..., 2006);

3) iesaiste jauniešu bezdarba atbalsta programmās. Apmācības mazkvalificētiem bezdarbniekiem sniedz iespēju sasniegt veiksmīgus darba rezultātus. Svarīgi, lai bezdarba atbalsta programmas būtu ne tikai profesionāli orientētas uz pašu indivīdu, bet arī uz vietējā darba tirgus vajadzībām. Ne vienmēr bezdarbā esošas personas iesaiste apmācībās veicina bezdarbnieka iekḷaušanos darba tirgū, ja pieprasījums pēc konkrētās nozares darbaspēka ir zemāks par piedāvājumu.

Autori De Konings (De Koning) un Klīvs (Kluve) savos pētījumos analizēja bezdarba programmu efektivitāti. De Konings izveidojis visaptverošu pārskatu par aktīvām darba tirgus programmām, ietverot 130 pētījumus dažādās valstīs, kuros lielākā dą̧a no mācību programmām ir paredzētas jauniem cilvēkiem. Autori atzīmē, ka ir vairāki pētījumi saistībā ar apmācību programmām, kas norāda uz programmu pozitīvo ietekmi uz jaunieša nākotni, tomēr tikpat liels īpatsvars ir pētījumu ar 
programmu negatīvo ietekmi, līdz ar to spriest par programmu efektivitāti ir neadekvāti (De Koning, 2005).

Saskaņā ar autoru Klīivu, kas veicis pētījumu par jauniešu programmu efektīgumu, no 70 mācību programmām - 38 ir pozitīva ietekme, bet 32 ir nulle vai negatīva ietekme. Viņš secina, ka mācību programmām ir salīdzinoši maza ietekme, labākajā gadījumā tām ir būtiska ietekme uz nodarbinātību tikai ilgākā laika posmā. Mācību periodi mēdz būt salīdzinoši ilglaicīgi (parasti no četriem līdz sešiem mēnešiem), un šajā laikā dalībniekiem ir mazākas iespējas meklēt darbu vai savienot dalību programmā ar darbu. Šie riski tiek aprakstîti daudzos pētījumos, un bieži noved pie negatīvām sekām - apmācībām īstermiņā. Lielā mērā tas ir neizbēgami, jo nav skaidrs, cik lielā mērā šie efekti ietekmē darba meklēšanas procesu (Kluve, 2006).

Pasaules Bankas attīstības ziņojumā 2013. gadā uzsvērts, kādi apstākḷi veicinātu jauniešu nodarbinātību vienā darba vietā un nenokḷūšanu bezdarbnieka statusā. Ziņojumā minēts, ka labs darbs jaunietim ir darbs, kas nodrošina ieguldījumu ilgtermiṇā, nodrošinot darba vietu ilgākam laika periodam. Lai nodrošinātu samērīga līmeña izglītību un veicinātu ekonomisko produktivitāti, izmantojamas divas pieejas:

- lai spētu nodrošināt akadēmiskās izglītības ieguvi, pietuvinātu privātā sektora vajadzībām, akadēmisko mācību process jāorientē uz darba tirgu, nodrošinot prakses iespējas pie darba devējiem mācību programmas ietvaros, iegūstot zināmu darba praksi. Valdībai ir jābūt atbildīgai par finansējuma piesaisti akadēmiskajai izglītībai un to sekmīgai programmu realizēšanai.

- jāveicina nodarbinātība, iesaistot jauniešus ES projektos, stimulējot ilgtspējīgu un formālu darba vietu radīšanu. Valstīs, kurās ir augsta neoficiālā nodarbinātība, veidojas šķēršļi augšupejošai mobilitātei un ekonomiskās politikas attīstībai. Ekonomiskā progresa politiku būtu jāveido tā, lai radītu vairāk uzṇēmumus formālajā sektorā, kas piedāvā oficiālas darba vietas. To var atrisināt ar ekonomikas politikas reformām, piemēram, birokrātisku uzñēmējdarbības reǵistrācijas procedūru atcelšana, nodokḷu reformas, veicinot investīciju piesaisti privātajā sektorā un radīt formālu starta uzņēmumu (start up) atbalsta sistēmu. Atsevišķās valstīs tiek bieži izmantota arī sistēma ar darba līgumu noslēgšanu uz noteiktu laiku, kas nodrošina piekl̦uvi darba tirgum un veicina stabilākas darba vietas atrašanas iespējamību. Vislabāk šo sistēmu var uzturēt, nodrošinot darba aizsardzības barjeras starp noteikta laika darbu un patstāvīgu darba vietu (The World Development Report..., 2013).

Iepriekš apskatīto autoru darbos uzsvērta būtiskā sakarība starp bezdarbu un izglītību, kas veicina nākotnes potenciālās iespējas iekļauties darba tirgū, jo zems izglīî̄bas līmenis veicina iespējamību nākotnē sastapties ar sociālo atstumtību no sabiedrības un iekḷaušanās problēmām darba tirgū.

\subsection{Bezdarbs reǵionālā kontekstā/ Unemployment in the regional context}

Vārds „reǵions” ir radies no latīṇu valodas (regio) un nozīmē ,apgabals, novads”. Reǵiona jēdziena izpratne var un mēdz būt ļoti plaša, tā var mainīties atkarībā no sabiedrības priekšstatiem (Goodall, 1987). Regions pēc kādām izvēlētām pazīmēm ir raksturojams kā iekšēji viendabīga telpa. Reǵionus mēdz uzlūkot kā lielas ǵeogrāfiskas telpas daļas, kuras tiek raksturotas ar iekšēju viendabību gan dabas apstākļu nosacījumos, gan galvenokārt kultūras, saimnieciskajos un politiskajos procesos. Regions ir liels ǵeogrāfisks apgabals, kuru var izdalīt no apkārtējiem apgabaliem pēc dažādām funkcionālajām pazīmēm (Amantova - Salmane, 2011). 
Brīvā tirgus ekonomika bez palīdzības no „ārpuses” nespēj būtiski samazināt reǵionālās sociāli ekonomiskās atšķirības. Tāpēc nepieciešams valsts un arī starptautisko institūciju atbalsts sociāli ekonomiskās attīstības zin̄ā atpalikušām teritorijām. Visas valsts politika izpaužas telpiski, tai ir telpiska ietekme. Valsts politiku var skatît divējādi - pirmkārt, kā vispārēju valsts politiku, kurai ir tūlītēja un nozīmīga teritoriāla ietekme (nodarbinātības, mājokḷu u.c. politika), un, otrkārt, kā reǵionālu politiku, kuras galvenais saturs ir teritorija un teritoriālā attīstība. Ar attīstību tiek saprasta sabiedrībai labvēlīga dabas, vides, kultūrvides, sociālās vides un saimnieciskās darbības pārmaiņu procesa virzība. Reǵionālā politika ir saskaņotu un organizētu pasākumu kopums attīstības nodrošināšanai visā valsts teritorijā. Reǵionālā ekonomiskā politika vai reǵionālā plānošana iekl̦auj visas publiskās intervences formas, kas domātas ekonomisko aktivitāšu ǵeogrāfiskai izvietošanai. Reǵionālā politika mēgina koriǵêt brīvā tirgus ekonomiku, lai sasniegtu divus savstarpēji saistītus mērķus: ekonomisko izaugsmi un sociālās sadales uzlabošanu (Vaidere u.c., 2006).

Autori Ārmstrongs (Armstrong) un Teilors (Taylor) aprakstījuši reǵionālās politikas klasifikāciju, kas sastāv no reǵionālas makro un mikro politikas.

Regionāla makropolitika ietver:

- dažādus reǵionāli diferencējošus pasākumus un līdzekḷus nodokḷu politikas ietvaros, kā arī ieņēmumu politiku;

- reǵionāli diferencējošus monetārās politikas pasākumus un līdzekḷus, piemēram, kredītu atvieglojumu piešķiršanu depresīvajos reǵionos;

- reǵionāli diferencējošus pasākumus un līdzekḷus ārējās tirdzniecības jomā, piemēram, ierobežojumus atseviškşu preču grupu ievešanai valstī, ja šīs preces ražo attiecīgās valsts depresīvais reǵions.

Reǵionāla mikropolitika ir politika, kas saistīta ar izmaiņām darbaspēka un kapitāla telpiskajā izvietošanā - darba resursu pārvietošanas shēmas, migrācijas plūsmu regulēšana, migrācijas subsīdijas un kredīti, palīdzība migrantiem ar mājokḷiem, izglītības programmas, personāla sagatavošana un kvalifikācijas paaugstināšana, investīciju stimulēšana u.c. koordinācijas mehānismiem, kas nodrošina efektīvu mijiedarbību starp reǵionālo mikropolitiku un makropolitiku, kā arī koordinē reǵionālo politiku, ko veic dažādos varas un pārvaldes līmeņos, t.i., ES, nacionālajās, reǵionālajās un vietējās varas un pārvaldes institūcijās (Armstrong, Taylor, 1985).

Apvienotajai Karalistei ir salīdzinoši senas reǵionālās politikas īstenošanas tradīcijas. Apvienotā Karaliste bija pirmā valsts Eiropā, kurā valdība jau 20. gadsimta 20. gadu beigās un 30. gados veltīja īpašu uzmanību ,iznīkušajiem” rūpniecības rajoniem. Šajā laikā bezdarba līmenis Skotijā un Velsā pārsniedza 30\%, un visos pārējos regionos tas bija virs 20\%, izṇemot Dienvidangliju (Button, Pentecost, 1999). Bezdarba līmeņa atšķirībām starp dažādām teritorijām bija tendence palielināties. 1928. gadā valdība pieñēma lēmumu par Rūpniecības pārvietošanas pārvaldes izveidošanu ar mērķi veicināt strādnieku pārvietošanu no teritorijām, kurās darbu atrast vairs nebija iespējams, uz citām teritorijām, kurās bezdarba problēma nebija tik izteikta. Bezdarbnieku pārvietošana vēl negarantēja, ka darba meklētājs dabūs darbu jaunajā dzīvesvietā. Tādēl šādu risku uzṇēmās un pārvietošanai piekrita pārsvarā jauni, uzņēmīgi un izglītoti cilvēki. Tieši ar šiem cilvēkiem saistījās cerības par ekonomiskā stāvokḷa stabilizāciju problēmreǵionos, kuros viṇi iepriekš dzīvoja. Tādēḷ šo strādnieku pārvietošanas pieredzi nevar nosaukt par sekmīgu (Fatejevs, 2004).

Arī autors Martins (Martin, 1997) uzsvēris, ka bezdarba atšķirības reǵionālā kontekstā ir vēsturiski visizteiktākās Apvienotajā Karalistē un ir bijušas politisko debašu uzmanības centrā vairāku gadu garumā (Martin, 1997). 
Pētnieki Korliss (Corliss) un Levis (Lewis) pētîjumos uzsvēruši reǵionālo bezdarba atšksirību nozīmību reǵionālā skatījumā, uzsverot to, ka ES valstīs reǵionālās atšķirības ir noturīgākas kā ASV (Organisation for Economic..., 1989).

Autori Krūgmans (Krugman), Frīmans (Freeman), Bertola (Bertola) un Ičino (Ichino) skaidrojuši reǵionālās atšķirības ar darba tirgus elastības pamatelementiem, salīdzinot ES un ASV. Autori uzsvēruši, ka reǵionālās atškşirības starp reǵioniem ASV mazinās darbaspēka migrācijas ietekmē un algu korekcijās, uzsverot, ka ES algu korekcija un migrācija starp reǵioniem nav tik efektīva (Krugman, 1993; Freeman, 1995; Bertola, Ichino, 1996).

Savukārt, Makklure (McClure) 2000. gadā veidojis ziņojumu par Austrālijas labklājības sistēmu, pievēršot īpašu uzmanību faktoru analīzei, kas veido pieprasījumu un piedāvājumu. Makklure uzsvēris, ka nodarbinātības pieaugums dažādās jomās nav vienmērīgi izplatīts visos reǵionos, augsts bezdarba līmenis turpināja saglabāties dažādos Austrālijas reǵionos (McClure, 2000). Tas liecina, ka teritorija, kurā indivīds strādā un dz̄̄vo ir nozīmīgs faktors, kas nosaka nodarbinātības iespējas.

Jau kopš 1990. gada Austrālijā dažādos pētījumos tika uzsvērts reǵionālo atšķirību nozīmīgums, analizējot bezdarba un nodarbinātības pieauguma tempu (Impact of Competition..., 1999; O’Connor et al., 2001; Ramakrishnan, Cerisola, 2004).

Levis (Lewis), Mitčels (Mitchell) un Karlsons (Carlson) savos pētījumos uzsvēruši Austrālijas ekonomikas pārmaiṇas globalizācijas un tehnoloǵisko procesu ietekmēe, kas palielināja pieprasījumu pēc kvalificētiem darbiniekiem un samazināja pieprasījumu pēc mazāk kvalificētiem darbiniekiem, kas izraisīja lielāku nevienlīdzību Austrālijas darba tirgū starp kvalificētiem un nekvalificētiem darba ņēmējiem. Pētījumos tika uzsvērts, ka teritorijās ārpus lielpilsētām netiek gūts labums no izmaiñām rūpniecības sektorā, kas saasina reǵionālās atšksirības nodarbinātības iespēju kontekstā (Lewis, 2008; Mitchell, Carlson, 2005).

Autori Garnets (Garnett) un Levis (Lewis) vēsturiski analizējot metodologiju reǵionālā kontekstā uzsvēruši, ka nepastāv viena reǵionālās klasifikācijas metode. Autori uzsvēra, ka jebkura metode būtu jāizmanto kā viendabīgs grupējums, sagrupējot faktorus, balstoties uz līdzīgām īpašībām. Š̄is faktoru pazīmes var izdalīt no disciplīnām, piemēram, ekonomiskie, geogrāfiskie, sociālie un kultūras faktori. Ir svarīgi, ka faktoru grupējums ir definēts tā, lai sasniegtu pētījuma izvirzīto mērķi būt nozīmīgi mērķi pētījuma (Garnet, Lewis, 2000; Garnet, Lewis, 2007). Austrālijas piemērā, reǵionālās klasifikācijas sistēma ietver divus klasifikācijas veidus, kam par iemeslu ir tas, ka citi lielpilsētu reǵioni bieži tiek iekḷauti lauku klasifikācijā, tomēr šie reǵioni pēc faktoriem ir vairāk kopīgi ar reǵionu pilsētām. Šī metode atdala piekrastes reǵionus no citiem reǵioniem, kas ir svarīgi saistībā ar straujo iedzīvotāju izaugsmi piekrastes rajonos. Austrālijas Lauksaimniecības un ekonomikas resursu pārvalde (Australian Bureau of Agriculture and Resource Economics, ABARE) (2001) klasifikācijas sistēmā atdala attālos reǵionus no lauku reǵioniem. Tas ir svarīgi, jo daudzi no attālajiem reǵioniem ir ar ļoti dažādām iezīmēm rūpniecības sektorā un darba tirgū, salīdzinot ar lauku teritorijām. Piemēram, attālajos reǵionos bieži ir ieguves nevis lauksaimniecības bāzes, kā arī plašas teritorijas ar lielu iedzīvotāju skaitu un savām darba tirgus īpatnībām (Garnett, Lewis, 2007). Tāpēc šì reǵionālā klasifikācijas sistēma ir daudz efektīvāka nekā citas reg̣ionālās klasifikācijas sistēmas citos reǵionos, kas parasti ir līdzīgas pieredzē un īpašībās vairākās kategorijās. Austrālijas piemērā reǵionālā klasifikācijas sistēma, ko izmantoja iepriekšminētajos pētījumos ir šāda:

- galvaspilsētas;

- citas metropoles, izņemot galvaspilsētas, kas ietver visu vai dalıu no pilsētas centra ar iedzīvotāju skaitu 100000 vai vairāk; 
- piekrastes teritorijas, kas atrodas $80 \mathrm{~km}$ attālumā no krasta;

- attālākas teritorijas, kas noteiktas, ñemot vērā attālumu no tuvākās pilsētas centra, kā arī nosakot pieejamības indeksu;

- iekšzemes teritorijas (Lewis, Corliss, 2012).

Ārvalstu literatūrā tiek analizēta darba tirgus rezultātu nevienlīizība starp reǵioniem, ñemot vērā dažādas metodes (Martin, 1997; Dewhurst 1998; Todaro, Smith 2003). Mērīšanas metodes ietver izmaiņu pārbaudi standartnovirzei, savukārt, Džini koeficientu izmanto, pārbaudot pẹ̦ņas (ienākumu) atšķirību.

Autors Martins (Martin) ierosināja dispersijas indeksu mērǐšanai n̦emt vērā izkliedi starp bezdarbu un ienākumiem, kā arī Džini koeficientu un relatīvās kvintiles, kurām pārbauda izmaiņas ienākumu nevienlīdzībā. Martins izmanto reǵionālā bezdarba dispersijas indeksu, kas ietver diferenciāli starp regiona bezdarba un valsts bezdarba līmeni, un svaru diferenciāli pēc relatīvā lieluma reǵiona darba tirgū (absolūto dispersiju), skatīt 1. 1. formulu (Martin, 1997).

$$
\mathrm{AJ}=\sum_{\mathrm{r}}\left|\frac{\text { WAPr }}{\text { WAPn }}(\mathrm{Jr}-\mathrm{Jn})\right|
$$

Apzīmējumi:

AJ - valsts bezdarba līmeña absolūtā dispersija;

WAP - darbspējīgo iedzìvotāju skaits;

$\mathrm{J}$ - bezdarba līmenis;

$\mathrm{r}$ - apzīmē reǵionu;

n - apzīmē valsti (Martin, 1997).

Populāra metode vienlīdzību mērīšanai ir relatīvo ienākumu kvintiļu pārbaude, izmantojot Džini koeficientu. Džini koeficients ir lietots, lai aprēķinātu atšķirības starp ienākumu mediānām dažādās statistiskajās reǵionālajās grupās. Jo zemāks Džini koeficients, jo zemāka nevienlīizības pakāpe (Martin, 1997).

Autori Levis (Lewis) un Korliss (Corliss) savos pētījumos saistībā ar Austrāliju atklāja un uzsvēra, ka, ņemot vērā pieaugošās nodarbinātības iespējas, tika gaidīts, ka darba tirgū iesaistīties vairāk darbspējīgā vecuma cilvēku. Tomēr pētījumos netika rasta skaidrība, kā tas ietekmē valsts regiionālās atšksirības un bezdarba īpatsvaru. Lai gan ekonomikas izaugsmes rezultātā ievērojami samazinājās bezdarbnieku līmenis visā Austrālijā un tās reǵionos, atšksirības starp reǵioniem saglabājās salīdzinoši nemainīgas, izṇemot attālos reǵionus, kur bija ievērojamas atšķirības. Autoru pētījumi liecina, ka bezdarbs attālajos regionos ir daudz noturīgāks nekā bezdarbs valstî kopumā. Autori uzsvēra, ka cīņai ar bezdarba radītajām sekām nepieciešama uz izaugsmi vērsta politika, kas sekmē bezdarba pamatcēloṇu rašanos, kā piemēram prasmju uzlabošana, mobilitātes palielināšana, veicinot lielāku stimulu atgriezties darba tirgū un veicinot negatīvo seku samazināšanos (Lewis, Corliss, 2012).

Demogrāfisko izmainu radītās sekas, kā arī ekonomikas un tehnologiju attīstības radītās izmaiṇas ḷoti asi skārušas tieši lauku teritorijas. Kā uzsvērts Berlīnes Iedzīvotāju un attīstības institūta pētījumā ,Lauku nākotne. Starp stabilitāti un demogrāfisko lejupslīdi” (Krohnert et.al., 2011), vērojama tendence, ka strukturālo izmaiņu rezultātā jaunas darbavietas tiek radītas galvenokārt pilsētās un piepilsētu teritorijā, lauku un nomaļajās teritorijās nodarbinātība samazinās. İpaši jauni cilvēki, kas būtu jaunu ǵimeņu veidotāji, pārceļas uz lielākām pilsētām. Lauku telpas piedāvājums jauniem cilvēkiem vairs nav pievilcīgs, un tas attiecas uz visām jomām: gan kultūras un 
izklaides, gan darba iespējām. Pamatā lauku teritorijā darba vietas ir lauksaimniecībā, un tradicionāli lauksaimniecībā nodarbināto atalgojums ir bijis zemāks par vidējo valstī. Arvien vairāk lauku jauniešu vēlas studēt - tie dodas uz pilsētām un laukos vairākums neatgriežas. Dzimstības pārsvars pār mirstību laukos agrāk spēja nodrošināt gan lauku stabilitāti, gan pilsētu demogrāfisko izaugsmi, bet mūsdienās ir otrādi - pilsētās dzimst vairāk bērnu, jo tur ir vairāk jaunu cilvēku, laukos mirstība ir augstāka, jo tur pārsvarā dzīvo pensionāri. Lauku iedzīvotāju skaits samazinās ne tikai dzimstības krituma, bet arī tehnologiskās attīstības dēḷ - lai paveiktu to pašu darba apjomu, ir vajadzīgs daudz mazāk darbaspēka nekā pirms dažiem desmitiem gadu. Lauksaimniecībā dominē lielsaimniecības, līdz ar to daudz mazāk izplatītas ir lielas zemnieku gimenes, kas agrāk bija nepieciešamas individuālo saimniecību apsaimniekošanai. Pētnieki prognozē, ka iedzīvotāju skaita samazināšanās laukos nākotnē tikai turpināsies (Reǵionālās politikas pamatnostādnes..., 2013).

Autors Meņšikovs uzsver teritoriālo sistēmu lomu konkurences cīṇā par kapitālu, īpaši inovatīvo, kurš dod multiplikatīvus efektus un rada jaunas darba vietas. Tomēr ne visām darba vietām ir vienāda nozīme attiecīgajā teritoriālajā sistēmā: visvērtīgākās ir augstas kvalitātes darba vietas. Pakalpojumu un tirdzniecības sfēras attīstība, kas ir balstīta uz nacionālo un transnacionālo tīklu, jaunu veikalu objektu atvēršanu, rada zemu apmaksātas, mazkvalificētas darba vietas un tiek uzskatîta par draudu vietējai ekonomikai (Meņšikovs, 2011).

Bezdarba mazināšanas pasākumu izstrādē noteikti jāņem vērā reǵionālā attīstība. Aktivitāte (nodarbināto un darba meklētāju īpatsvars darbaspējīgā vecumā esošo iedzīvotāju kopskaitā) reǵionos ir daudz zemāka nekā lielajās pilsētas, īpaši Rīgā. Laukos vairāk iedzīvotāju ir nošķirti no darba tirgus - viņi pat nemeklē darbu, jo ilgstoši ir bijuši bez darba un neredz perspektīvas to atrast. Tas norāda uz dziḷākām strukturālām problēmām tieši reǵionos (Augsts bezdarbs Latvijā...., 2010).

Darba tirgus attiecības Latvijas mazpilsētās un lauku teritorijās detalizēti savos pētījumos analizējusi L. Rasnača. L. Rasnača uzsvērusi, ka globālo procesu ietekme uz attiecībām starp darba devējiem un darba ņēmējiem izpaužas kā migrācijas intensitāte (Rasnača, 2011). Jo augstāks ir bezdarba līmenis, jo intensīvāka ir migrācija no apdzīvotās vietas (Dockery, 2000). Intensīvie migrācijas procesi no Latvijas uz citām Eiropas Savienības valstīm neapšaubāmi atstājuši iespaidu uz darba devēju un darba ñēmēju attiecībām, tādējādi globalizācijai skarot arī vietējās darba tirgus attiecības. Globalizācijas process paver jaunas iespējas darba tirgus dalībniekiem, bet globalizācijas spēki, „dominējošās plūsmas” dažādā mērā ietekmē atšķirīgus darba tirgus segmentus un tajos darbojošos aǵentus. 20. gadsimta beigās tehnoloǵiskā un informācijas revolūcija izmain̄̄jusi domāšanas, ražošanas, vadības un komunikācijas veidus, šajās darbībās iesaistītos aǵentus. Apdzīvoto vietu - teritoriālo vien̄ibu darba tirgu ietekmē globālo savstarpējo saistību un atkarību pieaugums, kā rezultātā bieži samazinās noteiktu ǵeogrāfisko vietu kultūras un darba tirgus atšksirības (Dockery, 2000).

L. Rasnača pētījumos pievērsusies autora Beka (Beck) analizētajiem ekonomiskās globalizācijas riskiem, atzīmējot, ka Latvijas lauku teritorijās un mazajās pilsētās būtiskas ir darba tirgus attiecību telpiskās atšksirīibas, kuru izpēte sevišķu nozīmi iegūst, pastiprinoties emigrācijas procesiem. Par Latvijas sociāli telpisko nevienlīdzību uzskatāmi liecina tās teritoriālās vien̄ibas, kurās ir maz darba devēju un zema darba tirgus aktivitāte un kurās ir sociāli neizdevīgi darba un dzīves apstākḷi. Kā iespējamo risinājumu šiem darba tirgu ietekmējošiem riskiem Beks (Holloway, Beck, 2004) iesaka pārnacionālu kooperāciju nacionālu problēmu risināšanā, t.i., plašāku starptautisko 
sadarbību tādu darba tirgus problēmu risināšanā kā ilgstoši augsts bezdarba līmenis, augsta starptautiskā migrācija, u.c. (Rasnača, 2011).

\section{Reğionālās atšksirības darba tirgus attiecībās nosaka:}

- darba tirgus iesaistīto pušu specifiskās īpašības,

- atšksirības darba tirgus iesaistīto pušu mijiedarbības veidā,

- regiionālās telpas sociālā un ekonomiskā vide (Rasnača, 2011).

Atšķirīgās reǵionālās telpās var veidoties dažādas darba devēju un darba ñēmēju attiecības, kuras ietekmē tajās pastāvoši sociālo attiecību modeḷi. Līdz ar to dažādās teritoriālās vienībās (pilsētās/ laukos, regionos, lielajās/ mazajās pilsētās, novados, bijušajos rajonos) var atšķirties darba tirgū iesaistīto pušu attiecības (Gottdiener, Hutchinson, 2006).

Bezdarba problēma reǵionos ir saistīta ar sociālo iekḷaušanos darba tirgū, līdz ar to darba autore turpmākajā nodạ̦ā analizēs sociālās iekḷaušanās būtību un aspektus darba tirgū dažādu autoru skatījumā.

\subsection{Jauniešu sociālā iekḷaušanās darba tirgū/ Youth's social inclusion in the labour market}

Zinātniskajā literatūrā dažādi autori vērsuši pastiprinātu uzmanību bērnības ietekmei uz jaunieša un pieauguša cilvēka turpmāko dzīvi un veiksmīgu iekḷaušanos (integrāciju) darba tirgū.

Bezdarbs ir sociāla problēma - tas ietekmē sociālos aspektus sabiedrībā, dažādās sabiedrības, piemēram, jauniešu, grupās: pazeminoties dz̄ives līmenim, degradējas morālie kritēriji, palielinās noziegumu skaits, saslimstību skaits un tml. Bezdarbnieki, arī jaunieši bezdarbnieki, bieži tiek raksturoti kā sociāli atstumta sabiedrības mērķa grupa. Sociālā atstumtība, ko rada ilgstošais bezdarbs, raksturīga visā Eiropā, bet atšķiras situācijas starp valstīm (Youth Unemployment, 2003). N̦emot vērā pētījuma aktualitāti, nozīmīgi ir analizēt jauniešu bezdarbnieku sociālo iekļaušanos darba tirgū.

Jaunieši, it īpaši vecumā no 15 - 24 gadiem, ir viena no sociālā ziṇā neaizsargātākajām grupām. Beidzot vidusskolu, jaunietim nav nedz profesionālās izglītības, nedz darba pieredzes, kā rezultātā viņa izredzes veiksmīgi konkurēt darba tirgū ir samērā niecīgas (Koroḷeva u.c., 1999).

Indivīdam viṇa agrīnās socializācijas laikā tiek mācīts par darba nozīmīgumu, un viṇi iemācās, ka viens no vinuu identitātes un statusa pamatnosacījumiem ir profesija. Viņi iemācās arī to, ka profesionālā izaugsme nozīmē arī sociālo izaugsmi. Iespēja iepazīt darba dzīvi un izsmel̦ošas informācijas, konsultāciju un atbalsta pieejamība ir galvenie komponenti, kas palīdz jauniešiem atrast darbu (Recent Policy Developments..., 2012).

Sociālās iekḷaušanas jēdziens mūsdienās ir galvenais Eiropas politikas darba kārtībā, kā arī notiek pārrunas un aizstāvības iniciatīvas tādu starptautisku organizāciju ietvaros kā, piemēram, SDO, ANO, UNESCO un PB (Estivill, 2003; Gore, Figueiredo, 1997).

Nodarbinātība ir svarīga sociālo aktivitāšu daḷa, nodrošinot ekonomiskā pamata esamību indivīdam un vienlaikus arī šīs personas sociālo statusu. Iekḷaušanās darba tirgū saistāma ar noteikumu, ka tiek novērstas atšķirības starp jauniešu un pieaugušo nodarbinātību, arī tiesības, pienākumi un iespējas, ko piedāvā jauniešiem darba tirgū, ir tādas pašas kā pieaugušajiem darbiniekiem. Iekḷaušanās tiek uzskatīta par veiksmīgu panākumu veidošanu jauniešu nodarbinātības jomā, kas neatšksiras no iespējām pieaugušajiem. Proti, piedāvātās iespējas jauniešiem darba tirgū ir identiskas pieaugušo 
iespējām un otrādi. Veiksmīgas iekḷaušanās rezultātā indivīdam netiek negatīvi ietekmēts materiālais stāvoklis un sociālā dzīve (Sileika et al., 2004).

Par sociālo iekḷaušanos aktīvas diskusijas pētnieku vidū sākušās 90. gados, savukārt, Latvijā tikai pēdējos gados, jo līdz tam ļoti aktīvi tika izmantots vārds ,integrācija” vai ,iespēju sniegšana”, kas lielā mērā ir saistīts ar sabiedrības attīstību un izpratnes veidošanos.

Analizējot dažādus literatūras avotus jāsaskaras ar diviem terminiem par jauniešu lomu darba tirgū. Latviešu un ārzemju autoru literatūrā sastopami tādi termini kā sociālā integrācija un sociālā iekḷaušanās. Darba autore turpmāk apskata šo terminu definīcijas, lai izprastu to būtību.

Pēc LR LM informācijas, sociālä ieklaušana ir process, kura mērķis ir nabadzības un sociālās atstumtības riskam pakḷautajām personām nodrošināt iespējas, pakalpojumus un resursus, kuri nepieciešami, lai pilnvērtīgi piedalītos sabiedrības ekonomiskā, sociālā un kultūras dzīvē, uzlabojot dzīves līmeni un labklājīibu, kā arī lielākas līdzdalības iespējas lēmumu pieņemšanā un pieejamību personas pamattiesībām (Sociālā iekļaušana, b.g.).

Tātad, varam apgalvot, ka sociāalä iekḷaušana ir visas darbības, kas virzītas uz jaunieša iekḷaušanās virzību sabiedrībā, lai tam būtu nodrošināti pilnvērtīgas dzīves apstākḷi.

Sociāla ieklaušana jeb vienlīdzīgu iespēju nodrošināšana darba tirgū nozīmē tādus pasākumus, kas nodrošina visu iedzīvotāju vienlīdzīgu piekḷuvi darba tirgum. Šādu pasākumu īstenošana visnelabvēlīgākā situācijā esošajām sabiedrības grupām, kurām ir paaugstināts bezdarba risks, palīdz ,nostāties uz viena pakāpiena” ar līdzcilvēkiem, t.i., tiek ņemtas vērā atšķirības starp dažādām sociālā riska grupām. Vienlīdzịgu tiesību un iespēju izmantošanai nereti ir nepieciešami papildu resursi, piemēram, finanšu līdzekḷi, laiks, informācija, kas visiem cilvēkiem nav vienlīdzīgi pieejami (Par iekļaujošas nodarbinātības..., 2015).

Savukārt, sociālā integrācija ir mērķtiecīga sociāla darbība, kuras mērḳis ir panākt sociālo vienotību, saglabāt sabiedrību kā vienotu veselumu, palīdzot iekḷauties sabiedrībā visām personām (personu kopām), arī tām, kuras no sabiedrības izstumtas vai attālinājušās, lai katrs izjustu savu nozīmīgo lomu sabiedrībā (Sociālā integrācija, 2009).

Balstoties uz iepriekšminēto definīciju, sociālā integrācija ir sociālās darbības, kas vērstas uz sabiedrības kā viena veseluma saglabāšanu - tas nozīmē, ka indivīds tiek pozicionēts kā sabiedrības daļa, kam ir tiesības uz darbu, dzīves vietu, brīvību utt.

Darba autore uzskata, ka nozīmīgi ir vērst uzmanību uz autoru pētījumiem, kuros analizēti gan sociālās iekḷaušanās, gan sociālās integrācijas aspekti, jo dažādi autori šo terminu izmanto attiecībā uz jauniešu darba tirgus un sociālās vides tendenču analīzi, lai noskaidrotu galvenos faktorus, kas veicina jauniešu bezdarbu un konkurētspējas samazināšanos darba tirgū.

Jauniešu sociālās iekḷaušanās jautājums ir aktuāls ES dalībvalstīs, bet pēdējās divās desmitgadēs tam ir pievērsta īpaša uzmanība. Kopš 2010. gada (līdz 2018. gadam) ir izveidots stratēgiskais dokuments „Jaunatne - investēšana un iespēju došana” (,, Youth - Investing and Empowering”) par politiku, kas saistīta ar jauniešiem Eiropā tādās jomās, kā izglītība, nodarbinātība, sociālā iekḷaušanās, pilsoniskā līdzdalība, uzņēmējdarbība u.c. (An EU Strategy..., 2009).

Jauniešu iekḷaušanās darba tirgū ir saistīta ar kritiski augstu prioritāšu izvirzīšanu visā ES un arī Latvijā. Izglītība un apmācība, kā arī pirmā darba pieredze jauniešiem tiek uzskatīta par ļoti svarīgu, lai sāktu savu darba karjeru (Buligina u.c., 2014).

Izveidojoties pozitīvam iesākumam darba tirgū, tiek atvieglota jauniešu integrācija darba pasaulē un ir pamats labas karjeras iesākumam, bet tas var būt grūti 
panākams pēc sākotnējas neveiksmes (Sonnet, 2010). Autori Bubanijs (Bubany) un Hansens (Hansen) uzskata, ka valsts pārvaldes iestādēm nepieciešams meklēt risinājumus gan valsts, gan reǵionālā līmen̄̄, lai risinātu jauniešu nodarbinātības problēmu sistēmiskā veidā (Bubany et al., 2011).

Nozīmīgi ir skatît arī jauniešu iespējas iekḷauties darba tirgū filozofiskā skatîjumā. Jauniešu iekļaušanos darba tirgū ietekmē arī sociālā attīstība, skatoties gan indivīda, gan valsts, gan pasaules prizmā. Latviešu filozofe M. Kūle uzskata, ka sociālā attīstība ved uz noteiktu, racionāli sasniedzamu mērķi- sociāli nodrošinātu labklājības valsti. Eiropā domas par taisnīgu sabiedrību tiek aizstātas ar cilvēktiesību koncepciju. Cilvēktiesību filozofisko pamatu veido ideja par brīvu un atbildīgu personību, 1948. gadā pieņemtā ANO Cilvēktiesību deklarācijā jēgpilnais centrs ir indivīds, nevis sociāla grupa vai kopiena (Kūle, 2006).

I. Kalve savos pētījumos vērsusi uzmanību uz cilvēku, kā sociālas sistēmas daļu. Attīstoties tehnologijām un paātrinoties informācijas apritei, būtiskas izmaiņas skar gan sabiedrību kopumā, gan katru tās locekli atsevišķi. Cilvēki mainās, izmaiņas notiek un līdz ar informētîbas un izglìtības līmeņa pieaugumu mainās cilvēku attieksme pašiem pret sevi un citiem- gimeni, draugiem, darba devējiem, padotajiem. Pirmais no jaunajiem atšksirību veidotājiem ir izglītība. Pieaug atšķirības starp izglītotajiem un neizglītotajiem. Tās ir jaunas šķiras un tā ir jaunu šķiru sabiedrība. Ja indivīdam nav nekādu īpašu prasmju, viņš ir aizvietojams, un tas nozīmē, ka indivīds tiešā veidā konkurē ar vairāk nekā diviem miljoniem ksīniešu un indiešu. Pieaug plaisa starp nodarbinātu cilvēku un bezdarbnieku. Otrs lielākais atšķirību veidotājs ir informācijas tehnologijas. Ir divu veidu paaudzes: pēc un pirms datoru parādīšanās. Tie, kas jaunāki par 35 gadiem, nav pieredzējuši informāciju tehnologiju revolūciju, bet tikai evolūciju. Šie jaunieši uzdod pavisam atšķirīgus jautājumus par dzīvi un darbu. Viņi vēlas darbu mainīt pašos pamatos, tā vietā, lai dzīvotu tāpēc, lai strādātu, viṇi vēlas strādāt tāpēc, lai dzīvotu. Augstskolās apgūstot vadības zinātni (menedžmentu), studenti tiek iepazīstināti ar dažādām darbinieku motivēšanas teorijām: Maslova, Hercberga, Makkinseja un citām. Daudz atbalstītāju ir Makgregora (McGregor) izstrādātajām X (pamatideja: cilvēks pēc dabas ir slinks un to ir jāpiespiež strādāt) un Y teorijām (pretēja pieeja: cilvēks grib strādāt) (Kalve, 2005).

Darba autore piekrīt I. Kalves viedoklim par globalizācijas procesa radītajām sekām, kas būtiski ietekmē cilvēka kā indivīda socializāciju darba tirgū. Indivīdam ir jāiztur sīva konkurence no apkārtējo puses, kas ne vienmēr rada to pozitīvāko nākotnes scenāriju uz indivīda iekḷaušanos darba tirgū un turpmāko karjeras attīstību. Būtiski ir indivīdam spēt iekḷauties sabiedrībā un pārzināt jaunākās tehnoloğijas, kuras nepieciešamas ikdienas darba pienākumu veikšanā, kā arī internacionalizācijas radītā spiediena iespaidā, būtisks uzsvars ir uz komunikāciju dažādās valodās. Nozīmīga ir arī indivīda iegūtā izglîtība un absolvētās mācību iestādes kotēšanās darba tirgū, kas viennozīmīgi veido salīdzinošo priekšrocību attiecībā pret citiem darba meklētājiem.

Savukārt, ārzemju autori pievērsušies jauniešu sociālās atstumtības analīzei un kopsakarību meklēšanai, analizējot jauniešu bezdarba tendences. Jauniešu sociālo atstumtību ietekmējošos faktorus dažādos aspektos pēta tādi ārzemju pētnieki kā Berghmans (Berghman), Hammers (Hammer), Kīselbaks u.c. kolēǵi (Kieselbach et. al.), Paugams (Paugam), Rooms (Room) u.c.

Autors Kīselbahs (Kieselbach) uzskata, ka ne vienmēr bezdarba (it îpaši ilgtermiņa bezdarba) situācijā esošs jaunietis ir pielīdzināms indivīda izslēgšanai no darba tirgus kā arī pakḷauts sociālās atstumtības riskam. 
Autors Rooms (Room) savos pētījumos analizējis sociālās atstumtības pamatelementus, pilsonisko integrāciju, politisko līdzdalību, sociālo aizsardzību, integrāciju labklājības valstīs utt.

Autori Paugams un Berghmans paplašināja sociālās atstumtības jēdziena nozīmi, analizējot finansiālā stāvokḷa pasliktināšanos, kas izriet no ilgtermiṇa bezdarba.

Saskaņā ar autoru Hammeru, sociālā atstumtība ietver veidus, kādos trūkumi vienā dzīves dimensijā var izraisīt jaunus un veicināt kopējo situācijas pasliktināšanos (Hammer, 2003). Darba autore piekrīt autora Hammera apgalvojumam, ka sociālā atstumtība ir cieši saistīta ar ilgtermiņa bezdarbu, kas ir būtiska sociālās iekḷaušanās problēma darba tirgū. Ja indivīds nevar pielāgoties darba tirgum, viņš arī nespēj sekmīgi integrēties sabiedrībā un veidot veiksmīgu nākotni.

Sociālajai atstumtībai ir strukturāli iemesli, tostarp darba iespēju trūkums, jo īpaši atsevišksos reǵionos, apgrūtinot jauniešiem iespēju pilnīgi iekļauties darba tirgū. Krīze ir saasinājusi šo jauniešu bezdarba problēmu daudzās valstīs, jo īpaši nelabvēlīgā situācijā esošām grupām. Vairāk nekā puse no jaunajiem vīriešiem un sievietēm, izvērtējot darba tirgus rādītājus, ir bezdarbnieki atsevišķās valstīs. Ir nepieciešama steidzama rīcība, lai nodrošinātu vairāk un labākas darba vietas jauniešiem un novērstu seku ietekmi gan uz jauniešiem, gan Eiropas ekonomiku un sabiedrības sistēmu kopumā (Framework of Actions..., 2013).

Pasaules Bankas attīstības ziņojumā 2013. gadā (World Development Report 2013) tika noteikti galvenie ieteikumi jauniešu veiksmīgai iekļaušanai darba tirgū. Kā pirmais ieteikums bija minēta iespēja pietuvināt akadēmisko izglītību orientētu uz privātā sektora tendencēm, akadēmiskajās mācību programmās kā obligātu prasību iekļaujot stažěšanos pie darba devējiem. Šo ieteikumu būtu noderīgi realizēt arī Latvijā, jo tad intelektuālā kapitāla virzība tiktu orientēta uz Latvijas uzṇēmēju interešu bāzes, nodrošinot jauniešu nodarbinātības attīstību un produktivitātes paaugstināšanu.

Otrais būtiskākais Pasaules Bankas attīstības ziņojuma 2013. gadā ieteikums vērsts uz formālu un ilgtspējīgu darba vietu radīšanu. Valstīs, kurās ir augsts neoficiālās nodarbinātības līmenis, veidojas šķēeršli augšupejošas mobilitātes un ekonomiskā progresa attīstībai. Būtu jāizstrādā politika, lai radītu vairāk uzṇēmumus formālajā sektorā, kas piedāvātu oficiālas darba vietas. To var atrisināt ar ekonomikas politikas reformām, piemēram, atcel̦ot birokrātiskas uzņēmējdarbības reǵistrācijas procedūras, ieviešot nodokļu reformas, veicinot investīciju piesaisti privātajā sektorā un radot formālu start-up uzñēmumu izveides atbalsta institūciju.

Autors Šũs (Schoof) norāda, ka, ignorējot jauniešu nodarbinātības jomu, tiek veicināta ne tikai sociālā neapmierinātība jauniešu vidū, bet arī tā veicina milzīgas ekonomiskās un sociālās izmaksas. Jauniešu bezdarbs ir milzīgs cilvēkresursu „pārpalikums”, kas varētu veicināt ekonomisko un sociālo attīstību. Jauniešu nodarbinātības pieaugums būtu pozitīvs efekts ekonomikā kopumā, veicinot patērētāju pieprasījumu un palielinot nodokḷu ieņēmumus (Schoof, 2006).

Bērna socializācija sabiedrībā un tās ietekme uz jaunieša turpmāko dz̄̄̄vi. Jaunieša socializāciju ietekmē bezdarbs un tā ilgums. Ilgāki bezdarba periodi atstāj nopietnu ietekmi uz indivīdu un tā socializāciju, kā arī uz ekonomiku kopumā. Liels skaits zinātnisko publikāciju un zinātniskā literatūra ir koncentrēta uz bezdarba līmeņa ietekmi uz indivīda labklājību, uzsverot tādus aspektus kā zems pašvērtējums, veselības problēmas un augstāks pašnāvību skaits.

Svarīgi apzināties savu vietu sabiedrībā un spēt pilnveidot sevi laikā, kad sabiedrībā viss mainās, pilnveidojas, attīstās. Indivīda audzināšana nevar pastāvēt ārpus sabiedrības. Tā attīstās līdz ar sabiedrības ražošanas, kultūras un politikas izmaiņām un izvirza audzināšanai noteiktas prasības sociālās attīstības sekmēšanai. Ja līdz pusaudžu 
vecumam vecākiem un skolotājiem bērna dzīvē ir noteicošā loma, tad pusaudžu vecumā lielākā loma ir draugiem gan personības tālākajā attīstībā, gan socializācijā. Arī identitātes veidošanās procesā identifikācijai ar vienaudžiem ir būtiska loma (Špona, 2004, 37).

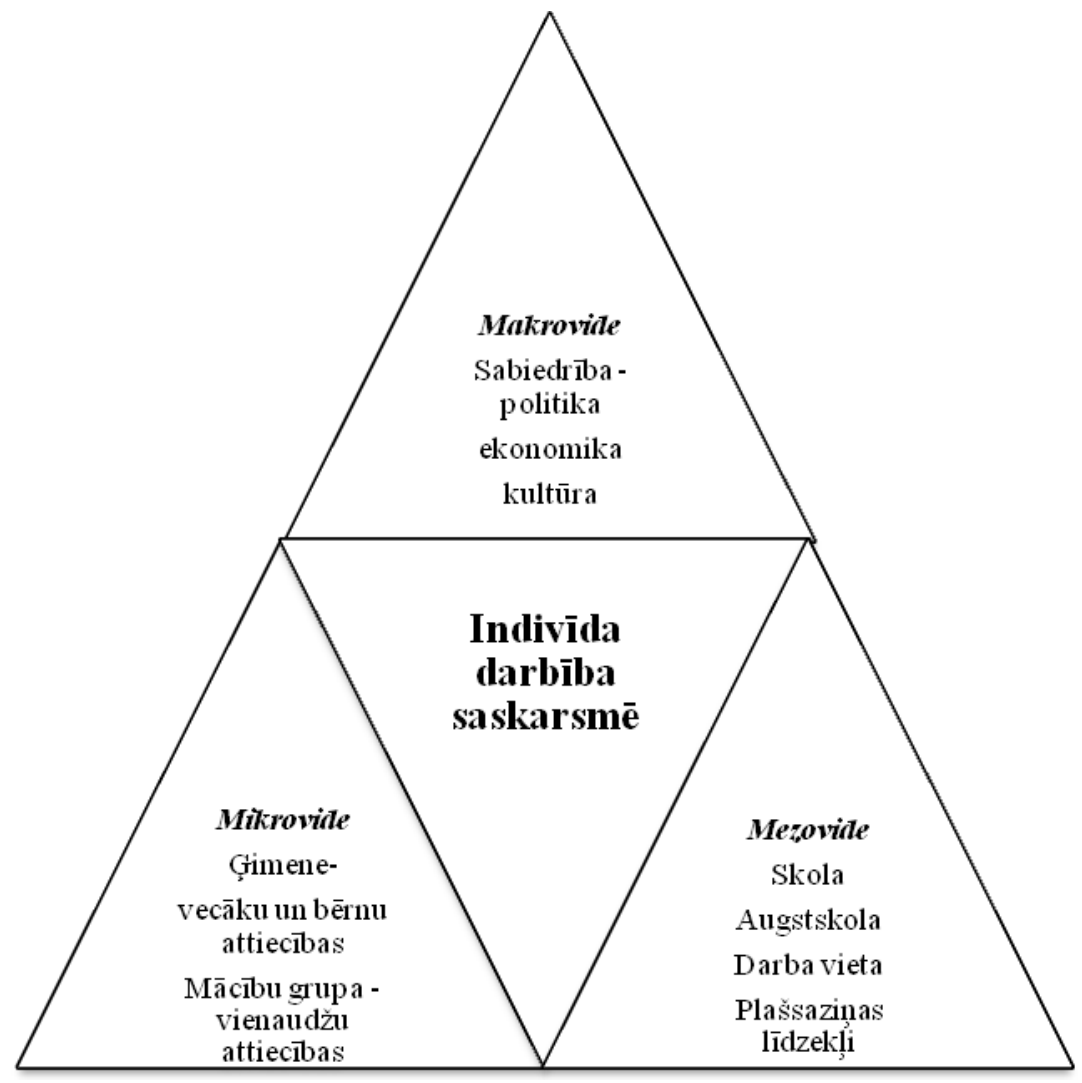

Avots: autores veidots pēc Špona, 2004

\section{3. att./ Fig. 1.3. Indivīda attīstības un vides mijiedarbība/ Interaction between the development of an individual and the environment.}

Audzināšana un attīstība ir nepārtrauktā mijiedarbībā. Audzināšana, iedzimtība un vide (dabas un sociālās, mikro-, mezo-, makro-,) (skat. 1.3. attēlu) ir paši nozīmīgākie cilvēka attīstību noteicošie faktori. Katrā vecumposmā veidojas savas īpašās attiecības ar mikrovidi- gimeni, klases biedriem, mācību grupu, darba kolektīvu, mezovidi skolu, darba vietu, konkrēto regínālo dzīvesvietu un makrovidi - sabiedrību kopumā un valsti. Attīstības un vides mijiedarbībā vienmēr attīstīsies cilvēku spējas kā prasmes darīt un pilnveidosies pieredze, bet svarīgākie mijiedarbības raksturlielumi ir vērtīborientācija, mērḳtiecība un emocionālā stabilitāte (Špona, 2004). Visi iepriekšminētie raksturlielumi būtiski ietekmē indivīda darba gaitas.

Pieckāršais Helix modelis jauniešu iekḷaušanai darba tirgū. Globalizācijas ietekmē ir mainījušās ekonomiskās un sociālās attiecības pasaulē. Uzṇēmumi, kas nodarbojas ar ražošanu vai arī pakalpojumu sniegšanu, nespēj veiksmīgi darboties pasaules tirgū bez ieguldījumiem zinātnē un tiem nav iespējams attīstīties bez iesaistes pētniecībā. Nozīmīgu lomu zināšanu pārneses nodrošināšanā ieņem izglīīîbas iestādes, t.i., būtiski jau bērnam bērnudārzā sniegt pilnvērtīgas zināšanas, lai viṇš veiksmīgāk spētu adaptēties sākumskolas vidē. Jau agrīni bērnam jādod iespēja saprast, kas viñam interesē un kas neinteresē, lai pusaudža gados jaunietis spētu apzināties intereses un uz tām virzîties. Ja šì pāreja indivīda dzīves laikā līdz jaunieša vecumam nav pilnvērtīga, 
jaunietis saskaras ar problēmām izvēlēties nākotnes profesiju, rodas grūtības sekmīgi absolvēt mācību iestādi, jaunietis var nenoteikt mērķus un iekḷūt sociālā riska grupā, kā arī saskarties ar bezdarba risku. Līdz ar to autore uzskata, ka pieckāršā Helix modeļa procesu mijiedarbība uzlabotu jauniešu pāreju no studijām uz darba tirgu un samazinātu jaunieša iespējamību iekḷūt kādā no sociālajām riska grupām vai kḷūt par bezdarbnieku.

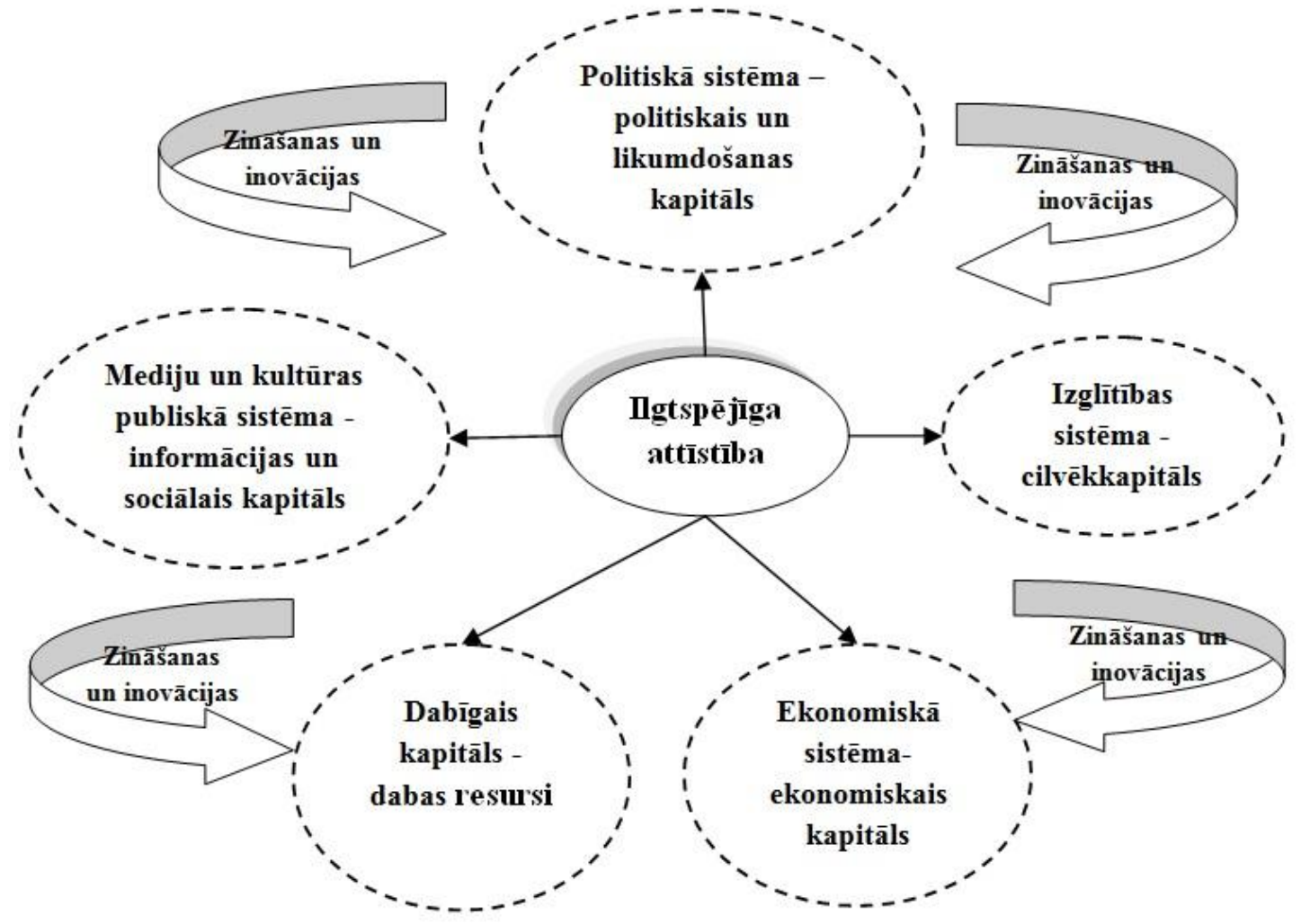

Avots: autores veidots pēc Carayannis et.al, 2012

\section{4. att./ Fig. 1.5. Zināšanu pārnese un faktoru mijiedarbība pieckāršajā Helix modelī/ Knowledge transfer and factor interaction in the Quintuple Helix model.}

Zināšanu transformācija ar pieckāršo Helix modeli (Quintuple Helix Model) ir galvenais spēks un dzinulis progresam. Pieckāršais Helix modelis virzịts uz sociālo (sabiedrības), akadēmisko zināšanu un valsts mijiedarbību, lai veicinātu un vizualizētu sadarbības sistēmu zināšanu, tehnologiskās kompetences (know-how) un inovācijas, kas nodrošinātu ilgtspējīgu attīstību. Pieckāršais Helix modelis ir starpdisciplinārs, kas apvieno visu piecu virzītājspēku struktūru un sniedz piln̄̄gu analītisku izpratni par visām iesaistītajām pusēm un, mijiedarbojoties, nepārtraukti iesaista procesā visas puses. Disciplinārais spektrs iekḷauj dabas zinātnes, sociālās un humanitārās zinātnes (sabiedrība, demokrātija un ekonomika) un eksaktās zinātnes (skat. 1.4. att.) (Carayannis et.al., 2012).

Helix modeḷa faktoru mijiedarbība un zināšanu pārnese veicinātu jauniešu iekḷaušanos darba tirgū. Zināšanu nodošana jaunajām paaudzēm veicina valsts nākotnes attīstību.

Autors Jakobs (Jacob) 1997. gadā pētījumos uzsvēra, ka pieaug nepieciešamība pēc zināšanām kā produkta. Zināšanas ir kā potenciālais produkts, kas var tikt izmantotas tirgū (Jacob, 1997).

Autors Fileps (Filep) ar kolēgiem uzsvēra, ka visa sabiedrība balstās uz zināšanām, mēs dzīvojam tīklveida orientētā sabiedrībā, kur attīstība ir atkarīga, 
galvenokārt, no spējas sadarboties. Agrāk attīstības stāvoklis vairāk bija specializēts uz pētniecību un izglītību, tāpēc būtu nepieciešams dzil̦āk pozicionēties uz noteiktu nozaru zinātnēm (Filep et al., 2013.).

Investīcijas cilvēkkapitālā ir būtiskas, lai atvieglotu pāreju no studijām uz darbu, un dotu iespēju jauniešiem veidot veiksmīgu karjeru. Cilvēkkapitāla veiksmīga izmantošana nodrošina labāk atalgotas darba vietas un veicina izglītības līmeña pieaugumu.

Ievērojot Helix modeḷa mijiedarbību, orientētu uz sabiedrību, ir iespējama produktīva jaunieša zināšanu un prasmju pielāgošana darba tirgum. Veicinot šajā modelī apskatīto ilgtspējīgas attīstības funkciju mijiedarbību, indivīda dzīves laikā tiktu nodrošināta pilnvērtīga vide jaunieša visattīstītāko prasmju realizācijai darba tirgū. Jāvirzās uz zināšanu kapitāla pārnesi no izglītības iestādēm uz uzṇēmumiem un institūcijām, kam š̄̄s konkrētās zināšanas ir nepieciešamas, lai spētu nodrošināt turpmāko attīstību, konkurētspēju un integrāciju. Jāattīsta šī modeļa koncepcija lauku reğionos, kur pāreja no izglîtības iestādes uz darba tirgu ir sarežğîtāka nepietiekamo darba vietu skaita un stagnējošās uzṇēmējdarbības attīstības dēḷ. To veicina lielāko uzņēmumu koncentrācija Rīgas un Pierīgas reǵionā, kā arī Latvijas lielākajās rūpniecības pilsētās, tādās kā Ventspils, Liepāja, Daugavpils, Rēzekne, Jelgava. Realizējot Helix modeḷa faktoru savstarpējo mijiedarbību un nodrošinot zināšanu pārnesi ilgtermiņā, iespējams veicināt valsts ekonomiskās situācijas attīstību.

Kā viens no scenārijiem darba 5.2. nodal̦ā, veicot analītisko hierarhiju analīzi, izmantots Helix modeļa faktoru savstarpējās mijiedarbības princips.

Informācijas tehnologiju attīstības ietekmē problēmas ar iekļaušanos darba tirgū rodas arī cilvēkiem gados, kuriem nav zināšanas informācijas tehnologiiju jomā un līdz ar to nav iespējas efektīvi veikt ikdienas darba pienākumus. Darba tirgū aktuālas vakances, kurās ir prasība pēc informācijas tehnologiju zināšanām ir vairāk kā tās, kurās nav šāda prasība. Ikdienas darba pienākumu veikšana nav iedomājama bez šīm zināšanām praktiski nevienā profesijā, izṇemot atsevišksās mazkvalificētās profesijas.

Jauniešiem ir informācijas tehnologiju zināšanas, jo tās māca skolā, bet tiem nākas saskarties ar neapmierinošu algu līmeni, aizkavētu algas izmaksu u.c. problēmām. Darba devēji nevēlas jauniešiem maksāt vakantajai profesijai atbilstošu algu un bieži vien izvēlas maksāt tikai valstī noteikto minimālo algu, ar ko liela daļa jauniešu nav apmierināti, ņemot vērā augsto studiju maksu līmeni valstī. Šis ir viens no iemesliem, kādēl jaunieši, it īpaši no lauku regioniem, izvēlas doties labāk apmaksāta darba meklējumiem ārvalstīs. Situācija, kad jaunietis ar iegūtu augstāko izglītību veic darbu, saņemot zemus ienākumus, nav pię̧aujama, it īpaši gadījumos, kad jaunietis ir maksājis par studijām un pabeidzis studijas, cenšoties studijas savienot ar darba pienākumu veikšanu.

Situācijāâ, kad nenotiek veiksmīga jaunieša iekļaušanās darba tirgū, absolvējot mācību iestādi, jaunietis tiek pakḷauts sociālajiem riskiem. Tiek ietekmētas arī jaunieša nākotnes iespējas. Jaunietis var kḷūt par nevēlamu sabiedrībai, tiek zaudēts viņa, kā indivīda, intelektuālais kapitāls, valsts negūst ienākumus no nodokḷiem, ko šis jaunietis samaksātu kā darba ņēmējs. Nozīmīga ir sabiedrības intelektuālā kapitāla pārnese, savstarpējā sadarbība starp izglītības iestādēm, uzṇēmumiem, valsts institūcijām, pašvaldībām un veiksmīga vides resursu izmantošana, lai nepieļautu cilvēkkapitāla neefektīvu izmantošanu.

Helix modeḷa struktūras principi ir saistīti ar veiksmīgu jauniešu bezdarbnieku iekļaušanos darba tirgū. Jaunieša nodarbinātību un iekl̦aušanos darba tirgū ietekmē jaunieša izglīīibas līmenis, sociālie apstākḷi, sociālā piederība sabiedrībai, kultūra, kas ietekmē indivīda mērķus, iespēju atrast labi apmaksātu darbu, iespēju veidot nākotni utt. 
Darba autore noteica galvenos faktorus, kas uzskatāmi parāda mijiedarbību starp jauniešu iekl̦aušanos darba tirgū ietekmējošiem faktoriem un Helix model̦a sistēmas būtību (skatīt 1.2. tab.).

1.2. tabula/ Table 1.2.

\section{Uz zināšanām balstītas sistēmas izveides mijiedarbību ietekmējošie faktori jauniešu iekḷaušanai darba tirgū/ \\ Factors influencing interaction in the creation of a knowledge-based system for youth's integration into the labour market}

\begin{tabular}{|c|c|c|}
\hline $\begin{array}{c}\text { Uz zināšanām } \\
\text { balstītas sistēmas } \\
\text { nodrošināšanas } \\
\text { faktori }\end{array}$ & $\begin{array}{c}\text { Zināšanu pārneses sistēmu } \\
\text { ietekmējošie rādītāji }\end{array}$ & Uz jauniešiem attiecināmie rādītāji \\
\hline Cilvēkkapitāls & $\begin{array}{l}\text {-Pirmsskolas izglītības iestādes, vidējās } \\
\text { izglīīibas iestādes, augstskolas, to } \\
\text { skolotāju un pasniedzēju izglìtīibas } \\
\text { līmenis un izglīitibas kvalitāte; } \\
\text {-zinātniskās pētniecības institūti; } \\
\text {-investīcijas pētniecībā; } \\
\text {-nākotnes attīstības tendences. }\end{array}$ & $\begin{array}{l}\text {-Izglītības iestāžu nodrošinātās izglītības } \\
\text { kvalitātes līmenis reǵionā, kurā dz̄ìvo } \\
\text { jaunietis; } \\
\text {-skolotāju, pasniedzēju atbildība pret } \\
\text { veicamajiem pienākumiem, to kvalitāti; } \\
\text {-intereses radīšana par pētniecību no } \\
\text { izglītības un zinātnes institūcijām; } \\
\text {-valsts finansējuma izglītībai apmērs. }\end{array}$ \\
\hline $\begin{array}{l}\text { Ekonomiskais } \\
\text { kapitāls }\end{array}$ & $\begin{array}{l}\text {-Iekšzemes kopprodukts; } \\
\text {-eksporta, importa apjoms; } \\
\text {-nodokļu slogs; } \\
\text {-nodarbinātības līmenis; } \\
\text {-dzīves līmeṇa standarti, sociālā } \\
\text { iekḷaušanās; } \\
\text {-inflācija; } \\
\text {-algu apmērs, intensitāte; } \\
\text {-uzṇēmējdarbības } \\
\text { pašnodarbinātības iespējas. }\end{array}$ & $\begin{array}{l}\text {-Valsts institūciju loma jaunieša dzīvē; } \\
\text {-uzñēmēju attieksme par jauniešu } \\
\text { nodarbināšanu; } \\
\text {-atalgojuma līmenis jauniešiem; } \\
\text {-uzñēmējdarbības attīstības līmenis un } \\
\text { darba vietu pieejamība regíionā; } \\
\text {-regiona attīstības līmenis, kas ietekmēen } \\
\text { pašvaldības ieņēmumu apjomu un } \\
\text { attīstību. }\end{array}$ \\
\hline Dabīgais kapitāls & $\begin{array}{l}\text {-Resursu pieejamība (meži, koksne, } \\
\text { ogles, grants, rūda, kallkakmens utt.); } \\
\text {-ğeogrāfiskais novietojums } \\
\text { pieejamība. }\end{array}$ & $\begin{array}{l}\text {-Resursu efektīva izmantošana } \\
\text { uzn̄ēmējdarbības attīstībai palielina } \\
\text { darba vietu skaitu regionā, kurā darbojas } \\
\text { uzņēmums; } \\
\text {-regiona attīstības līmenis, kurā jaunietis } \\
\text { dzīivo. }\end{array}$ \\
\hline $\begin{array}{l}\text { Informācijas un } \\
\text { sociālais kapitāls }\end{array}$ & $\begin{array}{l}\text {-Inovācijas; } \\
\text {-informāciju tehnoloǵiju attīstība, } \\
\text { pārnese; } \\
\text {-uz zināšanām balstītas tehnolog̣ijas; } \\
\text {-kultūrvide un kultūras iezīmes; } \\
\text {-sociālā iekḷaušanās, sociālā atstumtība; } \\
\text {-sabiedrība kopumā. }\end{array}$ & $\begin{array}{l}\text {-Informācijas tehnolog̣iju loma jaunieša } \\
\text { dzīvē; } \\
\text {-sociālās vides ietekme uz indivīda } \\
\text { dzīves līmeni; } \\
\text {-sabiedrības kultūras iezīmes, kas } \\
\text { ietekmē jaunieša nākotnes mērķus. }\end{array}$ \\
\hline $\begin{array}{l}\text { Politiskais un } \\
\text { likumdošanas } \\
\text { kapitāls }\end{array}$ & $\begin{array}{l}\text {-Likumdošanas ietekme; } \\
\text {-politiskā virzība; } \\
\text {-regínonālās ekonomikas attīstība; } \\
\text {-Eiropas Savienības politiskā situācija; } \\
\text {-globalizācija; } \\
\text {-sabiedrības integrācija; } \\
\text {-attiecības ar Eiropas Savienības } \\
\text { dalībvalstīm; } \\
\text {-attiecības starp valdību un sabiedrību, } \\
\text { starp valdību un uzñēmējiem, starp } \\
\text { uzñēmējiem un sabiedrību. }\end{array}$ & $\begin{array}{l}\text {-Sabiedrības attieksme pret jaunieti kā } \\
\text { indivīdu; } \\
\text {-normatīvo aktu loma jaunieša darba } \\
\text { tiesību jomā; } \\
\text {-iespējas iegūt starptautisku pieredzi } \\
\text { citās ES valstīs, jauniešu mobilitātes } \\
\text { programmu izmantošana dažāāām } \\
\text { jauniešu aktivitātēm, ko ietekmē valsts } \\
\text { attiecības ar citām ES dalībvalstīm; } \\
\text {-jauniešiem pieejamās iespējas un } \\
\text { aktivitātes konkrētajā regiionā. }\end{array}$ \\
\hline
\end{tabular}

Avots: autores veidota tabula pēc Carayannis et.al., 2012; Filep et. al., 2013; Jacob, 1997 
Balstoties uz analizēto literatūru, autore secināja, ja nepastāv spēcīga saikne starp valsts, privātā un publiskā sektora pusēm, turpmākā valsts sekmīga attīstība tiek apdraudēta, tajā skaitā arī jauniešu iekḷaušanās darba tirgū. Nozīmīgi ir veicināt iepriekšminēto faktoru mijiedarbību.

\section{1. nodalas secinājumi/ Conclusions for Chapter 1}

Darba tirgu regulējošo ekonomisko teoriju pirmsākumi meklējami Ā. Smita (1723-1790) ekonomiskajās koncepcijās. Ā. Smita galvenie atzinumi koncentrējas uz sakarību starp preču ražošanas apjomu un tirgu ietekmējošajām sakarībām un veicamo darba pienākumu grūtības pakāpes ietekmi uz atalgojuma apmēru.

Balstoties uz 1. nodal̦ā analizēto dažādu ekonomisko teoriju skolu pārstāvju uzskatiem, būtiska ir valsts nepieciešamība iejaukties valsts darba tirgus regulěšanā.

Ekonomiskās teorijas ir nozīmīgas valsts ekonomiskās situācijas attīstībai, tās ir iespējams pielietot, koncentrējoties uz vairāku teoriju pamatlicēju atziņām, jo tajās uzsvērtie argumenti neietver ietekmējošo faktoru kopumu, ko iespējams pielāgot mūsdienām, neņemot vērā citu teoriju ekonomisko koncepciju.

Bezdarbs rodas neefektīva darba tirgus funkcionēšanas rezultātā, dažādu ārēju, no bezdarba situācijā esoša indivīda neatkarīgu faktoru rezultātā.

Bezdarbu veicina gan darbaspēka pārpalikums, gan arī indivīda neatbilstība darba tirgus prasībām. Ir aktuālas vakantās darba vietas, kurās darba devējs vēlas algot darbinieku, kam piemīt augsts kompetences līmenis attiecīgajā jomā, bet tādu darbinieku nespēj atrast, jo bezdarbnieki neatbilst darba devēja prasībām. Indivīda kompetences līmeni un vēlmi apgūt profesiju veicina komponenti socializācijas nosacījumu struktūrā, piem., attiecības gimenē, kultūrvide, zināšanas, prasmes, kompetences utt.

Bezdarba līmenis nav precīzs rādītājs, jo tajā nav iekḷautas personas, kas nav reǵistrējušās kā darba meklētāji, atrodas piespiedu dīkstāvē vai bezalgas atvalinājumā un skaitās kā nodarbinātas personas un līdz ar to bezdarbu nav iespējams konstatēt.

Gan bezdarbs kopumā, gan tieši jauniešu bezdarbs tiek uzskatīts par sociālu un ekonomisku problēmu. Bezdarbs ir ekonomiska problēma, jo tā esamība atspogul̦o resursu zaudējumus ekonomikā kopumā. Ja bezdarbnieki būtu nodarbināti, tad valsts ražošanas apjoms būtu lielāks, jo būtu lielāks pieprasījums pēc pakalpojumiem un precēm. Savukārt, mazāki būtu valsts izdevumi bezdarbnieku pabalstiem.

Bezdarba mazināšanas pasākumu izstrādē un realizēšanā jāṇem vērā reǵgionāla attīstība. Aktivitāte darba tirgū reǵionos ir atšķirīga no pilsētām. Reǵionos un mazpilsētās ekonomiski aktīvo iedzīvotāju īpatsvars ir zemāks un līdz ar to aug bezdarbs un bezdarbā esošo personu ilgums bezdarba situācijā. Atšķirīgi ir arī instrumenti, ar kuriem sekmīgāk ir iespējams cīnīties pret bezdarbu reǵionos vai lielākajās pilsētās. Ir jāapzina galvenie virzītājspēki bezdarba samazināšanai gan reǵionos, gan lielākajās pilsētās.

Reǵionālās atšş̧irības darba tirgus attiecībās, galvenokārt, nosaka darba tirgū iesaistīto pušu specifiskās īpašības, atšķirības darba tirgū iesaistīto pušu mijiedarbības veidā un reg̣ionālās telpas sociālā un ekonomiskā vide.

Efektīvākās metodes teorētiķu skatījumā, kas veicina jaunieša darba atrašanu, ir šādas:

- ǵimenes un paziņu atbalsts darba meklējumos, iesakot jaunieti amatam ieteicējam zināmā institūcijā vai uzņēmumā;

- pašnodarbinātības vai uzṇēmējdarbības uzsākšana; 
- iesaiste jauniešu bezdarba atbalsta programmās.

Jauniešu sociālā ieklaušanās darba tirgū ir saistāma ar izglîtības iegūšanu un apmācībām, kā arī darba pieredzi, kas tiek uzskatīti par „virzītājspēkiem” jaunieša karjeras uzsākšanā. Ja jaunietim veidojas pozitīva pirmā darba pieredze, tiek atvieglota jaunieša iekļaušanās darba tirgū.

Jauniešu ieklaušanos darba tirgū ietekmē tādi komponenti, kā attiecības ǵimenē, attiecības izglītības iestādē, komunikācija ar sabiedrību un līdzcilvēkiem, kultūrvide, zināšanas, prasmes, pieredze utt.

Mūsdienu ekonomiskās un tehnologiskās attīstības iespaidā radītās prasības veicina darbaspēka kvalifikācijas nozīmīgumu un sniedz spēcīgu impulsu sociālās attīstības intensifikācijā. Jāatzīmēe ka efektīva darbaspēka izmantošana industriālajā sabiedrībā, nosaka produktu konkurētspēju un veicina sociālo attīstību. Šajā kontekstā, jauniešu bezdarbs ir īpaši nevēlama parādība, samazinot jauniešu darbaspēka līmeņa efektivitāti vispārējā darbaspēka tirgū, paaugstinot sociālās izmaksas un ierobežojot sabiedrības attīstību. Jauniešu stāvoklis darba tirgū ir atkarīgs no vairākiem sociālajiem, ekonomiskajiem un politiskajiem faktoriem, tādēḷ varam secināt, ka jauniešu bezdarbs kā sociāli ekonomiska parādība ir īpaši negatīva rezultāta mijiedarbība starp šiem faktoriem.

Apkopojot dažādu autoru viedokli tika secināts, ka jauniešu bezdarbu ietekmē tādi sociālie faktori, piemēram kā sociālā iekḷaušanās un sociālā atstumtība, finansiālais stāvoklis, izglītības līmenis un karjeras iespējas, darba pieredzes neesamība vai esamība utt. Jauniešu bezdarbs ir cieši saistīts ar veiksmīgu iekḷaušanos sabiedrībā.

Jauniešu bezdarba cēlongi iedalīti šādās grupās:

- sociālie, ekonomiskie un politiskie apstākḷi (valsts, sabiedrības radīiti);

- g gimenes sociālie apstākḷi (zemas sociālās prasmes, jaunie vecāki u.c.);

- izglīî̄bas ietekme (zema kvalifikācija, nav izglīīibas);

- kultūru atšksirības (nacionālās vai etniskās minoritātes);

- veselības problēmas (hroniskas vai garīga rakstura veselības problēmas, invaliditāte);

- ekonomiskie šksēršşi, ǵeogrāfiskie apstākḷi (jaunieši lauku teritorijās, transporta nepieejamība u.c.)

Zināšanu pārnesi ilgtspējīgai attīstībai, kā arī jauniešu iekḷaušanu darba tirgū ietekmē vairāki faktori un to mijiedarbība. Zināšanu pārnesi uzskatāmi iespējams parādīt ar Helix modeli, kas ir virzîts uz sociālo (sabiedrības), akadēmisko zināšanu un valsts mijiedarbību, lai veicinātu sabiedrības zināšanu, tehnologisko kompetenču un inovāciju ilgtspējīgu attīstību. Helix modelis ir starpdisciplinārs un mijiedarbojoties, procesā iesaista visas puses. Ievērojot Helix modeļa kopsakarības, orientētas uz sabiedrību, ir iespējama jauniešu zināšanu pielāgošana darba tirgus vajadzībām. 


\section{NORMATĪVAIS IETVARS UN VALSTS POLITIKA JAUNIEŠU BEZDARBA KONTEKSTĀ/ REGULATORY FRAMEWORK AND PUBLIC POLICY IN THE CONTEXT OF YOUTH UNEMPLOYMENT}

Šajā nodậā analizēti Latvijas Republikas normatīvā ietvara un politikas plānošanas dokumenti, kas regulē darba tiesiskās attiecības un nosaka personas tiesības uz to, kādu palīdzību no Latvijas valsts vai pašvaldības iestādes ir iespējams saṇemt personai, atrodoties bezdarba situācijā. Šo normatīvo aktu analīze uzskatāmi norāda uz iespējām un ierobežojumiem, ar kuriem varētu nākties saskarties jaunietim, iekḷaujoties darba tirgū. Bezdarba situācijā esošas personas aizsardzības tiesību aktu mērķis ir veicināt personas iekļaušanos sabiedrībā un veicināt tā labklājību. Dokumenti identificē pozitīvo un negatīvo ietekmi uz bezdarba situācijā esošo personu un valsts ekonomikas attīstîbu.

Likuma "Par Latvijas Republikas starptautiskajiem līgumiem" 13. pants nosaka, ka gadījumā, ja starptautiskajā līgumā, ko apstiprinājusi Saeima, paredzēti citādi noteikumi nekā Latvijas Republikas likumdošanas aktos, tiek piemēroti starptautiskā līguma noteikumi. Tas nozīmē, ka, veidojoties pretrunai starp starptautisku un nacionālu dokumentu, tiek piemērotas starptautiskā dokumenta normas. Šo aspektu ir būtiski iegaumēt, jo indivīdam, saskaroties ar problēmsituāciju, varētu būt noderīgi iegūt padzilıinātu informāciju par starptautisko dokumentu darbību un to piemērošanas iespējām (Par Latvijas Republikas..., 1994).

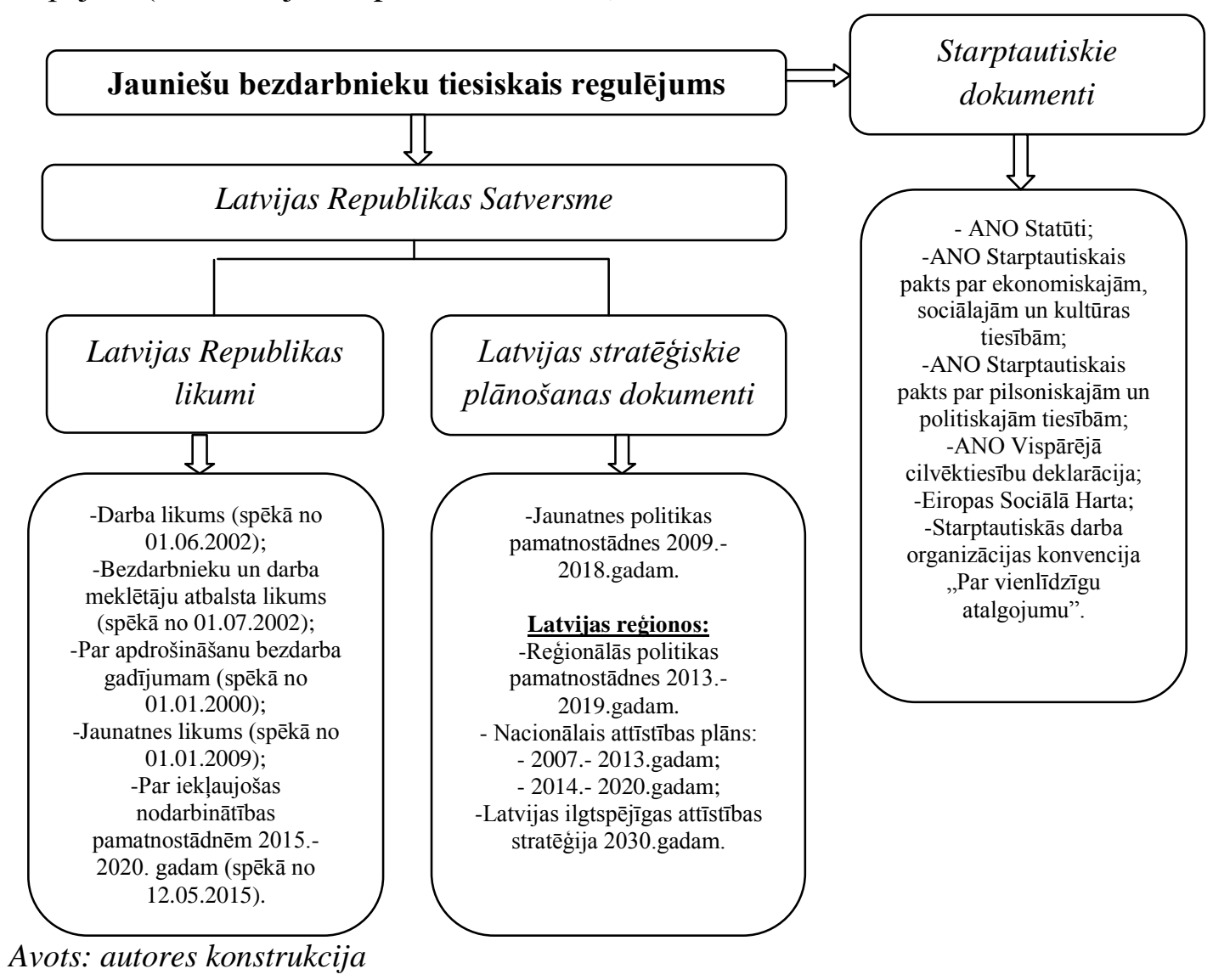

2.1. att. / Fig. 2.1. Jauniešu bezdarbnieku tiesiskā regulējuma hierarhija Latvijas Republikā/ Hierarchy of the legal framework for unemployed youth in the Republic of Latvia. 
Lai analizētu jauniešu bezdarbnieku tiesību regulējošo normatīvo un politikas dokumentu ietvaru Latvijas darba tirgū, ir jāsniedz ieskats normatīvajos dokumentos, kas ir saistošs darba tirgus politiku īstenojošajām institūcijām, ņemot vērā gan vietējos, gan starptautiskos dokumentus. Būtiskāko normatīvo un plānošanas dokumentu hierarhija Latvijas Republikā, kas tiešā veidā attiecināma uz bezdarba situācijā esošu jaunieti, redzama 2.1. attēlā.

\subsection{Starptautisko dokumentu ietvars, kas nosaka un regulē bezdarbnieku tiesības/ Framework of international documents specifying and regulating the rights of the unemployed}

Starptautiskā līmenī indivīdu tiesības (tajā skaitā arī jaunieša tiesības) regulē $A N O$ Statūti, kuros IX. nodaļas „Starptautiskā ekonomiskā un sociālā darbība” 55. pantā noteikts, ka dalība ANO ir ar mērḳi radīt nosacījumus stabilitātei un labklājībai, kas nepieciešama mierīgām un draudzīgām attiecībām starp nācijām un, kas balstītos uz tautu līdztiesības un pašnoteikšanās principu cien̄̄šanu.

ANO veicina:

- dzīves līmeņa, pilnas iedzīvotāju nodarbinātības, ekonomiskā un sociālā progresa palielināšanu un attīstību;

- starptautisko ekonomisko, sociālo, veselības aizsardzības un tamlīdzīgu problēmu risināšanu, starptautisko sadarbību kultūras un izglītības jomā;

- cilvēka tiesību un pamatbrīvību vispārēju cienīšanu un ievērošanu bez rases, dzimuma, valodas un ticības atšksirībām.” (Apvienoto Nāciju Organizācijas..., 1945).

ANO Statūti ir viens no nozīmīgākajiem starptautiskajiem dokumentiem, kas darbojas indivīdu diskriminācijas novēršanā, kas ir saistoši arī Latvijai jau no 1991. gada.

ANO Pakta par ekonomiskajām, sociālajām un kultūras tiesībām 7. pants nosaka: „Šā pakta dalībvalstis atzīst katra tiesības uz taisnīgiem un labvēlīgiem darba apstākḷiem, kas sekmē it īpaši:

- atlīdzību, kas nodrošina visiem strādājošajiem vismaz taisnīgu darba algu un vienādu atlīdzību par līdzvērtīgu darbu bez jebkādas atšķirības, turklāt sievietēm jāgarantē līdzvērtīgi darba apstākḷi ar vīriešiem, ar vienādu samaksu par vienādu darbu un apmierinošu eksistenci viṇiem pašiem un viņu ǵimenēm saskaṇā ar šā pakta noteikumiem;

- drošības un higiēnas prasībām atbilstošus darba apstākḷus;

- visiem vienādu iespēju izvirzīties darbā, pamatojoties vienīgi uz darba stāžu un kvalifikāciju;

- atpūtu, brīvo laiku un darba laika saprātīgu ierobežošanu, periodisku apmaksātu atvalinājumu, kā arī atlīdzību par svētku dienās veiktu darbu" (Starptautiskais pakts..., b.g.). ANO vispārējā cilvēktiesību deklarācijas 23. un 24. pantā noteikts, ka:

- Katram cilvēkam ir tiesības uz darbu, uz brīvu darba izvēli, uz taisnīgiem un labvēlīgiem darba apstākḷiem un uz aizsardzību pret bezdarbu.

- Katram cilvēkam, bez jebkādas diskriminācijas, ir tiesības uz vienādu atlīdzību par līdzvērtīgu darbu.

- Katram strādājošam ir tiesības uz taisnīgu un apmierinošu darba algu, kas nodrošina cilvēka cien̄̄gu dz̄ivi viņam un viṇa gimenei. Nepieciešamības gadījumā tā jāpapildina ar citiem sociālās nodrošināšanas līdzekḷliem. 
- Katram cilvēkam ir tiesības dibināt arodbiedrības un iestāties arodbiedrībās savu interešu aizsardzībai.

- Katram cilvēkam ir tiesības uz atpūtu un brīvo laiku, ieskaitot tiesības uz saprātīgu darbadienas ierobežojumu un uz apmaksātu periodisku atvaļinājumu (Vispārējā cilvēktiesību..., b.g.).

ANO Vispārējā cilvēktiesību deklarācija nosaka un uzsver katra indivīda tiesības uz līdzvērtīgu atzinību dažādos aspektos.

Latvijai ir saistošs arī ANO Pakts par pilsoniskajām un politiskajām tiesībām. Šì dokumenta 26. pants nosaka, ka visi cilvēki ir vienlīdzīgi likuma priekšā, un viniiem ir tiesības bez jebkādas diskriminācijas uz vienādu likuma aizsardzību. Jebkura diskriminācija jāaizliedz ar likumu, un likumam jāgarantē visām personām vienāda un efektīva aizsardzība pret jebkādu diskrimināciju. Ar ANO Pakta 3. pantu dalībvalstis apñemas nodrošināt vīriešiem un sievietēm vienlīdzīgas tiesības izmantot visas šajā paktā paredzētās pilsoniskās un politiskās tiesības. Tas nozīmē to, ka visiem indivīdiem, neatkarībā no dzimuma, ir tiesības uz vienlīdzīgām iespējām uzsākt darbu, sañemt līdzvērtīgu atalgojumu, bez jebkādiem ierobežojumiem (Latvijas un tās..., 2007).

ANO ietvaros pieņemtā ANO Vispārējā cilvēktiesību deklarācija nosaka vienlīdzības principu - visi cilvēki piedzimst brīvi un vienlīdzīgi savā cieñā un tiesībās. Tā arī nosaka visus iespējamos pamatus, uz kuriem cilvēks var būt diskriminēts. Attiecībā uz darbu deklarācija nosaka, ka katram cilvēkam ir tiesības uz darbu, uz brīvu darba izvēli, uz taisnīgiem un labvēlīgiem darba apstākḷiem un uz aizsardzību pret bezdarbu, uz taisnīgu un apmierinošu darba algu, ir tiesības dibināt arodbiedrības un iestāties arodbiedrībās savu interešu aizsardzībai un tiesības uz atpūtu un brīvo laiku. Deklarācija aizsargā arī pret diskrimināciju darbavietā, nodrošinot vienādu darba samaksu par līdzvērtīgu darbu (Vispārējā cilvēktiesību..., b.g.).

Tiesības uz vienlīdzību likuma priekšā un aizsardzība pret visu cilvēku diskrimināciju ir noteiktas ANO Vispārējo Cilvēktiesību deklarācijā, ANO Paktā „,Par pilsoņu un politiskajām tiesībām” un ANO Paktāa „Par ekonomiskajām, sociālajām un kultūras tiesībām”, Eiropas Pamattiesību Hartā, Starptautiskajā konvencijā „Par rasu visu veidu diskriminācijas likvidāciju”” un Eiropas Konvencijā „Par cilvēktiesību un pamatbrīvību aizsardzību”, kā arī virknē citu starptautisko tiesību aktu, tai skaitā arī ES direktīvās 97/80/EK par pierādīšanas pienākumu diskriminācijas gadījumos, kas pamatojas uz dzimumu, 2000/78/EK, ar ko nosaka kopēju sistēmu vienlīdzīgai attieksmei pret nodarbinātību un profesiju u. c. Šī ir arī viena no garantijām, kas aizsargāta ar ES Pamattiesību hartu) (Darba likums..., b.g.).

ES direktīva 2000/78/EK (2000. gada 27. novembris) nosaka kopēju sistēmu vienlīdzīgai attieksmei pret nodarbinātību un profesiju. Ar šo direktīvu ievieš kopēju sistēmu, lai nodrošinātu vienlīdzīgu attieksmi starp ES iedzīvotājiem neatkarīgi no to reliğijas vai uzskatiem, iespējamas invaliditātes, vecuma vai seksuālās orientācijas attiecībā uz pieeju darbam vai profesijai, paaugstinājumam amatā, profesionālajai izglītībai, darba nosacījumiem un arī pieeju attiecībā uz darbu vai iesaistîšanos noteiktās organizācijās (Padomes direktīva 2000/78/EC, 2012).

Nodarbinātībai un profesijai ir būtiska loma vienādu iespēju nodrošināšanā visiem, un tās lielā mērā dod ieguldījumu pilsoṇu līdzdalībā ekonomiskajā, sociālajā un kultūras dzīvē. Tomēr darba tirgū un nodarbinātības jomā ir novērojami daudzi diskriminācijas gadījumi.

Dalībvalstis aizliedz diskrimināciju nodarbinātībā vai profesijā. Tomēr šî aizlieguma piemērojamība, saturs un izpildāmība atšķiras. Līdz ar to šīs direktīvas mērḳis ir šajā jomā ieviest minimālu vispārēju sistēmu.

Direktīva attiecas uz šādām jomām: 
- nosacījumi par piekḷuvi algotai profesionālai darbībai vai pašnodarbinātībai, tostarp paaugstināšanai amatā;

- profesionālā izglītība;

- nodarbinātības un darba nosacījumi (ieskaitot atalgojumu un atlaišanu);

- iesaistīšanās un līdzdalība darba devēju vai darba ñēmēju organizācijā vai citā profesionālā organizācijā (Padomes direktīva 2000/78/EC, 2012).

ES direktīva 2000/78/EK mērķis ir apkarot gan tiešo diskrimināciju (dažāda attieksme pēc vienas skaidras īpašības), gan netiešo diskrimināciju (šķietami neitrāls noteikums, kritērijs vai prakse, kas tomēr rada aizdomas par nelabvēlīgas situācijas radīšanu vienam vai vairākiem noteiktiem cilvēkiem, vai arī diskriminācijas kurināšana). Cilvēka aizskaršanu, kas rada naidīgu vidi, uzskata par diskrimināciju. Ir paredzēta saprātīga darba vietas izveidošana, lai nodrošinātu vienādas attieksmes principu pret invalīdiem, šo principu piemērojot vien̄̄gi gadījumiem, kas nerada nepamatotas grūtības (Padomes direktīva 2000/78/EC, 2012).

Nozīmīga ir arī SDO loma. 1951. gada Konvencija Nr. 100 "Par vienlīdzīgu atalgojumu” ir viena no SDO pamatkonvencijām, Latvijā tā ir spēkā no 1993. gada 27. janvāra. SDO statūtu preambulā ir noteikts, ka starp darba apstākḷu uzlabošanas pasākumiem iekḷaujama arī vienādas darba samaksas principa nodrošināšana par vienādas vērtības darbu. Latvijā gan nevarētu skaidri apgalvot, ka visās jomās šī konvencija tiek piemērota un ievērota, un indivīdi saņem vienāda līmeņa atalgojumu attiecīgajā profesiju līmen̄̄ (Latvijas un tās..., 2007).

Savukārt, 1958. gada Konvencija Nr. 111 "Par diskrimināciju darbā un nodarbošanās jomā" uzskatāma par diskriminācijas aizlieguma pamatdokumentu SDO sistēmā, jo aptver vispārējos principus, nosakot dalībvalstij pienākumu nodrošināt aizsardzību pret jebkāda veida tiešo vai netiešo diskrimināciju nodarbinātības sfērā. Konvencija aizsargā darbinieku pret nevienlīdzīgas attieksmes pēc rases, dzimuma, ādas krāsas, politiskās vai reliǵiskās pārliecības u.c. pamatiem (Latvijas un tās..., 2007).

1961. gada starptautiskā dokumenta,,Eiropas Sociālā harta I. sadaḷā noteikts, ka Līgumslēdzējas puses atzīst tādu apstākḷu sasniegšanu, kuros var tikt efektīvi realizētas sekojošās tiesības un principi:

- ikvienam ir tiesības nopelnīt sev iztiku ar brīvi izvēlētas nodarbošanās palīdzību;

- visiem strādājošiem ir tiesības uz taisnīgu atalgojumu, kas ir pietiekams, lai nodrošinātu pienācīgus dz̄ives apstākļus sev un savām ǵimenēm;

- ikvienai personai ir tiesības izmantot attiecīgu arodorientācijas institūciju pakalpojumus ar nolūku palīdzêt izvēlēties tās personiskajām iemaņām un interesēm atbilstošu nodarbošanos;

- ikvienas Līgumslēdzējas puses pilsoņiem ir tiesības uz ienesīgu nodarbošanos jebkuras citas Līgumslēdzējas puses teritorijā uz vienlīdzīgiem noteikumiem ar šīs citas Līgumslēdzējas puses pilsoņiem, ar ierobežojumiem, kas balstās uz pamatotiem ekonomiskiem vai sociāliem iemesliem;

- migrējošiem strādājošiem, kas ir kādas Līgumslēdzējas puses pilsoṇi, un to gimenēm ir tiesības uz aizsardzību un palīdzību jebkuras citas Līgumslēdzējas puses teritorijā (Eiropas Sociālā harta..., 2003).

Eiropas Sociālās hartas II. sadaļas 1. pantā „Tiesības uz darbu” noteikts, ka, lai izmantotu efektīvu tiesību uz darbu izmantošanu, Līgumslēdzējas puses apņemas:

- uzskatīt iespējami augstākā un stabilākā nodarbinātības līmeņa sasniegšanu un uzturēšanu par vienu no saviem primārajiem mērķiem un saistībām, ar nolūku sasniegt pilnīgu nodarbinātību;

- efektīvi aizstāvēt strādājošā tiesības pelnīt savu iztiku ar brīvi izvēlētas nodarbošanās palīdzību; 
- izveidot vai uzturēt bezmaksas nodarbinātības dienestu, kas būtu pieejams visiem strādājošajiem;

- nodrošināt vai veicināt attiecīgu arodorientāciju, arodapmācību un rehabilitāciju. (Eiropas Sociālā harta..., 2003).

ES politikas plānošanas dokumentos ,jaunatne" kā jēdziens parādījās salīdzinoši nesen. Māstrihtas līgums 1993. gadā paplašināja ES politiku ar jaunatnes jomu, izvirzot, ka Eiropai vajadzētu ,veicināt jauniešu apmaiņu”. Līdz pat 2001. gadam Eiropas institūciju aktivitātes jauniešu jomā galvenokārt balstījās uz dažādu atsevišķku programmu īstenošanu, piemēram, „Jaunatne Eiropā” (1988. gads). Tomēr šīs programmas īstenošanās vienprātība tika panākta, ka jābūt lielākai sadarbībai ar citu politiku īstenošanu un ka pašiem jauniešiem ir jābūt vairāk iesaistītiem (Cienīgu darbu..., b.g.).

ES Jauniešu stratēgijā 2010. - 2018. gadam uzsvērts, ka jaunieši ir viena no visvieglāk ievainojamākajām grupām sabiedrībā, īpaši šajos - ekonomiskās krīzes apstākļos. Tās mērķis ir apvienot ES politikas, lai radītu vairāk un vienlīdzīgākas iespējas jauniešiem izglīî̄iā un darba tirgū.

Savukārt, stratēgijā Eiropa 2020 (pieņemta 2010. gada 3. martā) ir iekḷauts speciāls virziens jauniešiem - „Jaunatne kustībā”, kuras mērķis ir paaugstināt izglīîibas sistēmu darbības rādītājus un atvieglot jauniešiem ienākšanu darba tirgū, izvirzot sekojošas galvenās iniciatīvas - palielināt ES mobilitāti, nodrošināt efektīvus ieguldījumus visu līmeņu izglītības un mācību sistēmās (no pirmsskolas līdz augstākajai izglītībai); samazināt skolas priekšlaicīgu pamešanu; uzlabot jauniešu ienākšanu darba tirgū, izmantojot mācekḷa darbu, stažěšanos vai citu darba pieredzi. Salīdzinot ar esošā perioda nozīmīgāko stratēgiju ES - Lisabonas stratēg̣iju, šajā programmā jaunieši un to nodarbinātības veicināšana ir izvirzīta kā Eiropas līmeņa prioritāte, kas vieš cerības, ka jauniešu nodarbinātības rādītāji un dzīves kvalitātes līmenis uzlabosies (Cien̄̄gu darbu..., b.g.).

Programmā Jaunatne kustībā (Izveidota 2010. gada 15. septembrī) ir definētas specifiskas prioritātes jauniešu nodarbinātības veicināšanai. Programma paredz virkni pasākumu, lai palīdzētu jauniem cilvēkiem iegūt kvalifikāciju un prasmes, kas viniem vajadz̄igas, lai gūtu panākumus darba tirgū. Komisijas ierosinātie pasākumi galvenokārt pievēršas trijām jomām (Cien̄̄gu darbu..., b.g.):

- modernizēt izglītību un mācības tā, lai tās vairāk atbilstu jauniešu un darba devēju vajadzībām. Mērksis būs arī palielināt augstākās izglītības pievilcību, lai palielinātu to jauniešu īpatsvaru, kuriem ir augstākā izglītība. Darba autore uzskata, ka mūsdienās jauniešiem, kuriem nav stabila finansiālā situācija, ir grūtības iegūt profesionālo vai augstāko izglītību, jo budžeta vietu skaits ir ierobežots un tās ir pieejamas tiem jauniešiem, kuriem ir labas sekmes mācībās. Savukārt, tie jaunieši, kuri nāk no nelabvēlīgām ǵimenēm un sekmes nav bijušas pietiekami labas, nespēj integrēties izglītības sistēmā un bieži vien paliek bez profesionālās vai augstākās izglītības, un strādā gadījuma darbus. Daudzās darba vietās tiek prasīta iegūta izglītība vai vismaz uzsāktas studijas augstskolā. Atsevišksi darba devēji negatîvi vērtē studentus, kuri mācās pilna laika klātienes studijās un nevēlas tos pieņemt darbā, jo jaunietis nespēs apmeklēt darbu katru dienu un spēs strādāt tikai speciāli piemērotu darba grafiku, kuru vajadzēs apvienot ar studijām;

- atbalstît mācības un darba mobilitāti. Jaunas paaudzes ES finansējuma programmas izglîtībai un mācībām. Šì brīža ES programmas (Erasmus+, Šveices valdības stipendijas, ASV stipendijas utt.) ir pieejamākas studentiem, kuriem ir labas sekmes mācībās vai arī aktīvi iesaistās dažādās aktivitātēs pēc obligātajām 
mācībām, studentu pašpārvaldēs utt., bet netiek nodrošināta iespēja piedalīties dažādās ES programmās jauniešiem, ar ne tik labām sekmēm, vai tiem, kuriem sekmes nav izcilas tā iemesla dēḷ, ka tiek paralēli arī strādāts, lai varētu segt studiju maksu. Daļa projektu ir paredzēti jauniešiem, kas studē par budžeta līdzekḷiem, bet netiek dota iespēja saņemt stipendiju jaunietim, kurš studiju maksu sedz pats, vai kuram studiju maksu sedz gimene;

- izstrādāt jaunu ES ietvaru jauniešu nodarbinātībai, tostarp ieteikumus dalībvalstīm par darba tirgus reformu un plašāku palīdzību valstu nodarbinātības dienestiem, lai tie spētu efektīvāk atbalstīt jauniešus. Lielāka uzmanība būtu jāvērš tieši finansējuma saṇemšanas apmēram, ko jaunietis saṇem, piedaloties kādā no nodarbinātības programmām. Līdz šim finansējums dalībai programmās ir tik neliels, ka jaunietim no lauku reǵioniem ir problemātiski izbraukāt līdz darba vietai un viss finansējuma/ stipendijas apmērs jaunietim iziet ceḷa un pusdienu izdevumos.

Nodarbinātības problēmas pirmo reizi tika iekḷautas līgumos pēc Amsterdamas samita 1997. gada oktobrī (stājās spēkā 1999. gada 1. maijāâ). Līgumā tika iekḷauta VIII sadaļa par nodarbinātību, kas veicināja dalībvalstis un ES rīkoties tā, lai attīstītu koordinētu nodarbinātības stratēgiju un, it īpaši, lai veicinātu prasmīgu, apmācītu un pielāgoties spējīgu darba spēku, un darba tirgus, kas reaǵē uz ekonomiskajām izmaiņām (125.- 130. pants). 127. pantā ir noteikts, ka augsta nodarbinātības līmeņa uzdevums ir jāṇem vērā, formulējot un ieviešot „Kopienas politiku un aktivitātes” (Joint Employment..., 2007).

EK Nodarbinātības, sociālo lietu un iespēju vienlīdzības generāldirektorāts ir galvenais noteicējs moderna, inovatīva un stabila Eiropas sociālā model̦a izstrādē, kurā organiski tiek sasaistīti tādi faktori kā darba vietu pieaugums un dzīves kvalitāte, kas balstās uz visu sabiedrības locekḷu vienādām iespējām (Employment, Social..., b.g.). Direktorāts veicina saikni starp dažādiem ES ekonomiskās, sociālās un darba politikas virzieniem, nodrošinot galvenā stratēgiskā mērḳa realizāciju. Šis mērḳis ir noteikts Lisabonas stratēgijā un tas ir - ES jākḷūst par konkurētspējīgāko un dinamiskāko uz zināšanām balstīto ekonomiku pasaulē, kas ir spējīga uz pastāvīgu ekonomisko kāpumu, labākām darba vietām un ciešāku sociālo saliedētību (Dovladbekova u.c., 2008, 232).

ES sociālā progresa politikas vispārējā shēma ir šāda:

- brīva nodarbināto kustība;

- sociālā kohēzija: ESF un cilvēkresursu attīstība;

- nodarbinātības politika;

- izglītība, apmācība un jaunatnes problēmas;

- dzīves un darba apstākḷi (European Employment...., b.g.).

1997. gada novembrī Luksemburgā Eiropas Padomes ārkārtas sanāksmē par nodarbinātību tika formulēti ES nodarbinātības stratēgijas galvenie mērksi:

- cilvēku iemaņu un zināšanu (nodarbinātības spēju) uzlabošana;

- uzñēmējdarbības attīstība, atvieglojot gan biznesa uzsākšanu, gan tā funkcionēšanu;

- biznesa un darba ñēmēju pielāgošanās rosināšana;

- dzimumu vienlīdzības politikas stiprināšana (Dovladbekova u.c., 2008, 235).

Svarīga ir arī nodarbinātības iniciatīva, kas pieņemta 1994. gadā „Par nodarbinātību un cilvēkresursu attīstību”. Š̄̄s iniciatīvas mērķis bija uzlabot nodarbinātības apstākḷus nelabvēlīgajām grupām: invalīdiem, ilglaicīgi nenodarbinātajiem, sociāli atstumtajiem un jaunajiem bezdarbniekiem (Dovladbekova u.c., 2008, 235). 
Sociālo aizsardzību un nodrošinājumu iedzīvotājiem paredz arī Eiropas Savienības Ilgtspējīgas attīstības stratēgija (Pieņemta 2006. gada 6. oktobrī, Briselē), kas paredz ekonomisko, sociālo un teritoriālo iekḷaušanos. Stratēgijā atrunātas arī iedzīvotāju tiesības uz dzīves kvalitāti, veicinot sociālās neiekḷaušanās riska samazināšanu (Sustainable Development in..., 2015).

Eiropas Savienības Ilgtspējīgas attīstības stratēgijas punktā „Mūsu saistības attiecībā uz ilgtspējīgu attīstību" uzsvērts, ka ilgtspējīga attīstība nozīmē, ka pašreizējās paaudzes vajadzības jāapmierina, neapdraudot iespējas nākamām paaudzēm nodrošināt savas vajadzības. Tas ir visaptverošs ES mērķis, kas izklāstīts Līgumā un kas nosaka visu Savienības politiku un darbības. Kā arī punktā „Pamattiesību veicināšana un aizsardzība" uzsvērts, ka ES politikas jomās galvenā uzmanība jāpievērš cilvēkam, visā pasaulē veicinot pamattiesību ievērošanu, izskaužot visu veidu diskrimināciju un dodot ieguldījumu nabadzības mazināšanā un sociālās atstumtības izskaušanā (ES Ilgtspējīgas attīstības..., 2006).

ES politikas jomās galveno uzmanību pievērst cilvēkam, visā pasaulē veicinot pamattiesību ievērošanu, izskaužot visu veidu diskrimināciju un dodot ieguldījumu nabadzības mazināšanā un sociālās atstumtības izskaušanā.

ES plānošanas dokumentos kā būtiska ir uzsvērta sociālās iekḷaušanās nozīme un iniciatīvas, kas veicina sociālo iekḷaušanos gan sabiedrībā, gan darba tirgū.

Balstoties uz Latvijas Nacionālo Reformu programmas projektu ES 2020 stratēgijas īstenošanai, galvenie politikas virzieni un pasākumi bezdarba mazināšanai: strukturālas izmaiñas profesionālajā izglìtībā:

- $\quad \overline{1}$ stenot profesionālo izglītîbas iestāžu tīkla optimizāciju un diferenciāciju;

- veicināt profesionālo koledžu attīstību, nodrošināt mācību aprīkojuma modernizāciju un infrastruktūras uzlabošanu, ar mērḳi nodrošināt darba tirgum nepieciešamo vidējās profesionālās kvalifikācijas speciālistu sagatavošanu. Tādā veidā tiktu nodrošināta iespēja apgūt ne tikai profesiju, bet apgūt arī pamatprogrammas uzṇēmējdarbības uzsākšanai, grāmatvedībai, klientu apkalpošanai utt.;

- augstākās izglītības modernizācija:

- lai nodrošinātu zināšanu ekonomikai nepieciešamo zināšanu un cilvēkresursu bāzi, pilnveidot augstākās izglītības finansēšanas sistēmu, ieviešot uz rezultatīvajiem rādītājiem orientētu augstākās izglītības un zinātnes finansēšanas modeli ar mērķi nodrošināt augstākās izglītības un zinātnes resursu konsolidāciju un to efektīvu izmantošanu, saglabājot pieejamību. Veiksmīgi pozicionējot šo pasākumu, varētu tikt samazināta jauno speciālu aizplūšana ar mērḳi paaugstināt izglītības līmeni vai iegūtajai specialitātei atbilstošas darba vietas meklēšanā;

- pilnveidot studiju programmu kvalitāti un uzlabot to konkurētspēju, veicot studiju programmu kvalitātes, resursu pietiekamības un ilgtspējas starptautisku izvērtēšanu, izmantojot atbilstoši izstrādātu metodiku;

- jauniešu nodarbinātības veicināšana:

- uzlabot jauniešu ienākšanu darba tirgū, veicot integrētus pasākumus, kas ietver norādījumus, ieteikumus, mācekḷa darbu, stažěšanos vai citu darba pieredzi. Nepilnvērtīgi nodrošinot š̄ punkta aktivizēšanos darba tirgū, tiek samazināta jauniešu iespēja integrēties darba tirgū, iegūt jebkādas zināšanas no praktiskās pieredzes, kas arī samazina paša jaunieša iespēju turpmākai profesionālai darbībai;

- veicināt skolu nepabeigušo skolēnu mācību atsākšanu, nodrošinot atvieglotas zināšanu līmeņa noteikšanas un mācību atsākšanas procedūras. 
Arī ES plānošanas dokumentos uzsvērts, ka ERAF, ar Kohēzijas fonda un ESF palīdzību sniedz atbalstu:

- jaunai, novatoriskai uzņēmējdarbībai;

- atbalsta MVU;

- rada ilgtspējīgas darbavietas;

- uzlabo prasmes;

- cīnās pret nabadzību;

- veicina sociālo iekļaušanu;

- cīnās pret intelektuālā darbaspēka emigrāciju;

- veido būtiskus transporta savienojumus;

- palielina valsts pārvalžu efektivitāti utt. (Jauna kohēzijas politika...., 2014).

ES plānošanas dokumentos arī uzsvērts, ka ESF veicina darbavietu atrašanu un saglabāšanu, cīnās pret sociālo atstumtību, uzlabo izglītības kvalitāti un modernizē valsts pārvaldi, savukārt, Jaunatnes nodarbinātības iniciatīva sniedz mērķtiecīgu atbalstu jauniešiem 2014. - 2020. gadā (Jauna kohēzijas politika...., 2014).

Būtiska nozīme uznēēējdarbības attīstībā reǵionālā kontekstā ir pašvaldībai un tās aktivitātēm konkurētspējas nodrošināšanai, infrastruktūras attīstīšanai, publisko pakalpojumu pieejamības veicināšanā, uzṇēmēju aktivitāšu veicināšanā, ES finansējuma pieejamības veicināšanā u.c. darbībām, kas saistītas ar iedzīvotāju dzīves līmeņa uzlabošanu reǵionos.

EP 2010. gada 18. maija rezolūcijā par ES jaunatnes stratēgiju - ieguldīt jaunatnē, iesaistît jauniešus (Pieņemta 2009. gada 27. aprīlī, Briselē) uzvērts, ka:

- jauniešu vidū ir svarīgi izskaust jebkādu diskrimināciju, piemēram, diskrimināciju dzimuma, rases vai etniskās izcelsmes, reliǵiskās pārliecības, invaliditātes, vecuma vai dzimumorientācijas dēl;;

- ES sociālajā redzējumā jauniešus ir svarīgi uzskatīt par vienu no prioritārajām grupām;

- pieprasa pasākumus, kas nodrošinātu cieņu pret daudzveidību, kā arī bērnu un pusaudžu veiksmīgu integrāciju (iekl̦aušanos);

- aicina dalībvalstis īstenot vairāk iniciatīvu, kas nodrošinātu ieguldījumu pieprasītākajiem amatiem vajadzīgo prasmju veidošanā, un mudina dalībvalstis izglītības programmas piesaistīt darba tirgus prasībām, pieņemt īstermiņa arodizglītībai piemērojamus tiesību aktus (kur tie vēl nepieciešami) un, cik vien iespējams, īstenot prasmju apstiprināšanu un kvalifikācijas atzīšanu;

- mudina dalībvalstis, palielinot finansējumu, veicināt visu jauniešu izglītības un mācību mobilitāti, kas ḷoti palīdz gūt mācību un darba pieredzi;

- arī tajos reǵionos, kas robežojas ar ES, ir svarīga jauniešu mobilitāte, kas garantē plašāku līdzdalību jaunatnei izdevīgās Eiropas programmās;

- pārejas posmā no mācībām uz darbu ir svarīgi nodrošināt jauniešiem profesionālās orientācijas un konsultāciju iespējas;

- aicina dalībvalstis piedāvāt vairāk nodarbinātības iespēju, īstenot nelabvēlīgā situācijā esošu jauniešu sociālās aizsardzības politiku, nodrošināt vienlīdzīgas iespējas lauku un pilsētu jauniešiem un īpaši atbalstīt jaunās māmiņas;

- studiju laikā ir svarīgi iegūt praktisko apmācību uzņēmumos un iestādēs, jo pēc tam tas var palīdzēt vieglāk atrast darbu; 


\section{Starptautisko dokumentu ietvars, kas nosaka un regulē bezdarbnieka tiesības/ Framework of international documents specifying and regulating the rights of the unemployed}

\begin{tabular}{|c|c|c|}
\hline $\begin{array}{l}\text { Pieņemša- } \\
\text { nas gads }\end{array}$ & Dokuments & Pamatprincipi \\
\hline 1945 & $\begin{array}{l}\text { „Apvienoto Nāciju } \\
\text { Organizācijas Statūti” }\end{array}$ & $\begin{array}{l}\text {-Nediskriminējoša un vienlīdzīga attieksme pret indivīdu; } \\
\text {-iedzīvotāju stabilitātes un labklājīibas nodrošināšana; } \\
\text {-dzīves līmeņa, pilnas nodarbinātības, ekonomiskā un } \\
\text { sociālā progresa attīstība; } \\
\text {-starptautiska sadarbība kultūras un izglīī̄bas jomā, lai } \\
\text { veicinātu ekonomisko, sociālo, veselības aizsardzību. }\end{array}$ \\
\hline 1951 & $\begin{array}{l}\text { „SDO Koncencija Nr. } 100 \\
\text { „Par vienlīdzīgu } \\
\text { atalgojumu”" }\end{array}$ & -Darba apstākḷu uzlabošana, darba samaksas vienlīdzība. \\
\hline 1958 & $\begin{array}{l}\text { „SDO Konvencija Nr. } 111 \\
\text { „Par diskrimināciju darbā } \\
\text { un nodarbošanās jomā"”, }\end{array}$ & $\begin{array}{l}\text {-Diskriminācijas aizliegums nodarbinātības sfērā; } \\
\text {-Vienlīdzīgas attieksmes nodrošināšana. }\end{array}$ \\
\hline 1961 & „Eiropas Sociālā harta” & $\begin{array}{l}\text {-Vienlīizī̄bas principi darba tirgū, lai sasniegtu stabilu un } \\
\text { iespējami augstāku nodarbinātības līmeni. }\end{array}$ \\
\hline 1994 & $\begin{array}{l}\text { Nodarbinātības iniciatīva } \\
\text { „Par nodarbinātību un } \\
\text { cilvēkresursu attīstību” }\end{array}$ & $\begin{array}{l}\text {-Nodarbinātības apstākḷu uzlabošana nelabvēlīgajām } \\
\text { grupām: invalīdiem, ilglaicīgi nenodarbinātajiem, sociāli } \\
\text { atstumtajiem un jaunajiem bezdarbniekiem. }\end{array}$ \\
\hline 1997 & $\begin{array}{l}\text { „ES nodarbinātības } \\
\text { stratēgija” }\end{array}$ & $\begin{array}{l}\text {-Indivīda iemaņu zināšanu uzlabošana, lai paaugstinātu } \\
\text { nodarbinātības iespējas; } \\
\text {-izglītība, apmācība un jaunatnes problēmas; } \\
\text {-dzīves un darba apstākḷu sekmēšana. }\end{array}$ \\
\hline 2000 & „ES Direktīva 2000/78/EK” & 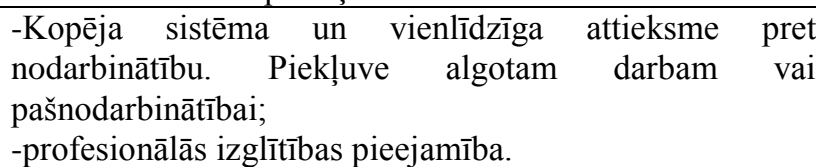 \\
\hline 2006 & $\begin{array}{l}\text { „ES Ilgtspējīgas attīstības } \\
\text { stratēgija” }\end{array}$ & $\begin{array}{l}\text {-Sociālās iekḷaušanās nozīmīgums un iniciatīvas, kas } \\
\text { veicina iekḷaušanos gan sabiedrībā, gan darba tirgū. }\end{array}$ \\
\hline 2009 & $\begin{array}{l}\text { „ES jaunatnes stratēgija - } \\
\text { ieguldīt jaunatnē, iesaistīt } \\
\text { jauniešus” }\end{array}$ & $\begin{array}{l}\text {-Diskriminācijas izskaušana jauniešu vidū; } \\
\text {-jaunieši, kā viena no prioritārajām grupām ES; } \\
\text {-jauniešu un bērnu veiksmīga iekḷaušanās; } \\
\text {-izglītības programmu piesaiste darba tirgus vajadzībām; } \\
\text {-mācību mobilitātes un izglītības finansējuma piesaiste; } \\
\text {-praktiskās apmācības apgūšana uzņēmumos mācību un } \\
\text { studiju procesā; } \\
\text {-uzñēmējdarbības kultūras veicināšana jauniešu vidū. }\end{array}$ \\
\hline 2010 & „Eiropa 2020” & $\begin{array}{l}\text {-Izglītības sistēmas rādītāju paaugstināšana; } \\
\text {-jauniešu nodarbinātības veicināšana; } \\
\text {-jauniešu ienākšanas darba tirgū uzlabošana, izmantojot } \\
\text { mācekḷa darbu, stažēšanos vai citu darba pieredzi. }\end{array}$ \\
\hline 2010 & $\begin{array}{l}\text { Programma „Jaunatne } \\
\text { kustībā”, }\end{array}$ & $\begin{array}{l}\text {-Izglītības un mācību modernizēšana, lai atbilstu jauniešu } \\
\text { un darba devēju vajadzībām; } \\
\text {-mācību un darba mobilitātes atbalstīšana. }\end{array}$ \\
\hline Bez gada & $\begin{array}{c}\text { „ANO Pakts par } \\
\text { ekonomiskajām, sociālajām } \\
\text { un kultūras tiesībām” }\end{array}$ & $\begin{array}{l}\text {-Ikviena indivīda tiesības uz taisnīgiem un labvēlīgiem } \\
\text { darba apstākliem, kas iekḷauj taisnīgu darba algu, darba } \\
\text { apstākḷus, attieksmi. }\end{array}$ \\
\hline Bez gada & $\begin{array}{l}\text { „ANO Vispārējā } \\
\text { cilvēktiesību deklarācija” }\end{array}$ & $\begin{array}{l}\text {-Ikviena indivīda tiesības uz darbu, kas nodrošina } \\
\text { cienīgus dzīves apstākḷus; } \\
\text {-noteikta aizsardzība pret bezdarbu. }\end{array}$ \\
\hline
\end{tabular}

Avots: autores veidots pēc Apvienoto Nāciju Organizācijas..., 1945; SDO Koncepcija Nr. 100 ...1951; SDO Konvencija Nr. 111..., 1957; Eiropas Sociālā harta, 1961; ES nodarbinātības stratēgija..., 1997; ES Direktīva 2000/78/EK, 2000; ES Ilgtspējīgas attīstības..., 2006 u.c. 
- ierosina jauniešu vidū veicināt uzn̦ēmējdarbības kultūru, uzlabojot komunikāciju par uzņēmējdarbību, šai nolūkā atbalstot attiecīgu Eiropas struktūru un tìklu veidošanu, kā arī mudinot jauniešus kḷūt par pašnodarbinātajiem un izmantot mikrokredīta un mikrofinansēšanas instrumentus (Eiropas jaunatnes stratēgija..., 2010).

EP 2010. gada 18. maija rezolūcijā par ES jaunatnes stratēgiju - ieguldīt jaunatnē, iesaistīt jauniešus (2009/2159(INI)) izteiktas bažas par to, ka jauniešu bezdarbnieku, nepietiekami nodarbinātu jauniešu un jauniešu, kam nav stabilas darba vietas, kḷūst aizvien vairāk.

2.1. tabulā apkopots starptautiskais dokumentu ietvars, kas attiecināms uz jauniešiem esošiem bezdarba situācijā.

2.1. tabulā apkopotajos starptautiskajos dokumentos, tādos kā ANO Statūti, SDO Konvencija Nr.100 „Par vienlīdzīgu atalgojumu”, SDO Konvencija Nr.111 „Par diskrimināciju darbāa un nodarbošanās jomā", ES jaunatnes stratēgijā - ieguldīt jaunatnē, iesaistīt jauniešus utt., uzsvērta nediskriminējošas attieksmes nozīmība pret ikvienu indivīdu, tajā skaitā arī jauniešiem.

Par sociālās iekḷaušanās nozīmīgumu uzsvērts tādos dokumentos kā ES Ilgtspējīgas attīstības stratēgija un ES jaunatnes stratēgija-ieguldīt nākotnē, iesaistīt jauniě̌us.

Starptautiskajos dokumentos nozīmīgs uzsvars likts arī uz profesionālās izglītības piemērošanu darba devēju prasībām, praktisko iemaṇu apgūšanu mācību un studiju procesā, kā arī izglītības modernizēšanu, jauniešu mobilitātes veicināšanu un intereses par uzṇēmējdarbību radīšanu jauniešos.

\subsection{Latvijas normatīvo dokumentu ietvars, kas nosaka un regulē bezdarbnieka tiesības/ \\ Framework of Latvian regulatory documents specifying and regulating the rights of the unemployed}

Nodal̦ā analizēts uz bezdarbniekiem (tajā skaitā uz jauniešiem bezdarbniekiem) attiecināmais normatīvo un politisko dokumentu ietvars, kas nosaka vienlīdzīgas indivīda tiesības darba tirgū, kā arī regulē bezdarba situācijā esošas personas tiesības uz atbalstu un iespējām kḷūt par nodarbinātu personu.

Darba tiesības Latvijā šobrīd regulē spēkā esošais Darba likums, kas tika pieņemts 2001. gada 20. jūnijā un stājās spēkā 2002. gada 1. jūnijā, nomainot Latvijas Darba likuma kodeksu, kurš bija spēkā no 1972. gada 1. oktobra. Darba likums ieviesa darba tiesībās daudz būtisku atšķirīibu salīdzinājumā ar iepriekšējo likumu. Darba likums attiecas uz visām personām, kuras ir darbspējas vecumā (Darba likums, 2001).

Darba likuma 7. pants nosaka, ka ikvienam ir vienlīdzīgas tiesības uz darbu, taisnīgiem, drošiem un veselībai nekaitīgiem darba apstākḷiem, kā arī uz taisnīgu darba samaksu. Šā panta pirmajā daḷā paredzētās tiesības nodrošināmas bez jebkādas tiešas vai netiešas diskriminācijas - neatkarīgi no personas rases, ādas krāsas, dzimuma, vecuma, invaliditātes, reliǵiskās, politiskās vai citas pārliecības, nacionālās vai sociālās izcelsmes, mantiskā vai gimenes stāvokḷa, seksuālās orientācijas vai citiem apstākḷiem (Darba likums, 2001). No Darba likuma izriet, ka ikvienam indivīdam ir tiesības tikt nediskriminētam darba tirgū un ieņemt amatu, ja indivīds ir tam atbilstošs pēc izglītības un profesionālās pieredzes, neatkarīgi no vecuma, dzimuma, rases utt. Likumā uzsvērts vienlīdzības princips.

2002. gada 1. jūlijā spēkā stājās Bezdarbnieku un darba meklētāju atbalsta likums, kura mērksis ir sniegt atbalstu bezarbniekiem, darba meklētājiem un bezdarba riskam 
pakḷautajām personām, lai veicinātu to spēju konkurēt darba tirgū. Likuma 2. pants nosaka bezdarbniekiem, darba meklētājiem un bezdarba riskam pakl̦autajām personām paredzētos aktīvos nodarbinātîbas pasākumus un bezdarba samazināšanas preventīvos pasākumus, valsts un pašvaldību kompetenci šo pasākumu īstenošanā, kā arī bezdarbnieka un darba meklētāja statusu, tiesības un pienākumus. Pēc šì likuma Latvijā valsts politiku bezdarba samazināšanas un bezdarbnieku, darba meklētāju un bezdarba riskam pakḷauto personu atbalsta jomā īsteno NVA (Bezdarbnieku un darba..., 2002).

Jāatzīmē, ka Latvijas tiesiskajā regulējumā noteikts, ka indivīds kḷūst par bezdarbnieku tikai tad, kad tas iegūst bezdarbnieka statusu. Tas nozīmē, ka personai jādodas uz NVA un jāreǵistrējas kā bezdarbniekam. Tās personas, kas nav reǵistrējušās NVA, statistikas datos netiek iekļautas kā bezdarbā esošas personas. Par nereǵistrētajām personām ziņu nav. Bezdarbnieku un darba meklētāju atbalsta likuma galvenais mērķis ir sniegt atbalstu bezdarbniekam, lai veicinātu indivīda konkurētspēju un iekḷaušanos darba tirgū.

Bezdarbnieku un darba meklētāju atbalsta likuma 3. nodaļas 10. pants „Bezdarbnieka statusa iegūšana” nosaka, ka tiesības uz bezdarbnieka statusu pēc registrēšanās NVA ir šă likuma 2. panta otrajā daļā minētajai personai, kura:

- nestrādā (nav uzskatāma par darba ņēmēju vai pašnodarbināto saskaņā ar likumu Par valsts sociālo apdrošināšanu);

- meklē darbu;

- ir darbspējīga un gatava nekavējoties stāties darba attiecībās;

- ir sasniegusi 15 gadu vecumu;

- nav sasniegusi vecumu, kas dod tiesības saṇemt valsts vecuma pensiju, vai kurai valsts vecuma pensija nav piešķirta (tai skaitā priekšlaicīgi);

- nav uzņemta pamatizglītības vai vidējās izglītības programmā klātienē;

- neveic komercdarbību vai tās komercdarbība apturēta saskaņā ar normatīvajiem aktiem;

- neatrodas ieslodzījuma vietā vai nesaņem pilnībā no valsts vai pašvaldības budžeta finansētus ilgstošas sociālās aprūpes vai sociālās rehabilitācijas pakalpojumus (Bezdarbnieku un darba..., 2002).

Tātad likums nosaka, ka jaunietis, kurš sasniedzis 15 gadu vecumu, nemācās un nestrādā, ir uzskatāms par bezdarbnieku un ir tiesīgs doties uz NVA iegūt bezdarbnieka statusu, kā arī iesaistīties NVA organizētajos bezdarba situācijā esošo personu mobilitātes pasākumos. Reǵistrējoties NVA, jaunietis iegūst arī tiesības pretendēt uz bezdarbnieka pabalstu.

Jaunatnes likums nosaka jaunieša bezdarbnieka tiesības uz dzīves kvalitāti, nepieciešamību pēc pienācīga darba, kā arī iesaisti sabiedriskajā dzīvē.

Jaunatnes likuma mērķis ir uzlabot jauniešu - personu vecumā no 13 līdz 25 gadiem - dzīves kvalitāti, veicinot vinuu iniciatīvas, darba tikumu un patriotismu, līdzdalību lēmumu pieņemšanā un sabiedriskajā dzīvē, kā arī atbalstot darbu ar jaunatni (Jaunatnes likums, 2008).

Jaunatnes likumā uzsvērta jaunieša pilnvērtīga sociālā iekļaušanās un dzīves kvalitātes nodrošināšana, kas veicina indivīda vispusīgu attīstību. Jaunatnes politika ir visās valsts politikas jomās īstenojamu mērḳtiecīgu darbību kopums, kas veicina jauniešu pilnvērtīgu un vispusīgu attīstību, iekḷaušanos sabiedrībā un dzīves kvalitātes uzlabošanos. Valsts jaunatnes politiku īsteno valsts pārvaldes iestādes un pašvaldību iestādes atbilstoši savai kompetencei, kā arī jaunatnes organizācijas un citas fiziskās un juridiskās personas saskaņā ar līgumu. Pamatuzdevumi darbā ar jaunatni ir šādi:

- atbalstīt un veicināt jauniešu iniciatīvas, radot labvēlīgus apstākḷlus vinuu intelektuālajai un radošajai attīstībai; 
- nodrošināt jauniešiem iespēju iegūt dzīvei nepieciešamās prasmes, zināšanas un kompetences neformālās izglīīîbas cel̦ā;

- nodrošināt jauniešiem iespēju lietderīgi izmantot brīvo laiku;

- nodrošināt jauniešiem viņu attīstîbas vajadzībām atbilstošas informācijas pieejamību (Jaunatnes likums, 2008).

Jaunatnes politikas pamatprincipi ir šādi:

- līdzdalības princips - nodrošināt jauniešiem iespēju iesaistīties jaunatnes politiku ietekmējošu lēmumu apspriešanā pirms to pieņemšanas;

- informācijas pieejamības princips - sekmēt jauniešu nodrošināšanu ar vinuu attīstības vajadzībām atbilstošu informāciju;

- vienlīdzīgu iespēju princips - nodrošināt jauniešiem iespēju bez jebkādas diskriminācijas aktīvi piedalīties sabiedriskās, politiskās, kultūras un ekonomiskās dzīves aktivitātēs;

- jauniešu interešu ievērošanas princips - risinot ar jaunatni saistîtus jautājumus, izvērtēt jauniešu intereses, tiesības, vajadzības un iespējas;

- labvēlīgu ekonomisko priekšnosacījumu princips - veicināt tādu apstākḷu veidošanos, kuros jauniešiem ir iespēja būt ekonomiski patstāvīgiem Latvijas iedzīvotājiem;

- jauniešu integrācijas princips - veicināt starpkultūru dialogu visos jaunatnes politikas izstrādes un īstenošanas posmos;

- mobilitātes un starptautiskās sadarbības princips - nodrošināt jauniešiem iespēju būt mobiliem, apgūt zināšanas un prasmes ārpus viṇu dzīvesvietas un veicināt citu valstu ieteikumu, kā arī labās prakses apmaiņu un ieviešanu Latvijas jaunatnes politikā (Jaunatnes likums, 2008).

Jaunatnes likumā uzsvērta jauniešu aktivitāšu nozīme turpmākās dzīves veidošanā, iekḷaujot vienlīdzības principus attiecībā uz dažādu aktīvo atbalsta pasākumu pieejamību un sociālās iekḷaušanās veicināšanu sabiedrībā un darba tirgū.

Jaunatnes likuma 8. pantā uzsvērta valsts un pašvaldības nozīme jauniešu kultūras dzīves un sabiedrisko aktivitāšu veicināšanā. Likumā noteikts, ka valstij un pašvaldībām jāveicina jauniešu darba tikums un patriotisms, neformālā izglītība, brīvprātīgais darbs, fiziskās aktivitātes un iesaistīšanās kultūras dzīvē kā būtiskus brīvā laika lietderīgas izmantošanas veids. Valsts un pašvaldības pēc iespējas atbalsta jauniešu brīvā laika lietderīgai izmantošanai nepieciešamās vides attiecīgu pielāgošanu (Jaunatnes likums, 2008).

Jaunatnes likuma 11. pantā uzsvērta jauniešu uzṇēmējdarbības veicināšanas aktualitāte - valsts veicina jauniešu komercdarbību un nodarbinātību, it īpaši:

- jauniešu apmācību komercdarbības uzsākšanas jautājumos;

- atbalstu jauniešu komercdarbības uzsākšanai;

- atbalstu jauniešu, īpaši sociālās atstumtības riskam pakḷauto jauniešu, nodarbinātības veicināšanas projektiem (Jaunatnes likums, 2008).

Jauniešu uzṇēmējdarbības veicināšanas aktualitāte plaši tiek uzsvērta arī stratēgiskajos plānošanas dokumentos, tādos kā Nacionālais attīstības plāns 2007-2013 un Nacionālais attīstības plāns 2014-2020, kā arī Reǵionālās attīstības likuma 2. pantā uzsvērta uzṇēmējdarbības veicināšanas nozīmība.

Jauniešiem, atrodoties bezdarba situācijāâ, būtiski ir tikt finansiāli nodrošinātam, tomēr ne vienmēr jaunietis ir tiesīgs pretendēt uz bezdarbnieka pabalstu. Tiesības uz bezdarba apdrošināšanas pakalpojumiem ir personām, kuras Bezdarbnieku un darba meklētāju atbalsta likumā noteiktajā kārtībā ir ieguvušas bezdarbnieka statusu (turpmāk arī - bezdarbnieks), ir apdrošinātas bezdarba gadījumam saskaņā ar likumu Par valsts 
sociālo apdrošināšanu un kurām ir šajā likumā noteiktais apdrošināšanas stāžs (Par apdrošināšanu bezdarba...., 2000).

Bezdarbnieka pabalstu izmaksu regule VSAA. Bezdarbnieka pabalstam jaunietis var pieteikties tādos gadījumos, ja

- jaunietim ir pieşķirts bezdarbnieka statuss (regulē Bezdarbnieku un darba meklētāju atbalsta likums);

- jaunieša kopējais apdrošināšanas (darba) stāžs ir ne mazāks par vienu gadu;

- ir veiktas obligātās sociālās apdrošināšanas iemaksas bezdarba gadījumam ne mazāk kā 9 mēnešus pēdējo 12 mēnešu periodā pirms bezdarbnieka statusa iegūšanas dienas (Bezdarbnieka pabalsts, 2015).

N̦emot vērā iepriekšminēto, jaunietis, kurš nav strādājis 12 mēnešu periodā vismaz 9 mēnešus, nav tiesīgs pretendēt uz bezdarbnieka pabalstu. Līdz ar to jauniešiem, kuriem nav darba pieredzes, reǵistrējoties bezdarbnieka statusā kā vienīgais mērķis var būt iesaiste bezdarbnieku mobilitātes pasākumos.

Bezdarbnieku un darba meklētāju atbalsta likuma 2. nodaļas 3. pantā „Aktīvie nodarbinātības pasākumi” iekl̦auti tādi pasākumi kā:

- profesionālā apmācība, pārkvalifikācija un kvalifikācijas paaugstināšana;

- algoti pagaidu sabiedriskie darbi - pasākumi bezdarbnieku darba iemanu iegūšanai un uzturēšanai, kuri rada sociālu labumu sabiedrībai un kurus īsteno pašvaldībās, biedrībās vai nodibinājumos bez nolūka gūt peḷnu. Par algotu pagaidu sabiedrisko darbu veikšanu bezdarbniekam izmaksā atlīdzību;

- pasākumi konkurētspējas paaugstināšanai, jo īpaši pasākumi sociālo un funkcionālo prasmju pilnveidei un psihologiskā atbalsta pasākumi, pasākumi darba tirgum nepieciešamo pamatprasmju un iemaņu, kā arī darba meklēšanas metožu apguvei, neformālās izglìtības ieguvei, tai skaitā valsts valodas apguvei, nodarbinātības pasākumi vasaras brīvlaikā personām, kuras iegūst izglīīîu vispārējās, speciālās vai profesionālās izglītības iestādēs, kā arī citi pasākumi, kas veicina bezdarbnieku un darba meklētāju konkurētspēju darba tirgū;

- darba meklēšanas atbalsta pasākumi - bezdarbnieka individuālā darba meklēšanas plāna izstrāde, bezdarbnieka profilēšana (klasifikācija secīgai iesaistei aktīvajos nodarbinātības pasākumos), piemērota darba noteikšana, informēšana par darba meklēšanas metodēm, darba meklēšanas pienākuma izpildes pārbaude un citi aktīvu darba meklēšanu veicinoši pasākumi, kas motivē bezdarbniekus un darba meklētājus aktīvāk meklēt darbu un iekḷauties darba tirgū;

- pasākumi noteiktām personu grupām, jo īpaši personām no 15 līdz 24 (ieskaitot) gadu vecumam; personām, kurām ir noteikta invaliditāte; personām sešu mēnešu laikā pēc bērna kopšanas atvalinājuma (bērna kopšanas perioda) beigām; personām, kurām līdz valsts vecuma pensijas piešķiršanai nepieciešamā vecuma sasniegšanai atlikuši ne vairāk kā pieci gadi; personām, kuras NVA ir ilgāk par vienu gadu (turpmāk - ilgstošie bezdarbnieki); personām pēc soda izciešanas brīvības atņemšanas iestādēs; personām, kurām ir alkohola, narkotisko, psihotropo vai toksisko vielu atkarība; personām, kuras aprūpē kādu gimenes locekli; personām, kuras bez darba ir ilgāk par vienu gadu; citiem bezdarbniekiem atbilstoši vietējā darba tirgus situācijai, kā arī citām politikas plānošanas dokumentos noteiktajām mērķa grupām;

- pasākumi komercdarbības vai pašnodarbinātības uzsākšanai;

- darba izmēginājumi darba vietā, kas dod iespēju noteikt profesionālo piemērotību;

- apmācība pie darba devēja; 
- kompleksie atbalsta pasākumi;

- citi ESF ietvaros paredzētie pasākumi (Bezdarbnieku un darba..., 2002).

Izvērtējot iepriekšminētos bezdarbnieku aktīvos nodarbinātības pasākumus, jāuzsver, ka likumā uzskaitīts plašs atbalsta pasākumu klāsts, kam vajadzētu ievērojami samazināt jauniešu - bezdarbnieku skaitu.

Balstoties uz iepriekšminētajiem pasākumiem, to mērķa grupām un uzdevumiem, jāsecina, ka jauniešiem- bezdarbniekiem konkrēti pasākumi ir paredzēti tikai vecuma grupā no 15 līdz 24 gadu vecumam (ieskaitot), savukārt jauniešiem no 25 līdz 29 gadu vecumam, kuri ES plānošanas dokumentos tiek iekḷauti jauniešu vecuma grupā, Latvijā atsevišksi pasākumi likumdošanas ietvaros nav paredzēti. Savukārt, balstoties uz NVA mājas lapā pieejamo informāciju par jauniešu garantijas pasākumiem Jauniešu garantija (Jauniešu garantijas pasākumi, 2015), ir ietverta šī mērķa grupa. Būtiski atzīmēt, ka ne visās aktivitātēs.

Likumā uzsvērts, ka aktīvo nodarbinātības pasākumu mērķis ir īstenot darba tirgus politiku, lai samazinātu bezdarbu un veicinātu iedzīvotāju ekonomiskās aktivitātes pieaugumu, jo īpaši lai:

- motivētu bezdarbniekus, darba meklētājus un ekonomiski neaktīvos iedzīvotājus aktīvāk meklēt darbu;

- veicinātu darba tirgus apstākliem piemēroties spējīga un apmācīta darbaspēka veidošanu;

- veicinātu indivīda konkurētspējas paaugstināšanu;

- veicinātu vienlīdzīgu iespēju radīšanu personām, kuras vēlas iekḷūt darba tirgū (Bezdarbnieku un darba..., 2002).

2.2. tabula/ Table 2.2.

Latvijas likumi, kas nosaka un regulē bezdarbnieka tiesības/ Latvian laws that apply to the unemployed

\begin{tabular}{|c|c|c|}
\hline $\begin{array}{c}\text { Spēkā } \\
\text { stāšanās } \\
\text { gads } \\
\end{array}$ & Likums & Pamatprincipi \\
\hline 2000 & $\begin{array}{l}\text { „Par apdrošināšsanu bezdarba } \\
\text { gadījumam” }\end{array}$ & $\begin{array}{l}\text {-Nosaka un regulē tiesības bezdarbnieka } \\
\text { pabalsta san̦emšanai. }\end{array}$ \\
\hline 2001 & „Darba likums” & $\begin{array}{l}\text {-Vienlīdzības princips un nediskriminējoša } \\
\text { attieksme no darba devēja puses. }\end{array}$ \\
\hline 2002 & $\begin{array}{c}\text { „Bezdarbnieku un darba meklētāju } \\
\text { atbalsta likums” }\end{array}$ & $\begin{array}{l}\text {-Kārtība kādā iegūstams bezdarbnieka statuss; } \\
\text {-konkurētspējas veicināšana darba tirgū; } \\
\text {-tiesības uz aktīvajiem nodarbinātības } \\
\text { pasākumiem un bezdarba } \\
\text { preventīvajiem pasākumiem. }\end{array}$ \\
\hline 2008 & „Jaunatnes likums” & $\begin{array}{l}\text {-Tiesības uz dzīves kvalitāti; } \\
\text {-integrācijas princips; } \\
\text {-vienlīdzības princips; } \\
\text {-attīstības vajadzībām atbilstošas informācijas } \\
\text { pieejamības nodrošināšana, prasmju un zināšanu } \\
\text { ieguves iespējamības veicināšana, darba tikuma, } \\
\text { iniciatīvas veicināšana no pašvaldības un valsts } \\
\text { iestāžu puses. }\end{array}$ \\
\hline
\end{tabular}

Avots: autores veidots pēc likumiem Par apdrošināššnu bezdarba...2000; Darba likums, 2001; Bezdarbnieku un darba..., 2002; Jaunatnes likums, 2008

Tātad likums nosaka, ka bezdarbnieku aktīvie nodarbinātības pasākumi ir galvenais virzītājspēks darba tirgus politikas efektīvai īstenošanai, līdz ar to ir būtiski šajos mobilitātes pasākumos iesaistīt pēc iespējas vairāk bezdarbniekus, vēršot arī 
pastiprinātu uzmanību uz jauniešu iesaisti šajos pasākumos, jo jaunieši ir tā sabiedrības daļa, kas veido valsts nākotnes attīstību.

2.2. tabulā uzskaitîtajos būtiskākajos likumos uzsvērtas jaunieša tiesības uz vienlīdzības principiem un nediskriminējošu attieksmi darba tirgū, tiesības uz aktīvajiem nodarbinātības pasākumiem un bezdarbnieka statusa iegūšanu, pabalstu bezdarba gadījumā, kā arī darba tirgū iekḷaujošas attieksmes saṇemšanu no atbildīgajām institūcijām.

\subsection{Stratēgeiskie plānošanas dokumenti Latvijā, kas nosaka pasākumus jauniešu bezdarba likvidēšanai/ \\ Strategic policy documents in Latvia that define measures for reducing youth unemployment}

Latvijā plānošanas dokumentos jaunieši ir noteikti kā viena no prioritārajām mērķa grupām aktīvās darba tirgus politikas pasākumos, izglītības, nabadzības un sociālās atstumtības mazināšanās jomā. Galvenie darbības virzieni šajās politikas jomās ir vērsti uz jauniešu bezdarba samazināšanu un jauniešu sociālo iekḷaušanos (sociālo integrāciju) darba tirgū, kā arī jauniešu sociālo aizsardzību un vienlīdzības principiem. Būtiska ir arī jauniešu izglītības kvalitātes un prasmju nodrošināšana.

Dokumentā Par ieklaujošas nodarbinātības pamatnostādnēm 2015.-2020. gadam uzsvērts, ka viena no pamatnostādnēm ir uzlabot nodarbinātības iespējas nepietiekami pārstāvētajām iedzīvotāju grupām, tajā skaitā mazkvalificētajiem, jauniešiem.

2005. gada 26. oktobrī LR Saeimā tika apstiprināts ilgtermiṇa konceptuālais dokuments Latvijas izaugsmes modelis: Cilvēks pirmajā vietāa. Dokumentā uzsvērts, ka galvenais izaugsmes resurss ir iedzīvotāju zināšanas un gudrība, to prasmīga izmantošana. Par izaugsmes mērķi ir izvirzīta ikviena cilvēka dažādu dzīves kvalitātes aspektu paaugstināšana, un tas sasniedzams, aktīvi izmantojot valsts iedzīvotāju uzkrāto zināšanu potenciālu (Latvijas izaugsmes modelis..., 2005).

Dokumentā uzsvērta iedzīvotāju zināšanu efektīva izmantošana, lai uzlabotu iedzīvotāju dzīves kvalitāti, tas nozīmēe, ka tiek uzsvērts arī jauniešu iesaistes nozīmīgums darba tirgū un bezdarba samazināšanas aktualitāte.

Arī Latvijas ilgtspējīgas attīstības stratēgijā lìdz 2030. gadam uzsvērta cilvēkkapitāla nozīme uz valsts nākotnes attīstības iespējām. Demogrāfiskā situācija Latvijā tagad un nākotnē ir tieši saistīta ar mūsu galvenā resursa - cilvēkkapitāla ietekmi uz ekonomisko kapitālu un tā attīstību. Nepieciešams maksimāli iesaistīt iedzīvotājus darba tirgū (Latvijas ilgtspējīgas attīstības..., 2010).

Dokumentā Latvijas ilgtspējīgas attīstības stratēgijā lìdz 2030. gadam uzsvērta arī gimenes ietekme uz jaunieša personības un prasmju veidošanos, kas ir nozīmīga jaunieša nākotnes dzīves veidošanā. Dokumentā uzsvērts, ka Latvijā, līdzīgi kā Eiropā, depopulācijai un novecošanai ir visai spēcīgi izteikta reǵionālā dimensija. Samazinoties bērnu un jauniešu īpatsvaram sabiedrībā, ilgākā laika posmā pieaugs nepieciešamība samazināt skolu skaitu mazāk apdzīvotās vietās, kas vēl vairāk veicinās cilvēku aizbraukšanu no šīm vietām. Latvijāa, līdzīgi kā vairākās citās Centrālās un Austrumeiropas valstīs, cilvēkkapitāla pamata vērtības primārais komponents ir izglītība skolā, bet otrajā vietā - vecāku ieguldījums bērnu izglītošanā un audzināšanā agrīnā vecumā. Šie komponenti noteikti jāstiprina, veicot ieguldījumus pamatskolas, vidusskolas, profesionālajā un augstākajā izglīīibā, kā arī vispārējā sabiedrības izglītošanā. Prasmes un kompetences nepieciešams pilnveidot pastāvīgi visa darba mūža laikā pieaugušo izglītībā un izglītībā darba vietās. Īpašas uzmanības lokā jābūt pirmsskolas izglītības kvalitātei un pieejamībai - gan tādēḷ, ka radoša personība 
veidojas agrīnā vecumā, gan arī tādēḷ, ka vecāku maksimāla un aktīva iesaiste darba tirgū palielina nepieciešamību rast valstiskus risinājumus arī šajā izglītības posmā (Latvijas ilgtspējīgas attīstības..., 2010).

Latvijas plānošanas dokumentos noteikts, ka viens no darba ar jaunatni uzdevumiem ir orientēts uz sociālās atstumtības riskam pakḷautajām jauniešu grupām, t.sk. jauniešiem, kas nemācās, nestrādā un neapgūst arodu. Jaunieši, kas ilgstoši nemācās, nestrādā vai neapgūst arodu pakḷauti daudzām sociālām problēmām diskriminācijai, sociālajai atstumtībai, nabadzībai, kam seko individuālās problēmas, tādām kā ticības zudums valsts iestādēm, motivācijas trūkums līdzdarboties politiskajā un sabiedriskajā dzīvē, vardarbības un noziedzības pieaugums, fizisko un garīgo slimību palielinājums, pašapziņas trūkums, alkohola un narkotiku lietošana un vēl daudzas citas individuālas, ekonomiskas un sociālo problēmu radītas sekas (Informatīvais ziņojums par jauniešu..., 2013).

Politikas dokumenta Jaunatnes politikas pamatnostādnes 2015. - 2020. gadam mērķis ir jauniešu dzīves kvalitātes uzlabošana, panākot saskaņotas jaunatnes politikas īstenošanu un tās koordināciju visos līmeņos, identificējot prioritāros rīcības virzienus un politikas rezultātus. Jaunatnes politikas būtiskākais uzdevums ir nodrošināt jauniešiem efektīvu pāreju no bērna uz pieaugušā statusu, paredzot atbilstošas aktivitātes jaunieša personības attīstībai, attīstot pakalpojumus un aktivitātes, lai veicinātu jauniešu pilnvērtīgu iekḷaušanos sabiedrībā, darba tirgū. Pievēršoties jaunatnes politikas mūsdienu izaicinājumiem būtiski stiprināt un veicināt jauniešu uzņēmību, lai vairāk jaunieši iesaistītos uzṇēmējdarībā un pilsoniskās sabiedrības aktivitātēs. Nepieciešams ir veicināt jauniešu piederīguma apziņu, kas stiprinās vinuu lojalitāti, pienākuma apziṇu un ieinteresētu attieksmi pret vidi, no kuras viṇš nāk - kā lokālā, tā reg̣ionālā, tā nacionālā līmenī. Pamatnostādnēs īpaša uzmanība tiek pievērsta jauniešu personības pilnveidei un attīstībai, sekmējot tādu zināšanu un prasmju apguvi, kas pilnveido jaunieša vispusīgu attīstību garīgi, intelektuāli un emocionāli (Jaunatnes politikas pamatnostādnes..., 2014).

Būtiski ir minēt arī Latvijas Nacionālā attīstības plāna 2014-2020 pamata būtību attiecībā uz nodarbinātības jautājumiem, kurā skaidri definēti stratēǵiskie mērķi nodarbinātības jautājumu identificēšanai un sakārtošanai Latvijā. Plāna 26. pantā minēts, ka sabiedrība atzīst, ka sociālo un reǵionālo nevienlīdzību, kā arī iespējamo nevienlīdzību var samazināt ar augstu nodarbinātības līmeni, kur katrs indivīds cenšas sasniegt produktivitāti. Tāpēc iekl̦aujoša, ilgtspējīga un konkurētspējīga ekonomikas attīstība līdzsvarotu izaugsmi dažādās tautsaimniecības nozarēs, kas uzreiz nodrošinātu pietiekamu skaitu darbavietu, saskaņojot esošās prasmes ar iedzīvotājiem un piedāvātu jaunus nodarbinātības veidus ar augstāku pievienoto vērtību un atalgojumu (Latvijas Nacionālais attīstības..., 2012).

Reǵionālās politikas pamatnostādnes 2013. - 2019. gadam nosaka Latvijas reǵionālo politiku, kuras mērķis ir sekmēt visu teritoriju straujāku attīstību un konkurētspējas pieaugumu un samazināt disproporcijas teritoriju attīstībā, teritorijām ar zemākiem attīstības rādītājiem pietuvojoties attīstītākajām teritorijām t.sk. attiecībā uz nodarbinātību. Īpaši būtiski vērst uzmanību uz pilsētu - lauku partnerību tāpēc, ka demogrāfisko izmainu radītās sekas, kā arī ekonomikas un tehnoloğiju attīstības radītās izmaiṇas ļoti asi skārušas tieši lauku teritorijas. Kā uzsvērts Berlīnes Iedzīvotāju un attīstības institūta pētījumā „Lauku nākotne. Starp stabilitāti un demogrāfisko lejupslīdi” (Krohnert et.al., 2011), vērojama tendence, ka strukturālo izmaiṇu rezultātā jaunas darbavietas tiek radītas galvenokārt pilsētās un piepilsētu teritorijā, lauku un nomaļajās teritorijās nodarbinātība samazinās. Īpaši jauni cilvēki, kas būtu jaunu ǵimeņu veidotāji, pārcel̦as uz lielākām pilsētām. Lauku telpas piedāvājums jauniem 
cilvēkiem vairs nav pievilcīgs, un tas attiecas uz visām jomām: gan kultūras un izklaides, gan darba iespējām. Nozīmīgākā kopīgā reǵionālās attīstības problēma, kas raksturīga visā valsts teritorijā, ir būtiskas sociālekonomiskās attīstības līmeņa atškkirības starp reǵioniem (Reǵionālās politikas pamatnostādnes..., 2013).

Latvijas Nacionālā attīstības plāna 2014-2020 27. pantā ietverta informācija par to, ka bezdarbniekiem ir neierobežota, fokusēta un attiecīga palīdzība no valsts, kas rosina mācīties un atgriezties darba tirgū, tiklīdz iespējams. Valsts palīdzības mērķis ir nediskriminējoša attieksme darba tirgū, jaunu kompetenču un prasmju attīstība, un kvalifikācijas uzlabošana vai pārkvalifikācija (Latvijas Nacionālais attīstības..., 2012).

Savukārt, 28. pantā minēts, ka darbā cilvēki realizē savas intereses un dotības, un uzlabo savu profesionalitāti. Nodarbinātība saistîta ar to valsti, kurā viņi dzīvo un citiem iedzīvotājiem/rezidentiem. Darbs nav tikai ikdienas uzturlīdzekḷu nodrošinājums, bet arī pašaktualizācijas metode, veids, kā uzturēt sociālās un civilās saites Latvijas iedzīvotājos (Latvijas Nacionālais attīstības..., 2012).

Darba autore pētījuma ietvaros apskata arī dokumentu kopu, kas bija spēkā laika periodā no 2012. gada līdz 2013. gada nogalei, kad tika uzsākts darbs pie pētījuma.

Savukārt Latvijas Nacionālajā attīstības plānā 2007-2013 bija minēts, ka ,cilvēku labklājību tieši ietekmē stabils darbs un pietiekams atalgojums. Zems nodarbinātības līmenis (īpaši ekonomiski vāji attīstītajās valsts dạ̦ās), ilgstošs bezdarbs (arī jauniešu vidū), sociālās atstumtības riski, nedeklarētā nodarbinātība satrauc sabiedrību. Par galvenajām sociālās vides problēmām uzskatāma sociālā noslāṇošanās un pieaugoša ienākumu atšksirība starp lauku un pilsētu iedzīvotājiem un starp centrālās daḷas un perifēro teritoriju iedzīvotājiem. Latvijā ir zemākā darba samaksa, minimālā alga un pensija ES, kas ir viens no iemesliem darbaspēka aizplūšanai uz Rietumeiropas vai Skandināvijas valstīm (Latvijas Nacionālais attīstības..., 2006).

Latvijas Nacionālajā attīstības plānā 2007-2013 uzsvars likts uz jaunu konkurētspējīgu uzñēmumu veidošanos. Ir nepieciešams veidot labvēlīgu sabiedrības attieksmi pret uzṇēmējiem un izpratni par uzṇēmējdarbības lomu valsts attīstībā un veicināt cilvēku ekonomisko aktivitāti un jaunu uzņēmumu veidošanos ar dažādu motivācijas un atbalsta mehānismu palīdzību. Īpaši nozīmīgi ir sekmēt jaunu inovatīvu uzñēmumu attīstību Latvijas reǵionos. Risināmie uzdevumi:

- veicināt sabiedrības, īpaši jauniešu, interesi kḷūt par uzņēmējiem un izveidot savus uzñēmumus, cel̦ot uzņēmējdarbības prestižu un reputāciju, kā arī realizējot uzņēmējdarbības uzsākšanas motivācijas programmas, apmācības un konsultācijas;

- nodrošināt vienotu un efektīvu atbalstu uzņēmējdarbības uzsākšanai (mentoru konsultācijas; finanšu atbalsta mehānismi - pirms sēklas granti, biznesa eņgệu tīklu atbalstīšana, sēklas fondi, mikrokredīti, investīciju garantijas, riska kapitāla fondi, resursu centri);

- izveidot atbalsta infrastruktūru jaunajiem uzṇēmumiem to agrīnās attīstības etapos (biznesa inkubatori u.c.);

- palielināt finanšu resursu (starta kapitāls, kredīti) pieejamību, mazināt administratīvās barjeras nacionālajā un pašvaldību līmenī uzṇēmējdarbības uzsācējiem;

- īpaši sekmēt uzñēmumu veidošanos Latvijas regionos, tostarp jaunu inovatīvu uzṇēmumu izveidi tradicionālajās nozarēs (Latvijas Nacionālais attīstības..., 2006).

Salīdzinot ar Latvijas Nacionālo attīstības plānu 2007-2013, Latvijas Nacionālajā attīstības plānā 2014-2020 nav likts akcents uz jauniešu kā jauno uzņēmēju pozicionēšanu darba tirgū un nepieciešamību uzņēmējdarbības attīstības veicināšanā. Ir 
akcentēta jau esošo uzṇēmumu attīstība, bet būtiski arī ir cīnīties ar bezdarba radītajām sekām jauniešu vidū, kas ir viens no nozīmīgākajiem ES prioritārajiem virzieniem. Savukārt Jaunatnes politikas pamatnostādnes 2015. - 2020. gadam ir uzvērta jauniešu uzṇēmējdarbības aktualitāte.

Latvijas Nacionālajā attīstības plānā 2014-2020 uzmanība vērsta uz uzņēmējdarbības vides attīstī̌sanu vēl lielākā mērā, neuzsverot jauniešu lomu uzṇēmējdarbības attīstībā. Plāna 18. punktā noteikts, ka sasniegtu būtisku ekonomisko labklājību, valsts un tās iedzīvotāji ir iesaistīti saglabāt biznesam draudzīgu vidi, palielinot ieguldījumus un īstenojot efektīvus pasākumus, lai veicinātu darbavietu radīšanu, cilvēku kompetenču attīstību un to konkurētspēju darba tirgū. Nodokļu sistēma ir prognozējama un konkurētspējīga vidējā termiņā, salīdzinājumā ar citām reğiona valstīm.

67. punktā minēts, ka Latvijas Nacionālā attīstības plāna 2014-2020 prioritāte „Tautsaimniecības izaugsme” ir atbilde uz makroekonomiskajiem izaicinājumiem un mums ir pieejamas iespējas, lai nodrošinātu attīstību, loti produktīvu un starptautiski konkurētspējīgu uzņēmējdarbības aktivitāti dažādās teritorijās, kā arī jaunas, uz progresīvu pētniecību un inovācijām, balstītas darbavietas. Īpaša uzman̄̄ba ir pievērsta izcilas uzņēmējdarbības vides radīšanai jau esošajiem uzṇēmējiem, kā arī jaunu darba vietu radīšanai, kas arī ir pozitīvs aspekts, jo būtiski ir radīt jaunas darba vietas.

ESF projektā ,Cien̄̄gu darbu jauniešiem” uzsvērts, ka kvantitatīva un kvalitatīva cienīga darba trūkums jauniem cilvēkiem ir problēma, ko nevar risināt izolēti. Tā attiecas uz jaunu cilvēku nodarbinātību, par pāreju no skolas uz darbu (jaunu cilvēku pārejas periodi no izglītības uz nodarbinātību ir palikuši nozīmīgi garāki un sarežg̀ìitāki), par kopējo ekonomisko situāciju darba tirgū, izglīî̄bas sistēmas kvalitāti. Viena problēma ir jauniešu iesaistīšanās darba tirgū pēc skolas beigšanas. Diemžēl daudzi jaunieši nepabeidz skolu, viņiem trūkst pamata rakstīšanas vai rēķināšanas prasmes, vai ir nepietiekošas prasmes, lai iegūtu un nodrošinātu droša un patstāvīga darba iespējas. Jauniešu bezdarbam ir dažādi iemesli, un tādēl ne vienmēr bezdarbs skar tikai tos jauniešus, kuriem ir zema kvalifikācija. Var izdalīt tos, kuriem ir zema vai nav izglītîbas un tos, kuriem ir laba izglītība. Tādēḷ arī uz problēmas risinājumu jāskatās no abu šo grupu viedokļa. Daudziem ir īstās prasmes un kvalifikācija, bet arī šì grupa saskaras ar grūtībām, jo trūkst atbilstošas informācijas par darba tirgu, ir nepietiekoši profesionālās orientācijas pakalpojumi, izpratnes trūkums par nākotnes darba iespējām un vāja karjeras plānošana (Cien̄̄gu darbu..., b.g.).

Tomēr jauniešu situācija darba tirgū un mēǵginājums nodrošināt cienīgu darbu visiem, neattiecas tikai uz bezdarba vai nodarbinātības rādītājiem. Jaunieša iespējas iegūt cienīgu darbu ietekmē vairāki faktori, piemēram, demogrāfija, pieprasījums pēc darbaspēka, valsts atbalsta mehānismi darba atrašanai, likumi darbiniekiem un darba devējiem, izglītības un apmācību kvalitāte, darba pieredze un uzṇēmējdarbības iespējas. Tādēḷ, lai risinātu jauniešu nodarbinātības iespējas, ir nepieciešama integrēta pieeja augstākminētajās jomās (Cien̄̄gu darbu..., b.g.). Darba tirgus piedāvājuma un pieprasījuma atbilstības nodrošināšanā būtiskāka loma ir izglîtības (jo îpaši profesionālās un augstākās izglītības) piedāvājumam un izglītības kvalitātei.

Izglìtības attīstības pamatnostādnēs 2014.- 2020. gadam izvirzīts izglīīîs attīstības politikas virsmērķis - kvalitatīva un iekḷaujoša izglītība personības attīstībai, cilvēku labklājībai un ilgtspējīgai valsts izaugsmei (Par izglîtības attīstības..., 2014).

Izglìtības attīstības pamatnostādnēs 2014. - 2020. gadam iekḷauti pasākumi, lai uzlabotu profesionālās izglītības un apmācības sistēmas atbilstību darba tirgus prasībām, kā arī veicinātu izglītības pasākumu īstenošanu ciešā sadarbībā ar darba devējiem, ieskaitot mehānismu izveidi izglītības satura atbilstības nodrošināšanai 
mainīgajam prasmju pieprasījumam un stiprinot darba vidē balstītu mācību nozīmi. Vienlaikus minētajās pamatnostādnēs plānots pārstrukturēt valsts atbalstu augstākās izglìtības zinātņu nozarēm atbilstoši vidējā termiņa darba tirgus prognozēm, palielinot budžeta vietu zinātnes, tehnologiju, inženierzinātnes un matemātikas programmās (Par iekḷaujošas nodarbinātības..., 2015).

2.3. tabula/ Table 2.3.

\section{Latvijas stratēǵiskie plānošanas dokumenti, kas attiecināmi uz jauniešiem bezdarbniekiem/ National strategic policy documents pertaining to youth being unemployed}

\begin{tabular}{|c|c|c|}
\hline $\begin{array}{l}\text { Pien̦emšanas } \\
\text { gads }\end{array}$ & Dokuments & Pamatprincipi \\
\hline 2005 & $\begin{array}{l}\text { "Latvijas izaugsmes modelis: } \\
\text { Cilvēks pirmajā vietā" }\end{array}$ & $\begin{array}{l}\text {-Iedzīvotāju zināšanas ir kā nozīmīgs izaugsmes } \\
\text { resurss; } \\
\text {-nozīmīga ir ikviena cilvēka dažādu dzīves kvalitātes } \\
\text { aspektu paaugstināšana. }\end{array}$ \\
\hline 2006 & $\begin{array}{l}\text { „Latvijas Nacionālais } \\
\text { attīstības plāns 2007-2013”, }\end{array}$ & $\begin{array}{l}\text {-Jaunu konkurētspējīgu uzņēmumu veidošanās } \\
\text { Latvijas regionos ar dažādu motivācijas un atbalsta } \\
\text { mehānismu palīdzību; } \\
\text {-sabiedrības, it īpaši jauniešu, intereses veicināšana } \\
\text { kḷūt par uznēēejiiem; } \\
\text {-profesionālās izglītîbas un kvalitātes sekmēšana un } \\
\text { pieejamība veicinās vieglāku jauniešu iekḷaušanos } \\
\text { darba tirgū. }\end{array}$ \\
\hline 2010 & $\begin{array}{l}\text { „Latvijas ilgtspējīgas } \\
\text { attīstības stratēğija } \\
\text { 2030. gadam” }\end{array}$ & $\begin{array}{l}\text {-Cilvēkkapitāla nozīme valsts nākotnes attīstībai; } \\
\text {-uzsvērta nepieciešamība maksimāli iesaistīt cilvēkus } \\
\text { darba tirgū. }\end{array}$ \\
\hline 2010 & $\begin{array}{l}\text { "Jaunatnes politikas } \\
\text { pamatnostādnes } \\
\text { 2015.- 2020.gadam" }\end{array}$ & $\begin{array}{l}\text {-Jauniešu dzīves kvalitātes uzlabošana; } \\
\text {-efektīvas pārejas nodrošināšana jauniešiem no bērna } \\
\text { uz pieauguša cilvēka statusu; } \\
\text {-aktivitātes jauniešu personības attīstībai; } \\
\text {-jauniešu pilnvērtīgas iekḷaušanās sabiedrībā } \\
\text { veicināšana; } \\
\text {-jauniešu uzn̄ēmības stiprināšana aktīvākai jauniešu } \\
\text { iesaistei uzņēmējdarbībā un pilsoniskās sabiedrības } \\
\text { aktivitātēs. }\end{array}$ \\
\hline 2010 & $\begin{array}{l}\text { „Profesionālās izglītības } \\
\text { iestāžu tīkla optimizācijas } \\
\text { pamatnostādnes } \\
\text { 2010.-2015. gadam" }\end{array}$ & $\begin{array}{l}\text {-Atbilstošs profesionālās izglītības materiālais un } \\
\text { tehniskais nodrošinājums, lai paaugstinātu } \\
\text { profesionālās izglītības kvalitāti un atbilstību darba } \\
\text { tirgus prasībām. }\end{array}$ \\
\hline 2012 & $\begin{array}{l}\text { „Latvijas Nacionālais } \\
\text { attīstîbas plāns 2014-2020” }\end{array}$ & $\begin{array}{l}\text {-Sociālās un reǵionālās nevienlīdzības mazināšana, } \\
\text { veicinot augstu nodarbinātības līmeni; } \\
\text {-ieklaujošas, ilgtspējīgas un konkurētspējīgas } \\
\text { ekonomikas attīstība, lai nodrošinātu pietiekamu } \\
\text { darba vietu skaitu un sekmētu jaunus nodarbinātības } \\
\text { veidus; } \\
\text {-ekonomiskās labklājības veicināšana; } \\
\text {-profesionālās izglītības un apmācības sistēmas } \\
\text { atbilstības veicināšana darba tirgus prasībām. }\end{array}$ \\
\hline 2015 & $\begin{array}{l}\text { „Par iekllaujošas } \\
\text { nodarbinātības } \\
\text { pamatnostādnēm } \\
\text { 2015.- 2020.gadam" }\end{array}$ & $\begin{array}{l}\text {-Iekļaujoša darba tirgus veidošanās; } \\
\text {-pilnvērtīga iedzīvotāju cilvēkresursu potenciāla } \\
\text { izmantošana; } \\
\text {-bezdarba sociālo seku mazināšana, atbalstot bez } \\
\text { darba palikušo cilvēku atgriešanos darba tirgū. }\end{array}$ \\
\hline
\end{tabular}

Avots: autores veidots pēc Latvijas izaugsmes modelis..., 2005; Latvijas Nacionālais attīstības...,2006; Latvijas ilgtspējīgas attīstības..., 2010; Jaunatnes politikas pamatnostādnes..., 2010; Profesionālās izglìtības iestāžu..., 2010; Latvijas Nacionālais attīitības...,2012 u.c. 
Darbaspēka pieprasījuma sagatavošana atbilstoši darba tirgus pieprasījumam ir būtiskākais uzdevums, kuru pēc iespējas veiksmīgāk jārealizē, lai samazinātu bezdarba līmeni valstī un ilgstošo bezdarbu. Arī Latvijas Nacionālajā attīstības plānā 2007- 2013 gadam uzsvērts, ka „panākot pamata un vidējās profesionālās, kā arī augstākās izglītības iestāžu piedāvāto programmu un to sniegto zināšanu un prasmju atbilstību tautsaimniecības vajadzībām, jauna cilvēka iekḷaušanās darba tirgū kḷūst ievērojami vieglāka, un kāpj izglītībā ieguldīto līdzekl̦u atdeve. Izglītības sistēmas uzdevums ir panākt izglītota cilvēka konkurētspēju darbaspēka tirgū, attīstīt cilvēkos iniciatīvu, uzn̦ēmību un radošu pieeju." Nozīmīgi ir arī turpmākajos stratēǵiskajos plānošanas dokumentos uzsvērt izglītības iestāžu nepieciešamību pēc tautsaimniecībā nepieciešamo profesionālu sagatavošanu darba tirgum.

Arī dokumentā Profesionālās izglìtības iestāžu tīkla optimizācijas pamatnostādnes 2010. - 2015. gadam uzsvērts, ka būtiski ir izveidot modernu, mūsdienu prasībām atbilstošu profesionālās izglītỉbas materiālo un tehnisko nodrošinājumu, sekmēt visu veidu resursu efektīvāku izmantošanu, paaugstinot profesionālās izglîtîbas kvalitāti un pieejamību. To īstenošana izveidos valstī diferencētu, demogrāfiskajām tendencēm atbilstošu profesionālās izglītības iestāžu tīklu un nodrošinās līdzsvarotu profesionālās izglītîbas programmu apguves iespēju piedāvājumu (regionālajā un nacionālajā līmenī), lai sagatavotu darba tirgum nepieciešamo speciālistu skaitu un nodrošinātu izglītības piedāvājuma atbilstību nodarbinātības struktūrai. Profesionālās izglītības iestāžu optimizācijas procesā tiks ievērots sadarbības princips starp valsts institūcijām, pašvaldībām un nozaru asociācijām, lai nodrošinātu elastīgu un efektīvu visu veidu resursu izmantošanu, kā arī iespēju âtri reaǵēt uz darba tirgus pieprasījuma izmaiṇām (Par Profesionālās izglītības..., 2010).

Profesionālās izglītības iestāžu tīkla optimizācijas pamatnostādnes 2010.2015. gadam dokumentā uzsvērta un apliecināta profesionālās izglītības nepieciešamība pēc pielāgošanās darba tirgus prasībām, izglītības iestādēs sagatavojot speciālistus darba tirgū nepieciešamās nozarēs. Uzsvars tiek likts uz savstarpējās komunikācijas starp izglītības iestādēm un darba devējiem nepieciešamību un aktualitāti darba tirgū, nodrošinot izglīîibas piedāvājuma atbilstību darba tirgus prasībām.

2.3. tabulā apkopoti Latvijas stratēgiskie plānošanas dokumenti, kas attiecināmi uz jauniešiem, esošiem bezdarba situācijā. Dokumentos vairākkārt uzsvērta profesionālās izglītības kvalitātes uzlabošanas ietekme uz jauniešu prasmju un zināšanu pielāgošanu darba tirgus vajadzībām, kas norāda uz nepieciešamību uzlabot komunikāciju starp izglītības iestādēm un darba devējiem, lai apzinātu tendences nozares tirgū un sagatavotu speciālistus pieprasītajās nozarēs. Cilvēkkapitālam un iedzīvotāju iesaistei darba tirgū ir nozīme valsts ekonomikas attīstībā, kas veicinās valsts ekonomisko labklājību. Tāpat uzņēmējdarbības attīstībai un jauniešu iesaistei uzn̦ēmējdarbībā ir nozīme jauniešu iekḷaušanā darba tirgū.

\subsection{Programmas un to pasākumi jauniešu bezdarba samazināšanai/ Programmes and their measures aimed at reducing youth unemployment}

Galvenās ministrijas, kas ir iesaistītas jauniešu integrēšanā darba tirgū vai izglīīibas sistēmā, ir LM kā atbildīgā institūcija par valsts politikas izstrādi bezdarba samazināšanai un IZM kā atbildīgā institūcija par valsts politikas izstrādi jaunatnes un izglìtības jomās.

Saskaņā ar EK, ESF jau kādu laiku ir bijis ES galvenais instruments, lai sagatavotu jauniešus darba tirgum. Fonds atbalsta programmas un projektus, veicinot 
strukturālās reformas, kas nodrošina piekl̦uvi apmācībai, dodot prasmes un pārliecību, kas nepieciešamas, lai attīstītos un konkurētu darba tirgū (Investing in People..., 2014).

Pēdējo gadu laikā viena no ES politikas programmas prioritātēm ir kḷuvusi jauniešu aktīvākas iesaistīšanās veicināšana darba tirgū. Attiecīgo aktivitāšu piemēri ir 2011. gada "Jaunatnes nodarbinātības ierosme" un "Jauniešu nodarbinātības pasākumu kopums", kas veicināja Jauniešu garantijas ieviešanu visās ES dalībvalstīs.

Jauniešu garantijas ieviešanu EP pieņēma 2013. gada 22. aprīlī. Lai paātrinātu Jauniešu garantijas ieviešanu un ieguldīšanu jauniešos, EK 2013. gadā uzsāka Jaunatnes nodarbinātības ierosmi un izplatīja paziņojumu Sadarbība Eiropas jauniešu labā - aicinājums vērsties pret jauniešu bezdarbu. Šīs programmas ietvaros jauniešu uzñēmējdarbībai ES diskusijās piešksirta ļoti augsta prioritāte, jo tai piemīt potenciāls radīt darbavietas un attīstīt cilvēkkapitālu. Piemēram, 2013. gadā EK publicēja paziņojumu "Rīcības plāns uzṇēmējdarbības jomā 2020.gadam". Šajā dokumentā ierosina izlēmīgi rīkoties, lai veicinātu uzn̦ēmējdarbības potenciālu Eiropā un likvidētu pastāvošos šķēeršlıs uzñēmējdarbībai (Jauniešu uzn̦ēmējdarbība: vērtības...., 2015).

Jauniešu garantijas izveidošanas dokumentā uzsvērts, ka jauniešiem ir grūti nostiprināties darba tirgū. Pašreizējā krīze ir saasinājusi šīs grūtības, un bieži vien šādos ekonomikas apstākḷlos jaunieši ir pirmie, kas zaudē darbu, un pēdējie, kas tiek pieņemti darbā. Tāpēc gan tagad, gan turpmāk ir jāīsteno īpaši jauniešiem veltīti pasākumi, un šajā saistībā EK ierosināja EP ieteikumu par Jaunatnes garantijas izveidošanu. Dalībvalstīm jānodrošina, ka jaunieši četru mēnešu laikā pēc tam, kad ir ieguvuši formālo izglītību vai ir kļuvuši par bezdarbniekiem, saņem kvalitatīvu darba, tālākizglītības, mācekḷa prakses vai stažěšanās piedāvājumu (Par jaunatnes garantijas..., 2012).

Jaunatnes garantijas koncepcija nav jaunums. Jau 1981. gadā Ziemeļu Ministru padome norādīja, ka tā ir ,sociāla situācija, kurā visiem jauniešiem tiek garantēta patiesa izglītības, mācību un darba iespēja atbilstoši indivīda cerībām, spējām un interesēm, no vienas puses, un sabiedrības vajadzībām un mērķiem, no otras puses". Jauniešiem ir jānodrošina tāds atbalsts, lai viņi varētu atrast darbu, turpināt studijas, sākt mācekḷa praksi vai stažēties. N̦emot vērā katru atsevišķo situāciju, arī nepieciešamais atbalsts būs citādāks. Lai noteiktajā periodā atrastu vēlamo darbavietu, daudziem jauniešiem pietiek ar īstermiņa un nelieliem ,iejaukšanās” pasākumiem, piemēram, ar vispārēju informāciju par profesionālo virzību, izglītību un darba tirgu. Savukārt, citiem būs nepieciešama lielāka palīdzība, kas izpaužas kā darba tirgus jaunpienācēja novērtěšana, piemērotu vakanču sameklēšana, kā arī vajadzības gadījumā neliels mācību kurss CV rakstǐšanā. Vēl citiem, parasti nelabvēlīgākā situācijā esošiem jauniešiem (piemēram, jauniešiem ar vājām prasmēm vai citiem šķēršliem), palīdzēs padzilı̄ināti, ilglaicīgāki, kā arī sarežg̀ītāki ,iejaukšanās” pasākumi un materiāli piedāvājumi, tādējādi nodrošinot, ka arī šie jaunieši var izmantot Jaunatnes garantijas priekšrocības. „Jaunatnes garantijas” mērķis ir gādāt par to, lai neviens netiktu atstāts novārtā un lai visiem jauniešiem, kuriem nav izdevies pašiem atrast piedāvājumu, noteiktā periodā piedāvātu darba, tālākizglītības, mācekḷa prakses vai stažěšanās iespēju (Par jaunatnes garantijas..., 2012).

EP 2013. gada 22. aprīḷa ieteikumā par garantijas jauniešiem izveidi minētā vecuma grupa ir jaunieši vecumā līdz 25 gadiem. Saskaņā ar ESF regulas 2014. 2020. gadam projektā noteikto Jauniešu garantija iekḷauj jauniešus vecumā līdz 25 gadiem, ar iespēju dalībvalstij plānot pasākumus arī jauniešiem vecumā līdz 29 gadiem ieskaitot. Minimālais vecuma slieksnis šajos dokumentos netiek noteikts. Saskaņā ar Jaunatnes likumu jaunietis ir persona vecumā no 13 līdz 25 gadiem, bet Darba likumā noteiktais nodarbinātības aizlieguma ierobežojums ir 15 gadi. LM un IZM vienojās 
sniegt atbalstu arī jauniešiem vecumā no $25 \mathrm{l}$ lidz 29 gadiem (Jauniešu garantijas pasākumi, 2015; Jauniešu garantija. 3. soḷi..., b.g.).

Latvijā NVA ir galvenā atbildīgā institūcija par jauniešu bezdarbnieku un darba meklētāju atbalstu pārejai no bezdarba vai ekonomiskās neaktivitātes uz mācībām vai nodarbinātību. NVA īsteno arī Jaunatnes garantijas pasākumus (Latvijā norisinās no 2014. līdz 2020. gadam) (Jauniešu garantija. 3. soḷi..., b.g.), un tajos ietilpst sekojoši pasākumi:

- karjeras konsultācijas;

- konkurētspējas paaugstināšanas pasākumi (individuālas konsultācijas un grupu nodarbības (kursi, semināri, lekcijas) darba meklēšanas metožu apguvei, psihologiskam atbalstam;

- konkurētspējas paaugstināšanas pasākumi darba tirgum nepieciešamo prasmju apguvei;

- darbnīcas jauniešiem, kurās tiek sniegta iespēja iepazīties ar profesionālajām izglītības programmām;

- neformālās izglītības programmu īstenošana;

- profesionālās tālākizglîtības un profesionālās pilnveides programmu īstenošana;

- pirmā darba pieredze jaunietim;

- subsidētā darba vieta jauniešiem bezdarbniekiem;

- darbam nepieciešamo iemaņu attīstība nevalstiskajā sektorā;

- atbalsts pašnodarbinātības un uzñēmējdarbības uzsākšanai (konsultatīvu un finanšu atbalsta pasākumu sniegšana);

- atbalsts jauniešu reǵionālajai mobilitātei.

Detalizēts NVA Jauniešu garantijas pasākumu apraksts pievienots 1. pielikumā un izpilde par NVA Jauniešu garantijas pasākumiem pievienota 2. pielikumā.

Arī VIAA īsteno Jauniešu garantijas pasākumu - profesionālās izglītības programmu īstenošana (1-1.5 gadi), kurā 31.12.2014. faktiski bija iesaistīti 2505 izglìtojamie (Nikolajeva, 2015).

NVA direktore Inese Kalvāne „DNB Latvijas barometra” pētījumā „Izglītība un jauniešu iesaistǐšanās darba tirgū" uzsvērusi, ka pašlaik Latvijā jauniešiem, kuri vēlas iegūt darba pieredzi, tāda iespēja tiek piedāvāta, tajā skaitā NVA jauniešu atbalstu pasākumu ietvaros. Piemēram, jaunieši bezdarbnieki vecumā no 15 līdz 24 gadiem Jauniešu garantijas atbalsta pasākumā Darbnīcas jauniešiem var iepazīt trīs profesionālās izglītības programmas, katrā programmā darbojoties trīs nedēlas, lai iepazītos ar to specifiku, teorētisko un praktisko ievirzi. Savukārt, jaunieši bezdarbnieki vecumā no 18 līdz 29 gadiem 12 mēnešu laikā var iesaistīties atbalsta pasākumā „Pirmā darba pieredze jaunietim", saņemot vismaz valstī noteiktās minimālās algas apmēru. Pasākuma mērķis ir sekmēt jauniešu bezdarbnieku integrēšanu darba tirgū, vienlaikus veicinot pastāvīgas darba vietas izveidi un jauniešu bezdarbnieku pastāvīgu nodarbinātību. Atbalsta pasākums „Subsidētā darba vieta jauniešiem bezdarbniekiem (pasākumi noteiktām personu grupām)" paredzēts jauniešiem vecumā no 18 līdz 29 gadiem (šis pasākums ir noteiktām personu grupām, piem., personām ar invaliditāti, sociāli maznodrošinātām utt.). Pasākuma mērḳis ir sekmēt jauniešu iekḷaušanos sabiedrībā, konkurētspēju un iekārtošanos pastāvīgā darbā, kā arī darba prasmju un iemaņu pilnveidošanu, organizējot jauniešu nodarbināšanu nelabvēlīgākā situācijā esošiem bezdarbniekiem un bezdarbniekiem - invalīdiem (Izglītība un jauniešu..., 2015).

I. Kalvāne īpaši uzsvērusi arī jauniešu garantijas atbalsta pasākumu Atbalsts pašnodarbinātības un uzñēmējdarbības uzsākšanai, kas palīdz jauniešiem bezdarbniekiem vecumā no 18 līdz 29 gadiem uzsākt komercdarbību vai 
pašnodarbinātību un veiksmīgi darboties izvēlētajā jomā ne mazāk kā divus gadus. Pasākuma laikā bezdarbnieki saņem nepieciešamo palīdzību un atbalstu komercdarbības vai pašnodarbinātības uzsākšanai - konsultācijas biznesa plāna sagatavošanā un izstrādāšanā, konsultācijas biznesa plāna īstenošanas pirmajā pašnodarbinātības vai komercdarbības gadā, komercdarbības dotāciju biznesa plāna īstenošanai (Izglītība un jauniešu..., 2015).

Savukārt, LB Monetārās politikas pārvaldes Makroekonomikas analīzes daḷas vecākais ekonomists $\mathrm{O}$. Krasnopjorovs uzsvēris, ka nodarbinātības atbalsta programmu rezultativitātes rādītājs var būt tikai viens - jāapzina, kāds ir to cilvēku īpatsvars, kas pēc programmu pabeigšanas atraduši pastāvīgu darbu un ir noturējušies šajā darba vietā vismaz vienu gadu. Pat pēc perfektu kvalifikācijas pilnveides semināru beigšanas cilvēks var neatrast darbu, jo darbaspēka pieprasījums ir zemāks par piedāvājumu. No otras puses, ir svarīgi, lai cilvēki apgūtu darba tirgū nepieciešamās profesijas atbilstošā apjomā un kvalitātē un pēc apmācības kursu pabeigšanas iekārtotos pastāvīgā darbā pēc iespējas ātrāk, jo ar laiku var tikt zaudētas ne vien iegūtās profesionālās prasmes, bet arī apñēmība atrast darbu, kuru mēǵina celt vairāki NVA mācību semināri (Krasnopjorovs, 2011).

Darba autore atzīmē, ka šo pasākumu efektivitāti nav iespējams noteikt, ja netiek apzināti pasākumos iesaistîtie jaunieši un noskaidrots to viedoklis par pasākuma kvalitāti. Kā arī noskaidrots tas, vai pieredze, iesaistoties kādā pasākumā, ir veicinājusi jaunieša iekḷaušanos darba tirgū. Lai detalizēti izpētītu šo jautājumu, ir nepieciešams veikt padziļinātu pētījumu sadarbībā ar NVA. Darba ietvaros autore šādu pētījumu neveica, jo darba galvenais uzdevums ir apzināt ārējos faktorus, kas ietekmē jauniešu iekļaušanos darba tirgū Latvijā.

Eurofound pētījumā secināts, ka veiksmīgākie atbalsta programmu projekti ir balstîti uz sekojošiem pamatprincipiem:

- prasmju attīstība, apmācības un darbā iekārtošanās - integrēta pieeja nodarbinātības veicināšanā;

- nodrošināt ātru darba uzsākšanu pēc mācībām, ir jāsaglabā prasmes;

- jādod iespēja indivīdam kontrolēt un ietekmēt savu karjeras ceḷu, lai viṇš varētu veikt izvēles;

- atbalstīt darba devējus ar darbā pieņemšanu, apmācībām darbiniekiem ar īpašām vajadzībām;

- darba tirgus orientācija - visiem projektiem jābūt pieejamiem un jāsniedz iespēja piedalīties tiem, kuri ir spējīgi pēc tam izmantot iegūtās zināšanas un pieredzi, un kuri ir ieinteresēti tajos;

- efektīvi projekti attīstās ilgtermiṇā, nevis īstermiņā (NEETs Young People..., 2012, 71).

Par jauniešu aktivitāšu veicināšanu un mobilitāti Latvijā ir atbildīga arī JSPA. JSPA ir IZM pakļautībā esoša tiešās pārvaldes iestāde, kuras mērķis ir veicināt jauniešu aktivitāti un mobilitāti, līdzdalību jaunatnes brīvprātīgā darba, neformālās izglìtîbas un jaunatnes informācijas programmās un projektos, kā arī veicināt jauniešu neformālo izglītību saistībā ar mūžizglītību.

Savukārt, pašvaldībās darbs ar jauniešiem pārsvarā tiek īstenots sadarbībā ar jauniešu centriem un jaunatnes lietu speciālistiem. Jauniešu centri ir viens no pašvaldības pamata instrumentiem darbā ar jaunatni, kur notiek aktīvs darbs ar jauniešiem.

Jauniešu centros jauniešiem tiek piedāvātas sekojošas aktivitātes:

- nodrošinātas lietderīga brīvā laika izmantošanas iespējas; 
- sekmēta nepieciešamo zināšanu un prasmju apgūšana ārpus formālās interešu izglītības, īstenojot dažādus neformālās izglītības pasākumus, projektus un programmas;

- labvēlīgu apstākḷu radīšana jauniešu intelektuālajai un radošai attīstībai;

- jauniešu līdzdalības veicināšana jaunatnes organizācijās, jauniešu iniciatīvu grupās un brīvprātīgajā darbā;

- nodrošināta piekḷuve jauniešu vajadzībām un interesēm atbilstošai informācijai;

- sekmēta sociālās atstumtības riskam pakḷauto jauniešu iekḷaušana vienaudžu vidē;

- sekmēts starpkultūru dialogs jauniešu mērķauditorijā;

- organizētas jauniešu individuālās un grupu konsultācijas par aktuālām tēmām;

- veicināta sadarbība ar jaunatnes darbā iesaistītajām personām vietējā, reǵionālā un starptautiskā līmenī;

- sekmēta pašvaldības jauniešu iesaistīšanās vietēja, reǵionāla, valsts un starptautiska mēroga pasākumos, projektos un programmās jaunatnes jomās (Informatīvais ziņojums par..., 2013).

Jauniešu iesaiste un dalība jauniešu centru rīkotajos pasākumos sekmē jaunieša iekḷaušanos gan darba tirgū, gan sabiedrībā, kā arī veicina papildus zināšanu apgūšanu un individuālo interešu izveidošanos.

\section{2. nodaļas secinājumi/ Conclusions for Chapter 2}

Tiesības uz nodarbinātību un vienlīdzīgu attieksmi ES darba tirgū ir ikvienam indivīdam, neatkarīgi no tā reliǵiskās piederības, tautības, rases, veselības stāvokḷa utt., to regulē vairāki ES dokumenti tādi kā Eiropas Sociālā harta, ANO Statūti, ANO Vispārējā cilvēktiesību deklarācija, ES Direktīva 2000/78/EK utt.

Darba autore uzsver, ka jaunieša kā bezdarbnieka diskriminācija attiecībā pret pieredzes bagātiem indivīdiem, kas pretendē uz to pašu vakanto pozīciju kā jaunietis, balstoties uz ES starptautisko dokumentu ietvaru, ir kvalificējama kā prettiesiska.

Izglīitibas sistēmas kvalitātes paaugstināšana un nozīmīga uzsvērta tādos ES plānošanas dokumentos kā Eiropa 2020, programma Jaunatne kustībā, ES jaunatnes stratēgija-ieguldìt jaunatnē, iesaistīt jauniešus un,, ES nodarbinātības stratēgijā.

Vienlīdzības principi attieksmē pret darbiniekiem, atalgojuma sistēmā, darba apstākḷu sekmēšanā, aizsardzībai bezdarba situācijā, tiesības darba tirgū uzsvērtas tādos starptautiskajos dokumentos kā ANO Statūti, SDO Konvencija Nr. 100 „Par vienlīdzīgu atalgojumu”, SDO konvencija Nr.111 „Par diskrimināciju darbā un nodarbošanās jomā”, Eiropas Sociālajā hartā un ANO Vispārējā cilvēktiesību deklarācijāa.

Starptautiskais dokumentu ietvars, kas attiecināms uz jauniešiem bezdarbniekiem ir pilnvērtīgs un detalizēts, konkrētajā dokumentā pievēršot uzmanību problēmjautājuma risinājumiem. Tomēr starptautisko dokumentu ietvarā netiek uzsvērtas atbildīgās institūcijas dokumentā uzsvērto risinājumu realizēšanai.

Bezdarbnieka tiesību regulējošais nozīmīgākais LR likums ir Bezdarba un darba meklētāju atbalsta likums, kas regulē bezdarba situācijā esošas personas tiesības uz darbu, uz pienākošos atbalstu gan finansiāli, saņemot bezdarbnieka pabalstu, ko regulē VSAA, gan iesaistoties aktīvajos nodarbinātības veicināšanas pasākumos, lai veicinātu personas konkurētspēju darba tirgū. Aktīvie nodarbinātības pasākumi ir efektīvs instruments darba tirgus politikas īstenošanai un bezdarbnieka iekļaušanai darba tirgū.

Ne mazāk būtisks ir arī LR Darba likums, kas visiem strādājošajiem nosaka tiesības un pienākumus, kā arī regulē darba devēju attieksmi pret darbinieku. Šis likums 
saistošs bezdarba situācijā nonākušai personai, kad darba devējs vēlas pārtraukt darba tiesiskās attiecības, vai arī darba ñēmējs vēlas izbeigt darba attiecības.

Savukārt, LR Jaunatnes likums nosaka jaunieša tiesības uz dzīves kvalitāti, iekḷaušanās principus, vienlīdzības principus, $k \bar{a}$ arī paredz indivīda attīstības vajadzībām atbilstošas informācijas pieejamību, prasmju un zināšanu apguves pieejamību, kā arī darba tikuma veicināšanu.

Latvijas stratēǵiskajos plānošanas dokumentos, tādos kā Latvijas Nacionālais attīstības plāns 2007.- 2013. gadam un Jaunatnes politikas pamatnostādnes 2015.2020.gadam, uzsvērta jauniešu intereses veicināšana par uzņēmējdarbību. Savukārt Latvijas Nacionālais attīstības plāns 2014.- 2020.gadam nav uzsvērta jauniešu uzņēmējdarbības veicināšana. Šajā attīstības plānā ir uzsvērta uzṇēmējdarbības attīstības veicināšanas aktualitāte kopumā valstī, neizdalot atsevišķas indivīdu grupas- Latvijas Nacionālajā attīstības plāna 2014.- 2020. gadam viens no mērķiem ir radīt līdzvērtīgus dzīves un darba apstākļus visiem iedzīvotājiem, neatkarīgi no to dzīves vietas, sekmējot uzṇēmējdarbību reǵionos un veicinot infrastruktūras attīstību un pieejamību.

Latvijas stratēgiskajos dokumentos Latvijas ilgtspējīgas attīstības stratēgijā 2030. gadam un Latvijas izaugsmes modelis: Cilvēks pirmajā vietā uzsvērta cilvēkkapitāla nozīme valsts attīstībā.

Tādos Latvijas stratēǵiskajos dokumentos kā Profesionālās izglìtības iestāžu tīkla optimizācijas pamatnostādnes 2010.- 2015.gadam, Latvijas Nacionālais attīstības plāns 2007.-2013. gadam un Latvijas Nacionālais attīstības plāns 2014.-2020. gadam uzsvērta profesionālās izglītības un apmācības sistēmas kvalitātes sekmēšana un pielāgošana darba tirgus prasībām.

Balstoties uz Latvijas stratēǵisko plānošanas dokumentu ietvara analīzi jāsecina, ka plānošanas dokumentos nav skaidri definētas konkrētās institūcijas un uzdevumi, kuri valsts institūcijām būtu jāveic, lai veicinātu jauniešu bezdarbnieku iekḷaušanos darba tirgū. Dokumentos tiek uzsvērts, ka būtiska ir jauniešu zināšanu un profesionālo prasmju pielāgošana darba tirgus prasībām, jauniešu uzñēmējdarbības vides attīstīšana, jauniešu dzīves kvalitātes uzlabošana utt., savukārt netiek noteiktas atbildīgās valsts institūcijas.

Latvijā jauniešu bezdarbnieku iekḷaušanai darba tirgū tiek organizēts pasākumu kopums "Jaunatnes garantija", kas paredz pasākumos iesaistīt jauniešus vecumā līdz 29 gadiem. Latvijā galvenā atbild̄̄gā institūcija par Jaunatnes garantijas pasākumu organizēšanu un koordinēšanu ir NVA, kas ir arī galvenā atbildīgā institūcija par jauniešu bezdarbnieku un darba meklētāju atbalstu pārejai no bezdarba vai ekonomiskās neaktivitātes uz mācībām vai nodarbinātību. Jaunatnes garantijas pasākumu norises periods Latvijā: 2014. -2020. gads.

Jaunatnes garantijā ietilpst tādi pasākumi kā karjeras konsultācijas, konkurētspējas paaugstināšanas pasākumi, darbnīcas jauniešiem, neformālās izglītības programmas, profesionālās tālākizglītības un profesionālās pilnveides programmas, pirmā darba pieredze jaunietim, subsidētā darbavieta jauniešiem bezdarbniekiem, darbam nepieciešamo iemaņu attīstība nevalstiskajā sektorā, atbalsts pašnodarbinātības un uzñēmējdarbības uzsākšanai un atbalsts jauniešu reǵionālajai mobilitātei.

Pašvaldību līmen̄̄ par jauniešu aktivitāšu veicināšanu un mobilitāti Latvijā ir atbildīga JSPA, kas atrodas IZM padotībā. JSPA mērķis ir veicināt jauniešu iesaisti aktivitātēs reǵionā un jauniešu mobilitāti, līdzdalību jaunatnes brīvprātīgajā darbā, iesaisti neformālās izglītības un jaunatnes informācijas programmās un projektos, kā arī veicināt jauniešu neformālo izglītību saistībā ar mūžizglītību. 


\section{DARBA TIRGUS UN BEZDARBA TENDENCES LATVIJĀ UN CITĀS EIROPAS VALSTĪS/ \\ LABOUR MARKET AND UNEMPLOYMENT TRENDS IN LATVIA AND OTHER EUROPEAN COUNTRIES}

Lejupslīde pasaules finanšu tirgos, kas skāra pasaules ekonomiku 2008. gada vidū, ietekmēja pasaules ekonomiku tās kopumā, kā arī tai bija liela ietekme uz darbaspēka tirgu Eiropas valstīs. Pēc vairāku gadu ekonomiskās izaugsmes un salīdzinoši augsto darbaspēka nodarbinātības līmeni, tas izraisīja ES nodarbinātības līmeņa samazināšanos, kas nebija reǵistrēts vairākus gadu desmitus (Balan et al., 2012).

Piemēram, vairumā OECD valstu darba tirgos ir pieredzēts darba vietu skaita pieaugums, pieprasot vairāk abstraktas un sarežğìtas prasmes no potenciālajiem kandidātiem, salīdzinot ar manuālajām un ikdienas prasmēm. Tajā pašā laikā Eiropa ir piedzīvojusi nepieredzētu imigrantu pieaugumu. Lielākā daļa no pieejamās ekonomikas literatūras par faktoru analīzi izskaidro tehnologiskās izmaiņas un sekas no tirdzniecības un ārzonām (Acemoglu et.al., 2010).

Saskaņā ar SDO, globālās atveseļošanās pavājināšanās 2012. un 2013. gadā vēl vairāk saasinājusi jauniešu nodarbinātības krīzi un rindas uz brīvajām darba vietām bija kḷuvušas laika ziņā ilgākas, kā rezultātā daudzi jaunieši izvēlas tikai studēt. Ilgstoša darba tirgus krīze liek pašreizējās paaudzes jauniešiem būt mazāk izvēlīgiem par darba pienākumu veidu, ko ir gatavi veikt. Arvien vairāk jaunieši izvēlas strādāt nepilna laika darbu vai pagaidu darbu. Drošas un stabilas darbavietas, kas bija pirms krīzes periodā un ir kā norma iepriekšējām paaudzēm ar attīstītu ekonomiku - ir kḷuvušas mazāk pieejamas mūsdienu jaunatnei (Global Employment Trends..., 2013).

Līdztekus jaunieša izglītības līmenim, sociālajām un profesionālajām prasmēm, jaunieša iespējas iekḷauties darba tirgū ietekmē arī reǵionālās atšķirības gan valstiskā, gan starptautiskā līmenī. Situācija Latvijā būtiski mainījās pēc tās iestāšanās ES, paplašinoties darba tirgiem, kad Latvijas darba ņēmēji devās strādāt uz citām valstīm, kā arī Latvijā ieradās viesstrādnieki. Lielākas iespējas veiksmīgi iekḷauties darba tirgū ir bezdarbniekiem, kas dz̄̄vo galvaspilsētā vai lielākajās pilsētās, kurās ir attīstìtāka infrastruktūra, ražošana, lielāks iedzīvotāju blīvums un līdz ar to arī pieprasījums pēc pakalpojumiem un produkcijas, kas rada iespēju nodarbināt lielāku iedzīvotāju ippatsvaru.

\subsection{Ekonomisko rādītāju analīze Latvijā/ Analysis of economic indicators for Latvia}

Pēc EM ziņojuma „Informatīvais ziņojums par darba tirgus vidēja un ilgtermiņa prognozēm" 2013. gadā tika novērota pakāpeniska ekonomisko aktivitāšu palielināšanās, kas pozitīvi ietekmēja situāciju darba tirgū - pieauga nodarbinātîba un samazinājās ekonomiskās krīzes izraisītais augstais bezdarbs. Tajā pašā laikā atsevišksas iedzīvotāju grupas, īpaši personas ar zemu izglītības līmeni un kvalifikāciju, gados vecāki cilvēki, kā arī jaunieši, situācijas uzlabošanos izjuta vājāk.

Uzlabojumus darba tirgū neizjūt iedzīvotāji, kas dz̄ivo Latvijas lauku reǵionos, ārpus republikas pilsētu centriem vai ārpus Latvijas lielāko mazpilsētu centriem. Reǵionos atrast darbu ir vēl aizvien sarežg̃ìti, jo bezdarbniekiem nākas saskarties ar dažādiem ārējiem no paša neatkarīgiem faktoriem, kas ietekmē darba atrašanas iespējas. Līdz ar to darba autore par nozīmīgu uzskatīja aptaujāt jauniešus no lielākajām Latvijas Republikas pilsētām, atsevišksi izdalot lauku reǵionus, lai apzinātu situāciju darba tirgū (skatīt. 4. nodaļu). 
Latvijas EM Tautsaimniecības struktūrpolitikas departamenta direktora vietnieks J. Salmiņšs uzskata, ka Latvijas darba tirgū situācija turpinās uzlaboties, tomēr uzlabojumi kḷūs arvien mērenāki, ko ietekmēs augstāks bāzes efekts darba tirgū. Nodarbinātības kāpums būs cieši saistīts arī ar ekonomikas izaugsmes tempiem, ko, savukārt, ietekmēs tendences ārējā vidē (Situācija Latvijas darba..., 2015).

Latvijā novērojama tendence, ka jaunieši kā galveno prioritāti izvirza labu izglītību un veiksmīgu darba karjeru, un tikai pēc tam gímeni. Jau deviņdesmitajos gados vidējais jaundzimušo mātes vecums palielinājās par vairākiem gadiem. Pēc aptaujas datiem, Latvijā sievietēm izteiktāk nekā vīriešiem novērojama likumsakarība, ka, pieaugot izglītības līmenim, iecerēto bērnu skaits samazinās (Eglīte u.c., 2002). Pozitīvi vērtējams, ka jaunieši izvēlas iegūt augstu izglītības līmeni, lai kḷūtu konkurētspējīgi darba tirgū un celtu labklājīibas līmeni. Savukārt, negatīvi, ka Latvijā ir salīdzinoši zems atbalsts gimenēm ar bērniem, līdz ar to dzimstība nav augsta un iedzīvotāju skaits samazinās (Pēc Latvijas CSP datiem 2014. gadā pret 2013. gadu iedzīvotāju skaits Latvijā samazinājās par 0.8\%; savukārt, 2015. gada sākumā pret to pašu periodu 2014. gadā, iedzīvotāju skaits Latvijā samazinājās par 15.4 tūkstošiem (2015. gada sākumā Latvijā..., 2015).

Bezdarba līmeņa kritums Latvijā 2014. gadā salīdzinājumā ar 2013. gadu būtiski palēninājās - līdz 1.1 procentu punktam (no $11.9 \%$ līdz $10.8 \%$ no ekonomiski aktīvajiem iedzīvotājiem). Tiek uzskatīts, ka tas ir likumsakarīgi, jo bezdarba cikliskā komponente, kas nodrošināja teju divkāršu bezdarba kritumu 2010. -2013. gadu periodā, ir izsmelta, savukārt strukturālā komponente nevar samazināties ātri. Turklāt gada beigās bezdarba kritumu piebremzēja tautsaimniecības attīstības tempu palēnināšanās. Lai arī 2014. gadā bezdarba līmenis samazinājies, šis krituma temps ekonomikas sabremzēšanās apstākḷlos pakāpeniski rūk. Sagaidāms, ka 2015. gadā bezdarba kritums būs līdz 0.5 procenta punktiem (Krasnopjorovs, 2015). Balstoties uz CSP datiem, 2015. gadā kopējais bezdarba līmenis bija 9.9\%, bet 2014. gadā $10.8 \%$, 2015. gadā salīdzinājumā ar 2014. gadu kopējais bezdarba līmenis ir samazinājies par 0.9 procenta punktiem (Ekonomiskās aktivitātes, nodarbinātības...., 2015).

Balstoties uz ES statistikas biroja Eurostat datiem, 2014. gada laikā Latvijā iedzīvotāju skaits saruka par 7.7 cilvēkiem, rēķinot uz tūkstoš iedzīvotājiem, kas bija trešais lielākais kritums ES dalībvalstu vidū. Salīdzinājumam, vismazākais iedzīvotāju skaita kritums ES 2014. gadā reǵistrēts Polijā (-0.3\%), Spānijā (-1.6\%), Igaunijā (1.9\%) (Statistikas dati par..., 2015).

Atsaucoties uz „SEB Bankas” ekonomistu D. Gaišputi, satraucošs fakts ir noturīgais jauniešu skaita sarukums. Pēdējo piecu gadu laikā jauniešu skaits ik gadu sarūk vidēji par 5.7\%. Samazinās arī jauniešu īpatsvars kopējā iedzīvotāju skaitā. Ja 2005. gadā katrs piektais iedzīvotājs bija jaunietis, tad 2010. gadā jauniešu īpatsvars saruka līdz 17.0\%, bet 2015. gadā jau līdz 14.0\% (Gaišputis, 2015).

Pēc 3.1. attēlā uzrādītās informācijas par pastāvīgo iedzīvotāju skaitu Latvijas plānošanas reǵionos no 2006. - 2015. gadam, Rīgas reǵionā ir vērojama tendence iedzīvotāju skaitam palielināties. Situācija ir atšķirīga pārējos Latvijas plānošanas reǵionos - Vidzemes, Kurzemes, Zemgales un Latgales reǵionos, kur pastāvīgo iedzīvotāju skaits katru gadu samazinās.

2015. gadā Rīgas plānošanas reǵionā bija 50.78\% Latvijas pastāvīgo iedzīvotāju, Vidzemes regionā $-10.02 \%$, Kurzemes regionā- $12.83 \%$, Zemgales reǵionā $-12.19 \%$ un Latgales regiionā- $14.18 \%$. 


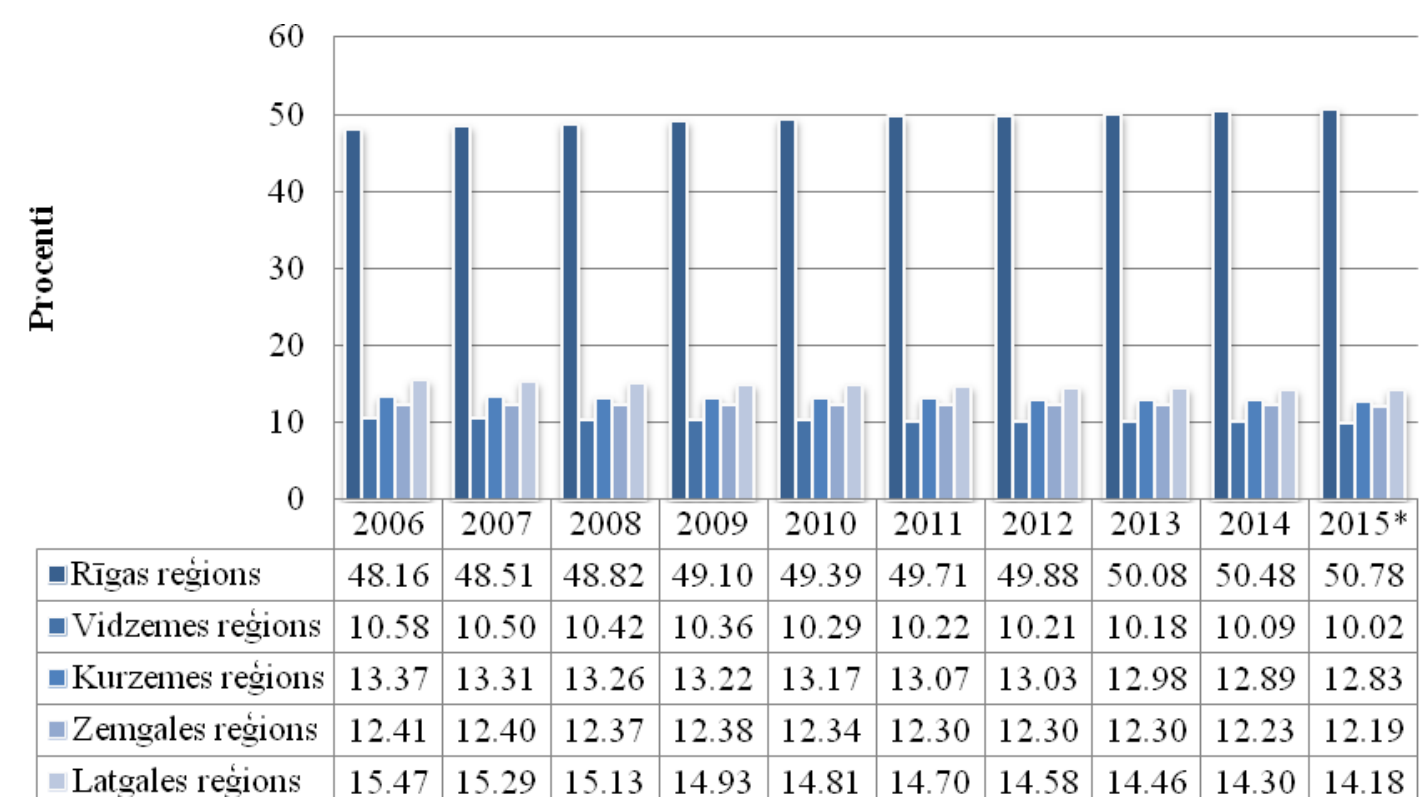

*2015. gadā dati gada sākumā

Avots: Autores aprēķini pēc Latvijas Centrālās statistikas pārvaldes datiem

\section{1. att./ Fig. 3.1. Pastāvīgo iedzīvotāju īpatsvars Latvijas plānošanas reǵionos 2006. - 2015. gadā (\%)/}

Proportion of permanent residents in the planning regions of Latvia from 2006 to $2015(\%)$.

2015. gadā salīdzinājumā ar 2006. gadu, Rīgas plānošanas reǵionā iedzīvotāju īpatsvars ir palielinājies par 2.62 procentu punktiem, bet iedzīvotāju ìpatsvars ir samazinājies - Vidzemes plānošanas reǵionā par 0.56 procentu punktiem, Kurzemes plānošanas reǵionā par 0.54 procentu punktiem, Zemgales plānošanas reǵionā par 0.22 procentu punktiem un Latgales plānošanas reǵionā par 1.29 procentu punktiem. Latgales plānošanas reǵionā novērojama iedzīvotāju īpatsvara vislielākā samazināšanās

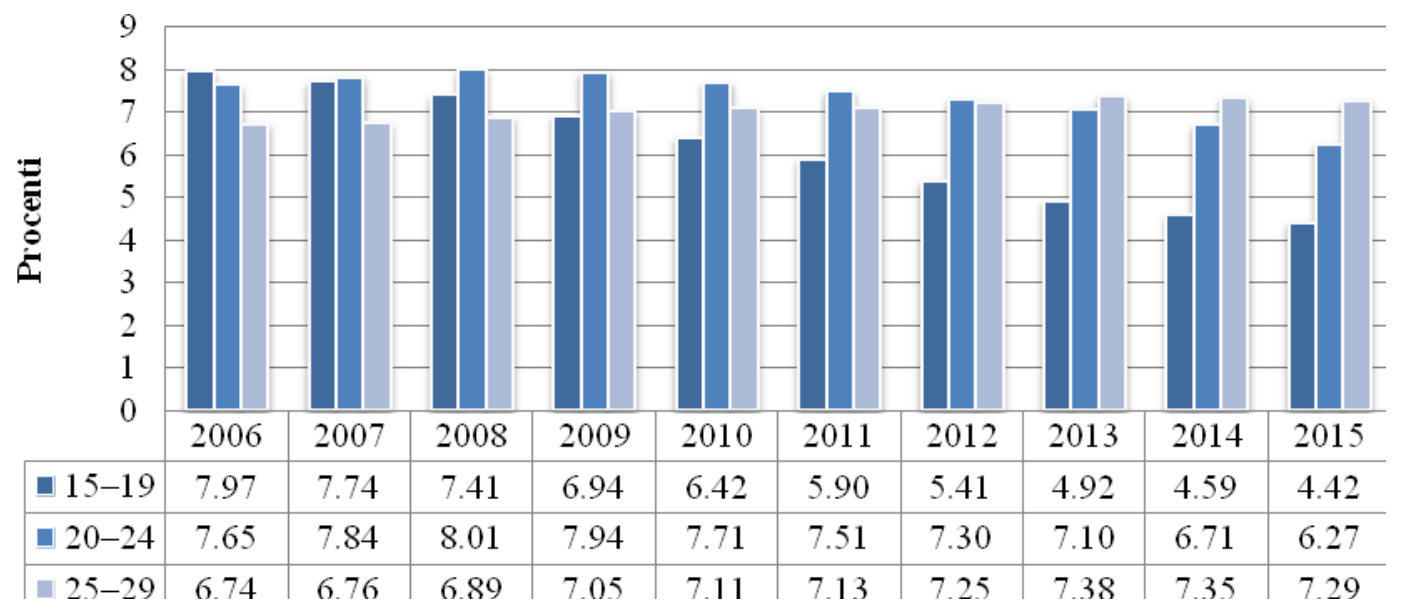

Avots: Autores veidots pēc Latvijas Centrālās statistikas pārvaldes datiem

3.2. att./ Fig. 3.2. Pastāvīgo iedzīvotāju īpatsvars vecumā 15 - 29 gadi iedzīvotāju kopskaitā Latvijā 2006.- 2015. gadā (\%)/

Proportion of the population aged 15-29 in the total population in Latvia from 2006 to $2015(\%)$. 
3.2. attēēā atspoguḷots jauniešu īpatsvars vecuma grupā no 15-29 gadiem pastāvīgo iedzīvotāju kopskaitā Latvijā. 2015. gadā Latvijā jaunieši pastāvīgo iedzīvotāju kopskaitā vecumā no 15-29 gadiem bija 17.98 \%, no kuriem vecuma grupā no $15-19$ gadiem $-4.42 \%$, 20-24 gadiem $-6.27 \%$ un no $25-29$ gadiem $-7.29 \%$.

Jauniešu īpatsvars vecumā 15-29 gadi 2015. gadā salīdzinājumā ar 2006. gadu ir samazinājies par 4.38 procentu punktiem. Jauniešu īpatsvars 2015. gadā salīizinājumā ar 2014. gadu ir samazinājies par 0.67 procentu punktiem.

Vērtējot 3.2. attēlā redzamos rādītājus, ik gadu jauniešu īpatsvars kopējo iedzīvotāju kopskaitā samazinās, līdz ar to darba tirgus atjaunotnes kontekstā jauniešu bezdarbs ir l̦oti aktuāla problēma.

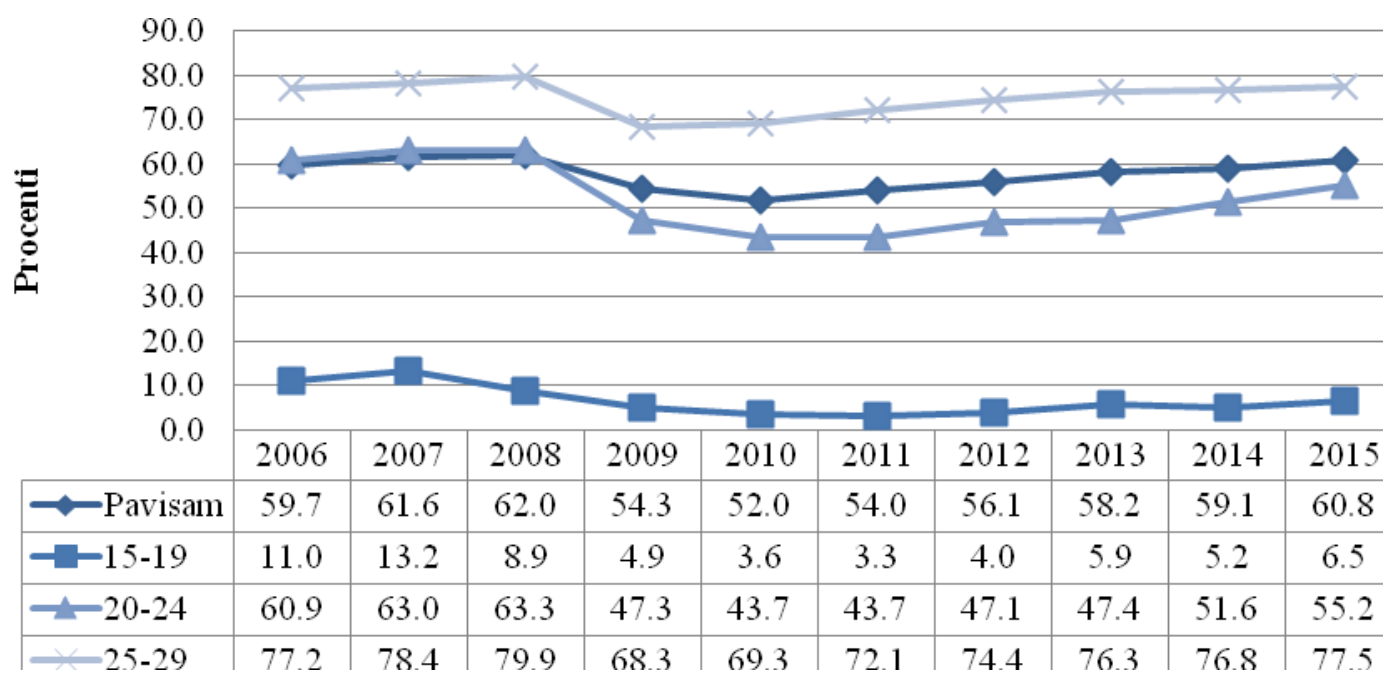

Avots: Autores veidots pēc Latvijas Centrālās statistikas pārvaldes datiem

\section{3. att. / Fig. 3.3. Nodarbinātības līmenis Latvijā kopumā un jauniešiem dažādās vecuma grupās 2006. - 2015. gadā (\%)/ \\ Employment rates overall and for youth in different age groups in Latvia from 2006 - $2015(\%)$.}

3.3. attēlā redzams nodarbinātības līmenis Latvijā kopumā un jauniešiem dažādās vecuma grupās. Viszemākais nodarbinātības līmenis laika periodā no 2006. 2015. gadam bija 2010. gadā - 52.0\%. Kopš 2011. gada kopējais nodarbinātības līmenis palielinās un 2015. gadā tas bija $60.8 \%$.

Periodā no 2006. - 2015. gadam jauniešu nodarbinātības līmenis vecuma grupā no 25-29 gadiem ir augstāks par kopējo nodarbinātības līmeni. Piemēram, jauniešu nodarbinātības līmenis 2015. gadā Latvijā vecuma grupā no 25-29 gadiem ir virs vidējā kopējā nodarbinātības līmeņa $-77.5 \%$, kas ir par 16.7 procentu punktiem vairāk.

Jauniešiem vecuma grupā no 20-24 gadiem nodarbinātības līmenis 2015. gadā bija par 5.6 procentu punktiem zemāks par vidējo kopējo nodarbinātības līmeni. No 2006. - 2008. gadam jauniešiem vecuma grupā no 20 - 24 gadiem nodarbinātības līmenis bija augstāks par vidējo nodarbinātības līmeni kopumā. Piemēram, 2007. gadā tas bija par 1.4 procentu punktiem augstāks kā vidējais nodarbinātības līmenis kopumā.

Jauniešu vecuma grupā no 15-19 gadiem nodarbinātība ir zema, jo šajā vecuma posmā jauniešiem jāapmeklē mācības. Pēc 3.1. tabulas jāsecina, ka jauniešu emigrācija vecumā grupā no 20 līdz 24 gadiem vislielākā ir bijusi 2009. un 2010. gadā, kad valstī bija sākusies krīze un liels īpatsvars jauniešu palika bez darba vietas, it īpaši jaunieši ar zemu izglītības līmeni un no Latvijas lauku reǵioniem. 
3.1. tabula / Table 3.1.

Starptautisko ilgtermiņa emigrantu dinamika dažādās vecuma grupās no 15 - 29 gadiem Latvijā no 2006. - 2015. gadam (\%)/

Changes in the number of international long-term emigrants aged 15-29 in Latvia in the period $2006-2015(\%)$

\begin{tabular}{|c|c|c|c|}
\hline \multirow[t]{2}{*}{ Gads } & \multicolumn{3}{|c|}{ Vecuma grupa } \\
\hline & 15-19 & $20-24$ & $25-29$ \\
\hline 2006 & 8.15 & 18.31 & 14.59 \\
\hline 2007 & 8.43 & 16.82 & 13.83 \\
\hline Ķēdes absolütais pieaugums & 0.28 & -1.49 & -0.76 \\
\hline Ķèdes augšanas temps & 1.03 & 0.92 & 0.95 \\
\hline Bāzes absolūtais pieaugums & 0.28 & -1.49 & -0.76 \\
\hline Bāzes augšanas temps & 1.03 & 0.92 & 0.95 \\
\hline 2008 & 6.92 & 18.99 & 16.04 \\
\hline Ķèdes absolütais pieaugums & -1.51 & 2.17 & 2.22 \\
\hline K̦ēdes augšanas temps & 0.82 & 1.13 & 1.16 \\
\hline Bāzes absolūtais pieaugums & -1.23 & 0.68 & 1.45 \\
\hline Bāzes augšanas temps & 0.85 & 1.04 & 1.10 \\
\hline 2009 & 7.29 & 22.12 & 17.47 \\
\hline Ķēdes absolütais pieaugums & 0.37 & 3.13 & 1.43 \\
\hline K̦ēdes augšanas temps & 1.05 & 1.16 & 1.09 \\
\hline Bāzes absolūtais pieaugums & -0.86 & 3.80 & 2.88 \\
\hline Bāzes augšanas temps & 0.89 & 1.21 & 1.20 \\
\hline 2010 & 6.46 & 18.70 & 17.62 \\
\hline Ķēdes absolütais pieaugums & -0.83 & -3.42 & 0.15 \\
\hline Ķēdes augšanas temps & 0.89 & 0.85 & 1.01 \\
\hline Bāzes absolūtais pieaugums & -1.69 & 0.39 & 3.03 \\
\hline Bāzes augšanas temps & 0.79 & 1.02 & 1.21 \\
\hline 2011 & 4.52 & 14.63 & 16.55 \\
\hline K̦ēdes absolūtais pieaugums & -1.94 & -4.07 & -1.08 \\
\hline K̦ēdes augšanas temps & 0.70 & 0.78 & 0.94 \\
\hline Bāzes absolūtais pieaugums & -3.63 & -3.68 & 1.96 \\
\hline Bāzes augšanas temps & 0.56 & 0.80 & 1.13 \\
\hline 2012 & 3.58 & 13.25 & 16.99 \\
\hline Ķèdes absolütais pieaugums & -0.94 & -1.38 & 0.44 \\
\hline Ķēdes augšanas temps & 0.79 & 0.91 & 1.03 \\
\hline Bāzes absolūtais pieaugums & -4.57 & -5.06 & 2.40 \\
\hline Bāzes augšanas temps & 0.44 & 0.72 & 1.16 \\
\hline 2013 & 4.70 & 14.36 & 18.41 \\
\hline K̦ēdes absolütais pieaugums & 1.12 & 1.11 & 1.42 \\
\hline Ķēdes augšanas temps & 1.31 & 1.08 & 1.08 \\
\hline Bāzes absolūtais pieaugums & -3.45 & -3.95 & 3.82 \\
\hline Bāzes augšanas temps & 0.58 & 0.78 & 1.26 \\
\hline 2014 & 4.15 & 13.92 & 18.19 \\
\hline Ķèdes absolütais pieaugums & -0.54 & -0.44 & -0.22 \\
\hline Ķēdes augšanas temps & 0.88 & 0.97 & 0.99 \\
\hline Bāzes absolūtais pieaugums & -4.00 & -4.40 & 3.60 \\
\hline Bāzes augšanas temps & 0.51 & 0.76 & 1.25 \\
\hline 2015 & 4.28 & 13.97 & 18.00 \\
\hline Ķēdes absolütais pieaugums & 0.13 & 0.05 & -0.19 \\
\hline K̦ēdes augšanas temps & 1.03 & 1.00 & 0.99 \\
\hline Bāzes absolūtais pieaugums & -3.87 & -4.34 & 3.41 \\
\hline Bāzes augšanas temps & 0.53 & 0.76 & 1.23 \\
\hline
\end{tabular}

Avots: Autores aprēķini pēc Latvijas Centrālās statistikas pārvaldes datiem 
Vislielākais īpatsvars jauniešu vecumā no 25 līdz 29 gadiem emigrēja uz citām valstīm visvairāk no 2008. līdz 2010. gadam. Savukārt kopš 2013. gada emigrējušo jauniešu lielākais īpatsvars vērojams vecuma grupā no 25 līdz 29 gadiem.

Visaugstākais bāzes augšanas temps 3.6\% vērojams vecuma grupā no 25-29 gadiem 2014. gadā, savukārt samazinājums par 4.40\% vērojams vecumā no 20-24 gadiem tajā pašā gadā. 2009. gadā vecuma grupā no 20-24 gadiem vērojams visaugstākais bāzes absolūtais pieaugums 3.8\% un ķēdes absolūtais pieaugums $3.13 \%$. Darba autore uzskata, ka šî tendence varētu būt skaidrojama ar to, ka šajā vecumā daļa jauniešu jau ir pabeiguši bakalaura, profesionālās studijas vai maǵistra studijas un labāk atalgota darba meklējumos izvēlējušies atstāt valsti. Šajā vecuma posmā arī ir medicīnas un informāciju tehnolog̣iju absolvējušie jaunieši, kuru intelektuālās zināšanas novērtējuši ārvalstu uzņēmēji un institūcijas un aicinājuši uz labāk apmaksāta darba vietu un prestižāku vakanci ārvalstīs.

3.4. attēlā redzams iedzīvotāju ekonomiskās aktivitātes līmenis iedzīvotāju kopskaitā atsevišksās jauniešu vecuma grupās un kopumā Latvijā no 2006. 2015. gadam. Vislielākais iedzīvotāju ekonomiskās aktivitātes līmenis ir jauniešiem vecuma grupā no 25 - 29 gadiem, kad jaunietis ir beidzis studijas un atradis patstāvīgu darbu. Viszemākā ekonomiskā aktivitāte jauniešiem vecumā no 25-29 gadiem bija 2006. gadā $-83.9 \%$, bet visaugstākais ekonomiskās aktivitātes līmenis 2010. gadā $87.9 \%$.

Jaunieši vecumā no 20 - 24 gadiem 2015. gadā $65.1 \%$ bija ekonomiski aktīvi. Jauniešu vecuma grupā no 20 - 24 gadiem vislielākā ekonomiskā aktivitāte bija 2008. gadā $-71 \%$ un viszemākā 2013. gadā $-60.6 \%$.

Jauniešu vecumā no 15 - 19 gadiem ekonomiskā aktivitāte ir zema $(7.8 \% 2014$. gadā, 9.1\% 2015. gadā), kas norāda uz pozitīvu tendenci, jo jauniešiem šajā vecuma posmā ir jāmācās.

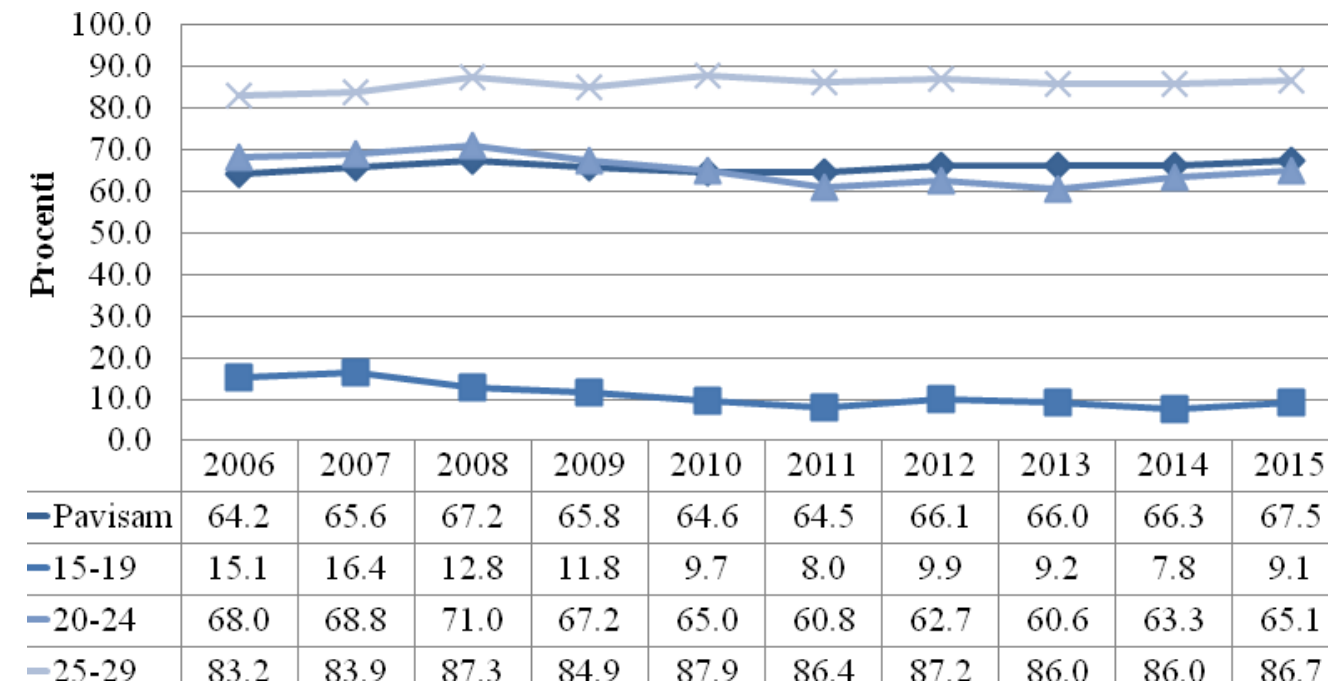

Avots: autores veidots pēc Centrālās statistikas pārvaldes datiem

\section{4. att./ Fig. 3.4. Iedzīvotāju ekonomiskās aktivitātes līmenis atsevišşās jauniešu vecuma grupās un kopumā Latvijā no 2006.- 2015. gadam (\%)/ \\ Level of economic activity of inhabitants for youths in certain age groups and overall in Latvia from 2006 to 2015 (\%).}

Latvijā 2014. gadā, salīdzinot ar 2013. gadu, 40.4\% no jauniešiem vecumā no 1524 bija ekonomiski aktīvi, t.i., strādā vai meklē darbu. Pārējie (59.6\%) bija ekonomiski 
neaktīvi t.i., lielākā daḷa no tiem joprojām mācās, nevis meklē darbu (Unemployment Rate Decreases..., 2015).

LB Monetārās politikas pārvaldes Makroekonomikas analīzes daļas galvenais ekonomists O. Krasnopjorovs (2014) uzsvēra, ka kvalitatīva izglītība joprojām ir galvenais faktors un ,apdrošinājums” pret bezdarbu. Pat spriežot tikai pēc izglītības diploma esamības (kas ne vienmēr atspoguḷo cilvēka prasmes), augstāko izglītību ieguvušo vidū bezdarbs $(5.7 \%)$ ir uz pusi zemāks nekā vidējo vai arodizglìtību ieguvušajiem, un četras reizes zemāks nekā tikai pamatizglītību saṇēmušajiem. Krasnopjorovs uzskata, ka Latvijas tautsaimniecība saglabā makroekonomisko līdzsvaru. Bezdarbs (2014. gada 2. ceturksn̄̄ - 10.7\% no ekonomiski aktīvajiem iedzīvotājiem) ir tuvu tā dabiskajam līmenim. Šajos apstākḷ os pakāpeniski un ilgtspējīgi samazināt bezdarbu var tikai ar struktūrpolitikas līdzekl̦iem, t. sk., efektīvi īstenojot aktīvās darba tirgus politikas pasākumus, nevis stimulējot pieprasījumu. Nodarbinātības kāpums 2014. gadā strauji saruka (2. ceturksnī nodarbināto skaits bija gandrīz tāds pats kā pirms gada). Šādas norises tika prognozētas iepriekš, un galvenokārt ir saistītas ar bezdarba cikliskās komponentes izsīkumu. Valsts ieņēmumu dienesta dati norāda, ka nodarbinātības kāpums lielākoties notiek uz pirmspensijas un pensijas vecuma iedzīvotāju rēķina. Arī turpmāk nodarbinātības kāpumu kavēs demogrāfiskās norises iedzīvotāju skaita un darbspējas vecuma iedzīvotāju īpatsvara samazinājums. Bezdarba cikliskās komponentes izsīkums, kā arī lēnāka ekonomikas izaugsme, nozīmēe, ka turpmāk bezdarbs nesamazināsies (un nodarbinātība nepieaugs) tik strauji kā 2010.2013. gadā. Arī iedzīvotāju līdzdalība darba tirgū (nodarbinātie un darba meklētāji) patlaban ir tuva vēsturiski augstākajam līmenim, un tās straujam pieaugumam pamata nav (Krasnopjorovs, 2014).

Arī saskaņāa ar OECD pētîjumu, indivīda izglîtības līmenim un prasmēm ir spēcīga ietekme uz darba tirgu, un efektīvus ieguldījumus jaunieša prasmju uzlabošanā nosaka valsts kapacitāte, saskaroties ar pārejas posmu, un spēja iegūt vislabāko no globalizācijas, tehnoloǵiskajām izmaiņām un jauninājumiem (OECD Economic Survey..., 2015).

Saskaņā ar OECD informāciju, Latvijas darbaspēks ir ar labu izglītību. Aptuveni trešdaļai ekonomiski aktīvo iedzīvotāju ir augstākā izglīitība, kas ir ievērojami palielinājusies no aptuveni 20\%, salīdzinot ar periodu pirms desmit gadiem. Vidusskolas izglītîbas iegūšana arī ir augstā līmen̄̄, 80\% no darbaspējīga vecuma iedzīvotājiem ir grupā, kas ieguvuši vismaz vidējo izglītību. Izglīî̄bas sistēma ir piedzīvojusi būtiskas reformas pārejas posmā (OECD Economoc Survey..., 2015.).

Savukārt, balstoties uz LR Labklājības ministrijas (LM) informatīvo ziņojumu „Jauniešu garantijas īstenošanas progresu 2014. gadā”, jauniešiem bezdarbniekiem ir nepietiekošs izglītības līmenis, kas ir viens no galvenajiem iemesliem augstam jauniešu bezdarba līmenim. Analizējot „Eurostat” datus par 2013. gadu, LM secināja, ka jauniešu bezdarbnieku ar vispārējo vidējo vai zemāko izglītības līmeni ir divreiz vairāk nekā jauniešu ar augstāko izglītību (Informatīvais ziņojums par..., 2015).

Analizējot Latvijas CSP datus par augstskolās un koledžās pamatstudijās uzñemto studentu sadalījumu pēc dzīvesvietas Latvijas statistisko reǵionu teritorijās un ārpus Latvijas no 2010. gada - 2014. gada mācību periodam, jāsecina, ka augstskolās un koledžās pamatstudijās uzņemto studentu sadalījums pēc reǵioniem ir vienmērīgs. Lielākais studentu īpatsvars, kas uzsācis studijas sākot ar 2010. gada novembri, ir no Rīgas reǵiona, kur ir vislielākā Latvijas iedzīvotāju koncentrācija. Savukārt, uz ārvalstīm studēt aizbraukušo studentu skaits ik gadus palielinās. Ja 2010. gada novembrī uz ārvalstīm devās studēt 2.3\% studentu, tad 2011. gada novembrī jau 3.61\%, 2012. 
gada un 2013. gada mācību periodā 5.26\% un 2013. gada un 2014. gada mācību periodā jau 6.3\%, kas ir trīs reizes vairāk, salīdzinājumā ar 2010. gada mācību periodu.

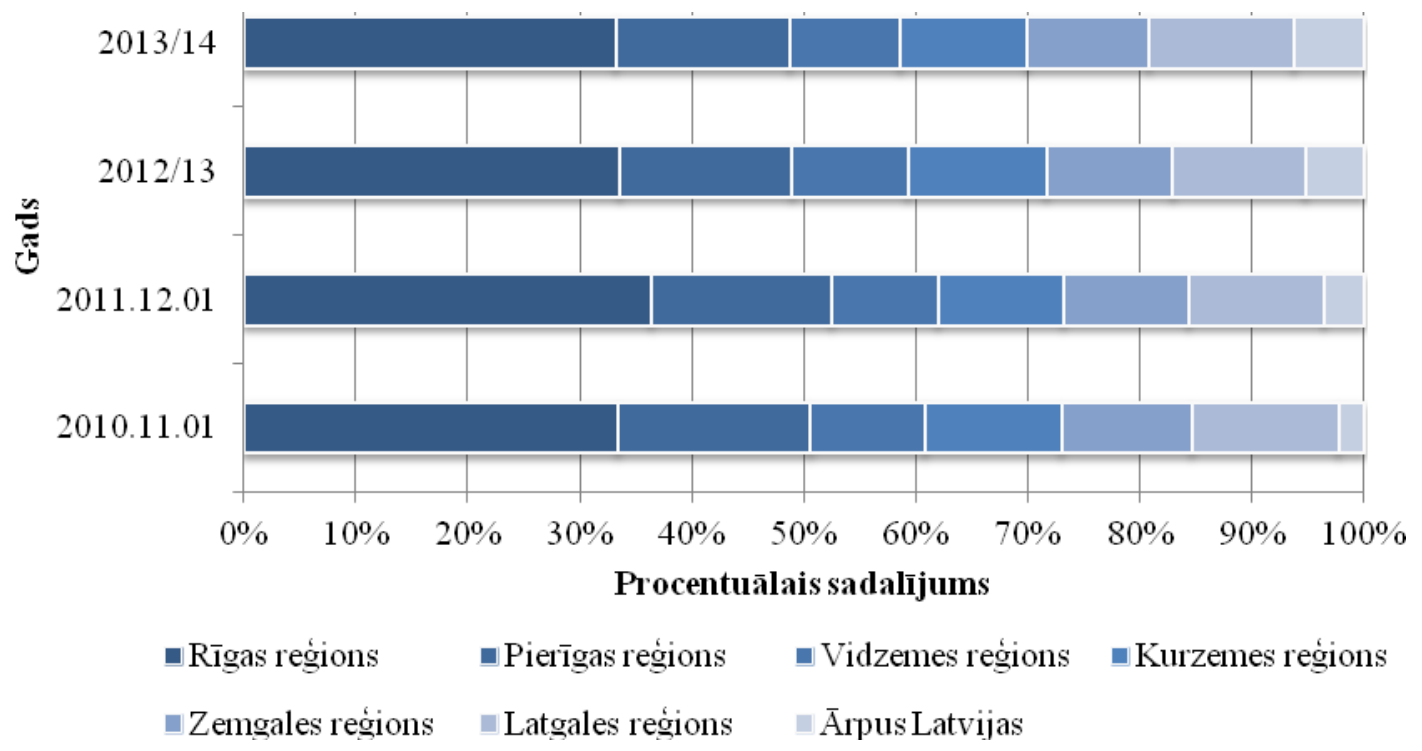

Avots: autores veidots pēc Centrālās statistikas pārvaldes datiem

\section{5. att./ Fig. 3.5. Augstskolās un koledžās pamatstudijās uzṇemto studentu sadalījums pēc dzīvesvietas Latvijas statistisko reǵionu teritorijās un ārpus \\ Latvijas 2010. gada - 2014. gada mācību periodam (\%)/ \\ Distribution of matriculated students in undergraduate studies at universities and colleges by residence in the statistical regions of Latvia and outside Latvia in the study period 2010-2014 (\%).}

Starptautiskai studiju videi ir ar katru gadu arvien būtiskāk piesaistīt arī ārvalstu studentus Latvijā, pirmkārt, jau tādēḷ, ka Latvijas jauniešu skaits ar katru gadu samazinās mazās dzimstības rezultātā, kā arī Latvijas jauniešiem ar katru gadu aug interese par starptautiska līmeņa studiju iespējām ārvalstīs, lai ievērojami uzlabotu kvalifikāciju un nodrošinātu pēc iespējas veiksmīgu nākotni citā valstī. Jauniešu interese par ārvalstīm ir neizbēgama, it īpaši jauniešu vidū, kas vēlas apgūt specifiskas profesijas.

Savukārt, vēršot uzmanību uz grādu vai kvalifikāciju ieguvušo studentu īpatsvaru pa nozarēm, visatzītākā studiju nozare gadu no gada ir sociālās zinātnes, komerczinības un tiesības, kurās katru gadu aptuveni puse no studējošajiem beidz studijas, 2013. gadā šīs nozares pārstāvji sastādīja 42\%. 2013. gadā palielinājusies studentu interese par studijām lauksaimniecībā.

2015. gadā 40.07\% no visiem absolventiem ir ieguvuši grādu sociālās zinātnēs, komerczinībās un tiesībās, tomēr salīdzinājumam, 2011. gadā šīs nozares absolventi sastādīja 47.52\% no kopējo absolventu skaita. 2015. gadā salīdzinājumā ar 2013. gadu samazinājies absolventu skaits veselības aprūpes un sociālās labklājības nozarē, tomēr 2015. gadā š̄ nozare ir otra populārākā absolventu vidū - absolvējuši 13.99\%. Trešajā vietā ir grādu ieguvušie studenti inženierzinātnēs, ražošanā un būvniecībā, sastādot $12.48 \%$ no studiju grādu ieguvušo īpatsvara (skat. 3.6. att.). 

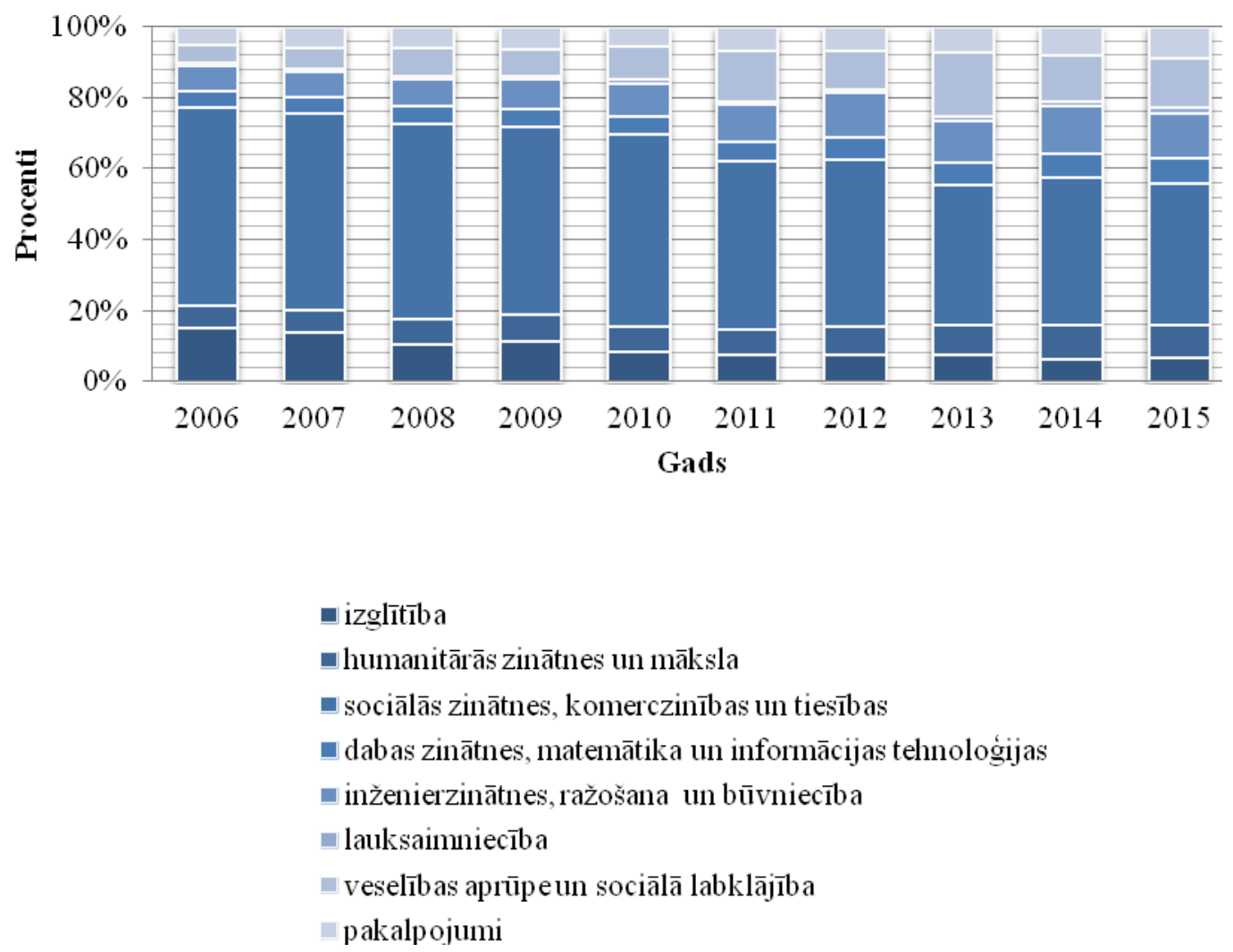

Avots: autores veidots pēc Centrālās statistikas pārvaldes datiem

3.6. att./ Fig. 3.6. Grādu vai kvalifikāciju ieguvušo studentu īpatsvars pa izglītības tematiskajām grupām augstskolās un koledžās Latvijā no 2006.- 2015.gadam (\%)/ Proportion of students who acquired a qualification or degree by thematic groups at universities and colleges in Latvia from 2006 to 2015 (\%).

Balstoties uz Latvijas Centrālās stratistikas pārvaldes datiem, lielākais darba ņēmēju īpatsvars visās vecuma grupās ir ar ienākumiem robežā no 300.01 EUR līdz 500.00 EUR mēnesī - 29.3\% jauniešu vecumā no 20 - 24 gadiem, 32.5\% jaunieši vecumā no 19 gadiem un jaunāki, 22.8\% jaunieši vecumā no 25 - 29 gadiem, kā arī citas vecuma grupas, piemēram, 30.4\% darba ņēmēji vecumā no 55 - 39 gadiem, $29.4 \%$ darba ñēmēji vecumā no 50 - 54 gadiem utt.

$20.4 \%$ jaunieši vecumā no 20 - 24 gadiem un $23 \%$ jaunieši vecumā no 25 - 29 gadiem 2015. gadā bija ar ikmēneša ienākumiem sākot ar 700.01 EUR - 1000.00 EUR mēnesī, pirms nodokḷu nomaksas, bet vislielāko īpatsvaru šajā ienākumu grupā ieñem darba ñēmēji vecumā no 30 - 34 gadiem.

Balstoties uz CSP datiem, jāsecina, ka gados jauni darba ņēmēji ienākumu grupā no 700.01-1000.00 EUR sastāda vislielāko īpatsvaru.

3.7. attēlā redzama strādājošo mēneša vidējā darba samaksa Latvijas statistiskajos reǵionos no 2006. - 2015. gadam. Latgales reǵionā vidējā bruto darba samaksa jau kopš 2006. gada ir viszemākā, vērtējot starp reǵioniem, otrā zemākā vidējā darba samaksa ir Vidzemes reǵionā, bet Rīgas reǵionā darba samaksa vēsturiski ir visaugstākā. 


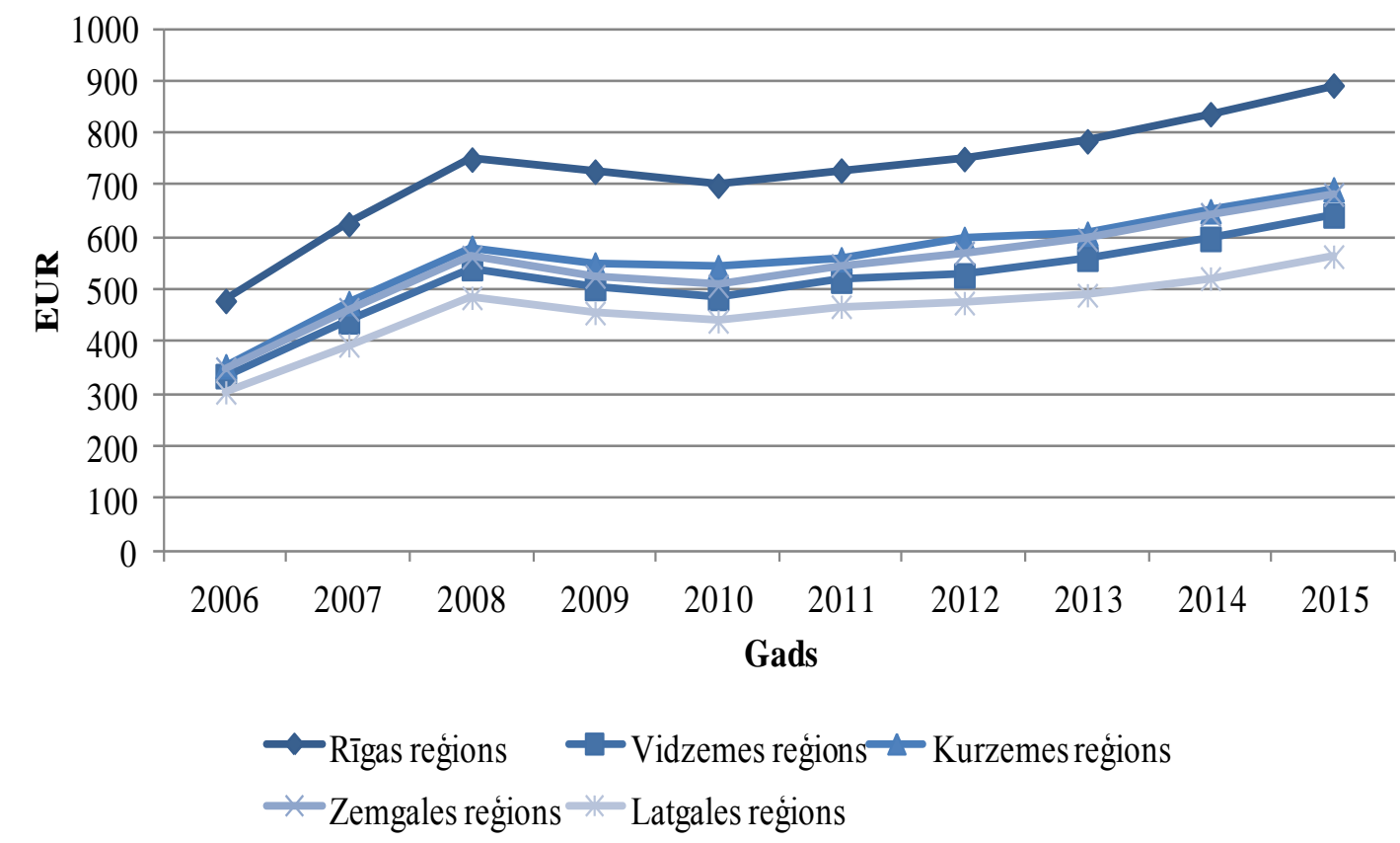

Avots: autores veidots pēc Centrālās statistikas pārvaldes datiem

\section{7. att./ Fig. 3.7. Strādājošo mēneša vidējā bruto darba samaksa Latvijas statistiskajos reg̣ionos no 2006. - 2015. gadam, EUR/ \\ Gross average monthly wage and salary of employees in the statistical regions of Latvia from 2006 - 2015 in EUR.}

2014. gadā Rīgas reǵionā vidējā darba samaksa bija 837 EUR, bet Latgales reg̣ionā - 522 EUR, Vidzemes reǵionā - 598 EUR, Zemgales regionā - 645 EUR, Kurzemes reǵionā - 651 EUR, savukārt 2015. gadā Rīgas reǵionā - 892 EUR, Latgales reǵionā - 564 EUR, Vidzemes reǵionā - 643 EUR, Zemgales reǵionā - 683 EUR, Kurzemes reǵionā - 693 EUR. Darba n̦ēmējiem atalgojuma ziṇā pievilcīgāks reǵions, kurā strādāt, ir Rīgas reǵions. Rīgas regions darba ņēmējam ir pievilcīgāks arī gadījumā, ja darba ñēmējs dzīvo citā reǵionā (skat. 3.7. att.).

\subsection{Bezdarba analīze Latvijā/ Analysis of unemployment in Latvia}

Balstoties uz DNB Latvijas barometra jaunākā pētījuma datiem, iedzīvotāji ir kritiski vērtējuši Latvijas jauniešu iespējas atrast darbu - no tiem $61 \%$ norādīja, ka darbu atrast ir grūtāk nekā vidēji ES, 26\% - ka tikpat grūti kā vidēji ES, bet tikai 5\% ka darbu ir atrast vieglāk (Izglīî̄ba un jauniešu..., 2015).

Atsaucoties uz LB Monetārās politikas pārvaldes Makroekonomikas analīzes daļas galvenā ekonomista O. Krasnopjorova pētījumiem pēc CSP darbaspēka apsekojuma datiem, kas atspoguḷo gan formālo, gan neformālo ekonomiku, ekonomists norāda uz nodarbinātības kritumu 2014. gadā. O. Krasnopjorovs uzskata, ka tas daļēji varētu atspoguḷot metodologijas pārmaiņas, kad 2013. gadā darbaspēka apsekojums pamatojās uz darbspējas vecuma iedzīvotāju skaitu gada sākumā, savukārt 2014. gadā tas tika aktualizēts katru ceturksni. Vērā ñemams arī iedzīvotāju skaita kritums un darbspējas vecuma iedzīvotāju īpatsvara sarukums, ko nespēj kompensēt lēns līdzdalības līmeņa kāpums un bezdarba samazinājums. Ekonomists arī uzskata, ka tas varētu liecināt par ēnu nodarbinātîbas kritumu, darba vietu skaitam valstī pieaugot. 
Oficiālo ekonomiku atspogulojošie statistisko datu avoti (CSP uzñēmumu apsekojuma dati par aizņemto darba vietu skaitu; Valsts ieņēmumu dienesta dati par darba ņēmēju skaitu, kas veic valsts sociālās apdrošināšanas obligātās iemaksas) joprojām uzrāda nodarbinātības kāpumu (Krasnopjorovs, 2015).

O. Krasnopjorovs uzskata, ka kopējais bezdarba līmenis Latvijas reǵionos samazinās tikai viena būtiska iemesla rezultātā, vēl aizvien ir novērojama ekonomiski aktīvo iedzīvotāju izbraukšana no valsts labāk apmaksāta darba meklējumos, nozares speciālistu pārcelšanās dzīvot uz citām valstīm, pārāk liela iedzīvotāju mirstība un mazā dzimstība, kas ietekmē kopējo bezdarba rādītāju. Savukārt ilgstošo bezdarbnieku skaits paliek praktiski nemainīgs, jo aktuālo darba vietu skaits nav būtiski palielinājies. Vēl aizvien ilgstošo bezdarbnieku būtiskākā problēma ir nepietiekošais izglītības līmenis, pārāk mazās algas, piedāvātie neapmierinošie darba apstākḷi, kā arī citas sociālās problēmas (Krasnopjorovs, 2013).

Piemēram, bezdarba līmeņa kritums Latvijā 2014. gadā būtiski palēninājās - līdz 1.1 procentu punktam (no $11.9 \%$ līdz $10.8 \%$ no ekonomiski aktīvajiem iedzìvotājiem). Tiek uzskatîts, ka tas ir likumsakarīgi, jo bezdarba cikliskā komponente, kas nodrošināja teju divkāršu bezdarba kritumu 2010. - 2013. gadu periodā, ir izsmelta, savukārt strukturālā komponente nevar samazināties ātri. Turklāt gada beigās bezdarba kritumu piebremzēja tautsaimniecības attīstības tempu palēnināšanās. Lai arī 2014. gadā bezdarba līmenis samazinājies, šis krituma temps ekonomikas sabremzēšanās apstākḷos pakāpeniski sarūk (Krasnopjorovs, 2015). Balstoties uz CSP datiem, 2015. gadā kopējais bezdarba līmenis bija 9.9\%, bet 2014. gadā $10.8 \%$, 2015. gadā salīdzinājumā ar 2014. gadu kopējais bezdarba līmenis ir samazinājies par 0.9 procenta punktiem (Ekonomiskās aktivitātes, nodarbinātības...., 2015).

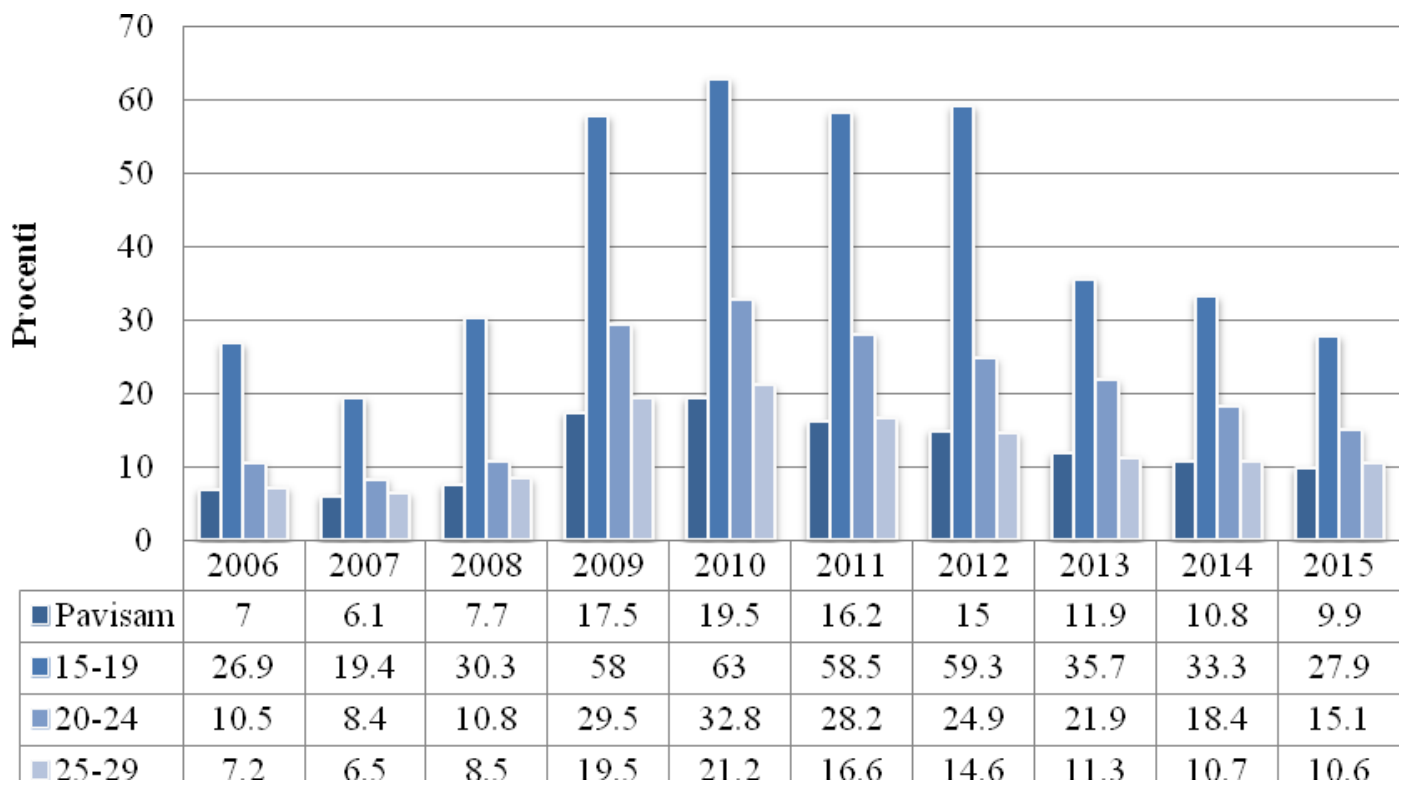

Avots: Latvijas Centrālās statistikas pārvaldes dati

3.8. att./ Fig. 3.8. Bezdarba līmenis jauniešiem dažādās vecuma grupās un kopumā Latvijā no 2006. gada līdz 2015. gadam (\%)/

Unemployment rate for youth in various age groups (aged 15 to 29 years) and the overall unemployment rate in Latvia from 2006 to 2015 (\%). 
3.8. attēlā redzams, ka no 2009. gadā salīdzinājumā ar 2008. gadu, kopējais bezdarba līmenis bija par 9.8 procentu punktiem augstāks. 2010. gadā kopējais bezdarba līmenis sasniedza visaugstāko rādītāju (19.5\%), vērtējot laika periodā no 2006. gada līdz 2015. gadam. 2010. gadā gan kopumā, gan jauniešiem vecuma grupās no 15 - 29 gadiem, bezdarba līmenis sasniedza visaugstākos rādītājus - jauniešiem vecumā no 15 19 gadiem $-63 \%$, no $20-24$ gadiem $-32.8 \%$, no $25-29$ gadiem $-21.2 \%$, pārsniedzot vidējo bezdarba līmeni kopumā. 2015. gadā bezdarbs kopumā ir samazinājies par 0.9 procenta punktiem salīdzinājumā ar 2014. gadu. 2015. gadā kopējais bezdarba līmenis bija $9.9 \%$, jauniešiem vecumā no 15 - 19 gadiem - 27.9\%, jauniešiem no $20-24$ gadiem - $15.1 \%$ un jauniešiem no 25 - 29 gadiem - $10.6 \%$.

Pēc 3.9. attēlā redzamajiem bezdarba līmeņa rādītājiem, jauniešiem vecumā no 15-29 gadiem vidējais bezdarba līmenis ir 17.9\%.

2015. gada oktobrī Latvijā kopējais bezdarbs bija 8.3\%, savukārt pēc Eurostat datiem, sezonāli izlīdzinātais bezdarba līmenis Latvijā 2015. gada augustā bija 9.9\%, bet ES-28 valstīs vidēji 9.4\%, kas ir par 0.5\% zemāks kā Latvijā (skat. 3.9. att.).

Saskan̄ā ar LR Prezidentūras ES Padomē publicēto informāciju, jaunatnes nodarbinātība ir viena no ES prioritātēm. Kopumā Eiropā ir aptuveni 5 miljoni bezdarbnieku jaunieši vecumā līdz 25 gadiem (Enhanced Cross-sectoral..., 2015).

Jauniešu (15-24 gadi) bezdarba rādītāji ES dalībvalstīs ir augstāki kā vidējie bezdarba rādītāji. Vidēji ES- 28 valstīs jauniešu bezdarbs 2015. gadā bija 20.4\%, savukārt divas reizes lielāks tas bija Grieķijā (49.8\%), Spānijā (48.3\%), Horvātijā (43.0\%) un Itālijā (40.3\%).

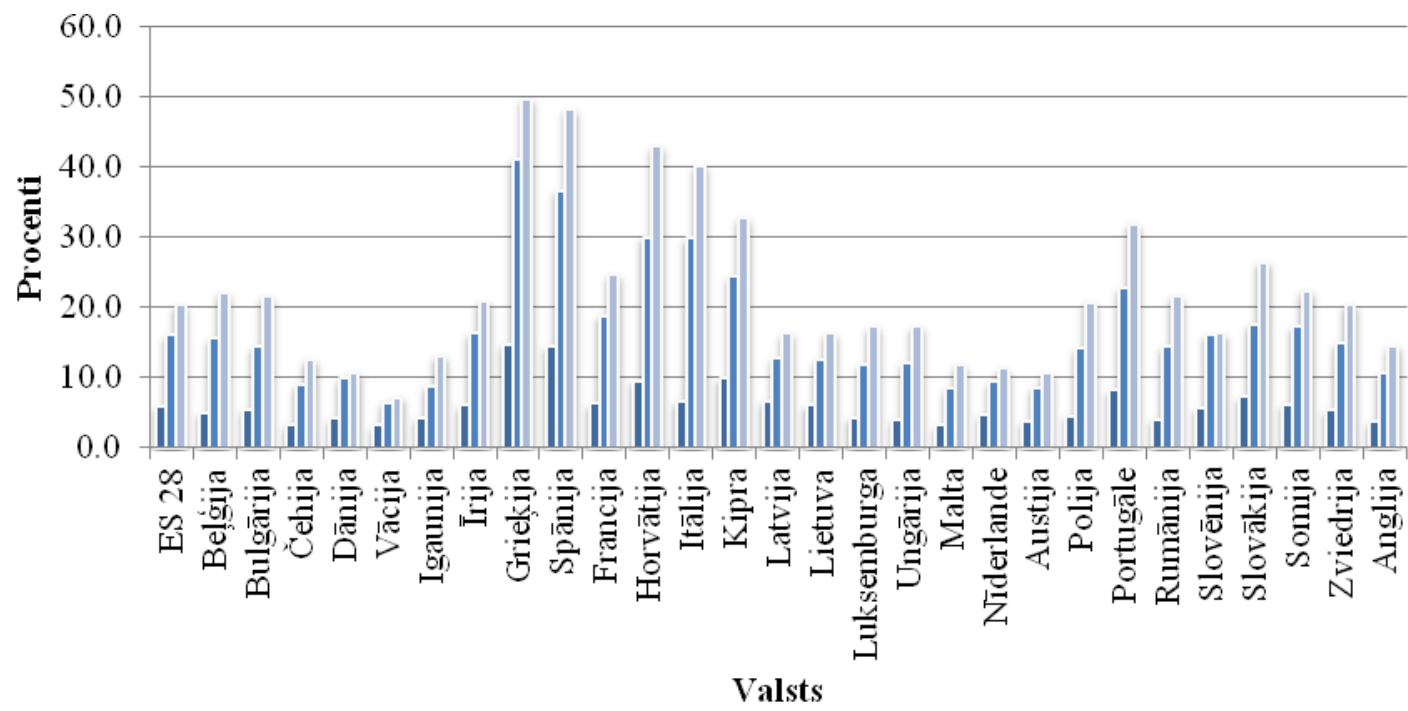

$$
\begin{aligned}
& \text { — Vidẹjais bezdarba līmenis kopumā } \\
& \square \text { Jauniešu vidējais bezdarba līmenis vecumā no 15-29 gadiem } \\
& \square \text { Jauniešu vidẹjais bezdarba līmenis vecumā no 15-24 gadiem }
\end{aligned}
$$

Avots: Eurostat dati

\section{9. att./ Fig. 3.9. Vidējais bezdarba līmenis un bezdarba līmenis jauniešiem vecumā līdz 29 gadiem kopumā ES dalībvalstīs 2015. gadā (\%)/}

Average unemployment rate and the unemployment rate for youth aged up to 25 years in the EU Member States in August 2015 (seasonally adjusted data) (\%).

Salīdzinoši augsts bezdarba līmenis 2015. gadā, kas ir augstāks arī par ES-28 valstu vidējo rādītāju, ir Kiprā (32.8\%), Portugālē (32.0\%), Slovākijāa (26.5\%), 
Rumānijā (21.7\%), Somijā (22.4\%), Francijā (24.7\%), Beḷgijā (22.1\%) un Bulgārijā $(21.6 \%)$.

Zemāks jauniešu (15-24 gadi) bezdarba līmenis par ES-28 vidējo līmeni ir Vācijā (7.2\%), Nīderlandē (11.3\%), Austrijā (10.6\%) un Dānijā (10.8\%).

Izvērtējot Baltijas valstis jauniešu (15-24 gadi) bezdarbs 2015. gadā - Latvijā bija $16.3 \%$, Lietuvā $-16.3 \%$ un Igaunijā $-13.1 \%$ (skatīt 3.9. att.).

Savukārt jauniešu vecumā no 15-29 gadiem vidējais bezdarba līmenis 2015. gadā ES-28 bija $16.1 \%$, kas ir par 4.3 procentu punktiem mazāk, kā jauniešiem vecuma grupā no 15 - 24 gadiem. Jauniešu vecumā no 15-29 gadiem bezdarba līmenis ir zemāks kā jauniešiem vecumā no 15-24 gadiem.

3.2. tabulā apkopoti jauniešu ilgstošā bezdarba un jauniešu bezdarba dinamika dažādās vecuma grupās no 15-29 gadiem no 2006. -2015. gadam.

Jauniešiem (vecumā no 15-29 gadiem) bezdarbniekiem vislielākais bāzes absolūtais pieaugums novērojams no 2008.- 2010. gadam. 2008. gadā salīdzinājumā ar 2006. gadu pieauga par $22.7 \%$, 2009. gadā - 25.6\%, 2010. gadā - 20.4\% un 2011. gadā $-17.9 \%$.

Jauniešiem (vecumā no 15-24 gadiem) bezdarbniekiem vislielākais bāzes absolūtais pieaugums novērojams 2009. gadā - salīdzinājumā ar 2006. gadu pieauga par $16.9 \%$ un 2010 . gadā $-17.7 \%$.

Vislielākais ķēdes absolūtais samazinājums novērojams jauniešiem bezdarbniekiem vecumā no 15-29 gadiem - 2011. gadā jauniešu bezdarbs šajā vecuma grupā samazinājās par $-5.2 \%$.

Savukārt vislielākais ķēdes absolūtais pieaugums novērojams jauniešiem bezdarbniekiem vecumā no 15 - 24 gadiem 2009. gadā jauniešu bezdarbam pieaugot par 19.7\% salīdzinājumā ar iepriekšèjo gadu.

3.2. tabula / Table 3.2.

Jauniešu ilgstošāā bezdarba un jauniešu bezdarba dinamika dažādās vecuma grupās no 15 - 29 gadiem Latvijā no 2006.- 2015. gadam (\%)/

Changes in the number of youth long-term unemployment (12 months and more) and youth uemployment aged 15-29 in Latvia in the period 2006 - 2015 (\%).

\begin{tabular}{|c|c|c|c|}
\hline & $\begin{array}{c}\text { Jauniešu (15- } \\
29 \text { gadi) } \\
\text { ilgtermiṇa } \\
\text { bezdarbs }\end{array}$ & $\begin{array}{c}\text { Jauniešu (15- } \\
29 \text { gadi) } \\
\text { bezdarbs }\end{array}$ & $\begin{array}{c}\text { Jauniešu (15- } \\
24 \text { gadi) } \\
\text { bezdarbs }\end{array}$ \\
\hline 2006 & 2.4 & 10.6 & 13.6 \\
\hline 2007 & 1.4 & 8.7 & 10.6 \\
\hline Ķēdes absolütais pieaugums & -1.0 & -1.9 & 3.0 \\
\hline Ķēdes augšanas temps & 0.6 & 0.8 & 1.3 \\
\hline Bāzes absolūtais pieaugums & -1.0 & -1.9 & 3.0 \\
\hline Bāzes augšanas temps & 0.6 & 0.8 & 1.3 \\
\hline 2008 & 1.8 & 11.2 & 13.6 \\
\hline K̦ēdes absolütais pieaugums & 0.4 & 2.5 & 3.0 \\
\hline K̦ēdes augšanas temps & 1.3 & 1.3 & 2.5 \\
\hline Bāzes absolūtais pieaugums & -0.6 & 0.6 & 22.7 \\
\hline Bāzes augšanas temps & 0.75 & 1.06 & 3.14 \\
\hline 2009 & 5.5 & 26.5 & 33.3 \\
\hline Ķēdes absolütais pieaugums & 3.7 & 15.3 & 19.7 \\
\hline Ķēdes augšanas temps & 3.1 & 2.4 & 1.1 \\
\hline Bāzes absolūtais pieaugums & 3.1 & 15.9 & 25.6 \\
\hline Bāzes augšanas temps & 2.3 & 2.5 & 3.4 \\
\hline
\end{tabular}

Avots: Autores aprēķini pēc Latvijas Centrālās statistikas pārvaldes datiem 
3.2. tabulas turpinājums / Continuation of Table 3.2.

Jauniešu ilgstošā bezdarba un jauniešu bezdarba dinamika dažādās vecuma grupās no 15 - 29 gadiem Latvijā no 2006.- 2015. gadam (\%)/

Changes in the number of youth long-term unemployment (12 months and more) and youth uemployment aged 15- 29 in Latvia in the period 2006 - 2015 (\%).

\begin{tabular}{|c|c|c|c|}
\hline Gads & $\begin{array}{c}\text { Jauniešu (15- } \\
29 \text { gadi) } \\
\text { ilgtermiṇa } \\
\text { bezdarbs }\end{array}$ & $\begin{array}{c}\text { Jauniešu (15- } \\
29 \text { gadi) } \\
\text { bezdarbs }\end{array}$ & $\begin{array}{c}\text { Jauniešu (15- } \\
24 \text { gadi) } \\
\text { bezdarbs }\end{array}$ \\
\hline 2010 & 10.1 & 28.3 & 36.2 \\
\hline K̦édes absolütais pieaugums & 4.6 & 1.8 & -5.2 \\
\hline Ķēdes augřanas temps & 1.8 & 1.1 & 0.9 \\
\hline Bāzes absolūtais pieaugums & 7.7 & 17.7 & 20.4 \\
\hline Bāzes augšanas temps & 4.2 & 2.7 & 2.9 \\
\hline 2011 & 9.3 & 23.0 & 31.0 \\
\hline Ķēdes absolütais pieaugums & -0.8 & -5.3 & -2.5 \\
\hline Ķèdes augšanas temps & 0.9 & 0.8 & 0.9 \\
\hline Bāzes absolūtais pieaugums & 6.9 & 12.4 & 17.9 \\
\hline Bāzes augšanas temps & 3.9 & 2.2 & 2.7 \\
\hline 2012 & 7.5 & 20.8 & 28.5 \\
\hline Ķēdes absolütais pieaugums & -1.8 & -2.2 & -5.2 \\
\hline Ķēdes augřanas temps & 0.8 & 0.9 & 0.8 \\
\hline Bāzes absolūtais pieaugums & 5.1 & 10.2 & 12.7 \\
\hline Bāzes augšanas temps & 3.1 & 2.0 & 2.2 \\
\hline 2013 & 5.7 & 16.4 & 23.3 \\
\hline K̦èdes absolütais pieaugums & -1.8 & -4.4 & -3.7 \\
\hline K̦ēdes augšanas temps & 0.8 & 0.8 & 0.8 \\
\hline Bāzes absolūtais pieaugums & 3.3 & 5.8 & 9.0 \\
\hline Bāzes augšanas temps & 2.4 & 1.6 & 1.9 \\
\hline 2014 & 4.0 & 14.4 & 19.6 \\
\hline Ķēdes absolütais pieaugums & -1.7 & -2.0 & -3.3 \\
\hline K̦ēdes augšanas temps & 0.7 & 0.9 & 0.8 \\
\hline Bāzes absolütais pieaugums & 1.6 & 3.8 & 5.7 \\
\hline Bāzes augšanas temps & 1.7 & 1.4 & 1.5 \\
\hline 2015 & 4.3 & 12.9 & 16.3 \\
\hline Ķèdes absolūtais pieaugums & 0.3 & -1.5 & -3.3 \\
\hline Ķēdes augšanas temps & 1.1 & 0.9 & 0.8 \\
\hline Bāzes absolūtais pieaugums & 1.9 & 2.3 & 13.9 \\
\hline Bāzes augšanas temps & 1.8 & 1.2 & 6.8 \\
\hline
\end{tabular}

Avots: Autores aprēķini pēc Latvijas Centrālās statistikas pārvaldes datiem

Analizējot kopējo bezdarba līmeni Latvijas reǵionos un LR pilsētās, pēc Latvijas Centrālās statistikas datiem, visaugstākais bezdarbs 2015. gada oktobrī bija Latgales reǵionā (18.1\%), otrs augstākais bezdarba līmenis bija Kurzemes reǵionā (10.2\%), savukārt vidēji viszemākais Rīgas regionā (5.2\%). Izvērtējot LR pilsētas, par 1.1 procentpunktu augstāks bezdarba līmenis nekā vidēji reǵionā bija Liepājā (11.3\%), par 1.5 procentpunktu Jēkabpilī (9.4\%) un par 0.3 procentpunktiem Jūrmalā (5.5\%).

Balstoties uz Latvijas CSP datiem, visaugstākais jauniešu bezdarba līmenis Latvijā ir bijis no 2009. līdz 2013. gadam.

Balstoties uz CSP datiem 2015. gada beigās jauniešu (vecuma grupā no 15-29 gadiem) bezdarbnieku īpatsvars no registrēto bezdarbnieku īpatsvara salīdzinoši augsts bijis Latgales reǵionā, Kurzemes reǵionā, Vidzemes reǵionā un Rīgas reǵionā, savukārt zemāks tas ir bijis Zemgales reǵionā (skat. 3.10. attēlu).

Augstāks jauniešu bezdarba īpatsvars jauniešiem vecuma grupā no 25-29 gadiem 2015. gada beigās ir bijis Kuzemes reǵionā. 
Jauniešu vecuma grupā no 15-24 gadiem viszemākais īpatsvars 2015. gada beigās ir bijis Vidzemes un Kurzemes reǵionos.

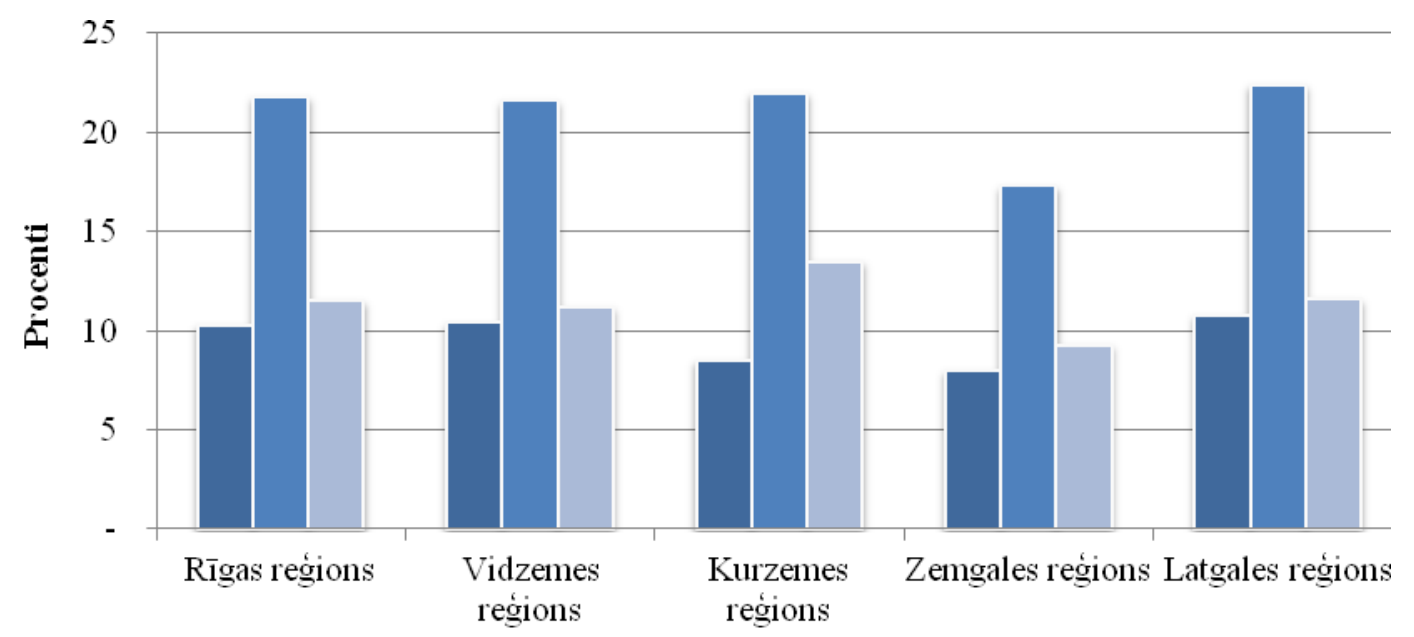

Plānošanas reğioni

@15-24 gadi $\square 15-29$ gadi $\square 25-29$ gadi

Avots: Autores veidots pēc Centrālās statistikas pārvaldes datiem

3.10. att./ Fig. 3.10. Jauniešu bezdarbnieku īpatsvars no reǵionā reǵistrēto bezdarbnieku kopskaita Latvijas plānošanas reǵionos 2015. gada beigās (\%)/ Youth unemployment proportion from total unemployed in the planning regions of Latvia in the end of 2015 (\%).

Statistiskajos datos rādītāji par jauniešu bezdarbu, ilgtermiņa bezdarbu, kā arī informāciju par situāciju darba tirgū nav precīzi, jo ir studenti, kas izvēlējušies studēt un nevēlas strādāt, kamēr studē. Visi jaunieši nav reǵistrējušies kā bezdarbnieki NVA. Ja jaunietis mācās vai studē un neplāno meklēt darbu, šo jaunieti nevar iekḷaut bezdarbnieku skaitā.

Arī jaunieti, kas nemācās un nestudē, kā arī nevēlas meklēt darbu nevar iekḷaut bezdarbnieku kopskaitā vai ekonomiski aktīvo iedzīvotāju kopskaitā. Tādēḷ ES politikas veidotāji izmanto koncepciju NEET, kas apzīmē, ka jaunieši nav iesaistīti izglītībā, nodarbinātībā vai apmācībā. Šì koncepcija tiek izmantota, lai šādas personas neiekḷautu to skaitā, kuri piedalās darba tirgū. Šie jaunieši ir pakḷauti lielākam sociālās atstumtības riskam nekā nodarbinātie jaunieši.

Eurofound ir identificējis astoņus galvenos noteicošos faktorus, kas palielina iespējamību jauniešiem iekḷūt to personu grupā, kuras nav nodarbinātas, neizglītojas un nav iesaistītas mācībās:

- invaliditāte;

- imigranta izcelsme;

- zems izglītības līmenis;

- dzīvesvieta attālā rajonā;

- ǵimene ar zemiem ienākumiem;

- vecāki bezdarbnieki;

- vecāki ar zemu izglītības līmeni un šksirta ǵimene.

Šie faktori var negatīvi ietekmēt ikviena jaunieša veiktspēju, bet jo īpaši tad, ja vairāki no tiem ir apvienoti. Viṇi var piedzīvot diskrimināciju gan skolā, gan darba 
vietās, kā rezultātā jauniešiem var rasties grūtības iekḷauties darba tirgū (Young People and..., 2011).

Balstoties uz Eurostat statistikas datiem, jauniešu, kas iekḷaujami NEET, vislielākais īpatsvars bija kopš 2009. gada Latvijā, kad vecuma grupā no 15-24 gadiem17.8\% no jauniešiem ietilpa šajā kategorijā. 2010. gadā Latvijā šis jauniešu īpatsvars vēl nedaudz palielinājās, sasniedzot 18\% īpatsvaru, tajā pašā laikā nevienā citā Baltijas valstī jaunieši, kas nemācījās un nestrādāja, nesastādīja tik lielu îpatsvaru kā jaunieši Latvijā. Arī ES- 28 valstīs vidējais rādītājs 2010. gadā bija pārsniedzis tikai 12\% robežu, kas bija par 6 procentpunktiem mazāk kā Latvijā kopumā (Eurostat, 2015).

2011. gadā Latvija jauniešu NEET īpatsvara apjoma dēḷ tika iekḷauta to valstu grupā, kur ir augsts jauniešu NEET īpatsvars (14\%-17\%), savukārt Lietuva un Igaunija to valstu grupā, kurās NEET īpatsvars tiek uzskatīts par vidēji augstu (10\%-14\%) (NEETs- Young People..., 2012).

2013. gadā situācija jauniešu vidū, kas iekḷaujami NEET, uzlabojās gan Latvijā, gan ES valstīs.

Saskaņā ar EK datiem, ES 7.5 milj. cilvēku vecuma grupā no 15- 24 gadiem iekļaujami NEET grupā. 2012. gadā 13.1\% no jauniešiem ieḳ̦āvās iepriekšminētajā grupā, kas bija par 2.2 procentpunktiem vairāk nekā pirms četriem gadiem, kas ir kopumā pieaudzis vairāk kā par 20\% (Youth Employment, 2014).

\subsection{Jauniešu bezdarba ekonomiskās izmaksas Latvijāa/ Economic costs of youth unemployment in Latvia}

Bezdarbs rada ievērojamus zaudējumus gan pašiem bezdarbniekiem, gan sabiedrībai kopumā, turklāt šie zaudējumi pieaug līdz ar bezdarba ilgumu (Dao, Loungani, 2010).

Bezdarbniekiem izmaksas ietver ienākumu zudumu, prasmju un kvalifikācijas zaudēšanu, negatīvu ietekmi uz veselību u.tml. Sabiedrībai tas ir nodokḷu ieņēmumu kritums un fiskālo izmaksu kāpums sakarā ar bezdarbnieku pabalstiem, ienākumu nevienlīdzības un nabadzības pieaugums, sociālās saliedētības vājināšanās (piem., mazāka uzticība valsts varai) un cilvēkkapitāla zudums. Strukturālo bezdarbu izraisa (piem., prasmju un ǵeogrāfiskās mobilitātes) neatbilstība starp darbaspēka piedāvājumu un pieprasījumu. Viens no iemesliem ir ilgstošs cenu un algu neelastīgums. Bezdarbs rada ievērojamus zaudējumus kā personīgi, tā visai sabiedrībai (Augsts bezdarbs Latvijā...., 2010).

2010. gadā bankas „Swedbank” pētîjumā eksperti lēsa, ka Latvijas gadījumā ļoti sāpīgas strukturālā bezdarba sekas būtu emigrācija. Tas nozīmētu palielinātu slogu Latvijā palikušajam darbaspēkam, un apdraudējumu sociālās aizsardzības un pensiju sistēmas ilgtspējai - budžeta sabalansēšanai šādā gadījumā būtu vajadzīgs mazināt sociālos tērinuus un/ vai palielināt nodokļus. Tā rezultātā var mazināties motivācija maksāt nodokḷus un palielināties izvairīšanās no nodokḷu nomaksas. Strukturālā bezdarba un/vai emigrācijas (īpaši augsti kvalificēta darbaspēka aizplūšanas) sekas ir ekonomikas potenciālās izaugsmes tempu samazināšanās. Darbaspēka resurss tiek noplicināts - ja uzņēmēji vēlēsies palielināt ražošanas apjomus, viṇiem būs jāsaskaras ar pieejamā darbaspēka trūkumu un nespēju atrast kvalificētus darbiniekus (Augsts bezdarbs Latvijā...., 2010).

Zaudējumus valstij no jauniešiem- bezdarbniekiem var aptuveni noteikt, aprēķinot nesaražotā IKP apjomu konkrētajā gadā, ņemot vērā jauniešu - bezdarbnieku aptuveno īpatsvaru strādājošo skaitā. 
IKP ir viens no nacionālo kontu sistēmas rādītājiem. Nacionālo kontu sistēma ir saskaņotu un savstarpēji atbilstošu makroekonomisko rādītāju kopums, kas sniedz vispārēju ieskatu ekonomiskajā situācijā un tiek plaši lietots ekonomikas analīzē, prognozēšanā, valsts politikas izstrādē. Iekšzemes kopprodukts ir valsts teritorijā saražoto gala produktu un pakalpojumu summārā vērtība gada laikā. To aprēķina, izmantojot datus par iekšzemes ražošanu (faktiskajās un salīdzināmajās cenās), izlietojumu (faktiskajās un salīdzināmajās cenās) un ienākumiem (tikai faktiskajās cenās) (Iekšzemes kopprodukts Latvijā..., 2015).

Ekonomiskās izmaksas rodas, jo bezdarba dēl netiek pilnīgi izmantoti ekonomiskie resursi, tā sekas ir preču un pakalpojumu ražošanas apjoma, iedzīvotāju ienākumu un valsts budžeta ieñēmumu samazinājums. Toties izdevumi no valsts budžeta pieaug. Ekonomikas izaugsme būs straujāka, ja nodarbinātība arvien pieaugs un bezdarbs samazināsies. Taču, lai nodrošinātu bezdarba līmen̦a samazināšanos, ir jāievēro cita būtiska sakarība - ekonomikas izaugsmes tempam ir jābūt lielākam par potenciālā IKP ikgada pieauguma tempu. Bezdarba līmeņa samazināšanās iespējama tad, ja reālā IKP ikgada pieauguma temps ir lielāks par potenciālā IKP pieauguma tempu ( pētījumi liecina, ka tas veido vidēji 3\% gadā). Tas nozīmē, ka reālam IKP jābūt lielākam par 3\% (Bikse, 2015).

Reālā IKP 2\% pieaugums virs potenciālā IKp nodrošina bezdarba līmeņa samazināšanos par 1\%. Turpretī reālā IKP samazinājums par 2\% palielina bezdarba limeni par 1\% (Bikse, 2015).

Ja faktiskais bezdarba līmenis salīdzinājumā ar iepriekšējo gadu paliek nemainīgs, reālā IKP pieauguma temps ir 3\% gadā. Šādu IKP pieauguma tempu nodrošina iedzīvotāju pieaugums, kapitāla uzkrāšana un zinātniski tehniskais progress. Ja bezdarbs salīdzinājumā ar iepriekšējo gadu pieaugs par $1 \%$, reālais IKP samazinās par $2 \%$. Ekonomiskie zaudējumi, kurus rada cikliskais bezdarbs, ir papildu produkcija, kuru varētu saražot katrs bezdarbnieks, ja viņš tiktu nodarbināts. Ekonomisti uzskata, ka bezdarba dēḷ nesaražotā vai zaudētā faktiskā produkcijas izlaide ir tas apjoms, kuru vajadzētu saražot, lai sasniegtu potenciālo ražošanas apjomu, ja ekonomikā ir dabiskais bezdarbs. To aprēķina kā starpību starp potenciālo IKP (apjoms, ko varētu saražot) un reālo IkP - faktisko produkcijas izlaidi (apjoms, kas ir saražots). Lai aprēķinātu bezdarba dēḷ nesaražoto reālā IKP starpību, 20.gs. 60. gados ASV ekonomists Arturs Oukens (Artur Okun) atklāja starpību starp bezdarba līmeni un reālā IKP starpību - 1:2 (Bikse, 2015).

Bezdarba līmena un nesaražotā IKP sakarība tiek izteikta ar Oukena likumu (Oukun's Law): ja faktiskais bezdarba līmenis pārsniedz dabisko bezdarba līmenis par $1 \%$, tad saražotais IKP atpaliek no potenciālā par $2-3 \%$ (koeficients- 2 tiek noteikts empīiriskā ceḷā un tas katrā valstī ir atšķirīgs. Šì atšķirība ir noteikta intervālā 2-3 (Bikse, 2003; Adams u.c., 1987).

Atbilstoši Oukena likumam zaudēto jeb nesaražoto IKP daļu, kas radusies bezdarba ietekmē, aprēķina, ja no faktiskā bezdarba procenta atskaita dabiskā bezdarba procentu valstī un iegūto starpību reizina ar 2 (intervālā no 2-3\%). Savukārt iegūto lielumu reizina ar dotā gada potenciālo IKP (Bikse, 2003).

Oukena likumu var izteikt arī formā, kas atspogulı sakarību starp IKP un bezdarba dinamiku. Ja faktiskais bezdarba līmenis pret iepriekšējā gada bezdarba līmeni ir palicis nemain̄̄gs, tad reālā faktiskā iekšzemes kopprodukta pieaugums būs $3 \%$ gadā. Šãdu IKP pieauguma tempu nodrošina iedzīvotāju pieaugums, kapitāla uzkrāšana un zinātniski tehniskais progress (Bikse, 2003, 83). 
Oukens ir atklājis sakarību starp IKP un bezdarba dinamiku, kas atspoguļota 3.1. formulā:

$$
\frac{\mathrm{Y}-\mathrm{Y}}{\mathrm{Y}-1}=3 \%-2\left(\mathrm{u}-\mathrm{u}_{-1}\right)
$$

Pēc kuras:

Y - dotā gada faktiskais ražošanas apjoms,

$\mathrm{Y}_{-1}$ - iepriekšējā gada faktiskais ražošanas apjoms,

u -faktiskais bezdarba līmenis dotajā gadā,

$\mathrm{u}_{-1}$ - faktiskais bezdarba līmenis iepriekšējā gadā (Bikse, 2003, 82).

Aprēķinos izmantota Oukena likuma pirmā forma.

Lai aprēķinātu jauniešu bezdarba ekonomiskās izmaksas tika noteikts bāzes gads, kad Latvijā tiek sasniegta pilnīga resursu nodarbinātība, t.i., potenciālais ražošanas līmenis.

Tiek ņemts vērā 2007. gads, kad reālais IKP ir 22'557.0 milj. EUR un tika sasniegta pilnīga nodarbinātība.

Atbilstoši aprēķiniem gada vidējam reālā IKP (aprēķinā tiek izmantots IKP 2010. gada salīdzināmajās cenās) pieaugumam vajadzētu sasniegt 3\% (aprēķinā tiek pieņemti 3\%) (Bikse, 2005; Bikse, 2015).

Tika aprēksināts potenciālais IKP no 2008. gada - 2015. gadam, piemēram potenciālajam IKP 2013. gadā vajadzēja palielināties par $19.41 \%$, salīdzinot ar 2007.gadu un 2015. gadā vajadzēja palielināties par 26.67\%, salīdzinot ar 2007. gadu.

Izmantojot Latvijas Centrālās statistikas pārvaldes datus par kopējo bezdarba līmeni Latvijā no 2008. - 2015. gadam, tika noteikta starpība starp faktisko un dabisko bezdarba līmeni.

3. 3. tabula/ Table 3.3.

Jauniešu bezdarba ietekmē nesaražotā IKP aprēķina dati no 2008. 2015. gadam/

Lost GDP due to youth unemployment from 2008 to 2015

\begin{tabular}{|c|c|c|c|c|c|c|}
\hline Gads & $\begin{array}{l}\text { Potenciālais } \\
\text { IKP ar ar } \\
\text { pieaugumu } \\
\text { 3\% gadā, } \\
\text { milj. EUR }\end{array}$ & $\begin{array}{l}\text { Apjoms \%, par } \\
\text { cik } \\
\text { potenciālajam } \\
\text { IKP vajadzēja } \\
\text { palielināties } \\
\text { salīdzinājumā } \\
\text { ar } 2007 . \text { gadu }\end{array}$ & $\begin{array}{l}\text { IKP } \\
\text { pieaugums } \\
\text { pret 2007. } \\
\text { gadu, milj. } \\
\text { EUR }\end{array}$ & $\begin{array}{l}\text { Nesaražotais } \\
\text { IKP } \\
\text { bezdarba dēḷ, } \\
\text { milj. EUR }\end{array}$ & $\begin{array}{l}\text { Nesaražotais } \\
\text { IKP jauniešu } \\
\text { bezdarba dēl, } \\
\text { milj. EUR }\end{array}$ & $\begin{array}{l}\text { Jauniešu } \\
\text { bezdarba } \\
\text { dēḷ } \\
\text { nesaražot } \\
\text { ais IKP no } \\
\text { potenciālā } \\
\text { IKP, \% }\end{array}$ \\
\hline 2007 & 22557 & - & - & - & - & - \\
\hline 2008 & 23233.71 & 3 & 676.71 & 1758.79 & 386.93 & 1.67 \\
\hline 2009 & 23930.72 & 5.91 & 1373.72 & 4159.16 & 939.97 & 3.93 \\
\hline 2010 & 24648.64 & 8.74 & 2091.64 & 4776.91 & 984.04 & 3.99 \\
\hline 2011 & 25388.10 & 11.49 & 2831.10 & 4082.41 & 779.74 & 3.07 \\
\hline 2012 & 26149.75 & 14.15 & 3592.75 & 3891.08 & 723.74 & 2.77 \\
\hline 2013 & 26934.24 & 19.41 & 4377.24 & 3172.85 & 567.94 & 2.11 \\
\hline 2014 & 27742.26 & 22.99 & 5185.26 & 2962.87 & 465.17 & 1.68 \\
\hline 2015 & 28574.53 & 26.68 & 6017.53 & 2794.59 & 385.65 & 1.35 \\
\hline \multicolumn{4}{|c|}{ Kopā periodā } & 27598.66 & 5233.18 & 20.57 \\
\hline
\end{tabular}

Avots: autores aprēķins pēc Centrālās statistikas pārvaldes datiem

Piemēram, 2013. gadā faktiskais bezdarba līmenis $=11.9 \%$ 
Dabiskais bezdarbs (pieṇemts lielums) $=6 \%$, pamatojoties uz reālā IKP sasniegtā lìmena.

Starpība starp faktisko bezdarba līmeni un dabisko bezdarba līmeni:

$11.9 \%-6 \%=5.9 \%$

Bezdarba dēḷ nesaražotais IKP: $5.9 \% * 2 \%=11.8 \%$

Tiek aprēķināts bezdarba dēl nesaražotais IKP (11.8\% * Potenciālais IKP), kas ir $11.8 \% * 26934.23$ milj. EUR = 3172.85 milj. EUR.

Aprēķina noslēgumā tiek noteikts jauniešu īpatsvars (no 15 - 24 gadu vecumam) bezdarbnieku skaitā, kas 2013. gadā (pēc CSP datiem) bija 17.9\%. Aprēķinā tiek pieņemts, ka jauniešu devums IKP pieaugumā neatšķiras no pieaugušo devuma.

Tiek aprēķināts, kādu daļu no nesaražotā IKP nav saražojuši jaunieši.

Piemēram, 2013. gadā jauniešu bezdarba dēl nesaražotais IKP bija 567.95 milj. EUR, kas ir 2.11\% no potenciālā IKP 2013. gadā (skatīt 3.1. tabulu).

Iepriekšminētie aprēķini tiek veikti katram gadam periodā no 2008. - 2015. gadam.

Kā redzams 3.1. tabulā, izmantojot iepriekšminēto metodologiju, vislielākie zaudējumi no nesaražotā IKP jauniešu bezdarba dēl bija 2010. gadā - 984.04 milj. EUR, bet 2009. gadā - 939.97 milj. EUR.

2014. gadā zaudējumi no nesaražotā IKP jauniešu bezdarba dēl bija 465.17 milj. EUR un 2015. gadā tie bija zemāki - 385.65 milj. EUR.

\subsection{Eiropas valstu pieredze/ Experience of European countries}

Nodaḷā tiks analizēti pozitīvie piemēri jauniešu nodarbinātības un iekḷaušanās darba tirgū veicināšanā atsevišķās Eiropas valstīs.

„Jaunatnes garantijas” pasākumi, ko Latvijā koordinē NVA, tiek veiksmīgi koordinēti vairākās ES dalībvalstīs.

Eiropas Ziemel̦valstis bija pirmās, kas uzsāka īstenot jauniešu garantijas pasākumus 1980. un 1990. gados. Tie ietver Zviedriju (1984), Norvēgiju (1993), Dāniju (1996) un Somiju (1996). Šobrīd jau vairākas ES valstis ir uzsākušas līdzīgu jauniešu nodarbinātības programmu attīstīšanu, piemēram, Austrija, Vācija, Nīderlande un Polija (Youth Guarantees a..., b.g.).

Eiropas valstu nodarbinātības dienesti aktīvi iesaistās jauniešu integrēšanā, un vairums no tiem piedāvā īpaši izstrādātas programmas jauniešu integrēšanai darba tirgū. Jauniešu integrēšanai darba tirgū ES valstīs realizētie pasākumi analizēti darba turpinājumā.

Vācijā darba tirgus tiek stingri regulēts un tiek realizēta duālā izglìtības sistēma, kurai līdzīga sistēma tiek izmantota arī Austrijā un Šveicē. Šajās valstīs ir mazāk gados jaunu bezdarbnieku. Duālā izglītības sistēma paredz vienlaicīgu akadēmiskā diploma un darba pieredzes iegūšanu. Duālā izglīî̄ba nozīmē, ka līdzekḷus jauniešu apmācībā iegulda ne tikai valsts, bet arī uzņēmumi, kuri ir ieinteresēti konkrētu speciālistu sagatavošanā.

Darba tirgus pētījumu institūta pārstāvis Hilmārs Šneiders (Hilmar Schneider) (2012) uzsvēra, ka Vācijas jaunieši, kuri faktiski apvieno mācību procesu ar praksi, darba tirgus tendences izprot daudz labāk nekā viṇu vienaudži citās Eiropas valstīs. Darba devējiem savukārt ir pietiekami daudz laika iepazît savus jaunos darbiniekus, noskaidrot viṇu vājās puses, nepieciešamības gadījumā palīdzēt novērst trūkumus un nepilnības. Tas nozīmē, ka Vācijā darba devēji, parakstot līgumu ar gados jaunu darbinieku, faktiski neriskēe, jo jau zina, uz ko šis darbinieks ir spējīgs. Sistēma 
funkcionē tik efektīvi, ka Vācijā jaunatnes bezdarba līmenis ir zemāks nekā valstīs ar daudz atvērtāku darba tirgu. Piemēram, Lielbritānijā tas ir gandrīz divas reizes augstāks. Izglīīibas sistēma iet roku rokā ar stingro darba tirgus regulēšanu. Ja uzñēmumiem dotu iespēju vienkāršot darbinieku atlaišanu, mazāk nozīmīgas būtu kḷūdas, kas piel̦autas darbinieku izvēlē. Līdz ar to darba devēji vairs nebūtu ieinteresēti finansēt iekšèjās apmācības sistēmas, kas tomēr izmaksā ḷoti dārgi. Vācijā darba tirgus regulēšana un duālā apmācības sistēma veido ilgtermiņa attiecības starp abām iesaistītajām pusēm jaunieti un uzṇēmēju. Šo modeli ievērojamo izmaksu dēḷ būtu sarežḡîti ieviest citās valstīs, kurās ir stingra darba tirgus regulēšana. Savukārt valstīs, kurās darba tirgus ir liberalizēts, pēc tā neredzētu vajadzību paši uzñēmēji (Hjūza, Borbējs-Pece, 2012).

Vācijā Valsts nodarbinātības dienesta realizētā "Profesionālās orientācijas programma" ir virzīta uz jauniešu karjeras izvēli, balstoties gan uz profesionālās orientācijas kursiem, gan uz stažējoties gūto praktisko pieredzi darba vietā (Hjūza, Borbējs-Pece, 2012).

Vācijā arī darba devēji tiek stimulēti pieņemt darbā tādus jauniešus, kas nav spējuši atrast prakses vietu vai kas to ir zaudējuši uzṇēmuma likvidācijas dēḷ (Hjūza, Borbējs-Pece, 2012).

Somijā tiek nodrošināta garantija, kas vistuvāk atbilst EK priekšlikumā Padomes ieteikumam izklāstītajai garantijai, proti, jauniešiem piedāvā darba, mācekḷa prakses, stažěšanās vai tālākizglītības iespējas. Pamatojoties uz ilgstošo pieredzi jaunatnes garantiju jomā, Somijas valdības mērķis ir padarīt jauno garantiju vispusīgāku un profilaktiskāku, kā arī apvienot darba un izglītîbas elementus. Garantija tika ieviesta no 2013. gada sākuma un būtībā ir raksturojama šādi: „Ikvienam jaunietim līdz 25 gadu vecumam, kā arī studijas tikko beigušiem jauniešiem līdz 30 gadu vecumam tiks piedāvāts darbs, stažēšanās iespēja, mācības darbavietā vai studiju vieta, vai 3 mēnešu laikā pēc tam, kad jaunietis ir kḷuvis par bezdarbnieku, tam tiks dots periods darbnīcā vai rehabilitācijā.” „Katrai personai, kura ir pārtraukusi mācības, tiks nodrošināta vieta vidusskolā, piedāvātas arodmācības, mācekḷa prakse, vieta jaunatnes darbnīcā vai rehabilitācijā vai citāda palīdzība" (Par jaunatnes garantijas..., 2012).

Papildus Somijas risinājumam virkne iniciatīvu pastāv arī citās dalībvalstīs, kas veicina pilnīgu „Jauniešu garantijas” veiksmīgu ieviešanu (piem., Čehijā, Dānijā un Francijā). Tās, piemēram, ir programmas, kas paredzētas karjeras vadības iemaņu pilnveidei un profesionālai virzībai skolās, profesionālai orientācijai, mazaizsargāto jauniešu mācībām ar nolūku sekmēt pāreju un mazināt to personu skaitu, kuras pārtrauc programmu, kā arī paredzētas palīdzības nodrošināšanai darba meklējumos, individuālai vadībai, piemērotu vietu atrašanai, dotāciju garantēšanai darba devējiem un mācekḷu prakses un profesionālo mācību shēmu izstrādei (Par jaunatnes garantijas..., 2012).

Dažādās dalībvalstīs atšķirīigā apmērā to piedāvā studentiem, jauniešiem, kuri nav nodarbināti, jauniešiem, kuri ir pārtraukuši mācības, jauniešiem, kuri ir NEET, kā arī jauniešiem ar invaliditāti. Lai atbalstîtu jauniešus, kuri nav nodarbināti, īpaši bieži izmanto mācekḷa prakses un/vai stažēšanās iespēju. Parasti shēmas ir paredzēts sākt konkrētu dienu vai mēnešu laikā pēc reǵistrēšanās par bezdarbnieku - lai gan netiek dots solījums, ka to rezultātā tiks piedāvāts darbs, mācekḷa prakses, stažēšanās vieta vai profesionālo mācību vieta. Parasti visas iniciatīvas īsteno valstu nodarbinātības dienesti vai kāda cita valsts pārvaldes iestāde (Par jaunatnes garantijas..., 2012).

Somijā ieviesta prakse, ka jauniešiem vecumā no 25 - 30 gadiem, kas ir bijuši bez darba 6 mēnešus, tiek izsniegta "Sanssi" karte, kas darba devējiem apliecina, ka viniiem būs tiesības uz 10 mēnešu ilgu algas subsīdiju, ja viņi šo cilvēku pieñems darbā. Pieejamās subsīdijas apmērs 2012. gadā bija 650 EUR mēnesī par pilnas slodzes darbu (Hjūza, Borbējs-Pece, 2012). 
Somijā "Jauniešu garantija" ir sekmējusi agrīnu karjeras atbalsta pasākumu īstenošanu, reǵionālo vienlīdzību, sadarbību starp dažādām institūcijām, kā arī attiecības starp institūcijām un jauniešiem (Hjūza, Borbējs-Pece, 2012).

Austrijā 2008. gadā tika ieviesta „Mācību garantija”, kas attiecās uz jauniešiem līdz 18 gadu vecumam, dodot jauniešiem, kuri nevar atrast mācekḷa vietu uzṇēmumā, iespēju apgūt arodu māceklībā uzñēmumu augstākajā mācību iestādē (šo pasākumu finansējuma Austrijas Nodarbinātības dienests). Šā pasākuma ietvaros mācekḷi ar īpašām vajadzībām var izmantot integrētas mācību shēmas priekšrocības, kas paredz daḷēju vai paildzinātu mācekḷa praksi. Rīcības programmā „Nākotne jaunatnei” paredzētā „Darba un mācību garantija” jauniešiem vecumā no 19 līdz 24 gadiem , kas nodrošina, ka jauniešiem, kuri nestrādā, pirmo sešu mēnešu laikā pēc tam, kad viņi ir reǵistrējušies valsts nodarbinātības dienestā, tiek piedāvāts darbs, mērḳtiecīgas mācības vai subsidēts darbs. Papildus dotācijām, kas paredzētas tam, lai nodrošinātu pamatvajadzības un darba samaksu, par kuru ir panākta vienošanās koplīgumā, tiek piedāvāti arī kvalitatīvi un ar darba tirgu saistīti stimuli, lai mudinātu darba devējus izveidot papildu mācību vietas un uzlabot mācību kvalitāti. Tādā veidā darba devējiem tiks sniegts atbalsts, ja viņu mācekḷi māceklības gala eksāmenā saṇems izcilu vai labu atzīmi (Par jaunatnes garantijas..., 2012).

Saskan̄ā ar Eurofound informāciju, pozitīvs piemērs būtu jāṇem no Austrijas saistībā ar valsts centieniem finansiāli veicināt nodarbinātību. Austrijas Valsts nodarbinātības dienests 2011. gadā atvēelēja aptuveni 382 milj. EUR aktīviem darba tirgus politikas virzieniem ( jauniešiem līdz 25 gadu vecumam). Vairāk nekā trešā daļa šo izdevumu tika iztērēti mācekḷu praksei uzṇēmumu augstākajā iestāžu līmenī (aptuveni EUR 11000 gadā par katru šādu mācekḷa prakses vietu jauniešiem līdz 18 gadu vecumam (ja apgrozījums bija liels, viena gada laikā vienu prakses vietu izmantoja vairāki cilvēki). 2011. gada decembrī uzṇēmumu augstākajā mācību shēmā Austrijā piedalījās 10463 jaunieši līdz 18 gadu vecumam (Youth and Work..., 2012). Papildus tam jauniešiem paredzētu jaunu darbavietu mērķfinansējums izmaksā aptuveni EUR 3600 par katru atbalstīto darbavietu. Papildus n,emot vērā aktīva darba tirgus politiku, piemēram, mācību turpināšanu vai profesionālo orientāciju, ar pasākumu saistītās izmaksas par katru nenodarbināto jaunieti (vecumā no 19 līdz 24 gadiem) ir aptuveni EUR 5500 (Par jaunatnes garantijas..., 2012).

Austrija joprojām ES ir viena no aktīvākajām izpildītājām šajā politikas jomā, pateicoties tās duālai apmācības sistēmai, ieviešot papildu politikas instrumentus un iniciatīvas, lai cīnītos pret jauniešu bezdarbu, kā novirzot būtisku valsts finansējuma apjomu šai mērķa grupai. 2012. gadā Austrijas valdības izdevumi par darbu tirgus un mācekḷu programmām jauniešiem (no 15 līdz 24 gadiem) sasniedza 620 milj. EUR un 2013. gadā 650 milj. EUR (jeb aptuveni 0,2\% no Austrijas IKP) (Youth and Work..., 2013/2014).

Kopš 2012. gada Austrijā jauniešus iesaista aktīvajos darba tirgus pasākumos, apmācībās, vai izglītībā jau no pirmās bezdarba dienas. Nemitīgi tiek rīkotas arī pārbaudes par šo pasākumu efektivitāti un kopš 2007. gada Austrijā „Jauniešu garantiju" pasākumu efektivitāte ir īpaši uzlabojusies (Youth Employment Policies..., 2014).

Zviedrijā 2009. gadā tika ieviesta darba garantija jauniešiem jeb „Jauniešu garantija" tiem jauniešiem, kas ir reǵistrējušies Zviedrijas Valsts nodarbinātības dienestā. Šajā pasākumā ir tiesīgi iesaistîties jaunieši vecumā no 15-26 gadiem. Projekta īstenotās pieejas mērķis ir stimulēt nenodarbinātos jauniešus aktīvi meklēt darbu. Programmas sākotnējais periods ilgst trīs mēnešus, un tā laikā jaunietim nodrošina intensīvu atbalstu un izvērtē viņa individuālos centienus atrast darbu. Pēc sākotnējā 
perioda sākas aktīvs piemērotas darbavietas meklēšanas process, kura laikā papildus tiek veiktas citas darbības, piemēram, jaunietis sāk mācekḷa praksi vai iesaistās tālākizglītībā (Par jaunatnes garantijas..., 2012; Hjūza, Borbējs-Pece, 2012).

2013. gadā „Jauniešu garantijas” pasākumos Zviedrijā mēnesī iesaistìjās vidēji 38'000 dalībnieku. Zviedrijā visi jaunieši- bezdarbnieki saņem atbalstu un finansiālu kompensāciju pēc trīs mēnešu reg̣istrācijas Publiskajā nodarbinātības dienestā (Public Employment Service). Pēdējos gados Publiskais nodarbinātības dienests un valdība Austrijā ir centušies palielināt darbības līmeni un iesaistīto dalībnieku īpatsvaru garantijas pasākumos. Turklāt darbības, ko finansē ESF (tostarp jauniešu nodarbinātības iniciatīva ir laba papildus iespēja nostiprināt un papildināt garantijas efektivitāti (Youth Employment Policies..., 2014).

Zviedrijas valdība uzskata, ka darba tirgus politikas iniciatīvas vajadzētu mērķēt uz tiem, kuriem visvairāk tā ir vajadzīga, t.i., ilgtermiņa bezdarbniekiem. Tomēr atsevišķus pasākumus jāveic bezdarba sākumā periodā, lai novērstu risku kḷūt par ilgtermiņa bezdarbnieku. Jauniešiem, kas ir bijuši nodarbināti salīdzinoši īsu laiku un tie, kuri nav beiguši vidējās izglītības iestādes, ir risks kḷūt par ilgtermiṇa bezdarbniekiem (Youth Employment Policies..., 2014).

Nīderlandē jauniešiem tiek piedāvātas mācību un darba vietas, ko nodrošina atzīti “mācību uzņēmumi”, kur jauniešiem piedāvā iegūt darba pieredzi un vienlaikus saņemt algu. Jauniešiem, pārejot uz darba tirgu, tiek sniegts efektīvs karjeras atbalsts. Studentiem ir iespēja tiešsaitē izvēlēties tādu darba vietu, kas atbilst viña vajadzībām, un vakances tiek ātri aizpildītas (Hjūza, Borbējs-Pece, 2012).

Nīderlandē tiek realizēta arī iniciatīva "XXL darbi" jauniešiem, kas piedāvā darba vietas tādās nozarēs, kur vecāka gada gājuma cilvēku aiziešana no darba var izraisīt prasmju un zināšanu trūkumu (Hjūza, Borbējs-Pece, 2012).

Nīderlandē tiek aktīvi īstenoti arī fiskālie pasākumi darba devēju atbalstīšanai, lai viṇi varētu veikt nepieciešamos pielāgojumus un nodrošināt darbu arī jauniešiem ar invaliditāti (Hjūza, Borbējs-Pece, 2012).

Dānijā galvenie iemesli salīdzinoši zemam jauniešu bezdarbam ir īstenotie "Jauniešu garantijas" pasākumi, kā arī salīdzinoši vienmērīgā pāreja "no skolas uz darbu", ko ir veicinājusi duālā apmācības sistēma un plaši izmantotās stažěšanās iespējas, kas veicinājušas izglītîbas apgūšanu un darba pieredzi, ko daudzi jaunieši ieguvuši, apvienojot studijas ar nepilna laika nodarbinātību. Pēdējos gados visos līmeņos, sākot no pamatskolas līdz universitātes līmenim, Dānijā ir veiktas izglìtības reformas (Youth Unemployment and..., 2015).

Dānijā Bērnu un izglîtības ministrija piedāvā "Karjeras atbalsta programmas tiešsaitē un klātienē”. Dānijā ir arī atsevišķa jauniešu datu bāzes sistēma, kurā tiek apkopoti dati par visiem jauniešiem vecumā no 15 - 29 gadiem (saskaņā ar civilstāvokḷa aktu reǵistrācijas sistēmu) (Hjūza, Borbējs-Pece, 2012).

Francijas piemērs ir atšķirīgs. Francijā darba devēji netiek subsidēti, ja uzņem jauniešus mācību praksēs. Darba devējiem ir jāmaksā noteikta maksa, ja darba devējs nevēlas un nepieñem uzñēmumā praksē noteiktu māceklı skaitu. Visiem uzņēmumiem Francijā, kuros ir nodarbināts vairāk par 250 darbiniekiem un mācekḷu proporcija ir mazāka par 4\% no kopējā darbinieku skaita, ir jāmaksā "papildu prakses maksa", kas ir $0.1 \%$ no algu izmaksām (Hjūza, Borbējs-Pece, 2012).

Atsevišķās Eiropas valstīs aktuālas ir darba vidē balstītas apmācības. Arī pētniece I. Buligina savu disertāciju "Publiskās pārvaldes pieejas konkurētspējīga darbaspēka sagatavošanā profesionālajā izglītībā Latvijā" veltījusi publiskās pārvaldes lomai un uzdevumiem konkurētspējīga darbaspēka sagatavošanā profesionālajā izglītībā Latvijā jaunajos sociāli ekonomiskajos un demogrāfiskajos apstākḷos. Disertācijas centrālais 
jautājums ir esošie un topošie institucionālie un sadarbības mehānismi, kas l̦autu publiskajai pārvaldei nodrošināt šāda konkurētspējīga darbaspēka sagatavošanu. I. Buligina uzsvērusi, ka tā kā konkurētspējīgs darbaspēks ir nacionālās tautsaimniecības izaugsmes pamatā, tad šāda darbaspēka sagatavošana ir svarīga visos līmeños (Buligina, 2015).

Profesionālās izglītības un apmācības sistēmai, kas bastīta darba vidē, īpaša uzman̄ība pievērsta Austrijā, Dānijāa, Vācijā un Šveicē. Šajās valstīs pastāv sekojoša sistēma:

- Tiek nodrošināta akreditēta profesionālās kvalifikācijas apmācība un mācību saturs tiek nepārtraukti pielāgots mainīgajām darba tirgus prasībām.

- Apmācībās tiek iesaistīti partneri - komitejas, kas attīsta un uztur mācību programmas pienācīgā līmenī.

- Profesionālās koledžas nodrošina skolā iegūstamo zināšanu bāzes daḷu un aptver gan vispārējo, gan profesionālo izglītību. Valdība sedz izdevumus par apmācībām.

- Uzṇēmumiem, kas iesaistīti profesionālajā apmācībā, ir jāatbilst noteiktiem tehniskajiem standartiem. Apmācību uzņēmums nevar iegūt akdeditāciju, ja neievēro valstī noteiktos standartus. Apmācību uzñēmumi sedz mācību prakses izmaksas un nodrošina praktikantiem algas, kādas darbinieki saņem par nepilnu darba laiku ( Eichhorst et. al., 2015).

Darba autore par būtisku uzskatīja minēt arī Eiropas valsts piemēru, kurā ir atšķirīga ekonomiskā situācija. Pētījuma ietvaros tika izvēlēts apskatīt Baltkrievijas piemēru, kur pozitīva ir izglītības iestāžu cieša sadarbība ar valsts uzņēmumiem un uzṇēmējiem, nodrošinot studentus ar prakses vietām. Arī Latvijā atsevišķas izglìtības iestādes praksē ir ieviesušas ciešu sadarbību ar uzņēmumiem, tomēr šāda prakse vēl ir attīstības līmenī. Piemēram, OT direktore I. Brante veicinājusi sadarbību ar vietējiem uzņēmumiem, kuriem ir interese par nākamo speciālistu sagatavošanu, profesionālajā izglītībā paredzot audzēkṇu darba vidē balstītas izglītības iegūšanu. OT izveidota sadarbība ar SIA „Hanzas Elektronika”, SIA „Malevs”, SIA „Skābardis”, SIA „Pildiṇš” u.c. uzñēmumiem, kur jauniešiem jau no pirmā kursa praktiskās mācības notiek speciālistu vadībā uzṇēmumā un turpinās arī nākamajos kursos. Audzēkṇiem ir iespēja iegūt ne tikai praktisku pieredzi, bet, atbilstoši padarītajam darbam, par to saņemt arī atalgojumu. Pēc mācību beigšanas jauniešiem ir iespēja pretendēt uz darba vietu uzñēmumos (Ogres tehnikums nemitīgā..., 2015).

Līdzīga prakse tiek realizēta ar̄̄ AS „Latvenergo”. Uzņēmuma vadība ir ieinteresēta nākotnē uzņēmumā nodrošināt kvalitatīvu darbaspēku, popularizējot profesijas, kas nepieciešamas uzņēmuma pamatdarbībai, un iepazīstina jauniešus ar izaugsmes iespējām AS „Latvenergo” grupā (Latvenergo koncerna ilgtspējas..., 2009, $37)$.

Baltkrievijā ir 9.7 miljoni iedzīvotāju, no tiem trīs ceturtdaļas dz̄ivo pilsētās un lielpilsētās, un aptuveni tāds pats īpatsvars no darbspējīgajiem iedzīvotājiem ir nodarbināti. Baltkrievijā ir augsti kvalificēts darbaspēks. Pieaugušo lasītprasmes līmenis Baltkrievijā ir viens no augstākajiem pasaulē, un tajā ir 28 universitātes un 8 speciālistu akadēmijas. Iedzīvotāju- studentu skaits (340 studenti uz 10’000 iedzīvotājiem ir viens no augstākajiem rādītājiem Eiropā). Gandrīz puse darbinieku ir ieguvuši augstāko izglīīibu. Saskaņā ar oficiālo statistiku, aptuveni 55\% no darbaspēka strādā valstij, 48.4\% ir nodarbināti privātajā sektorā un 1.6\% ārvalstu uzṇēmumos. Mēneša vidējā alga Baltkrievijā 2009. gadā bija 358 USD jeb 324.75 EUR (Kurss pēc Latvijas Bankas informācijas uz 08.07.2015., 1 EUR= 1.10240 USD) (Labour Market in..., b.g.). 
Baltkrievija ir viena no nedaudzajām post- sociālisma ekonomikām, kas saglabāja valsts sektora dominanci un veidoja komplicētas subsīdiju sistēmas un ekonomisko atbalstu, kas paredzēts iedzīvotājiem, lai pārvaldītu politisko biznesa ciklu (Chubrik, Kazlou, 2013). Šis modelis l̦āva ekonomikai augt diezgan vienmērīgi. Tomēr radās nepieciešamība pēc korekcijām uzṇēmumos un mājsaimniecībās, kas rosināja 2011. gada valsts maksājumu bilances krīzi.

2009. gada beigās Baltkrievijā bezdarba līmenis bija salīdzinoši zems $-6.1 \%$. Tas bija laiks, kad Baltkrievija pirmo reizi saskārās ar pasaules ekonomikas krīzi un darba spēka migrācija tika ietekmēta Krievijas recesijas dēḷ. Krievija bija galvenais Baltkrievijas darbaspēka sañēmējs. Sekojoši faktori palīdz izskaidrot šo parādību:

- bezdarbs kā tendence dramatiski palielina nabadzības risku, jo sociālā bezdarbnieku aizsardzība ir zema. Bezdarba pabalsts Baltkrievijā ir ļoti zems un to ir grūti iegūt. Lai saņemtu bezdarbnieka pabalstu, ir jāpiedalās publiskajos darbos un tie ir īstermiņa (ne vairāk kā 6 mēneši) (Chubrik et.al., 2009; Chubrik, Kazlou, 2012). Jāsecina, ka bezdarbnieki nevar rēķināties ar valsts atbalstu un ir jāspēj atrast darba vieta;

- augstas nodarbinātības nodrošināšana ir viens no valdības ekonomiskās politikas pīlāriem. Valsts sektors cenšas uzturēt augstu nodarbinātības līmeni;

- neesamība vīzu režīmam un pasu kontrolei uz Krievijas robežas, kā arī valodas barjeras neesamība, nodrošina iespēju strādāt Krievijas darba tirgū (Chubik, Kazlou, 2012).

Baltkrievijas vald̄̄bas realizētie pasākumi, lai mazinātu darba spēka migrāciju:

- programma „Migrācijas procesa optimizācija” (Optimisation of Migration Processes) no valsts programmas par Baltkrievijas demogrāfisko drošību 20112015 (National Programme of Demographic Security of the Republic of Belarus 2011- 2015) ar mērķi piesaistìt zemi kvalificētu darbaspēku lauku regionos;

- visaptveroša valsts programma, lai attīstītu mazos un vidējos uzņēmumus mazo pilsētu apkaimē, lai veicinātu migrāciju un urbanizāciju uz lauku reǵioniem;

- doktorantus nodrošināt ar darbu valsts uzṇēmumos, tādā veidā nodrošinot valsts uzñēmumus ar augsti kvalificētu darbaspēku u.c. pasākumi un normatīvie akti, kas regulē migrāciju (Chubrik, Kazlou, 2012).

2015. gadā publicētajā Pasaules Bankas ziņojumā (Doing Business 2015) Baltkrievija 189 valstu vidū ir ierindota 57. vietā, saglabājot nemainīgu pozīciju kopš 2014. gada. Ienākumu pozīijā Baltkrievija novērtēta kā valsts ar ienākumiem virs vidējā līmeña (Ease of Doing..., 2015).

Lai izprastu Baltkrievijas darba tirgus tendences jauniešu vidū un to interesi par uzṇēmējdarbību, darba autore sadarbībā ar valsts zinātņu uzṇēmuma „Baltkrievijas Sistēmpētniecības Institūts agrotehniskajā kompleksā" (The Republican Scientific Unitary Enterprise „, The Institute of System Research in Agroindustrial Complex of NAS of Belarus") generāldirektoru Zenonu Lovki (Zenon Lovkis) un valsts vienotā uzṇēmuma „Baltkrievijas pārtikas nacionālās akadēmijas zinātniski praktiskais centrs” (Republican Unitary Enterprise „, The Scientific and Practical Center of the National Academy of Sciences of Belarus for Foodstuffs") direktoru Aleksandru Špaku (Alexander Shpak) veica jauniešu aptauju ar mērķi noskaidrot Baltkrievijas jauniešu bezdarbu veicinošos faktorus un to ietekmi uz nodarbinātību. Jauniešu aptauja Baltkrievijā veikta 2015. gada jūnija beigās un jūlija sākumā.

Darbā tiek atspoguḷoti būtiskākie rezultāti no jauniešu aptaujas Baltkrievijā, lai apzinātu tendences Baltkrievijas darba tirgū. Aptaujas forma apskatāma 1. pielikumā. Jauniešiem no Baltkrievijas aptaujā netika iekḷauts jautājums par Latvijā pieejamajām uzņēmējdarbības atbalsta programmām. 
Pētījumā piedalījās 96 jaunieši no Baltkrievijas, no kuriem 36 bija vīrieši un 60 sievietes. Vidējais jauniešu vecums, kas piedalìjās pētījumā bija 26 gadi. Pēc tautības $90.6 \%$ no jauniešiem, kas piedalījās aptaujā, ir baltkrievi, 5.2\% krievu tautības pārstāvji, savukārt 4.2\%, bija norādījuši atbildi „,cits” un minējuši poḷu vai ukraiņu tautību. Praktiski visi jaunieši, kas sniedza atbildes uz jautājumiem, bija jau ieguvuši profesionālo vai augstāko izglītību un ir nodarbināti - 60.4\% atzīmēja, ka vinuu statuss ir nodarbināts, 29.2\% norādīja, ka ir nodarbināti un šobrīd studē, 9.4\% norādīja, ka šobrīd tikai studē un $1 \%$ bija atzīmējis, ka šobrīd nestudē un nestrādā.

Jauniešiem no Baltkrievijas tika uzdots arī jautājums, kādā veidā jaunietis ir atradis savu līdzšinējo darbu. Vislielākais respondentu skaits $(41.9 \%)$ atzīmēja, ka šà brīža darba vietu atrada, studiju ietvaros pie darba devēja izejot praksi un prakses beigās darba devējs piedāvāja patstāvīgu darbu, 23.3\% atbildēja, ka darbu atrada pašu spēkiem, sūtot pieteikumus uz interneta resursos izvietotiem darba sludinājumiem, $20.9 \%$ no jauniešiem atbildēja, ka darbu atrada ar pazinuu un draugu starpniecību, 7\% atzīmēja, ka darba devējs izteica piedāvājumu, atrodot jaunieša pieteikumu interneta vietnēs, kā arī 7\% no respondentiem atzīmēja ,cits variants”, minot, ka ir pašnodarbināta persona, darbu nav meklējis, darba devējs uzaicināja strādāt pēc savas iniciatīvas. Uz jautājumu „Cik ilgi Jūs esat darba meklējumos?" respondenti, kas bija bez darba vai tikai studēja, $62.5 \%$ atbildēja, ka šobrīd nemeklē darbu, $12.5 \%$ atbildēja, ka ir darba meklējumos 1-3 mēnešus, 6.3\% respondenti uz katru no atbildēm - šobrīd ir darba meklējumos 6-9 mēnešus, 9-12 mēnešus, 12 mēnešus un ilgāk, sniedza vienādu skaitu atbilžu. Arī 6.3\% no respondentiem minēja atbildi - „cits variants”, pieminot, ka darbu nemeklē vispār vai nemeklē kādu iemelsu dēl, piemēram, tādēl, ka šobrīd studē.

Balstoties uz pētījuma rezultātiem, darba autore secināja, ka 35.4\% Baltkrievijas jauniešu ļoti traucēja un $26 \%$ traucēja atrast atbilstošo darbu neapmierinoša piedāvātā darba samaksa, savukārt $25 \%$ no respondentiem minēja, ka nebija problēmas ar piedāvāto darba samaksu, un tas nebija ietekmējošais faktors, kas traucēja atrast darbu.

Zināšanu un prasmju trūkums attiecīgajā jomā 52.1\% no respondentiem arī nebija traucēklis darba atrašanai, savukārt $17.7 \%$ minēja, ka šis faktors atstāja neitrālu ietekmi uz darba meklējumiem. $14.6 \%$ zināšanu un prasmju trūkums traucēja darba meklējumus un 5.2\% - l̦oti traucēja atrast pienācīgu darbu.

Ar nepieciešamās darba pieredzes trūkumu 46.9\% no aptaujas dalībniekiem nav saskārušies tādā līmen̄̄, ka tas traucētu darba meklējumiem, 17.7\% darba pieredzes trūkums bijis neitrāls faktors, savukārt $10.4 \%$ tas traucējis lototi un $13.5 \%$ - traucējis darba meklējumos.

Izteiktas problēmas Baltkrievijas jauniešu redzējumā nav bijušas arī ar darba vietu skaitu, 41.7\% minējuši, ka „nav traucējis” darba meklējumos mazs brīvo darba vietu skaits, $19.8 \%$ sniedza atbildi, ka tas ,gandrīz nav traucējis” darba meklējumos, savukārt, 16.7 \% ,„̧oti traucēja” un $8.3 \%$ „traucēja” atrast darbu.

Līdzvērtīgs redzējums jauniešiem ir arī attiecībā uz iegūtās/ iegūstamās izglìtības ietekmes neatbilstību piedāvātajām darba vietām: $52.1 \%$ no respondentiem sniedza atbildi, ka šis faktors nemaz nav traucējis darba meklējumos, 20.8\% - gandrīz nav traucējis, $12.5 \%$ - atstājis neitrālu iespaidu, savukārt $9.4 \%$ - traucēja un $5.2 \%$ - lioti traucēja atrast darbu. 


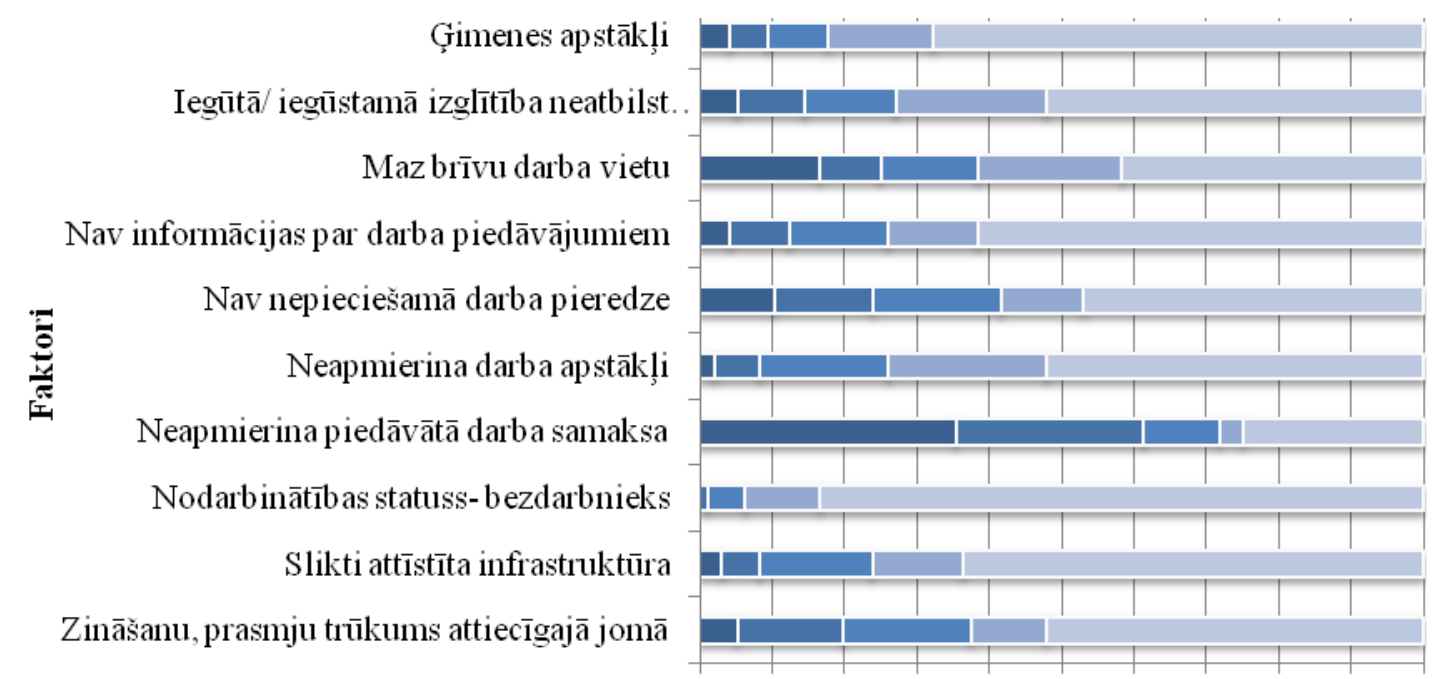

$0 \% 10 \% 20 \% 30 \% 40 \% 50 \% 60 \% 70 \% 80 \% 90 \% 100 \%$

Procentuālais sadalījums

Loti traucēja $\square$ Traucēja $\square$ Neitrāls $\square$ Gandrīznav traucējis $\square$ Nemaz nav traucējis

Avots: autores pētījums un konstrukcija

\subsection{1. att./ Fig. 3.11. Baltkrievijas jauniešu aptaujas (n=96) rezultāti jautājumam „Lūdzu, novērtējiet, cik lielā mērā dažādi ārēji, no Jums paša zināmā mērā neatkarīgi, faktori ir Jums iepriekš traucējuši atrast darbu?" (\%)/ \\ Results of a youth survey $(n=96)$ in Belarus to the question "Please rate, how significant are the following exogenous factors that hindered you from finding a job before" (\%).}

Izvērtējot ietekmējošo faktoru - neapmierinoši darba apstākḷi, 52.1\% no jauniešiem atbildējuši, ka nemaz nav traucējis šis faktors, $21.9 \%$ snieguši atbildigandrīz nav traucējis, $17.7 \%$ no aptaujātajiem šis faktors atstājis neitrālu ietekmi, $6.3 \%$ traucēja un $2.1 \%$ ļoti traucējis darba meklējumos.

$61.5 \%$ no jauniešiem nav saskārušies ar informācijas trūkumu par darba piedāvājumiem, 63.5\% no jauniešiem nav bijušas problēmas arī ar slikti attīstītu infrastruktūru, kā arī 67.7\% no aptaujātajiem nav traucējuši darba meklējumos gímenes apstākḷi un $83.3 \%$ nav traucējis arī nodarbinātības statuss - bezdarbnieks (skat. 3.11. att.).

Darba autore uzskata, ka jauniešu sniegtās atbildes liecina par ciešo izglītības iestāžu sadarbību ar valsts uzṇēmumiem, kas veicina jauniešu iesaisti darba tirgū prakses ietvaros, nodrošinot un veicinot jauniešu vēlāku nodarbināšanu uzņēmumos, kuros jaunietis ir izgājis praksi.

Jaunieši tika aicināti sniegt vērtējumus par attieksmi, ar kādu nācies saskarties no darba devēju puses, izvērtējot jaunieša kandidatūru uz vakanto vietu. Apgalvojumi vērtēti sekojoši:

- 35.5\% jaunieši saskārušies ar kandidatūras pozitīvu izvērtējumu uz vakanto vietu, neatkarīgi no jaunieša līdzšinējās pieredzes un izglîtības līmeņa;

- $47.3 \%$ tika dota iespēja iegūt pieredzi un apgūt nepieciešamās prasmes konkrētā amata izpildei;

- $2.7 \%$ saskārās ar negatīvi vērtētu konkurētspēju attiecībā pret pieredzes bagātākiem pretendentiem;

- $\quad 1.8 \%$ saskārās ar negatīvu vērtējumu studiju dēḷ; 
- 1.8\% saskārās ar negatīvu attieksmi, ko ietekmēja dažādi faktori, piemēram, valodu prasmju trūkums, līdzšinējā pieredze u.c. faktori);

- $9.1 \%$ saskārās ar neitrālu attieksmi;

- $1.8 \%$ atzīmēja variantu cits, minot to, ka ir pašnodarbināta persona, līdz ar to jaunietis nebija saskāries ar darba devēju attieksmi.

Balstoties uz iepriekšminēto, darba autore secina, ka aptaujā iesaistītie jaunieši no Baltkrievijas ir saskārušies ar pozitīvu attieksmi no darba devēju puses un tiem tiek dota iespēja iegūt nepieciešamo pieredzi darba pienākumu izpildei. Jāsecina, ka jauniešu potenciāls tiek efektīvi izmantots.

Jaunieši tika aicināti arī izteikt viedokli par savām interesēm attiecībā uz uzņēmējdarbības uzsākšanu. Uz jautājumu „Vai Jūs esat domājis par savas uzņēmējdarbības uzsākšanu?", 42.7\% no jauniešiem atbildēja, ka neplāno uzsākt uzṇēmējdarbību, savukārt 36.5\% - plāno uzsākt uzņēmējdarbību, 19.8\% neinteresē uzņēmējdarbība un 1\% jeb 1 respondents minējis, ka uzṇēmējdarbību ir jau uzsācis. Vairākums no jauniešiem Baltkrievijā neplāno uzsākt savu uzṇēmējdarbību. Atbildes ir pamatojamas, jo ne visi var būt uzṇēmēji un ne visiem par tādiem jākḷūst, būtiski ir izprast esošo darba tirgus situāciju un meklēt risinājumus tās uzlabošanai. Vērtējams pozitīvi, ka jaunieši Baltkrievijā ir apmierināti ar uzņēmēju un valsts piedāvātajām darba vietām un spējīgi iekḷauties darba tirgū. Šì tendence arī izskaidrojama ar Krievijas valsts tuvumu, jauniešiem ir iespēja šķērsot robežu un doties darba meklējumos uz Krieviju, jo nepastāv valodas barjera.

Uz jautājumu „Ja Jūs uzsāktu uzn̦ēmējdarbību, kurā no nozarēm Jūs vēlētos darboties?", jaunieši sniedza sekojošas atbildes: 19.4\% - tūrisms, viesnīcu bizness; $16.7 \%$ - tirdzniecība, pakalpojumi; $13.9 \%$ - lauksaimniecība; $11.1 \%$ - mediji, reklāma, poligrāfija; $8.3 \%$ - izglītība, zinātne; $5.6 \%$ - finanses, grāmatvedība; $2.8 \%$ - medicīna, farmācija, veselība; $2.8 \%$ - cits, piem., sports.

Darba autore, izvērtējot sniegtās atbildes, pozitīvi vērtē vairākuma interesi par biznesa uzsākšanu tūrisma un viesnīcu biznesa nozarē, jo būtiski ir attīstīt tieši lauku tūrismu, lai veicinātu reǵionālo attīstību, kā arī pozitīva ir jauniešu interese par lauksaimniecību un ar to saistītajām nozarēm. Arī Latvijā lauksaimniecības un ar to saistîto nozaru attīstību ir būtiski veicināt, radot jauniešos interesi par šo uzṇēmējdarbības veidu.

\section{3. nodaļas secinājumi/ Conclusions for Chapter 3}

Darba tirgus tendences Latvijā. Rīgas reǵionā ir vērojama tendence iedzīvotāju skaitam palielināties, toties situācija ir atšķirīga pārējos Latvijas plānošanas reǵionos Vidzemes, Kurzemes, Zemgales un Latgales reǵionos, kur pastāvīgo iedzīvotāju skaits katru gadu samazinās. 2015. gadā Rīgas plānošanas reǵionā bija 50.78\% pastāvīgo iedzīvotāju, Vidzemes reǵionā - 10.02\%, Kurzemes reǵionā- $12.83 \%$, Zemgales reǵionā - $12.19 \%$ un Latgales regionā $-14.18 \%$.

Latvijā 2014. gadā, salīdzinot ar 2013. gadu, 40.4\% no jauniešiem vecumā no 15 - 24 bija ekonomiski aktīvi, t.i., strādā vai meklē darbu, bet pārējie (59.6\%) bija ekonomiski neaktīvi t.i., lielākā daḷa no tiem joprojām mācās, nevis meklē darbu.

Ekonomiskās globalizācijas ietekmē reǵionos gan Eiropā, gan Latvijā darba devēji koncentrējas stratēg̣iski izdevīgākās vietās - lielākajās pilsētās valstī, savukārt lauku teritorijās darba devēju aktivitāte ievērojami samazinās un veidojas sociāli neizdevīgi gan darba, gan dzīves apstākḷi, kas veicina lauku reǵionu ekonomiskās situācijas pasliktināšanos. 
Bezdarba tendences Latvijā. Bezdarba problēma Latvijā ir jārisina kompleksi, iesaistot gan pašvaldības, gan izglītības iestādes un uzṇēmējus.

Ekonomisti uzskata, ka Latvijas reǵionos bezdarba līmenis kopumā samazinās, jo vēl aizvien ir ekonomiski aktīvie iedzīvotāji, kas izvēlas pārcelties uz dzīvi citā valstī, labāk atalgota darba piedāvājuma dēḷ. Būtisku ietekmi uz tendencēm darba tirgū atstāj iedzīvotāju mirstība un mazā dzimstība, ko veicina sociālie aspekti.

Vislielākais jauniešu bezdarba līmenis Latvijā 2013. gada 3. ceturksn̄̄ bija Latgales reǵionā, kur bez darba bija 47.2\% jaunieši, Kurzemes reǵionā - 30\%, Vidzemes reǵionā $-25.2 \%$, Rìgas reǵionā $-24.7 \%$, Zemgales reǵionā $-21.6 \%$, savukārt, Pierīgas reǵionā tas bija vismazākais - $19 \%$.

Zaudējumi no jauniešu bezdarba Latvijā. Balstoties uz teorētisko bāzi, darba autore veica aprēksinu par zaudējumiem valstij no jauniešiem bezdarbniekiem. Latvijas valstij zaudējumi no bezdarbā esošiem jauniešiem nesaražotā IKP apmērā 2014. gadā bija 465.17 milj. EUR un 2015. gadā - 385.65milj. EUR, savukārt 2010. gadā - 984.04 milj. EUR.

Jauniešu ilgstošais bezdarba līmenis ES dalībvalstīs. 2013. gadā ES 28 vidējais jauniešu ilgstošais bezdarba līmenis (12 mēneši un vairāk) bija 35\%.

Vērtējot starp Baltijas valstīm - Latvijā- 29.2\%, Lietuvā - 20\% un Igaunijā $35 \%$.

Visaugstākais jauniešu ilgstošā bezdarba līmenis 2013. gadā bija Slovākijā (61\%), Itālijā (53\%) un Grieķijā (52\%).

Savukārt, izvērtējot starp ES valstīm, Somijā jauniešu ilgstošā bezdarba līmenis bija vismazākais - 5\%, otrais zemākais līmenis bija Zviedrijā - 7\%, trešais zemākais Dānijā $-10 \%$.

ES dalībvalstu darba tirgus pieredze. Izanalizējot ES valstu piedāvātos risinājumus jauniešu bezdarba mazināšanai, ES dalībvalstīs ir aktuāla „Jaunatnes garantijas" pasākumu realizēšana jau vairāku gadu garumā. Katrā dalībvalstī ir atšķirīga pieredze un iesaistīto jauniešu apjoms.

Darbā analizēto ES dalībvalstu pieredze būtu noderīga Latvijas jaunatnes bezdarba mazināšanas politikas izstrādē.

Zviedrijas valdība finansiāli atbalsta ikvienu jaunieti bezdarbnieku, nodrošinot iespēju saņemt finansiālu kompensāciju pēc trīs mēnešu reǵistrācijas Publiskajā nodarbinātības dienestā. Arī situācijā, ja jaunietis nav iepriekš strādājis, viņam ir iespējas kandidēt uz bezdarba kompensāciju neatkarīgi no iepriekšējā darba stāža ilguma un esamības.

Austrijas valdība aktīvi realizē pasākumus jauniešu nodarbinātības veicināšanai, pateicoties tās duālai apmācības sistēmai, ieviestajiem papildus politikas instrumentiem un iniciatīvām, lai cīnītos pret jauniešu bezdarbu, kā arī novirzot būtisku valsts finansējuma apjomu šai mērķa grupai. Kopš 2012. gada Austrijā jaunieši tiek iesaistīti aktīvajos darba tirgus pasākumos, apmācībās, vai izglītībā jau no pirmās bezdarba dienas. Kopš 2007. gada Austrijā „Jaunatnes garantiju” pasākumu efektivitāte ir īpaši uzlabojusies.

Dānijā īstenotie ,Jaunatnes garantijas” pasākumi ir veicinājuši zemu jauniešu bezdarbu. Dānijā tiek realizēta duālā apmācības sistēma un plaši tiek izmantotas stažěšanās iespējas, kas veicinājušas gan izglīî̄bas, gan darba pieredzes iegūšanu.

Arī Vācijā tiek îstenota duālā izglīitíbas sistēma, kas paredz vienlaicīgu akadēmiskā diploma un darba pieredzes iegūšanu, līdzekḷlus apmācībām iegulda ne tikai valsts, bet arī uzņēmumi, kas ir ieinteresēti konkrētas nozares speciālistu sagatavošanā. 
Vācijā tiek piekopta prakse, kad darba devēji tiek stimulēti pieņemt darbā tādus jauniešus, kas nav spējuši atrast prakses vietu vai kas to ir zaudējuši uzņēmuma likvidācijas dēḷ.

Somijā ir ieviesta prakse, ka jauniešiem bezdarbniekiem vecumā no 25 līdz 30 gadiem, kas ir bijuši bez darba 6 mēnešus, tiek izsniegta karte, kas darba devējiem apliecina, ka jaunietim būs tiesības uz 10 mēnešu ilgu algas subsīdiju, gadījumā, ja darba devējs šo jaunieti izlems nodarbināt.

Nīderlandē jauniešiem tiek piedāvātas mācību un darba vietas, ko nodrošina valstī atzīti "mācību uzņēmumi”. Jauniešiem tiek piedāvāts iegūt darba pieredzi un vienlaikus saņemt algu. Nīderlandē tiek realizēta arī iniciatīva "XXL darbi" jauniešiem. Iniciatīvas mērķis ir izskaust zināšanu un prasmju trūkumu tajās nozarēs, kurās iespējama vecāka gada gājuma cilvēku aiziešana no darba.

Nīderlandē tiek aktīvi īstenoti arī fiskālie pasākumi darba devēju atbalstīšanai, lai viņi varētu veikt nepieciešamos pielāgojumus un nodrošināt darbu arī jauniešiem ar invaliditāti (Jauniešu bezdarbs: mūslaiku..., 2012).

Francijas valdība piekopj atšķirīgu praksi jauniešu nodarbinātības veicināšanā atšķirībā no citām ES dalībvalstīm. Francijā netiek paredzētas subsīdijas darba devējiem, kas praksē nodarbina jauniešus. Francijā ir ieviestas sankcijas, kas attiecas uz tiem darba devējiem, kas nevēlas pieņemt uzņēmumā praksē konkrētu mācekḷu skaitu. Uzñēmumos, kuros ir nodarbināts vairāk par 250 darbiniekiem un mācekḷu proporcija ir mazāka par 4\% no kopējā darbinieku skaita, ir jāmaksā "papildu prakses maksa", kas ir $0.1 \%$ no uzṇēmuma izmaksātajām algām. Šādu sankciju ieviešana un prasība pret uzñēmumiem veicina jauniešu nodarbināšanu.

Austrijjā, Dānijāa, Vāeijā un Šveicē īpaša uzmanība pievērsta profesionālās izglìtības un apmācības sistēmai, kas bastīta darba vidē. Šajās valstīs tiek nodrošināta profesionālās kvalifikācijas apmācība, kas pielāgota darba tirgus prasībām. Apmācību sistēmu uzrauga speciāli izveidotas komitejas. Uzṇēmumi skolniekus/ studentus nodrošina ar prakses vietu un atalgojumu, kas atbilst nepilna laika darba algas līmenim.

Baltkrievijas darba tirgus pieredze. Baltkrievijā ir augsti kvalificēts darbaspēks, no kuriem aptuveni 55\% strādā valsts iestādēs un uzṇēmumos, veidojot valsts sektora dominanci un ietekmi uz izglītības sistēmu valstī, veicinot potenciālo darbinieku kvalifikācijas iegūšanu atbilstoši valstij nepieciešamajām nozarēm. Baltkrievijas ciešā izglītības iestāžu sadarbība ar valsts iestādēm un uzņēmumiem ir minams kā pozitīvs piemērs, jo tiek veicināta jauniešu iekl̦aušanās darba tirgū gan studiju laikā, gan arī pēc studiju beigšanas.

Līdzīga prakse tiek realizēta arī Latvijā atsevišksās izglìtības iestādēs, piemēram, Ogres tehnikuma vadība veicinājusi sadarbību ar vietējiem uzņēmējiem, veicinot jauniešu praktisko iemaņu apgūšanu jau no pirmā mācību gada. Jaunieši par praksi saņem atalgojumu, kā arī teorētiskās zināšanas pielieto praksē un, mācības beidzot, jauniešiem ir iespējas turpināt darbu uzņēmumā. Piekopjot izglītības iestāžu ciešu sadarbību ar uzñēmējiem varētu tikt sekmēts jauniešu nodarbinātības pieaugums.

Balstoties uz jauniešu pētījumā iegūtajiem rezultātiem, jaunieši, kas piedalījās aptaujā bija jau ieguvuši augstāko vai profesionālo izglītību, kā arī iekārtojušies darbā darba devēja pārstāvētajā institūcijā/ uzņēmumā, pie kura izgājis praksi. Baltkrievijā izteikta jauniešu algošana patstāvīgā darbā pēc studiju prakses beigšanas un studiju absolvēšanas. Pēc aptaujā iegūtās informācijas jāsecina, ka darba devēji ir ieinteresēti kvalificēta jaunieša nodarbināšanā kā arī apmācīšanā, veidojot ciešu sadarbību ar izglīīibas iestādēm. Jāpiebilst, ka 55\% strādā valsts iestādēs vai valstij piederošos uzñēmumos, līdz ar to valsts stratēgija ir noteicošais virzìtājs šādas stratēgijas realizēšanā. 
Baltkrievijas jaunieši tādus faktorus kā nodarbinātības statuss- bezdarbnieks, neapmierinoši darba apstākḷi, slikti attīstīta infrastruktūra utt., bija vērtējuši kā faktorus, kas neietekmēja darba meklējumus. Kā traucējošāko faktoru, kas ietekmēja darba meklējumus jaunieši bija vērtējuši neapmierinātību ar piedāvāto darba samaksu, no kuriem $35.4 \%$ ḷoti traucēja šis faktors, un $26 \%$ traucēja. 


\section{JAUNIEŠU IESPĒJU DARBA TIRGŪ APZINĀŠANA UN TO IETEKMĒJOŠO FAKTORU NOTEIKŠANA LATVIJĀ / IDENTIFICATION OF OPPORTUNITIES FOR THE YOUTH IN THE LABOUR MARKET AND THE DETERMINATION OF FACTORS INFLUENCING THE OPPORTUNITIES IN LATVIA}

\subsection{Jauniešu bezdarba virzītājspēki un tendences darba tirgū/ Driving forces of youth unemployment and tendencies into the labour market}

Lai izprastu jauniešu bezdarba virzītājspēkus un galvenās tendences, kas šobrīd dominē darba tirgū Latvijā, kā arī noskaidrotu jauniešu interesi par uzṇēmējdarbības uzsākšanu un uzṇēmējdarbības atbalsta instrumentu nepieciešamību jauniešu skatîjumā, pētījuma ietvaros tika veikta jauniešu aptauja.

Jauniešu aptauja tika veikta dažādos laika posmos - 2014. gada septembrī un oktobrī tika apzināti Latvijas Lauksaimniecības universitātes studenti, 2015. gada martā - Latvijas Universitātes studenti. Periodiski aptauja tika aktualizēta interneta vietnē www.visidati.lv, ar mērķi apzināt jauniešus no dažādiem Latvijas reǵioniem. Pētījuma ietvaros tika veidota sadarbība un uzrunāti jaunieši no dažādām jauniešu organizācijām visā Latvijā. Aptaujas ietvaros, sasniedzamākie respondenti bija tie jaunieši, kas iesaistās jauniešu organizācijās un citās augstskolu aktivitātēs, kā arī sieviešu dzimuma pārstāves, kas skaidrojams ar sieviešu vēlmi iegūt augstāko izglītību un profesiju.

Iegūtie aptaujas dati tika apstrādāti ar statistikas programmu SPSS un Microsoft Excel. Aptaujas forma apskatāma 3. pielikumā.

Kopumā aptaujā piedalījās 764 respondenti, no tiem 617 sievietes un 147 vīrieši. Sieviešu dzimuma pārstāvju lielais īpatsvars skaidrojams ar sieviešu izteikto aktivitāti gan izglīin̄bas jomā, gan iesaisti dažādās jauniešu aktivitātēs, līdz ar to arī lielākas iespējas sasniegt šos respondentus. Aptaujā iesaistīto respondentu vidējais vecums ir 23 gadi.

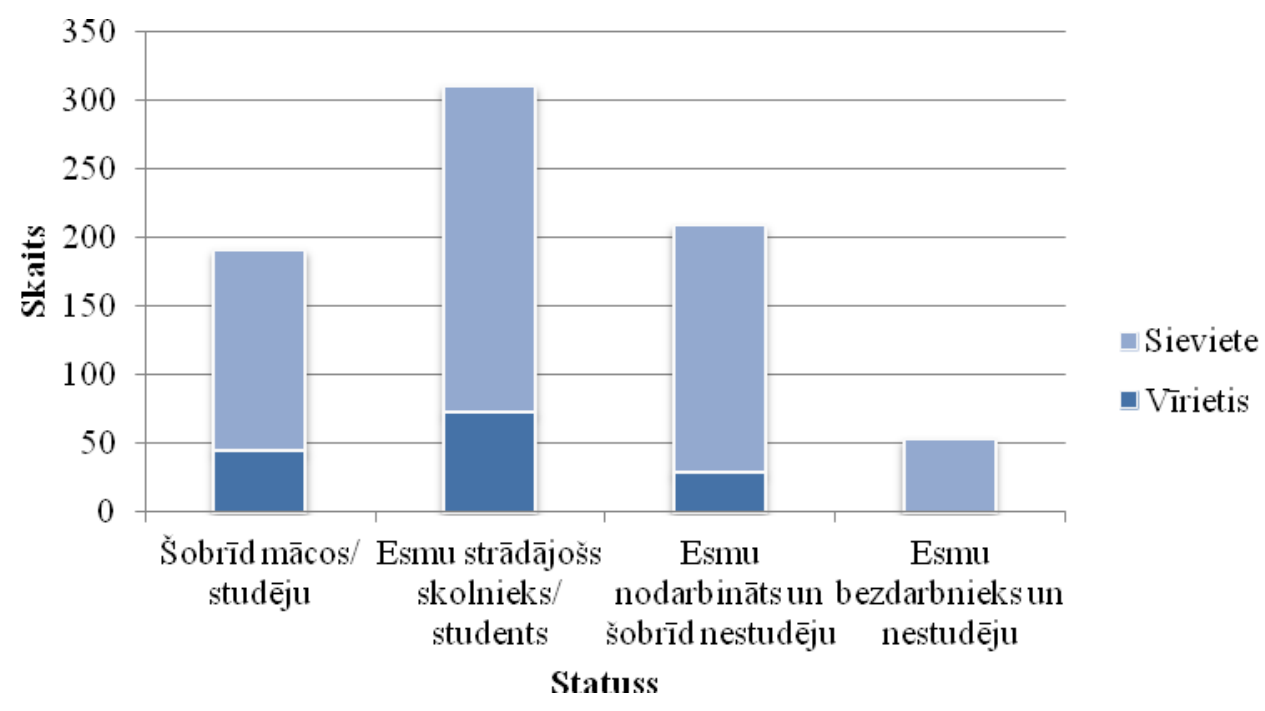

Avots: autores pētījums un konstrukcija

4.1. att./ Fig. 4.1. Respondenta statuss sadalījumā pēc dzimuma (n=764) $(\mathbf{\%}) /$ Status of respondents by gender $(n=764)(\%)$. 
Respondentu ǵenerālkopa tika noteikta, balstoties uz „DNB Latvijas barometra” Nr. 82 veiktā pētījuma pamata, kur kā ǵenerālais kopums tika izvēlēti Latvijas pastāvīgie iedzìvotāji vecumā no 18 - 74 gadiem un kopumā sasniegtais izlases apjoms bija 1006 respondenti. Tā kā Latvijā jauniešu īpatsvars 2014. gadā vecumā no $15-24$ gadiem ir $11.3 \%$ no iedzīvotāju kopskaita, tad sasniegtais izlases apjoms- 764 respondenti ir pietiekams, lai noteiktu tendences Latvijas Republikas pilsētās un lauku teritorijās. Aptaujas respondenti tika izvēlēti nejaušā veidā, nedefinējot konkrētas pazīmes, pēc kurām izvēlēties respondentus. Pētījuma mērḳis bija apzināt jauniešu darba tirgus tendences un to iekļaušanos darba tirgū Latvijā.

Pēc 4.1. attēla redzams, ka $31 \%$ sieviešu un $10 \%$ vīriešu no aptaujas dalībniekiem ir strādājoša skolnieka/studenta statusā, savukārt, 19\% sieviešu un 6\% vīriešu šobrīd tikai mācās/studē. 7\% no aptaujā iesaistītajām sievietēm šobrīd ir bezdarbnieces un nestudē un $24 \%$ no sievietēm un $4 \%$ no vīriešiem ir nodarbināti un nestudē.

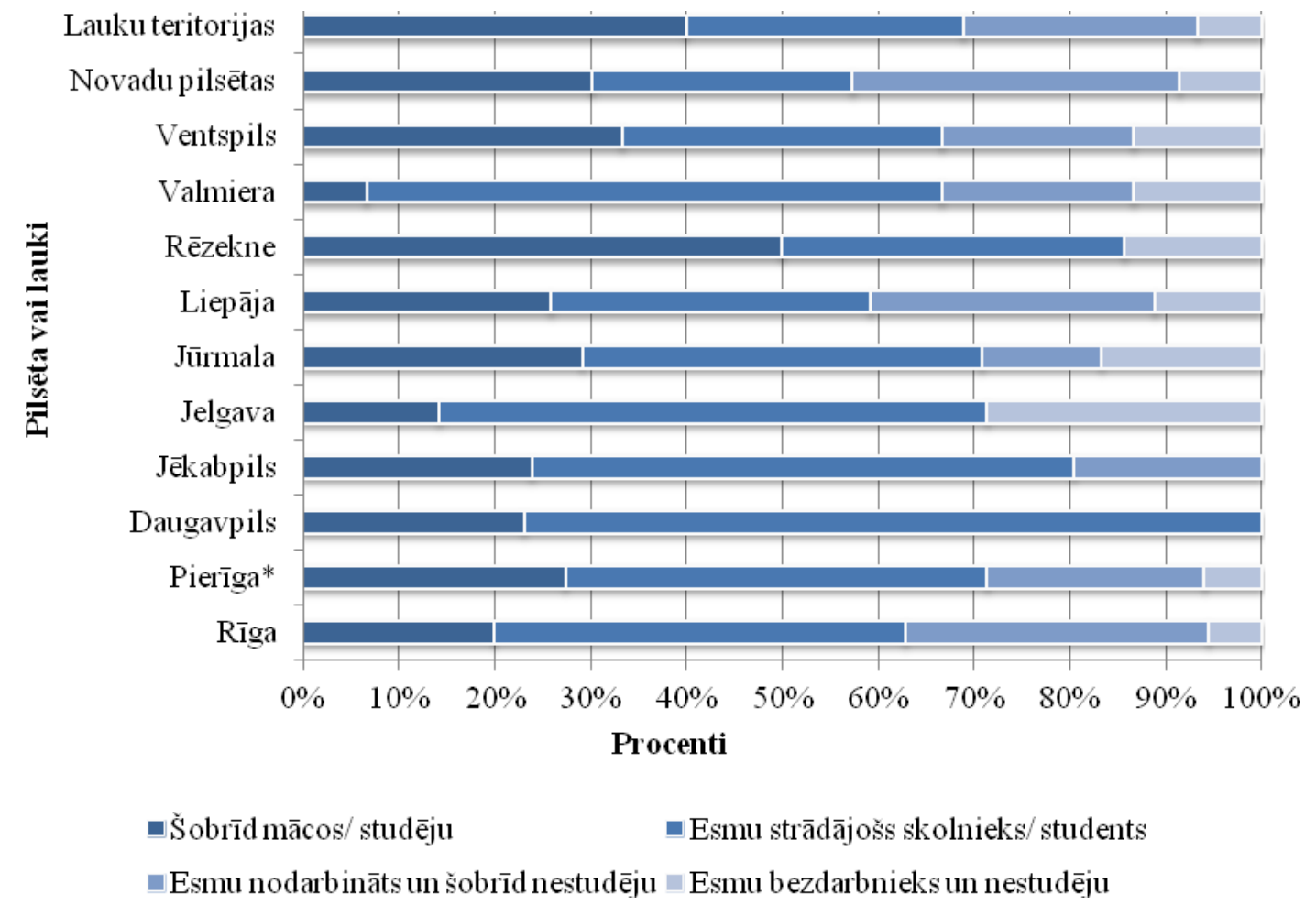

*Pierīga: ieklauti Pierīgas novadi-Ādažu novads, Babītes novads, Garkalnes novads, Ķekavas novads, Mārupes novads, Olaines novads, Ropažu novads, Salaspils novads, Stopiņu novads

Avots: autores pētījums un konstrukcija

\section{2. att./ Fig. 4.2. Respondentu, kas piedalījās aptaujā, sadalījums pa Latvijas pilsētām (n=764) (\%)/}

Distribution of respondents who participated in the survey by city of Latvia $(n=764)$

(\%).

$40.7 \%$ no respondentiem kā savu šì brīža statusu uzrādīja - strādājošs students, $27.4 \%$ - šobrīd strādā un nestudē, $25 \%$ - šobrīd tikai studē, savukārt, $6.9 \%$ ir bezdarbnieki un nestudē. Iegūtie rādītāji vērtējami pozitīvi un tas nozīmē, ka lielākā dạ̧a no aptaujātajiem jauniešiem ir spējuši atrast darba vietu un darba pienākumus savienot ar studijām. 4.2.att. redzams, ka vislielākais jauniešu īpatsvars no tiem, kas 
piedalījās aptaujā, šobrīd nemācās/ nestudē un nestrādā ir Jelgavas pilsētā (30\%). Savukārt, vislielākais jauniešu īpatsvars, kas gan strādā, gan studē, koncentrējas Daugavpilīe Jēkabpilī un Valmierā. Gan lauku reǵionos, gan Rēzeknes pilsētā no respondentiem vislielākais jauniešu īpatsvars studē vai mācās un nestrādā. Šì situācija saistāma ar darba vietu trūkumu Latgales reǵionā, kā arī Latvijas lauku teritorijās, kurās ir nepietiekami attīstīta infrastruktūra (transports).

Aktuāls ir jautājums par studējošo jauniešu iegūto zināšanu kvalitāti un neadekvāti augsto studiju maksas līmeni, salīdzinājumā ar citām ES valstīm. Tajā pašā laikā ne mazāk būtisks ir jautājums, par kādu atalgojumu ir gatavs strādāt studējošais jaunietis, lai spētu nopelnīt iztikas līdzekḷus vai segt studiju maksu, gadījumā, ja nav bijusi iespēja saņemt studiju kredītu. Studiju kredīts jau sākotnēji jaunietim ir kā saistības, ar kurām jārēķinās pēc studiju beigšanas un jāspēj atmaksāt vairāku gadu garumā. Šis kredīta slogs uzliek papildus atbildību un pienākumus gan pret studiju beigšanu, gan „noturēšanos” darba vietā un konkurenci par konkurētspējīgu atalgojumu. Diemžēl šì brīža ekonomiskajā situācijā, kad mājokḷu tirgū īres maksas un dzīvokḷu, mājokḷu cenas ir ES līmenī, savukārt, minimālā alga ir viena no zemākajām Eiropā, jaunietim ir jāspēj pašam veidot sava dzīve un karjera, iekḷauties darba tirgū, lai spētu vairot savu labklājīibu. Jaunietim šajos pārmaiṇu laikos jāspēj iekḷauties darba tirgū, lai netiktu izstumts no sabiedrības.

Balstoties uz aptaujā iegūtajiem rezultātiem, lielākais īpatsvars respondentu jeb 43.1\% atzīmēja, ka darbu atrada pats, regulāri sūtot pieteikumu (CV) uz internetā izvietotiem darba sludinājumiem, savukārt, 37.6\% jauniešu atrada darbu ar paziņu un draugu starpniecību, tikai $6.8 \%$ darba vietā palika strādāt pēc studiju ietvaros izietas prakses beigām, saņemot piedāvājumu no darba devēja par darba turpināšanu jau kā oficiālam darbiniekam. Savukārt tikai 3.3\% jauniešiem darba devējs izteica piedāvājumu, atrodot jaunieša darba sludinājumu interneta vietnēs, 9.3\% no jauniešiem bija snieguši atbildi- cits. Citi veidi, kā jaunietis kḷuva par nodarbinātu bija minēti: pats esmu kḷuvis par uzņēmēju, nodibinot SIA, mikrouzņēmumu vai kā pašnodarbināta persona; iesaistos gimenes biznesā; veicu brīvprātīgo darbu, kas pēc tam kḷuva par apmaksātu un patstāvīgu; nosūtīju savu pieteikumu uz uzņēmumu, kur nebija izsludināts darba piedāvājums; viens no agrākajiem darba devējiem izteica piedāvājumu; darba devējs manus kontaktus ieguva no mācību iestādes un piedāvāja darbu; NVA projekta ietvaros „Pirmais darbs jaunietim”.

Izvērtējot jauniešu sniegtās atbildes „cits”, autore secina, ka jaunieši ir uzņēmīgi un izmanto arī citus veidus, kā iekḷauties darba tirgū, uzsākot darba gaitas, veicot mazkvalificētus darbus bez samaksas vai par nelielu samaksu. Kā arī atsevišķi jaunieši ir uzdrošinājušies interesēties uzṇēmumā par aktuālajām vakancēm, kur tās nav izsludinātas un kḷūt par nodarbinātu, neskatoties uz šo aspektu.

Balstoties uz 4.3. attēlu, 51.7\% no jauniešiem, kas šobrīd ir bez darba - darbu nemeklē. Darba autore uzskata, ka šo jauniešu īpatsvars, kas nemeklē darbu šobrīd mācās vai studē izglītības iestādē. Pārējie respondenti snieguši sekojošu informāciju $16.1 \%$ no jauniešiem ir darba meklējumos $1-3$ mēnešus, $11.3 \%-3-6$ mēnešus, $5.5 \%-6-9$ mēnešus, $1.7 \%$ - 12 mēnešus un vairāk, savukārt, 9.9\% jaunieši snieguši atbildi cits.

Kä citas atbildes jaunieši bija minējuši sekojošo:

- meklē iespēju piestrādāt periodiski;

- periodiski dodas strādāt uz ārzemēm;

- meklē darbu tikai vasaras sezonā;

- Šobrīd nav vērā ņemamu darba piedāvājumu;

- apgūst profesiju, plāno meklēt darbu pēc studijām; 
- apzināti nemeklē darbu, bet izskata piedāvājumus;

- nespēj apvienot darbu ar mācībām;

- atrodas bērna kopšanas atvaļinājumā.

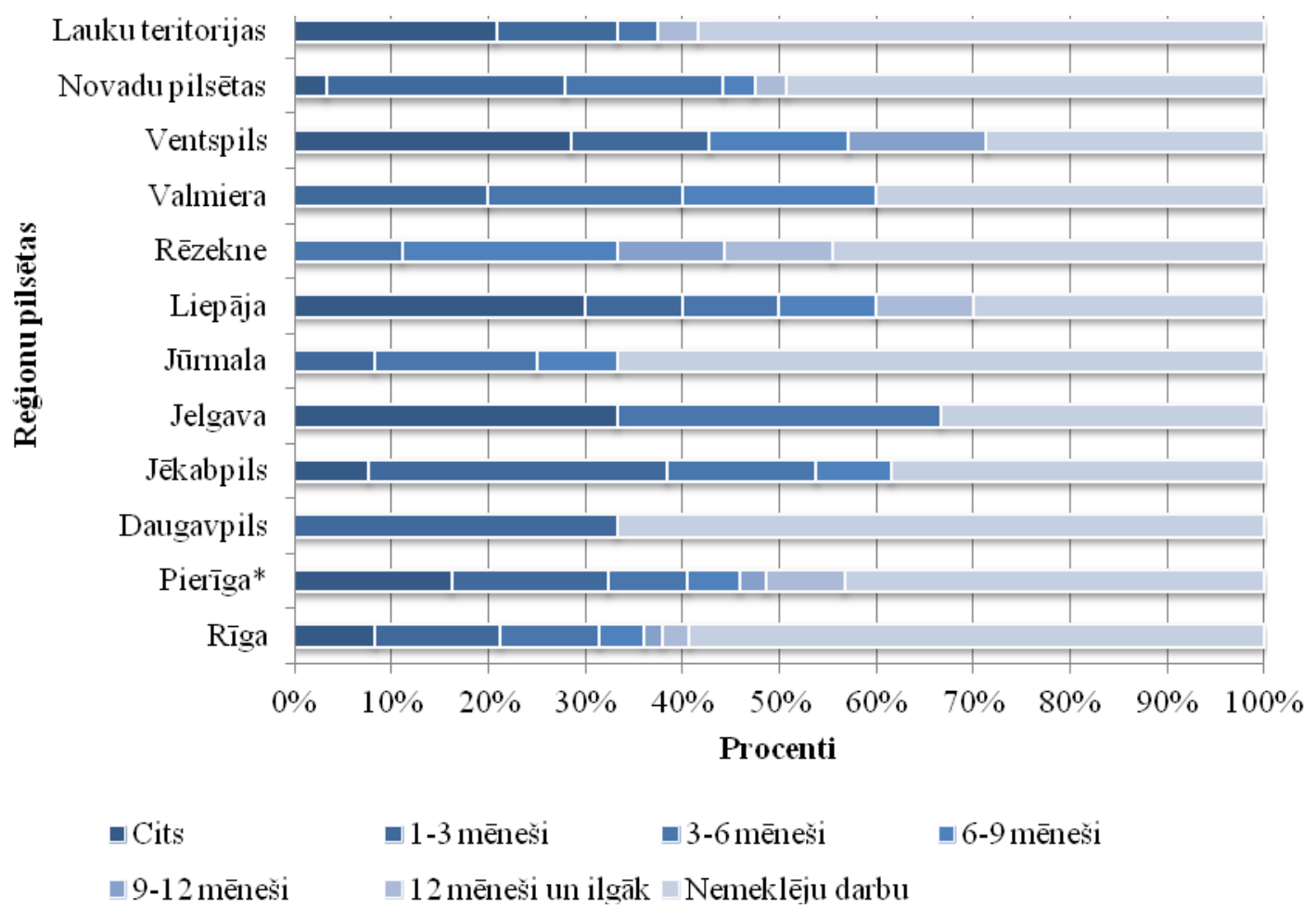

*Pierīga: iekļauti Pierīgas novadi - Ādažu novads, Babītes novads, Garkalnes novads, Ķekavas novads, Mārupes novads, Olaines novads, Ropažu novads, Salaspils novads, Stopiņu novads

Avots: autores pētijums un konstrukcija

\section{3. att./ Fig. 4.3. Jauniešu, kuri šobrīd ir bez darba, darba meklējumu ilgums mēnešos Latvijā (n=292) (\%)/}

Job search duration for youth who are currently unemployed in Latvia, months, $(n=$ 292) (\%).

Balstoties uz 4.4. attēlu, jāmin, ka pret jauniešiem, kas iegūst augstāko izglītību vai ir jau ieguvuši maǵistra grādu, attieksme no darba devēja, izvērtējot jaunieša kandidatūru uz vakanto vietu, ir bijusi pozitīva, neatkarīgi no jaunieša iegūtās darba pieredzes un izglītības līmeņa. Pozitīvu attieksmi no darba devēja puses saņēmuši aptuveni 64\% jauniešu ar maǵistra izglītību, 61\% ar augstāko profesionālo izglītību, $55 \%$ ar bakalaura izglītību, savukārt $67 \%$ jauniešu, kas piedalījās aptaujā un nav vēl ieguvuši augstāko izglītību, bet šobrīd to iegūst, ir vērtējuši darba devēju attieksmi vispozitīvāk.

Jāsecina, ka darba meklējumos galvenokārt izvēli no darba devēju puses ietekmē paša jaunieša attieksme un vēlme strādāt konkrētajā uzṇēmumā/ iestādē un ne vienmēr noteicošā loma ir darba pieredzei un iegūtajai izglītîbai. 


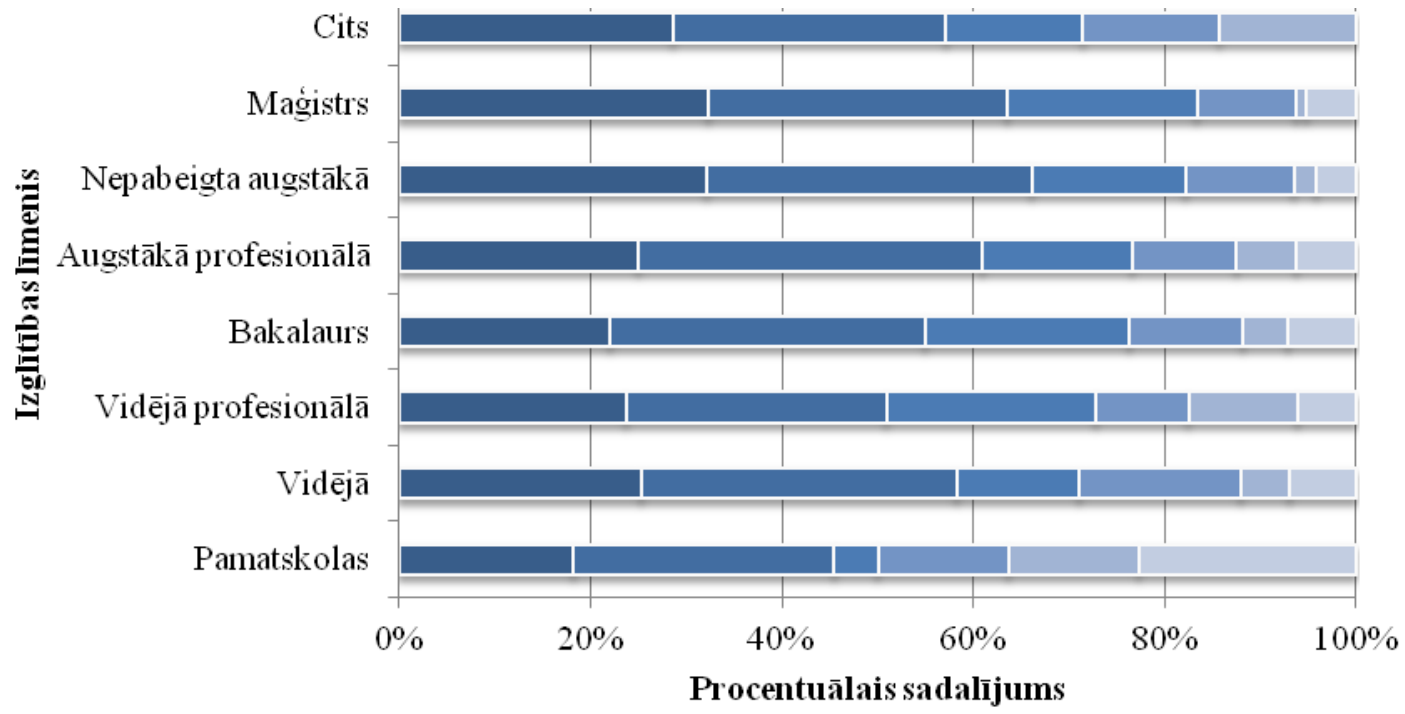

- Tika pozitīvi vêrtēta kandidatūra uz vakanto vietu neatkarīgi no līdzšinējās pieredzes un izglítības līmeña

- Tika dota iespèja iegūt pieredzi un apgūt nepieciešamās prasmes konkrētā amata izpildei

- Tikanegatīvi vērtēta konkurētspe èja attiecībā pret pieredzes bagātākiem pretendentiem

- Tikanegatīvi vērtēts tas, ka šobrīd studēju

- Negatīva attieksme, ko ietekmējusi, piemēram, tautība, vecums, valodu zināšanas, lìdzšinejjā pieredze utt. devēju puses, izvērtējot Jūsu kandidatūru uzizvirzîto vakanci

Neitrāla attieksme

Avots: autores pētījums un konstrukcija

\section{4. att./ Fig. 4.4. Aptaujas dalībnieku izglītības līmenis un iegūtā darba} meklējumu pieredze Latvijā $(\mathbf{n}=764)(\%) /$ Level of education and acquired job search experience of respondents in Latvia $(n=$ 764) (\%).

Arī jaunieši, kas ieguvuši vidējo izglītību ir saskārušies ar pozitīvu attieksmi no darba devēju puses, no tiem 58\%, kā arī vidējo profesionālo izglîtību ieguvušie (52\%), savukārt 46\% jaunieši ar pamatskolas izglìtību darba tirgū nav saskārušies ar grūtībām. 


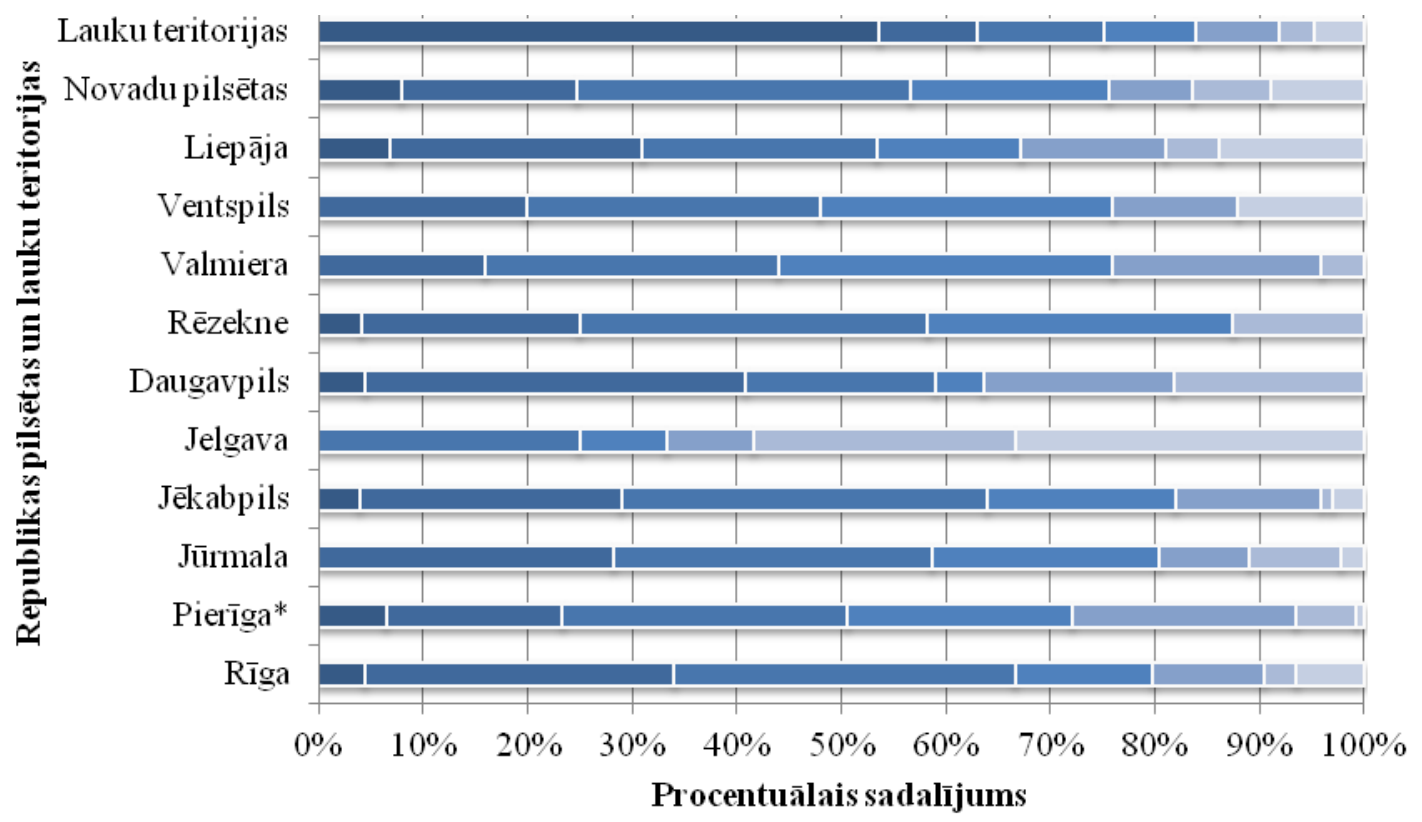

- Cits

- Tika pozitīvi vêrtēta kandidatūra uz vakanto vietu neatkarīgi no līdzšinējās pieredzes un izglīīibas līmeña

- Tika dota iespēja iegūt pieredzi un apgūt nepieciešamās prasmes konkrētā amata izpildei

— Tika negatīvi vērtēta konkurētsp ēja attiecībā pret pieredzes bagātākiem pretendentiem

- Tikanegatīvi vērtēts tas, ka šobrīd studēju

- Negatīva attieksme, ko ietekmējusi, piem., tautība, vecums, dzimums utt.

Neitrāla attieksme

*Pierīga: iekļauti Pierīgas novadi - Ādažu novads, Babītes novads, Garkalnes novads, Ķekavas novads, Mārupes novads, Olaines novads, Ropažu novads, Salaspils novads, Stopiņu novads

Avots: autores pētījums un konstrukcija

\section{5 att./ Fig. 4.5. Aptaujas dalībnieku sadalījums par pieredzi darba meklējumos pēc dzìves vietas Latvijā $(\mathbf{n}=764)(\%) /$ \\ Distribution of survey participants by place of residence regarding their experience in search of a job in Latvia $(n=764)(\%)$.}

4.5. attēlā redzams, ka pēc jauniešu vērtējuma to jauniešu vidū, kas piedalījušies aptaujā, jauniešiem no Jelgavas ir dota iespēja iegūt pieredzi un apgūt nepieciešamās prasmes konkrēta amata pienākumu izpildei. Tomēr jaunieši neatzīmēja apgalvojumu, ka to kandidatūra tika vērtēta pozitīvi neatkarīgi no līdzšinējās pieredzes un izglītības līmeņa. Jaunieši no Jelgavas savos vērtējumos ir bijuši skeptiskāki attiecībā pret citiem jauniešiem. Darba devēju vērtējumu un izvēli bieži vien nosaka jaunieša paša iniciatīva un vēlme strādāt konkrētajā amatā, un tas var būt izšksirošais rādītājs, kādēl darba devējs izvēlas konkrēto kandidātu. 


\subsection{Jauniešu bezdarbu ietekmējošo faktoru analīze/ Analysis of the factors affecting youth unemployment}

Lai apzinātu būtiskākos faktorus, kas ietekmē jauniešu nodarbinātību Latvijā, aptaujas ietvaros jauniešiem tika lūgts novērtēt, cik lielā mērā dažādi ārēji, no jaunieša zināmā mērā neatkarīgi, faktori ir līdz šim jaunietim traucējuši vai viṇu kavējuši atrast darbu.

Kā galvenie jauniešu bezdarbu ietekmējošie faktori tika definēti:

- ǵgimenes apstākḷi;

- iegūtā/ iegūstamā izglītība neatbilst darba tirgus prasībām;

- maz brīvu darba vietu;

- nav informācijas par darba piedāvājumiem;

- nav nepieciešamā darba pieredze;

- neapmierina darba apstākl̦i;

- neapmierina piedāvātā darba samaksa;

- nodarbinātības statuss - bezdarbnieks;

- slikti attīstīta infrastruktūra;

- zināšanu un prasmju trūkums attiecīgajā jomā.

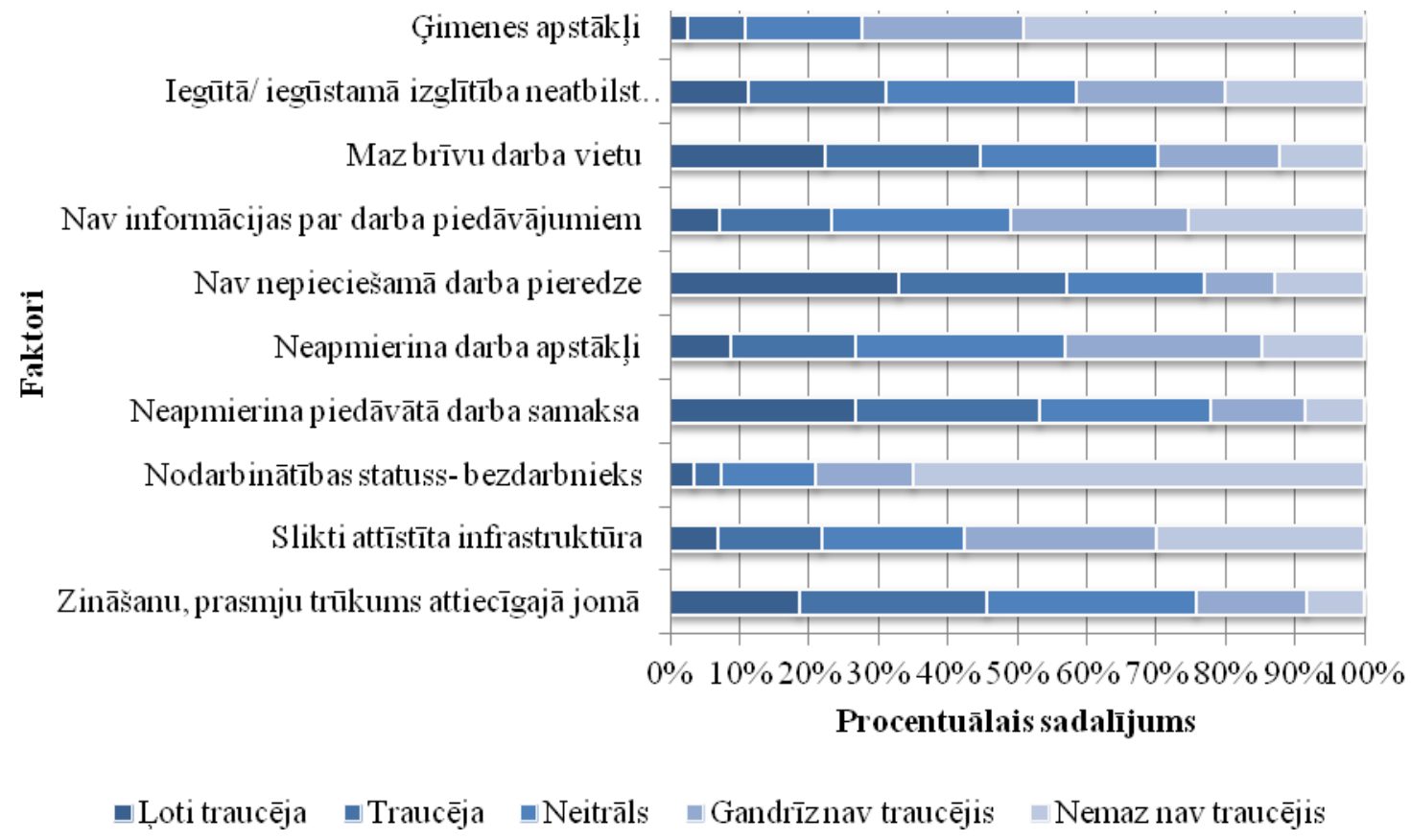

Avots: autores pētījums un konstrukcija

4.6. att./ Fig. 4.6. Jauniešu Latvijā aptaujas rezultāti $(n=764)$ jautājumam „Lūdzu, novērtējiet, cik lielā mērā dažādi ārēji, no Jums paša zināmā mērā neatkarīgi, faktori Jums ir iepriekš traucējuši atrast darbu?" (\%)/

Distribution of the answers of youth $(n=764)$ to the question "Please rate, how significant are the following exogenous factors that hindered you from finding a job before?" (\%).

Iegūtie jauniešu aptaujas rezultāti tika interpretēti un analizēti dažādos skatījumos - faktori attiecībā pret jaunieša dzīves vietu iedalījumu pa Latvijas Republikas pilsētām un jaunieša iegūto izglìtības līmeni. 
Kā redzams pēc 4.6. attēla, nodarbinātības statuss- bezdarbnieks $65 \%$ no jauniešu īpatsvara, kas piedalījās aptaujā nemaz nav traucējis darba meklējumos, 49\% no jauniešiem gimenes apstākḷi bija minēts kā faktors, kas nemaz nav traucējis atrast darbu.

Pie faktoriem, kas visvairāk traucēja jauniešiem darba meklējumos, jāmin neapmierinātība ar piedāvāto darba samaksu (ḷoti traucēja - 27\%, traucēja - 27\%), nepieciešamās darba pieredzes trūkums (ḷoti traucēja - 33\%, traucēja - 25\%) un mazs īpatsvars ar brīvām darba vietām (lıoti traucēja - 22\%, traucēja - 22\%) (4.6. att.).

2006. gadā NVA veica pētījumu „Jauniešu - bezdarbnieku kvalitatīvā sastāva atbilstības darba tirgus pieprasījumam izvērtēšana” ESF nacionālās programmas „Darba tirgus pētījumi” projekta „Nodarbinātības valsts aǵentūras pētījumi” ietvaros. Pētījumā jaunieši tika aicināti izvērtēt ārējo faktoru ietekmi uz darba meklējumiem. 2006. Gada pētījumā piedalījās 602 jaunieši. Salīdzinājumam, 2006. gadā jauniešiem darba meklējumus visvairāk ietekmēja neapmierinātība ar piedāvāto darba samaksu (38\%), iegūtā izglītība neatbilst piedāvātajām darba vietām (32\%), zināšanu un prasmju trūkums attiecīgajā jomā (31\%), nepieciešamās darba pieredzes trūkums (28\%) un maz brīvu darba vietu (24\%). Savukārt, vismazāk darba meklējumos traucēja gímenes apstākḷi (64\%), nodarbinātības statuss - bezdarbnieks (60\%), slikti attīstīta infrastruktūra (50\%), informācijas trūkums par darba piedāvājumiem (40\%) un iegūtās izglītības neatbilstība piedāvātajām darba vietām (32\%) (Jauniešu - bezdarbnieku kvalitatīvā..., 2006).

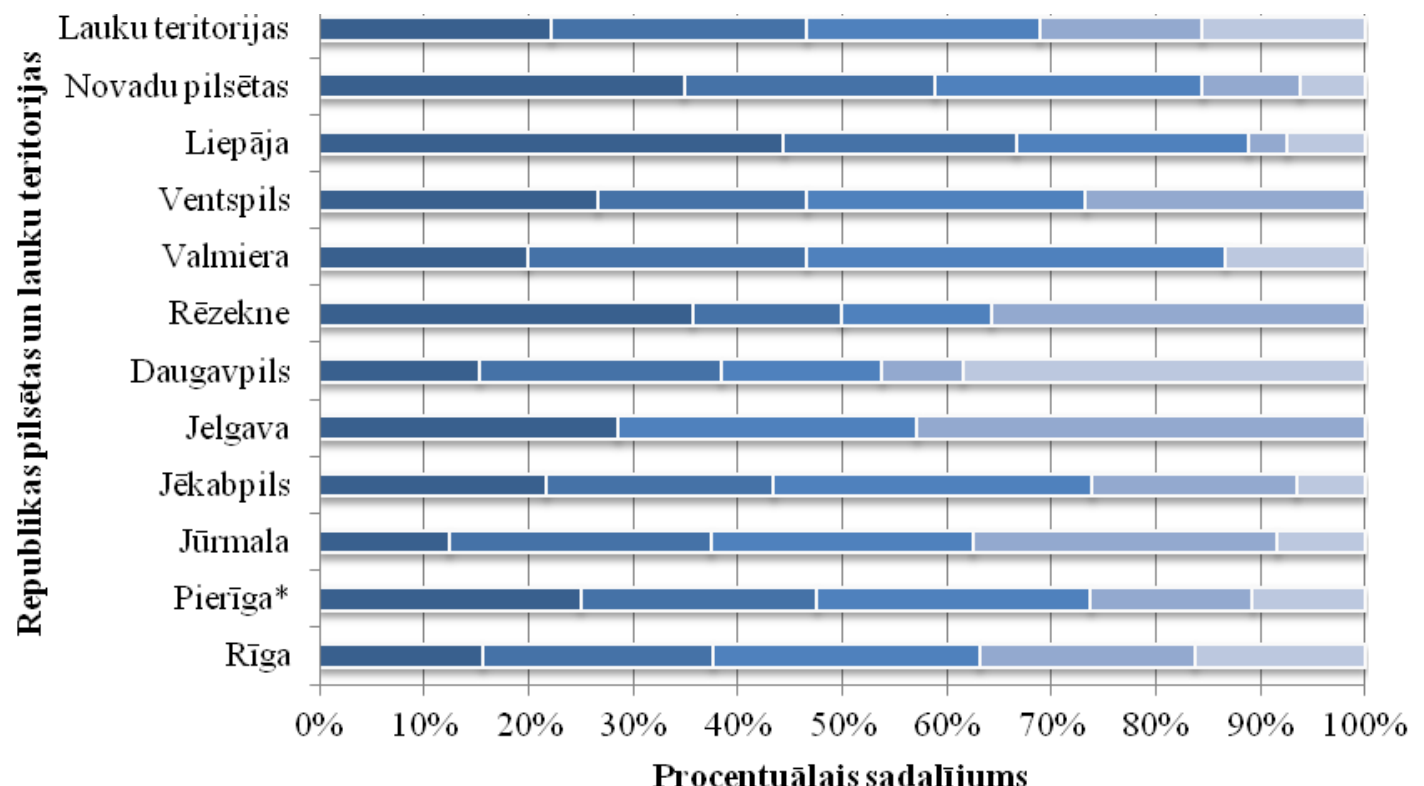

¿Loti traucēja $\square$ Traucēja $\square$ Neitrāls $\square$ Gandrīznav traucējis $\quad$ Nemaz nav traucējis

*Pierīga: iekl̦auti Pierīgas novadi - Ādažu novads, Babītes novads, Garkalnes novads, Kuekavas novads, Mārupes novads, Olaines novads, Ropažu novads, Salaspils novads, Stopiņu novads

Avots: autores pētijjums un konstrukcija

\section{7. att./ Fig. 4.7. Jauniešu nodarbinātību Latvijā ietekmējošā faktora „maz brīvu darba vietu" izvērtējums jauniešu skatījumā $(n=764)$ pēc respondentu dzives vietas Latvijā (\%)/ \\ Assessment of the factor influencing youth employment "there are few vacancies" by youth $(n=764)$ by residence of the respondents in Latvia $(\%)$.}


Balstoties uz jauniešu aptaujā iegūtajiem rezultātiem (4.7. attēls) izvērtējot faktora „,maz brīvu darba vietu” ietekmi uz jaunieša iespējām atrast darbu, vislielākā gradācija $67 \%$ tiek novērota Liepājā, kur darba vietu trūkums $43 \%$ ļoti traucēja un 24\% traucēja darba meklējumos. Arī liels īpatsvars jauniešu (58\% no respondentiem) kā dz̄ives vietu bija atzīmējis citu republikas pilsētu vai mazpilsētu, no kuriem 34\% ļoti traucēja un 24 $\%$ traucēja darba vietu trūkums darba meklējumos. Kā arī 57\% jaunieši no Jelgavas atzīmēja, ka darba vietu trūkuma dēl saskaras ar bezdarba problēmu (no tiem 28\% ļoti traucēja darba meklējumos, $29 \%$ - traucēja).

Arī 50\% jaunieši no Rēzeknes bija atzīmējuši, ka ir saskārušies ar brīvu darba vietu trūkumu (no tiem 35\% - ļoti traucēja, 15\% - traucēja), savukārt, 48\% no Pierīgā dzīvojošajiem jauniešiem kopumā šo faktoru vērtēja kā traucējošu ( $25 \%$ - lıti traucēja, 23\%- traucēja). Lauku teritorijās situāciju jaunieši vērtējuši līdzvērtīgi Pierīgā dzīvojošajiem jauniešiem, kopumā kā traucējošu darba vietu trūkumu minējuši 47\% no aptaujā iesaistītajiem jauniešiem. Darba autore uzskata, ka šī tendence skaidrojama ar jauniešu darba meklējumiem un studijām lielākajās republikas pilsētās, jo mazajās pilsētās brīvo darba vietu skaita īpatsvars ir neliels, kā arī ir salīdzinoši maz institūciju un uzṇēmumu, kuros ir iespējams strādāt.

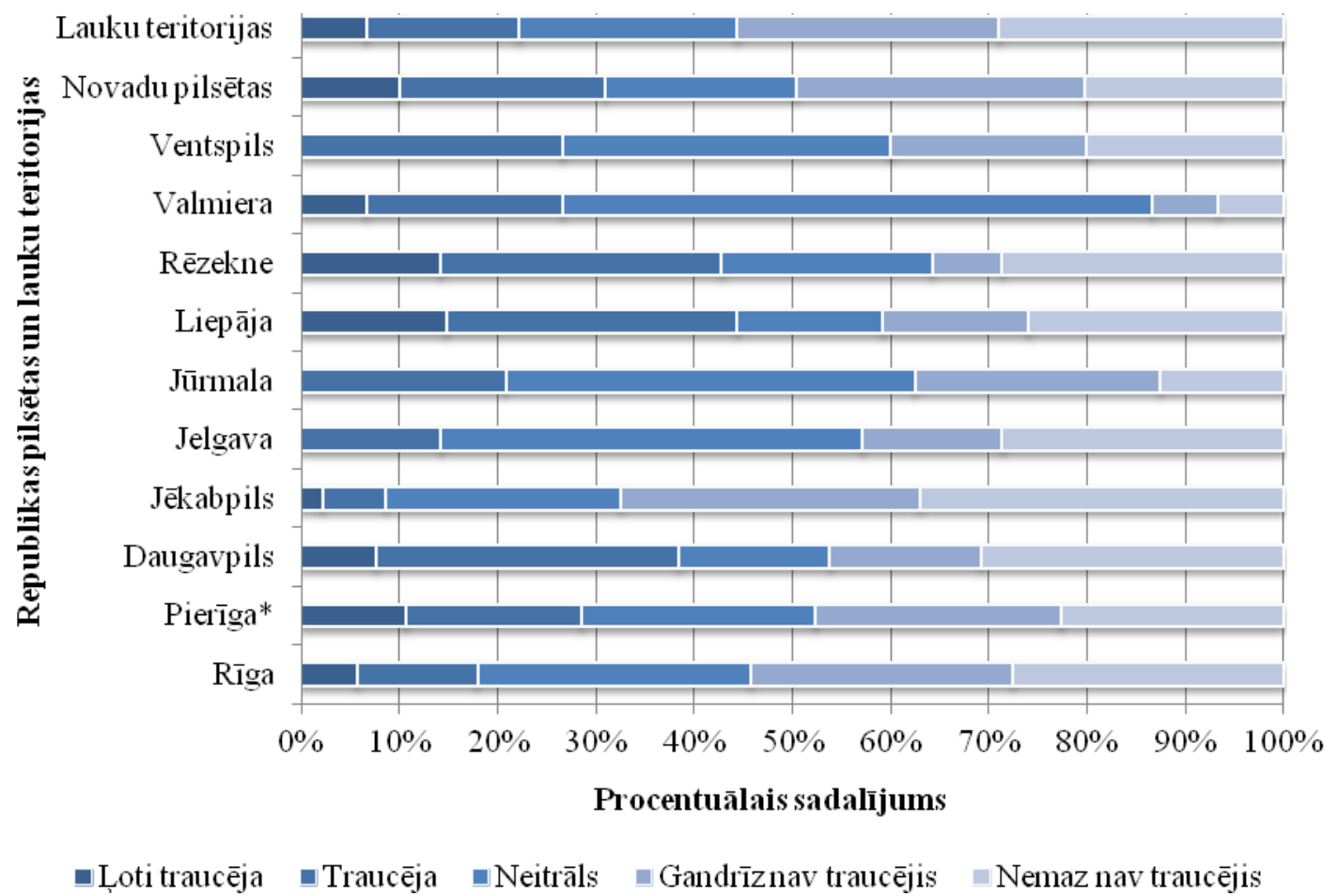

*Pierīga: ieklauti Pierīgas novadi - Ādažu novads, Babītes novads, Garkalnes novads, Ķekavas novads, Mārupes novads, Olaines novads, Ropažu novads, Salaspils novads, Stopiņu novads

Avots: autores pētījums un konstrukcija

4.8. att./ Fig. 4.8. Jauniešu nodarbinātību Latvijā ietekmējošā faktora ,nav

informācijas par darba piedāvājumiem" izvērtējums jauniešu skatījumā $(n=764)$

pēc respondentu dzīves vietas Latvijā (\%)/

Assessment of the factor influencing youth employment "I do not have information

about job vacancies" by youth $(n=764)$ by residence of the respondents in Latvia (\%).

Ar informācijas trūkumu par darba piedāvājumiem vislielākais īpatsvars jauniešu ir saskārušies Liepājā (44\%) no kuriem 15\% l̦oti traucēja un 29\% traucēja darba 
meklējumos un jaunieši Rēzeknē $43 \%$ - no kuriem 15\% ļoti traucēja un $28 \%$ traucēja atrast darbu. 38\% no jauniešiem Daugavpilī saskārās ar informācijas trūkumu par darba piedāvājumiem, no kuriem $8 \%$ - l̦oti traucēja un 30\% traucēja darba meklējumos (skat. 4.8. att.).

Lielākais īpatsvars no jauniešiem atsevišķāàs republikas pilsētās nav saskārušies ar informētības trūkumu par brīvajām vakancēm.

Tendence, kas iezīmējas jauniešu vērtējumā ir pozitīva, jo norāda uz jauniešu informētību par iespējām un zināšanām par izmantojamajiem instrumentiem darba meklējumos.

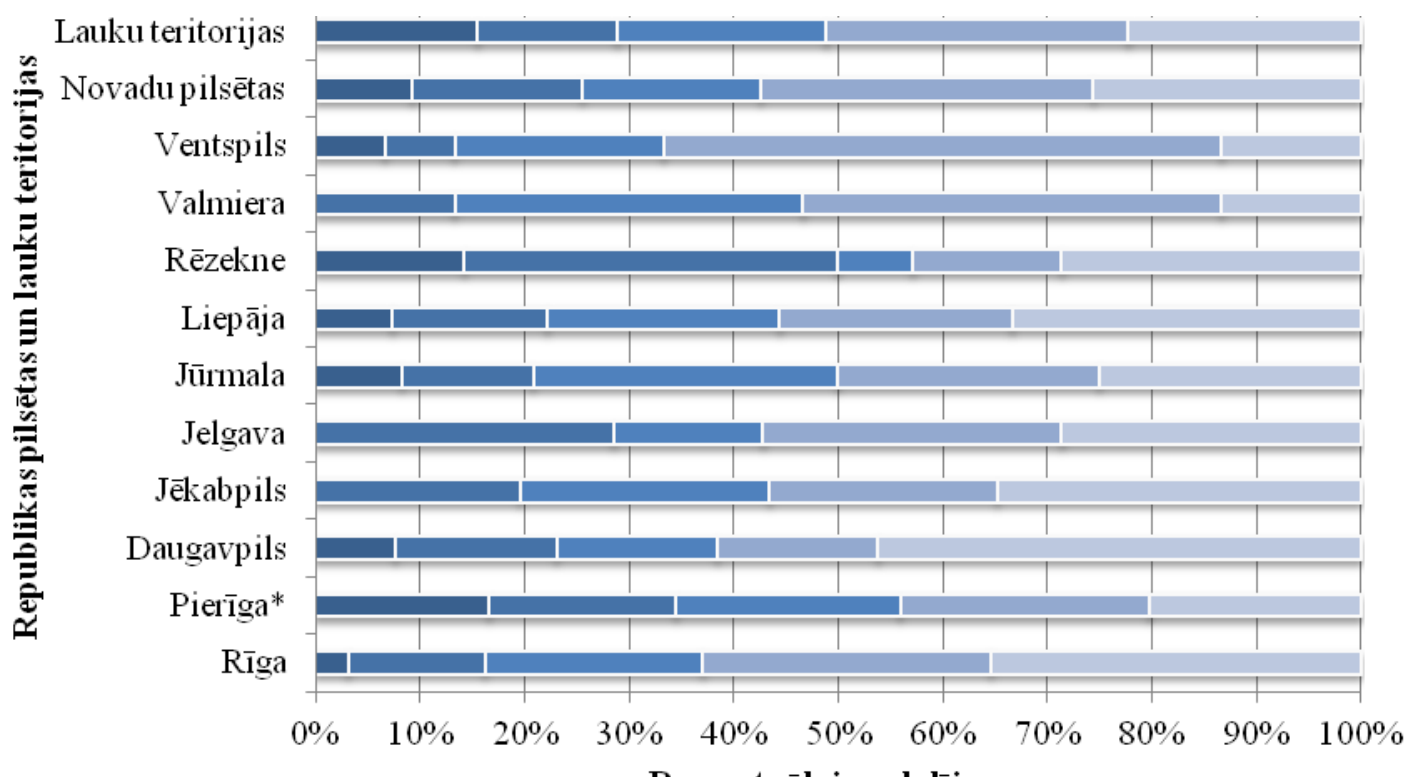

Procentuālais sadalījums

¿Loti traucēja $\square$ Traucēja $\square$ Neitrāls $\square$ Gandrīznav traucējis $\quad$ Nemaz nav traucējis

*Pierīga: iekļauti Pierīgas novadi - Ādažu novads, Babītes novads, Garkalnes novads, Ķekavas novads, Mārupes novads, Olaines novads, Ropažu novads, Salaspils novads, Stopiņu novads

Avots: autores pētijjums un konstrukcija

\section{9. att./ Fig. 4.9. Jauniešu nodarbinātību Latvijā ietekmējošā faktora ,slikti attīstìta infrastruktūra" izvērtējums jauniešu skatījumā $(n=764)$ pēc respondentu dzīves vietas Latvijā (\%)/ \\ Assessment of the factor influencing youth employment "poorly developed infrastructure" by youth $(n=764)$ by residence of the respondents in Latvia (\%).}

Pēc 4.9. attēla jāsecina, ka lielākajam īpatsvaram no respondentiem nav nācies saskarties ar slikti attīstītu infrastruktūru, kas būtiski ietekmētu nokḷūšanu no mājām līdz darbam un atpakal̦.

Vislielākā respondentu gradācija, kas nav apmierināti ar infrastruktūru, ir jaunieši Rēzeknē, kopumā 50\% ir neapmierināti ar infrastruktūras attīstību, no kuriem 14\% šis faktors l̦oti traucējis un 36\% traucējis darba meklējumos. Ar̄̄ 34\% no jauniešiem Pierīgā ir neapmierināti ar infrastruktūras attīstību, 17\% minēja, ka tas ir ļoti traucējis un arī $17 \%$ minēja, ka traucējis darba meklējumos. Jauniešu neapmierinātība ar infrastruktūras attīstību Pierīgā saistāma ar infrastruktūras pieejamību un intensitāti Rīgā, jo uz Pierīgu iespējams nokḷūt ar starppilsētu autobusiem vai vilcieniem, kas nekursē tik bieži kā Rīgā. Uz Pierīgu ir grūtības nokḷūt, jo starppilsētu autobusi un sabiedriskais transports kursē reti. Nozīmīgs faktors, kas ietekmē nokļūšanu uz darba vietu, ir arī vairāku 
sabiedrisko transportu izmantošanas nepieciešamība, kas ievērojami palielina nokḷūšanas izmaksas un patērēto laiku līdz darba vietai un atpakaḷ.

$29 \%$ respondentu no Jelgavas, kā arī no lauku teritorijām, minējuši, ka nav apmierināti ar infrastruktūru. Tendences skaidrojums jauniešiem no Jelgavas varētu būt saistīts ar to, ka jaunieši no Jelgavas novada lauku teritorijām atzīmējuši Jelgavu kā ši brīža dz̄ives vietu arī tādā gadījumā, ja dz̄ivo augstskolas kopmītnēs. Lielākais īpatsvars respondentu no Jelgavas studē Latvijas Lauksaimniecības universitātē. Pārvietošanās lauku reǵionos uz darba vietu lielākajā Latvijas teritorijā ir ievērojami apgrūtināta, jo darba meklētājiem jāpielāgojas starppilsētu autobusiem vai vilcienu kustības sarakstam, kā arī jārēksinās ar izmaksām, nokḷūšanai uz darba vietu un atpakal̦ (skat. 4.9. att.).

Izvērtējot jauniešu bezdarbu ietekmējošos faktorus, ņemot vērā jaunieša iegūtās izglītības līmeni, pēc 4.10. att. jāsecina, ka ar zināšanu un prasmju trūkumu visvairāk ir saskārušies jaunieši ar bakalaura izglītību (22\%), vidējo profesionālo izglītību (21\%) un nepabeigtu augstāko izglītību (20\%). Savukārt, no jauniešiem, kam ir pamatskolas izglītība, saskārušies ar zināšanu un prasmju trūkumu amata izpildei ir tikai 11\%. Darba autore uzskata, ka šāda tendence iezīmējas, jo jaunieši, kas ieguvuši bakalaura izglītību, vidējo profesionālo izglītību vai vēl nav pabeiguši augstākās izglītîbas studijas, uzskata, ka nav pietiekamās prasmes un zināšanas, jo visbiežāk saskaras tieši ar valodas zināšanu nepietiekamību, kā arī vēlas ieņemt izglītībai un pieredzei neatbilstošu amatu. Kā arī liels jauniešu īpatsvars izvēlas uzsākt studijas vai studē nozarēs, kuras ir pārsātinātas, nevis nozarēs, kurās ir darbinieku trūkums.

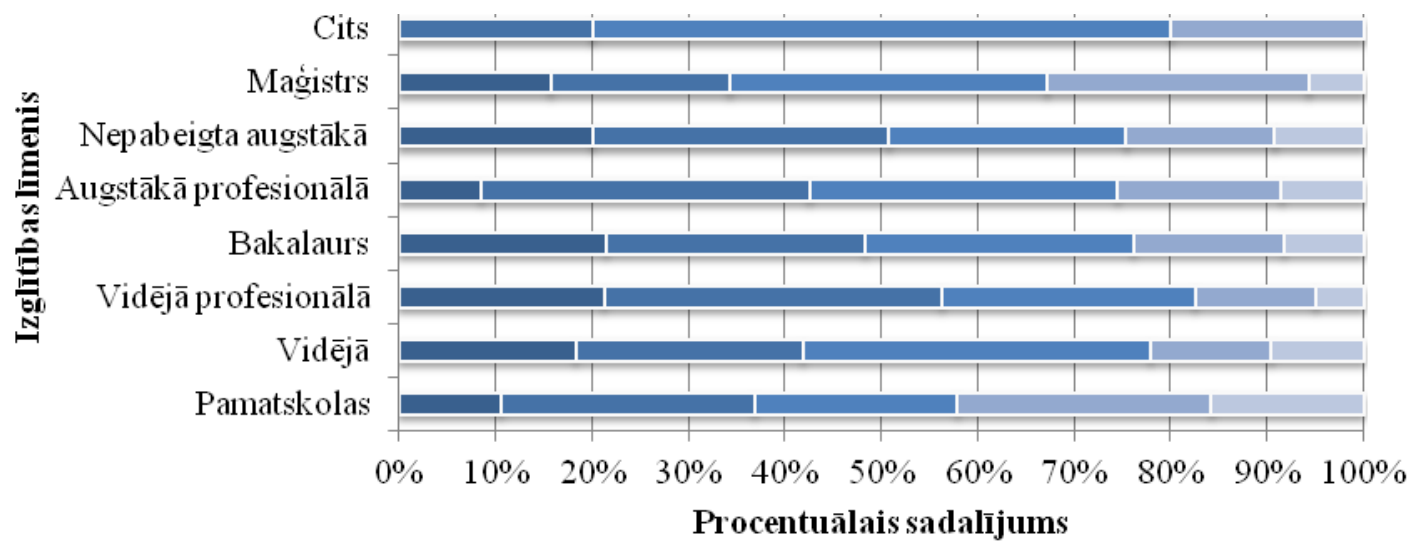

¿ Loti traucēja $\square$ Traucēja $\square$ Neitrāls $\square$ Gandrīznav traucējis $\quad$ Nemaz nav traucējis

Avots: autores pētījums un konstrukcija

4.10. att./ Fig. 4.10. Jauniešu nodarbinātību Latvijā ietekmējošā faktora „zināšanu, prasmju trūkums attiecīgajā jomā” izvērtējums jauniešu skatījumā pēc iegūtā izglītības līmen̦a $(n=764)(\%) /$

Assessment of the factor influencing youth employment "the lack of skills and knowledge in the relevant field" by youth $(n=764)$ by residence of the respondents in Latvia (\%).

Vislielākā respondentu gradācija novērojama, saskaroties ar nepieciešamās darba pieredzes trūkumu. $40 \%$ no respondentiem, kas nebija norādījuši izglītības līmeni un atzīmējuši izvēlni - cits, ir saskārušies ar vislielāko darba pieredzes trūkuma ietekmi darba meklējumos. 38\% no respondentiem ar iegūtu augstāko profesionālo izglītību, $37 \%$ ar bakalaura izglìtību, $34 \%$ ar nepabeigtu augstāko un $29 \%$ ar vidējo izglìtību saskārās ar pieredzes trūkumu darba pienākumu veikšanai (skat. 4.11. att.) 


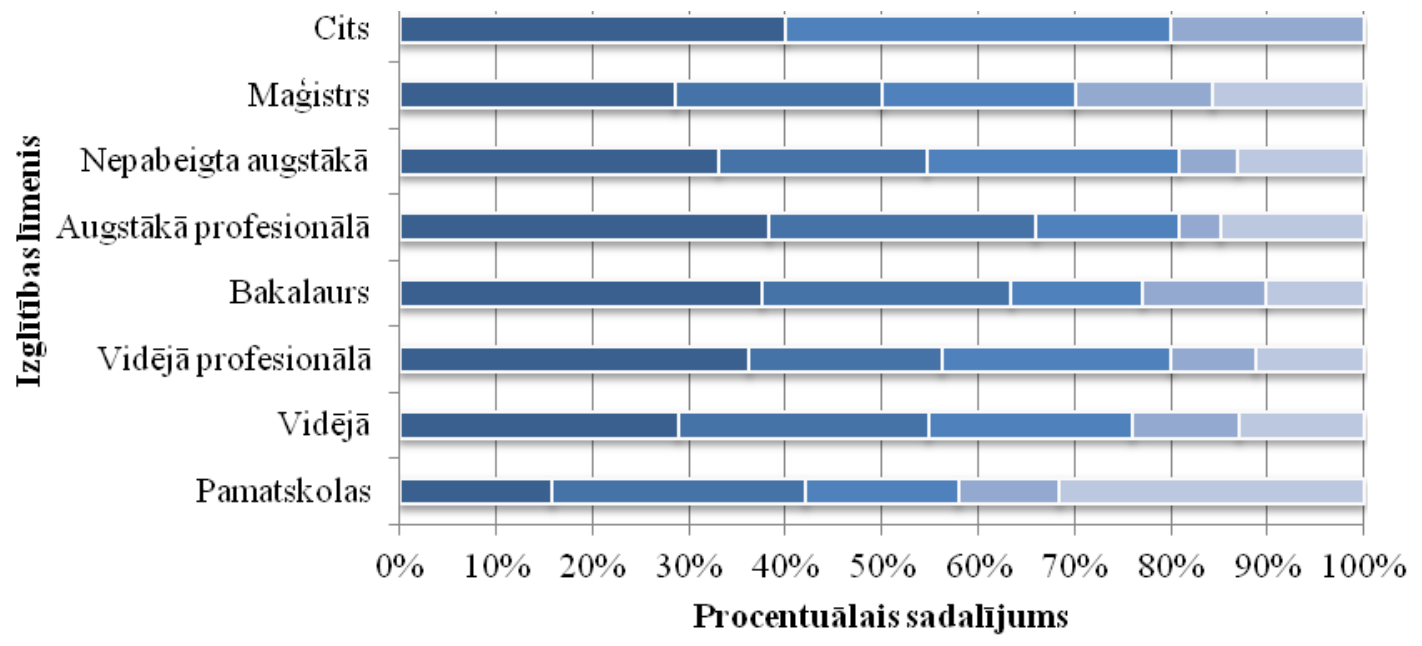

¿ Loti traucēja $\square$ Traucēja $\square$ Neitrāls $\square$ Gandrīznav traucējis $\square$ Nemaz nav traucējis

Avots: autores pētījums un konstrukcija

4.11. att./ Fig. 4.11. Jauniešu nodarbinātību Latvijā ietekmējošā faktora „nav nepieciešamā darba pieredze" izvērtējums jauniešu skatījumā pēc iegūtā izglītības līmena $(\mathbf{n}=764)(\%) /$

Assessment of the factor influencing youth employment "I do not have the necessary work experience" by youth $(n=764)$ by residence of the respondents in Latvia (\%).

4.12. attēlā redzams, ka 40\% no jauniešiem, kas piedalījās aptaujā un ir ieguvuši vidējo izglītību ir saskārušies ar iegūtās izglîtības neatbilstību piedāvātajām darba vietām. Arī aptuveni 35\% jaunieši, kas ieguvuši bakalaura izglītīibu vai nepabeigtu augstāko izglīî̄ibu, aptuveni $27 \%$ augstākās profesionālās izglītîbas ieguvēji un $20 \%$ no maǵistra grāda un pamatskolas izglītību ieguvušajiem ir saskārušies ar izglītības neatbilstību piedāvātajām darba vietām.

Pamatskolas izglītību ieguvušo un magistra izglītību ieguvušo vienādais redzējums par izglītības neatbilstību darba tirgum saistāms ar vakances pozīcijas līmeni, proti, pamatskolas izglītību ieguvušais savu vērtējumu izteicis saistībā ar profesijām uz kurām var pretendēt attiecīgo izglītību ieguvušais, savukārt, maǵistra grāda ieguvējs saskāries ar izglītības nozares izvēli, kurā ir izglītību ieguvušo pārprodukcija.

Citu pētījuma rezultātu tendences norāda uz to, ka darba tirgū pastāv nepietiekama komunikācija starp izglītības iestādēm un darba devējiem. Dažādu līmeṇu izglītības studiju programmas netiek pietiekošā līmenī pielāgotas darba devēju prasībām, lai gan OECD pētījumā Latvijas darbaspēks tika vērtēts kā izglītots. Aptuveni trešā daļa no ekonomiski aktīvajiem iedzīvotājiem ir ar augstāko izglītību, ar nozīmīgu pieaugumu par 20\%, salīdzinājumā ar periodu pirms desmit gadiem. Arī vidējās izglītības līmenis ir augsts, $80 \%$ no darbspējīgajiem ir ar vidējo izglìtību. Izglīīibas sistēmā ir veiktas nozīmīgas reformas un studenti ir tām labi pielāgojušies (OECD Economic Surveys..., 2015). 


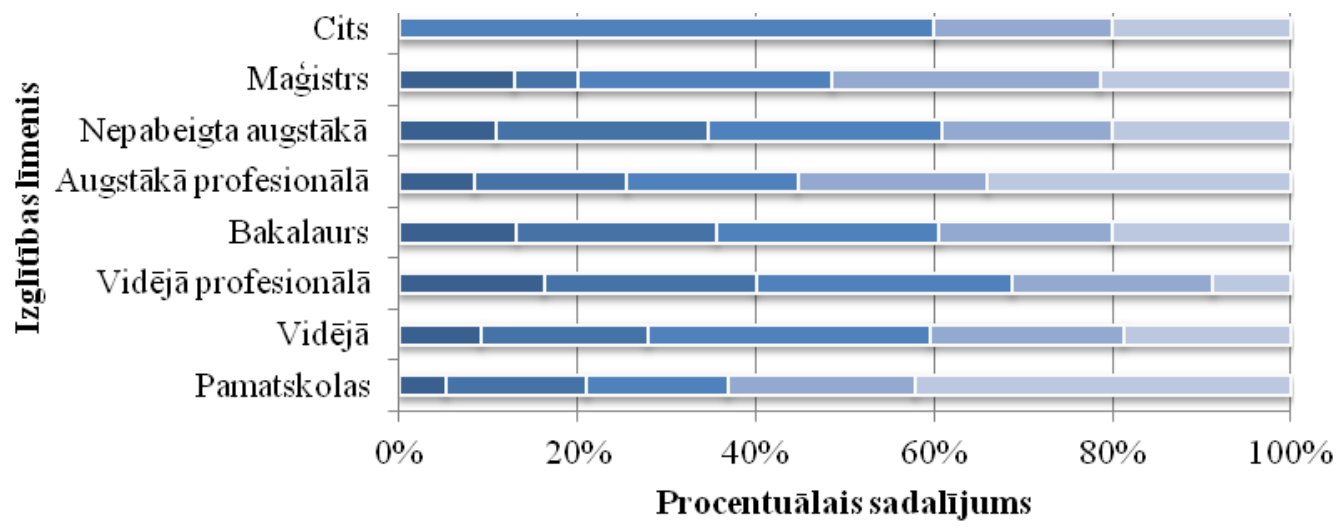

- Lioti traucēja $\square$ Traucēja $\square$ Neitrāls $\square$ Gandrīznav traucējis $\quad$ Nemaz nav traucējis

Avots: autores pētījums un konstrukcija

4.12. att./ Fig. 4.12. Jauniešu nodarbinātību Latvijā ietekmējošā faktora ,iegūtā/ iegūstamā izglītība neatbilst piedāvātajām darba vietām" izvērtējums jauniešu skatījumā pēc iegūtā izglītības līmeṇa $(n=764)(\%) /$ Assessment of the factor influencing youth employment "another education field" by youth $(n=764)$ by residence of the respondents in Latvia $(\%)$.

Izvērtējot iegūtos aptaujas rezultātus saistībā ar neapmierinātību ar darba apstākḷiem, lielākais īpatsvars respondentu ir apmierināti ar darba apstākḷiem. 27\% no jauniešiem ar vidējo profesionālo izglītību, 26\% ar nepabeigtu augstāko izglītību un $24 \%$ ar vidējo izglītību bija neapmierināti ar darba apstākḷiem, kas sastāda mazāku respondentu īpatsvaru (skat. 4.13. att.). Jāsecina, ka vairums darba devēju spēj nodrošināt jauniešiem pienācīgus darba apstākḷus.

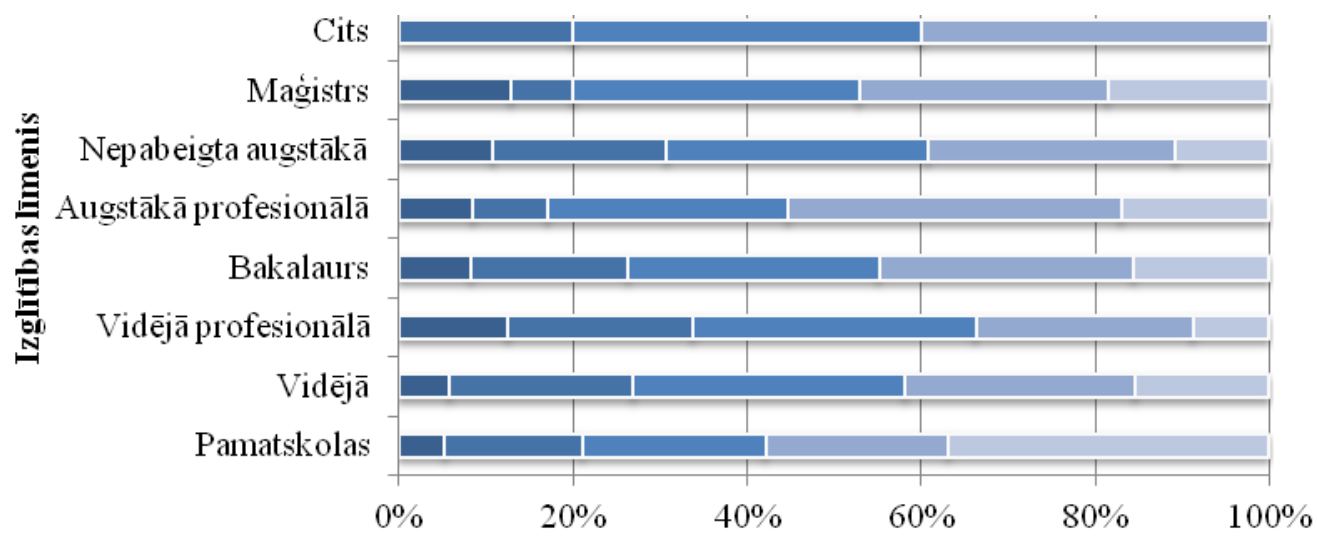

Procentuālais sadalījums

$\square$ Loti traucēja $\square$ Traucēja $\square$ Neitrāls $\square$ Gandrīznav traucējis $\square$ Nemaz nav traucējis

Avots: autores pētījums un konstrukcija

4.13. att./ Fig. 4.13. Jauniešu nodarbinātību Latvijā ietekmējošā faktora „neapmierina darba apstākḷi” izvērtējums jauniešu skatījumā, balstoties uz iegūto izglītības līmeni $(\mathbf{n}=764)(\%) /$

Assessment of the factor influencing youth employment "unsatisfactory working conditions" by youth $(n=764)$ by residence of the respondents in Latvia (\%). 
Savukārt, pēc 4.14. attēla redzams, ka nodarbinātības statuss - bezdarbnieks spēj ietekmēt darba meklējumus jauniešiem, kam ir pamatskolas izglītība. 23\% no respondentiem bija atzīmējuši, ka viņiem darba meklējumos ļoti traucēja tas, ka jaunietis ir bezdarbnieks.

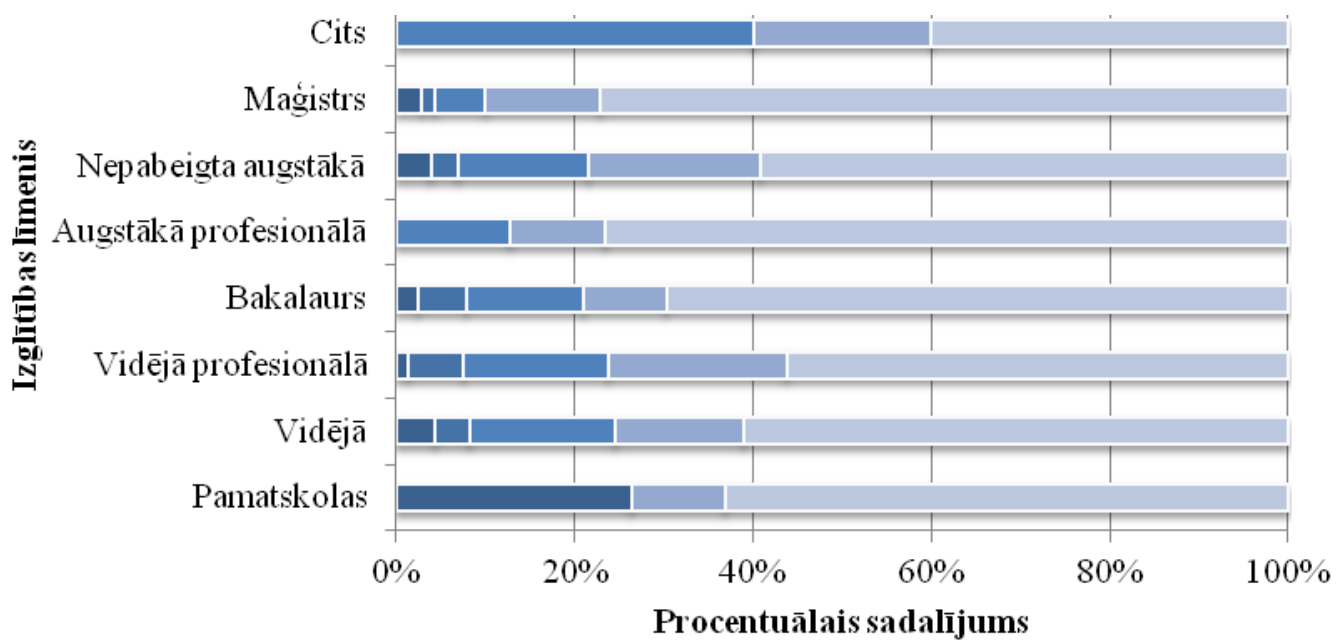

$\square$ Loti traucēja $\square$ Traucēja $\square$ Neitrāls $\square$ Gandrīznav traucējis $\square$ Nemaz nav traucējis

Avots: autores pētījums un konstrukcija

4.14. att./ Fig. 4.14. Jauniešu nodarbinātību Latvijā ietekmējošā faktora „nodarbinātības statuss - bezdarbnieks" izvērtējums jauniešu skatîjumā balstoties uz iegūto izglītības līmeni $(n=764)(\%) /$

Assessment of the factor influencing youth employment "status- unemployed" by youth $(n=764)$ by residence of the respondents in Latvia $(\%)$.

Darba autore uzskata, ka tie ir jaunieši bez darba pieredzes un ilgstošie bezdarbnieki, kas jau kādu laiku nemācās un nestrādā. Šie jaunieši ir potenciālie mazkvalificēta darba veicēji, parasti šajos amatos arī algu līmenis nav augsts. Līdz ar to liela daļa bezdarbnieku, bez izglītības un iegūtas profesijas nav saistoši darba devējiem, jo tiem nav uzticības par veicamo darbu kvalitatīvu izpildi, ja persona nav ieguvusi arodu un neizglìtojas.

Balstoties uz 4.15. attēlu, jāsecina, ka ǵimenes apstākḷi nav būtiski ietekmējuši jaunieša iespējas atrast darbu un iekl̦auties darba tirgū. Tomēr jāatzīmēe, ka, jauniešiem, piemēram, no nelabvēlīgām ǵimenēm ir grūtāk iekḷauties darba tirgū, jo varētu būt bijušas problēmas ar pienācīgas izglîtības vai aroda iegūšanu, nokḷūšanu līdz mācību iestādei vai darba vietai, lai iegūtu zināšanas un pieredzi, kā arī nepieciešamo mācību materiālu un līdzekḷu pieejamība, kas var kavêt jaunieša izglītības programmas apguvi.

Aptaujā iegūtie jauniešu vērtējumi norāda uz to, ka ǵimenes apstākḷi nav bijis viens no būtiskākajiem faktoriem, kas ir ietekmējis darba meklējumus un ieguvi.

Iepriekš skatîtie jauniešu bezdarbu ietekmējošie faktori iezīmē tendences, ar kādām jauniešiem nākas saskarties meklējot darbu. 


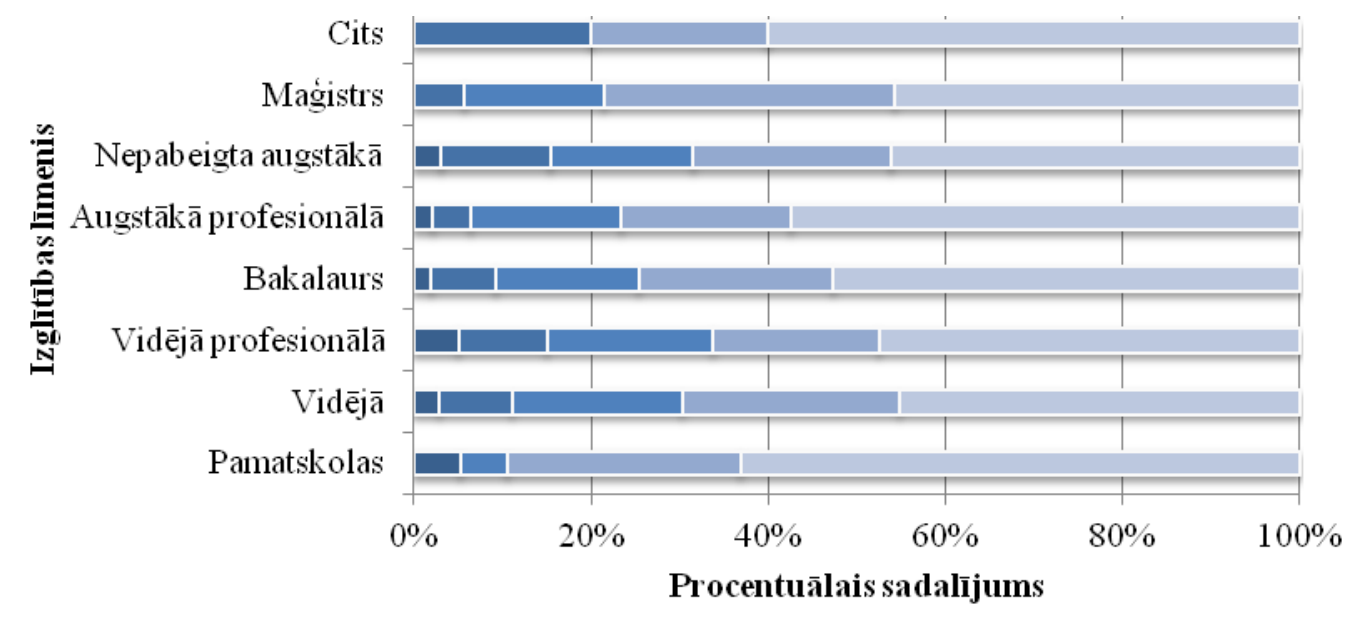

$\square$ Loti traucēja $\square$ Traucēja $\square$ Neitrāls $\square$ Gandrīznav traucējis $\square$ Nemaz nav traucējis

Avots: autores pētījums un konstrukcija

\subsection{5. att./ Fig. 4.15. Jauniešu nodarbinātību Latvijā ietekmējošā faktora ,ǵimenes apstākliı" izvērtējums jauniešu skatījumā, balstoties uz iegūto izglītības līmeni (n=764) (\%)/ \\ Assessment of the factor influencing youth employment "family circumstances" by youth $(n=764)$ by residence of the respondents in Latvia $(\%)$.}

Vislielākais īpatsvars jauniešu, kas piedalījās aptaujā un bija neapmierināti ar piedāvāto darba samaksu bija no Jelgavas (72\%), Jūrmalas (59\%), lauku teritorijām (58\%), Rēzeknes (57\%), citas pilsētas vai mazpilsētas (54\%) un Liepājas (52\%). Savukārt, 22\% jaunieši no Rīgas neapmierinātību ar darba samaksu atzīmēja kā ļoti traucējošu un $26 \%$ kā traucējošu (skat. 4.16. att.).

Balstoties uz darba autores veikto pētījumu attiecībā uz jauniešu apmierinātību ar piedāvāto darba samaksu, jāsecina, ka liels pārsvars jauniešu, kas piedalījās aptaujā, nebija apmierināti ar darba devēja piedāvāto darba samaksu. Neapmierinātību ar darba samaksu veicina darba devēju nevēelěšanās maksāt samērīgas un amatam atbilstošas algas, kā arī darba meklētāju nevēlēšanās strādāt par zemu atalgojumu. Darba devēju nevēlēšanās un nespēja maksāt lielāku atalgojumu saistāma arī ar darba devēja ienākumu līmeni un pozicionēšanos konkrētajā nozarē, savukārt, darba meklētāja nevēlēšanās strādāt par zemu atalgojumu saistāma ar izmaksām, kas nepieciešamas nokḷūšanai līdz darba vietai kā arī sociālām vajadzībām. 


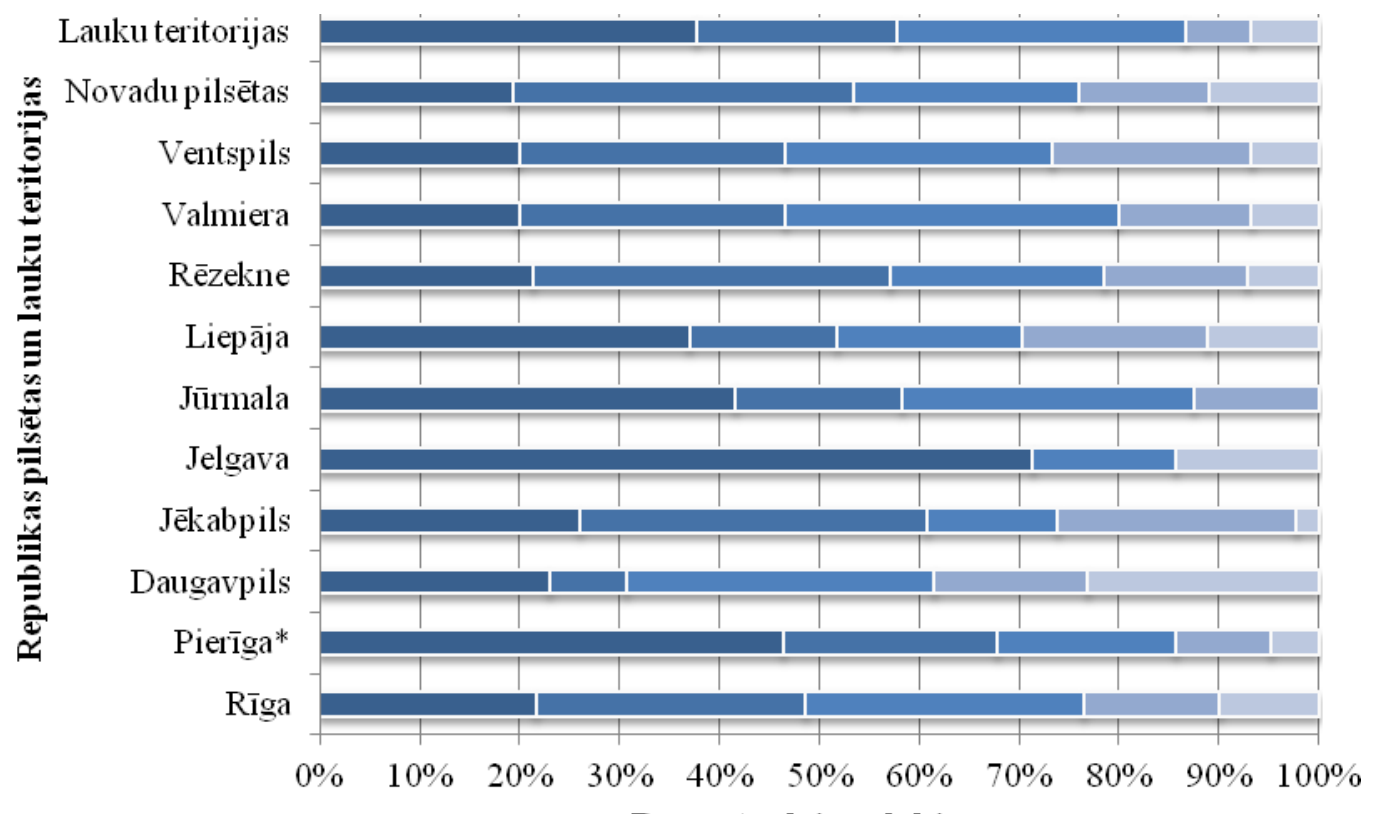

Procentuālais sadalījums

$\square$ Lioti traucēja $\square$ Traucēja $\square$ Neitrāls $\square$ Gandrīznav traucējis $\quad$ Nemaz nav traucējis

*Pierīga: iekļauti Pierīgas novadi - Ādažu novads, Babītes novads, Garkalnes novads, Ķekavas novads, Mārupes novads, Olaines novads, Ropažu novads, Salaspils novads, Stopiņu novads

Avots: autores pētījums un konstrukcija

\subsection{6. att./ Fig. 4.16. Jauniešu nodarbinātību Latvijā ietekmējošā faktora „neapmierina piedāvātā darba samaksa" izvērtējums jauniešu skatījumā (n=764) pēc respondentu dzīves vietas Latvijā $(\%) /$ \\ Assessment of the factor influencing youth employment "not satisfied with the salary" by youth $(n=764)$ by residence of the respondents in Latvia $(\%)$.}

Viens no vadošajiem darba sludinājumu portāliem Latvijā „CV Market” 2015. gada septembrī un oktobrī veicis pētījumu par bezdarbnieku vēlmi strādāt, saņemot valsts noteikto minimālo atalgojumu (2015. gadā minimālā alga Latvijā - 360 EUR). Kopumā pētījumā piedalìjās 437 respondenti, no kuriem 95.5\% atbildējuši noliedzoši. Savukārt CSP darbaspēka apsekojuma informācija liecina, ka 22.7\% strādājošo 2015. gada 3. ceturksnī sañēma minimālo darba algu vai mazāk, un šo darba ñēmēju īpatsvars salīdzinājumā ar 2014. gada 3. ceturksni ir palielinājies par 4.9 procentpunktiem. „CV Market” Latvijas filiāles vadītāja R. Zīverte uzsvērusi, ka grūti ticēt, ka Latvijā katrs ceturtais nodarbinātais strādā par minimālo atalgojumu, minot, ka lielāks atalgojums tiek saņemts neoficiāli (Darba meklētāji vēlas..., 2015).

Savukārt „CV Market” citā veiktajā pētījumā, jaunieši, kas piedalījušies uzṇēmuma rīkotajā aptaujā (vecumā no 18-25 gadiem), norādījuši, ka piekristu strādāt par atalgojumu, kas ir mazāks par minimālo algu. Kopumā no jauniešiem, kas piedalījās aptaujāa, vairāk nekā 50\% darba meklētāju norādījuši vēlamo atalgojumu no 100 līdz 360 eiro, kas ir mazāk par valstī noteikto minimālo algu, kas kopš 2015.gada 1.janvāra ir 360 eiro. Salīdzinājumā ar Igaunijas jauniešiem, kur tikai 14\% būtu gatavi strādāt par šādu atalgojumu, Latvijā jauno darba meklētāju centieni darba tirgū konkurēt ar zemu atalgojumu skaidri norāda uz lielāku jauniešu pesimismu darba tirgū. Kā liecina speciālistu darba portāla „CV Market” novērojums, mērķtiecīgam un pozitīvam jaunietim, vēl studējošam vai ar nelielu darba pieredzi, uzņēmumi ir gatavi maksāt arī 
700 eiro atalgojumu pēc nodokļiem. Uzṇēmumi arvien lielāku uzmanību pievērš darbinieka personiskajām īpašībām un meklē atvērtus komandas cilvēkus, ar interesi pret veicamo darbu, ieinteresēti mācīties papildus un spējīgus pielāgoties. Savukārt kā nevēlamās īpašības norāda nevēlēšanos mācīties un strādāt (Informācija iegūta Latvijas un Igaunijas portālos cvmarket.lv un cvkeskus.ee, apkopojot vairāk nekā 9500 darba meklētāju vecumā no $18-25$ gadu norādīto vēlamo atalgojumu) (Puse jauniešu neprasa..., 2015).

Pēc Eurofound pētījumiem, LBAS ir veikusi vairākus protestus valdībai par nepietiekamo ienākumu īpatsvaru bezdarbniekiem un zemi atalgotiem darba ñēmējiem, kā arī par nodarbinātības grūtībām jauniešiem, kuri saskaras ar bezdarba radītajām sekām. Savukārt LDDK ir uzsvērusi nepieciešamību veicināt jauniešu piekḷuvi ienākumiem, lai atbalstītu to studijas un aicināja veicināt uzlabojumus studiju kredītu sistēmā, kā arī pārskatīt pārmaksātā iedzīvotāju nodokḷa atgriežamo summu tiem jauniešiem vai indivīdiem, kam ir izdevumi par izglītību (Social Inclusion of..., 2015) (Pašlaik maksimālā summa ko var iegūt no pārmaksātā iedzīvotāju ienākuma nodokḷa ir 213.43 EUR gadā (Ienākumu deklarācija..., 2014), bet izglītības izmaksas var sasniegt vairākus tūkstošus eiro gadā) (Darba tirgū pārliecinoši..., 2015).

„CV Market” Latvijas filiāles vadītāja R. Zīverte norādījusi, ka pašpārliecinātāki darba tirgū ir speciālisti, kas ieguvuši starptautiskiem standartiem atbilstošu augstāko izglītību, bez šauras specializācijuas, un speciālisti ar labu, praktiskā pieredzē pilnveidotu aroda izglītību.

Darba sludinājumu uzn̦ēmums un portāls „CV Market” regulāri veic darba tirgus apsekojuma aptaujas, lai noskaidrotu darba meklētāju darba tirgus tendences. „CV Market" veiktā aptaujā, apsekojot darba meklētāju tendences darba tirgū, secināja, ka jo augstāks ir darba meklētāju izglīî̄bas līmenis, jo lielāku atalgojumu viṇi prasa par savu darbu. Ja darba meklētājs, kam ir profesionālā izglīīiba, arodizglītība vai pirmā un otrā līmeņa profesionālā izglîtība kā vēlamo atalgojumu norāda vidēji 845 EUR pirms nodokḷu samaksas, tad augstskolā bakalauru grādu ieguvis darba meklētājs prasa par 25\% vairāk - vidēji 1059 EUR mēnesī. Pētījumā secināts, ka ir arī atšksirība starp augstākās izglītības grādu ieguvējiem - jo augstāka līmeņa grāds, jo lielāku atalgojumu vēlas potenciālais darbinieks. Atšksirība starp bakalauru un maǵistru prasībām ir aptuveni $21 \%$ - maǵistri kā vēlamo atalgojumu norāda vidēji 1285 EUR mēnesī pirms nodokḷu nomaksas. Turpretī doktora grādu ieguvušie vēlas saņemt vidēji 2300 EUR mēnesī, kas ir par 79\% vairāk nekā darba meklētāji ar maǵistra grādu un divreiz vairāk par darba meklētājiem ar bakalaura grādu. „CV Market” Latvijas filiāles vadītāja R. Zīverte uzsvēra, ka šie dati liecina ne tikai par izglītības un darba samaksas sasaisti, bet arī par izglîtīibas nozīmi cilvēka pašapziñas celšanā. Cilvēks, kurš novērtē sevi, vēlas gūt maksimālu labumu no iegūtās izglītības un attaisnot savā izglītībā ieguldītos līdzekļus. Darbinieks ar pašapziņu būs mērkstiecīgs, orientēts uz rezultātu un sevis pilnveidošanu, un darba devējs no viņa san̦ems lielāku atbildību un iniciatīvu (Darba meklētāji ar..., 2015).

Darba autore uzskata, ka „CV Market” veiktais apsekojums norāda būtisku nozīmi izglītības lomai darba meklējumos kā arī atalgojuma līmeņa prasībām, savukārt, darba devēji ne vienmēr ir spējīgi nodrošināt šis darba meklētāju prasības, līdz ar to jauniešiem, vecuma posmā, kad studijas ir jau pabeigtas, ir lielākas prasības pret atalgojuma līmeni, kā arī papildus motivācijām, kas var ietekmēt arī darba meklējumu sekmes. 


\subsection{Jauniešu uzņēmējspēju veicināšanas aktualitāte/ Urgency of a youth entrepreneurial incentive}

Tā kā jauniešu uzñēmējdarbības aktualitāte analizēta darba 2. nodaļā aprakstîtajos stratēgiskajos plānošanas dokumentos, darba autore par svarīgu uzskatīja noskaidrot jauniešu interesi par uzṇēmējdarbību. Jauniešu uzṇēmējdarbības attīstība vai kḷūšana par pašnodarbinātu personu ir viens no veidiem kā jaunietim kḷūt nodarbinātam.

Jauniešu aktīva interese par uzņēmējdarbību ir ne tikai pašu jauniešu nākotnes attīstības veicināšanas potenciāls, bet arī valsts interesēs atbalstāms un veicināms instruments, kas ir viena no iespējām valsts tautsaimniecības attīstības veicināšanā.

Līdz ar to darba autore par nozīmīgu uzskatīja noskaidrot jauniešu interesi par uzṇēmējdarbību, noskaidrot tās nozares, kurās jauniešiem varētu būt interese veidot savu turpmāko darbību, uzzināt jauniešu intereses un zināšanas par uzñēmējdarbības atbalsta instrumentiem, kā arī noskaidrot ar kādu instrumentu palīdzību, jauniešu skatījumā, iespējams veicināt uzņēmējdarbības attīstību jauniešu vidū.

Balstoties uz jauniešu aptaujas datiem, $60 \%$ no jauniešiem kā visbūtiskāko instrumentu jauniešu uzņēmējdarbības attīstības veicināšanai uzskata nodokḷu atvieglojumus jaunajiem uzņēmējiem, 53\% no jauniešiem uzskata, ka būtiska ir arī prakses iespēju nodrošināšana studiju procesā, $50 \%$ jauniešu uzskata, ka nozīmīgas ir finansējuma piesaistes iespējas uzṇēmējdarbības uzsākšanai bez apgrūtinājuma/ ķīlas piesaistes, savukārt, 45\% uzskata, ka nozīmīgs ir pašvaldību atbalsts jaunajiem uzṇēmējiem un $42 \%$ - studiju laikā nodrošināta iespēja sadarboties ar uzņēmējiem (skatīt 4.17. att.).

Plašāka finansiālo programmu pieejamība Mentoru piesaiste

Pašvaldību atbalsts jaunajiem uẓ̣̂̄ēmējiem Prakses iespẹju nodrošināšana studiju procesā Studiju laikānodrošināta iespēja sadarboties.

Dalība darba grupās, kurās iespe ēja izveidot. Izglītojoši kursi jaunajiem uzṇēmējiem. Biznesa enǵgel̦u piesaiste Biznesa inkubatoru pieejamība Nodokḷu atvieglojumi jaunajiemuzṇēmējiem Finansējuma piesaistes iespējas bez.

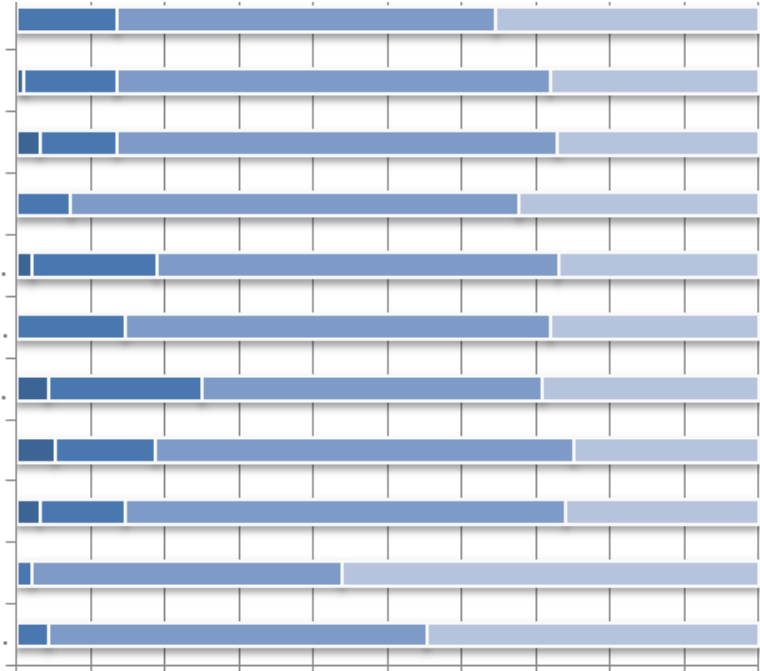

$0 \% 10 \% 20 \% 30 \% 40 \% 50 \% 60 \% 70 \% 80 \% 90 \% 100 \%$ Procentuālais sadalījums

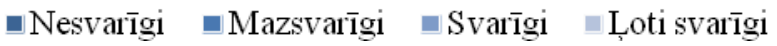

Avots: autores pētījums un konstrukcija

4.17. att./ Fig. 4.17. Jauniešu Latvijā aptaujas rezultāti $(\mathbf{n}=\mathbf{7 6 4})$, izvērtējot apgalvojumu svarīgumu attiecībā uz jauniešu uzṇēmējdarbības attīstības iespēju veicināšanu $(\%) /$

Results of a survey of youth $(n=764)$ on the importance of promotion of opportunities for youth entrepreneurship development (\%). 
Kā svarīgi un ļoti svarīgi tiek vērtēti visi uzskaitītie uzņēmējdarbības atbalsta instrumenti un ikviens no tiem ir nozīmīgs jauniešu uzṇēmējdarbības veicināšanā (skatìt 4.17. att.).

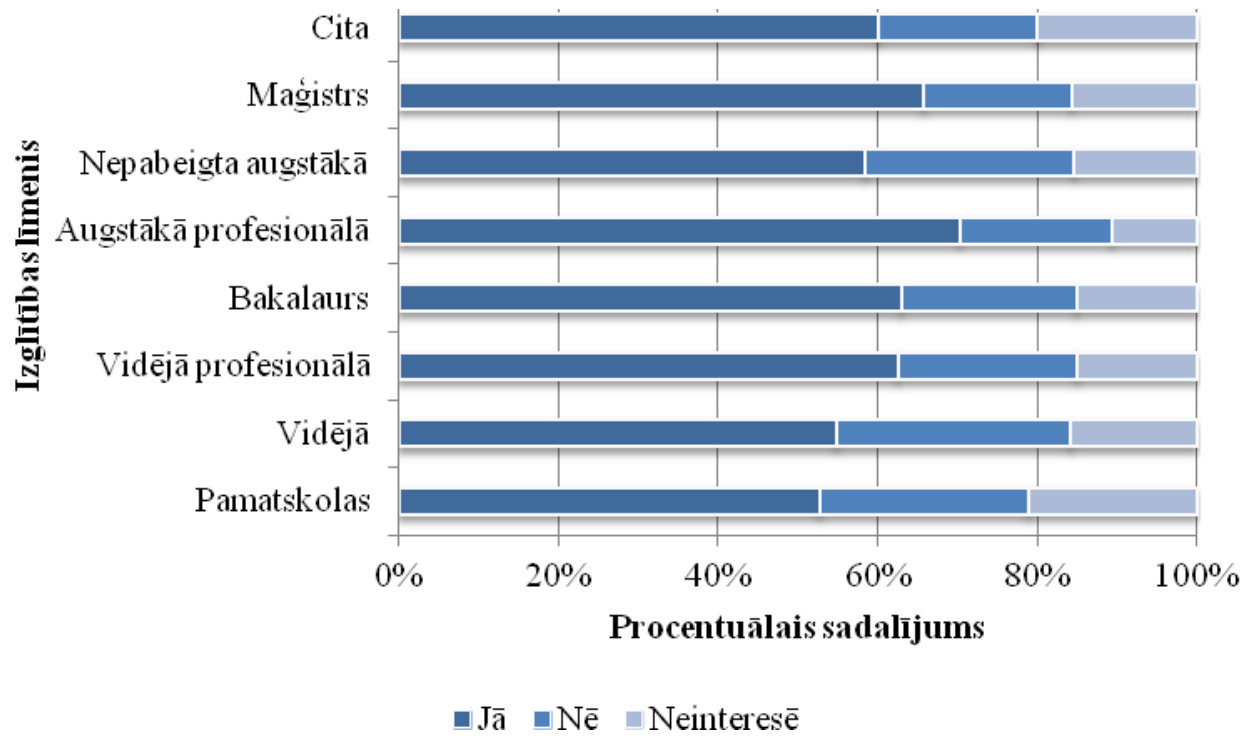

Avots: autores pētījums un konstrukcija

4.18. att./ Fig. 4.18. Jauniešu interese par uzṇēmējdarbības uzsākšanu Latvijā atkarībā no iegūtā izglītības lìmeņa $(\mathbf{n}=764)(\%) /$

Youth's interest in starting up their own business in Latvia $(n=764)(\%)$.

Darba autore par būtisku uzskatīja arī noskaidrot jauniešu interesi par uzņēmējdarbības uzsākšanu ņemot vērā jaunieša iegūto izglīitības līmeni.

Pēc 4.18. attēla redzams, ka vislielākā interese, $70 \%$ no aptaujā iesaistītajiem jauniešiem, kas ieguvuši augstāko profesionālo izglīīibu, ir interese par uzṇēmējdarbības uzsākšanu, kā arī jauniešiem, kas ieguvuši maǵistra izglīìibu - 66\% no aptaujātajiem. Balstoties uz aptaujas rezultātā iegūtajiem datiem, jauniešiem ir liela interese par uzņēmējdarbības uzsākšanu, neatkarīgi no iegūtā izglītības līmeņa. Darba autore uzskata, ka tas ir pozitīvs rādītājs, jo būtiska ir jaunieša vēlme un iniciatîva uzņemties atbildību par uzñēmumu un veidot veiksmīgu uzņēmuma attīstības stratēgiju.

Vislielākais jauniešu īpatsvars vēlētos uzsākt uzn̦ēmējdarbību tirdzniecības un pakalpojumu jomā (23\%), savukārt 12.5\% jauniešu vēlētos darboties mediju, reklāmas un poligrāfijas nozarē un $12 \%$ - tūrisma un viesnīcu biznesā, bet par lauksaimniecības nozari interesi izrādīja 5\% no respondentiem (skat. 4.19. att.). 


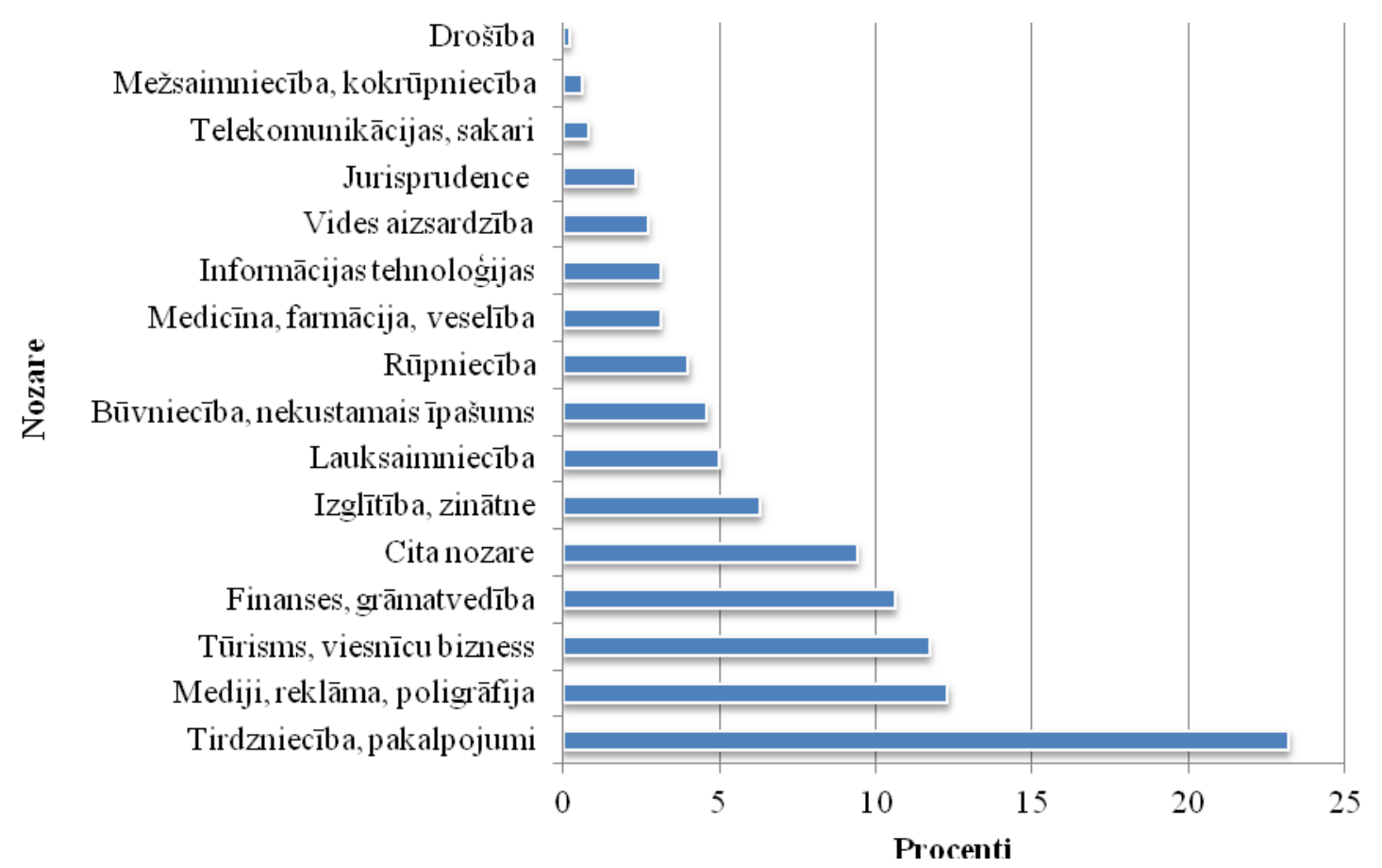

Avots: autores pētījums un konstrukcija

4.19. att./ Fig. 4.19. Jauniešu Latvijā aptaujas rezultāti $(n=764)$ sniedzot informāciju par nozari, kurā vēlētos darboties, ja uzsāktu uzņēmējdarbību (\%)/ Results of a survey of youth $(n=764)$ on industries in which the youth would like to start up a business in Latvia (\%).

Kā citas nozares jaunieši bija minējuši sociālās uzṇēmējdarbības jomu, arhitektūru, auto nozari, mākslu, izklaidi un mūzikas industriju.

Jauniešiem Latvijā pieejams plašs klāsts uzṇēmējdarbības atbalsta programmu, tomēr finansējumu uzñēmējdarbības uzsākšanai ne vienmēr ir iespējams iegūt, kā arī iegūstamā summa var būt nepietiekama uzņēmuma attīstībai.

Pēc LIAA mājas lapā pieejamās informācijas, jauniešiem, kas vēlas uzsākt uzñèmējdarbību, ir iespējas pieteikties atbalstam sekojošās programmās:

- uzñēmējdarbības attīstības atbalsta programmas AS „Attīstības finanšu institūcija Altum” (Mikrokreditēšanas programma, Start-up programma);

- biznesa (start-up) akselerators „Commercialization Reactor”;

- ERASMUS jaunajiem uzṇēmējiem (nebija atspoguḷots LIAA mājas lapā 2012. gada nogalē, kad tika izveidota jauniešu aptauja);

- start-up informatīvā platforma „Labs of Latvia” (nebija atspogulıtots LIAA mājas lapā 2012. gada nogalē, kad tika izveidota jauniešu aptauja) (Atbalsta programmas uzn̄ēmējiem, b.g.).

Citas atbalsta programmas uzņēmējdarbības uzsākšanai:

- inovatīvās uzṇēmējdarbības motivācijas programma „Ideju kauss”;

- grantu programma „Atspēriens” (Rīgas pilsētas reǵionā);

- biznesa inkubatori Latvijas Universitātē, Jelgavā u.c.

Kopš 2015. gada augusta tiek periodiski realizēta programma „Atbalsts jaunajiem lauksaimniekiem uzņēmējdarbības uzsākšanai”, kuras mērķis ir sekmēt gados jaunu cilvēku iesaistīšanos pastāvīgā lauksaimniecības darbībā un nodrošināt darbaspēka atjaunošanos lauksaimniecības sektorā, atbalstot gados jaunus cilvēkus, kas 
saimniecības vadītāja statusā pirmo reizi dibina ekonomiski dzīvotspējīgu saimniecību, lai ražotu lauksaimniecības produkciju vai savā īpašumā pārn̦emtu esošu saimniecību. Programmu koordinē LAD un pirmās kārtas pieejamais publiskais finansējums apakšpasākumā „Atbalsts jaunajiem lauksaimniekiem uzņēmējdarbības uzsākšanai” bija 6950466 EUR (Atbalsts jaunajiem lauksaimniekiem..., 2015).

Pētījuma ietvaros, darba autore par būtisku arī uzskatīja apzināt jauniešu zināšanas par jauniešu informētību par biznesa atbalsta programmām. Jāsecina, ka visvairāk jauniešus ir piesaistījusi biznesa inkubatoru (24.8\%) attīstība gan Jelgavā, gan Rīgā. Jauniešu interese un zināšanas par šiem biznesa atbalsta instrumentiem ir pozitīvas, jo tas nozīmē to, ka jaunieši ir interesējušies par šo jomu, noklausījušies lekcijas, studiju procesa ietvaros un arī noteikti kāds no jauniešiem ir uzsācis aktīvu dalību kādā no biznesa inkubatoriem, kas izvietoti augstskolas telpās. 22.5\% jauniešu ir arī informēti par jauniešu programmu biznesa attīstībai „Ideju kauss”, kāa arī 16\% jaunieši ir informēti par vienotās finanšu institūcijas AS „Attīstības finanšu institūcija Altum" aktivitātēm un iespējam atbalstam biznesam (skat. 4.20. att.).

Kā citas biznesa atbalsta programmas jaunieši bija minējuši:

- dažādu banku piedāvājumi;

- NVA programma uzñēmējdarbības uzsākšanai;

- biznesa augstskolas „Turība” konkurss/ programma;

- biznesa eñgelsi;

- dažādi pašvaldību konkursi;

- jauno zemnieku atbalsta ES projekts.

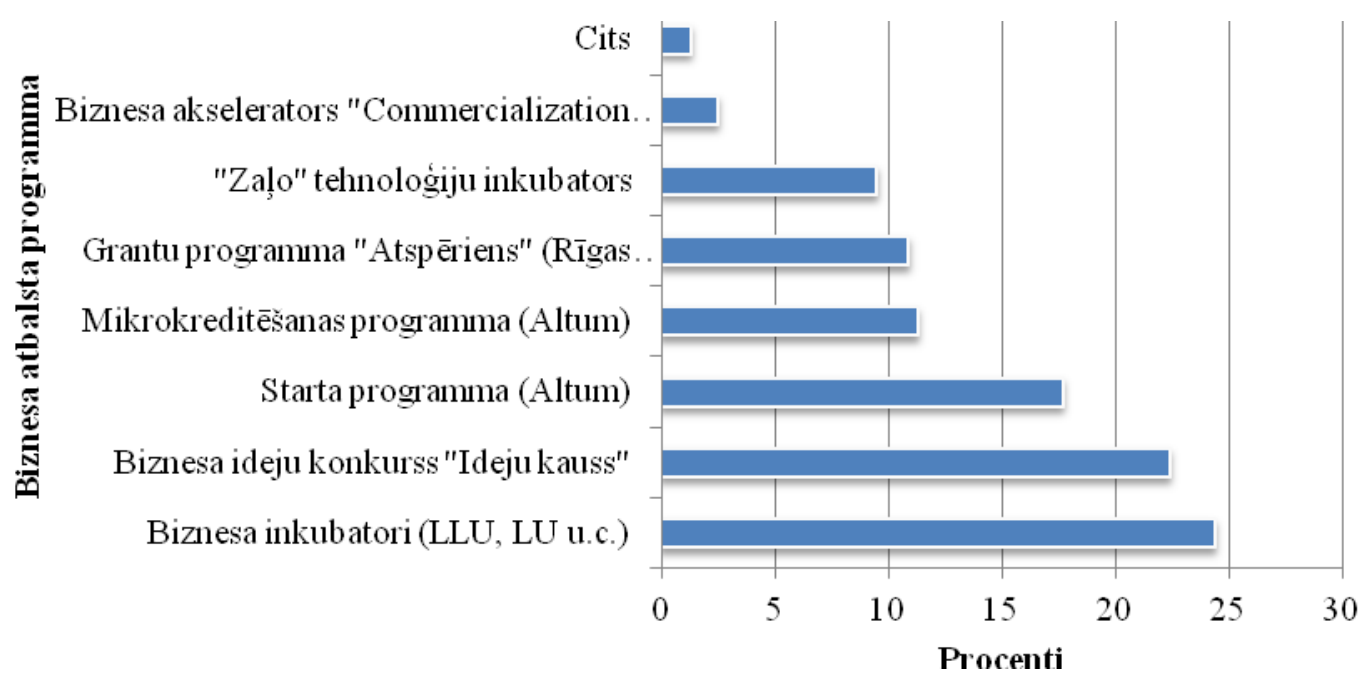

Avots: autores pētījums un konstrukcija

\subsection{0. att./ Fig. 4.20. Jauniešu Latvijā aptaujas rezultāti $(\mathbf{n}=764)$ sniedzot atbildi uz jautājumu „Par kuru/ kurām no uzņēmējdarbības atbalsta programmām esat informēts un zināt?" (\%)/ \\ Results of a survey of youth $(n=764)$ giving an answer to the question "Which business support programs you are informed and know more information?" in Latvia} (\%).

Jāatzīmē, ka 2015. gadā publicētajā Pasaules Bankas ziņojumā (Doing Business 2015) Latvija 189 valstu vidū ir ierindota 36. vietā biznesa uzsākšanas vērtējumā, 
savukārt, Lietuva 11. vietā, Norvēgija 22. vietā, Dānija - 25. vietā, Somija - 27. vietā, Igaunija - 26. vietā, Polija- 85. vietā. Valstu uzņēmējdarbības vide ziņojumā vērtēta 10 aspektos. Latvijas vērtējums šajā ziņojumā (36. vieta) ir pozitīvs, ņemot vērā valsts iedzīvotāju īpatsvaru, tomēr 2015. gadā salīdzinājumā ar 2014. gadu, rādītājiem ir tendence samazināties.

\subsection{Jauniešu nodarbinātības iespējas un to konkurētspēja darba devēju skatījumā/ Youth employability and competitiveness from employers' point of view}

Promocijas darba ietvaros tika veiktas intervijas ar dažādu nozaru darba devējiem ar mērķi noskaidrot darba devēju viedokli par jauniešu nodarbinātības iespējām uzṇēmumā vai institūcijā, kuru pārstāvēja intervijas dalībnieks. Darba devēji vai to pārstāvji tika izvēlēti nejaušas izlases veidā, aptaujājot darba devējus no visiem Latvijas plānošanas reǵioniem.

4.1. tabula/ Table 4.1.

Darba devēju pārstāvētās nozares, darbinieku skaits un Latvijas reǵions, kurā uzṇēmums/institūcija reğistrēts $(n=14) /$

Industries represented by employers, the number of employees and the region of Latvia where the company / institution is registered $(n=14)$

\begin{tabular}{|c|c|c|c|c|}
\hline Sektors & $\begin{array}{l}\text { Uzṇ̦ēmums/ } \\
\text { institūcija }\end{array}$ & Pārstāvētā nozare & $\begin{array}{l}\text { Darbinieku } \\
\text { skaits }\end{array}$ & Latvijas reǵions \\
\hline \multirow{9}{*}{$\begin{array}{l}\text { Privātais } \\
\text { sektors }\end{array}$} & SIA A & Auto rezerves dalu tirdzniecība & 3 & Vidzemes reǵions \\
\hline & SIA B & Mazumtirdzniecība & 4 & Vidzemes regions \\
\hline & SIA C & Tirgus un sociālie pētījumi & 8 & Rīgas reǵions \\
\hline & SIA D & $\begin{array}{c}\text { Dzīvojamo un nedzīvojamo ēku } \\
\text { būvniecība }\end{array}$ & 85 & Zemgales regiions \\
\hline & SIA E & $\begin{array}{c}\text { Mērīšanas, pārbaudes, } \\
\text { izmēgénāšsanas un navigācijas } \\
\text { instrumentu un aparātu ražošana }\end{array}$ & 94 & Latgales reǵions \\
\hline & SIA F & $\begin{array}{c}\text { Mērī̌šanas, pārbaudes, } \\
\text { izmēḡināšanas un navigācijas } \\
\text { instrumentu un aparātu ražošana }\end{array}$ & 56 & Rīgas reǵions \\
\hline & SIA G & $\begin{array}{l}\text { Elektromotoru, ǵeneratoru un } \\
\text { transformatoru ražošana }\end{array}$ & 57 & Kurzemes reǵions \\
\hline & SIA H & $\begin{array}{l}\text { Tērauda armatūras velvējumi } \\
\text { dzelzsbetona konstrukcijām }\end{array}$ & 550 & Kurzemes reǵions \\
\hline & SIA I & Šūšanas pakalpojumi, mode & 2 & Zemgales regions \\
\hline \multirow[t]{5}{*}{$\begin{array}{c}\text { Valsts } \\
\text { sektors }\end{array}$} & $\begin{array}{l}\text { Pirmsskolas } \\
\text { izglītības } \\
\text { iestāde }\end{array}$ & Pirmsskolas izglītība & 26 & Rīgas reǵions \\
\hline & Vidusskola & Izglītība & 35 & Zemgales regions \\
\hline & $\begin{array}{c}\text { Novada } \\
\text { Dome }\end{array}$ & $\begin{array}{c}\text { Sociālais sektors, kultūra un } \\
\text { izglìtīiba }\end{array}$ & 105 & Zemgales reǵions \\
\hline & $\begin{array}{l}\text { Reǵionālais } \\
\text { tūrisma } \\
\text { centrs }\end{array}$ & Tūrisms & 12 & Zemgales regions \\
\hline & Muzejs & Pētniecība, vēsture & 30 & Zemgales regions \\
\hline
\end{tabular}

Avots: autores apkopota informācija par ekspertiem pēc ekspertu intervijas datiem

Nozīmīgi bija izprast darba devēju vēlmi un motivāciju nodarbināt jaunieti, to viedokli par jauniešu iekḷaušanos darba tirgū un nepieciešamajām izmaiṇām darba 
tirgus regulēšanas pamatprincipos. Būtisks uzstādījums no darba autores puses bija arī izprast darba devēju viedokli par jauniešu iespējām uzsākt uzṇēmējdarbību vai kḷūt pašnodarbinātam. Tika veiktas intervijas ar darba devējiem gan no valsts, gan privātā sektora, lai iegūtu plašāku redzējumu par darba tirgus tendencēm un aktualitātēm Latvijā kopumā un Latvijas plānošanas reǵionos (skatît 4.1. tab.).

Intervijas ar darba devējiem tika veiktas no 2014. gada 4. ceturkšña līdz 2016. gada 1. ceturksnim. Uzrunātie darba devēji piekrita piedalīties intervijā un sniegt atbildes, neatklājot savu identitāti un pārstāvēto institūciju/ uzṇēmumu. Intervijas jautājumi apskatāmi 4. pielikumā.

Darba devēji tika aicināti paust viedokli par to, kāda ir attieksme no pārstāvamā uzn̄èmuma/ institūcijas puses par to, ka jaunietis papildina, uzkrāj zināšanas un

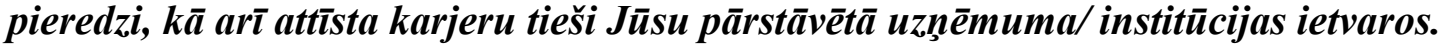

Valsts pirmsskolas izglītības iestādes vadītāja uzsvēra, ka attieksme par jaunieša karjeras attīstīšanu iestādē ir pozitīva. Iestādē ir l̦oti minimāla kadru mainība, jo atrast darbu pagastā ir grūti. Jebkurš jaunietis, kurš patiešām vēlas strādāt, cenšas sevi pierādīt no labās puses. Reizi gadā tehniskajiem darbiniekiem notiek darbinieku darba kvalitātes vērtēšana, no kuras rezultātiem ir iespējams algas paaugstinājums. Jebkurš jauns darbinieks nāk ar savām idejām.

Regionālā tūrisma centra vadītāja uzsvēra, ka mācības noteikti atbalsta, piemēram, maǵistratūras studijas. Jauniešiem jābūt nodarbinātiem, jāpaliek Latvijā, jāskatās, kā piesaistīit tos. Izglîtība ir l̦oti svarīga, izcili, ja jaunietim ir kāda izglīî̀ba iegūta, bet pat ja nav, tāpat aicinātu strādāt un veicinātu jaunieša vēlmi studēt attiecīgajā jomā, kas noderētu darba pienākumu veikšanai.

Vidusskolas direktore ir gatava nodarbināt jauniešus. Vidusskolā daudzi studenti tiek ņemti praksēs un pēc prakses beigšanas atsevišķi indivīdi paliek patstāvīgā darbā.

Muzeja vadītājas attieksme pret jauniešu nodarbināšanu ir pozitīvi vērtējama, jo nepieciešams radošums, jaunas idejas un tehnologiju pārzināšana.

SIA B vadītāja, kas pārstāo mazumtirdzniecības nozari, attieksme pret jauniešu nodarbināšanu ir pozitīva, jaunietim ir jādod iespēja sevi pierādīt uzṇēmuma ietvaros.

SIA I vadìtāja un Novada Domes priekšsēèetāja vietniece attiecās pozitīvi pret jauniešu nodarbināšanu institūcijas ietvaros.

SIA C vadītājs, kas pārstāv tirgus un sociālo pētījumu nozari arī attiecās pozitīvi pret jauniešu nodarbināšanu uzñēmuma ietvaros un SIA Z, kas pārstāv celtniecības nozari arī attiecas pozitīvi, jo jauna darbinieku maina nepieciešama.

SIA F vadītājs, kas pārstāv ražošanas nozari uzsvēra, ka uzn̄ēmumam ir problēmas ar atbilstošas izglītības darbinieku atrašanu, līdz ar to, ja šāds potenciālais darbinieks ir gatavs uzsākt strādāt, tad uzṇēmums ir atvērts ar potenciālajām iespējām.

SIA H uzñèmuma pārstāve, kas darbojas mašinnbūvē un metālapstrādē uzsvēra, ka ir problēmas atrast darbiniekus un apmācīt tos darbam, izglītības sistēmā ir „robs”, netiek gatavoti pietiekami daudz speciālisti inženierzinātnēs, līdz ar to uzņēmumā ir darbinieku trūkums. Uzñēmums būtu gatavs nodarbināt jaunos darbiniekus.

SIA A, SIA E un SIA $G$ vadība uzsvēra, ka nozares ir specifiskas, darbinieku netrūkst, bet darbinieku konkurētspēja uzṇēmumā ir atkarīga no pašiem darbiniekiem.

Darba autore pozitīvi vērtē darba devēju attieksmi par jauniešu nodarbinātību. Būtiska ir darba devēju pretimnākoša attieksme pret jauniešu nodarbināšanu lauku teritorijās, kur ir salīdzinoši maz brīvu darba vietu. Lauku reǵionos ir lielākais izbraukušo skaits darba meklējumos uz ārvalstīm, kā arī jauniešiem no lauku reǵioniem nereti trūkst iespējas iegūt augstāko izglītību, nepietiekamā finansējuma dēḷ. Līdz ar to jaunieša nākotnei ir nozīmīga turpmāka sadarbība ar darba devēju, kas ne vien nodrošina jaunietim patstāvīgu un ilgstošu darbu, bet arī veicina jaunieša iekḷaušanos 
darba tirgū, piemēram, motivējot jaunieti studēt ar darba pienākumiem saistītā jomā, kāa arī dodot iespēju studijas savienot ar darba pienākumiem.

Nozīmīga ir būtiskāko kritēriju apzināšana, pēc kuriem darba devēja pārstāvētajā institūcijä/uzñēmumā tiek izvērtēta jaunieša atbilstība vakancei.

Darba devēji no privātā sektora uzskaitīja sekojošus kritērijus: darba kvalitāte; prasmes konkrētajā jomā; kompetence; izpildes termiṇi; disciplīna; lojalitāte; griba/ vēlme strādāt; vēlme mācīties, uzkrāt zināšanas par savu profesiju; iniciatīva.

SIA $C$ vadītājs uzsvēra, ka nav specifiski kritēriji tieši jauniešiem, pēc kura izvērtēt atbilstību vakancei, visi kandidāti tiek izvērtēti vienlīdzīgi.

Darba devēji no valsts sektora uzskaitīja sekojošus kritērijus: griba/ vēlme strādāt; izglītība; tehnolog̣iju zināšanas; zināšanas par institūciju, kurā vēlas strādāt; komunikabilitāte; iekḷaušanās kolektīvā; tolerance attiecībā pret kolēǵiem; radošums, jaunas idejas.

Apkopojot iepriekšminēto, jāsecina, ka ikvienam darba devējam nepieciešams izglītots, motivēts, strādāt gribošs un inteliğents darba ñēmējs, kas ir loǵisks arguments, jo darba devējs ir ieinteresēts pēc iespējas vairāk gūt peļnu un pozicionēt institūciju/ uzņēmumu kā iestādi, kur tiek nodrošināts pakalpojums vai produkts atbildīgo un regulējošo institūciju prasībām atbilstošā līmenī.

Laikraksta "Dienas Bizness" rīkotajā konferencē "Biznesa prognozes 2015", kas norisinājās 2014. gada 26. novembrī (Radisson Blu Daugava) tika uzsvērts, ka darba tirgū lielākie izaicinājumi 2015. gada ietvaros ir nepietiekama kvalificētu strādnieku pieejamība, spiediens celt algu līmeni, kā arī talantīgu darbinieku noturēšana viena uzṇēmuma ietvaros. Ieguvēji būs darba devēji, kas varēs maksāt lielākas algas vai spēs piedāvāt citas motivējošas lietas, tostarp iespēju iegūt jaunu pieredzi. Tika uzsvērts, ka laba stratēgija uzṇēmējiem, kas ilgtermiṇā attaisnosies, būs piesaistît gados jaunus cilvēkus bez pieredzes un skolot viņus (Knipše, 2014).

„TNS Latvia” valdes locekle, lielo klientu direktore S. Kaņejeva norāda, ka vispārējās statistikas dati liecina, ka darba tirgus darba devējiem kḷūst sūrāks: demogrāfisko procesu dēḷ darbspējas vecuma cilvēku skaits samazinās. Statistika arī norāda uz strukturālo bezdarbu, t.i., no bezdarbniekiem procentuāli lielākā daļa ir mazkvalificēto darbu veicēji. Savukārt starp piedāvātajām vakancēm pirmajā vietā ir kvalificēti speciālisti. Balstoties uz „TNS Latvia” veikto pētijjumu (ticis veikts 2014. gada oktobra beigās un novembra sākumā) 37\% no darba devējiem par lielāko izaicinājumu 2015. gadā uzskata kvalificētu speciālistu trūkumu (Knipše, 2014).

Darba autore uzsver, ka uzņēmumā nozīmīga ir ne tikai jaunu darbinieku, bet arī gados vecāku cilvēku nodarbināšana, jo tieši pieredzes bagāti darbinieki nodot savas zināšanas jaunajiem, palīdzot tiem ātrāk iekl̦auties uzņēmumā un veicināt uzñēmuma attīstību. Nozīmīga ir zināšanu pārnese un veiksmīga cilvēkkapitāla izmantošana un iekļaušanās sabiedrībā.

Darba autore uzskatīja, ka būtiski ir noskaidrot darba devēju attieksmi jaunieša, kuram izglītība ir zemāka par profesionālo, nodarbināšanā.

SIA B, SIA C, SIA F un SIA G uzņēmumu vadītājiem un pārstāvjiem attieksme par jaunieša nodarbināšanu ir pozitīva, plašāki komentāri netika sniegti.

SIA E vadība uzsvēra, ka uzņēmums pats apmāca darbiniekus ārpus Latvijas.

SIA I vadītāja uzsvēra, ka jauniešiem bez izglītības nav piemērots darbs viṇas pārstāvētajā uzṇēmumā un nav paredzēti tādi amati, kurus var veikt persona bez attiecīgās izglìtības.

SIA $D$ vadītājs, kas pārstāv celtniecības nozari uzsvēra, ka šī uzņēmuma profesijās visu var iemācīties praksē, jo uzṇēmumā ir spējīgs pieredzējušo darbinieku sastāvs. 
SIA B uzñèmuma vadītājs uzsver, ka jaunietim būtu jāmācās, jo bez iegūtas izglītības normālu darbu ne tikai šobrīd, bet arī vēlāk nebūs iespējams atrast.

SIA $H$ pārstāve uzsvēra, ka uzṇēmums darbojas pārāk specifiskā nozarē, līdz ar to darbiniekus bez pieredzes nav iespējams nodarbināt.

Valsts pirmsskolas izglìtības iestādes vadītāja uzskata, ka ja amata aprakstā netiek prasīta augstākā izglītība un jaunietis ir centīgs, apzinīgs, pozitīvs, vēlas strādāt, tad attieksme ir pozitīva.

Muzeja vadītāja uzskata, ka ir grūti ir piedāvāt kādu amatu, ja cilvēks vēl pats nav izvēlējies izglīîibas jomu. Jāvērtē personība.

Reǵionālà tūrisma centra vadītāja min, ka jaunieti bez izglītības var nodarbināt tikai ar īslaicīgiem palīgdarbiem. Ja uz vakanci pieteikušies vairāki darba meklētāji un ir iespējas izvēlēties, iestāde algotu tikai jauniešus ar profesionālo izglītību tūrismā.

Vidusskolas direktore un Novada Domes priekšsēètāja vietniece minēja, ka šādus jauniešus nav iespējams nodarbināt viṇu pārstāvētajās institūcijās.

Darba autore par nozīmīgu izglītības jomā uzskatīja arī uzsvērt laikraksta "Dienas Bizness" rakstā “ Klimats labvēlīgs darba ņēmējam” uzṇēmuma SIA “Hanzas elektronika" valdes loceklis A. Vagulis atzīmēja, ka uzņēmumi Latvijā attiecībā uz darbinieka kvalifikāciju un izglìtību ir prasīgi. Tomēr uzṇēmuma vadība ir sapratusi, ka gatavu speciālistu darbam elektronikas nozarē dabūt nevar, tādēḷ uzņēmums ir sācis darba vidē attīstīt mācības jeb t.s. duālo izglīitîbu. Savukārt inženierus uzṇēmums cenšas iegūt, cieši sadarbojoties ar augstskolām, galvenokārt, Rīgas Tehnisko universitāti. Uzṇēmums pagaidām ārvalstīs speciālistus nav rekrutējis (Knipše, 2014).

Darba autore atzīmēe, ka jau šobrīd darba devējiem specifiskās nozarēs trūkst kvalificēts darbaspēks un rodas iespēja veidot ciešāku sadarbību starp darba devējiem un izglītības iestādēm. Izglītības un zinātnes ministrijai vajadzētu vērst pastiprinātu uzmanību uz sadarbības veicināšanu starp šīm institūcijām, tādā veidā nodrošinot gados jaunā cilvēkkapitāla neaizplūšanu uz ārvalstīm. Iepriekšminētais apgalvojums varētu būt kā sākuma virzịtājspēks lielākam jauniešu īpatsvaram tikt motivētam iegūt izglītîbu specifiskās nozarēs un būt drošam par nākotnes iespējām iegūt praktiskās iemaņas attīstîtā uzṇēmumā un vēlāk arī kḷūt par patstāvīgu un ilgstošu darbinieku uzņēmuma ietvaros, nodrošinot stabilus dzīves apstākḷus un sociālo drošību.

Pētījuma ietvaros tika noskaidrota arī darba devēju attieksme jaunieša, kurš šobrīd studē augstākā lìmeņa studijās un vēl nav ieguvis augstāko izglītību, nodarbināšanā.

SIA A, SIA B, SIA C un SIA E uzņēmumu vadītājiem attieksme pret šāda jaunieša nodarbināšanu ir pozitīva.

SIA $D$ vadītājs atbalsta izglītības iegūšanu un dod iespēju apmeklēt studijas, kā arī vajadzības gadījumā sniedz konsultācijas.

SIA G uzņēmumā darbinieki tiek speciāli apmācīti, lai spētu pildīt nepieciešamos darba pienākumus, līdz ar to studijas izglīitibas iestādē var būt citā jomā, nekā strādā darbinieks.

SIA F uzņēmuma vadība uzsvēra, ka uzņēmums darbojas specifiskā nozarē, galvenā problēma ir tāda, ka Latvijā nav mācību bāzes, nav darbinieku ar atbilstošu izglìtību - inženieri, tehniskie darbinieki utt. Vajadzētu Latgales reǵionā izveidot mācību bāzi šāda veida darbiniekiem, bet reǵionā trūkst potenciālo darbinieku, neapmācīs pāris darbiniekus vairāku gadu garumā.

SIA H uzņēmuma pārstāve uzsvēra, ka Latvijā netiek sagatavoti pietiekoša skaita speciālisti inženierzinātnēs. Pārāk daudz tiek sagatavoti speciālisti ekonomikā un jurisprudencē. Nav „laba prakse” speciālistu trūkuma dēḷ likvidēt ražojošos 
uzņēmumus. Gudrie un izglītotie speciālisti aizbrauc uz ārvalstīm, kur tiem piedāvā lielāku atalgojumu. Uzṇēmums cenšas meklēt nozares speciālistus, bet tā ir problēma.

SIA I vadītāja uzskata, ja ir prasmes un vēlme studēt, tad šādu jaunieti būtu iespējams nodarbināt, bet ja nav ne prasmes un vēl talanta, tad šādu jaunieti nenodarbināsim.

Novada Domes priekšsēèetāja vietniece izsakās, ka iespējams nodarbināt tikai tos jauniešus, kas studē attiecīgajā darba specialitātē.

Valsts pirmsskolas izglītības iestādes vadītāja min, ka pašlaik iestādē strādā divas jaunietes, kuras turpina mācīties augstskolā. Viņas tiek atbalstītas, tiek piešķirts atvalıinājums studiju ietvaros, ja tas nepieciešams mācībām.

Muzeja vadītāja, Regionālā tūrisma centra vadītāja un Vidusskolas direktore apgalvo, ka attieksme ir pozitīva pret šiem jauniešiem, sīkākus komentārus respondentes nesniedza.

Ņemot vērā iepriekšminētos apgalvojumus, jāsecina, ka viennozīmīgi ir atbalstāma jauniešu izglîtības iegūšana no darba devēju puses. Rodas jautājums - kādēl bieži gan no zinātnieku puses, gan pašu jauniešu puses, apkopojot jauniešu aptaujas anketas, nākas sastapties ar apgalvojumu, ka jauniešiem, kas studē, ir problēmas apvienot studijas ar darbā veicamajiem pienākumiem. Darba autore uzskata, ka š̄̄ problēma ir aktuāla un ciešāka sadarbība starp uzņēmējiem un izglītības iestādēm veicinātu šīs problēmas samazināšanu, jo darba devēji būtu ieinteresētāki, lai jaunais speciālists tiktu sagatavots darba pienākumu veikšanai pēc iespējas augstākā līmen̄̄ un justos droši, ka jaunais darbinieks ne tikai izietu praksi uzņēmuma ietvaros, bet nākotnē arī ieņemtu nozīmīgu pozīciju uzṇēmuma attīstības virzībā. Šis ierosinājumus nozīmīgs varētu būt uzñēmumiem un institūcijām, kuru darbība ir virzīta uz elektronikas, bioekonomikas, biomedicīnas, biotehnoloǵiju, inženiersistēmu, viedās enerǵētikas u.c. jomām, kur nepieciešami īpaši augstā līmenī sagatavoti speciālisti, kas veicinātu jaunu un inovatīvu produktu izstrādi, kas tiktu atzīti pasaules mērogā.

Jauniešu iespēju izvērtējums no darba devēju puses, pierādot sevi kā motivētu un uz panākumiem virzītu darbinieku, tikt paaugstinātam amatā, uz algas pakāpenisku pieaugumu, individuālo spēju un prasmju attīstī̌sanu attiecīgās nozares un amata ietvaros.

SIA D uzñèmuma vadītājs uzsver, ka uzņēmumā ir tikai 11 inženiertehniskie darbinieki ar lielu praksi, jaunietim būtu sevi jāmotivē pierādot spējas praktiskā darbībā.

SIA B un SIA F vadība uzsver, ka, ja jaunietis sevi pierādītu kā spējīgu darbinieku, viņš tiktu arī attiecīgi novērtēts.

SIA E vadība uzsver, ka, ja darbinieks ir konkurētspējīgs, tad ir izaugsmes iespējas. Algas uzṇēmumā ir vidējā līmen̄i, salīdzinājumā ar citām valstīm.

SIA $H$ pārstāve uzsver, ka uzņēmumā varētu būt konkurētspējīgāks atalgojums, bet nav iespēju to palielināt. Uzṇēmumā ir augstas kategorijas un plaša profila speciālisti, par darbiniekiem „stāvam un krītam”, bet finansiālā situācija šobrīd ir „smaga”.

SIA $G$ pārstāve uzsver, ka darbinieka nākotni ietekmē cilvēka ,iekšējā inteliǵgence", kas norāda uz darbiem.

SIA I, SIA C vadītājs, Muzeja vadītāja, Vidusskolas direktore un Novada Domes priekšsēètāja vietniece apgalvo, ka vērtējums ir apstiprinošs un jaunietim būtu realizējamas iepriekšminētās iespējas.

Savukārt Reǵionālā tūrisma centra vadītāja uzsver, ka darbinieks tiks novērtēts, kaut arī gados jauns. 
Valsts pirmsskolas izglītības iestādes vadìtāja uzsver, ka viņas vadītajā izglītības iestādē nav šādu iespēju, jo nepieciešama pedagoǵiskā izglītība. Lai gan ir gadījumi, kad tehniskais darbinieks sāk mācīties, lai kḷūtu par pedagogu.

Darba devēju pozīcija attiecībā uz jaunieša iespējām attīstît karjeru institūciju/ uzņēmuma ietvaros ir atbalstāma. Kā iepriekš tika minēts, uzṇēmēji ir gatavi sadarboties ar jaunieti, ja viņš ir motivēts attīstīties uzṇēmuma ietvaros, jo šajā gadījumā arī uzñēmums būs ieguvējs.

Darba devēju vērtējums par Nodarbinātūbas Valsts ağentūras ìstenotajiem jauniešu mobilitātes pasākumiem, kuros ar Eiropas Savien̄̄bas Fondu atbalstu tiek piesaistīts līdzfinansējums jauniešu darba algas dal̦ējai segšanai, ar nosacījumu, ka darba devējs nodarbina jaunieti, iesaistoties projektā noteiktu laika periodu.

SIA I vadītāja šo pasākumu vērtē pozitīvi, bet uzskata, ka negatīvais aspekts ir tāds, ka NVA programmās jauniešiem zināšanas sniedz tikai teorētiskā līmenī, bet neparedz prakses vadītājiem un prasmju sniedzējiem atlīdzību un iespējas jaunietim iegūt praktiskās iemaņas.

SIA A, SIA B, SIA F un SIA H vadītāju un pārstāvju attieksme ir pozitīiva, plašākus apgalvojumus respondenti nesniedza.

SIA $C$ vadītājs šos pasākumus vērtē kritiski.

SIA $D$ vadītājs uzsvēra, ka šāda veida pasākumi uzṇēmumā netiek izmantoti, bet darbā tiek pieņemti jaunieši, kaut arī nav aktuāla noteiktas profesijas vakance. Šos jauniešus nodarbina tajos gadījumos, kad vecākajiem darbiniekiem nepieciešama nomaiņa un praksi sniedz jau esošie darbinieki.

Valsts pirmsskolas izglìtības iestādes vadìtāja atbalstīja šo iespēju, ja jaunietis tiek nodrošināts ar darbu un viņam tas nav jāmeklē citā valstī.

Muzeja vadītāja minēja, ka institūcijā tika iesaistīti jaunieši vasaras darbos un vērtē pozitīvi šo iespēju, jo tā bija papildus iespēja jaunietim iegūt pieredzi.

Reğionālà tūrisma centra vadītāja šo iespēju vērtēja pozitīvi, bet uzsver, ka 2014. gada vasarā iespējas nodarbināt jauniešus nebija, jo nebija pietiekami labi sagatavots projekts un konkurss netika izturēts.

Novada Domes priekšsēdētāja vietniece uzsvēra, ka šādus pasākumus novada Dome neizmanto.

Vidusskolas direktore šos pasākumus vērtēja tikai daļēji pozitīvi un no plašākiem komentāriem atturas.

Darba autore uzskata, ka darba devēji netiek pietiekamā līmen̄̄ informēti par šiem Nodarbinātības Valsts aǵentūras atbalsta pasākumiem un tiem ir tikai vispārējs priekšstats vai viedoklis par pieteikšanos šiem pasākumiem, to mērķiem, uzdevumiem un iespējām. Pasākumiem, kas tiek finansēti no ESF līdzekḷiem, vajadzētu tikt pozicionētiem plašākai auditorijai un piesaistītam lielākam finansējuma apjomam, lai šajos pasākumos varētu iesaistīt pēc iespējas plašāku jauniešu loku un veicinātu jauniešu palikšanu pie darba devēja arī pēc projekta beigām.

Darba devēju viedoklis par uznēemuma/ institūcijas pārstāvētajai nozarei un amata pienākumu veikšanai sagatavotu jauniešu nodarbināšanu, respektīvi, jaunietis noteiktu laika periodu tiktu apmācīts konkrēta amata pienākumu izpildei Eiropas Savienības projektu ietvaros.

SIA A, SIA B, SIA F un SIA $H$ vadìtāji un pārstāvji, Vidusskolas direktore, Novada Domes priekšsēdètāja vietniece, Muzeja vadītāja un Valsts pirmsskolas izglìtības iestādes vadītāja atbildēja apstiprinoši, detalizētākus komentārus nesniedza.

Regionālā tūrisma centra vadītāja pieņem, ka teorētiski varētu nodarbināt šādus jauniešus, piemēram, vasaras periodā, kad tūrisma sezonā lielāka aktivitāte, bet tas atkarīgs arī no budžeta līdzekļu apjoma. 
SIA I vadìtāja uzsver, ka viņai galvenokārt esot svarīga padarītā darba kvalitāte.

SIA $C$ vadītājs uzsver, ka tirgus un sociālo pētījumu nozarē nav iespējams sagatavot darbiniekus projektu ietvaros, nepieciešama augstākā izglītība konkrētajā jomā.

SIA G pārstāve uzvēra, ka uzñēmums pats apmāca speciāli katru darbinieku.

Muzeja vadītāja, Valsts pirmsskolas izglītības iestādes vadītāja, Novada Domes priekšsēdētāja vietniece dotu priekšroku šādu jauniešu nodarbināšanai.

Apkopojot darba devēju sniegtās atbildes, jāsecina, ka darba devēji būtu gatavi nodarbināt jaunieti, kas tiktu speciāli apmācīts konkrētā uzñēmuma darba pienākumu izpildei. Darba autore atzīmē, ka ESF finansētajos projektos jaunieši varētu iegūt arodu vai arī papildināt jau iegūtās zināšanas, piemēram, ar valodu apguvi. Jāatzīmēē, ka projektu ietvaros nebūtu iespējams nodrošināt jaunietim apmācības vairāku gadu garumā. Izvērtējot arī š̀̃ brīža Nodarbinātības Valsts aǵentūras organizētos pasākumus, jauniešu iesaiste apmācības programmās nav iespējama visiem reǵistrētajiem bezdarbniekiem.

Darba devēju viedoklis par nodokļu atvieglojumu ietekmi uz lēmuma pieņemšanu par jaunieša kandidatūras apstiprināšanu uz vakanto vietu attiecībā pret citiem pretendentiem.

SIA B, SIA C, SIA F un SIA $H$ vadītāji un pārstāvji, kā arī Muzeja vadītāja pieņemtu izvēli par jaunieša nodarbinātību, ja būtu nodokḷu atvieglojumi.

SIA I vadìtāja apgalvo, ka dotu priekšroku jaunieša nodarbināšanai, ja būtu nodokḷu atvieglojumi, bet tikai jaunietim, kuram ir nepieciešamās prasmes un ieman̦as.

Regionālā tūrisma centra vadītāja uzskata, ka teorētiski būtu gatava nodarbināt šādu jaunieti.

Valsts pirmsskolas izglītības iestādes vadītāja uzsvēra, ka šī ir pašvaldības iestāde, tādēl šis jautājums viņu neskar.

Novada Domes priekšsēdētāja vietniece, Muzeja vadītāja, SIA A, SIA B un SIA G vadītāji, Vidusskolas direktore apstiprina, ka nodokḷu atvieglojumi ietekmētu pozitīvo lēmumu par jaunieša nodarbināšanu.

Vidusskolas direktore uzsver, ka nedotu priekšroku jaunieša nodarbināšanai tikai tādēl, ka būtu nodokḷu atvieglojumi, viṇa uzskata, ka galvenais ir jaunieša izglìtîbas atbilstība nozares prasībām.

Arī SIA $D$ vadìtājs nedotu priekšroku jaunieša nodarbināšanai tikai tāpēc, ka būtu pieejamas nodokḷu atlaides.

Jauniešu potenciālo iespēju izvērtējums uzsākt uzņēmējdarbību, ņemot vērāa mūsdienu ekonomisko situāciju.

SIA A, SIA F vadība un Vidusskolas direktore uzskata, ka uzņēmējdarbības uzsākšanas iespējas nav atkarīgas no ekonomiskās situācijas, bet gan no personības tipa.

SIA I vadītāja un SIA G pārstāve uzskata, ka iespējas ir plašas, jautājums ir tāds, vai jaunieši prot tās izmantot.

Reǵionālā tūrisma centra vadītāja uzskata, ka jauniešiem ir iespējas uzsākt uzṇēmējdarbību, piemēram, vasaras un ziemas sezonā atsevišķās pilsētās, kurās ir tūrisma galamērķu centri, būtu aktuāla velosipēdu noma un slēpju noma, kas varētu būt sākums uzn̄ēmējdarbībai.

Valsts pirmsskolas izglītības iestādes vadītāja uzsver, ja ir zināšanas, vēlēšanās, enerğija, nepieciešamie resursi, tad ir iespējas uzsākt uzņēmējdarbību.

Muzeja vadītāja uzskata, ka nav pietiekoša atbalsta uzṇēmējdarbības uzsākšanai, tādēḷ iespējas vērtē kā zemas.

Novada Domes priekšsèdètāja vietniece uzskata, ka ir labas iespējas uzsākt uzņēmējdarbību, ir pieejami biznesa inkubatori, kompetenču centri, aktīva ir Latvijas 
Tirgotāju asociācija, kā arī jauniešiem no Jelgavas ir iespējama sadarbības veidošana ar Latvijas Lauksaimniecības universitātes Zināšanu un tehnologiju pārneses centru.

SIA $D$ vadītājs uzskata, lai uzsāktu uzṇēmējdarbību, nav nepieciešamas specifiskas zināšanas, bet, lai noturētos, attīstītos un gūtu pel̦nu, ir smagi jāstrādā.

SIA $B$ vadītājs un SIA $H$ pārstāve uzskata, ka jauniešu iespējas uzsākt uzņēmējdarbību šobrīd ir vērtējamas kā diezgan apšaubāmas.

Darba autore uzskata, ka jauniešiem ir iespējas uzsākt uzņēmējdarbību tādā gadījumā, ja piedāvātais produkts vai pakalpojums ir inovatīvs, kas nodrošina iespēju gūt peļnu starptautiskā līmenī, produktu eksportējot un pakalpojumu nodrošinot arī ārvalstīs.

Inovatīvas un specifiskas uzṇēmējdarbības attīstīšanai mūsdienās jaunietim neiztikt bez iesaistes uzñēmējdarbības atbalsta pasākumos, kā arī iegūtas specifiskas augstākās izglītības. Pasaules mērogā pieprasījums ir pēc informāciju un komunikāciju tehnologiju, biomedicīnas, biotehnoloǵiju, inženiersistēmu u.c. specifiskiem prioritārajiem virzieniem. Līdz ar to jaunieša aktīva darbība un zināšanu iegūšana jau studiju gados kādā no iepriekšminētajām nozarēm nodrošinās jaunietim iespēju veiksmīgi pozicionēties ne tikai Latvijas, bet arī pasaules mēroga uzṇēmumos, gūt pieredzi un turpmākajos gados, ja pašam būs iniciatīva, uzsākt savu uzņēmējdarbību. Mūsdienās neiztikt arī bez vairāku valodu zināšanām un iespējām tās izmantot ikdienas komunikācijā.

Darba devēju viedoklis par Latvijā pieejamo uznēmējdarbības uzsākšanas atbalsta instrumentu nodrošinājumu pietiekoš $\bar{a}$ līmen̄̄ (piemēram, tādi atbalsta instrumenti kā mikrokreditēšanas programmas, starta programmas uzñēmējdarbübas uzsākšanai, mentoru konsultācijas, biznesa inkubatori utt.).

SIA A, SIA C, SIA F uznēemumu pārstāvji un Vidusskolas direktore uzskata, ka uzņēmējdarbības uzsākšanai potenciālie atbalsta instrumenti ir pietiekami nodrošināti.

Savukārt SIA B vadītājs uzskata, ka uzņēmējdarbības atbalsta instrumenti nav nodrošināti pietiekamā līmenī.

SIA I vadītāja uzskata, ka vislielāko atbalstu iespējams saņemt, iesniedzot projektu VAS „Latvijas Attīstības finanšu institūcija Altum”.

Reǵionālà tūrisma centra vadītāja apgalvo, ka jaunieši baidās izrādīt interesi par šiem atbalsta instrumentiem, jo gados vecāki cilvēki arī baidās un nav pārliecināti par zināšanām. Sākums šai attīstībai varētu būt virzī̌sanās uz nodokḷu atvieglojumiem, vismaz pirmos divus uzñēmējdarbības gadus.

Valsts pirmsskolas izglītības iestādes vadìtāja uzskata, ja jaunu uzṇēmumu ir tik cik viņi šobrīd ir un ņem vērā viņu „dzīvotspēju”, tad jāsecina, ka atbalsta instrumentu pieejamība nav pietiekošā līmen̄i.

Muzeja vadìtāja uzskata, ka atbalsta instrumentu pieejamība nav līdz galam pārdomāta, tie ir pieejami jaunajiem lauksaimniekiem. Būtu nepieciešams plašāk pievērsties šim jautājumam.

SIA H pārstāve un Novada Domes priekšsēdētāja vietniece uzskata, ka instrumenti ir nepietiekamā apjomā. Vēlama lielāka mērkstiecība arī no pašu jauniešu puses, it īpaši to, kas ieguvuši kādu konkrētu profesiju.

SIA $D$ vadìtājs uzskata, ka šobrīd pieejamie atbalsta instrumenti ir liels solis uz priekšu, jo pirms desmit gadiem nebija pieejams nekas no tā, kas ir tagad, drīzāk problēma ir tajā, ka jaunieši nezina par šìm iespējām un pietiekoši tās neizmanto.

Darba autore secina, ka nav pietiekošas informācijas par biznesa uzsākšanas atbalsta instrumentiem. Jāveicina vienotas platformas izveidi valsts līmen̄̄, kas sniegtu iespēju jaunajiem uzņēmējiem iepazīties ar uzņēmējdarbības attīstības aktualitātēm, veidot sadarbības iespējas ar uzn̦ēmumiem un valsts institūcijām, uzzināt par 
jaunākajiem sasniegumiem citos uzṇēmumos savas nozares ietvaros, kā arī uzturēt saziņu ar atbalstošajām valsts institūcijām un uzṇēmumiem.

Interesants risinājums ir izveidotā AS „Swedbank” digitālā platforma uzñēmumu tīkls Biznesa tīkls (Business Network), kurā bankas jaunie klienti uzņēmēji, atverot kontu attiecīgajā bankā, var pievienoties biznesa platformai un nodrošināt komunikāciju ar citiem bankas klientiem, kas pievienojušies šai platformai.

Šādu platformu būtu nozīmīgi ieviest ne tikai bankas ietvaros, bet arī valsts līmenī. Platformas koordinēšanu varētu nodrošināt, piemēram AS "Attīstības finanšu institūcija Altum" vai LIAA.

Jāatzīmē, ka LIAA šobrīd koordinē tiešsaites datu bāzi "Latvijas eksporta, importa portāls" (Latvian Export Import Directory (EXIM), saite uz datu bāzi: http://www.exim.lv) jau esošiem uzñēmējiem, kas ir orientēti uz ārējo tirdzniecību. Šī portāla mērķis ir nodrošināt informācijas apmaiņu par importa un eksporta iespējām no Latvijas un ārvalstu uzņēmumiem ar interneta starpniecību.

Galvenās portāla sadaļas:

- Latvijas uzñēmumu datu bāze;

- priekšlikumi - biznesa reklāmas un tirdzniecības idejas Latvijas un ārvalstu uzñēmējiem;

- pasākumi - saraksts ar notikumiem Latvijā un ārvalstīs;

- tirgus informācija - informācija par Latvijas ekonomisko nozaru attīstību un tirdzniecības iespējām (Latvian Export..., b.g.).

Portāla mērķa auditorija ir Latvijas un ārvalstu uzņēmēji, līdz ar to iespējas jaunajiem uzn̄ēmējiem atrast sadarbības partnerus šajā portālā nav iespējams.

4.2. tabulā apkopots darba devēju vērtējums par atbalsta instrumentiem jauniešu iekl̦aušanai darba tirgū par iepriekšminētajiem aptaujas jautājumiem.

Aptaujas nobeigumā darba devējiem tika lūgts sniegt komentārus par nozīmīgākajiem valsts institūciju ìstenojamiem pasākumiem jauniešu darba tirgus situācijas stabilizēěsanai.

SIA A un SIA C vadītāji uzskata, ka nav atsevišķu atbalsta pasākumu tieši jauniešu darba tirgum. Ja ir problēmas kopējā darba tirgū, tad tas atsaucas arī uz jauniešiem.

SIA I vadītāja uzskata, ka jauniešiem nepieciešama vairāk praktiskā pieredze, piemēram, skolēnu firmu izveide mācību ietvaros. Jaunieši no arodvidusskolas praksē strādā mazkvalificētus darbus, kas nākotnes pieredzei nav pietiekami. Lai prakse būtu efektīvāka, prakses vadītājiem vajadzētu ieviest atalgojuma sistēmu.

Regionālà tūrisma centra vadītāja uzskata, ka nepieciešama nodokḷu sistēmas sakārtošana. Arī tūrisma centrā darba apjoms ir milzīgs un, it īpaši sezonā, nepieciešams papildus darbaspēks. Ja jauniešu nodarbināšanai būtu nodokḷu atlaides, viņas tūrisma centrs noteikti nodarbinātu vairāk jauniešus.

Valsts pirmsskolas izglītības iestādes vadìtāja uzsver, ka nepieciešami nodokḷu atvieglojumi uzṇēmējiem un jānodrošina atbalsta pasākumi, tiem, kuri nodarbina tieši jauniešus.

Muzeja vadītāja uzskaita šādus īstenojamos pasākumus: nodokḷu atlaides; prakses vietu pieejamība; papildus ,atlaides” darba devējiem par jauniešu nodarbināšanu; profesionālajās skolās budžeta vietās studējošos jauniešus nepieciešams sasaistīt ar darba devējiem jau mācību laikā, jauniešus nodarbinot uzņēmumos un piešķirot stipendijas.

Novada Domes priekšsèdètāja vietniece iesaka izveidot speciālas programmas darba vietas iekārtošanai, nodrošināt plašāku mentoru pieejamību, kā arī nodokḷu atvieglojumus. 


\section{Atbalsta instrumentu izvērtējums par jauniešu iespējām iekḷauties darba tirgū darba devēju vērtējumā/}

Evaluation of support instruments for youth to enter the labour market by employers

\begin{tabular}{|c|c|c|}
\hline Atbalsta instruments & Pozitīvie aspekti & Problemātiskie aspekti \\
\hline $\begin{array}{l}\text { NVA piedāvātie } \\
\text { profesionālās } \\
\text { pilnveides kursi }\end{array}$ & $\begin{array}{l}\text {-Jaunietim iespēja iegūt arodu vai } \\
\text { papildināt jau esošās zināšanas, } \\
\text { piem., valodu apguve. }\end{array}$ & $\begin{array}{l}\text {-NVA programmās jauniešiem } \\
\text { zināšanas sniedz tikai teorētiskā } \\
\text { līmenī un iespējas jaunietim iegūt } \\
\text { praktiskās iemaņas; } \\
\text {-iesaiste apmācībās nav iespējama } \\
\text { visiem reǵistrētajiem bezdarbniekiem. }\end{array}$ \\
\hline $\begin{array}{l}\text { Lïdzfinansējums } \\
\text { daḷējai jaunieša darba } \\
\text { algas segšanai } \\
\text { (sadarbībā ar NVA) }\end{array}$ & $\begin{array}{l}\text {-Jaunietis tiek nodrošināts ar darbu. } \\
\text {-papildus iespēja jaunietim iegūt } \\
\text { pieredzi. }\end{array}$ & $\begin{array}{l}\text {-Netiek paredzēta atlīdzība prakses } \\
\text { vadītājiem un prasmju sniedzējiem; } \\
\text {-darba devējiem pastāv risks neizturēt } \\
\text { konkursu, nesagatavojot pietiekami } \\
\text { labu projekta pieteikumu; } \\
\text {-nav pietiekama informācija darba } \\
\text { devējiem par šādiem pasākumiem, } \\
\text { pastāy tikai vispārējs viedoklis un } \\
\text { priekšstats; } \\
\text {-finansējuma apjoma nepietiekamība; } \\
\text {-nozares specifika var ierobežot } \\
\text { jauniešu iespējas tikt nodarbinātiem } \\
\text { konkrētā uzñēmumā. }\end{array}$ \\
\hline $\begin{array}{l}\text { Atvieglojumi nodoklu } \\
\text { joma } \bar{a}\end{array}$ & $\begin{array}{l}\text {-Priekšroka tiktu dota tikai tādam } \\
\text { jaunietim, kuram būtu atbilstošas } \\
\text { prasmes un iemaņas; } \\
\text {-nodokḷu atvieglojumi ietekmētu } \\
\text { darba devēja izvēli par jaunieša } \\
\text { nodarbināšanu. }\end{array}$ & $\begin{array}{l}\text {-Netiktu dota priekšroka jaunieša } \\
\text { nodarbināšanai tikai tādēl, ka būtu } \\
\text { nodokḷu atvieglojumi. }\end{array}$ \\
\hline $\begin{array}{l}\text { Uznēèēejdarbības } \\
\text { uzsākšanas iespējas }\end{array}$ & $\begin{array}{l}\text {-Uzn̄ēmējdarbības uzsākšanu un } \\
\text { iespējas attīstîties ietekmē } \\
\text { personības tips; } \\
\text {-iespējas ir uzsākt uzn̄ēmējdarbību, } \\
\text { tikai vai jaunieši spēj tās izmantot, } \\
\text { jo ir pieejami biznesa inkubatori, } \\
\text { kompetenču centri utt. }\end{array}$ & $\begin{array}{l}\text {-Lai uzñēmējdarbību attīstītu un } \\
\text { noturētos tirgū ir ,smagi”, jāstrādā. }\end{array}$ \\
\hline $\begin{array}{l}\text { Atbalsta instrumenti } \\
\text { uzn̦ēmējdarbības } \\
\text { attīstībai } \\
\text { (mikrokreditēšanas } \\
\text { programmas, starta } \\
\text { programmas, mentoru } \\
\text { konsultācijas, biznesa } \\
\text { inkubatori utt.) } \\
\end{array}$ & $\begin{array}{l}\text {-Atbalsta instrumentu pieejamība ir } \\
\text { pietiekoši nodrošināta. }\end{array}$ & $\begin{array}{l}\text {-Nepārliecinātība par savām spējām } \\
\text { ietekmē izvēli par uzṇēmējdarbības } \\
\text { uzsākšanu; } \\
\text {-instrumentu pieejamība nav līdz } \\
\text { galam pārdomāta; } \\
\text { - nodokḷu atvieglojumu saņemšana } \\
\text { uzņēmuma attīstîbas sākumā. }\end{array}$ \\
\hline $\begin{array}{l}\text { Atbalsts jaunajiem } \\
\text { lauksaimniekiem }\end{array}$ & $\begin{array}{l}\text {-Atbalsta instrumenti } \quad \text { pieejami } \\
\text { vairāk jaunajiem lauksaimniekiem. }\end{array}$ & $\begin{array}{l}\text {-Nepietiekama informācija masu } \\
\text { medijos par atbalsta instrumentu } \\
\text { pieejamību. }\end{array}$ \\
\hline
\end{tabular}

Avots: autores pētījums un konstrukcija

SIA $B$ vadītājs uzskata, ka nepieciešams pievērst uzmanību jauniešu izglītības kvalitātes līmenim un SIA G pārstāve uzsver, ka jāgatavo speciālisti jomās, kurās tie ir nepietiekami, piemēram, inženierzinātnēs.

SIA $F$ vadība uzsvēra, ka neefektīva apmācību sistēma valstī ietekmē indivīda konkurētspēju. Situācijai risinājumu visdrīzāk nav.

SIA E pārstāve uzsver, ka nozīmīga problēma ir nepietiekamās valodu zināšanas. Vajadzētu izglītības iestādēs uzmanību vērst vairāk uz valodu apguvi. 
SIA $D$ vadītājs uzsver, ka būtiska ir ES darbības programmas „Izaugsme un nodarbinātība" realizācija.

Kopumā, izvērtējot darba devēju sniegtās atbildes, jāsecina, ka nepieciešami:

- nodokļu atvieglojumi uzņēmējiem, kas nodarbina jauniešus;

- konkurētspējīgu nozares speciālistu sagatavošana nozarēs, kurās ir nepietiekams darbinieku skaits;

- valodu zināšanu uzlabošana studējošo vidū;

- prakses vietu nodrošināšana studiju laikā.

\subsection{Jauniešu konkurētspēju darba tirgū ietekmējošie faktori/ Factors influencing youth's competitiveness in the labour market}

Lai izvērtētu jauniešu konkurētspēju darba tirgū, pētījuma ietvaros iegūtās informācijas apkopošanai tiek izmantota SVID (S - stiprās puses, V - vājās puses, I iespējas, D - draudi) analīze mikro, mezo un makro līmeņos.

Klasiskā SVID analīze ir tuva 20. gs. 60. gados tapušajam pamatmodelim, kura būtība bija pēc iespējas precīzāk izmērīt organizācijas, produkta vai pakalpojuma konkurētspēju un iezīmēt attīstības iespējas vai uzlabojumu virzienus. Arī patlaban tā uzskatāma par ērtu rīku, ja nepieciešams pētīt gan iekšējo, gan ārējo vidi, iegūstot izvērtējumu un vizualizējot rezultātus (Kalve, 2005).

SVID analīzē iekḷautas stiprās un vājās puses, kā arī iespējas un draudi, kas ietekmē jauniešu sekmīgu iekḷaušanos darba tirgū Latvijā, balstoties uz jauniešu aptaujā iegūtajiem rezultātiem $(\mathrm{n}=764)$.

Balstoties uz iepriekš veiktajiem pētījumiem un jauniešu aptaujas rezultātiem, SVID analīze veikta, lai detalizētāk izvērtētu jauniešu konkurētspēju darba tirgū ietekmējošos faktorus t.i., faktorus, kas traucē jauniešiem bezdarbniekiem kḷūt par nodarbinātām personām no jaunieša atkarīgu vai neatkarīgu apstākḷu ietekmē, kā rezultātā iekḷaušanās darba tỉrgū ir sarežg̀îta un ilgstoša. SVID analīze pievienota 5. pielikumā.

Lai noteiktu nozīmīgākos SVID analīzes faktorus, kas ietekmē jauniešabezdarbnieka konkurētspēju darba tirgū, tika izmantota pāru salīdzināšanas analīze.

Pāru salīdzināšanas analīzē alternatīvas tiek salīdzinātas pa pāriem. Pirmais solis ir, balstoties uz parametru punktu skaitiem un to īpatsvariem noteikt, kurai no divām alternatīvām dot priekšroku. To dara neievērojot, cik lielā mēra atšksiras punktu skaiti un īpatsvari. Otrais solis ir noteikt, cik lielā mērā viena alternatīva dominē pār otru. Š̀̄ analīze balstās uz to, cik lielas ir atškirīibas starp (standartizētajiem) punktu skaitiem un īpatsvariem. Katram alternatīvu pārim, šo analīžu rezultāts tiek norādīts indeksa veidā. Alternatīvu skaitu var samazināt, salīdzinot š̄is vērtības ar sliekšņa vērtībām (Salīdzinošās metodes, b.g.).

4.21. attēlā, izmantojot pāru salīdzināšanas metodi, atspoguḷotas būtiskākās stiprās puses, kas jauniešu skatījumā, ietekmē to konkurētspēju darba tirgū Latvijas jauniešiem. Darba autore salīdzināja pēc svarīguma jauniešu uzskaitītos kritērijus, kā būtiskāko, salīdzinājumā ar citiem kritērijiem, uzskatot starptautiskas un vietēja līmeņa aktivitātes, kas tiek organizētas jauniešu organizāciju ietvaros, jo iesaistoties jauniešu organizācijās, jaunieši paplašina savu redzesloku, iepazīst jaunus cilvēkus un ir sociāli aktīvi, kas veicina vinu nākotnes iespējas arī veiksmīgi iekḷauties darba tirgū. Būtiski arī vērtētas Erasmus + ES finansēto projektu ietvaros sniegtās aktivitātes, kas sniedz iespēju jauniešiem pieteikties un doties pieredzes apmaiņas braucienos uz ārvalstīm, kā arī prakses iespēju nodrošināšana studiju laikā, ar samaksu vai bez samaksas, kas dod iespēju jaunietim iepazīt uzņēmuma/ institūcijas darbības pamatprincipus, kā arī pēc 
prakses beigām tikt uzrunātam kā patstāvīgam darbiniekam. 4.21. attēls, pēc autores domām, ietver visus svarīgākos aktivitāšu kopumus, kas ir viena no iespējām, kā jaunietim iekḷauties darba tirgū.

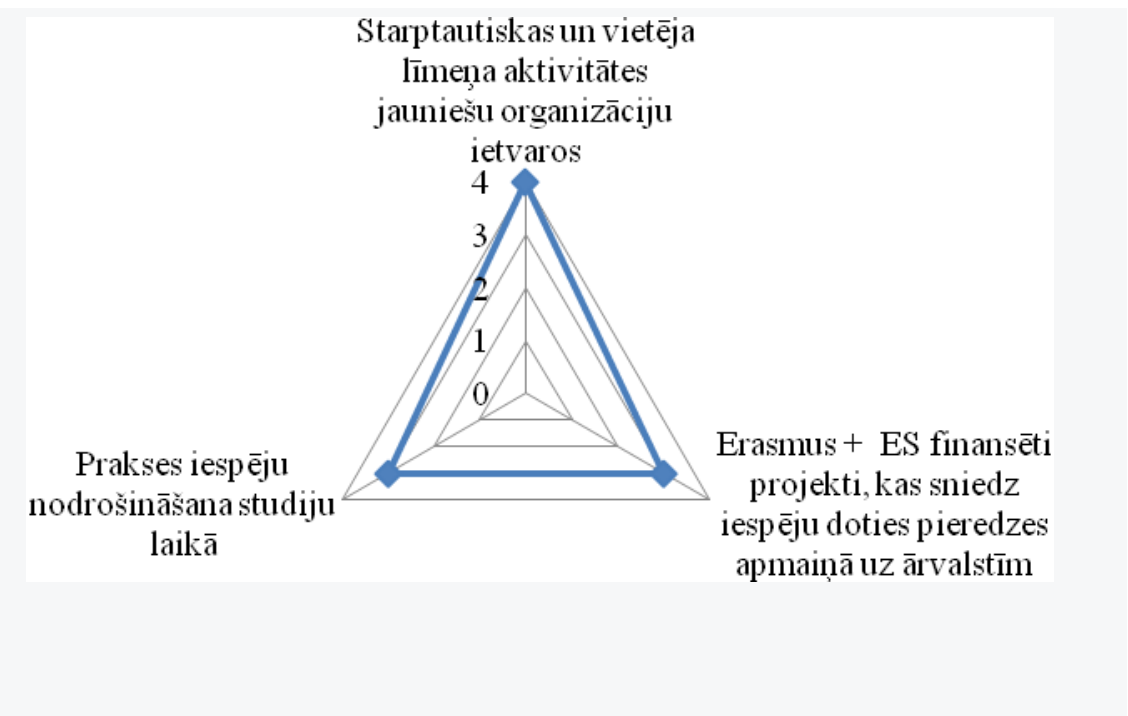

Avots: autores pētījums un konstrukcija

4.21. att./ Fig. 4.21. Jauniešu apgalvojumu par to konkurētspēju darba tirgū stipro pušu izvērtējuma rezultāti pēc pāru salīdzināšanas metodes/ Results of the comparison of youth assertions about their competitiveness strengths in the labour market employing the pairwise method

4.22. attēlā redzamas nozīmīgākās vājās puses, kas ietekmē jauniešu iekḷaušanos darba tirgū. Kā nozīmīgākais SVID analīzes vājo pušu faktors minams nekonkurētspējīgs atalgojums gan par mazkvalificēta, gan kvalificēta darba veikšanu, ko kā apgrūtinošu faktoru bija minējis vislielākais īpatsvars no jauniešiem, kas piedalījās aptaujā.

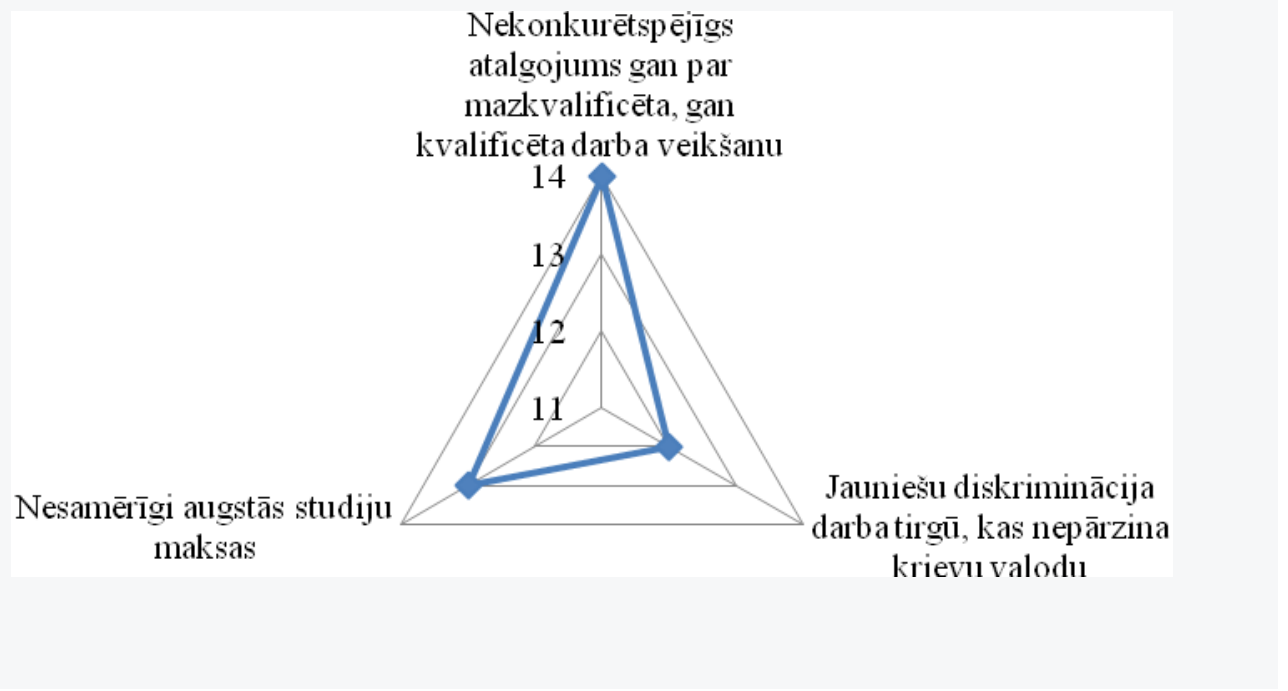

Avots: autores pētijums un konstrukcija

4.22. att./ Fig. 4.22. Jauniešu apgalvojumu par to konkurētspēju darba tirgū vājo pušu izvērtējuma rezultāti pēc pāru salīdzināšanas metodes/

Results of the comparison of youth assertions about their competitiveness weaknesses in the labour market employing the pairwise method. 
Jauniešu iespējas veiksmīgi iekḷauties darba tirgū ietekmē arī augstās studiju maksas, jo daudziem jaunieši nevar iegūt studiju kredītu un samaksāt par studijām, līdz ar to nākas izvēlēties studēt tajā nozarē, kur ir iespējams iegūt budžeta vietu studijām. Studēšana nozarē, kur ir brīvas budžeta vietas, var veicināt nepiemērotas kvalifikācijas izvēli, kas var veicināt jaunieša nokļūšanu bezdarba situācijā.

Jauniešu vērtējumā aktuāla Latvijā ir arī jauniešu, kas nepārzina krievu valodu, diskriminācija darba tirgū - jaunieši ir saskārušies ar situāciju, ka viņu kandidatūra netiek izvēlēta uz aktuālo vakanci, jo nav pietiekoši labas krievu valodas zināšanas. Balstoties uz aptaujā sniegtajām jauniešu atbildēm, darba autore secināja, ka darba devēji nedod jauniešiem iespēju apgūt krievu valodu darba procesā.

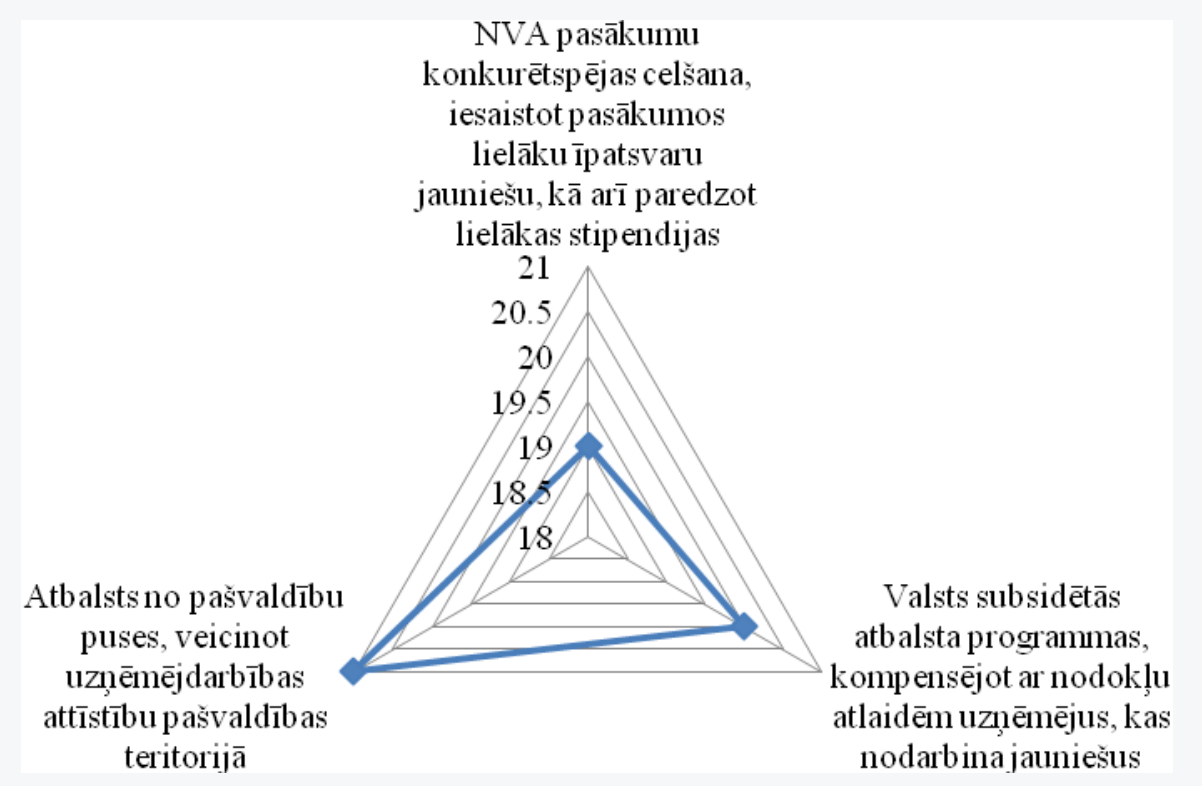

Avots: autores pētījums un konstrukcija

\subsection{3. att./ Fig. 4.23. Jauniešu apgalvojumu par to konkurētspēju darba tirgū iespēju izvērtējuma rezultāti pēc pāru salīdzināšanas metodes/ Results of the comparison of youth assertions about their competitiveness opportunities in the labour market employing the pairwise method.}

4.23. attēlā redzams, ka autores vērtējumā nozīmīgākais faktors jauniešu iespējas iekļauties darba tirgū veicinošais ir atbalsts no pašvaldību puses, veicinot uzņēmējdarbības attīstību pašvaldības teritorijā.

Kā otrais nozīmīgākais faktors (skat. 4.24. att.) ir valsts subsidētās atbalsta programmas, kompensējot ar nodokḷu atlaidēm uzñēmējus, kas nodarbina jauniešus. Šis apgalvojums vairakkārt tika pieminēts no jauniešu puses, līdz ar to darba autore arī, izvērtējot šo apgalvojumu attiecībā pret citiem apgalvojumiem, novērtēja to kā būtisku. Trešais nozīmīgākais apgalvojums ir NVA pasākumu konkurētspējas celšana, iesaistot pasākumos lielāku jauniešu îpatsvaru, kā arī paredzot lielākas stipendijas par iesaisti pasākumā, lai jaunietis par stipendiju varētu ne tikai apmeklēt pasākumu, izmantojot to nokḷūšanas apmaksai līdz un no pasākuma, bet arī izmantot citām vajadzībām, piemēram, pusdienām un pirmās nepieciešamības precēm. 


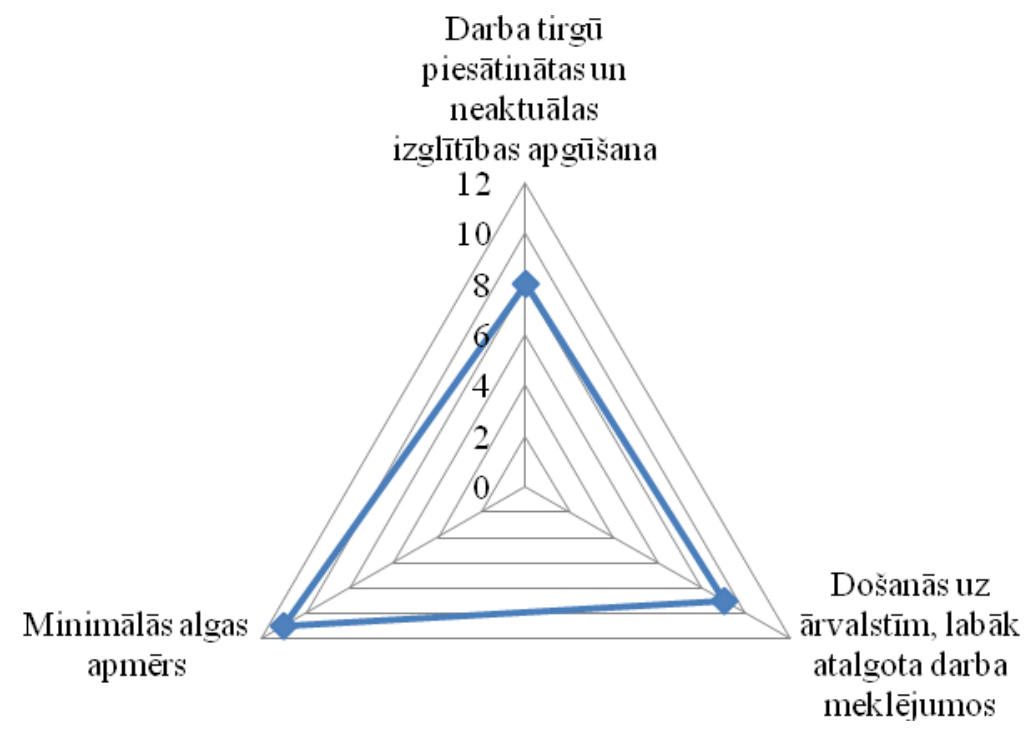

Avots: autores pētījums un konstrukcija

\subsection{4. att./ Fig. 4.24. Jauniešu apgalvojumu par to konkurētspēju darba tirgū draudu izvērtējuma rezultāti pēc pāru salīdzināšanas metodes/ Results of the comparison of youth assertions about their competitiveness threats in the labour market employing the pairwise method.}

Kā nozīmīgāko draudu, no jauniešu minētajiem apgalvojumiem to konkurētspējas ietekmei, darba autore uzskata minimālās algas apmēru, kas būtiski ietekmē nodarbinātā jaunieša, kas saņem minimālo atalgojumu, iespējas iekl̦auties darba tirgū, kā arī socializēties. Jaunietim no ienākumiem jāspēj arī segt studiju maksa un citas saistītās izmaksas, bet ne vienmēr jaunietis strādā pilnu slodzi un saņem pienācīgu atalgojumu. Aptaujas ietvaros jaunieši bija minējuši, ka darba devēji ļaunprātīgi izmanto jauniešus, par padarīto darbu maksājot mazāk, nekā pienāktos, kā arī liekot strādāt vairāk stundas bez papildus piemaksām pie atalgojuma. Vēl aizvien jauniešu vidū ir aktuāli darba meklējumi ārvalstīs, kas veicina jauniešu aizplūšanu uz ārvalstīm.

Balstoties uz statistikas datu izpēti, liels īpatsvars jauniešu izvēlas studēt darba tirgū pārsātinātu nozares speciālistu profesijās, tādās kā, sociālās zinātnes, jurisprudence, mārketings utt., līdz ar to darba autore attiecībā pret citiem minētajiem apgalvojumiem, šo vērtēja kā vienu no būtiskiem draudiem, kas ietekmē jaunieša iekļaušanos darba tirgū.

Pētījumu un jauniešu aptaujas rezultātā iegūtie ietekmējošie faktori sagrupējot tos, izmantojot pāru salīdzināšanas metodi, tika apkopoti kritēriju grupās (stiprās un vājās puses, iespējas un draudi) un iekḷauti Eilera - Venna diagrammā (kopu vizualizācijas metode) (skat. 4.21. att.).

Džons Venns (1834-1923) bija ang̣lu filozofs un matemātiķis. Viņš radīja ērtu paṇēmienu - Venna diagrammas, kas l̦āva vizuāli attēlot kopas un visus to savstarpējos mijiedarbības stāvokļus. Šādas diagrammas mēdz saukt arī pat Eilera - Venna diagrammām, jo ar̄̄ šveiciešu matemātiķis Leonards Eilers (1707-1783) izmantoja līdzīgas diagrammas, lai attēlotu kopu savstarpējo stāvokli (Cīrulis, 2007).

4.21. attēlā parādīts arī PEST analīzes pielietojums, nosakot ārējos spēkus, kas ietekmē jauniešu konkurētspēju darba tirgū Latvijā, lai apzinātu nākotnes attīstības virzienus. 


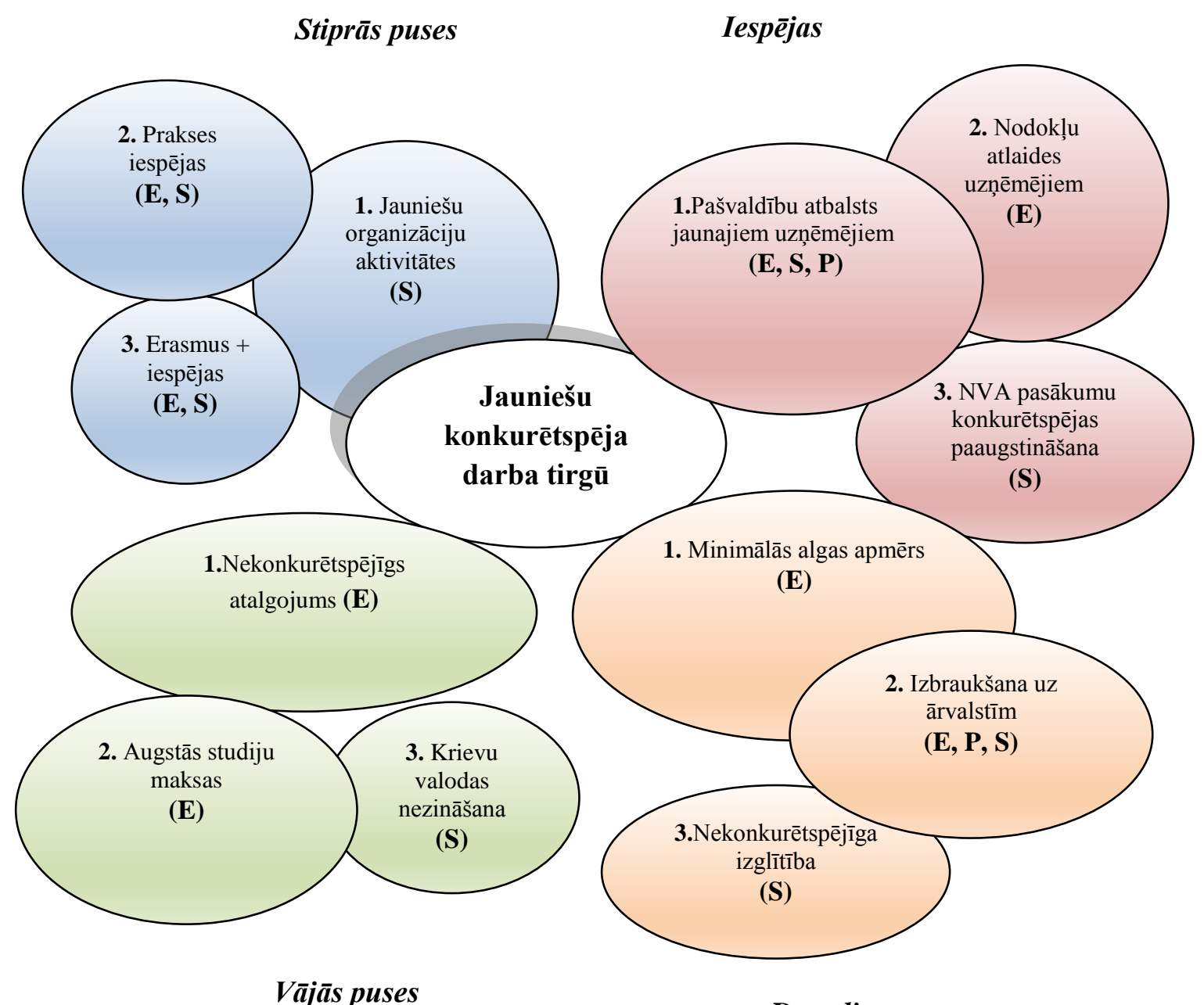

Väjās puses

Draudi

\section{Apzīmējumi:}

Faktori jauniešu konkurētspējai darba tirgū Eilera- Venna diagrammā sagrupēti pēc SVID analīzes un to svarīguma, izvēlēti 3 būtiskākie faktori.

Eilera - Venna diagrammā katrs faktors analizēts arī pēc ārējo faktoru PEST analīzes. Attēlā veiktas šâdas atzìmes:

$\boldsymbol{P}$ - politiskie faktori;

$\boldsymbol{E}$ - ekonomiskie faktori;

$\boldsymbol{S}$ - sociālie faktori;

T- tehnoloğiskie faktori (šajā attēlā tehnologiskie faktori nav identificēti).

Avots: autores pētījums un konstrukcija

\subsection{1. att./ Fig. 4.21. Eilera - Venna diagramma jauniešu konkurētspējai darba tirgū Latvijā/ \\ Euler - Venn diagram for youth's competitiveness in the labour market of Latvia.}

PEST analīze ietver ārējo faktoru (P - politiskie faktori, E - ekonomiskie faktori, $\mathrm{S}$ - sociālie faktori, T - tehnoloǵiskie faktori) analīzi. PEST analīzes uzdevums ir palīdzēt iepazīt galvenos makroekonomiskos faktorus, kas ietekmē visus noteiktā valstī mērķa grupā iekḷautos jauniešus. Šì analīze pagātnes notikumiem īpašu uzmanību nepievērš, tiek analizēta pašreizējā situācija un notiek mēǵinājums prognozēt attiecīgā 
faktora izmaiṇu vai potenciālās stabilitātes tendences - kas varētu mainīties un uz kuru pusi (Kalve, 2005).

\section{4. nodaļas secinājumi/ Conclusions for Chapter 4}

Balstoties uz nodaļā analizēto jauniešu aptaujā $(n=764)$ iegūto informāciju, 43.1\% no aptaujas dalībniekiem darbu atradis pats, savukārt $37.6 \%$ no jauniešiem darbu atraduši ar paziņu un draugu starpniecību, bet tikai $6.8 \%$ no jauniešiem palika strādāt darba vietā, kur tika izieta prakse. Salīdzinājumam ar iepriekš veiktajiem pētījumiem, $41.9 \%$ no jauniešiem Baltkrievijāa, kas piedalījās aptaujā (n=96), bija atzīmējuši, ka šobrīd strādā darba vietā, kurā iepriekš tika izieta prakse.

Pēc aptaujas datiem, jaunieši, kas strādā un studē pārsvarā bija no Daugavpils, Jēkabpils un Valmieras. Vairākums jauniešu, kas piedalījās aptaujā un ir no lauku reǵioniem vai Rēzeknes - pārsvarā mācās vai studē un nestrādā.

Balstoties uz aptaujas datiem no jauniešiem, kas nestrādā $(n=292)$, lielākais ippatsvars, jeb 16\% ir darba meklējumos 1 - 3 mēnešus, $11.3 \%$ - 3 - 6 mēnešus, $9.9 \%$ no jauniešiem sniedza atbildi „cits”, minot, ka strādā periodiski, dodas strādāt uz ārzemēm, strādā vasaras sezonā, nespēj apvienot darbu ar mācībām utt.

Analizējot aptaujā iegūto jauniešu atbildes, darba autore secina, ka noteicošais darba meklējumos ir jauniešu vēlme sevi pierādīt darba devējam, vēlme ieņemt vakanto pozīciju un motivācija veikt darba pienākumus, atbilstoši iegūtajai izglīîibai.

Balstoties uz aptaujā iegūtajiem datiem, būtiskākie faktori, kas jauniešiem traucēja iekḷauties darba tirgū Latvijāa, ir neapmierinātība ar piedāvāto darba samaksu, nepieciešamās darba pieredzes trūkums un mazais īpatsvars ar brīvām darba vietām.

Visvairāk jaunieši ar darba vietu trūkumu saskārās Liepājā (67\%), novadu pilsētās (58\%), Jelgavā (57\%), Rēzeknē (50\%), Pierīgā (48\%) un lauku teritorijās (47\%).

Ar informācijas trūkumu par darba piedāvājumiem vislielākais jauniešu īpatsvars saskārās no Liepājas (44\%), Rēzeknes (43\%) un Daugavpils (38\%). Jautājumus rosinošs ir jauniešu izvērtējums attiecībā uz darba vietu trūkumu lauku regionos un citās pilsētās vai mazpilsētās, kas šo faktoru bija vērtējuši salīdzinoši zemāk kā traucējošu salīdzinājumā ar iepriekšminētajām lielākajām republikas pilsētām.

Visvairāk jauniešus no Latvijas darba meklējumos ietekmēja slikti attīstīta infrastruktūra, ko kā traucējošu bija atzīmējuši 50\% jaunieši no Rēzeknes, 34\% no Pierīgas, 29\% no Jelgavas un lauku teritorijām.

Ar zināšanu un prasmju trūkumu pārstāvētajā specialitātē ir saskārušies 22\% jaunieši, kas ieguvuši bakalaura izglītību, 21\% - vidējo profesionālo izglītību, 20\% ar nepabeigtu augstāko izglīitibu un $11 \%$ ar pamatskolas izglīīîbu.

Vislielākais respondentu īpatsvars, kas nav apmierināti ar piedāvāto darba samaksu dzīvo Jelgavā (72\%), Pierīgā (68\%), Jūrmalā (59\%), lauku teritorijās (58\%), Rēzeknē (57\%), novadu pilsētās (54\%) un Liepājā (52\%).

Jaunieša izglītîbas līmenim ir būtiska ietekme uz jaunieša prasībām par darba algas apjomu, kā arī iespējām iekḷauties darba tirgū.

Pēc aptaujā iegūtajiem rezultātiem, darba autore secināja, ka jauniešiem ir liela interese par uzṇēmējdarbības attīstī̌sanu neatkarīgi no iegūtās izglītības līmeṇa vai profesijas.

Balstoties uz jauniešu aptaujas rezultātā iegūto informāciju, $60 \%$ no jauniešiem kā visbūtiskāko instrumentu jauniešu uzņēmējdarbības attīstîbas veicināšanai uzskata nodoķ̣u atvieglojumus jaunajiem uzņēmējiem, 53\% no jauniešiem uzskata, ka būtiska ir arī prakses iespēju nodrošināšana studiju procesā, $50 \%$ jauniešu uzskata, ka nozīmīgas 
ir finansējuma piesaistes iespējas uzṇēmējdarbības uzsākšanai bez apgrūtinājuma/ ķ̄̄las piesaistes. Pašvaldību atbalstu jaunajiem uzn̦ēmējiem kā nozīmīgu atbalsta instrumentu vērtējuši $45 \%$ jauniešu. Savukārt $42 \%$ jauniešu uzskata, ka nozīmīgs instruments jauniešu uzņēmējdarbības attīstībai ir jau studiju laikā nodrošināta iespēja sadarboties ar uzņēmējiem.

Izvērtējot jauniešu informētību par atbalsta instrumentiem, vislielākā respondentu skaits bija atzīmējuši informētību par biznesa inkubatoriem (24.8\%), jauniešu ir arī informēti par jauniešu programmu biznesa attīstībai „Ideju kauss” (22.5\%) un par vienotās finanšu institūcijas AS „Attīstības finanšu institūcija Altum” aktivitātēm un finansējuma ieguvi biznesa uzsākšanas iespējām (16\%).

Pētījuma ietvaros, balstoties uz jauniešu aptaujās iegūtajiem rezultātiem, darba autore 4.5. nodalāa Eilera - Venna diagrammā sagrupējusi faktorus, kas ietekmē jauniešu konkurētspēju darba tirgū, faktoru grupējumā izmantots SVID analīzes princips:

- Stiprās puses:

- prakses iespējas;

- jauniešu organizāciju aktivitātes;

- iespēja piedalīties Erasmus + pasākumos.

- Vājās puses:

- nekonkurētspējīgs atalgojums;

- krievu valodas zināšanu trūkums;

- augstās studiju maksas.

- Iespejjas:

- pašvaldību atbalsts jaunajiem uzṇēmējiem;

- nodokļu atlaides uzņēmējiem;

- NVA pasākumu konkurētspējas paaugstināšana.

- Draudi:

- nekonkurētspējīga izglītība;

- jauniešu izbraukšana uz ārvalstīm;

- minimālās algas apmērs.

Balstoties uz ekspertu intervijā iegūtajiem rezultātiem $(n=14)$, darba autore secina, ka darba devēju attieksme par jauniešu nodarbināšanu ir pozitīva. Darba devēji pozitīvi izteicās par jauniešiem, kas studē vai iegūst arodu, it îpaši, ja iegūstamā izglîtība ir piemērojama veicamajiem darba pienākumiem, kā arī, ja jaunietis spēj apvienot studijas ar darba pienākumu veikšanu.

Darba autore intervijās ar darba devējiem secināja, ka darba devējiem nepieciešams jaunietis ar potenciālu, skaidru nākotnes vīziju, motivāciju, vēlmi strādāt, pozitīvu attieksmi pret klientiem un kolēgiem utt., veicinot uzņēmuma/ institūcijas attīstību un pel̦nu.

Nozīmīgu ietekmi uz jaunieša konkurētspēju darba tirgū veicinātu darba devēju un izglītības iestāžu ciešāka sadarbība, kas sekmētu jaunieša izglītības iegūšanu darba tirgū pieprasītākajās nozarēs.

Jauniešiem ir interese par savas nākotnes vīzijas realizēšanu turpmākās dzīves nodrošināšanai. Jaunieši cenšas ikdienā apvienot studijas ar darba pienākumiem, lai spētu samaksāt par studijām augstskolā. Latvijā studiju maksa augstākajās izglīî̀bas iestādēs ir viena no lielākajām ES, līdz ar to liela daļa jauniešu izvēlas doties studēt uz ārvalstīm, jo atsevišķās ES valstīs studijas augstākajās izglītības iestādēs ir bez maksas, jaunietis ârvalstīs saņem stipendiju par studijām un spēj izdzīvot ar to citā valstî. Šobrīd augstās studiju maksas veicina jauniešu bezdarbu, jo liela daļa jauniešu uzreiz pēc vidusskolas beigšanas izvēlas uzsākt darbu vai doties darba meklējumos uz ārvalstīm, neiegūstot augstāko vai profesionālo izglītību. Vislielākā problēma ir tieši jauniešiem 
bez izglītības, kas dzīvo lauku teritorijās. Jaunieši ir spiesti doties uz ārvalstīm labāk atalgota darba meklējumos, lai spētu izdzīvot. Dotais scenārijs raksturo šā brīža situāciju, kas veicina jauniešu kapitāla aizplūšanu uz ārvalstīm, labākas dzīves un karjeras iespēju meklējumos. Nozīmīgi ir valsts līmenī pārskatīt izglītības iegūšanas izmaksas, pielīdzināt tās citu ES valstu līmenim, padarot Latvijā augstāko izglìtību pieejamāku.

Darba devēju intervijās iegūtie galvenie rezultāti un tendences darba tirgū Latvijas plānošanas reǵionos:

- Rigas regions:

- nozīmīga ir darbinieka vēlme strādāt un parādīt sevi no labās puses, kā arī izglītība un valodu zināšanas, daudziem kandidātiem tās ir nepietiekamā līmen̄i;

- pozitīvi tiek vērtētas fundamentālās zināšanas;

- darba samaksa ir vidējā līmenī.

- Vidzemes regions:

- personāla mainība nav tik izteikta, līdz ar to ir iespējas pierādīt sevi un savas spējas;

- iespējas saņemt atalgojuma paaugstinājumu;

- izglīīibai ir liela nozīme, atbalsts studijām un pretimnākšana no darba devēju puses;

- jaunieti bez izglītības var nodarbināt mazkvalificētos darbos, līdz ar to nozīme ir izglītības līmenim, pieredzei.

- Kurzemes regions:

- darbinieku trūkums, uzņēmēji ir gatavi nodarbināt jaunos speciālistus;

- problēmas darbiniekus apmācīt konkrētā amata izpildei, jo nav iespējas izveidot sadarbību ar izglīîibas iestādēm, izglītîbas sistēmā ir „robs”;

- atalgojums ir apmierinošs, bet ne tāds, ko jaunais darbinieks vēlētos;

- izglìtotie speciālisti izbrauc no valsts, ārvalstīs saņem lielāku atalgojumu.

- Zemgales reǵions:

- nozīmīga ir darba kvalitāte, citādi atbalsta pasākumiem nav nozīmes;

- nepieciešama ciešāka sasaiste starp darba devējiem un izglītības iestādēm;

- jauniešu studiju process tiek vērtēts pozitīvi, nereti pēc apmācību prakses beigšanas jauniešiem tiek piedāvāta iespēja darbu turpināt.

- Latgales regions:

- trūkst darbinieku ar atbilstošu izglītību inženierzinātnēs, tehniskajās zinātnēs u.c. zinātnēs;

- nepieciešams izveidot mācību bāzi, bet, ja ko tādu veido, nepieciešamas darba vietas pēc studiju beigšanas, uzṇēmēja skatījumā nav risinājumu šai problēmai;

- nepietiekamā apmācības sistēma valstī ietekmē darbinieku konkurētspēju;

- darbinieki ir svarīgākais uzṇēmuma konkurētspēju veicinošais faktors. 


\section{JAUNIEŠU IEKLAUUŠANĀS LATVIJAS DARBA TIRGŪ/ YOUTH INCLUSION INTO THE LATVIAN LABOUR MARKET}

Latvija ārvalstu pētījumos (The ESPON 2013 Programme) 2030. gadā tiek pozicionēta kā „depresīvais” reǵions, kurā būs nepietiekošs iedzīvotāju skaits. Latvija kā valsts ar uzn̄ēmējdarbības attīstībai draudzīgu vidi, nespēs būt konkurētspējīga attiecībā pret citām Eiropas valstīm. Tiks apdraudēta investīciju plūsma, kā arī novirzìta uz citiem, konkurētspējīgākiem un demogrāfiskā ziņā attīstītākiem regioniem. Tādēḷ jāanalizē jauniešu nodarbinātības tendences un jāstrādā pie Latvijas ekonomiskās attīstības apstākḷiem atbilstošas sistēmas ieviešanas un realizēšanas, lai veicinātu cilvēkkapitāla iekḷaušanos darba tirgū un samazinātu to aizplūšanu uz ārvalstīm. Jārod atbildes uz jautājumiem: Kuru no jauniešu bezdarbnieku nodarbinātības veicināšanas scenārijiem iespējams realizēt Latvijā tuvākajā laika periodā? Kurš no scenārijiem ir atbilstošākais Latvijas attīstības veicināšanai? Kurš no scenārijiem ir vērsts uz visu iesaistīto pušu interešu apmierināšanu? Kurš no scenārijiem nodrošinās veiksmīgu valsts ekonomikas attīstību?

\subsection{Jauniešu bezdarbnieku nodarbinātības veicināšanas scenāriju izvērtējums pēc hierarhiju analīzes metodes/ Assessment of employment promotion scenarios for unemployed youth by the Analytic Hierarhy Process}

Lai noteiktu piemērotāko attīstības scenāriju jauniešu bezdarbnieku nodarbinātības veicināšanai Latvijā, izmantota amerikāņu zinātnieka T. L. Satī (Thomas L. Saaty) izveidotā hierarhiju analīzes metode (The Analytic Hierarhy Process, AHP).

Pēc autoriem Satī (Saaty), Penivati (Peniwati) un Šanga (Shang), analìtisks hierarhijas process nodrošina veidu, kā sagrupēt problēmas alternatīvas, balstoties uz prioritātēm. Jautājumi, kas izriet no prakses: „Kāda ir labākā alternatīvu kombinācija? Kurai prioritātei ir lielākā vērtība? Vai apmierina dotie ierobežojumi?" (Saaty et al., 2007).

Pēc Satī (Saaty), lēmumi ir atkarīgi no nosacījumiem nākotnē un apstākḷiem, kas mainās laika gaitā. Veiksmīgs lēmums prasa spriedumus par to, kas ir vairāk iespējams vai kam būtu vairāk jādod priekšroka dažādos laika periodos. Pastāv vismaz trīs veidi, kā tikt galā ar dinamiskiem lēmumiem. Viens no tiem ir iekḷaut struktūrā dažādus faktorus, kas norāda izmaiņas laikā, piemēram, scenāriji un dažādi laika periodi. Pēc tam ir jāveic salīdzinājumus par laika periodiem, izmantojot fundamentālo hierarhiju analīzes metodes skalu. Otrais ir veikt pāru salīdzinājumus kā likmju relatīvo izmaiņu attiecību pret laiku. Tas tiek darīts dažādos laika posmos. Šie intervāli var būt dažāda garuma. Katram intervālam jānodrošina pāru vērtējums par relatīvo pārmaiņu tempu vienai alternatīvai pār otru un jāgūst matemātiskās funkcijas attiecībā uz šo matricu salīdzināšanu vienam no laika periodiem. Trešais veids ir izmantot funkcijas salīdzinājumus un iegūt funkcijas. Šajā gadījumā parasti ir grūti saprast, kādas funkcijas izmantot un ko tās nozīmē. Šìs idejas sniedz piemērus par teoriju dinamisku lēmumu pieņemšanā. Matricas pāru salīdzinājumi tiek veidoti, novērtējot elementa dominējošo stāvokli, izmantojot absolūtos skaitļus no 1 līdz 9 (Saaty, 2007).

Hierarhijas analīzes algoritms piemērots esošās situācijas un jaunu iespējamo scenāriju izvērtēšanā jauniešu nodarbinātības veicināšanai un sociālajai iekḷaušanai darba tirgū. Sākotnējās hierarhijas izveidošana paredz pētāmās problēmas sadalīšanu vairākās sastāvdaḷās. Pēc hierarhijas matricu aizpildīšanas tiek aprēḳināts prioritātes vektors katram no hierarhijas elementiem, kas norāda to nozīmīgumu attiecībā pret 
katra augstākā līmeņa kritēriju. Gala rezultātā visām vispārējās problēmas sastāvdaļām, kuras ir pakārtotas vienam mērķim, jābūt savstarpēji salīdzinātam. To panāk, izmantojot īpašu relatīvā svarīguma skalu, kas l̦auj vārdisko informāciju pārvērst skaiţ̦os. Prioritāšu vektoru iegūst, aprēķinot katrai pāru vērtējuma matricai īpašvektoru kopu un pēc tam normalizējot rezultātu par 1 (Kronbergs u.c., 1988). Prioritātes vektoru noteikšanas shēma parādīta 5.1. attēlā.

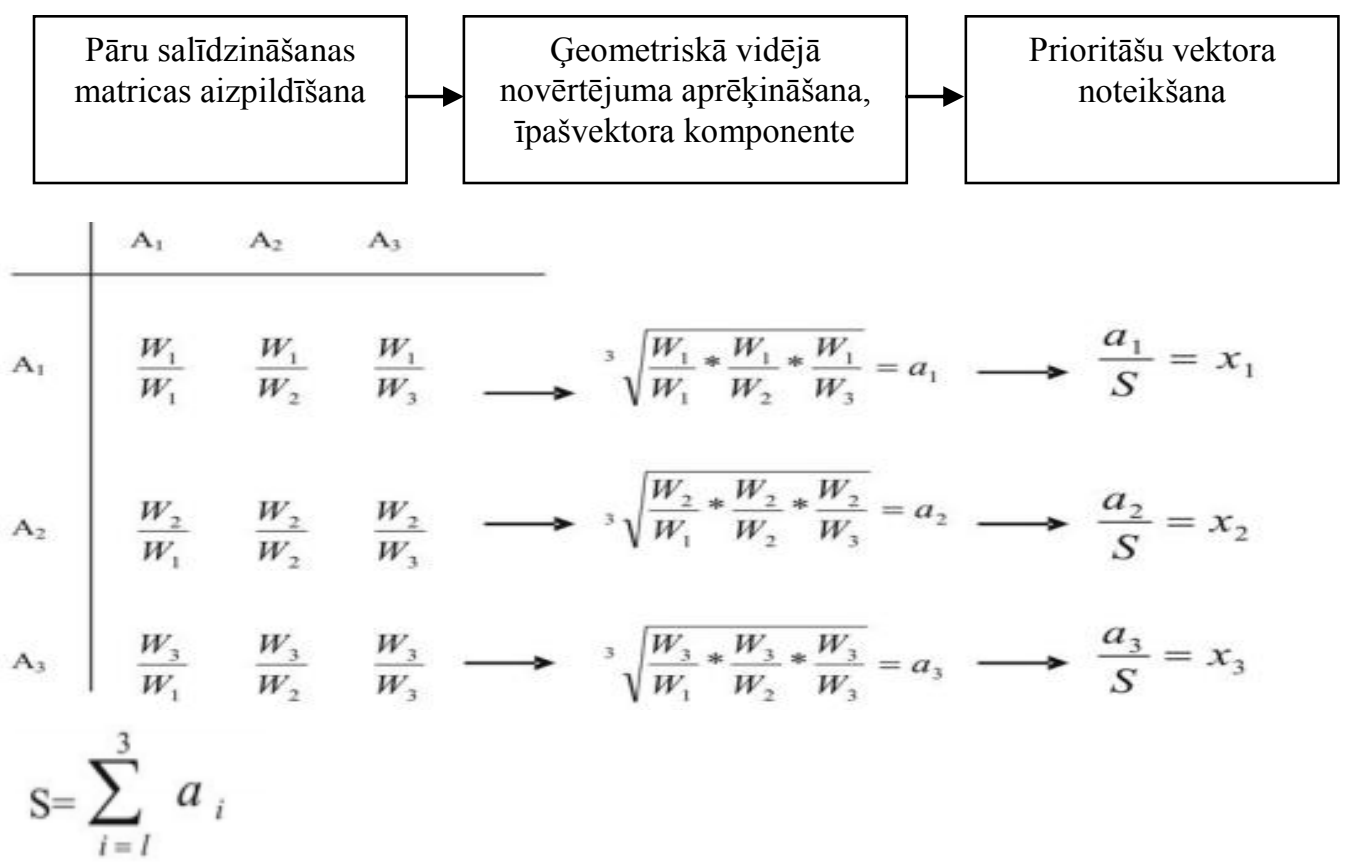

Apzìmējumi:

A - salīdzināmās otrā lìmeña kritēeriju grupas;

W- salìdzināmo elementu novērtējums;

A-salìdzināmo elementu vidējais geometriskais novērtējums;

$X-$ salīdzināmo elementu prioritātes vektors.

Avots: Saaty, 1980

\section{1. att./ Fig. 5.1. Prioritāšu vektoru noteikšanas shēma/ \\ Scheme for the determination of priority vectors.}

Saskaņotības attiecību C.R. (Consistency Ratio) aprēķina ar sekojošu 5.1. formulu:

$$
C . R .=\frac{C I_{*}}{R I_{*}},
$$

kur C.I. aprēķina ar 5.2. formulu:

$$
\text { C.I. }=\frac{\lambda_{\max -n}}{n-1} \text {, }
$$

un $\lambda_{\max }$ aprēķina ar 5.3. formulu:

$$
\lambda_{\max }=\sum_{j=1}^{n}\left(x_{i} \sum_{i=1}^{n} \frac{w_{i}}{w_{j}}\right),
$$

R.I. (Random Index) - Varbūtējais indekss. 
Pamatojoties uz zinātniskās literatūras un stratēgisko dokumentu analīzi par jauniešu bezdarbu un iekl̦aušanos darba tirgū, kā arī ekspertu viedokl̦iem par jauniešu darba tirgus situāciju un nodarbinātības veicināšanas iespējamajiem risinājumiem, lai panāktu veiksmīgu jauniešu bezdarbnieku iekḷaušanos darba tirgū, uz iegūtās informācijas bāzes ir definētas hierarhiju analīzes model̦a interešu grupas, interešu grupu faktori, kā arī sagatavoti scenāriji. Hierarhiju analīzes pamatā ir atšķirīgu jauniešu bezdarbnieku iekl̦aušanos veicinošu scenāriju izvērtējums.

Izstrādātā vērtēšanas kritēriju hierarhija parādīta 7. attēlā. Tās pirmajā līmenī ir definēta aktuāla problēma - jauniešu bezdarbnieku nodarbinātības veicināšana Latvijā. Otrajā līmenī ir kritēriju grupas, kas pārstāv dažādu ar procesu saistīto pušu intereses, katrā grupā ir definēti 5 kritēriji. Trešajā līmen̄̄ ir uzskaitīiti iespējamie scenāriji jauniešu bezdarbnieku nodarbinātības veicināšanai Latvijā. Autore ekspertiem izvērtēšanai piedāvāja četrus iespējamos scenārijus jauniešu bezdarbnieku nodarbinātības veicināšanai Latvijā. Ekspertu aptaujas anketa hierarhiju analīzes metodei apskatāma 6. pielikumā.

Ekspertu izvērtēšanai tika piedāvāti četri iespējamie scenāriji jauniešu bezdarbnieku nodarbinātības veicināšanai Latvijā:

1. scenārijs: jauniešu uzñēmējdarbūbas vides attīstübu veicinošais scenārïjs. ES fondu līdzekļu piesaiste jauniešu pašnodarbinātības un uzņēmējdarbübas finansēšsanai, paredzot speciāla finansiālā un administratīvā atbalsta programmas izveidošanu VAS „Latvijas Attīstības finanšu institūcija Altum”.

Raksturojums. Nozīmīga ir intereses raisīšana jauniešos par uzņēmējdarbības attīstību un uzñēmējspēju veicināšanu. Valstiskā līmen̄̄ ir jāvērš uzmanība uz finansējuma piesaisti un tā apjomiem start-up uzņēmumiem un pašnodarbinātības uzsākšanai, lai sekmētu jauniešu kḷūšanu par uzņēmējiem Latvijā un nodrošinātu efektīvu valsts resursu izmantošanu.

Nozīmīga ir arī mentoru un biznesa enggelu piesaiste, un ieinteresētības radīšana par šiem biznesa atbalsta pasākumiem, nodrošinot atgriezenisko saiti, gūstot labumu visām iesaistītājām pusēm. Piemēram, sadarbībā ar "Altum" valsts reǵionu līmenī jāveido finansējuma piesaistes iespēju nodrošināšana jauniešu uzṇēmējdarbības finansēšanai un biznesa atbalsta programmu efektivitātes paaugstināšanai. Mijiedarbojoties šiem procesiem, tiks veidota sekmīga savstarpēja sadarbība vairāku gadu garumā starp jau esošajiem uzņēmējiem, jaunajiem uzņēmējiem un valsts reǵionu institūcijām.

2. scenārïjs: izglītības iestāz̆u un uznēmēju sadarbības scenārijjs. Uzn̄ēmēju interese par darba tirgū konkurētspējīgu speciälistu sagatavošanu.

Raksturojums. Nozīmīga ir uzņēmēju sadarbība ar profesionālās un augstākās izglītības iestādēm, lai veicinātu jauniešu iekl̦aušanos darba tirgū, veicinot profesionālās izglītības apmācību sistēmas attīstību, kas balstìta darba vidē. Izglītības iestādēm sadarbībā ar uzṇēmējiem jāveido darba tirgū konkurētspējīgas mācību programmas, kuru ietvaros jauniešiem būtu iespējams iziet praksi attiecīgajā uzṇēmumā. Cieša mijiedarbība starp izglîtības un uzṇēmējdarbības sektoru nodrošinātu nozares speciālistu sagatavošanu specifisku darbu veikšanai un ar speciālistiem apgādātu nozares, kurās tie trūkst. Izglīīības institūciju sadarbība ar uzṇēmējiem arī ierobežotu intelektuālā kapitāla aizplūšanu no valsts. Nozīmīgi ir par valsts budžeta līdzekḷiem finansētos jauniešus nodarbināt valstī un nepiel̦aut to izceḷošanu. Neefektīva ir valsts piešķirto budžeta līdzekḷu izmantošana, jo nozares speciālisti pēc studiju absolvēšanas bieži vien dodas studēt un strādāt uz ārvalstīm. Piemēram, medicīnas, informācijas tehnoloǵiju, inženierzinātņu studentiem, kas studijas apgūst par valsts budžeta līdzekḷiem, vajadzētu 3 gadus pēc studiju beigšanas strādāt Latvijā, lai, maksājot nodokḷus, atpelnītu valsts 


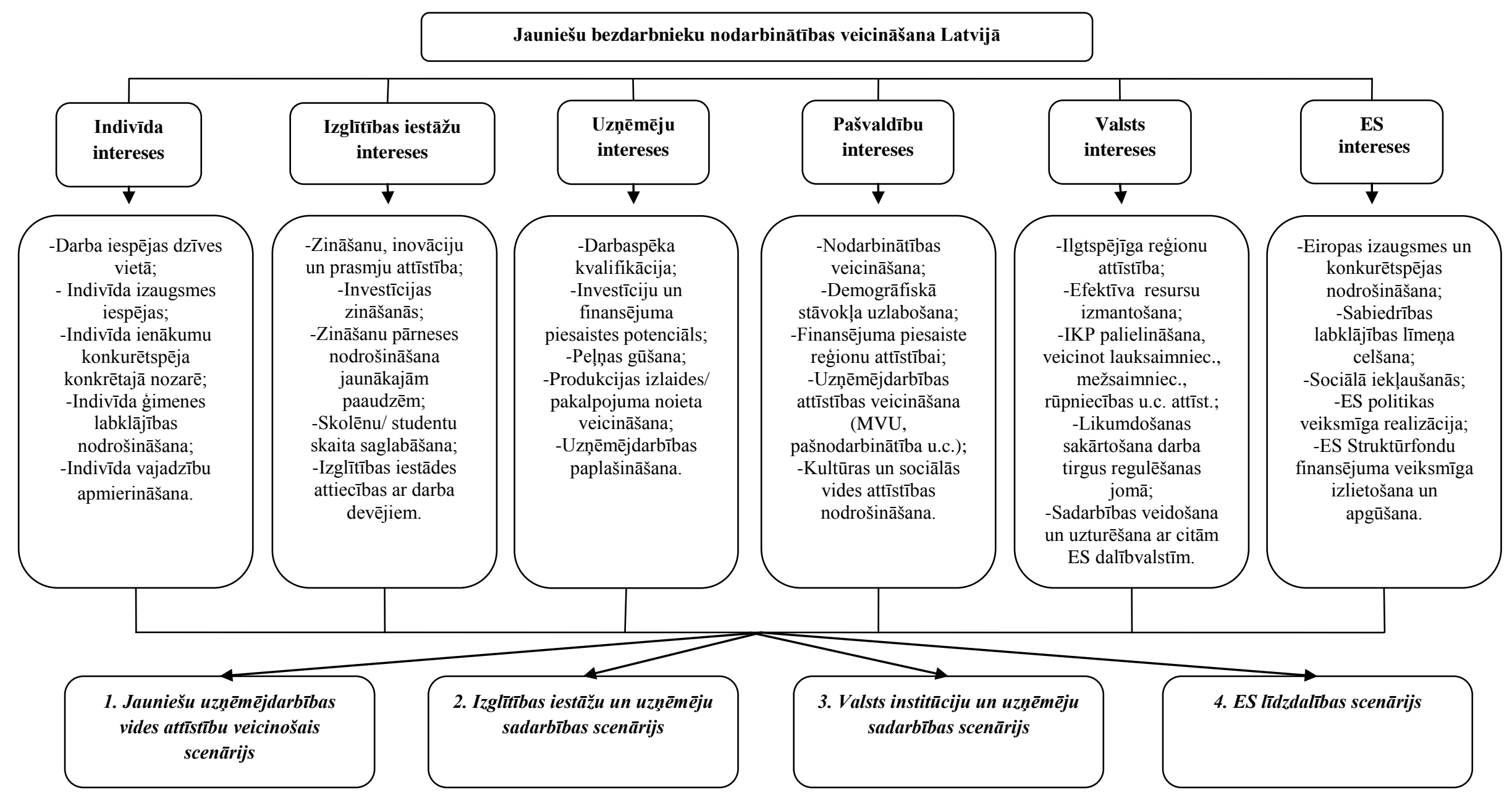

Avots: autores pētijums un konstrukcija

\section{2. att./ Fig. 5.2. Vērtēšanas kritēriju hierarhija jauniešu bezdarbnieku nodarbinātības veicināšanai Latvijā/}

Hierachy of evaluation criteria for promoting the employment of unemployed youth in Latvia. 
izdevumus. Pēc šāda principa sagatavoti speciālisti, kas ir apguvuši studijas par budžeta līdzekḷiem, izgājuši praksi pie darba devēja un ieguvuši iespēju turpināt turpat stažēties, uzlabotu valsts ienākumus no nodokḷiem.

3. scenārijs: valsts institūciju un uzn̄ēmēju sadarbübas scenārïjs. Atvieglojumi uzn̄ēmējiem, kas nodarbina jauniešus.

Raksturojums. Pozitīvu ietekmi uz jauniešu nodarbinātības veicināšanu dotu nodokḷu atvieglojumi uzņēmējiem, kas nodarbina jauniešus. Tikai nodrošinot veiksmīgu savstarpēju mijiedarbību starp valsti, tās pārvaldītajām institūcijām, finansējuma apjomu un cilvēkkapitālu, ir iespējams uzlabot valsts ekonomisko situāciju nodarbinātības jomā un demogrāfijas jomā. Demogrāfijas joma šì brǐ̌za ekonomiskās situācijas rezultātā Latvijā virzās uz negatīvo pusi, līdz 2014. gadam dzimstība bija mazāka par mirstību, darba spējīgie jaunie valsts iedzīvotāji ir spiesti izbraukt ārpus valsts studiju un darba meklējumos, lai spētu nodrošināt pilnvērtīgu dzīvi. Ir jāatrod risinājumi, kā valstī ,noturēt” neaizbraukušos jauniešus.Viens no veidiem, kā veidot pozitīvāku vidi jauniešiem, ir pārskatīt normatīvo aktu ietvaru par nodarbinātības jautājumiem, motivējot darba devējus nodarbināt pēc iespējas vairāk jauniešus un mainīt savu attieksmi pret jauno cilvēku zināšanām un profesionālajām prasmēm (palīdzēt tās attīstīt, ne tikai vēlēties saņemt gatavus profesionāļus, kuru no izglītības iestādēm).

Piln̄̄gi noteikti uzsvars ir jāliek uz valsts un reǵionālo institūciju ciešu sadarbību ar darba devējiem, lai virzītu uz zināšanām balstītas ekonomikas attīstību un efektîvu resursu izmantošanu, it īpaši lauksaimniecībā, rūpniecībā un mežsaimniecībā, kas tiek pozicionēta starp iespējām, kā panākt ekonomikas izaugsmi un cilvēkkapitāla neaizplūšanu uz ārvalstīm. Nozīmīga joma ir arī informācijas tehnoloǵijas un inovācijas, kas jauniešiem var pavērt plašas karjeras iespējas. Ne mazāk būtisks priekšnoteikums ir pienācīgs algu līmenis arī gados jauniem cilvēkiem, izvērtējot padarītā darba kvalitāti.

4. scenārijs: ES līdzdalības scenārijs. ES interese izaugsmes nodrošināšanā, veicinot efektīvu ES piešķirtā finansējuma izmantošanu Nodarbinātūbas valsts aǵentūras rīkotajos jauniešu mobilitātes pasākumos.

Raksturojums. Tā kā Latvija ir ES dalībvalsts, nozīmīgu lomu ekonomikas attīstībā ieņem ES fondu finansiālā atbalsta piesaistīšanas apmēri. ES ir ieinteresēta, lai dalībvalstis spētu palielināt ieñēmumus un uzlabotu valsts ekonomisko izaugsmi. Nepieciešams ES struktūrfondu līdzekḷus izmantot efektīvi Nodarbinātības valsts aǵentūras rīkotajos jauniešu mobilitātes pasākumos. Latvijas valsts nevar atḷauties šo līdzekḷu neefektīvu un formālu izlietošanu, tie ir efektīvi jāiegulda jauniešu potenciāla attīstīšanā un izmantošanā. Nozīmīgi ir šajos NVA organizētajos pasākumos, kā arī augstskolās vērst jauniešu uzmanību uz uzņēmējdarbības iespējām un informēt par biznesa atbalsta programmām, finansējuma apmēriem.

Lai jaunieši ătrāk iekḷautos darba tirgū, būtisks devums ir tādam NVA mobilitātes pasākumam kā kursiem konkrētās jomās. Izejot krievu valodas, latviešu valodas, projektu vadības u.c. kursus, jaunietis ir uzlabojis zināšanas un paaugstinājis konkurētspēju darba tirgū.

Lai izvērtētu jauniešu iekḷaušanās darba tirgū iespējamos scenārijus pēc $A H P$ metodes, pētījumā tika pieaicināti 5 eksperti, lai tie scenārijiem (skat. 7. tab.) dotu savu vērtējumu. Ekspertu izvēlē tika ņemts vērā nosacījums, lai viṇi būtu saistīti ar darba tirgu un pārstāvētu darba tirgus telpiskos līmeņus. Pētījuma datu apstrādei un grafiskajai attēlošanai izmantota Microsoft Excel programma. Ar izstrādātajiem jauniešu nodarbinātības veicināšanas scenārijiem Latvijas reǵionos iepazīstinātie pieaicinātie eksperti veica hierarhiju analīzes matricu aizpildīšanu. 
Hierarhiju analīzes ekspertu pārstāvētās darbības jomas/

Industries represented by experts for hierarchy analysis

\begin{tabular}{|c|c|c|}
\hline \multicolumn{2}{|r|}{ Eksperts } & \multirow{2}{*}{$\begin{array}{l}\text { Darbības telpiskais } \\
\text { līmenis }\end{array}$} \\
\hline Apzīmējums & Ienemamais amats & \\
\hline A & Analītiķis & Valsts intereses \\
\hline B & $\begin{array}{l}\text { Uzṇēmējdarbības attīstības } \\
\text { finansēšanas vecākais speciālists }\end{array}$ & $\begin{array}{l}\text { Eiropas Savienības } \\
\text { intereses }\end{array}$ \\
\hline $\mathrm{C}$ & Uzņēmējs & Uzņēmēju intereses \\
\hline $\mathrm{D}$ & Pašvaldības deputāts & $\begin{array}{l}\text { Pašvaldības un } \\
\text { izglìtîbas iestāžu } \\
\text { intereses }\end{array}$ \\
\hline $\mathrm{E}$ & Jaunietis, ieņem privātbaņķiera amatu & Indivīdu intereses \\
\hline
\end{tabular}

Avots: autores pētījums un konstrukcija

Ekspertiem bija jāaizpilda izveidotās aptaujas anketas, lai izteiktu savu viedokli, izmantojot svarīguma pakāpes novērtēšanas skalu (skat. 5.2. tab.).

5.2. tabula/ Table 5.2.

\section{Relatīvā svarīguma skala/ Relative importance scale}

\begin{tabular}{|c|c|c|}
\hline $\begin{array}{c}\text { Relatīvā } \\
\text { svarīguma } \\
\text { intensitāte }\end{array}$ & Definīcija & Paskaidrojums \\
\hline 1 & Vienāds svarīgums & $\begin{array}{l}\text { Divu kritēriju, kritēriju grupu vai alternatīvu } \\
\text { vienāds ieguldījums mērksa sasniegšanā }\end{array}$ \\
\hline 3 & $\begin{array}{l}\text { Mērens viena pārākums } \\
\text { par otru }\end{array}$ & $\begin{array}{l}\text { Pieredze un spriedumi dod vieglu pārsvaru } \\
\text { vienam kritērijam, kritēriju grupai vai alternatīvai } \\
\text { par otru }\end{array}$ \\
\hline 5 & $\begin{array}{l}\text { Būtisks vai stiprs } \\
\text { pārākums }\end{array}$ & $\begin{array}{l}\text { Pieredze un spriedumi dod stipru pārsvaru } \\
\text { vienam kritērijam kritēriju grupai vai alternatīvai } \\
\text { par otru }\end{array}$ \\
\hline 7 & Nozīmīgs pārsvars & $\begin{array}{l}\text { Vienam no kritērijiem, kritēriju grupām vai } \\
\text { alternatîvām tiek dots tik stiprs pārsvars par } \\
\text { otru, ka tas klūust praktiski nozīmīgs }\end{array}$ \\
\hline 9 & Ļoti stiprs pārsvars & $\begin{array}{l}\text { Viena kritērija, kritēriju grupas vai alternatīvas } \\
\text { pārākums par otru apstiprinās visstiprāk }\end{array}$ \\
\hline $2,4,6,8$ & Starpvērtības & Tiek lietotas kompromisa gadījumos \\
\hline
\end{tabular}

Avots: Saaty, 2008

Ar izstrādātajiem jauniešu nodarbinātības veicināšanas scenārijiem Latvijas reǵionos tika iepazīstināti pieaicinātie eksperti, kuri uz scenāriju pamata un balstoties uz iegūto pieredzi, veica hierarhiju analīzes matricu aizpildīšanu.

Katrs eksperts vispirms sāk ar kritēriju grupu vērtēšanu, tā, piemēram, ekspertam A kritēriju grupu vērtēšanas tabula apskatāma 5.3. tabulā.

Pēc Satī teorijas, C.R. ir jābūt mazākai par 0.10 (t.i. jābūt mazākam par $10 \%$ vai 0.10 , atsevišķos gadījumos var pieļaut $20 \%$, bet ne lielāku). Ja saskaņotības attiecība iziet ārpus šìm robežām, tad ekspertiem ir vēlreiz rūpīgi jāpēta uzdevums un jāpārbauda 
savi vērtējumi. Piemērā C.R. $=0.10$, kas ir vienāds ar 0.10 un tas nozīmē ka eksperta A darbs aizpildot kritēriju grupu vērtējumu matricu ir korekts (skat. 5.3. tab.).

5.3. tabula/ Table 5.3.

Eksperta A kritēriju grupu vērtēšanas matrica/

Comparison matrix of criteria groups by expert $A$

\begin{tabular}{|c|c|c|c|c|c|c|c|}
\hline 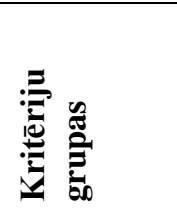 & 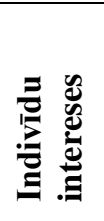 & 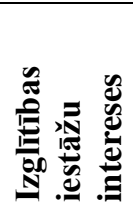 & 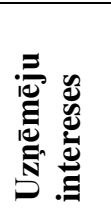 & 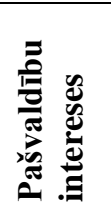 & 党 & 赵 & $\begin{array}{c}\text { Vidējā } \\
\text { prioritātes } \\
\text { vektora } \\
\text { koordināte }\end{array}$ \\
\hline $\begin{array}{l}\text { Indivīdu } \\
\text { intereses }\end{array}$ & 1 & 8 & 1 & 6 & 6 & 7 & 0.39 \\
\hline $\begin{array}{l}\text { Izglīitības } \\
\text { iestāžu } \\
\text { intereses }\end{array}$ & $1 / 8$ & 1 & $1 / 3$ & $1 / 4$ & $1 / 4$ & $1 / 4$ & 0.04 \\
\hline $\begin{array}{l}\text { Uznēèmēju } \\
\text { intereses }\end{array}$ & 1 & 3 & 1 & 4 & 5 & 6 & 0.31 \\
\hline $\begin{array}{l}\text { Pašvaldību } \\
\text { intereses }\end{array}$ & $1 / 6$ & 4 & $1 / 4$ & 1 & 1 & 1 & 0.09 \\
\hline $\begin{array}{l}\text { Valsts } \\
\text { intereses }\end{array}$ & $1 / 6$ & 4 & $1 / 5$ & 1 & 1 & 1 & 0.08 \\
\hline $\begin{array}{l}\text { ES } \\
\text { intereses }\end{array}$ & $1 / 7$ & 4 & $1 / 6$ & 1 & 1 & 1 & 0.08 \\
\hline C.R. $=$ & 0.10 & & & & & Kopā: & 1.00 \\
\hline
\end{tabular}

Avots: autores pētijums un konstrukcija

Līdzīgā veidā eksperts aizpildīja pārējās atsevišksu kritēriju un scenāriju vērtējumu tabulas attiecībā pret katru no kritērijiem, kopumā 37 tabulas. Katrai tabulai tika aprēķināti prioritātes vektori un SA skaitliskās vērtības.

Pēc tam tika apkopoti atsevišksu ekspertu vērtējumi, 5.4. tabulā redzamā piemērā, tabulā parādīts kritēriju grupu novērtējums un aprēksinātā prioritātes vidējā vērtība.

Apkopojot ekspertu vērtējumus, tika iegūts kritēriju grupu izvērtējums ekspertu skatījumā (skat. 5.4. tab.).

Analizējot ekspertu izteikto viedokli par ES interešu izvērtējumu, gandrīz visu ekspertu domas sakrita, kā vismazsvarīgākās intereses vērtējot ES intereses. Bet eksperts C ES intereses vērtējis kā otru nozīmīgāko interešu grupu (prioritātes vektora koordināte 0.21) pēc indivīdu interesēm (prioritātes vektora koordināte 0.38).

Eksperts E uzskata, ka pašvaldību intereses (prioritātes vektora koordināte ir 0.22) ir otrā būtiskākā interešu grupa pēc indivīdu interesēm (prioritātes vektora koordināte 0.31 ).

Izvērtējot ekspertu sniegto viedokli, eksperti A (prioritātes vektora koordināte 0.23) un D (prioritātes vektora koordināte 0.23) ar pārsvaru vērtējuši arī uzņēmēju intereses, bet eksperts $\mathrm{C}$ uzņēmēju intereses vērtējis kā vienu no vismaznozīmīgākajām interešu grupām (prioritātes vektora koordināte 0.06).

Eksperts A kā vismaznozīmīgāko interešu grupu ir vērtējis izglītības iestāžu intereses (prioritātes vektora koordināte 0.05). 
5.4. tabula/ Table 5.4.

Kritēriju grupu prioritātes vektoru izvērtējums ekspertu skatījumā/ Evaluation of the criteria group priority vector by experts

\begin{tabular}{|c|c|c|c|c|c|c|}
\hline \multirow[t]{2}{*}{ Kritēriju grupas } & \multicolumn{5}{|c|}{ Eksperti } & \multirow{2}{*}{$\begin{array}{c}\text { Vidējās } \\
\text { prioritātes } \\
\text { vektora } \\
\text { koordinātes }\end{array}$} \\
\hline & $\mathrm{A}$ & $\mathrm{B}$ & $\mathrm{C}$ & $\mathrm{D}$ & $\mathrm{E}$ & \\
\hline Indivīdu intereses & 0.45 & 0.47 & 0.38 & 0.35 & 0.52 & 0.43 \\
\hline $\begin{array}{l}\text { Izglītības iestāžu } \\
\text { intereses }\end{array}$ & 0.05 & 0.18 & 0.06 & 0.18 & 0.17 & 0.13 \\
\hline $\begin{array}{l}\text { Uznēèēju } \\
\text { intereses }\end{array}$ & 0.23 & 0.14 & 0.06 & 0.23 & 0.10 & 0.15 \\
\hline $\begin{array}{l}\text { Pašvaldību } \\
\text { intereses }\end{array}$ & 0.09 & 0.07 & 0.17 & 0.12 & 0.07 & 0.10 \\
\hline Valsts intereses & 0.09 & 0.09 & 0.12 & 0.08 & 0.10 & 0.10 \\
\hline ES intereses & 0.09 & 0.04 & 0.21 & 0.05 & 0.04 & 0.08 \\
\hline
\end{tabular}

Avots: autores pētijums un konstrukcija

Eksperti kā visieinteresētāko grupu jauniešu nodarbinātības veicināšanai Latvijā ir atzinuši indivīdu intereses (šajā gadījumā jauniešu intereses), kur vidējā prioritātes vektora koordināte ir 0.43. Šis vērtējums ir loǵisks, jo jaunieši ir visieinteresētākie jauniešu nodarbinātības veicināšanā - tiek ietekmēta indivīda spēja iekl̦auties sabiedrībā, veidot nākotni un karjeru. Pārējās ieinteresētās puses tāpat ir saistìtas ar jauniešiem un to iekļaušanos sabiedrībāa, kā arī ir labuma guvējas no jauniešu nodarbinātības veicināšanas, jo tiek ietekmēta to labklājība, peḷna, konkurētspēja utt.

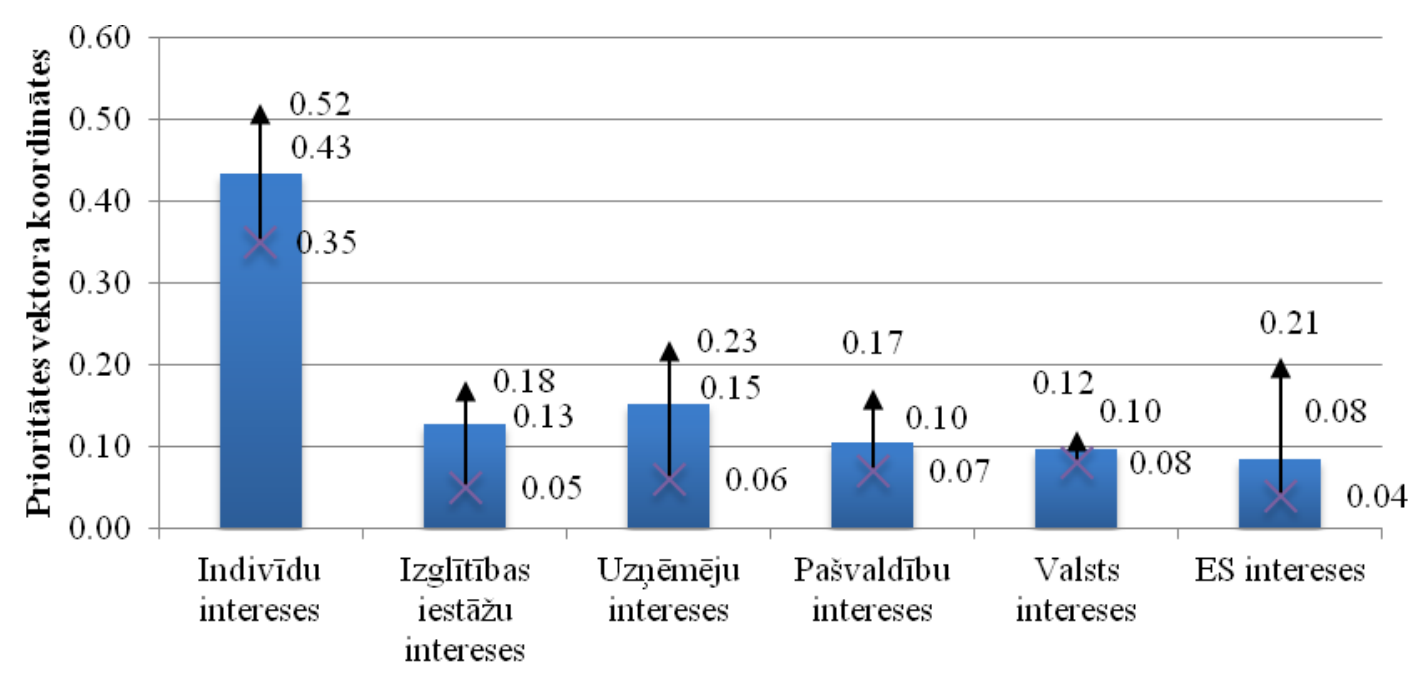

Kritēriju grupas

- Vid.aritm. Max. $\times$ Min.

Avots: autores pētījums un konstrukcija

5.3. att./ Fig. 5.3. Interešu grupu nozīmīguma vērtējums ekspertu skatījumāa

Evaluation of the significance of interest groups by experts. 
Nākamā ieinteresētākā grupa, izvērtējot ekspertu sniegtos vērtējumus, ir uzņēmuтu intereses, vidējā prioritātes vektora koordināte šai grupai ir 0.15 , zemāk eksperti vērtējuši izglìtības iestāžu intereses (vidējā prioritātes vektora koordināte 0.13). Savukārt pašvaldību intereses (vidējā prioritātes vektora koordināte 0.10), valsts intereses (prioritātes vektora koordināte 0.10) un ES intereses (prioritātes vektora koordināte 0.08 ) vērtētas kā maznozīmīgākas (skat. 5.3. att.).

Kā jau iepriekš tika uzsvērts, hierarhiju analīzes trešajā līmenī visas kritēriju grupas veidojas pēc loǵiskiem kritērijiem attiecībā uz otrajā hierarhijas līmenī iekḷautajām interešu grupām. Katrai interešu grupai tika definēti pieci kritēriji, balstoties uz autora veikto pētījumu par jauniešu bezdarbu un to iespējām iekḷauties darba tirgū.

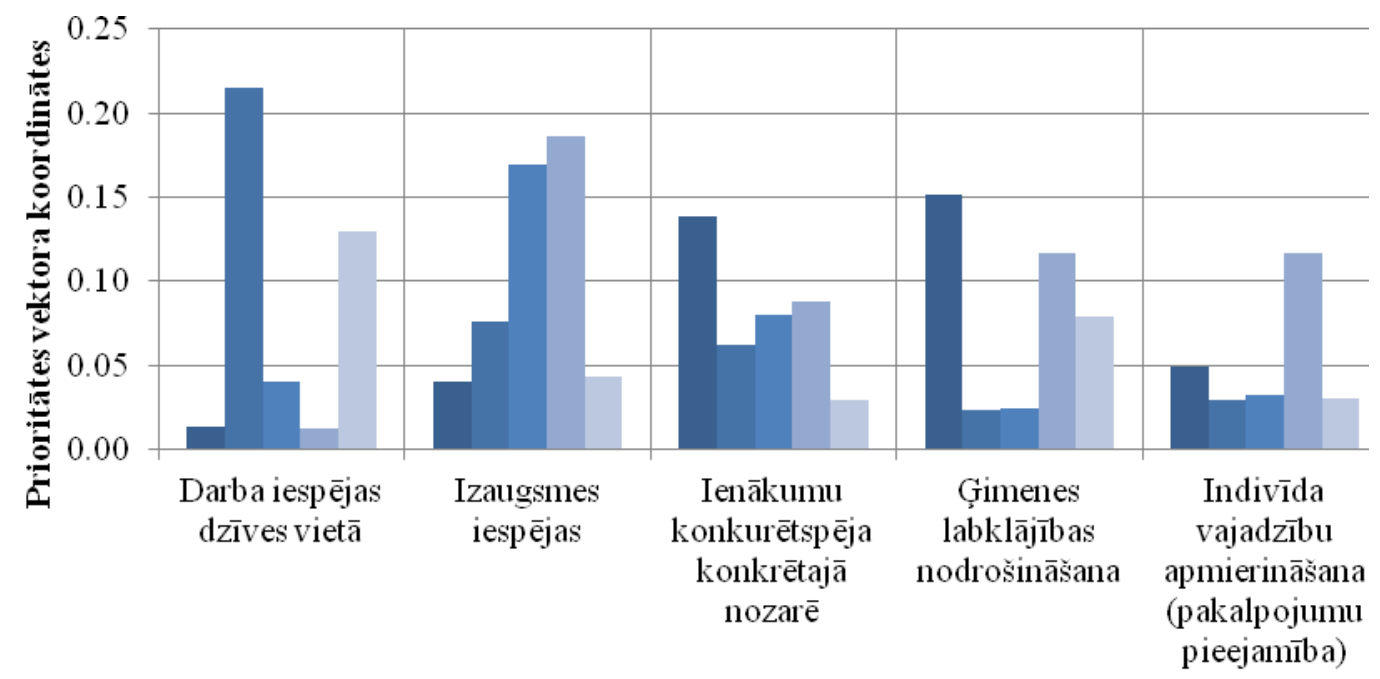

Kritēriji

$\square \mathrm{A}=\mathrm{B} \square \mathrm{C}-\mathrm{D} \square \mathrm{F}$

Avots: autores pētījums un konstrukcija

\section{4. att./ Fig. 5.4. Ekspertu viedoklis par indivīda interesēm jauniešu nodarbinātības veicināšanā/ \\ Expert opinions on individual interests in promoting youth employment.}

Indivīda intereses tiek saistîtas ar izglīīîbas iegūšanu un izaugsmes iespējām, darba iespējām, lai indivīds spētu nodrošināt labklājību sev un savai gimenei.

Indivīda interešu līmenī tika iekḷauti sekojoši kritēriji:

- darba iespējas dzīves vietā;

- indivīda izaugsmes iespējas;

- indivīda ienākumu konkurētspēja konkrētajā (nozarē, kurā indivīds apgūst izglītību un/ vai ir nodarbināts) nozarē;

- indivīda ǵimenes labklājības nodrošināšana;

- indivīda vajadzību apmierināšana (pakalpojumu pieejamība).

5.4. att. redzams, ka eksperts A kā visnozīmīgāko kritēriju indivīda interešu grupā vērtē ,ǵgimenes labklājības nodrošināšana" (prioritātes vektora koordināte 0.152) un ,ienākumu konkurētspēja konkrētajā nozarē” (0.139). Eksperts D indivīdu interešu ietvaros kā visbūtiskākos kritērijus vērtējis „,izaugsmes iespējas” (0.186), 
„ǵimenes labklājības nodrošināšana" (0.117) un ,indivīda vajadzību apmierināšana” (0.117). Savukārt eksperts E (0.130) un eksperts B (0.215) kā visbūtiskāko kritēriju indivīda interešu grupā vērtējis „darba iespējas dzives vietā”. Eksperts C kā visnozīmīgākos kritērijus indivīda interešu grupā vērtējis „izaugsmes iespējas” (0.169) un ,ienākumu konkurētspēja konkrētajā nozarē” (0.080). Kopumā eksperti indivīda interešu blokā kā visnozīmīgāko kritēriju atzīmējuši ,izaugsmes iespējas” (vidējā prioritātes vektora koordināte 0.103$)$, „darba iespējas dzīves vietā” (0.082) un „giimenes labklājības nodrošināšana” (0.079).

Darba autore izvēlējās iekļaut ekspertiem vērtěšanā arī interešu blokuizglītības iestāžu intereses, jo izglītības iestādes ir atbildīgās institūcijas un tām ir nozīmīga loma jaunieša izglītības līmeņa veidošanā un attīstībā, kāa arī jaunieša ambīciju un dzìves prioritāšu veidošanas pamats. Izglītības institūcijas jau no bērna pirmajiem dzīves gadiem ir nozīmīgs indivīda sociālās vides, kurā indivīds attīstās un dzīivo, veidotājs.

Izglìtības iestāžu interešu blokā darba autore iekḷāva sekojošus kritērijus:

- zināšanu, inovāciju un prasmju attīstība;

- investīcijas zināšanās;

- zināšanu pārneses nodrošināšana jaunākajām paaudzēm;

- skolēnu/ studentu skaita saglabāšana;

- izglīinibas iestādes attiecības ar darba devējiem.

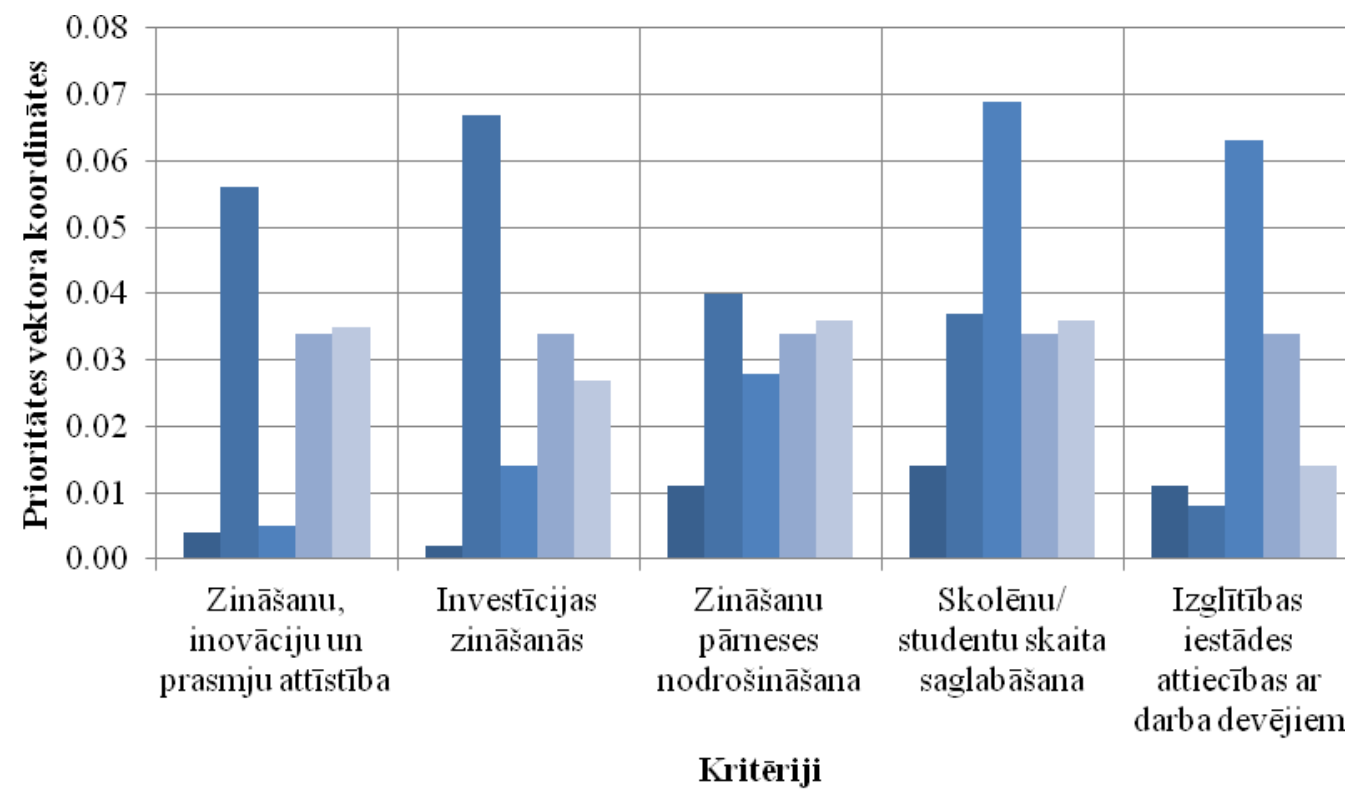

$\square \mathrm{A} \square \mathrm{B} \backsim \mathrm{C} \backsim \mathrm{F}$

Avots: autores pētījums un konstrukcija

\section{5. att./ Fig. 5.5. Ekspertu viedoklis par izglītības iestāžu interesēm jauniešu nodarbinātības veicināšanā/}

\section{Expert opinions on education institution interests in promoting youth employment.}

Balstoties uz 5.5. att., eksperts C kā visbūtiskāko kritēriju izglìtības iestāžu interešu blokā vērtējis „studentu skaita saglabāšana” (prioritātes vektora koordināte 0.69) un „izglīīibas iestādes attiecības ar darba devējiem” (0.063). Eksperts E kā nozīmīgākos kritērijus izglītības iestāžu interešu blokā vērtējis „zināšanu pārneses 
nodrošināšana” (0.036), ,zināšanu, „,skolēnu/ studentu skaita saglabāšana” (0.036) un „inovāciju un prasmju attīstība” (0.035).

Kopumā eksperti izglìtības iestāžu interešu blokā kā visnozīmīgāko kritēriju vērtējuši „,skolēnu/ studentu skaita saglabāšana" (vidējā prioritātes vektora koordināte 0.036), „zināšanu pārneses nodrošināšana” (0.030) un ,investīcijas zināšanās” (0.027).

Kā nākamais interešu bloks, kam aktuāli nodarbināt jauniešus, kuriem ir laba izglītība, lai spētu nodrošināt un attīstīt uzņēmējdarbību, kā arī gūt peḷnu šobrīd un nākotnē, no veiksmīgas cilvēkkapitāla ,izmantošanas” ir uznēemēju interešu grupa. Uzņēmēju interešu blokā iekḷaujami arī potenciālie jaunie uzṇēmēji (jaunieši), kas plāno uzsākt vai ir jau uzsākuši savu uzñēmējdarbību.

Uzņēmēju interešu blokā tika iekļauti sekojoši kritēriji:

- darbaspēka kvalifikācija;

- investīciju un finansējuma piesaistes potenciāls;

- peļnas gūšana;

- produkcijas izlaides/ pakalpojuma noieta veicināšana;

- uzñēmējdarbības paplašināšana.

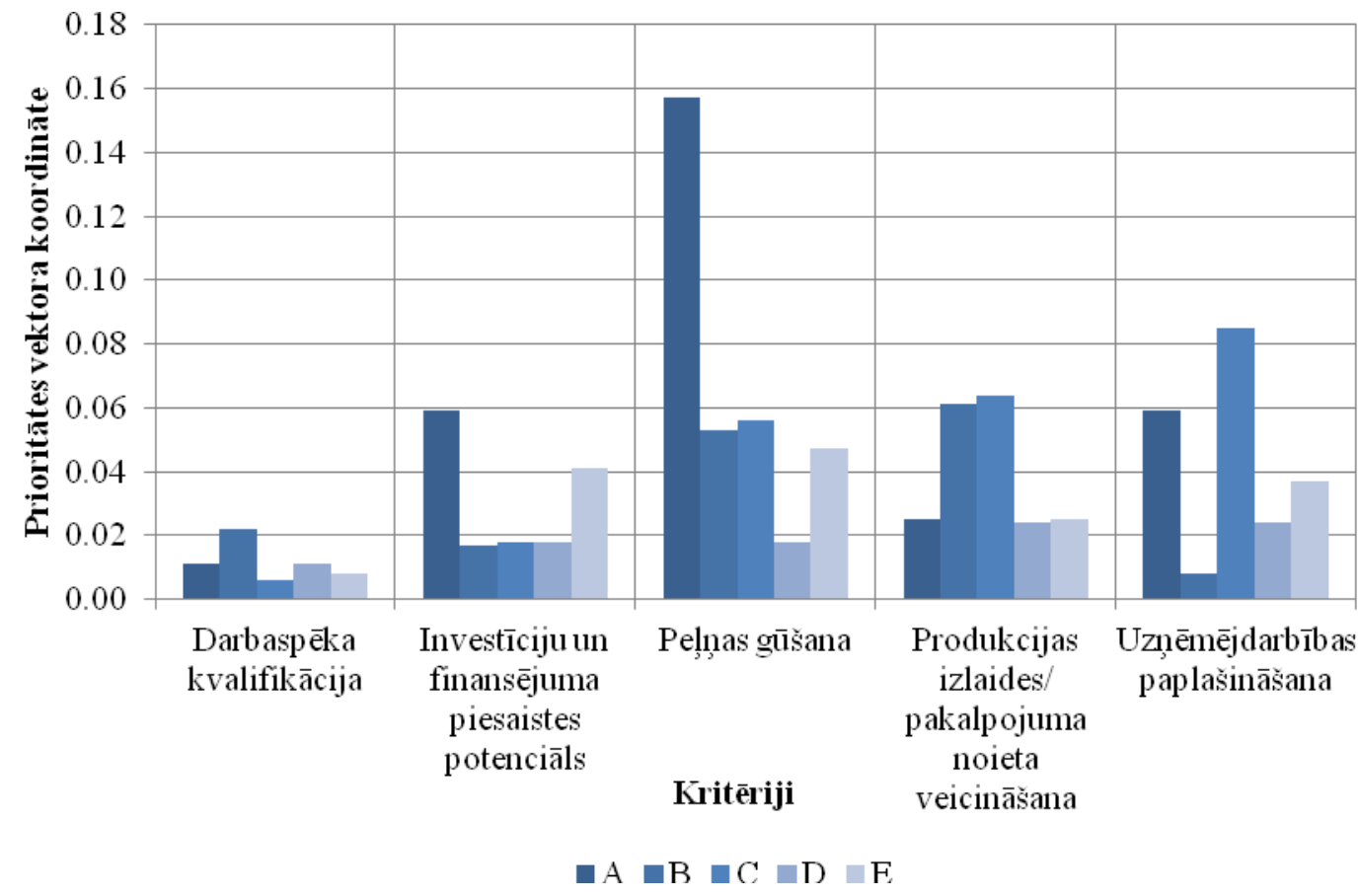

Avots: autores pētījums un konstrukcija

\section{6. att./ Fig. 5.6. Ekspertu viedoklis par uzṇēmēju interesēm jauniešu nodarbinātības veicināšanā/}

Expert opinions on business interests in promoting youth employment.

Pēc 5.6. att. redzams, ka eksperts A (prioritātes vektora koordināte 0.157) un eksperts E (0.047) kā būtiskāko kritēriju uzņēmēju interesēs vērtējis ,„peļnas gūšanu”, savukārt, eksperts C, kā būtiskāko vērtējis „uzñēmējdarbības paplašināšana” (0.085).

Izvērtējot ekspertu vērtējumus, kā visbūtiskākie kritēriji uzn̄èmēju interešu blokā vērtēti „pel̦ñas gūšana” (vidējā prioritātes vektora koordināte 0.066), 
„uzņēmējdarbības paplašināšana” (0.043) un ,produkcijas izlaides/ pakalpojuma noieta veicināšana" $(0.040)$.

Pašvaldību interešu bloka kritēriju grupā ietverti kritēriji, kas nozīmīgi pašvaldībām reǵionālā aspektā, jo ietekmē pašvaldības attīstību gan šobrīd, gan tuvākajā un tālākajā nākotnē. Nozīmīga ir turpmāk minēto kritēriju attīstības veicināšana, lai nodrošinātu reǵionālo attīstību un ilgtspēju. Pašvaldību un tās pārziñā ietilpstošo reǵionu ekonomika nevar attīstìties ilgtspējīgi, ja netiek ievērotas indivīdu intereses, t.i., netiek veicināta finansējuma piesaiste reǵionam, lai veicinātu jaunu darba vietu radīšanu un pieejamību, un veicinātu iedzīvotāju dzīves līmeņa pieaugumu, kā arī nodrošinātu kultūras un sociālās vides attīstību. Attīstot iedzīvotāju dzīves līmeni un kvalitāti, tiek veicināta arī demogrāfiskā stāvokḷa uzlabošana, jo iedzīvotājiem palielinās pirktspēja un rodas iespējas nodrošināt ne tikai savas vajadzības, bet arī citu ǵimenes locekḷu labklājību.

Pašvaldības interešu blokā iekḷauti sekojoši kritēriji, kas nozīmīgi gan pašvaldībai, gan indivīdam, kas dzīvo un strādā pašvaldības teritorijā:

- nodarbinātības veicināšana;

- demogrāfiskā stāvokḷa uzlabošana;

- finansējuma piesaiste reǵionu attīstībai;

- uzñēmējdarbības attīstības veicināšana (MVU, pašnodarbinātība u.c.);

- kultūras un sociālās vides attīstības nodrošināšana (skat. 5.7. att.).

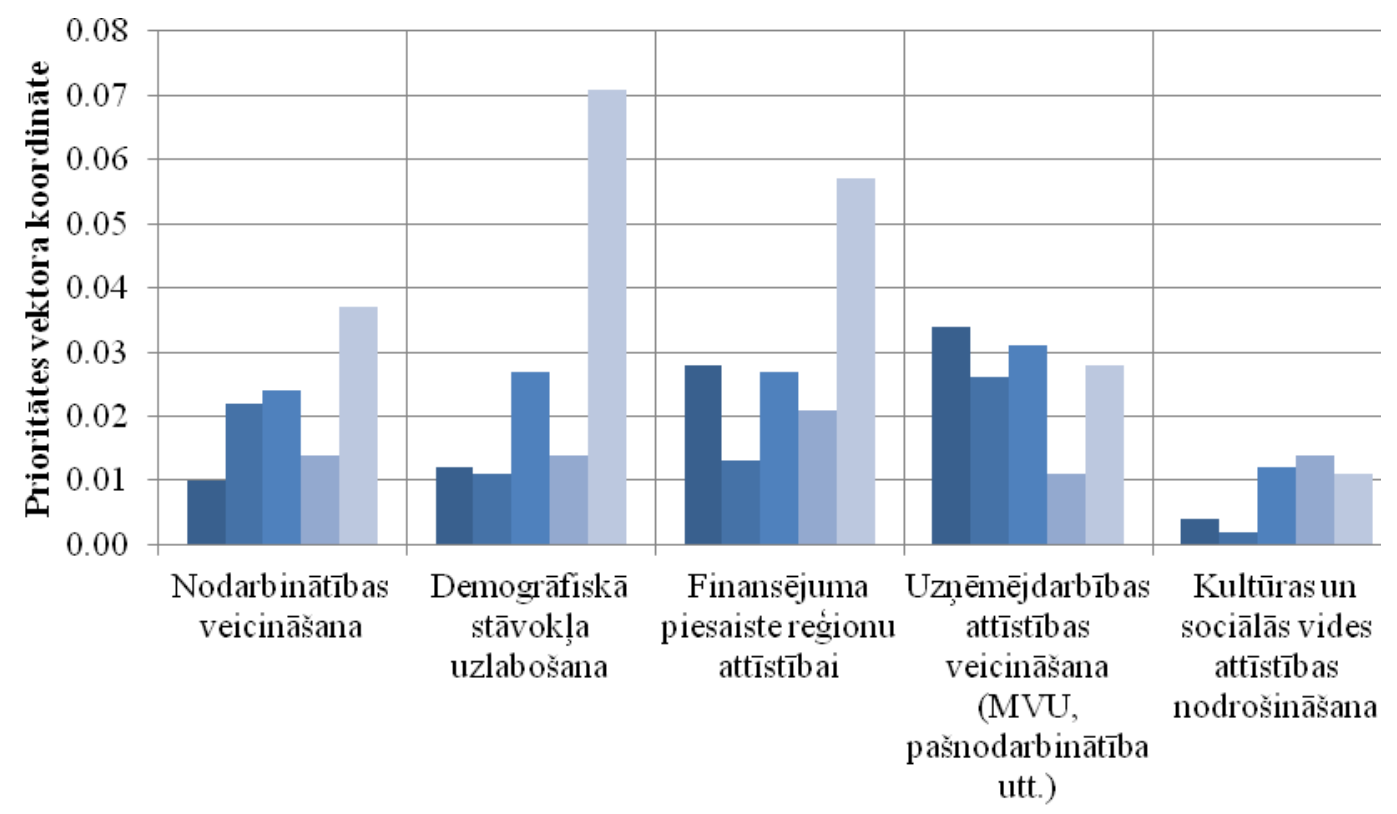

Kritēriji

$\square=\mathrm{B} \square \mathrm{C}-\mathrm{D} \square \mathrm{F}$

Avots: autores pētījums un konstrukcija

\section{7. att./ Fig. 5.7. Ekspertu viedoklis par pašvaldību interesēm jauniešu} nodarbinātības veicināšanā/

Expert opinions on local government interests in promoting youth employment.

Pašvaldību interešu blokā kā būtiskākos kritērijus - prioritāros virzienus eksperts A (prioritātes vektora koordināte 0.034), eksperts B (0.026) un eksperts C (0.031) vērtējuši „uzṇēmējdarbības attīstības veicināšanu”, eksperts D - „finansējuma 
piesaisti reg̣ionu attīstībai” (0.021) un eksperts E - „demogrāfiskā stāvokḷa uzlabošanu" (0.071). Kopumā, izvērtējot ekspertu vērtējumus kā būtiskākais pašvaldību interešu blokā ietilpstošais prioritārais virziens ir „finansējuma piesaiste reǵionu attīstībai” (vidējā prioritātes vektora koordināte 0.029), „demogrāfiskā stāvokḷa uzlabošana” (0.027) un ,uzñēmējdarbības attīstības veicināšana” (0.026).

Valsts interešu blokā iekḷauti kritēriji, kas ietekmē visu iepriekšminēto interešu realizēšanu. Visi interešu bloki ir savstarpēji saistīti un papildinoši, un tiešā veidā attiecināmi uz indivīda iespējām darba tirgū, uz indivīda dzīves līmeni, izglītības līmeni, sociālo iekḷaušanos utt.

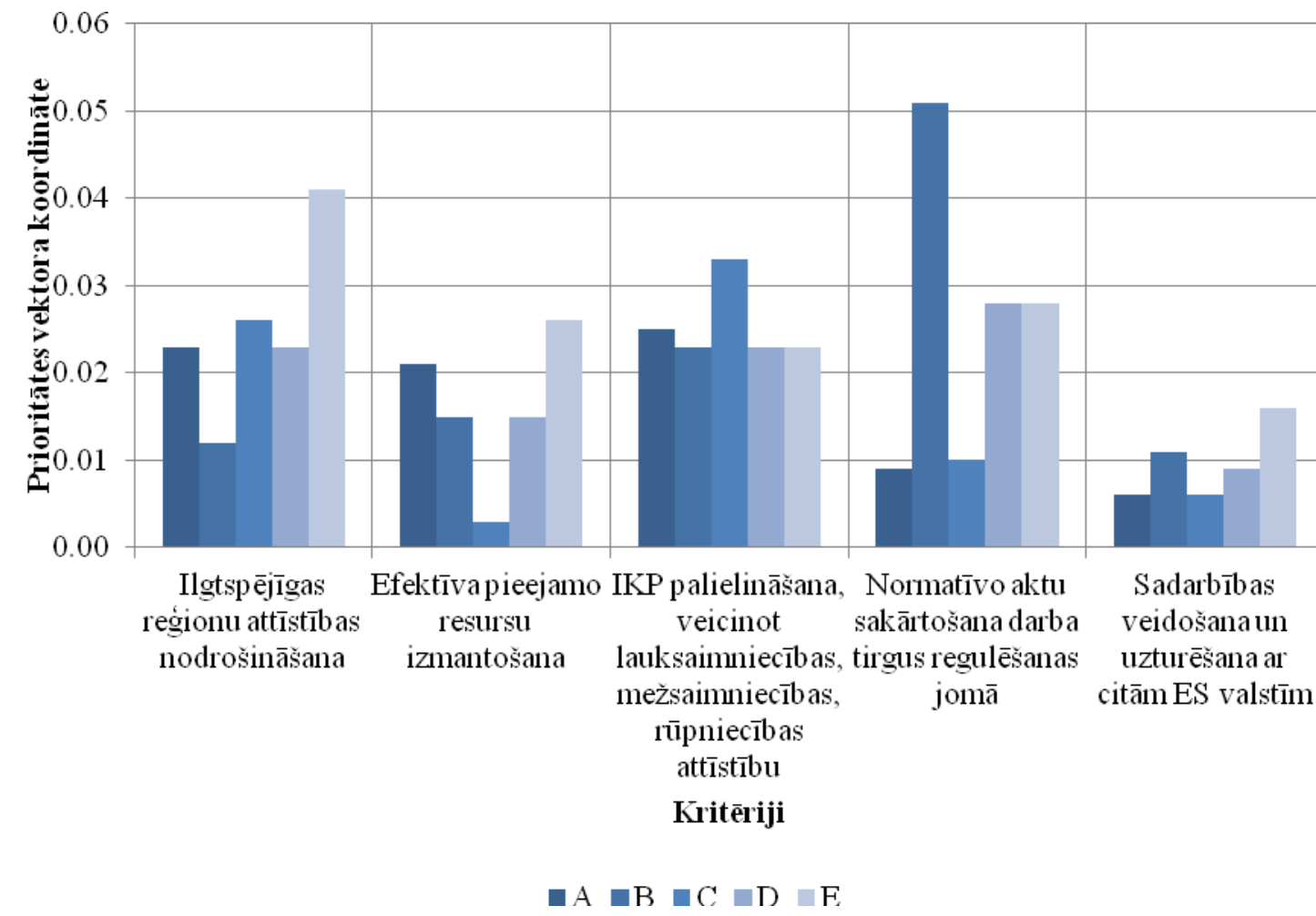

Avots: autores pētījums un konstrukcija

\section{8. att./ Fig. 5.8. Ekspertu viedoklis par valsts interesēm jauniešu nodarbinātības veicināšanā/} Expert opinions on national interests in promoting youth employment.

Valsts interě̌u blokā iekḷauti sekojoši kritēriji:

- ilgtspējīgas reǵionu attīstības nodrošināšana;

- efektīva pieejamo resursu izmantošana;

- IKP palielināšana, veicinot lauksaimniecības, mežsaimniecības, rūpniecības u.c. stratēgiskajos dokumentos pieminētās nozares, kurās jāveicina attīstība;

- Normatīvo aktu sakārtošana darba tirgus regulēšanas jomā;

- sadarbības veidošana un uzturēšana ar citām ES valstīm.

Izvērtējot ekspertu vērtējumus valsts interešu blokā, tika secināts, ka eksperts E (prioritātes vektora koordināte 0.041) kā visbūtiskāko kritēriju blokā vērtējis „,ilgtspējīgas reǵionu attīstības nodrošināšanu”. Eksperts D kā visbūtiskāko vērtējis „,normatīvo aktu sakārtošanu darba tirgus regulēšanas jomā” $(0.028)$, bet eksperts B (0.049) un eksperts D (0.028) - ,efektīvu pieejamo resursu izmantošanu”. Eksperts A 
kā visbūtiskāko kritēriju vērtējis „IKP palielināšanās, veicinot lauksaimniecības, mežsaimniecības, rūpniecības attīstību" (0.025) (skatît 5.8. att.).

Balstoties uz ekspertu vērtējumiem par valsts interešu bloka kritēriju izvērtējumu kā visnozīmīgākie kritēriji vērtēti „ilgtspējīgas reǵionu attīstības nodrošināšana” (vidējā prioritātes vektora koordināte 0.025), „,normatīivo aktu sakartošana darba tirgus regulěšanas jomā” (0.025) un „IKP palielināšana, veicinot lauksaimniecības, mežsaimniecības, rūpniecības attīstību" (0.025).

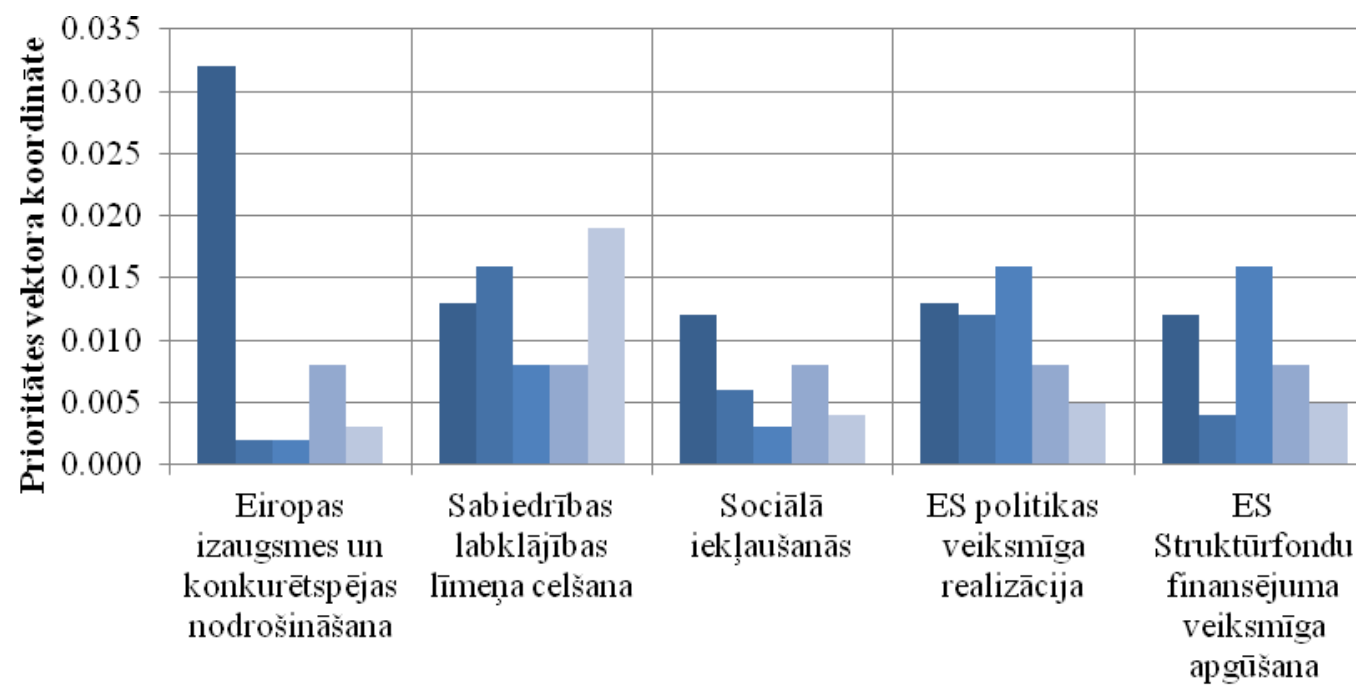

Kritēriji

$\square \mathrm{A} \square \mathrm{B} \square \mathrm{C} \square \mathrm{D} \sim \mathrm{F}$

Avots: autores pētījums un konstrukcija

\section{9. att./ Fig. 5.9. Ekspertu viedoklis par ES interesēm jauniešu nodarbinātības veicināšanā/}

Expert opinions on the EU's interests in promoting youth employment.

Pētījumā iekḷautas ES intereses, jo ES stratēgiskajos plānošanas dokumentos uzsvērts demogrāfiskā stāvokḷa uzlabošanas nozīmīgums Eiropas reǵionā, uzņēmējdarbības attīstības veicināšana jauniešu vidū, nodarbinātības veicināšana, samazinot augsto bezdarba līmeni ES valstīs, kā arī iedzīvotāju labklājīibas līmeņa celšana.

ES interešu blokā kā nozīmīgākie kritēriji iekḷauti:

- Eiropas izaugsmes un konkurētspējas nodrošināšana, kas nav iespējama bez veiksmīgas cilvēkkapitāla ,izmantošanas”, iesaistot tos pārmaiņu procesā;

- sabiedrības labklājības līmeṇa celšana;

- sociālā iekḷaušanās;

- ES politikas veiksmīga realizācija;

- ES Struktūrfondu finansējuma veiksmīga izlietošana un apgūšana.

ES intereses pret citām interesēm ekspertu skatījumā vērtētas kā vienas no maznozīmīgākajām interesēm.

Pēc 5.9. att. redzams, ka eksperts A (prioritātes vektora koordināte 0.032) kā visbūtiskāko kritēriju vērtējis „Eiropas izaugsmes un konkurētspējas nodrošināšana”. Eksperts B (0.016) un eksperts E (0.019), kā visnozīmīgāko kritēriju ES intere ̌̌u grupā vērtējuši „sabiedrības labklājīibas līmeņa celšanu”. Apkopojot ekspertu vērtējumus ES interešu kritēriju blokā kā nozīmīgākais kritērijs ir vērtēts „ES 
politikas veiksmīga realizācija" (vidējā prioritātes vektora koordināte 0.011) un „sabiedrības labklājīibas līmeņa celšana” (0.013).

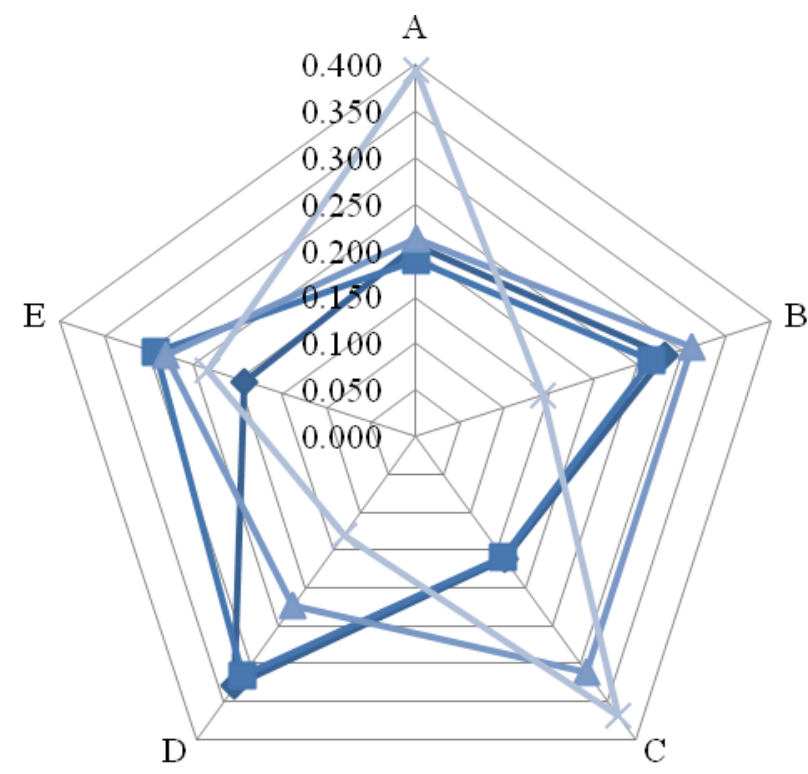

1. scenārijs: Jauniešu uẓ̂̉ēmējdarbības vides attīstību veicinošais scenārijs

2. scenārijs: Izglītības iestāžu un uzṇēmēju sadarbības scenārijs

3. scenārijs: Valsts institūciju un uznẹēmēju sadarbības scenārijs

4. scenārij̣s: ES līdzdalības scenārijs

Avots: autores pētījums un konstrukcija

\subsection{0. att./ Fig. 5.10. Piemērotākā scenārija izvēle jauniešu nodarbinātības veicināšanai ekspertu skatījumā/ \\ Selection of the most appropriate scenario for promoting youth employment in Latvia by experts.}

Eksperts A (prioritātes vektora koordināte 0.39), kas ieņem analītiķa amatu un pārstāv valsts intereses un eksperts C (prioritātes vektora koordināte 0.37), kas ir ilggadējs uzṇēmējs un pārstāv uzņēmēju intereses, kā optimālāko scenāriju novērtējuši 4. scenāriju: ES līdzdalības scenāriju (skatīt 5.10. att.).

Eksperts B (prioritātes vektora koordināte 0.31), kas darbojas uzñēmējdarbības attīstības projektu finansēšanas jomā un pārstāv ES intereses, kā optimālāko scenāriju izvēlējies 3. scenāriju: Valsts institūciju un uzn̄ēmēju sadarbības scenāriju.

Eksperts D (prioritātes vektora koordināte 0.33), kas ieṇem pašvaldības deputāta amatu un pārstāv pašvaldību intereses, kā optimālāko scenāriju ir atzinis 1. scenāriju: Jauniešu uzn̄ēmējdarbības vides attīstību veicinošo scenāriju.

Eksperts E, kas ieņem privātbanķiera amatu un pārstāv jauniešu intereses, par optimālāko scenāriju ir atzinis 2. scenāriju: Izglītības iestāžu un uzṇēmēju sadarbības scenāriju (prioritātes vektora koordināte 0.29). 


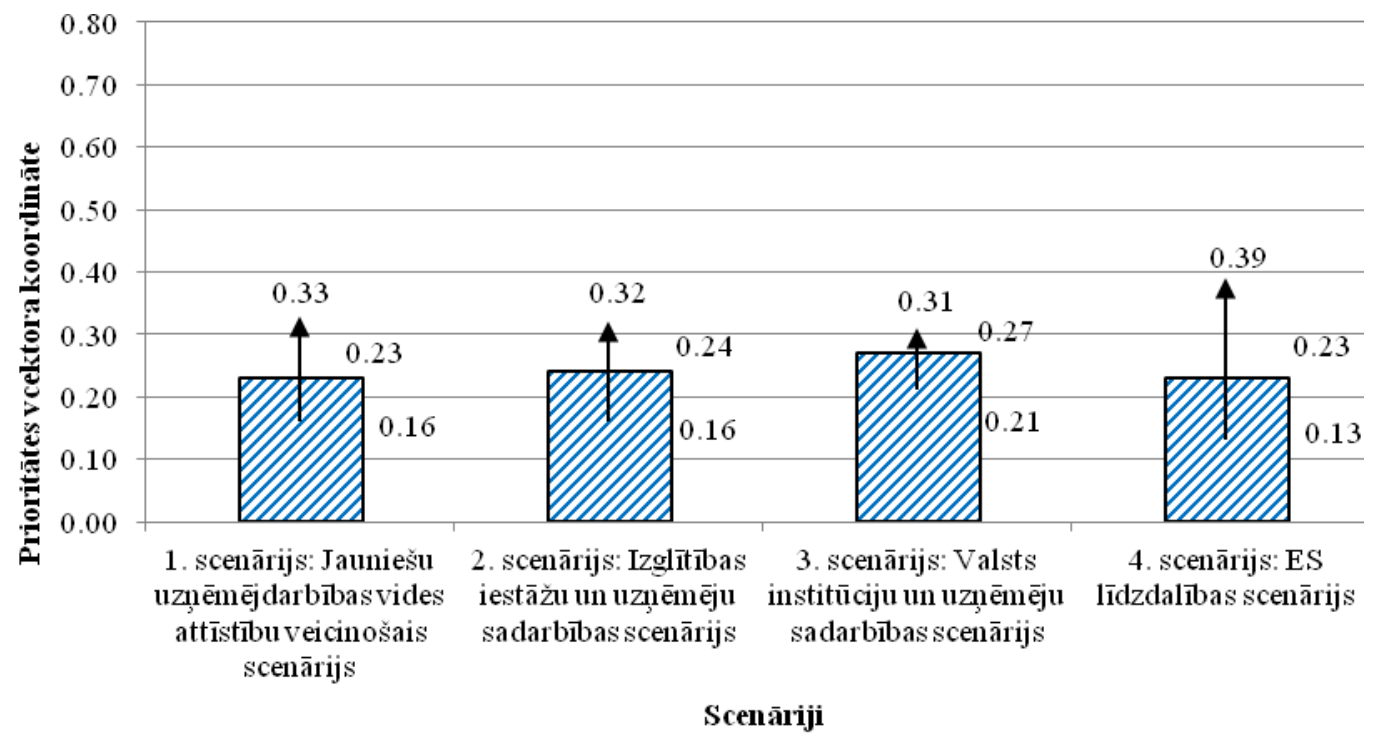

שVid. Aritm. Max. Min.

Avots: autores pētījums un konstrukcija

\subsection{1. att./ Fig. 5.11. Piemērotākais scenārijs jauniešu nodarbinātības veicināšanai ekspertu vērtējumā/}

Selection of the most appropriate scenario for promoting youth employment in Latvia by experts.

Analizējot iegūtos ekspertu vērtējumus, ņemot vērā sešu kritēriju grupu pozīcijas, eksperti kā optimālāko scenāriju ir izvēlējušies 3. scenāriju: valsts institūciju un uzṇēmēju sadarbības scenāriju, paredzot nodokḷu atvieglojumus uzṇēmējiem, kas nodarbina jauniešus (prioritātes vektora koordināte 0.27).

Kā otrs optimālākais scenārijs ir vērtēts 2. scenārijs: izglīī̄bas iestāžu un uzņēmēju sadarbības scenārijs, prioritātes vektora koordināte 0.24 .

1. scenārija: jauniešu uzn̄ēmējdarbības vides attīstību veicinošā scenārija un 4. scenārija: ES līdzdalības scenārija prioritātes vektora koordināte ir 0.23 (skat. 5.11. att.).

5.5. tabula/ Table 5.5.

Ekspertu scenāriju ticamības izvērtēšana/ Evaluation of the reliability of scenarios by experts

\begin{tabular}{|c|c|c|c|c|c|c|c|c|}
\hline Eksperti & \multicolumn{4}{|c|}{ Kritēriju vērtēšana } & \multicolumn{4}{|c|}{ Scenāriju vērtēšana } \\
\hline & ن. & 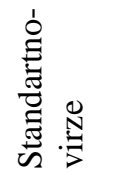 & 貣营 & 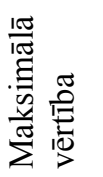 & ن & 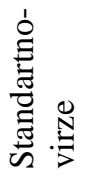 & 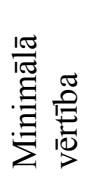 & 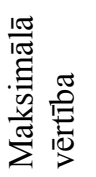 \\
\hline $\mathbf{A}$ & 0.03 & 0.03 & 0.00 & 0.13 & 0.06 & 0.03 & 0.02 & 0.11 \\
\hline B & 0.12 & 0.06 & 0.00 & 0.20 & 0.16 & 0.06 & 0.03 & 0.20 \\
\hline C & 0.10 & 0.07 & 0.00 & 0.20 & 0.09 & 0.04 & 0.04 & 0.15 \\
\hline $\mathbf{D}$ & 0.05 & 0.05 & 0.00 & 0.19 & 0.06 & 0.07 & 0.00 & 0.19 \\
\hline $\mathbf{E}$ & 0.07 & 0.06 & 0.01 & 0.18 & 0.08 & 0.03 & 0.04 & 0.13 \\
\hline
\end{tabular}

Avots: autores pētījums un konstrukcija 
5.5. tabulā redzami ekspertu kritēriju un scenāriju vērtēšanas rezultāti un to ticamība. Izvērtējot kritēriju un scenāriju ekspertu vērtējumu C.R. vidējos katram ekspertam, šie rezultāti ir ticami, jo nepārsniedz 10\% (atsevišksos gadījumos piel̦aujami 20\%). Atsevišķ eki eksperti pētījuma procesā tika lūgti pārskatīt savus vērtējumus un vēlreiz kritērijus pārvērtēt objektīvi.

\subsection{Jauniešu iekḷaušanās darba tirgū ekspertu skatījumā/ Young people entering the labour market in the experts' view}

Lai apzinātu jauniešu iespējas iekḷauties darba tirgū ekspertu skatîjumā, 2015. gada decembrī tika veiktas ekspertu intervijas. Ekspertu intervijas jautājumi tika sagatavoti, balstoties uz iepriekš veikto pētījumu rezultātiem. Kopumā ekspertu intervijās piedalījās 8 eksperti (skat. 5.6. tab.). Ekspertu aptaujas jautājumi apskatāmi 7. pielikumā.

5.6. tabula/ Table 5.6.

Ekspertu darbības joma un ieņemamais amats $(\mathrm{n}=8) /$

Field of activity and profession of experts $(n=8)$

\begin{tabular}{|c|c|c|}
\hline Apzīmējums & Ienemamais amats & Darbības joma \\
\hline A & Dr.sc.ing., docents & $\begin{array}{l}\text { Izglītība un zinātne, } \\
\text { inženiertehniskās zinātnes }\end{array}$ \\
\hline B & Dr.habil.phys., profesors, pētnieks & $\begin{array}{l}\text { Izglītība un zinātne, fizika, } \\
\text { matemātika }\end{array}$ \\
\hline $\mathrm{C}$ & Mg. oec., jaunatnes lietu koordinators & Sociālā joma \\
\hline $\mathrm{D}$ & $\begin{array}{l}\text { Mg. oec., jaunatnes lietu koordinators, } \\
\text { mūžizglìtîbas koordinators }\end{array}$ & Sociālā joma, izglītība \\
\hline $\mathrm{E}$ & Dr. oec., ekonomists, pētnieks & Ekonomika, zinātne \\
\hline $\mathrm{F}$ & Dr. oec., profesors & Izglītība un zinātne \\
\hline G & $\begin{array}{l}\text { Dr.pol.sc., asoc. prof., pētnieks, valsts } \\
\text { pettijumu programmas projekta vadītājs }\end{array}$ & Izglītība un zinātne \\
\hline $\mathrm{H}$ & Dr. oec., pētnieks & Izglītība un zinātne \\
\hline
\end{tabular}

Avots: autores pētījums un konstrukcija

Eksperti tika aicināti sniegt viedokli par šādiem jautājumiem:

Kā Jūs vērtējat jaunieša, ar izglìt̄̄bu zemāku par vidējo vai profesionālo, iespējas iekļauties darba tirgū?

Eksperts A uzvēra, ka ir būtiskas atšķirības starp jauniešiem ar vidējo izglītību un profesionālo izglîtību. Jaunieši, kas ieguvuši profesionālo izglìtību ir konkurētspējīgi darba tirgū, jo ir nepieciešamība pēc dažādu profesiju un arodu pārstāvjiem. Piemēram, studenti, kas mācās eksperta pārstāvētajā institūcijāa, ir jau ieguvuši profesionālo izglītîbu, tādu kā oficianta, celtnieka, santehniḳa utt., un paši maksā par savām studijām. Ir arī atšksirīgi gadījumi, citiem jauniešiem ir turīgi vecāki, kas sedz studiju maksu. Vērtējot jaunieša konkurētspēju, kuram izglīīiba zemāka par vidējo un profesionālo, tā ir vāja. Lielākas iespējas ir tiem, kas jau apguvuši profesiju un apzinās to, ko vēlas sasniegt.

Eksperts B uzskata, ka ir iespējas atrast darbu vienmēr, ja cilvēks ir uzņēmīgs. Piemērs no dzīves, jaunietis no nelabvēlīgas ǵimenes spēj atrast vienkāršu darbu, piemēram, veikalā. Bet situācijā, kad jaunietis gaida, ka viss notiks pats no sevis, rodas problēmas. Problēmas ir arī jauniešiem ar nelāgiem ieradumiem. Jaunieša raksturam ir jābūt stipram un jābūt vēlmei darīt. 
Eksperts C un eksperts D uzskata, ka jaunietim ar zemāku izglītību par vidējo iekḷauties darba tirgū ir grūtāk, nekā jaunietim ar profesionālo izglītību.

Eksperts $\mathrm{C}$ atzīmēja, ka darba tirgū ir nepieciešamas gan zināšanas, gan profesionālas iemaņas, lai pilnvērtīgi spētu pildīt darba pienākumus.

Eksperts D atzīmēja, ka iegūstot profesionālo izglītību (absolvējot kādu mācību iestādi ar iegūtu konkrētu profesiju), iekļauties darba tirgū ir daudz vieglāk nekā jauniešiem ar tikko iegūtu vidējo izglīitību. Jauniešiem, kas izvēlējušies sākt strādāt jau pēc vidusskolas, būtu ieteicams iziet izglītību papildinošus kursus, lai vieglāk iekļautos darba tirgū. Augsti kvalificētu darbu iegūt ir vieglāk, ja ir uzsāktas vai pabeigtas studijas kādā no augstākās izglītības iestādēm.

Eksperts E uzsvēra, ka „bezdarbnieku struktūras analīze pārliecinoši liecina, ja nav kādi īpaši apstākḷi (piemēram, taupības pasākumi un štatu samazināšanas valsts pārvaldē, izglìīibā vai veselības aprūpē), cilvēkiem ar zemāku izglītîbas līmeni ir augstāks bezdarba līmenis, kā cilvēkiem ar augstāku izglītību. Arī cilvēki ar vidējo un profesionālo izglītību darba tirgū iekārtojas grūtāk, nekā cilvēki ar augstāko izglîtību. Tomēr jāṇem vērā, ka izglītotie cilvēki var vieglāk iekārtoties darbā vispār, bet ne vienmēr specialitātē, kurā iegūta izglītîba. Tas sevišķi raksturīgi cilvēkiem, kuri ieguvuši vidējo profesionālo izglîtību. Tas ir tāpēc, ka izglìtotiem cilvēkiem, ja tiem nav iespējams atrast darbu savā specialitātē, ir priekšrocības zemāk kvalificētos darbos salīdzinot ar zemāk izglītotiem strādājošajiem. Citiem vārdiem, skolotājs, kas nav varējis atrast darbu skolā vai atbilstošas kvalifikācijas nodarbē, zemākas kvalifikācijas darbus veic ,gudrāk” un apzinīgāk, nekā vidēji cilvēki bez izglītības, un darba devēji to izmanto (sevišķi ārzemēs, kur Latvijas skolotāji lasa zemenes)".

Arī eksperts E uzskata, ka jauniešu iekḷaušanos darba tirgū apgrūtina un augstāku bezdarba līmeni jauniešu vidū rada darba pieredzes trūkums - gan izglītotajiem, gan neizglītotajiem. Kā arī ir nepamatotas darba samaksas un attieksmes ambīcijas izglìtoto jauniešu vidū. Atvērta darba tirgus apstākḷlos ambīcijas tiek slāpētas emigrējot - ja tas nebūtu iespējams, izglītoto jauniešu bezdarba līmenis, iespējams, būtu augstāks.

Eksperts F uzsvēra, ka, ja cilvēks nevēlas mācīties, tas nozīmē, ka vinam nav nekādu dzīves mērķu. Tāpēc arī viņa attieksme pret saviem pienākumiem darbā varētu būt līdzīga kā pret mācībām. Tāds cilvēks nav uzṇēmīgs. Jo mācības un studijas ir visgrūtākais darbs.

Eksperts G un eksperts H uzskata, ka iespējas iekļauties darba tirgū ar izglītību, kas zemāka par vidējo vai profesionālo ir zemas, jo darba devēji no potenciālajiem darbiniekiem prasa izglītību un darba pieredzi.

Apkopojot ekspertu vērtējumus, darba autore atzīmē, ka jauniešiem, kam nav iegūta izglītîba, ir grūtāk iekḷauties darba tirgū, nekā jaunietim, kas apguvis kādu profesiju vai ieguvis izglītību. Atsevišksi eksperti uzsvēra, ka lielākas izredzes iekḷauties darba tirgū ir jauniešiem, kas apguvuši profesionālo izglītību un ieguvuši jau konkrētu profesiju. Pozitīvi vērtējams, ja š̄̄ profesija ir pieprasīta darba tirgū. Eksperti kopumā uzsvēra, ka būtiska nozīme ir izglīî̀bai, jo izglītotajiem bezdarbniekiem ir lielākas izredzes iekl̦auties darba tirgū, ja ne savai izglîtībai atbilstošā amatā, tad citā. Vairāku ekspertu skatījumā izglītotie bezdarbnieki ir kompetentāki darbu veicēji.

Kā Jūs vērtējat jaunieša, kurš šobrīd studē bakalaura studijās un vēl nav ieguvis augstāko izglītību, iespējas ieklauties darba tirgū?

Eksperts A uzsvēra, ka jauniešiem, kas studē ir grūtāk iekḷauties darba tirgū, jo ir grūtības atrast darbu atbilstošu profesijai. Gadījumi ir ļoti individuāli un atkarīgi no katra cilvēka personiskajām iezīmēm. Piemēram, zināms gadījums, kad zinoša un 
gudra meitene vēlējās kḷūt par arhitekti, bet gimenei nebija naudas, lai segtu studiju maksu. Jauniete vēejēās studēt RTU. Jauniete izveidoja kontaktus ar arhitektu biroju un pēc laika viņai tika piedāvāta iespēja bez maksas iziet praksi šajā birojā. Jauniete parādīja savas spējas izveidojot projektu, kas spēja konkurēt ar jau pieredzējušu arhitektu projektiem. Arhitektu biroja vadība nolēma meitenei finansēt studijas RTU, jo saskatīja potenciālu un piedāvāja turpināt ar viņiem sadarbību jau kā darba ņēmējai. Ir arī minams pretējs piemērs - jaunietis, students, kurš nemitīgi traucē lekcijas ar neatbilstošiem izteicieniem veic darba pienākumus, kuros ir paredzēta komunikācija ar klientiem. Jaunieti darba devēji ilgstoši darbā nepatur. Jaunietis neizprot, ka viņš nevar strādāt ar klientiem un turpina meklēt darbu klientu apkalpošanā. Šis jaunietis var veikt tikai darbu ar dokumentiem vai kur nav nepieciešamība pēc komunikācijas ar klientiem. Šis ir gadījums, kad jaunietis „neredz” savus trūkumus un nevēlas tos pieņemt, līdz ar to nespēj atrast darba vietu, kas viņam būtu piemērota.

Eksperts B uzsvēra, ka vieglāk iekḷauties darba tirgū ir jauniešiem, kas studē dabas zinātnes vai fiziku. Jauniešiem jāskatās, lai darbs saistîts ar profesiju un, lai tiktu sasniegti izvirzītie mērķi.

Eksperts G uzskata, ka iespējas ir atkarīgas no jaunieša ambīcijām, mazkvalificētu, bez prestiža, nepilna laika darbu atrast var.

Eksperts C uzskata, ka jaunietim, kurš studē, palielinās iespēja iekḷauties darba tirgū, tomēr bez praktiskas pieredzes iekļauties darba tirgū būs grūti. Darba devējiem ir prasība pēc darba pieredzes attiecīgajā nozarē. Pieredze nav pietiekama ar studiju ietvaros izietu praksi.

Eksperts D uzsvēra, ka jaunieša iekl̦aušanās darba tirgū, uzsākot bakalaura studijas, ir plašākas, nekā, ja jaunietis ieguvis tikai vidējo izglītību. Lielākoties darba devējs par sev tīkamāku izvēlēsies studentu, kurš uzsācis mācības augstskolā. Taču darba devējs vērtē arī jaunieša praktiskās zināšanas, tādēl lielākas iespējas iekḷauties darba tirgū būtu tādam jaunietim, kas iepriekš ieguvis pieredzi konkrētajā nozarē, speciālos kursos, prakses vietās u.c.

Eksperts $F$ vērtē pozitīvi studējoša jaunieša iespējas iekļauties darba tirgū. PSRS laikā izglîtību iegūt nebija vieglāk, īpaši tiem jauniešiem, kuriem vecāki nevarēja palīdzēt. Tāpēc daudzi ieguva izglītību vienlaicīgi strādājot kādu darbu, jo tas attīsta uzņēmību, atbildību un iemāca lietderīgāk izmantot laiku. Arī teoriju ir vieglāk apgūt, jo ir iegūta praktiskā pieredze.

Eksperts H uzskatīja par būtisku minēt sekojošu piemēru: ekspertam ir pazīstami jaunieši, kas izvēlējušies no sākuma iegūt izglîtību un pēc izglītības iegūšanas meklējuši darbu pilsētā, kurā dz̄ivo, sadarbībā ar NVA. Jauniešu vēlmes nesakrita ar darba piedāvājumiem. Viens no jauniešiem vēlējās strādāt Jelgavā nevis Rīgā, bet Jelgavā darba profesijā nebija. Vakantās darba vietas bija tikai mazāk kvalificētiem darbiem, par kuriem darba devējs bija gatavs maksāt mazāku algu par minimāli noteikto. Atsevišķos gadījumos jaunietis bija strādājis diennaktī pat $12 \mathrm{~h}$ un vairāk. Ar tādu algu nav iespējams izdzīvot. Līdz ar to uzņēmumos ir liela darba ņēmēju mainība, kuros ir šādas vakances. Algas ir zemas, darba vietas ir, bet samaksa tiek piedāvāta zema. Veidojas ,apburtais loks”, jo uzn̄ēmēji nespēj nomaksāt nodokḷus, tādēl maksā mazas algas, līdz ar to šis zemais algu līmenis nemainās.

Apkopojot ekspertu sniegtos viedokḷus par iepriekšminēto jautājumu, studējošajiem jauniešiem iespējas iekļauties darba tirgū ir atkarīgas no viņu pašu ambīcijām, vēlmēm un spējām. Eksperti kā nozīmīgu vērtē jaunieša pieredzi un iegūstamo izglītību. Darba devēju izvēli ietekmē arī nodokḷu apmērs. 
Izglīin̄bas līmeņa ietekme uz jaunieša iespējām iekḷauties darba tirgū ekspertu vērtējumā/

Influence of the education level on youth's entering the labour market in the experts' view

\begin{tabular}{|c|c|c|}
\hline Izglītības līmenis & Pozitivie aspekti & Problemātiskie aspekti \\
\hline $\begin{array}{l}\text { Izglìtības līmenis } \\
\text { zemāks par vidējo vai } \\
\text { profesionālo }\end{array}$ & Netika minēti pozitīvi aspekti. & $\begin{array}{l}\text {-Iespēja veikt tikai mazkvalificētus } \\
\text { darbus; } \\
\text {-zemāks atalgojums; } \\
\text {-zemāka konkurētspēja attiecībā pret } \\
\text { tiem jauniešiem, kas ieguvuši arodu } \\
\text { vai augstāko izglītību; } \\
\text {-darba devējam veidojas priekšstats kā } \\
\text { par cilvēku, kuram nav ambīciju un } \\
\text { mērķu. }\end{array}$ \\
\hline $\begin{array}{l}\text { Iegūta profesionālā } \\
\text { izglītība }\end{array}$ & $\begin{array}{l}\text {-Jaunieši, kas ieguvuši profesionālo } \\
\text { izglītību, ir konkurētspējīgāki darba } \\
\text { tirgū; } \\
\text {-darba tirgū nepieciešami dažādu } \\
\text { arodu un profesiju pārstāvji; } \\
\text {-jaunieši, kas ieguvuši arodu un } \\
\text { strādā, ir paši spējīgi maksāt par } \\
\text { turpmākajām studijām; } \\
\text {-jaunietis, kas ir apguvis profesiju, } \\
\text { apzinās nākotnes mērksus; } \\
\text {-profesionālo izglītību ieguvušajiem } \\
\text { jauniešiem ir vieglāk ieklıauties } \\
\text { darba tirgū, nekā jaunietim, kas } \\
\text { ieguvis tikai vidējo izglīīibu. }\end{array}$ & $\begin{array}{l}\text {-Nepietiekami apgūtas profesionālās } \\
\text { iemaņas un zināšanas; } \\
\text {-darba pieredzes trūkums; } \\
\text {-cilvēki ar vidējo vai profesionālo } \\
\text { izglītību darba tirgū iekārtojas grūtāk, } \\
\text { nekā cilvēki ar augstāko izglītību. }\end{array}$ \\
\hline $\begin{array}{l}\text { Augstākā izglìtība tiek } \\
\text { apgūta }\end{array}$ & $\begin{array}{l}\text {-Lielākas iespējas iekļauties darba } \\
\text { tirgū jaunietim, kas iepriekš ieguvis } \\
\text { pieredzi konkrētajā nozarē, } \\
\text { speciālos kursos, prakses vietās } \\
\text { u.c.; } \\
\text {-nozīme ir iegūstamās izglītības } \\
\text { līmenim un nozarei. }\end{array}$ & $\begin{array}{l}\text {-Jauniešiem, kas studē, ir grūtāk } \\
\text { ieklauties darba tirgū, jo ir grūtības } \\
\text { atrast darbu atbilstoši profesijai; } \\
\text {-pieredze nav pietiekama ar studiju } \\
\text { ietvaros izietu praksi. }\end{array}$ \\
\hline $\begin{array}{l}\text { Iegūta } \\
\text { izglītība }\end{array}$ & $\begin{array}{l}\text {-Cilvēks, kas ieguvis izglīitìbu, ir } \\
\text { konkurētspējīgāks darba tirgū, jo, ja } \\
\text { nespēj atrast iegūtajai izglītībai } \\
\text { piemērotu darbu, var veikt } \\
\text { profesionālāk un ,gudrāk" citus } \\
\text { darbus. }\end{array}$ & $\begin{array}{l}\text {-Darba devēju piedāvātais atalgojums } \\
\text { neatbilst potenciālā darbinieka } \\
\text { kvalifikācijai un vidējam atalgojuma } \\
\text { līmenim. }\end{array}$ \\
\hline
\end{tabular}

Avots: autores pētījums un konstrukcija

5.7. tabulā apkopots ekspertu vērtējums par jauniešu iespējām iekḷauties darba tirgū, izvērtējot iegūto izglìtības līmeni. 5.7. tabulā uzsvērti galvenie pozitīvie un negatīvie aspekti, kas ietekmē jaunieša konkurētspēju un iespējas iekḷauties darba tirgū, atkarībā no iegūtās izglītības līmeņa. Eksperti kā konkurētspējīgākos jauniešus vērtē tos, kas iegūst augstāko izglītību vai to jau ir ieguvuši. Atzin̄igi tiek vērtēti arī jaunieši, kas apguvuši darba tirgū pieprasītu profesionālo kvalifikāciju. Jaunieši ar izglītību, kas ir zemāka par vidējo vai profesionālo, tiek vērtēti kā nekonkurētspējīgi darba tirgū.

Kā Jūs vērtējat Nodarbinātības Valsts aǵentūras īstenotos jauniešu garantijas pasākumus, kuros ar Eiropas Savien̄̄bas Fondu atbalstu jaunietim tiek dota iespēja apgūt profesionālās pilnveides kursus, piem., valodas, grāmatvedība, projektu vadība, auto vadītäju kursi utt.? 
Eksperts A uzskata, ja jaunietis ir ieguvis izglītību, tad kursi ir kā papildinājums izglītîbai.

Eksperts B uzsvēra, ka nedrīkst kursus uzskatīt par augstāko prioritāti, tomēr tie ir vērtīgi. Ja jaunietis ir bezdarbnieks, tad šie kursi ir prioritāri.

Eksperts G vērtē kursus atzin̄̄gi, uzsverot, ka iespējas ir vairāk jāpopularizē visu veidu masu medijos.

Arī eksperts C NVA īstenotos pasākumus vērtē pozitīvi, uzsverot, ka jebkura šāda veida aktivitāte pilnveido jaunieti, tādejādi palielinās iespēja labāk iekḷauties darba tirgū.

Eksperts F kursus vērtē pozitīvi, piebilstot, ka vajadzētu to darīt kopā ar uzņēmējiem, lai naudu izlietotu to profesiju apguvei, kurās jaunietis varēs strādāt, jo viņam būs nodrošināta darba vieta. Tas vairāk jauno cilvēku motivēs.

Eksperts D uzskata, ka jaunietim, kurš kāda iemesla dēl ir palicis bez darba vai nav spējis to atrast, NVA piedāvātie kursi ir laba iespēja, lai iekḷautos darba tirgū, apgūstot kādu specialitāti. Šādu iespēju izmanto daudz jaunieši (un ne tikai), kas apgūst dažāda veida kursus - angl̦u valodu, grāmatvedību u.c., papildus iegūtajām zināšanām saṇemot arī ikmēneša stipendiju.

Eksperts E šos pasākumus nevērtē, jo rezultatīvie rādītāji par NVA pasākumiem jauniešiem neatspoguḷo ietekmi (nav zināms, cik no kursus beigušajiem ir iekārtojušies darbā un tur palikuši ilgāku laika periodu).

Savukārt eksperts H uzskata, ka šie pasākumi ir neefektīvi, ja pilsētā ir tikai 2 jaunieši, kas vēlas apgūt šos pasākumus.

Izvērtējot ekspertu sniegtos apgalvojumus, jāsecina, ka kursi ir nozīmīgi, jo sniedz iespēju jaunietim papildināt jau iegūto izglìtîbu un kursi darba pieteikumā uzskatāmi kā papildinājums iegūtajai izglîtībai. Jaunietim, kam nav vēl iegūta izglītība, kursi var būt kā apliecinājums un iespēja iegūt profesiju, piemēram, grāmatveža, manikīra, friziera u.c. NVA pasākumi veicina jaunieša konkurētspēju darba tirgū.

Kā Jūs vērtējat Nodarbinātības Valsts agentūras īstenotos jauniešu garantijas pasākumus, kuros ar Eiropas Savien̄̄bas Fondu atbalstu tiek piesaistīts līdzfinansējums jauniešu darba algas daḷējai segšanai?

Eksperti A, B, C, D, F un G NVA īstenotos jauniešu garantijas pasākumus, piesaistot ESF līdzfinansējumu jaunieša darba algas dạ̦ējais segšanai, vērtē pozitīvi.

Eksperts A uzsvēra, ka NVA garantijas pasākumi ir svarīgi, it īpaši, kad jaunietim tā ir pirmā darba vieta un jaunietis nav vēl apguvis nekādas prasmes. Darba devējam šāda iespēja ir kā atbalsts periodā, kamēr jaunietis apgūst veicamos pienākumus. Darba devējam arī nav tik liels risks nodarbināt jaunieti.

Eksperts B atzīmēja, ka vajag precīzi procesu noorganizēt, lai nerodas situācija, kad pieņem jaunieti darbā finansējuma dēḷ. NVA jāuzrauga, lai jaunieti nenodarbina tikai zemas kvalifikācijas darbos.

Eksperts C uzsvēra, ka ar šāda veida pasākumiem tiek dota iespēja jaunietim iegūt pirmo darba pieredzi, ko var uzrādīt arī CV.

Eksperts D uzsvēra, ka jaunietim tiek dota iespēja iegūt pirmo darba pieredzi. Uzņēmumiem šis ir labs risinājums, lai darbā varētu pieņemt cilvēku, maksājot tikai daļu algas (puse tiek segta no Eiropas Savienības fondu līdzekḷiem). Citāda situācija rodas, kad garantijas pasākums ir noslēdzies. Darba devējam uz līguma pamata ar NVA (atkarībā pēc nosacījumiem katrā konkrētajā pasākumā), nākas pieņemt cilvēku darbā un nu jau maksāt darbinieka algu (t.sk. visus nodokḷus) tikai no saviem līdzekļiem. Darba devēji izvērtē apstākḷıs, lai, pieņemot cilvēku darbā uz projekta laiku, arī pēc projekta noslēguma varētu turpināt darba attiecības. 
Arī eksperts $\mathrm{F}$ atzīmēja, ka jaunietim uzņēmumā būtu jāturpina strādāt arī pēc iesaistes garantijas pasākumā, kad līdzfinansējums vairāk netiek dots. ESF naudai ir jābūt izlietotai efektīvi.

Eksperts G uzskata, ka NVA pasākums ir labs, bet neuzskata, ka par šo pasākumu zina daudzi jaunieši.

Eksperts H uzskata savādāk - laukos, arī Latgales reǵionā, šie pasākumi būs neefektīvi.

Balstoties uz ekspertu vērtējumiem, jāsecina, ka līdzfinansējuma piesaiste jaunieša darba algai varētu tikt minēts kā viens no virzîtājspēkiem darba devēja izvēlei par jaunieša nodarbināšanu. Tomēer, ekspertu skatījumā, diskutabls ir jautājums par to, vai arī pēc iesaistes NVA jauniešu garantijas pasākumā darba devējsarī turpmāk vēlēsies un spēs nodarbināt jaunieti un piedāvāt ne mazāku atalgojumu, kā projekta laikā. Eksperti atzīmēja, ka NVA pasākumu ietvaros, jaunietis nedrīkstētu būt nodarbināts mazkvalificētos darbos.

Vai, Jūsuprāt, atvieglojumi nodokļu jomā spētu ietekmēt darba devēju lēmumu par jaunieša pieņemšanu darbā?

Eksperts A uzskata, ka nodokļu atlaides vienmēr ir interesējušas darba devējus, jo tad ir mazākas izmaksas jaunieša nodarbināšanai un apmācības procesam ir iespējams sniegt lielākus ieguldījumus.

Eksperts B uzskata, ka jaunietim jābūt ar stingriem uzskatiem un interese no jaunieša puses ir noteicošā. ja jaunietis ir pretendents, jābūt spēcīgam. Noteikti nepieciešama pedagoğiskā līdzdalība, lai izvērtētu kandidatūru.

Savukārt eksperts C un eksperts D uzskata, ka nodokḷu atvieglojumi varētu ietekmēt darba devēja lēmumu, taču tas nebūtu noteicošais faktors. Darba devējam jāizvērtē jaunieša iegūtā izglītība, zināšanas un praktiskās iemaņas, kā arī spēja ātri apgūt jaunas prasmes.

Eksperts $\mathrm{G}$ uzsver, ka ir jāierobežo laiks (12, 18 vai 24 mēneši), kad tiek piešķirti nodokḷu atvieglojumi.

Eksperts E uzsvēra, ka nodokļu atvieglojumi uzņēmējiem, kas nodarbina jauniešus, veicinātu labvēlīgāku attieksmi pret jauniešiem, ja ieguvums no nodokḷu atvieglojuma kompensētu darba devēja izmaksas, kas saistītas ar jaunieša nodarbināšanu.

Eksperts F uzskata, ka nodokḷu atlaides tikai dal̦ēji spētu ietekmēt darba devēja izvēli par jaunieša nodarbināšanu, jo nodokḷi jāmaksā visiem. Pretējā gadījumā var tikt veicināta neoficiāla nodarbinātība. Eksperts nodokḷu atlaides atbalsta tikai jauno tehnologiju ieviešanas gadījumos.

Kopumā eksperti nodokḷu atlaides darba devējiem, kas nodarbina jauniešus, vērtē pozitīvi, jo tas var ievērojami veicināt jaunieša kandidatūras apstiprināšanu uz vakanto amatu. Tomēr darba devēji arī vērš uzmanību uz jaunieša zināšanām un pieredzi.

Kädas, Jūsuprāt, ir jauniešu potenciālās iespējas uzsākt uznēēējdarbību, ņemot vērā mūsdienu ekonomisko situāciju?

Eksperti A, B un G uzskata, ka jauniešiem ir iespējas uzsākt uzṇēmējdarbību.

Eksperts A uzskata, ka iespēja uzsākt uzn̄ēmējdarbību ir tikai jauniešiem ar darba pieredzi, pretējā gadījumā jaunietis pats vēl nezin, kas viņam interesē un kādā jomā viņš vēlas sevi realizēt.

Eksperts B uzsvēra, ka ekonomikai vajag uzṇēmējus. Vajag vecināt normatīvo aktu "caurspīdīgumu". 
Eksperts G uzskata, ka jauniešus uzņēmējdarbībai ir jāgatavo vidusskolā vai tehnikumā. Jaunieši jāiedrošina, uzņēmējiem jāstāsta par pozitīvo pieredzi, registrācijas pamatprincipiem un VID kontroles sistēmu.

Eksperts C uzskata, ka jauniešiem iespējas uzsākt uzṇēmējdarbību nav vieglas, tomēr tās arī nav neiespējamas. Pastāv jauno uzṇēmēju atbalsta programmas un iespēja iesaistīties un izmantot biznesa inkubatoru piedāvātās iespējas. Svarīgākais, uzsākot biznesu, ir izveidot pārdomātu biznesa plānu, kurā tiktu ietverti arī nepieciešamie aprēķini.

Arī eksperts D uzskata, ka, ņemot vērā mūsdienu ekonomisko situāciju, jaunietim uzsākt uzṇēmējdarbību nebūt nav viegli, taču ne neiespējami. Mūsdienās jaunieši ir uzņēmīgi. Tam piemērs ir skolu jauniešu veidotās mācību firmas. Ir dzirdēts, ka no šìm idejām "dzimst" jaunie uznēmēji. Tāpat ir pieejamas dažādas jauno uzņēmēju atbalsta programmas. Ir iespējams piedalīties projektos ar iespēju iegūt finansējumu uzņēmējdarbības uzsākšanai. Iespējas ir dažādas, tikai jaunietim ir jāprot atrast nepieciešamo informāciju un pieejamos projektu konkursus, kuros varētu startēt. Labas idejas atbalsta arī biznesa inkubatori, šajos gadījumos svarīgi ir izstrādāt kvalitatīivu biznesa plānu, kurā būtu ietverti arī precīzi aprēķini. Ir pieejami lauku partnerības "Lielupe" izsludinātie projektu konkursi, kurā ir iespēja saņemt finansējumu jaunu lauksaimniecības uzṇēmumu dibināšanai, kā arī uzṇēmumiem, kas tiek dibināti tieši lauku apvidos.

Eksperts H uzskata, ka iekšējais pieprasījums ir ļoti zems, tomēr ir pozitīvi piemēri, kad, piemēram, kosmetolog̣e mazpilsētā veiksmīgi uzsāka uzņēmējdarbību un viņas pakalpojumiem ir liels pieprasījums. Reǵionos situācija ir ļoti problemātiska, ja neattīstām uzṇēmējdarbību, tad valsts zaudē. Iespēja uzsākt uzn̦ēmējdarbību ir, jo ir finanšu institūcijas "Altum" piedāvātās iespējas, biznesa inkubatori u.c. atbalsta instrumenti.

Izvērtējot ekspertu sniegtos viedokḷus, vieglāk uzsākt uzṇēmējdarbību ir tiem jauniešiem, kas jau ieguvuši izglìtību un darba pieredzi. Uzņēmējdarbības jomai un nozarei ir jābūt inovatīvai vai arī jābūt pieprasījumam pēc konkrētajiem pakalpojumiem. Iespējas uzsākt uzņēmējdarbību un pieejamo atbalsta instrumentu klāsts ir pietiekošs, tikai jāmāk tos izmantot un jāiegūst informācija par tiem.

Vai, Jūsuprāt, Latvijā pieejamie atbalsta instrumenti uzñ̄ēmējdarb̄̄bas uzsākšanai (t.sk. jauniešiem) ir nodrošināti pietiekošā līmen̄̄ (mikrokreditēšanas programmas, starta programmas uzņēmējdarbības uzsākšanai, mentoru konsultācijas, biznesa inkubatori, utt.)?

Eksperts A nav analizējis un pētījis informāciju saistībā ar šo jautājumu, nevar komentēt kāda ir šo uzṇēmumu attīstība un vai tie turpina darbību.

Eksperts B uzskata, ka mentoru konsultācijas ir labākais instruments jauniešiem. Jebkurš cilvēks praktiskos jautājumos ir labāks.

Eksperts G uzsver, ka televīzijas sižetos nav manījis šādu pasākumu informāciju pārraidīšanu. Varbūt sociālie tīkli ir iesaistīti, eksperts tiem neseko, taču zina, ka jaunieši seko. NVA, IZM, EM - šo vidi un arī citas ir jāizmanto daudz aktīvāk.

Eksperts C uzskata, ka Latvijā pieejamie atbalsta instrumenti jauniešu uzņēmējdarbības uzsākšanai ir daudzveidīgi, taču vienmēr vēl kāds pārdomāts atbalsta instruments var iedrošināt uzsākt uzñēmējdarbību. Tā kā pieejamie atbalsta instrumenti ir daudz, jaunietim noderīgi būtu jau skolas laikā iegūt pamatzināšanas, lai veiksmīgāk varētu orientēties piedāvājuma klāstā.

Eksperts D uzskata, ka atbalsta instrumenti jauniešu uzņēmējdarbības uzsākšanai ir pieejami, taču galvenais ir, vai jaunietis spēj orientēties piedāvātajā klāstā un izvēlēties tieši to, kas viņam būtu nepieciešams. Iespējams jau skolās 
jauniešiem vairāk būtu jāstāsta par nepieciešamo uzņēmējdarbības uzsākšanai, t.sk. kādi ir pieejamie atbalsta instrumenti un kādas prasības jāizpilda, lai varētu iegūt finansējumu uzṇēmējdarbības uzsākšanai. Biznesa inkubatoru piedāvātās iespējas jaunajiem uzṇēmējiem ir liels atspaids biznesa uzsākšanas procesā.

Arī eksperts F uzskata, ka instrumenti ir pieejami, tikai, sākot jau no bērnības, nepieciešams attīstīt katram jaunajam cilvēkam EK izstrādātās rekomendācijas par astonnu kompetenču attīstību izglîtības sistēmā, tai skaitā uzņēmējkompetenci, lai iedrošinātu kḷūt par pašnodarbinātu personu un veidot savu uzņēmumu. Pārējais jau ir atkarīgs no radošuma, idejas un vēlmes to komercializēt. Iespēju ir daudz, lai to îstenotu.

Eksperts E uzskata, ka "šo pasākumu sekmīgums ir atkarīgs no jauniešu spējas sagatavot efektīvus projektus un tos īstenot. Vai tādas ir - nevaru pateikt, jo NVA pasākumus šādā aspektā neanalizē - vērtē tikai, cik dalībnieki piedalījušies, un dažkārt- cik tūlìt iekārtoti darbā. Šāda analīze pa vecuma grupām nav veikta. Atbildi varētu iegūt, aptaujājot jauniešus, kas šādus piedāvājumus ir izmantojuši”".

Apkopojot ekspertu sniegtās atbildes, jāsecina, ka pieejamo atbalsta instrumentu klāsts un to pieejamība ir pietiekošā līmenī. No katra jaunieša individuāli atkarīgs, vai jaunietis spēj un māk uzṇēmējdarbības atbalsta instrumentus izmantot efektīvi un gudri, uzñēmējdarbības attīstīšanai ilgtermiņā.

Vai, Jūsuprāt, Lauku atbalsta dienesta izsludinātais projekts „Atbalsts jaunajiem lauksaimniekiem uznēmējdarbības uzsākšanai” (1. periodā EUR 6'950'466) spēs efektīvi veicināt jauniešu nodarbinātību lauku reğionos?

Eksperts A uzskata, ka šāds atbalsts ir efektīvs tādos gadījumos, ja jaunietis tajā nozarē, kurā vēlas darboties, ir ieguvis profesiju vai izglîtību, pretējā gadījumā efektivitāte nebūs. Šì projekta ietvaros noteikti vajadzētu padomāt ne tikai par finansiālu atbalstu, bet arī par konkrētu profesiju pārstāvju izglītības iegūšanas veicināšanu.

Eksperts B uzskata, ka šī iespēja vērtējama pozitīvi tad, ja, piemēram, jaunietis dzīvo ar vecākiem, ir pieejama infrastruktūra, tad iespējas ir. Savukārt Latgalē, kur ir slikti attīstīta infrastruktūra, tad iespēja realizēt šo projektu ir zema.

Eksperts G uzskata, ka projekta finansējums ir liels, bet vajadzētu vairāk popularizēt šo iespēju, izveidot projektu kaut vai par $0.1 \%$ no šīs summas, kas popularizētu esošās iespējas, uzrunājot mēerķa auditorijas.

Eksperts C uzskata, ka projekta ietvaros nodarbinātība lauku reǵionos palielinātos. Tas ir atkarīgs arī no pašiem jauniešiem un viņu aktīvas rīcības. Jāņem vērā arī tas, ka lauku reǵionos cilvēku skaits sarūk, kā arī tie, kas vēlas pārcelties uz laukiem un uzsākt tur uzņēmējdarbību, paliek arvien mazāk.

Eksperts D uzskata, ka LAD izsludinātais projekts "Atbalsts jaunajiem lauksaimniekiem uzņēmējdarbības uzsākšanai" veicinās nodarbinātību reǵionos. Tomēr viss atkarīgs arī no jauniešiem, cik uzṇēmīgi un ieinteresēti viṇi būs uzsākt uzņēmējdarbību lauku reǵionos. Bieži vien jaunieši pēc lauku skolas beigšanas pārcelıas uz pilsētu vai arī dodas studēt uz kādu no lielākajām Latvijas pilsētām. Šādā gadījumā ir svarīgi ieinteresēt jaunieti pēc studiju beigšanas atgriezties laukos.

Eksperts F uzsver, ka finansējums ir lietderīgi jāizmanto, plašākus komentārus nesniedzot.

Balstoties uz iepriekšminētajiem ekspertu viedokḷiem, tiek secināts, ka projektu vajadzētu vairāk popularizēt, lai veicinātu efektīvāku finansējuma izmantošanu, kā arī rosinātu plašāku sabiedrības interesi.

Nozīmīga ir projekta procesa administrēšana un kontrole, lai iegūtu pēc iespējas lielāku atdevi no ieguldītajiem finansiālajiem resursiem. Pirms jaunietim tiek piešķirts 
finansējums lauksaimniecībā, nozīmīga ir aroda apgūšana, lai nerastos situācija, kad nav izpratnes par to, kā turpināt attīstīt uzṇēmējdarbību. Atbalstam no LAD būtu jābūt pirmos inkubācijas gadus, līdz uzṇēmums ir nostiprinājies.

Par pasākuma realizāciju plaša informācija interneta resursos nav pieejama un par pasākuma turpmākajiem rezultātiem var tikai veidot diskusijas. Jautājums tika iekḷauts ekspertu intervijā, jo šăds atbalsts ir pieejams un jauniešiem no reǵioniem šāda projekta esamība ir nozīmīga. Tā ir viena no iespējām tiem, kas vēlas uzsākt uzņēmējdarbību saistītu ar lauksaimniecību. LAD projekta "Atbalsts jaunajiem lauksaimniekiem uzņēmējdarbības uzsākšanai" realizācija ir jākontrolē, lai iegūtu pēc iespējas lielāku atdevi no ieguldītajiem resursiem. Pirms jaunietim tiek piešķirts finansējums lauksaimniecībā, nozīmīga ir jaunieša apmācīšana konkrētajam arodam, lai nerastos situācijas, kad nav izpratnes, kā efektīvi veicināt uzsāktās uzñēmējdarbības attīstību. Atbalstam no LAD vajadzētu būt pirmos inkubācijas gadus, līdz uzṇēmums ir nostiprinājies.

5.8. tabulā apkopots iepriekšminēto atbalsta instrumentu analīze jauniešu iekḷaušanās darba tirgū veicināšanai ekspertu skatījumā. Atbalsta instrumentiem definēti nozīmīgākie pozitīvie un negatīvie aspekti.

Kopumā vērtējot ekspertu viedokli par atbalsta instrumentiem, kā visefektīvākais instruments tiek uzskatīts izglītības papildināšana kursos, kas var veicināt amata iegūšanu. Savukārt profesionālo kursu apgūšana sasniedz iespēju jaunietim apgūt kādu profesiju, piemēram, manikīra, friziera utt., kas var veicināt jaunieša iekḷaušanos darba tirgū, kḷūstot par algotu darbinieku vai pašnodarbinātu personu.

Eksperti tika aicināti izteikt viedokli par to, kas būtu jādara valsts institūcijām, lai sekmētu jauniešu iekḷaušanos darba tirgū.

Lūdzu, miniet, Jūsuprāt, svarīgākos valsts institūciju īstenojamos pasākumus jauniešu darba tirgus situācijas stabilizēěsanai Rīgā un Latvijas lielākajās pilsētās.

Eksperts A uzsvēra, ka visa uzņēmējdarbība koncentrējas pilsētās.

Eksperts B uzskata, ka darba devējiem plašāk jāinformē valsts institūcijas par darba iespējām un vajadzībām. Nepieciešams mobilizēt darba devējus aktīvi informēt sabiedrību.

Eksperts G uzsver, ka pasākumiem trūkst publicitātes.

Eksperts C uzskata, ka "vienus no nozīmīgākajiem pasākumiem jauniešu darba tirgus stabilizēšanai īsteno NVA, piedāvājot plašu klāstu ar projektiem un citām iespējām. Šie pasākumi ir vieni no svarīgākajiem. Piemēram, NVA aicina darba devējus iesaistīties „,Jauniešu garantijas” atbalsta pasākumā „Pirmā darba pieredze jaunietim", kur darba devējam ir dažādi ieguvumi no dalības pasākumā. Šobrīd aktuāls ir ESF projekts „PROTI un DARI”.

Projekta mērksis ir motivēt un aktivizēt jauniešus, kuri nemācās, nestrādā vai neapgūst arodu un nav registrēti NVA kā bezdarbnieki. Projekta ietvaros tiks sniegts atbalsts apmēram 5260 jauniešiem vecumā no 15 līdz 29 gadiem, kuri nemācās, nestrādā vai neapgūst arodu un nav reg̣istrēti NVA kā bezdarbnieki. Šāda veida aktivitātes ir noderīgas un veicina jauniešu veiksmīgu iesaistīšanos darba tirgū".

Eksperts D uzskata, ka svarīgākos valsts institūciju īstenotos pasākumus jauniešiem īsteno NVA. NVA jauniešiem piedāvā iesaistīties „Jauniešu garantijas” pasākumos, kur jaunietim ir iespēja iegūt pirmo darba pieredzi. Jaunietis strādā kādā konkrētā uzņēmumā, iegūst gan praktiskas iemaņas, gan pirmo darba pieredzi, kā arī saņem ikmēneša stipendiju. Pagājušajā gadā tika uzsākts arī ESF projekts "PROTI UN DARI” (tā īstenošanas terminsš: no 2014. līdz 2018. gadam). 
Atsevišksi eksperti uzsvēra NVA īstenoto pasākumu nozīmīgumu jauniešu darba tirgus situācijas stabilizēšanā. Eksperti uzsvēra, ka atbalsta pasākumiem trūkst publicitātes, kā arī nav informētības sabiedrībā.

Uzṇēmējdarbība koncentrējas pilsētās, līdz ar to pilsētās ir arī lielākas iespējas jauniešiem iekļauties darba tirgū.

Lüdzu, miniet, Jūsuprāt, svarīgākos valsts institūciju ìstenojamos pasākumus jauniešu darba tirgus situācijas stabilizēěs̆nai Latvijas lauku reǵionos.

Eksperts A uzsvēra, ka jāsekmē jauniešos interese par konkrētu profesiju apguvi, kurās ir nepietiekams speciālistu skaits, piemēram, mežsaimniecībā, lauksaimniecībā, lopkopībā, veterinārmedicīnā utt., attīstot lauku reǵionus.

Eksperts B atzīmēja teritoriālās reformas nozīmi, lai teritorijas padarītu pievilcīgas. Latvijā ir mazs iedzīvotāju blīvums. Piemēram, labs piemērs ir Dānija un Holande, kur ir pievilcīga vide, bet Latvijā to realizēt nebūtu iespējams. Ir izvēle pārdomāti taisīit reformu, jāveido vietas, apgabali, kur var veidot unikālu nodarbošanos. Piemēram, purvu vai ezeru veidot pievilcīgu tūristiem un tajā arī audzēt dzērvenes, ko pārdot uzṇēmējiem, kas tās uzpērk. Jāmeklē jaunas iespējas, saglabājot tradicionālo. Arī Latgalē, kur tradicionāli ir amatniecība, jāmeklē unikālas iespējas.

Eksperts C uzskata, ka NVA ir viena no institūcijām, kas piedāvā jauniešiem iesaistīties pasākumos neatkarīgi no deklarētās dzīves vietas. Lauku reǵionu jaunieši arī tiek aicināti izmantot NVA iespējas.

Arī eksperts D uzskata, ka "NVA ir viena no valsts institūcijām, kas piedāvā jauniešiem no lauku reǵioniem iesaistīties pasākumos darba tirgus situācijas stabilizēšanai. Jau vairākus gadus sadarbībā ar biedrību piedalījies NVA pasākumā, ko finansē ES no ESF līdzekḷiem - ESF projekts "Jauniešu garantijas" atbalsta pasākumā „Darbam nepieciešamo iemaņu attīstība nevalstiskajā sektorā” (projektā var iesaistīt jauniešus vecumā no 18 līdz 24 gadu vecumam, kas nemācās vai nestrādā). Projekta ietvaros organizācijā nodarbina vairākus jauniešus sešu mēnešu periodā. Šo mēnešu periodā jaunietis iegūst pieredzi un praktiskās iemaņas, kā arī ikmēneša stipendiju. Projektā tiek iesaistīti arī pilsētas jaunieši, taču pārsvarā pasākumā iesaistām jauniešus no laukiem”.

Eksperts E uzsver, ka svarīgākie valsts institūciju īstenojamie pasākumi: uzņēmības (uzņēmējdarbības) prasmju izkopšana izglīīībā, līdzsvarotas attīstības plānošana teritorijās (līdzsvarota infrastruktūras attīstība), pētniecība un jauniešu bezdarba problēmu noskaidrošana. Pašvaldības ir atbildīgas par teritoriju attīstību un ir vairāk ieinteresētas, lai viņu teritorijā nebūtu jauniešu bezdarbs.

Atbalsta instrumentu izvērtējums par jauniešu iespējām iekḷauties darba tirgū ekspertu vērtējumā uzskatāmi parādīts 5.8. tabulā, uzsverot nozīmīgākos pozitīvos un problemātiskos aspektus katram atbalsta instrumentam. 


\section{Atbalsta instrumentu izvērtējums par jauniešu iespējām iekḷauties darba tirgū/ Evaluation of support instruments for youth to enter the labour market}

\begin{tabular}{|c|c|c|}
\hline Atbalsta instruments & Pozitīvie aspekti & Problemātiskie aspekti \\
\hline $\begin{array}{l}\text { NVA piedāvātie } \\
\text { profesionālās } \\
\text { pilnveides } \\
\text { kursi }\end{array}$ & $\begin{array}{l}\text {-Kursi ir kā papildinājums } \\
\text { izglìtībai; } \\
\text {-kursos iespējams apgūt specialitāti, } \\
\text { kas iespējams palīdz iekḷauties } \\
\text { darba tirgū. }\end{array}$ & $\begin{array}{l}\text {-Kursus nedrīkst uzskatīt par augstāko } \\
\text { prioritāti, kas jāsasniedz, tomēr tie ir } \\
\text { vērtīgi; } \\
\text {-kursi ir neefektīvi, ja iegūstamajai } \\
\text { specialitātei reǵionā nav pieprasījuma } \\
\text { un par kursiem interesi izrāda mazs } \\
\text { jauniešu skaits. }\end{array}$ \\
\hline $\begin{array}{l}\text { Līdzfinansējums } \\
\text { daḹejai jaunieša darba } \\
\text { algas segšanai } \\
\text { (sadarbībā ar NVA) }\end{array}$ & $\begin{array}{l}\text {-Darba devējam finansiāli šāda } \\
\text { iespēja ir liels atbalsts, kamēr } \\
\text { jaunietis apgūst veicamos darba } \\
\text { pienākumus; } \\
\text {-darba devējs uzņemas mazāku } \\
\text { risku, nodarbinot jaunieti bez } \\
\text { profesionālajām iemaņām; } \\
\text {-iespēja iegūt jaunietim pirmo darba } \\
\text { pieredzi; } \\
\text {-pozit̄̄vi, ja pēc projekta noslēguma } \\
\text { iespējams turpināt darba attiecības } \\
\text { ar jaunieti. }\end{array}$ & $\begin{array}{l}\text {-Pastāv iespēja, ka darba devējs } \\
\text { jaunieti nodarbinās mazkvalificētos } \\
\text { darbos; } \\
\text {-nedrīkstētu rasties situācija, ka darba } \\
\text { devējs pieñem darbā jaunieti tikai } \\
\text { tādēl, lai gūtu finansiālu atbalstu; } \\
\text {-negatīvi, ja pēc projekta laika darba } \\
\text { devējs nav ieinteresēts turpināt darba } \\
\text { attiecības ar jaunieti; } \\
\text {-pēc projekta noslēguma pastāv } \\
\text { iespēja, ka darba devējs var jaunietim } \\
\text { piedāvāt turpināt strādāt par mazāku } \\
\text { darba algu. }\end{array}$ \\
\hline $\begin{array}{l}\text { Atvieglojumi nodoklu } \\
\text { jomā }\end{array}$ & $\begin{array}{llr}\text {-Mazākas } & \text { izmaksas } & \text { jaunieša } \\
\text { nodarbināšanai; } & \\
\text {-lielākus ieguldījumus } & \text { iespējams } \\
\text { sniegt } & \text { jaunieša } & \text { apmācības } \\
\text { procesam. } & & \end{array}$ & 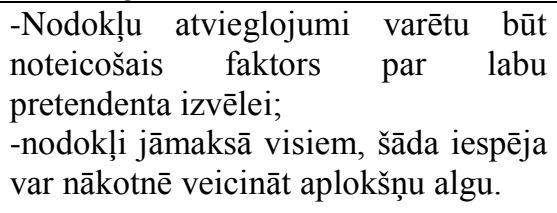 \\
\hline $\begin{array}{l}\text { Uznnèn } \\
\text { uzsāak }\end{array}$ & $\begin{array}{l}\text {-Iespēja uzsākt uzṇēmējdarbību un } \\
\text { efektīvi turpināt uzņēmējdarbības } \\
\text { attīstību ir jauniešiem, kam ir } \\
\text { praktiskā pieredze; } \\
\text {-pietiekamā apjomā ir pieejami } \\
\text { dažādi atbalsta instrumenti; } \\
\text {-studiju procesā iespējas izveidot } \\
\text { jauniešu mācību uzņēmumus, kas, } \\
\text { atsevišksos gadījumos, turpina savu } \\
\text { darbību un attīstîbu. }\end{array}$ & $\begin{array}{l}\text {-Nepieredzējis jaunietis nav } \\
\text { apzinājies, ko viņš vēlētos sasniegt un } \\
\text { kādā jomā sevi realizēs; } \\
\text {-nepieciešams normatīvo aktu } \\
\text { caurspīīīgums un pretimnākšana } \\
\text { šādai iniciatīvai no valsts institūcijām, } \\
\text { uzņēmējiem, izglīin̄bas iestādēm utt.; } \\
\text {-zems pieprasījums pēc } \\
\text { pakalpojumiem un produkcijas, liela } \\
\text { konkurence. }\end{array}$ \\
\hline $\begin{array}{l}\text { Atbalsta instrumenti } \\
\text { uzņēmējdarbības } \\
\text { attīstībai } \\
\text { (mikrokreditēšanas } \\
\text { programmas, starta } \\
\text { programmas, mentoru } \\
\text { konsultācijas, biznesa } \\
\text { inkubatori utt.) }\end{array}$ & $\begin{array}{l}\text {-Piedāvātie instrumenti r ir } \\
\text { daudzveidīgi, tomēr vēl kāds } \\
\text { pārdomāts atbalsta instruments } \\
\text { varētu iedrošināt ruzsākt } \\
\text { uzṇēmējdarbību; } \\
\text {-nepieciešams zināšanas par } \\
\text { uzn̦ēmējdarbību sniegt skolas laikā, } \\
\text { attīstot uzņēmējkompetenci. }\end{array}$ & $\begin{array}{l}\text {-Nepietiekama atbalsta instrumentu } \\
\text { popularizēšana masu medijos; } \\
\text {-jaunieša spēja orientēties atbalsta } \\
\text { instrumentu klāstā var būt } \\
\text { nepietiekama. }\end{array}$ \\
\hline $\begin{array}{l}\text { Atbalsts jaunajiem } \\
\text { lauksaimniekiem }\end{array}$ & $\begin{array}{l}\text {-Atbalsts ir efektīvs tādā gadījumā, } \\
\text { ja jaunietis ir apguvis profesiju } \\
\text { jomā, kurā vēlas darboties; } \\
\text {-liels ipatsvars jauniešu dodas } \\
\text { studijās uz pilsētām, pēc studiju } \\
\text { beigšanas svarīgi ir radīt iespēju } \\
\text { šiem jauniešiem atgriezties } \\
\text { dzimtajā vietā un radīt interesi par } \\
\text { šo projektu. }\end{array}$ & $\begin{array}{l}\text {-Vajadzētu domāt ne tikai par } \\
\text { finansiālu atbalstu, bet arī par } \\
\text { konkrētu profesiju pārstāvju izglītības } \\
\text { iegūšanas veicināšanu; } \\
\text {-projekts realizējams tad, ja ir } \\
\text { nepieciešamā infrastruktūra, ja } \\
\text { infrastruktūra nav attīstīta, iespējas ir } \\
\text { zemas. }\end{array}$ \\
\hline
\end{tabular}

Avots: autores pētījums un konstrukcija 
Apkopojot ekspertu viedokļus, darba autore secina, ka NVA jauniešu garantijas pasākumos aktīvi tiek iesaistîti jaunieši no lauku reǵioniem, ne tikai no pilsētām. Nozīme ir jaunieša uzṇēmējspēju attīstīšanai un interesei par izvēlētās uzņēmējdarbības nozari, kā arī iniciatīva uzņemties atbildību. Nozīme ir arī iegūtajai izglîtībai, un kā jau minēts iepriekš, arī pieredzei. Pētījumi rāda, ka pilsētās jaunieši ir ar augstāku izglītības līmeni kā jaunieši, kas nāk no lauku reǵioniem, līdz ar to nozīmīga ir jauniešu iekl̦aušanās darba tirgū iesaistoties atbalsta pasākumos, kas var paaugstināt profesionālās iemaņas un papildināt izglītības līmeni.

Pēc ekspertu domām, lauku teritorijās lielāka atbildība par jauniešu iekļaušanos darba tirgū ir pašvaldību kompetencē, jo pašvaldības ir ieinteresētā puse, kas būs labuma guvējas no nodarbinātiem jauniešiem, saņemot lielāku nodokḷu apjomu. Pašvaldību kompetencē ietilpst reǵionu attīstība, līdz ar to arī uzņēmējdarbības attīstības veicināšana, savukārt pašvaldības darbu regulē arī valsts institūcijas, kas koncentrējas galvaspilsētā un izstrādā attiecīgo likumdošanas ietvaru, kas ietekmē pašvald̄̄bu darbu. Nozīmīga ir savstarpējā mijiedarbība starp ieinteresētajām pusēm, lai veiksmīgi attīstītu darba tirgu.

Lai noskaidrotu izglītības institūciju pārstāvju viedokli par jauniešu iekḷaušanos darba tirgū un to izglītības kvalitāti Latvijas reǵionos, tika organizēta apaļā galda diskusija, kurā piedalījās 6 nozares eksperti (skat. 5.9. tab.).

5.9. tabula/ Table 5.9.

\section{Izglītības institūcijas pārstāvja ieņemamais amats un pārstāvētais reğions $(\mathbf{n}=6) /$}

Position and represented region of a representative from an educational institution

$$
(n=6)
$$

\begin{tabular}{|c|l|l|l|}
\hline Apzīmējums & \multicolumn{1}{|c|}{ Ien̦emamais amats } & \multicolumn{1}{c|}{ Reğions } & \multicolumn{1}{c|}{ Institūcija } \\
\hline A & Dr.sc.admin., vecākā pasniedzēja & $\begin{array}{l}\text { Kurzemes } \\
\text { reğions, Rīgas } \\
\text { reǵions }\end{array}$ & Universitāte \\
\hline B & Dr.oec., pētniece & R̄igas reǵions & Universitāte \\
\hline C & Direktors & Vidzemes reǵions & Vidusskola \\
\hline D & Direktora vietnieks & Rīgas reğions & Vidusskola \\
\hline E & Direktore & Latgales reǵions & Tehnikums \\
\hline F & Dr.paed., direktore & Rīgas reğions & Pētījumu centrs \\
\hline
\end{tabular}

Avots: autores pētījums un konstrukcija

Eksperti tika lūgti paust viedokli koncentrētā veidā. Eksperte F uzsvēra, ka nozīmīga ir jaunieša motivācija, ieinteresētîba un vēlme veikt gan darba pienākumus, gan iziet praksi. Ir bijuši gadījumi, kad jaunietis vēlas iziet institūcijā praksi, bet viņš vēlas saņemt pretī arī visādus „labumus” (atalgojumu augstāku par vidējo, veselības apdrošināšanu u.tml.), bet nav gatavs piedāvāt savas prasmes, zināšanas.

Eksperts D un eksperts C uzsvēra, ka vajadzētu izskaust vispārējās vidējās izglītības prasību kā obligātu. Lielāka uzmanība būtu jāvērš uz profesionālo izglītību.

Eksperte E uzsvēra, ka vislielākā problēma ir tā, ka jaunietim nav motivācijas, nav konkrēti mērksi un uzdevumi, ko viņš vēlētos turpmāk dzīvē sasniegt. Tehnikuma absolventi ir izgājuši praksi, apguvuši iemaņas pie darba devējiem, viņi saņem atalgojumu par praksi, pēc prakses beigšanas šie skolēni zina, kur viņi strādās, viņiem jau ir darba vietas. Problēmas ir augstskolu absolventiem, kur mācoties akadēmisko izglītību, nepagūst profesionālās iemaņas. Konkurētspējīgāki ir tie jaunieši, kas ir apguvuši arodu tehnikumā, piemēram, santehniķa profesiju. Mūsdienās ir tendence 
uzskatīt arodu kā apkaunojumu vai kā mazsvarīgu kvalifikāciju, tomēr tā nav, šie speciālisti ir konkurētspējīgi darba tirgū. Daugavpilī jauniešiem nav arī problēmu ar krievu valodas zināšanām. Nozīmīga problēma ir arī izglītības kvalitātei, mācību programmām, kurās tiek apgūti tādi studiju priekšmeti, kuros jaunieši neapgūst tādas iemaņas, prasmes, zināšanas, kuras viņiem varētu būt noderīgas arī nākotnē. Konkurētspējīgāka bija ,agrākā” izglītība, esmu pateicīga par to, ka skolā ǵeogrāfiju iemācījos tik labi, ka tagad visu varu uzreiz kartē atrast, bet pajautājot mūsdienu skolēniem, kur piemēram atrodas Itālija, viṇi to nespēj atrast.

Eksperte A uzsvēra, ka krievu tautības jaunieši ir konkurētspējīgāki darba tirgū par latviešu tautības pārstāvjiem, jo viniiem ir divas sarunvalodas, ko viņi ikdienā izmanto. Valodas ir l̦oti būtiskas. Lielu lomu spēlē arī ǵimenes attieksme pret skolēna attieksmi pret mācībām un turpmāk pret studijām, ja ğimene skolēnu nemotivē mācīties un gímenē ikdienā nerada labvēlīgu vidi, kā arī interesi skolniekā par mācībām, tad rodas situācija, kad skolniekam un pēc tam arī sasniedzot jaunieša vecumu, šīs zināšanas ir nepilnīgas. Arī skolotājas raksturs un attieksme pret skolēniem/ studentiem ietekmē jaunieša vēlmi mācīties un apgūt zināšanas, jāspēj mācību priekšmeti pasniegt interesanti.

Arī eksperts $\mathrm{C}$ atzīmēja, ka jaunieši no Latgales reǵiona valodu zināšanu dēl ir konkurētspējīgāki darba tirgū.

Eksperts C uzsvēra, ka vidusskolā strādāja jauns fizikas skolotājs, kas ļoti ieinteresēja skolēnus apgūt fiziku, visi l̦oti gribēja apmeklēt nodarbības un priekšmetu sāka mācīties, kļuva ieinteresēti. Tomēr skolotājs aizgāja no skolas, jo viņam piedāvāja daudz konkurētspējīgāku atalgojumu. Problēma arī ir atalgojuma sistēmā. Skolotāju algas ir zemas.

Eksperte F atzīmēja: , kādu algu var vēlēties jaunietis, ja skolotājs uz papīra saņem 450 EUR mēnesī??" Problēma arī ir jaunieša uzstādījumos, mācību iestādes jauniešos veicina domāšanu - uzreiz būs labs darbs, liels atalgojums, „viegls” darbs, pabeidzot izglītības iestādi jaunietis domā, ka uzreiz tiks novērtēts kā labs un konkurētspējīgs speciālists, reti kuram paveicas, ne visi uzreiz iegūst labas profesijas, jāsaprot, ka pa karjeras kāpnēm ir jāvirzās pamazām. Uzreiz visu nevar iegūt.

Eksperts C uzsvēra, ka paziņa, pabeidzot kosmetologiijas augstskolu, pirms diviem gadiem sāka strādāt par algu 150 EUR mēnes̄î, šobrīd viña pelna virs 1000 EUR. Galvenais ir apzināties, ko jaunietis vēlas sasniegt.

Eksperte E atzīmēja, ka jauniešiem bieži vien nākas saskarties ar situāciju, kad jāstrādā vairāku darbinieku vietā, institūcija ekonomē uz darbiniekiem, nekas nemainās, izaugsmes iespējas praktiski nav, jo vadošos amatos algo paziņas.

Eksperte B uzsvēra, ka vēlme strādāt un atrast darbu ir saistīta ar izglītības programmām, to ko māca izglìtîbas iestādēs, tās ir tendētas uz Rietumu praksi. Jaunieši „sapn,o” par augstām algām, to, ka iegūs uzreiz labu amatu. Būtu jāpiekopj Padomju pieeja - jāmāca jaunietim amats, un ja jaunietis būs labs speciālists, vin̄š attiecīgajā jomā mācīsies tālāk.

Eksperts D uzsvēra, ka svarīgi, lai valstī tiktu nodrošinātas pensijas tādā līmenī, lai pensionārs ar to spētu izdzīvot un nebūtu jāstrādā, tad veidotos brīvās darba vietas un nebūtu bezdarbniekiem jāmaksā pabalsti. Šāda prakse ir Somijā, nekur neredz strādājam pensionārus.

Diskusijas dalībnieki uzsvēra, ka augstākās izglītības iestādes nesagatavo darba tirgum nepieciešamos speciālistus, piem., profesionālo izglītības programmu absolventus pietiekamā līmenī. Valstī sāk trūkt „roku darbs”, jo arods tiek uzskatīts par „zemu” izglītîbu. Vajadzētu mainīt sabiedrības domāšanu. 


\section{5. nodaḷas secinājumi/ Conclusions for Chapter 5}

Lai analizētu jauniešu bezdarbnieku iekḷaušanas scenārijus Latvijas darba tirgū, tika pielietota hierarhiju analīzes metode. Zinoši eksperti tikai aicināti pēc hierarhiju analīzes metodes izvērtēt scenārijus jauniešu bezdarbnieku nodarbinātības veicināšanai Latvijas darba tirgū. Analizējot iegūtos ekspertu vērtējumus, ņemot vērā sešu kritēriju grupu pozīcijas, eksperti kā optimālāko scenāriju ir izvēlējušies 3. scenāriju: ,Valsts institūciju un uzn̄èmēju sadarbības scenāriju”. Scenārija pamatā paredzēti nodokḷu atvieglojumi uzņēmējiem, kas nodarbina jauniešus (prioritātes vektora koordināte 0.27 ).

Kā otrs optimālākais scenārijs ekspertu skatījumā bija vērtēts 2. scenārijs: „Izglìtības iestāžu un uzņēmēju sadarbības scenārijs” (prioritātes vektora koordināte 0.24). 1. scenārija: „Jauniešu uzņēmējdarbības vides attīstību veicinošă scenārija” un 4. scenārija: „ES līdzdalības scenārija prioritātes vektora koordināte ir 0.23”- šie scenāriji ekspertu skatījumā vērtēti kā mazsvarīgākie scenāriji. Darba autore aprēķināja ar̄i ekspertu izvērtēto scenāriju ticamību, C.R. vidējais katram no ekspertiem, kas piedalìjās hierarhiju analīzes procesā, nepārsniedza 10\% (pię̧aujama arī 20\%) ticamību.

Darba autore ekspertu intervijas ietvaros vēlējās noskaidrot ekspertu viedokli par jauniešu potenciālajām iespējām uzsākt uzņēmējdarbību. Kā secināts iepriekšējās nodaļās, viens no veidiem, kā paaugstināt jauniešu nodarbinātību un samazināt bezdarbu, ir uzn̦ēmējdarbības un pašnodarbinātības attīstība. Nozīmīgi ir jau mācību laikā un studiju procesā vērst jauniešu uzman̄̄bu un radīt jauniešos interesi par uzṇēmējdarbību, veicinot jauniešos zināšanu uzkrāšanas vēlmi un to izmantošanu praksē. Lai spētu pilnvērtīgi nodrošināt zināšanu pārnesi no profesionālajām mācību iestādēm un augstākās izglîtības iestādēm, nozīmīgi ir mācību un studiju periodā jauniešus ieinteresēt un tiem rosināt uzņēmējspēju attīstīšanu. Piel̦aujams, ka atsevišķi jaunieši, kas ieguvuši kādu arodu vai profesiju, attīstot tiem uzñēmējspējas un radot interesi par potenciālajām iespējām nākotnē, spētu attīstīt savu uzñēmējdarbību.

Ekspertu viedoklis par jauniešu iespējām uzsākt uzņēmējdarbību bija atšķirīgs. Atsevišksi eksperti uzsvēra, ka Latvijā ir nepieciešami jauni uzñēmumi, tomēr, lai attīstītu uzņēmējdarbību, jauniešiem pirms tam ir jābūt darba pieredzei, pretējā gadījumā rezultāts varētu būt negatīvs. Sekmēt uzn̦ēmējdarbības attīstību jauniešu vidū varētu izglìtības iestādes, kur jau skolas laikā jauniešos radītu interesi par uzņēmējdarbības pamatprincipiem. Tādā gadījumā tie jaunieši, kuriem ir interese par uzņēmējdarbību, jau laikus sāktu interesēties par iespējām un virzītu savus mērķus.

Ekspertu vērtējumā, nozīmīga ir jaunās paaudzes veiksmīga integrācija darba tirgū, inovatīvu ideju radīšana un realizācija uzņēmējdarbībā, kas nodrošinās jaunās paaudzes nākotnes perspektīvas starptautiskā mērogā.

Eksperti uzsvēra, pašvaldībām ir nozīmīga loma jauniešu iekḷaušanās darba tirgū veicināšanā, nodrošinot jauniešiem pievilcīgu vidi uzṇēmējdarbības uzsākšanai un atbalsta pasākumu piesaistei reǵionam. Bez pašvaldību aktivitātēm jauniešu uzñēmējdarbības iespējas ir ierobežotas.

Eksperti pozitīvi vērtējuši NVA īstenotos "Jaunatnes garantijas" pasākumus un akcentējuši to nozīmi jaunieša nākotnes attīstīšanā. Eksperti uzsvēra, ka lielākas iespējas iekļauties darba tirgū ir jauniešiem, kas apguvuši profesionālo izglītību vai ieguvuši izglîtību, jo darba devēji vērtē jaunieša zināšanas un izglîtības līmeni. Izglītība norāda uz jaunieša pozitīvajām pusēm- jaunietis ir apguvis izglītību un tas norāda uz jaunieša ambīcijām. 
NVA ,Jaunatnes garantijas” pasākuma ietvaros pieejamais līdzfinansējums jaunieša darba algas daḷējai segšanai ir augsti vērtējams finansiāls atbalsts darba devējam, kamēr jaunietis apgūst veicamos darba pienākumus. Darba devējs, nodarbinot šādu jaunieti, uzņemas mazāku risku, kā arī sniedz jaunietim iespēju iegūt pirmo darba pieredzi. Pasākumam, ekspertu skatījumā, ir arī negatīvās puses, piemēram, darba devējs var jaunieti nodarbināt mazkvalificētos darbos un jaunietis var neapgūt profesionālās prasmes, pēc pasākuma beigām darba devējs var izlemt par jaunieša turpmāku nenodarbināšanu vai atalgojuma samazināšanu.

Atvieglojumi nodokḷu jomā ekspertu skatījumā veicinātu jauniešu nodarbinātību, jo uzņēmējam būtu mazākas izmaksas, saistībā ar jaunieša nodarbinātību, kā arī rastos finansiāli lielākas iespējas ieguldīt jaunieša apmācības procesā. Tomēr nodokḷu atvieglojumiem var būt arī negatīva ietekme - jaunietim nākotnē varētu tikt veicināta atalgojuma neoficiāla izmaksa.

Ekspertu vērtējumā nozīmīga ietekme uz jaunieša iespējām iekḷauties darba tirgū ir iegūtajam izglītības līmenim, apgūtajiem papildu kursiem un praktiskā darba pieredzei. Jaunietim bez izglītības ir lielāka varbūtība tikt nodarbinātam mazkvalificētos darbos un saņemt mazāku atalgojumu, kā arī vinam ir zemāka konkurētspēja attiecībā pret tiem jauniešiem, kas ieguvuši augstāko izglītỉbu vai apguvuši profesiju. Indivīds bez izglītības rada priekšstatu darba devējam kā par cilvēku ar zemām ambīcijām un prasībām pret sevi un ar iespējamu tamlīdzīgu attieksmi pret veicamo darbu.

Apkopojot izglītības iestāžu pārstāvju diskusijā apspriesto informāciju, ir secināts, ka jāmaina vērtību sistēma ar akcentu uz atbildīgas audzināšanas koncepcijas īstenošanu, lai jauniešiem būtu vieglāk iekḷauties darba tirgū. 


\section{SECINĀJUMI/ \\ CONCLUSIONS}

1. Līdz ar straujo industriālo attīstību mainās arī tās radīto seku ietekme uz indivīda sociālo dzīvi. Ir aizvien lielāka nepieciešamība pēc intelektuālā kapitāla. Ja jaunietis neiegūst arodu vai izglīî̄bu un praktisku darba pieredzi, viņam arvien vairāk palielinās draudi kḷūt par bezdarbnieku.

2. Bezdarbs rada draudus ne tikai pašam indivīdam kā sabiedrības loceklim, bet arī kopumā ietekmē valsts attīstību un ekonomikas izaugsmi. Nozīmīga ir savstarpējā mijiedarbība starp cilvēkkapitālu un valsti, tās attīstības instrumentiem.

3. Jauniešu bezdarbu ietekmējošie faktori ir cieši saistīti ar tendencēm darba tirgū, kā arī valsts ekonomisko situāciju kopumā. Jau 20. gs. 80. gados ārvalstu pētîjumos daudz tika diskutēts par jauniešu bezdarba problemātiku un apspriesti tā cēloṇi, izstrādātas teorijas, lai meklētu kopsakarības starp bezdarbu ietekmējošajiem faktoriem un rosinātu pasākumu realizāciju to novēršanai.

4. ES dalībvalstīs nepastāv vienota koncepcija, kā novērst bezdarba problēmu. Nozares teorētiķu un praktiķu skatījumā norisinās diskusijas par tādiem ietekmējošiem faktoriem kā nepietiekama infrastruktūras attīstība, pieredzes un izglīî̄bas trūkums, neapmierinātība ar darba algu utt.

5. Tādu autoru kā Berghmana (Berghman), Hammera (Hammer), Rūma (Room) u.c. pētījumi liecina, ka jaunieši, kuriem agrīni ir grūtîbas iekḷauties darba tirgū, saskaras ar iekḷaušanās problēmu visa mūža garumā. Tas mazina jaunieša iespējas attīstîties darba tirgus prasībām atbilstošā līmenī.

6. Latvijai ir saistošas veiktās iestrādes stratēgiskajos dokumentos, kuros minēta jauniešu uzņēmējdarbības attīstības aktualitāte un veicināšana. Tomēr jāuzsver, ka plānošanas dokumentos nav skaidri izteikti attīstības scenāriji un uzdevumi konkrētajām atbildīgajām valsts institūcijām, kam būtu jārealizē šie pasākumi.

7. ES ir atbilstošs dokumentu ietvars, kas attiecināms arī uz Latvijas iedzīvotājiem. Dokumenti nodrošina kopēju sistēmu, lai veicinātu vienlīdzīgu attieksmi starp ES iedzīvotājiem neatkarīgi no to reliğijas vai uzskatiem, iespējamas invaliditātes, vecuma vai seksuālās orientācijas par pieejamību darbam vai profesijai, paaugstinājumam amatā, profesionālajai izglīî̄bai, darba nosacījumiem un arī iespējai iesaistîties noteiktās organizācijās.

8. Globālajā ekonomikas krīzē par galveno ekonomikas atveseļošanas pamatnostādni kḷūst bezdarbā esošo personu iesaiste darba tirgū un to prasmju attīstīšana atbilstoši plānotajiem karjeras nākotnes scenārijiem.

9. Kā viens no galvenajiem jauniešu bezdarba (it îpaši ilgstošā bezdarba) samazināšanas iespējamajiem risinājumiem ir iesaiste uzņēmējdarbības attīstības un nodarbinātības veicināšanas atbalsta programmās, ar kuru palīdzību jauniešiem iespējams realizēt inovatīvu biznesa ideju, darboties savā specialitātē un kḷūt pašnodarbinātiem.

10. Negatīvais aspekts, ko sekmē pasaules ekonomikas globalizācija, ir jaunatnes intelektuālā kapitāla aizplūšana uz ārvalstīm. Tas veicina Latvijas iedzīvotāju skaita samazināšanos un inovatīvu produktu un pakalpojumu attīstību ārvalstīs. Inovatīvu produktu un pakalpojumu radīšana un realizācija ir viens no priekšnoteikumiem veiksmīgai uzņēmējdarbības attīstībai starptautiskā līmenī, kas nodrošina lielāko daļu no uzņēmuma ienākumiem, kā arī veicina 
valsts tautsaimniecības attīstību, līdz ar to jāveicina jauniešu izglītības iegūšana inovatīvās nozarēs.

11. Pēc statistikas datiem darba meklējumu aktivitātes līmenis lauku teritorijās un mazpilsētās ir zemāks, kas norāda uz iedzīvotāju pasivitāti, meklējot darbu. İpaši lauku iedzīvotāji ir vairāk ,izstumti” no darba tirgus - daudzi ilgstoši ir bezdarbnieki, rezultātā zaudē cerības atrast darbu un paliek ekonomiski neaktīvi. Iepriekšminētie faktori norāda uz bezdarba radītajām dziḷajām sekām lauku teritorijās.

12. Balstoties uz darba teorētisko bāzi, tika aprēksināti Latvijas zaudējumi no bezdarbā esošajiem jauniešiem nesaražotā IKP dēl 2008.-2015. gadā, zaudējumi šajā laika periodā ir 5233.18 milj. EUR.

13. Izvērtējot atšķirības starp jauniešu bezdarbnieku iekḷaušanos darba tirgū Latvijas Republikas pilsētās un lauku teritorijās, secināts, ka lielākas iespējas iekḷauties darba tirgū ir jauniešiem, kas dzīvo un mācās republikas pilsētās vai galvaspilsētā. Šos jauniešus mazāk ietekmē tādi faktori kā infrastruktūras attīstība, reǵiona ekonomiskā attīstība, darbavietu pieejamība, informācijas trūkums par darba piedāvājumiem un izmaksas „no un uz” darbavietu. Visvairāk jauniešus darba meklējumos ietekmē slikti attīstīta infrastruktūra, ko kā traucējošu atzīmējuši 50\% jauniešu no Rēzeknes, 34\% no Pierīgas, 29\% no Jelgavas un $29 \%$ no lauku reǵioniem.

14. Faktori, kas jauniešiem visvairāk traucē iekļauties darba tirgū Latvijā, ir neapmierinātība ar piedāvāto darba samaksu, nepieciešamās darba pieredzes trūkums un mazais brīvo darbavietu īpatsvars.

15. Dažādos Latvijas reǵionos situācija ir atšķirīga. Visvairāk jauniešu, kurus neapmierina piedāvātā darba samaksu, ir no Jelgavas (72\%), Jūrmalas (59\%), lauku teritorijām (58\%), Rēzeknes (57\%), novadu pilsētām (54\%) un Liepājas $(52 \%)$.

16. Vislielākā respondentu gradācija novērojama, saskaroties ar nepieciešamās darba pieredzes trūkumu. No aptaujas respondentiem, kuri nebija norādījuši izglītības līmeni un atzīmējuši izvēlni - „cits”, 40\% bija saskārušies ar vislielāko darba pieredzes trūkuma ietekmi darba meklējumos, kā arī 38\% no respondentiem ar iegūtu augstāko profesionālo izglītību, 37\% ar bakalaura izglītību, 34\% ar nepabeigtu augstāko un $29 \%$ ar vidējo izglīîibu saskārās ar pieredzes trūkumu darba pienākumu veikšanai.

17. Izvērtējot faktora „,maz brīvu darbavietu” ietekmi uz jaunieša iespējām atrast darbu, tas bija traucējošs $67 \%$ jauniešu no Liepājas, $58 \%$ no citām republikas pilsētām vai mazpilsētām un 57\% no Jelgavas. Lauku teritorijās situāciju jaunieši vērtējuši līdzvērtīgi Pierīgā dzīvojošajiem jauniešiem, kopumā kā traucējošu darbavietu trūkumu minējuši $47 \%$.

18. Vislielākais jauniešu īpatsvars, kuri saskārušies ar nepietiekamu infrastruktūras attīstību, ir no Latgales reǵiona (50\%). Arī jaunieši no Pierīgas (34\%) ir saskārušies ar nepietiekamu infrastruktūras attīstību, jo nokḷūšanai līdz darbavietai ir jāizmanto vairāki transporta veidi vai arī transporta līdzekḷi kursē reti.

19. Darba devēju un ekspertu intervijās secināts, ka līdzfinansējuma pieejamība jaunieša darba algas dal̦ējai segšanai sadarbībā ar NVA veicinātu darba devēju interesi par jauniešu nodarbināšanu.

20. Balstoties uz ekspertu un darba devēju intervijās iegūto viedokli, nodokḷu atvieglojumi veicinātu uzņēmēju vēlmi nodarbināt jauniešus. Kā pozitīvie 
aspekti minēti uzṇēmēju riska samazināšana, nodarbinot jaunieti bez pieredzes un uzņēmēja finanšu resursu novirzīšana jaunieša praktisko iemaņu apgūšanai.

21. Gan darba devēju, gan ekspertu vērtējumā nozīmīgs ir jaunieša iegūtais izglītības līmenis, kas norāda uz jaunieša ambīcijām, spējām, prasmēm un zināšanām. Jauniešus bez izglītības var nodarbināt tikai mazkvalificētos darbos, savukārt, ja izglītots jaunietis nevarēs atrast iegūtajai izglìtībai atbilstošu darbu, mazkvalificētāku darbu šis jaunietis, iespējams, veiks atbildīgāk.

22. Analizējot darba devēju intervijās iegūtos rezultātus secināts, ka darba devējiem Kurzemes reǵionā ir problēmas ar darbinieku apmācību konkrēta amata pienākumu izpildei, jo nav iespējas izveidot sadarbību ar izglītības iestādēm. Komunikācijas trūkums starp darba devējiem un izglītības iestādēm darba devēju skatījumā ir arī Zemgales reǵionā un Latgales reǵionā, kur trūkst speciālisti inženierzinātņu u.c. tehnisko zinātņu jomā.

23. NVA „Jaunatnes garantijas” pasākumi veicina jauniešu konkurētspēju darba tirgū, jo jauniešiem ir iespējas iegūt profesionālo izglītību vai papildus iegūtajai izglītībai iziet kursus, kā arī iegūt praktiskās iemaņas. Tomēr ierobežotā finansējuma dẹl pasākumos tiek iesaistīts salīdzinoši neliels jauniešu skaits.

24. Ekspertu vērtējumā, pielietojot hierarhiju analīzes metodi, secināts, ka optimālākais scenārijs jauniešu bezdarbnieku nodarbinātības veicināšanai Latvijā ir 3. scenārijs: „Valsts institūciju un uzņēmēju sadarbība”, paredzot nodokḷu atvieglojumus uzṇēmējiem, kas nodarbina jauniešus.

25. Pētniecisko darbu un attīstības prognožu izstrādi apgrūtina statistisko datu neesamība par bezdarbniekiem Latvijas reǵionos.

\section{IDENTIFICĒTĀS PROBLĒMAS UN PRIEKŠLIKUMI/ IDENTIFIED PROBLEMS AND THEIR POSSIBLE SOLUTIONS}

- PIRMĀ PROBLĒMA. Latvijā un ES nepastāv vienots jauniešu vecuma posma iedalījums, lìdz ar to bezdarbā esošo jauniešu problēmas teorētiskai analīzei nav vienota pamatojuma.

Problēmas risinājums. Latvijas Zinātņu akadēmijas Terminologijas komisijai jāizstrādā ES dokumentu ietvaram atbilstošs jauniešu vecuma posma definējums, lai, veicot pētîjumus ES ietvaros, varētu skaidri identificēt šo vecuma posmu un ar to saistītos problēmjautājumus.

- OTRĀ PROBLĒMA. Uz Latviju attiecināmajā normatīvajā un plānošanas dokumentu ietvarā nav skaidri definētas institūcijas un to veicamie uzdevumi jauniešu nodarbinātz̄bas veicināšanai.

Problēmas risinājums. Labklājības ministrijai: likumdošanas ietvarā, plānošanas dokumentos definēt konkrētās atbildīgās institūcijas (NVA, VIAA u.c.) par realizējamajiem pasākumiem, mērķiem un uzdevumiem, kas atbildīgajai institūcijai jāveic bezdarba situācijas samazināšanai un jauniešu bezdarbnieku nodarbinātības veicināšanai.

- TRE ̌́̃̄ PROBLĒMA. Lielākas iespējas jauniešiem atrast darbu ir Latvijas galvaspilsētā un republikas pilsētās, kurās koncentrēts lielāks uzñèmumu 
īpatsvars. Lauku reǵgionos un mazpilsētās bezdarbs ir nozīmīga ekonomiskā problèma, kuru risināt var tikai ilgstošā laika periodā.

\section{Problēmas risinājums}

- Pašvaldībām, Finanšu ministrijai, Satiksmes ministrijai jāveicina infrastruktūras attīstība, radot labvēlīgākus apstākļus indivīdiem no lauku regiioniem un mazpilsētām, nokļūšanai līdz darba vietām lielākajās republikas pilsētās un galvaspilsētā.

- Finanšu ministrijai jāievieš nodokḷu atvieglojumi uzṇēmējiem, kas nodarbina jauniešus.

- Finanšu ministrijai jāievieš sankcijas uzṇēmumiem, kuros ir nodarbināti vairāk nekā 250 darbinieki un praktikantu proporcija ir zemāka par 4\% no kopējā darbinieku skaita, nosakot sankciju $0.1 \%$ apmērā no uzn̄ēmuma izmaksātajām algām.

- CETURTĀ PROBLEMAA. Latvijā ir nepietiekama komunikācija starp izglītības institūcijām un darba devējiem.

\section{Problēmas risinājums}

- Profesionālās izglītības iestādèm sagatavot nozares speciālistus atbilstoši uzñēmēju specifiskajām prasībām.

- Jauniešiem apgūt profesiju darba tirgū pieprasītās un nepiesātinātās nozarēs.

- Darba devējiem veidot ciešu sadarbību ar Izglītības un zinātnes ministriju kā arī ar izglītības iestādēm, informējot institūcijas par konkrētā uzṇēmuma prasībām.

- Nodarbinātības valsts aǵentūrai sadarbībā ar darba devējiem "Jauniešu garantijas" pasākumos jāiesaista divas reizes lielāks jauniešu bezdarbnieku ipatsvars.

- Izglītības iestādēm sadarbībā ar darba devējiem jāsekmē jaunieša praktisko iemaņu apgūšana prakses laikā.

- Nodarbinātības valsts aǵentūrai, izglītības iestādēm un vakanču portālu uzņēmumiem sadarbībā ar darba devējiem jāizveido vienota platforma informācijas apmaiņai par kvalifikācijas paaugstināšanu, prakses un darba iespējām, programmām pašnodarbinātības uzsākšanai utt.

- PIEKTĀ PROBLẼMA. Latvijas un ES stratēgiskajos plānošanas dokumentos uzsvērta jauniešu uzņēmējdarbības un pašnodarbinātības aktualitāte, tomēr Latvijā ir nepietiekams finansiālais un administratīvais atbalsts, $k \bar{a}$ arī nav pietiekami nodokļu atvieglojumi jaunajiem uzņēmējiem.

\section{Problēmas risinājums}

- Ekonomikas ministrijai, Finanšu ministrijai jānodrošina nodokḷu atlaižu piemērošana jaunajiem uzņēmējiem pirmajos uzņēmējdarbības inkubācijas gados.

- Lauku atbalsta dienestam jāatbalsta jauno uzṇēmumu attīstība Latvijas lauku teritorijās, nodrošinot finansējuma pieejamību jaunajiem lauksaimniekiem ES projektu ietvaros.

- Izglītības un zinātnes ministrijai, Labklājūbas ministrijai un tās padotībā esošajai Nodarbināt̄̄bas valsts aǵentūrai jāpaaugstina jauniešu bezdarbnieku informētība par uzṇēmējdarbības atbalsta pasākumiem un pieejamība tiem, paredzot atbilstošu finansējumu.

- Latvijas valstij piederošajai “Attīstības finanšu institūcijai Altum” jāattīsta ES fondu līdzekḷu piesaiste jauniešu pašnodarbinātības un uzṇēmējdarbības 
finansēšanai, paredzot speciāla finansiālā un administratīvā atbalsta programmas izveidošanu.

\section{SLĒDZIENI/ CONCLUSION}

- Promocijas darba uzdevumi ir izpildīti, tā mērķis ir sasniegts un izvirzītā hipotēze ir pierādīta.

- Izpētīti jauniešu bezdarbu ietekmējošie faktori, to tendences Latvijas Republikas pilsētās un lauku teritorijās.

- Apkopots bezdarba situācijā esoša indivīda tiesiskais regulējums Latvijas un ES dokumentu ietvarā.

- Izpētītas jauniešu darba tirgus tendences Latvijas Republikas pilsētās un lauku teritorijās, kā arī aprēķināti Latvijas ekonomiskie zaudējumi no jauniešu bezdarba.

- Noskaidrots darba devēju un ekspertu viedoklis par jauniešu iespējām iekļauties darba tirgū.

- Apzinātas problēmas, kas veicina jauniešu bezdarbu ietekmējošo faktoru attīstību un izstrādāti priekšlikumi jauniešu bezdarba mazināšanai.

- Izstrādāti scenāriji jauniešu bezdarbnieku iekḷaušanai darba tirgū Latvijā.

- Iegūtie pētījuma rezultāti ir izmantojami pašvaldībām, NVA, LAD, IZM, LM, SM, EM, FM, VAS “Attīstības finanšu institūcija Altum" un izglītības institūcijām, veicinot jauniešu iekḷaušanos darba tirgū, kā arī uzņēmējiem, nodarbinot jauniešus. 


\section{IZMANTOTĀS LITERATŪRAS AVOTI/ LIST OF THE BIBLIOGRAPHIC SOURCES USED}

1. Acemoglu A., Autor D. (2011) Skills, Tasks and Technologies: Implications for Employment and Earnings. In: Handbook of Labour Economics, Vol. 4b. Elsevier B. V., p. 1043-1171.

2. Adams C., Fenton P. R., Larsen F. (1987) Potential Output in Major Industrial Countries. In: World Economic and Financial Surveys, Staff Studies for the World Economic Outlook, The Research Department of the International Monetary Fund, p. 1-14.

3. Akadēmiskā terminu datubāze AkadTerm. Bezdarbs [b.g.] [tiešsaite] [skatīts 2015.g. 21.jūl.]. Pieejams: http://termini.lza.lv/term.php?term=bezdarbs\&list=\&lang=LV\&h=yes

4. Amantova- Salmane L. (2011) Reǵions- reǵionālās attīstības un integrācijas pamatjēdziens. No: Starpreǵionālās ekonomiskās integrācijas attīstības stratēgija ES apstāklos, Starptautiskās zinātniskās conferences materiāli 2010. gada 3.- 4. decembris, Daugavpils: Daugavpils Universitātes Akadēmiskais apgāds "Saule", 7. -10. lpp.

5. Anča G., Barisa L., Cimdin̦š P. (2002) Tautas attīstība. Rīga: Apvienoto Nāciju Attīstības programma, 266 lpp.

6. An EU Strategy for Youth: Investing and Empowering - A Renewed Open Method of Coordination to Address Youth Challenges and Opportunities (2009). Communication from the Commission to the Council, The European Parliament, The European Economic and Social Committee and the Committee of the Regions, p. 1-15.

7. Apvienoto Nāciju Organizācijas Statūti (1945) [tiešsaiste] [skatīts 2013.g. 25.febr.]. Pieejams: http://www.humanrights.lv/doc/vispaar/anostat.htm

8. Armstrong H., Taylor J. (1985) Regional Economics and Policy, Oxford: Philip Allan Publishors.

9. Arulampalam, W. (2001) Is Unemployment Really Scarring? Effects of Unemployment Experiences on Wages. In: The Economic Journal, No.111, p. 585-606.

10. Atbalsts jauniešu reǵionālajai mobilitātei (2014) [tiešsaite] [skatīts 2015. g. 16. jūl.]. Pieejams: http://www.nva.gov.lv/index.php?cid=433\&mid=440\&txt=3651

11. Atbalsts jaunajiem lauksaimniekiem uzñēmējdarbības uzsākšanai [b.g.] [tiešsaite]: Lauku atbalsta dienests [skatīts 2016. g. 7. janv.]. Pieejams: http://www.lad.gov.lv/lv/atbalsta-veidi/projekti-un-investicijas/atbalstapasakumi/6-1-atbalsts-jaunajiem-lauksaimniekiem-uznemejdarbibasuzsaksanai-223

12. Atbalsta programmas uzņēmējiem [b.g.] [tiešsaite]: Latvijas Investīciju un attīstības aǵentūra [skatīts 2016. g. 7. janv.]. Pieejams: http://www.liaa.gov.lv/lv/atbalsta-programmas-uznemejiem

13. Audas, R., Berde, E., Doliton, P. (2005) Youth Unemployment and Labour Market Transitions in Hungary. In: Education Economics, No. 13., Vol.1., UK: London, Routledge, p.1 -25.

14. Augstāko un profesionālo mācību iestāžu absolventu profesionālā darbība pēc mācību beigšanas (2007) Eiropas Savienības struktūrfondu nacionālā programma „Darba tirgus pētījumi”, projekts „Latklājības ministrijas pētîjumi” Nr. VPD1/ESF/NVA/04/NP/3.1.5.1/0001/0003, Rīga: LU, 241 lpp. 
15. Augstskolās, koledžās pamatstudijās uznemto studentu sadalījums pēc dzìvesvietas (2015) [tiešsaite]: Centrālās statistikas pārvaldes datu bāze [skatīts 2015.g. 20.2 apr.]. Pieejams: http://data.csb.gov.lv/pxweb/lv/Sociala/Sociala_ikgad_izg1/IZ0300.px/?rxid= cdcb978c-22b0-416 a-aacc-aa650d3e2ce0.

16. Augstskolu un koledžu studentu sadalījums pēc vecuma un dzimuma (2015) [tiešsaite]: Centrālās statistikas pārvaldes datu bāze [skatīts 2015.g. 20. apr.]. Pieejams: http://data.csb.gov.lv/pxweb/lv/Sociala/Sociala_ikgad_izgl/IZ0241.px/?rxid=

17. Augsts bezdarbs Latvijā - nolemtība vai izvēle? (2010) [tiešsaite]: A/S Swedbank, [skatîts 2015. g. 06. okt.]. Pieejams: https://www.swedbank.lv/files/analitiskie_materiali/swedbank_petijums/Swedb ank_Petijums_2010_12_LV.pdf

18. Babbie E., Halley F. (1995) Adventures in Social Research. Data Analysis Using SPSS for Windows, USA: Pine Forge Press. 346 pp.

19. Balan M., Uzlau C. M., Ene C. M. (2012) Evolutions of Unemployment among the Young over the Economic and Financial Downturn. In: Annales Universitatis Series Oeconomica, 14 (1), p. 193-203.

20. Balan M., Vasile V. (2013) Features, Dimensions and Costs of Romanian "NEET" Youth in the European Context. In: Proceedings of the IER Seminar in Empirical Economics, p.141-158.

21. Balan M. (2014a) Analysis of Unemployment among Young Individuals from Romania by Econometric Methods. In: International Auditing \& Risk Management, No. 3 (35), p. 90-97.

22. Balan M. (2014b) Youth Labour Market Evolutions at Regional Level in Romania. In: Internal Auditing \& Risk Management, Vol. 9, Issue 2, p. 29-37.

23. Bell N. F. D., Blanchflower G. D. (2009) Youth unemployment: Déjà vu?, Division of Economics, Stirlong Management School, University of Stirling and IZA, p. 1-55.

24. Berghman, J. (1995) Social Exclusion in Europe: Policy Context and Analytical Framework. In: The Measurement and Analysis of Social Exclusion, Bristol: Policy Press, p. 10-28.

25. Berghman, J. (1997) The Resurgence of Poverty and the Struggle against Exclusion: A New Challenge for Social Security in Europe? In: International Social Security Review, 50 (1), p. 3-21.

26. Berthelot Y. (1995) European and General Global issues influencing employment and unemployment, Global employment: An International Investigation into Future Work. Tokyo: United Nations University Press. p. 3041.

27. Bertola G., Ichino A. (1996) Wage Inequality and Unemployment: US Versus Europe, Discussion Paper No. 1186, Centre for Economic Policy Research, London, p. 13- 66.

28. Bezdarbnieka pabalsts (2015) [tiešsaiste]:Valsts sociālās apdrošināšanas aǵentūra, publicēts 2015. gada 27. aprīlī. [skatīts 2015. g. 23. jūlijs]. Pieejams: http://www.vsaa.lv/lv/pakalpojumi/stradajosajiem/bezdarbnieka-pabalsts

29. Bezdarbnieku un darba meklētāju atbalsta likums (2002): Saeima 2002. gada 9. maija noteikumi. Latvijas Vēstnesis, Nr. 80 (2655), 2002. gada 29. maijāa, [tiešsaiste] [skatīts 2014. g. 06. janv.]. Piejams: http://likumi.lv/doc.php?id=62539 
30. Biavaschi C., Eichhorst W., Giulietti C., Kendzia J. M., Muravyev A., Pieters J., Rodriguez- Planas N., Schmidl R., Zimmermann K. F. (2013) Youth Unemployment and Vocational Training [tiešsaiste]: World Development Report 2013. [skatīts 2015. g. 01. marts]. Pieejams: http://siteresources.worldbank.org/EXTNWDR2013/Resources/82580241320950747192/8260293-1320956712276/82610911348683883703/WDR2013_bp_Youth_Unemployment.pdf

31. Bikse V. (2003) Makroekonomika. Tālmācības kurss. Rīga: SIA "Izglītības soli'”. 314 lpp.

32. Bikse V. (2005) Ekonomikas attīstības problēmas mūsdienās. No: Latvijas Universitātes raksti Vadības zinātnē, 690. sējums, 160.-174. lpp.

33. Bikse V. (2009) Latvijas progress uzñēmējdarbības izglītības attīstībā pēc iestājas Eiropas Savienībā. Rīga: Eiropas Savienības pārstāvniecība Latvijā, 47. lpp.

34. Bikse V. (2015) Makroekonomika: teorija un politika. Liepāja: Liepājas Universitāte, iespiests "LiepU LiePA tipogrāfijāa", 69. - 91. lpp.

35. Biznesa inkubatori [b.g.] [tiešsaite] [skatīts 2015. g. 27. jūn.]. Pieejams: http://www.liaa.gov.lv/lv/biznesa-abc/biznesa-inkubatori

36. Blanchard O. J., Summers L.H. (1986) Hysteresis and the European Unemployment Problem. In: National Bureau of Economic Research, Macroeconomic Annual, p. 15.

37. Blanchflower D. G., Freeman R. B. (2000) Youth Employment and Joblessness in Advanced Countries. Chicago: University of Chicago Press, p. 1-16.

38. Bubany S. T., Hansen J. I. C. (2011) Birth Cohort Change in the Vocational Interests of Female and Male College Students. In: Journal of Vocational Behaviour, Vol. 78, p. 59-67.

39. Buligina, I., Putans, R., Sloka, B. (2014) Coherence of Work Based Learning and Regional Development in Latvia. In: Ekonomika un uzņēmējdarbība, Nr. 25, p. 19- 26.

40. Buligina I. (2015) The Approaches of Public Administration in the Development of Competitive Labour Force in Vocational Education and Training in Latvial Publiskās pārvaldes pieejas konkurētspējīga darbaspēka sagatavošanā profesionālajā izglītībā Latvijā. Latvia: University of Latvia, Faculty of Economics and Management, Doctoral Thesis, 247 lpp.

41. Carayannis E. G., Barth T. D., Campbell D. F. J. (2012) The Quintuple Helix innovation model: global warming as a challenge and driver for innovation [tiešsaite]: Journal of Innovation and Entrepreneurship. [skatīts 2015. g. 15. febr.]. Pieejams: http://www.innovationentrepreneurship.com/content/1/1/2,15 February 2015.

42. Cien̄̄gu darbu jauniešiem (2.daļa) [b.g.] ESF projekts "Latvijas Brīvo arodbiedrību savienības administratīvās kapacitātes stiprināšana", 4.2. aktivitāte "Normatīvo aktu un politikas dokumentu ekspertīze", Ekspertīze par Sociālo jomu un darba tirgus attīstību, 23. lpp.

43. Clark K. B., Summers L. H. (1982) The Dynamics of Youth Unemployment. In: The Youth Labor Market Problem: Its Nature, Causes, and Consequences, University of Chicago Press, p. 199 - 234.

44. Chubrik, A., Haiduk, K., Pelipas, I., Tochitskaya, I., Shymanovich, G. (2009) Social Protection and Social Inclusion in Belarus, European Commission, Directorate General for Employment, Social Affairs and Equal Opportunities, p. 1-82. 
45. Chubrik A., Kazlou A. (2012) Belarus Country Study, Belarus: Minsk, EuropeAid/130215/C/SER/Mult, Project "Costs and benefits of Labour Mobility Between the EU and the Eastern Partnership Partner Countries", p. 173.

46. Chubrik A., Kazlou A. (2013) Costs and benefits of Labour Mobility Between The EU and The Eastern Partnership Partner Countries. Country Report: Belarus, Poland: Warsaw. In: CASE (Center for Social and Economic Research) Network Studies and Analyses, No. 462, p. 1- 81.

47. Communication from the Commision to the European Parliament, The Council, The European Economic and Social Comittee and The Committee of The Regions. An Integrated Industrial Policy for the Globalization Era. Putting Competitiveness and Sustainability at Centre Stage (2010) [tiešsaiste]: Brussels, COM (2010) 614. [skatîts 2013. g. 14. martā]. Pieejams: http://www.em.gov.lv/em/2nd/?cat=30109

48. Cox M., Alm R. (2008) Joseph Schumpeter. [tiešsaite]: Library of Economics and Liberty, Liberty Fund, Inc. [skatīts 2016.g. 09.martā]. Pieejams: http://www.econlib.org/library/Enc/CreativeDestruction.html

49. Cyclical Unemployment [b.g.] [tiešsaite]: Investopedia [skatīts 2016. g. 31. okt.].

Pieejams: http://www.investopedia.com/terms/c/cyclicalunemployment.asp

50. Dao M., Loungani P. (2010) The Human Cost of Recessions: Assessing it, Reducing it. IMF Staff Position note SPN/10/17.

51. Darba likums ar komentāriem (2010) [tiessaite]: Brīvo arodbiedrību savienība, Zvērinātu advokātu birojs „BDO Zelmenis \& Liberte”. [skatīts 2013. g. 03. apr.] Pieejams: http://www.lbas.lv/upload/stuff/201102/dl_ar_kom.pdf

52. Darba likums (2001): Saeima 2001. gada 20. jūnija noteikumi. Latvijas Vēstnesis, Nr. 105 (2492), 2001.gada 06. jūlijā [tiešsaiste] [skatīts 2013. g. 03. apr.]. Pieejams:_http://www.likumi.lv/doc.php?id=26019

53. Darba meklètāji sadalījumā pa vecuma grupām un dzimuma [b.g.] [tiešsaiste] [skatīts 2013. 2 g. $15 . \quad$ maijā]. http://data.csb.gov.lv/Dialog/varval.asp?ma=NB0250\&ti=NBG25\%2E+DARB $\mathrm{A}+\mathrm{MEKL} \% \mathrm{C} 7 \mathrm{~T} \% \mathrm{C} 2 \mathrm{JI}+\mathrm{SADAL} \% \mathrm{CEJUM} \% \mathrm{C} 2+\mathrm{PA}+\mathrm{VECUMA+GRUP} \% \mathrm{C} 2$ $\mathrm{M}+\mathrm{UN}+\mathrm{DZIMUMA \& path=../DATABASE/Iedzsoc/Ikgad \% E7jie \% 20statistikas}$ $\%$ 20dati/Nodarbin\%E2t\%EEba/\&lang=16

54. Darba meklētāji vēlas adekvātāku samaksu (2015) [tiešsaite]: CV Market [skatîts 2015. $22 . \quad$ g. 2 dec.]. Pieejams: http://www.cvmarket.lv/career.php?menu=769\&lastmenu=906\&career_style=

55. Darba meklētāji ar augstāku izglìtību prasa augstāku atalgojumu (2015) [tiešsaite]: CV Market [skatīts 2015. g. 22. dec.]. Pieejams: http://www.cvmarket.lv/career.php?menu=769\&lastmenu=896\&career_style=

56. Darba ñēmēju skaita sadalījums pēc darba ienākumiem pa vecuma grupām (2015) [tiešsaiste]: Centrālā statistikas pārvalde [skatīts 2013. g. 15. maijāa]. Pieejams:

http://data.csb.gov.lv/pxweb/lv/Sociala/Sociala_isterm_dsamaksa/?tablelist=t rue\&rxid=cdcb978c-22b0-416a-aacc-aa650d3e2ce0

57. Darba tirgū pārliecinoši jūtas biznesa studiju absolventi un konkrēta aroda meistari (2) (2015) [tiešsaite]: CV Market [skatîts 2015. g. 22. dec.]. Pieejams: http://www.cvmarket.lv/career.php?menu=769\&lastmenu=899\&career_style=

58. Darba tirgus sakarības [b.g.] [tiešsaite]: Latvijas Republikas Labklājības ministrija[skatîts $2016 . \quad$ g. $30 . \quad$ aug.]. Piejams: 
http://www.lm.gov.lv/upload/darba_tirgus/darba_tirgus/darba_tirgus_sakaribas. pdf

59. De Koning J. (2005) Active labour Market Policies: Relevance, Expenditure and Effectiveness. In: SEOR Working Paper, Rotterdam, p. 1-29.

60. Dewhurst J. (1998) Convergence and Divergence in Regional Household Incomes Per Head in the United Kingdom, 1984-93'. In: Applied Economics, No. 30, p. 31-35.

61. Dietrich H. (2012) Youth Unemployment in Europe. Theoretical Considerations and Empirical Findings. Friedrich Ebert Stiftung. p. 1-42.

62. Dockery A. (2000) Regional Unemployment Rate Differentials and Mobility of the Unemployed. In: International Journal of Manpower, Vol. 21, No.5, pp. $400-423$.

63. Doing Business 2015. Going Beyond Efficiency. Economy Profile 2015 Latvia (2015) [tiešsaite]: A World Bank Group Flagship Report, The International Bank for Reconstruction and Development/ The World Bank [skatīts 2015. g. $25 . \quad$ jūn.]. Pieejams: http://www.doingbusiness.org/data/exploreeconomies/latvia/ /media/giawb/doi ng\%20business/documents/profiles/country/LVA.pdf?ver=2

64. Dovladbekova I., Eteris E., Zelmenis D. (2008) Eiropas Savienības ekonomiskā politika un Latvija. Rīgas Stradiṇa Universitāte. Madona: SIA „Madonas poligrāfists". 232.- 250. lpp.

65. Ease of Doing Business in Latvia (2015) [tiešsaite] [skatîts 2015. g. 25. jūn.]. Pieejams:

http://www.doingbusiness.org/data/exploreeconomies/latvia/\#starting-abusiness

66. Ease of Doing Business in Belarus (2015) [tiešsaite] [skatīts 2015. g. 20. jūl.]. Pieejams: http://www.doingbusiness.org/data/exploreeconomies/belarus/

67. Edmunds S. Phelps [b.g.] [tiešsaite]: Columbia University, Economics. [skatīts 2016.g. 09. martā]. Pieejams: http://www.columbia.edu/ esp2/

68. Eglīte P., Markusa I., Pavlina I., Gņedovska I., Ivbulis B., Brants M. (2002) Ģimeņu veidošanās un valsts atbalsts gimenēm atjaunotajā Latvijas Republikā, Apcerējumi par Latvijas iedzīvotājiem, Rīga: DO SIA LZA Ekonomikas institūts, Nr. 9. 65 lpp.

69. Eichhorst W., Rodriguez-Planas N., Schmidl R., Zimmermann K. F. (2015) A Road Map to Vocational Education and Training in Industrialized Countries. In: ILR Review, No. 68 (2), p. 314 -337.

70. Eiropas Sociālā harta (1961): Eiropas Padome 1961. gada 18. oktobra starptautisks dokuments, Strasbūra [tiešsaite] [skatīts 2013. g. 25. febr.]. Pieejams: http://www.likumi.lv/doc.php?id=56660

71. Eiropas Centrālās bankas publicētie eiro atsauces kursi [b.g.] [tiešsaite] [skatīts 2015. g. 08. jūl]. Pieejams: https://www.bank.lv/statistika/valutu-kursi/aktualie

72. Eiropas Savienības programma “Jaunatne darbībā” 2007.-2013. gadam kursi [b.g.] [tiešsaite] [skatīts 2016. g. 02. marts]. Pieejams: http://jaunatne.gov.lv/sites/default/files/web/Jaunatne_darbiba/Info_materiali/Br osuras/2012/Info_lapas/jd_2011.pdf

73. Ekelund R. B., Hebert R. F. (1997) A History of Economic Theory and Method, $4^{\text {th }}$ Edition, New York: The McGraw-Hill Companies, Inc, p. 602.

74. Ekonomiskās aktivitātes, nodarbinātības līmenis, darba meklētāju ìpatsvars (\%) [b.g.] [tiešsaiste] [skatīts 2015. g. 01. marts]. Pieejams: 
http://data.csb.gov.lv/pxweb/lv/Sociala/Sociala_ikgad_nodarb/NB0020.px/?r $\mathrm{xid}=\mathrm{cdcb} 978 \mathrm{c}-22 \mathrm{~b} 0-416 \mathrm{a}-\mathrm{aacc}-\mathrm{aa} 650 \mathrm{~d} 3 \mathrm{e} 2 \mathrm{ce} 0$

75. Ellwood D. T. (1982) Teenage Unemployment: Permanent Scars or Temporary Blemishes? In: University of Chicago Press, p. 349 - 390.

76. Employment, Social Affairs \& Inclusion [b.g.] [tiešsaite] [skatīts 2015. g. 06. maijs]. Pieejams: http://ec.europa.eu/social/main.jsp?langId=en\&catId=656

77. ES ilgtspējīgas attīstības stratēgija (2006) [tiešsaite]: Eiropas Savienības Padome, 10917/3/06, REV 3 (lv) [skatīts 2016.g. 26. febr.]. Pieejams: www.varam.gov.lv/lat/darbibas_veidi/ilgtspejiga_attistiba/files/text/Darb_jomas //ST10917-RE03[1].LV06.DOC.doc

78. ES jaunatnes stratēgija — ieguld̄̄t jaunatnē, iesaistīt jauniešus (2010) [tiešsaite]: Eiropas Parlamenta 2010. gada 18. maija rezolūcija par ES jaunatnes stratēgiju — ieguldīt jaunatnē, iesaistìt jauniešus (2009/2159(INI)) [skatīts 2016. $\quad$ g. $24 . \quad$ febr.]. $\quad$ Pieejams: lex.europa.eu/LexUriServ/LexUriServ.do?uri=OJ:C:2011:161E:0021:0031:LV: $\mathrm{PDF}$

79. ES jaunatnes stratēgija - ieguld̄̄t jaunatnē, iesaistīt jauniešus. Atjaunināta atvērtās koordinācijas metode, kā risināt jauniešu problēmas un tiem pavērt jaunas iespējas (2009) [tiešsaite]: Eiropas Kopienu Komisija [skatīts 2016.g. 26. febr.]. Pieejams: http://lakrs.lv/wpcontent/uploads/2015/03/ek_jaunatnes_strategija_2010-2018.pdf

80. Estivill J. (2003) Concepts and strategies for combating social exclusion, In: $A n$ overview, International Labour Office, Geneva, p. 137.

81. European Employment Strategy [b.g.] [tiešsaite] [skatīts 2015. g. 06. maijs] Pieejams: http://ec.europa.eu/social/main.jsp?catId=101\&langId=en

82. Fadinger H., Mayr K. (2014) Skill-Based Technological Change, Unemployment, and Brain Drain. In: Journal of the European Economic Association, European Economic Association, Vol. 12, Issue 2, p. 397-431.

83. Fatejevs V. (2004) Menedžments un regiionālā politika ārzemēs.

84. Framework of Actions on Youth Employment (2013) [tiešsaite]: European Social Partners [skatīts 2014. $\quad$ g $20 . \quad$ sept.] Piejams: http://www.ueapme.com/IMG/pdf/201306_Framework_of_Actions_Youth_Em ployment_final.pdf

85. Freeman R. (1995) The Limits of Wage Flexibility to Curing Unemployment, In: Oxford Review of Economic Policy, No. 11, p. 63-72.

86. Gaga V. (2009) Darba ekonomikas un sociologijas daudzlìmeņu sistēmas. Rīga: SIA Madris, 152 lpp.

87. Gaišputis D. (2015) Darba tirgū arvien aktuālāki kļūs strukturālie izaicinājumi [tiešsaite]: Leta [skatīts 2015.g. 12. aug.]. Pieejams: http://financenet.tvnet.lv/viedokli/571377gaspuitis_darba_tirgu_arvien_aktualaki_klus_strukturalie_izaicinajumi

88. Garnett M., Lewis, P. (2000) Explaining Trends in Rural Employment in Australia, Paper presented to the 29th Conference of Economists, Centre for Labour Market Research, University of Canberra, Australia, p. 1-23.

89. Garnett M., Lewis P. (2007) Population and Employment Changes in Regional Australia'. In: Economic Papers, No. 26 (1), p. 29-43

90. Garrouste, C., Kozovska, K., Perez, E. A. (2010) Education and Long-Term Unemployment. In: JRC Scientific and Technical reports, p. 4-29. 
91. Germany's Youth Employment Recipe (2012) [tiešsaite] [skatīts 2016. g. 4. aprīlī]. Pieejams: http://www.dw.com/en/germanys-youth-employment-recipe/a15917476

92. George J. B. (2005) Labor Economics. In: McGraw-Hill, University of California, Berkeley, $680 \mathrm{p}$.

93. Global Employment Trends for Youth 2010 (2010) [tiešsaite]: International Labour Organisation, Geneva: ILO [skatīts 2015. g. 13. febr.]. Pieejams: http://www.ilo.org/wcmsp5/groups/public/---ed_emp/---emp_elm/--trends/documents/publication/wcms_143349.pdf

94. Global Employment Trends for Youth 2012 (2012) [tiešsaite]: International Labour Organisation, Geneva: ILO [skatīts 2015. g. 13. febr.]. Pieejams: http://www.ilo.org/wcmsp5/groups/public/---dgreports/--dcomm/documents/publication/ wcms_180976.pdf

95. Goodall B. (1987) City Region. In: Dictionary of Human Geography, London, p. 512.

96. Gore C., Figueiredo J. B. (1997) Social exclusion and anti-poverty policy: A debate. Geneva: International Institute for Labour Studies, United Nations Development Programme, Research Series No. 110, p. 144.

97. Gottdiener M., Hutchinson R. (2006) The New Urban Sociology. In: Westview Press, New-York, pp.18-19.

98. Grantu programma "Atspēriens" [b.g.] [tiešsaite] [skatîts 2016. g. 7. janv.]. Pieejams: http://www.investeriga.lv/lat/our-services/grant-program/

99. Grādu vai kvalifikāciju ieguvušo studentu skaits pa izglītības tematiskajām grupām augstskolās un koledžās [b.g.] [tiešsaite]: Centrālā statistikas pārvalde $\begin{array}{lllll}\text { [skatîts } 2015 . & \text { g. } & 20 . & \text { martā]. } & \text { Pieejams: }\end{array}$ http://data.csb.gov.lv/pxweb/lv/Sociala/Sociala_ikgad_izgl/IZ0290.px/?rxid= cdcb978c-22b0-416a-aacc-aa650d3e2ce0

100. Hammer, T. (2003) Youth Unemployment and Social Exclusion in Europe. In: Policy Press, Bristol, p. 1-20.

101. History of Economic Theory (1989). USA: Houghton Hifflin Company, p. 429.

102. Hjūza D., Borbējs- Pece T. B., (2012) Jauniešu bezdarbs: mūslaiku krīze. Mūžilga karjeras atbalsta rīcībpolitikas nozīme darba piedāvājuma un pieprasījuma jomā, Eiropas Mūžilga karjeras atbalsta politikas tīkls, 20 lpp.

103. Hoffman N. (2011) Schooling the in the Workplace - How Six of the World's Best Vocational Education Systems Prepare Young People for Jobs and Life. In: Harvard Education Press, Cambridge, MA.

104. Holloway L., Beck U. (2004) Key Thinkers on Space and Place, London, SAGE Publications, pp. 45-46.

105. Iedż̄votāji pēc ekonomiskās aktivitātes un dzimuma [b.g.] [tiešsaiste]: Latvijas Centrālā statistikas pārvalde [skatîts 2015. g. 26. jūn.]. Pieejams: http://data.csb.gov.lv/pxweb/lv/Sociala/Sociala_ikgad_nodarb/NB0010.px/?r $\mathrm{xid}=\mathrm{cdcb} 978 \mathrm{c}-22 \mathrm{~b} 0-416 \mathrm{a}-\mathrm{aacc}-\mathrm{aa} 650 \mathrm{~d} 3 \mathrm{e} 2 \mathrm{ce} 0$

106. Ienākumu deklarācija. Kā atgūt pārmaksātos nodokḷus (2014) [tiešsaiste]: Latvijas Vēstneša portāls par likumu un valsti [skatîts 2015. g. 16. dec.]. Pieejams: http://m.lvportals.lv/visi/skaidrojumi/261265-ienakumu-deklaracijaka-atgut-parmaksatos-nodoklus/

107. Iekšzemes kopprodukts Latvijā kopā (EKS-95) (2015) [tiešsaiste]: Centrālā statistikas pārvalde [skatīts 2015. g. 16. dec.]. Pieejams: http://www.csb.gov.lv/statistikas-temas/metodologija/iekszemes-kopproduktslatvija-kopa-eks-95-34403.html 
108. Impact of Competition Reforms on Rural and Regional Australia (1999) Productivity Commission, Report No. 8, Commonwealth of Australia, Canberra, p. 1- 516.

109. Informatīvais ziņojums „Par darba tirgus īsterminga prognozēm 2013. gadam un bezdarbnieku un darba meklētāju prioritārajiem apmācību virzieniem” (2013) [tiešsaiste]: Labklājības Ministrija [skatīts 2015. g. 11. febr.]. Pieejams: http://www.lm.gov.lv/upload/darba_tirgus/darba_tirgus/lmzino_1504131.pdf

110. Informatīvais ziņojums par jauniešu garantijas īstenošanu Latvijā 2014. - 2018. gadam (2013) [tiešsaiste] [skatīts 2016. g. 10. aprīlīi]. Pieejams: http://www.lm.gov.lv/upload/jauniesiem/lmzin_jg_171213.pdf

111. Informatīvais zinojums „Par Eiropas Savienības fondu darbības programmas „Izaugsme un nodarbinātība” 7.2.1.specifiskā atbalsta mērķa „,Veicināt nodarbinātība $\bar{a}$, izglìtī $\bar{a} \bar{a}$ vai apmācībās neiesaistītu jauniešu nodarbinātību Jauniešu garantijas ietvaros" 1. un 2.kārtas īstenošanu” (2013) [tiešsaiste]: Labklājības Ministrija [skatīts 2015. g. 22. dec.]. Pieejams: http://www.lm.gov.lv/upload/jauniesiem/lmzino_jg_17122013.pdf

112. Inovatīvās uzņēmējdarbības motivācijas programma "Ideju kauss" [b.g.] [tiešsaiste] [skatīts 2015. g. 28. dec.]. Pieejams: http://www.idejukauss.lv/

113. Investing in People: EU Funding for Employment and Social Inclusion (2014). European Commission, Directorate-General for Employment, Social Affairs and Inclusion, Social Europe Guide, Vol. 7, p. 1-95.

114. Izglītība un jauniešu iesaistǐšanās darba tirgū (2015). No. DNB Latvijas barometrs, Nr. 82, 24 lpp.

115. Jacob M. (1997) Life in the Triple Helix: The Contract Researcher, The University and The Knowledge Society. In: Science Studies, 10 (2). p. 35-49.

116. Jaunatnes likums (2008) [tiešsaite]: Saeima, 2008. gada 08. maijs, Latvijas Vēstnesis, Latvijas Vēstnesis, Nr. 82 (3866). [skatīts 2015. gada 27. jūn.]. Pieejams: http://likumi.lv/doc.php?id=175920

117. Jaunatnes politikas pamatnostādnes 2009. - 2018. gadam (2009) Bērnu, gimenes un sabiedrības integrācijas lietu ministrijas Jaunatnes lietu departments, prezentācija.

118. Jaunatnes politikas pamatnostādnes 2015. - 2020. gadam (2014) [tiešsaite] [skatîts $2015.26 . \quad$ g. 26 julijā]. http://www.izm.gov.lv/images/sabiedriska_lidzdaliba/aktualitates/IZMPamn201 5-2020_26022015.pdf

119. Jauniešu bezdarbs joprojām ir nopietna problèma Latvijā (2013) [tiešsaite]: Centrāāā statistikas pārvalde [skatīts 2015. g. 25. jūlijā]. Pieejams: http://www.csb.gov.lv/notikumi/jauniesu-bezdarbs-joprojam-ir-nopietnaproblema-latvija-39292.html

120. Jauna kohēzijas politika darbvietu radīšanai un izaugsmei Eiropā (2014). Eiropas Komisija. 2 lpp.

121. Jaunatnes politikas pamatnostādnes 2015.- 2020. gadam (2014) [tiešsaite]: LR Ministru cabinets [skatīts 2016.g. 24. febr.]. Pieejams: http://www.izm.gov.lv/images/sabiedriska_lidzdaliba/aktualitates/IZMPamn201 5-2020_26022015.pdf

122. Jauniešu garantijas pasākumi (2015) [tiešsaite]: Nodarbinātības valsts aǵentūra $\begin{array}{lllll}\text { [skatits } & 2015 . & \text { g. } & 23 . & \text { jūlijā]. }\end{array}$ http://nva.gov.lv/index.php?cid=2\&mid=491 
123. Jauniešu garantija. 3 soļi darba atrašanai [b.g.] [tiešsaite]: Latvijas Republikas Labklājīibas Ministrija [skatīts 2015. g. 18. dec.]. Pieejams: http://www.lm.gov.lv/text/2607

124. Jauniešu- bezdarbnieku kvalitatīvā sastāva atbilstības darba tirgus pieprasījumam izvērtēšana (2006) Eiropas Sociālā fonda nacionālās programmas "Darba tirgus pētìjumi" projekts "Nodarbinātības valsts aǵentūras pētījumi”, 127 lpp.

125. Jaunieši Latvijā 2014 (2014) Rīga: Latvijas Republikas Centrālā statistikas pārvalde. 136 lpp.

126. Jauniešu uzn̄èmējdarbība: vērtības, attieksme, politikas pasākumi (2015) [tiešsaite]: EUROFOUND [skatīts 2015. g. 15. dec.]. Pieejams: http://www.eurofound.europa.eu/lv/publications/executivesummary/2015/labour-market/youth-entrepreneurship-in-europe-valuesattitudes-policies-executive-summary

127. Joint Employment Report 2006/2007 (2007) [tiešsaite]: Council of the European Union [skatīts 2015. g. 06. maijā]. Pieejams: http://register.consilium.europa.eu/doc/srv?l=EN\&f=ST\%206706\%202007\%20 INIT

128. Junankar P. N. (2011) The Global Economic Crisis: Long-Term Unemployment in the OECD. The Institute for the Study of Labour. Germany. No. 6057. p. 172.

129. Kalve I. (2005). Apseglot pārmainu vējus. Statēgiskā un pārmainuu vadība. Rīga: SIA "Biznesa Augstskola Turība". 296 lpp.

130. Keep E. (2012) Youth Transitions, the Labour Market and Entry into Employment: Some Reflections and Questions. In: SKOPE, Cardiff University, Research Paper No. 108, p. 39.

131. Kieselbach, T., Beelmann, G., Stritzl, A., Traiser, U. (2001) Comparative Analysis of the Risk of Social Exclusion. p. 27-74.

132. Kluve J. (2006) The Effectiveness of European Active Labor Market Policy. In: IZA Discussion Paper, No. 2018; RWI Discussion Paper No. 37. [tiešsaiste] [skatīts 2015. gada 6. apr.] Pieejams: http://ssrn.com/abstract=892341

133. Krohnert S., Kuhn E., Karsch M., Klingholz R., Bennert W. (2011) Die Zukunft der Dörfer. Zwischen Stabilität und demografischen Niedergang/ The Future of Germany's Villages: Between Stability and Demographic Decline. [tiešsaiste] [skatīts 2016. gada 01. okt.] Pieejams: http://www.berlininstitut.org/fileadmin/user_upload/Doerfer_2011/Die_Zukunft_der_Doerfer_We bversion.pdf

134. Komisijas pazinojums Eiropas Parlamentam, Padomei, Eiropas Ekonomikas un sociālo lietu komitejai un regionu komitejai (2012) [tiešsaiste] [skatīts 2016. g. 1. aprīlis]. Pieejams: http://ec.europa.eu/transparency/regdoc/rep/1/2012/LV/12012-727-LV-F1-1.Pdf

135. Koroḷeva I., Rungule R., Sebre S., Trapenciere I. (1999) Latvijas jaunatnes sociologiskais portrets. Rīga: LU Filozofijas un sociologijas institūts. 252 lpp.

136. Krasnopjorovs O. (2011a) Latvijas bezdarba anatomija [tiešsaiste] [skatīts 2015. g. 25. jūn.]. Pieejams: https://www.makroekonomika.lv/latvijas-bezdarbaanatomija

137. Krasnopjorovs O. (2013) Bezdarbs samazinās, tomēr augstā bezdarba anklāviem ir nepieciešama struktūrpolitika [tiešsaiste] [skatīts 2015. g. 25. jūn.]. Pieejams: https://www.makroekonomika.lv/bezdarbs-samazinas-tomer-augstabezdarba-anklaviem-ir-nepieciesama-strukturpolitika 
138. Krasnopjorovs O. (2014) Uzlabojums darba tirgū - stabils [tiešsaiste] [skatīts 2015. g. 25. jūn.]. Pieejams: https://www.makroekonomika.lv/uzlabojumsdarba-tirgu-stabils

139. Krasnopjorovs O. (2015) Darba tirgus sniegums 2014. gadā - bezdarba un nodarbinātības kritums [tiešsaiste] [skatīts 2015. g. 20. martā]. Pieejams: https://www.makroekonomika.lv/darba-tirgus-sniegums-2014-gada-bezdarbaun-nodarbinatibas-kritums

140. Krohnert, S., Kuhn, E., Karsch, M., Klingholz, R., Bennert, W. (2011) The Future of Germany's Villages: Between stability and demographic decline. [tiešsaiste] [skatīts 2015. g. 11. dec.]. Pieejams: http://www.berlininstitut.org/en/publications/studies/the-future-of-germanys-villages.html

141. Krugman P. (1993) The Lessons of Massachusetts for EMU', in Torres, F. and Giavazzi, F. (eds.), In: Adjustment and Growth in the European Monetary Union. Cambridge University Press, Cambridge; p. 241-69.

142. Kūle M. (2006) Eirodzīve: formas, principi, izjūtas. Rīga: LU Filozofijas un sociologijas institūts, 435 lpp.

143. Labour Markets at Regional Level [b.g.] [tiešsaiste] [skatîts 2015. g. 18. dec.]. Pieejams: http://ec.europa.eu/eurostat/statisticsexplained/index.php/Labour_markets_at_regional_level

144. Labour Market in Belarus [b.g.] [tiešsaiste] [skatīts 2015. g. 08. jūl.]. Pieejams: http://www.belarus.by/en/invest/investment-climate/labour-market

145. Labs of Latvia [b.g.] [tiešsaiste] [skatīts 2015. g. 29. dec.]. Pieejams: http://www.labsoflatvia.com/

146. Lagendijk A. (2005) Regionalisation in Europe. Stories, Institutions and Boundaries. In: Bordering Space, No. 8, pp. 77-92.

147. Latvijas ilgtspējīgas attīstības stratēgija lìdz 2030. gadam (2010) [tiešsaiste] $\begin{array}{lllll}\text { [skatîts 2016.g. } & 24 . & \text { febr.]. }\end{array}$ http://www.liepaja.lv/upload/attistibas_planosana/lias_2030_10jun2010_saeima _apstiprina.pdf

148. Latvijas izaugsmes modelis: Cilvēks pirmajā vietā (2005) [tiešsaiste]: Saeimas lēmums par ilgtermiņa konceptuālā dokumenta "Latvijas izaugsmes modelis: Cilvēks pirmajā vietā" apstiprināšanu [skatīts 2016. g. 24. febr.]. Pieejams: http://www.saeima.lv/Likumdosana/8S_DK/lasa-dd=LM0815_0.htm\#a

149. Latvijas Nacionālais attīstības plāns 2007. - 2013. gadam (2006) [tiešsaite]: Saeima [skatīts 2016.g. 24. febr.]. Pieejams: http://www.innovation.lv/wpcontent/uploads/2013/10/Latvijas_Nacionalais_attistibas_plans_2007-2013.pdf

150. Latvijas Nacionālais attīstības plāns 2014. - 2020. gadam (2012) [tiešsaite]: Saeima [skatîts 2016.g. 24. febr.]. Pieejams: file:///C:/Documents\%20and\%20Settings/Ilga/My\%20Documents/Downloads/2 0121220_NAP2020_apstiprinats_LV.pdf

151. Latvijas Nacionālais Reformu programmas „ES 2020” stratēgijas ìstenošanai projekts (2010) [tiešsaiste] [skatīts 2015. g. 24. febr.]. Pieejams: http://polsis.mk.gov.lv/view.do?id=3517

152. Latvijas un tās regionu darba tirgus specifiskās problēma (2007) [tiešsaiste]: Labklājības Ministrijas pētījumi [skatīts 2013. g. 04. apr.]. Pieejams: http://www.va.lv/sites/default/files/regiona_darba_tirgus.pdf

153. Latvijas pilsētu sociāli ekonomiskās attīstības tendences (2007), Rīga: SIA "Analītisko pētījumu un stratēgiju laboratorija”.

154. Latvian Export Import Directory (EXIM). About Us [b.g.] [tiešsaite] [skatīts 2015.g. 27. jūn.]. Pieejams: http://exim.lv/about-us 
155. Latvenergo koncerna ilgtspējas pārskats 2009 (2009) [tiešsaite] [skatīts 2016.g. 1. aprī1ī]. Pieejams: https://www.latvenergo.lv/files/text/2009_IP.pdf

156. Lee N., Sissons P., Balarm B., Jones K., Cominetti N. (2012) Short-term Crisis - long-term Problem? Addressing the Youth employment challenge. The Work Foundation, Part of Lanchester University, p. 1-50.

157. Lewis P. (2008) The Labour Market, Skills Demand and Skills Formation. In: Research Report No. 6, The Academy of Social Sciences in Australia, Canberra, p. $1-22$.

158. Lewis P., Corliss M. (2012) Regional Labour Market Convergence and Economic Growth. In: Global Business \& Economics Anthology, No. 2 (2), p. $31-42$.

159. Lindbeck A., Snower D. (1990) Demand- and Supply-Side Policies and Unemployment: Policy Implications of the Insider-Outsider Approach. In: The Scandinavian Journal of Economics, Unemployment- Inflation Tradeoffs in Europe, Vol. 92, No. 2, pp. 279-305.

160. Markso U., Tammaru T. (2011) Long-Term Unemployment in Economic Boom and Bust: The Case of Estonia. In: Proceedings of University of Tartu, Estonia. Vol. 15(65/60)3, p. 215-234.

161. Martin R. (1997) Regional Unemployment Disparities and Their Dynamics. In: Regional Studies, No. 31 (3), p. 237-52.

162. McClure R. (2000) Participation Support for a More Equitable Society, Final Report to the Reference Group on Welfare, Reform July of 2000, Canberra, p. 71.

163. Meņšikovs V. (2011) Reǵiona konkurētspējas izpētes metodologiija. No: Starpreǵionālās ekonomiskās integrācijas attīstības stratēgija ES apstākļos, Starptautiskās zinātniskās conferences materiāli 2010. gada 3.- 4. decembris, Daugavpils: Daugavpils Universitātes Akadēmiskais apgāds "Saule", 98. -106. lpp.

164. Mitchell W.F., Carlson, E. (2005) Exploring Employment Growth Disparities Across Metropolitan and Regional Australia'. In: Australasian Journal of Regional Studies, No. 11 (1), p. 25-40.

165. Mroz, T. A., Savage, T. H. (2006) The Long-Term Effects of Youth Unemployment. In: Human Resources, 41(2), p. 259-293.

166. NEET's - Young People not in Employment, Education or Training: Characteristics, Costs and Policy Responses in Europe (2012) European Foundation for the Improvement of Living and Working Conditions, In: Publications Office of the European Union, Luxembourg, p. 172.

167. Nickell [b.g.] The Beveridge Curve, Unempoloyment and Wages in the OECD from the 1960s to the 1990s [tiešsaite] [skatīts 2016. g. 14. martā]. Pieejams: http://econpapers.repec.org/paper/cepcepdps/dp0502.htm

168. Nikolajeva A. (2015) Situācija jauniešu nodarbinātības un bezdarba mazināšanas jomā. Citu dalībvalstu progress Jauniešu garantijas īstenošanā. Labklājības Ministrija, Darba tirgus politikas departments. Latvijas pašvaldību izpilddirektoru asociācijas sanāksme Garkalnē, 06.03.2015, Prezentācijas materiāli.

169. Nodarbinātība un bezdarbs (2015) [tiešsaite] [skatīts 2016. g. 12. martā]. Pieejams: http://www.csb.gov.lv/statistikas-temas/nodarbinatiba-un-bezdarbsjaunumi-30031.html

170. O’Connor K., Stimson R., Daly M. (2001) Australia's Changing Economic Geography: A Society Dividing, In: Oxford University Press, Sydney, p. 233. 
171. OECD Economic Surveys: Latvia 2015 (2015). In: OECD Publishing, Paris, p. 1-115.

172. OECD Factbook 2010 (2010) [tiešsaite] [skatīts 2016. g. 4. aprīilī]. Pieejams: http://www.oecd-ilibrary.org/economics/oecd-factbook-2010_factbook-2010-en

173. OECD Work on Genders (2012) [tiešsaite] [skatīts 2016. g. 1. aprīilī]. Pieejams: https://www.oecd.org/gender/oecdworkongender-wwwoecdorggender.htm

174. Ogres tehnikums - nemitīgā pārmaiņu procesā [tiešsaite] [skatīts 2016. g. 1. aprīin].

Pieejams: http://www.ogresnovads.lv/lat/izglitiba/aktualitates_/?page $=7 \&$ doc $=23903$

175. Organisation for Economic Co-operation and Development OECD (1989), Regional Unemployment in OECD Countries, In: Employment Outlook, p. 95131.

176. Padomes direktīva 2000/78/EC (2012) [tiešsaite] [skatīts 2015. g. 26. oktobrī]. Pieejams: http://cilvektiesibas.org.lv/lv/database/padomes-direktiva-200078ec/

177. Par apdrošināšanu bezdarba gadījumam (1999) [tiešsaite]: Saeima 1999. gada 25. novembra noteikumi. Latvijas Vēstnesis, Nr. 416/419 (1876/1879), 1999.gada 15. decembrī [skatīts 2015. g. 26. oktobrī]. Pieejams: http://likumi.lv/doc.php?id=14595

178. Par ieklaujošas nodarbinātības pamatnostādnēm 2015.- 2020. gadam (2015) [tiešsaite]: Ministru kabineta rīkojums Nr. 244, 2015. gada 12. maijs, Latvijas Vēstnesis, Nr. 93 (5411), 2015. gada 14. maijs [skatīts 2015. g. 23. jūlijs]. Pieejams: $\quad$ http://likumi.lv/ta/id/273969-par-ieklaujosas-nodarbinatibaspamatnostadnem-2015-2020-gadam

179. Par izglītības attīstības pamatnostādņu 2014.-2020.gadam apstiprināšanu (2014) [tiešsaiste]: Saeima, paziņojums „Latvijas Vēstnesis”, 103 (5163), 2014. gada 29. Maijs [skatīts 2016.g. 24. febr.]. Pieejams: http://likumi.lv/doc.php?id=266406

180. Par jaunatnes garantijas izveidošanu (2012) Eiropas Komisija, Komisijas dienestu darba dokuments, Priekšlikums Padomes ieteikumam, Oficiāls dokumenta tulkojums, Pēdējā versija, Brisele, 49 lpp.

181. Par Latvijas Republikas starptautiskajiem līgumiem (1994) [tiešsaite]: Saeima 1994. gada 13. jnavāra noteikumi. Latvijas Vēstnesis, Nr. 11 (142), 1994.gada 29. janvārī [skatīts 2015. g. 26. oktobrī]. Pieejams: http://likumi.lv/doc.php?id=57840

182. Par profesionālās izglìtības iestāžu tīkla optimizācijas pamatnostādnēm 2010.2015.gadam (2010) [tiešsaiste]: Ministru Kabineta paziņojums „Latvijas Vēstnesis", 4 (4196), 2010. gada 8. janvāris [skatīts 2016.g. 24. febr.]. Pieejams: http://likumi.lv/doc.php?id=203373

183. Par valsts sociālo apdrošināšanu (1997) [tiešsaite]: Saeima 1997. gada 01. oktobra noteikumi. Latvijas Vēstnesis, Nr. 277/276 (989/991), 1997.gada 21. $\begin{array}{lllll}\text { oktobrī } \quad \text { [skatīts } 2015 . & \text { g. } & \text { 26. oktobrī]. Piejams: }\end{array}$ http://likumi.lv/doc.php?id=45466

184. Pastāvīgo iedzīvotāju skaits un vecuma struktūra gada sākumā (pa 5 gadu vecuma grupām) (2015) [tiešsaite]: centrālā statistikas pārvalde. [skatīts 2016.g. 4. aprīlīi].

Pieejams: http://data.csb.gov.lv/pxweb/lv/Sociala/Sociala_ikgad_iedz_iedzskaits/ISO0 22.px/?rxid=cd

185. Paugam S. (1995) The Spiral of Precariousness: A Multidimensional Approach to the Process of Social Disqualification. The Measurement and Analysis of Social Exclusion. In: Policy Press, Bristol, p. 49-79. 
186. Paugam S. (1996) Poverty and Social Disqualification: A Comparative Analysis of Cumulative Social Disadvantage in Europe. In: Journal of European Social Policy, 6(4), p. 287-303.

187. Pelše M. (2007) Zemnieku sociālā kapitāla attīstības iespējamo scenāriju izvērtējums. No: LLU Raksti 19 (314), 89.- 98. lpp.

188. Pīgozne T. (2014) Pieaugušo izglītības resursi jauniešu bezdarba mazināšanai. IZM projects "Eiropas programmas īstenošana pieaugušo izglītības jomā. 134 lpp.

189. Policies to Support Youth (2010) Thematic Review, European Commission Employment Committee, Brussels: Ad Hoc Group Report 2010.

190. Puse jauniešu neprasa pat minimālo algu (2015) [tiešsaite] [skatīts 2015. g. 22. dec.].

Pieejams: http://www.cvmarket.lv/career.php?menu=769\&lastmenu=879\&career_style=

191. Purmalis K. (2011) Latvijas darba tirgus analīze un tā attīstības perspektīvas, Rīga: Latvijas Universitāte, Ekonomikas un vadības fakultāte, Tautsaimniecības katedra, promocijas darbs, 227 lpp.

192. Ramakrishnan U., Cerisola, M. (2004) Regional Economic Disparities in Australia, In: Working Paper WP/04/144, Asia and Pacific Department, International Monetary Fund, p. 1- 24.

193. Rasnača L. (2011) Darba tirgus attiecības Latvijas mazajās pilsētās un laukos. Rīga: Latvijas Universitātes Sociālo zinātņu fakultāte, Socioloǵijas nodaļa, Promocijas darbs, 246 lpp.

194. Recent Policy Developments Related to Those Not in Employment, Education and Training (NEETs) (2012) [tiešsaite] [skatīts 2016. g. 1. aprīlī]. Pieejams: http://www.eurofound.europa.eu/observatories/emcc/comparative-

information/recent-policy-developments-related-to-those-not-in-employmenteducation-and-training-neets

195. Reǵionālās attīstības indikatoru modulis (b.g.) [tiešsaite] [skatīts 2016. g. 1. aprīlī]. Pieejams: http://raim.gov.lv/pub/pases/RAIM_atvasin_raditajs.18.pdf

196. Regionālās politikas pamatnostādnes 2013. - 2019. gadam (2013) [tiešsaite]: Rīga: Ministru kabineta 2013. gada 29. oktobra rīkojums Nr. 496 [skatīts 2015. g. $11 . \quad \mathrm{dec}$.$] \quad Pieejams:$ file://C:/Documents\%20and\%20Settings/Ilga/My\%20Documents/Downloads/p amatnostadnes.pdf

197. Ricardo D. (2015) On Wages. In: On the Principles of Political Economy and Taxation, Chapter 5, Cambridge: Cambridge University Press.

198. Room, G. (1995) Poverty and Social Exclusion: The New European Agenda for Policy and Research. The Measurement and Analysis of Social Exclusion, In: Policy Press, Bristol, p. 1-9.

199. Saaty T. L. (1980) The Analytic Hierarchy Process. In: McGraw-Hill, New York.

200. Saaty T. L. (2007) Time Dependent Decision-making; Dynamic Priorities in the AHP/ANP: Generalizing from Points to Functions and from Real to Complex Variables. In: Mathematical and Computer Modelling, USA: Elsevier Ltd., Vol. 46., Issues 7- 8, p. $860-891$.

201. Saaty T. L., Peniwati K., Shang J. S. (2007) The Analytic Hierarchy Process and Human Resource Allocation: Half the Story. In: Mathematical and Computer Modelling, USA: Elsevier Ltd., Vol. 46., Issues 7- 8, p. 1041-1053.

202. Salvador R. G., Leiner- Killinger R. (2008) An Analysis of Youth Unemployment in the Euro Area. In: ECB Occasional Paper, No. 89. p. 1- 45. 
203. Salīdzinošās metodes [b.g.] [tiešsaite] [skatîts 2015. g. 29. dec.]. Pieejams: http://vide.lu.lv/coastlearncd/policy_analysis/PolicyAnalysis_rankingalternative s_aggregatemethods.htm

204. Schoof U. (2006) Stimulating Youth Entrepreneurship: Barriers and incentives to enterprise start-ups by young people. In: SEED Working Paper, International Labour Organization, Geneva: ILO, No.76. p. 1-123.

205. Sileika A., Rupsys V., Gruzevskis B. (2004) Youth Unemployment and Its Reduction Measures. In: Journal of Business, Economics and Management, Vol.V, No.3., p. 119-131.

206. Situācija Latvijas darba tirgū turpinās uzlaboties (2015) [tiešsaite] [skatīts 2015. g. 27. nov.]. Pieejams: http://apollo.tvnet.lv/zinas/situacija-latvijas-darbatirgu-turpinas-uzlaboties/701385

207. Sloka B. [b.g.] Bezdarba veidi [tiešsaite]: Latvijas Universitāte, studiju kurss: Profesionālajā izglìtībā iesaistîto ekonomikas skolotāju kompetenču pilnveide $\begin{array}{lllll}\text { [skatîts } 2015 . & \text { g. } & 27 . & \text { Jūn.]. } & \text { Pieejams: }\end{array}$ http://profizgl.lu.lv/mod/book/view.php?id=22290\&chapterid $=6820$

208. Social Inclusion of Young People (2015) Eurofound, Publications Office of the European Union, Luxembourg, p. 154.

209. Sociālā ieklaušana [b.g.] [tiešsaite]: Latvijas Republikas Labklājības Ministrija [skatîts 2015. g. 15. jūn.]. Pieejams: http://www.lm.gov.lv/text/548

210. Sociālā integrācija (2009) [b.g.] [tiešsaite] [skatīts 2016. g. 1. aprīlis]. Pieejams: http://www.letonika.lv/groups/default.aspx?r=10621033\&q=soci\%C4\%81liem $\& \mathrm{cid}=628215 \& \mathrm{~g}=2$

211. Sonnet A. (2010) Off to a Good Start? Jobs for Youth. In: OECD Publishing.

212. Starptautiskais pakts par ekonomiskajām, sociālajām un kultūras tiesībām [b.g.] [tiešsaiste] [skatīts 2015. g. 25. febr.]. Pieejams: http://www.humanrights.lv/doc/vispaar/escpakc.htm

213. Starptautiskais pakts par pilsoniskajām un politiskajām tiesībām [b.g.] [tiešsaiste] [skatīts 2015. g. 15. martā]. Pieejams: http://www.humanrights.lv/doc/vispaar/pptpakc.htm

214. Starptautisko ilgtermiņa migrantu vecuma un dzimuma struktūra [b.g.] [tiešsaiste]: Centrālā statistikas pārvalde [skatīts 2015. g. 20. martā]. Pieejams: http://data.csb.gov.lv/pxweb/lv/Sociala/Sociala_ikgad_iedz_migr/IB0040.px /table/tableViewLayout1/?rxid=cdcb978c-22b0-416a-aacc-aa650d3e2ce0

215. Statistikas dati par iedzīvotājiem regionu lìmen̄̄ (2015) [tiešsaiste]: Eurostat [skatîts 2015. g. 22. dec.]. Pieejams: http://ec.europa.eu/eurostat/statisticsexplained/index.php/Population_statistics_at_regional_level/lv

216. Stiglics Dž. E., Drifils Dž. (1994) Makroekonomika, Rīga: Latvijas Universitāte, 415 lpp.

217. Stimulating Youth Entrepreneurship: Barriers and incentives to enterprise startups by young people (2006) [tiešsaite] [skatīts 2016. g. 1. aprīî̄]. Pieejams: http://www.ilo.org/wcmsp5/groups/public/---ed_emp/--emp_ent/documents/publication/wcms_094025.pdf

218. Swedbank atklāj digitālu platformu - uzņēmumu tīklu Business Network (2012) [tiešsaite] [skatīts 2015. g. 27. jūn.]. Pieejams: https://www.swedbank.lv/zinas/01.11.2012/

219. Sustainable Development in the European Union. 2015 Monitoring Report of the EU Sustainable Development Strategy (2015) Luxembourg: Publications Office of the European Union, Eurostat, p. 113-122.

220. Špona A. (2004) Audzināšanas process teorijā un praksēe. Rīga: Raka. 191 lpp. 
221. OECD Better Policies for Better Lives. The Challenge of Promoting Youth Employment in the G20 Countries (2012) [tiešsaite] [skatīts 2015. g. 27. febr.]. Pieejams: http://www.oecd.org/els/emp/50304960.pdf

222. Takami N. (2011) Pigou on Business Cycles and Unemployment: An Anti-goldstandard View. In: European Journal of the History of Economic Thought, Vol. 18, Issue 2, p. 203-215.

223. Termini [b.g.] [tiešsaiste] [skatīts 2015. g. 21. jūl.]. Pieejams: http://www.lm.gov.lv/upload/darba_tirgus/darba_tirgus/darba_tirgus_termini.pd $\mathrm{f}$

224. The Concisce Encyclopedia of Economics (2008) [tiešsaite]: Liberty Fund, Inc. [skatîts 2016.g. 09. martā]. Piejams: http://www.econlib.org/library/Enc/bios/Keynes.html

225. The World Development Report 2013 (2013) [tiešsaiste]: World Bank [skatīts 2014. g. 04. okt.]. Pieejams: http://www.europarl.europa.eu/meetdocs/ 2009_2014/documents/empl/dv/wdr_2013_ppt_/wdr_2013_ppt_en.pdf

226. Territorial Observation No. 1. (2008), Belgium: The ESPON 2013 Programme, European Regional Development Fund, p. 15.

227. Todaro S., Smith S. (2003), Economic Development, 8th Edition. Pearson Addison Wesley, London, p. 829.

228. Ulnicāns E. (2013) Bezdarba uzskaites un skaitliskās attīstības jaunākās tendences Baltijas valstīs. No. Latgales tautsaimniecības pētījumi, Sociālo zinātņu žurnāls Nr. 1(5), Rēzekne: Rēzeknes Augstskola, 213.-225. lpp.

229. Unemployment Rate Decreases in 2014 (2015) [tiešsaite]: Central Statistical Bureau of Latvia [skatîts 2015. g. 03. martā]. Pieejams: http://www.csb.gov.lv/en/notikumi/unemployment-rate-decreases-201442339.html

230. Vaidere I., Vanags E., Vanags I., Vilka I. (2006) Reǵionālā politika un pašvaldību attīstība Eiropas Savienībā un Latvijā, Rīga: Latvijas Universitātes Akadēmiskais apgāds, Latvijas Statistikas institūts, 295 lpp.

231. Villeruša A., Godiṇa I. (2007) Latvijas jauniešu veselība demogrāfiskās situācijas kontekstā, No. Paaudžu nomainga un migrācija Latvijā, Stratēgeiskās analīzes komisija, Latvija, Rīga: Apgāds "Zinātne", 179. - 197. lpp.

232. Vilne D., Birzniece J. (2001) Ekonomika, Kamene, 93 lpp.

233. Vispārējā cilvēktiesību deklarācija [b.g.] [tiešsaiste] [skatīts 2013. g. 25. febr.] Pieejams: http://www.humanrights.lv/doc/vispaar/vispcd.htm

234. Vodopivec M. (2004) Income Support Systems for the Unemployed: Issues and Options. In: World Bank Publications, Washington, DC, USA, p. 240.

235. Youth Employment (2014). Social Agenda, European Commission, No.36, p. 127.

236. Youth Employment [b.g.] [tiešsaite] [skatīts 2015. g. 26. jūn.] Pieejams: http://ec.europa.eu/social/main.jsp?catId=1036\&langId=en

237. Youth in Europe. A Statistical Portrait (2009) [tiešsaite]: Luxembourg: Publication Office of the European Union, Eurostat Statistical Books [skatits 2015. $\quad$ g. $27 . \quad$ jūn.]. Pieejams: http://pjpeu.coe.int/documents/1017981/1668203/YouthinEurope.pdf/40f42295-65e4407b-8673-95e97026da4a

238. Youth and Work in Austria (2012) [tiešsaite] [skatîts 2015. g. 18. dec.] Pieejams:

https://broschuerenservice.bmask.gv.at/PubAttachments/ArbeituJugend2012eng 1.pdf? $\mathrm{db}=-1$ 
239. Youth and Work in Austria (2013/2014) [tiešsaite]: Federal Ministry of Labour, Social Affairs and Consumer Protection, Vienna [skatīts 2015. g. 18. dec.] Pieejams:

http://www.sozialministerium.at/cms/siteEN/attachments/7/8/3/CH2394/CMS1 320223144806/webversion_youth_and_work_in_austria_reporting_year_2013_ 20141.pdf

240. Youth Employment Policies in Sweden - the Swedish Response to the Council Recommendation on Establishing a Youth Guarantee (2014) [tiešsaite]: Government Offices of Sweden [skatits 2015. g. 16. dec.] Pieejams: http://www.government.se/contentassets/92e8785ae4c6468fb60291118acffddd/ youth-employment-policies-in-sweden--the-swedish-response-to-the-councilrecommendation-on-establishing-a-youth-guarantee

241. Youth Guarantees: a Response to the Youth Employment Crisis? [b.g.] [tiešsaite]: International Labour Office [skatīts 2015. g. 18. dec.] Pieejams:

242. Youth Unemployment by Sex, Age and Educational Attainment Level (2015) [tiešsaite]: Eurostat [skatîts 2015. g. 28. dec.] Pieejams: http://appsso.eurostat.ec.europa.eu/nui/submitViewTableAction.do

243. Youth Unemployment and the Skills Mismatch in Denmark (2015) [tiešsaite]: $\begin{array}{lllll}\text { Eurostat } & \text { [skatīts } 2016 . & \text { g. } & 1 . & \text { aprīlis.] Piejams: }\end{array}$ http://www.europarl.europa.eu/RegData/etudes/IDAN/2015/536322/IPOL_IDA (2015)536322_EN.pdf

244. Young People and NEETs in Europe: First Findings (2011) [tiešsaite]: $\begin{array}{lllll}\text { Eurofound } & \text { [skatits } 2015 . & \text { g. } & 18 . & \text { dec.] Piejams: }\end{array}$ http://www.eurofound.europa.eu/sites/default/files/ef_files/pubdocs/2011/72/en/ 2/EF1172EN.pdf

245. Young People Neither in Employment Nor in Education and Training by Sex, Age and Educational Attainment Level (NEET Rates) (2015) [tiešsaite]: Eurostat [skatīts 2015. $28 . \quad$ g. 28 dec.] Pieejams: http://appsso.eurostat.ec.europa.eu/nui/show.do

246. 2015. gada sākumā Latvijā par 15,4 tūkstošiem iedzīvotāju mazāk (2015) [tiešsaite]: Central Statistical Bureau of Latvia [skatīts 2015. g. 27. nov.]. Pieejams: http://www.csb.gov.lv/notikumi/2015-gada-sakuma-latvija-par-154tukstosiem-iedzivotaju-mazak-41755.html 
PIELIKUMI/ ANNEXES 
1. pielikums/ Annex 1

1. tabula/ Table 1

NVA pasākumi „Jauniešu garantijas” ietvaros/ „Youth Guarantee” measures of State Employment agency

\begin{tabular}{|c|c|c|c|c|c|c|}
\hline $\begin{array}{l}\text { Pārstāvošā } \\
\text { institūcija }\end{array}$ & $\begin{array}{c}\text { „'Jauniešu } \\
\text { garantijas" } \\
\text { pasākums }\end{array}$ & Mērḳis & $\begin{array}{c}\text { Noteikumi } \\
\text { dalībniekiem }\end{array}$ & Pozitīvais & Negatīvais & Ieteikumi \\
\hline $\begin{array}{l}\text { Nodarbinātības } \\
\text { Valsts aǵentūra }\end{array}$ & $\begin{array}{l}\text { Karjeras } \\
\text { konsultācijas }\end{array}$ & & 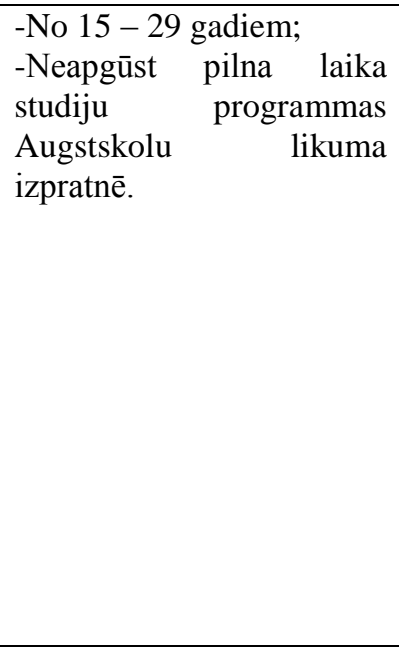 & $\begin{array}{l}\text {-Ar profilēšanas metodi } \\
\text { tiks noteikti tieši katram } \\
\text { jaunietim nepieciešamie } \\
\text { nodarbinātības vai } \\
\text { apmācību pasākumi; } \\
\text {-Konkurētspējas } \\
\text { sekmēšana darba tirgū }\end{array}$ & $\begin{array}{lr}\text {-Nav } & \text { paredzama } \\
\text { profilēšanas } & \text { metodes } \\
\text { efektivitāte, uz visiem } \\
\text { jauniešiem tā var } \\
\text { neiedarboties līdzvērtīgi }\end{array}$ & $\begin{array}{l}\text {-Karjeras } \\
\text { konsultācijām jābūt } \\
\text { pieejamām piln̄̄gi } \\
\text { visiem } \\
\text { esošajiem jauniešiem, } \\
\text { arī tiem, kas apgūst } \\
\text { pilna laika studiju } \\
\text { programmas, } \\
\text { karjeras konsultants } \\
\text { var ieteikt kā uzlabot } \\
\text { CV, ieteikumus darba } \\
\text { intervijai, papildus } \\
\text { zināšanu apguvei un } \\
\text { kursiem, } \\
\text { nepieciešami } \\
\text { jaunietim. }\end{array}$ \\
\hline $\begin{array}{l}\text { Nodarbinātības } \\
\text { Valsts aǵentūra }\end{array}$ & $\begin{array}{l}\text { Konkurētspējas } \\
\text { paaugstināšanas } \\
\text { pasākumi }\end{array}$ & $\begin{array}{l}\text {-Individuālās } \\
\text { konsultācijas un } \\
\text { grupu nodarbības } \\
\text { (kursi, semināri, } \\
\text { lekcijas) darba } \\
\text { meklēšanas metožu } \\
\text { apguvei, } \\
\text { psihologiskam } \\
\text { atbalstam; }\end{array}$ & 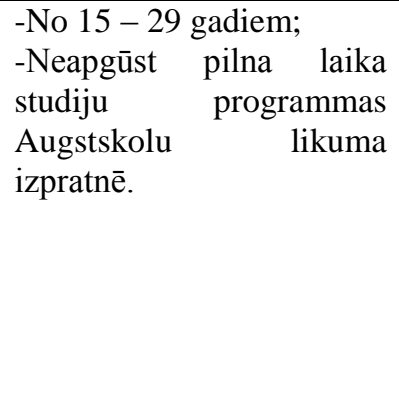 & $\begin{array}{lr}\text { - Semināros un lekcijās } \\
\text { iespējams iegūt } \\
\text { piemēram, } \\
\begin{array}{l}\text { sagatavošanā, } \\
\text { komunikācijas } \\
\text { attīstīšanā utt. }\end{array}\end{array}$ & 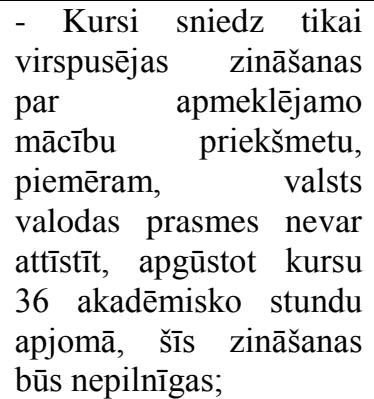 & $\begin{array}{lr}\text { - Paredzēt } & \begin{array}{r}\text { kursus } \\
\text { vairākos } \\
\text { studiju } \\
\text { posmos, }\end{array} \\
\text { iespiedzōju interesentiem, } \\
\text { tos apgūt dziḷāk un } \\
\text { uzlabot zināšanas } \\
\text { profesionālā līmen̄i, lai } \\
\text { spētu ikdienā efektīvi } \\
\text { zināšanas izmantot } \\
\text { turpmāk; }\end{array}$ \\
\hline
\end{tabular}


1. pielikuma turpinājums/Continuation of Annex 1

1. tabulas turpinājums/Continuation of Table 1

NVA pasākumi „Jauniešu garantijas” ietvaros/ „Youth Guarantee” measures of State Employment agency

\begin{tabular}{|c|c|c|c|c|c|c|}
\hline $\begin{array}{l}\text { Pārstāvošā } \\
\text { institūcija }\end{array}$ & $\begin{array}{l}\text { „Jauniešu } \\
\text { garantijas" } \\
\text { pasākums }\end{array}$ & Mērķis & $\begin{array}{c}\text { Noteikumi } \\
\text { dalībniekiem }\end{array}$ & Pozitīvais & Negatīvais & Ieteikumi \\
\hline $\begin{array}{l}\text { Nodarbinātības } \\
\text { Valsts } \\
\text { aǵentūra }\end{array}$ & $\begin{array}{l}\text { Konkurētspējas } \\
\text { paaugstināšanas } \\
\text { pasākumi } \\
\text { (turpinājums) }\end{array}$ & $\begin{array}{l}\text {-Darba tirgum } \\
\text { nepieciešamo } \\
\text { prasmju un iemaņu } \\
\text { apguvei }\end{array}$ & & & $\begin{array}{l}\text {-Pasākums nav paredzēts } \\
\text { jauniešiem, kas studē, bet } \\
\text { pastāv iespēja, ka tieši šis } \\
\text { jaunietis vēlas kaut kur } \\
\text { iesaistīties un ir aktīvāks } \\
\text { par nestudējošajiem } \\
\text { jauniešiem. }\end{array}$ & $\begin{array}{l}\text { Nav izmērāms, cik } \\
\text { efektīva ir līdzeklıu } \\
\text { izmantošana šiem } \\
\text { kursiem, šāda veida } \\
\text { semināri pieejami arī } \\
\text { augstskolās } \\
\text { studējošajiem, } \\
\text { piemēram LU, LLU, } \\
\text { RTU karjeras centros. }\end{array}$ \\
\hline $\begin{array}{l}\text { Nodarbinātības } \\
\text { Valsts } \\
\text { aǵentūra }\end{array}$ & $\begin{array}{l}\text { Darbnīcas } \\
\text { jauniešiem }\end{array}$ & $\begin{array}{l}\text { Iespēja jaunietim } \\
\text { iepazīties izglìtības } \\
\text { iestāde ar trīs } \\
\text { profesionālajām } \\
\text { izglīitibas } \\
\text { programmām un } \\
\text { katrā izglītības } \\
\text { programmā } \\
\text { iesaistîties } \\
\text { nedēlas, lai iepazītos } \\
\text { ar specifiku un gūtu } \\
\text { pieredzi. }\end{array}$ & 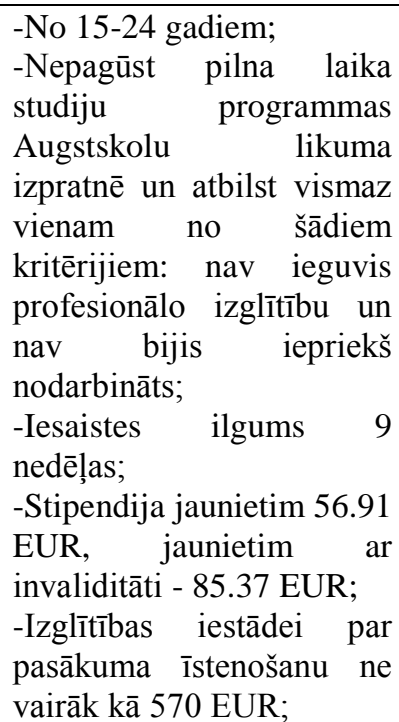 & $\begin{array}{l}\text {-Teorijas } 40 \% \text { apgūšana, } \\
\text { prakse } 60 \% \text {; } \\
\text {-Iespējas sanemt nelielu } \\
\text { stipendiju. }\end{array}$ & \begin{tabular}{l}
\multicolumn{3}{l}{-Programmas } \\
efekt̄̄gums, savā zin̄ā \\
nelietderīga \\
izmantošana, līdzekḷu \\
iespējams, jaunietim \\
neapmierinās neviens no \\
studiju virzieniem.
\end{tabular} & 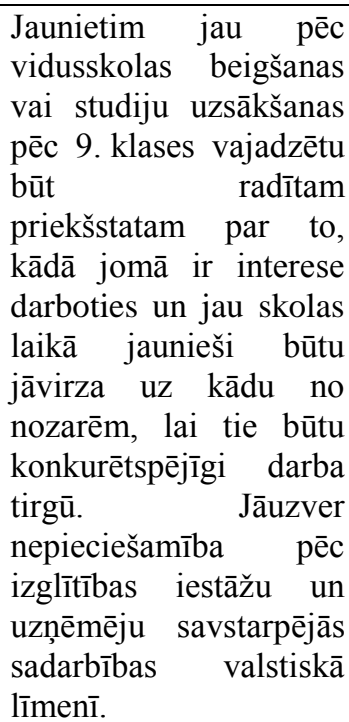 \\
\hline
\end{tabular}


1. pielikuma turpinājums/Continuation of Annex 1

1. tabulas turpinājums/ Continuation of Table 1

NVA pasākumi „Jauniešu garantijas” ietvaros/ „,Youth Guarantee” measures of State Employment agency

\begin{tabular}{|c|c|c|c|c|c|c|}
\hline $\begin{array}{l}\text { Pārstāvošā } \\
\text { institūcija }\end{array}$ & $\begin{array}{l}\text { „Jauniešu } \\
\text { garantijas" } \\
\text { pasākums }\end{array}$ & Mērķis & $\begin{array}{c}\text { Noteikumi } \\
\text { dalībniekiem }\end{array}$ & Pozitīvais & Negatīvais & Ieteikumi \\
\hline $\begin{array}{l}\text { Nodarbinātības } \\
\text { valsts aǵentūra }\end{array}$ & $\begin{array}{l}\text { Darbnīcas } \\
\text { jauniešiem } \\
\text { (turpinājums) }\end{array}$ & & $\begin{array}{l}\text {-Pasākuma laikā iespējams } \\
\text { saņemt regionālo } \\
\text { mobilitāti, ja darba vieta } \\
\text { atrodas vismaz } 20 \text { km } \\
\text { attālumā no deklarētās } \\
\text { dzīvesvietas. }\end{array}$ & & & \\
\hline $\begin{array}{l}\text { Nodarbinātības } \\
\text { valsts aǵentūra }\end{array}$ & $\begin{array}{l}\text { Neformālās } \\
\text { izglītības } \\
\text { programmu } \\
\text { īstenošana }\end{array}$ & $\begin{array}{l}\text { Sociālās un } \\
\text { profesionālās } \\
\text { pamatprasmes, } \\
\text { kurās atbilstoši } \\
\text { darba tirgus } \\
\text { pieprasījuma un } \\
\text { tautsaimniecības } \\
\text { nozaru attīstības } \\
\text { prognozēm } \\
\text { nepieciešams veikt } \\
\text { apmācību }\end{array}$ & 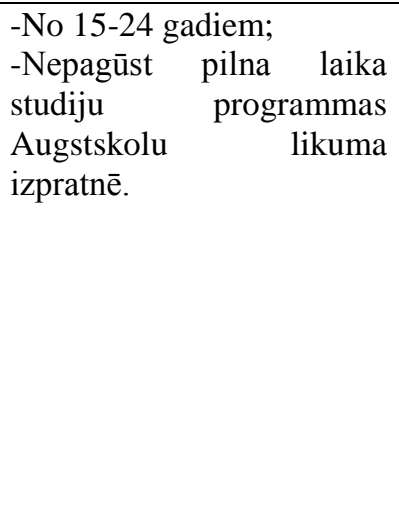 & $\begin{array}{l}\text {-Stipendija } 99.60 \quad \text { EUR } \\
\text { apmērā; } \\
\text {-Iespējams } \\
\text { regionionālo mobilitāti. }\end{array}$ & $\begin{array}{l}\text {-Netiek ieklauta jauniešu } \\
\text { grupa no } 25-29 \text { gadiem; } \\
\text {-Programmas efektivitāte } \\
\text { nav nosakāma, vai pēc } \\
\text { programmas apgūšanas } \\
\text { šīs zināšanas būs } \\
\text { izmantojamas turpmāk, } \\
\text { neturpinot apmācības, } \\
\text { piemēram valodu } \\
\text { apguve; } \\
\text {-Jaunieši var izvēlēties } \\
\text { apgūt šīs programmas, } \\
\text { lai sañemtu stipendiju. }\end{array}$ & $\begin{array}{lr}\text { - Detalizēti jāizvērtē } \\
\text { nepieciešamība pēc } \\
\text { programmas apguves, } \\
\text { piemēram, valodu } \\
\text { nevar apgūt vai uzlabot } \\
\text { pietiekoši } \\
\text { līmenī neilgu laika } \\
\text { periodu. }\end{array}$ \\
\hline
\end{tabular}


1. pielikuma turpinājums/Continuation of Annex 1

1. tabulas turpinājums/ Continuation of Table 1

NVA pasākumi „Jauniešu garantijas” ietvaros/ „Youth Guarantee” measures of State Employment agency

\begin{tabular}{|c|c|c|c|c|c|c|}
\hline $\begin{array}{l}\text { Pārstāvošā } \\
\text { institūcija }\end{array}$ & $\begin{array}{c}\text { „Jauniešu } \\
\text { garantijas" } \\
\text { pasākums }\end{array}$ & Mērḳis & $\begin{array}{c}\text { Noteikumi } \\
\text { dalībniekiem }\end{array}$ & Pozitîvais & Negativais & Ieteikumi \\
\hline $\begin{array}{l}\text { Nodarbinātības } \\
\text { valsts aǵentūra }\end{array}$ & $\begin{array}{l}\text { Profesionālās } \\
\text { tālākizglītības } \\
\text { un } \\
\text { profesionālās } \\
\text { pilnveides } \\
\text { programmu } \\
\text { îstenošana }\end{array}$ & $\begin{array}{l}\text { Paaugstināt } \\
\text { jauniešu } \\
\text { bezdarbnieku } \\
\text { konkurētspēju, } \\
\text { spēju pielāgoties } \\
\text { mainīgajam darba } \\
\text { tirgus } \\
\text { pieprasījumam un } \\
\text { palielināt iespēju } \\
\text { integrēties darba } \\
\text { tirgū. }\end{array}$ & 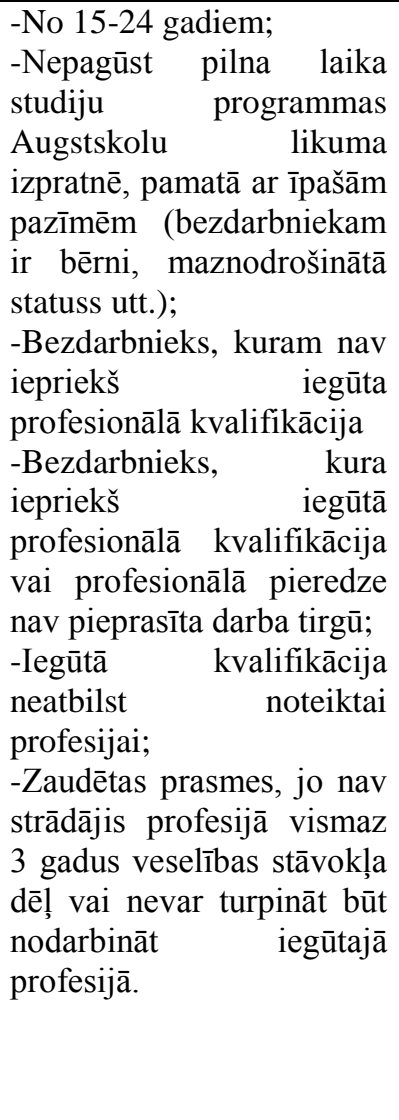 & $\begin{array}{l}\text { - Programma dod iespēju } \\
\text { maznodrošinātiem } \\
\text { jauniešiem un jauniešiem } \\
\text { ar bērniem iesaistīties } \\
\text { darba tirgū; } \\
\text {-Stipendija } 99.60 \text { EUR } \\
\text { apmērā. }\end{array}$ & 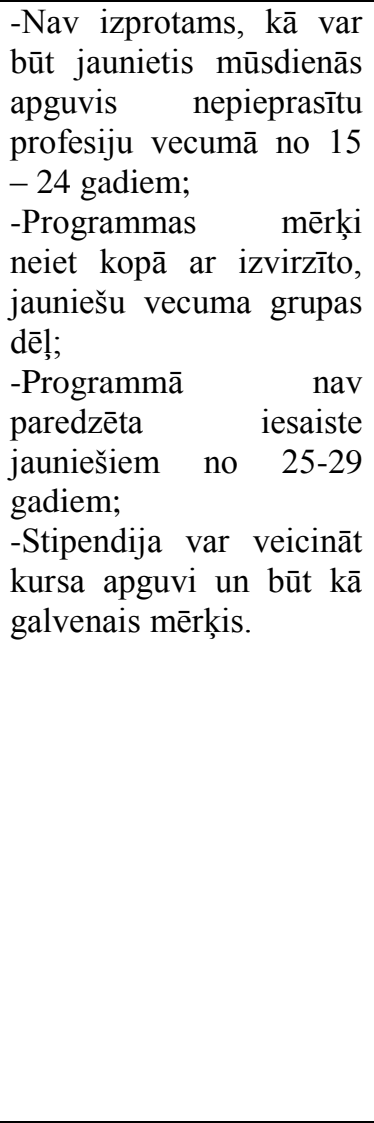 & 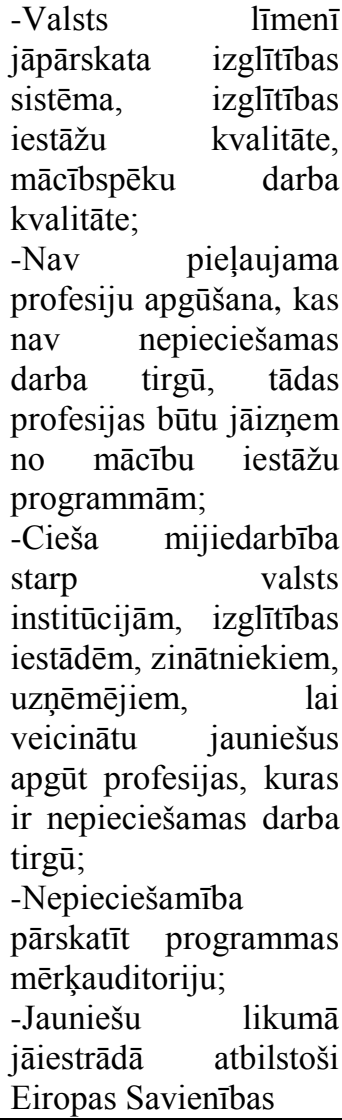 \\
\hline
\end{tabular}


1. pielikuma turpinājums/Continuation of Annex 1

1. tabulas turpinājums/Continuation of Table 1

NVA pasākumi „Jauniešu garantijas” ietvaros/ „Youth Guarantee” measures of State Employment agency

\begin{tabular}{|c|c|c|c|c|c|c|}
\hline $\begin{array}{l}\text { Pārstāvošā } \\
\text { institūcija }\end{array}$ & $\begin{array}{c}\text { „Jauniešu } \\
\text { garantijas" } \\
\text { pasākums }\end{array}$ & Mērḳis & Noteikumi dalībniekiem & Pozitivaais & Negativais & Ieteikumi \\
\hline $\begin{array}{l}\text { Nodarbinātîbas } \\
\text { valsts aǵentūra }\end{array}$ & $\begin{array}{l}\text { Profesionālās } \\
\text { tālākizglītības } \\
\text { un } \\
\text { profesionālās } \\
\text { pilnveides } \\
\text { programmu } \\
\text { îstenošana } \\
\text { (turpinājums) }\end{array}$ & & & & & $\begin{array}{l}\text { plānošanas dokumentiem } \\
\text { tiesības un noteikumi } \\
\text { jauniešiem no } 25-29 \text { gadiem. } \\
\text { Latvija ir ES valsts, līdz ar } \\
\text { to jāpiemērojas citām ES } \\
\text { valstīm, lai paaugstinātu } \\
\text { efektivitāti un neizslēgtu šo } \\
\text { jauniešu vecuma grupu; } \\
\text {-Nav izprotams cik jaunieši } \\
\text { no mērka grupām var tikt } \\
\text { iesaistīti šādā pasākumā; } \\
\text {-Pasākuma kvalitāte, } \\
\text { izglītības institūciju } \\
\text { kvalitāte, kas nodrošina šīs } \\
\text { programmas. }\end{array}$ \\
\hline $\begin{array}{l}\text { Nodarbinātības } \\
\text { valsts aǵentūra }\end{array}$ & $\begin{array}{l}\text { Pirmā darba } \\
\text { pieredze } \\
\text { jaunietim }\end{array}$ & $\begin{array}{l}\text { Sekmēt jauniešu } \\
\text { integrēšanu darba } \\
\text { tirgū, vienlaikus } \\
\text { veicinot } \\
\text { patstāvīgas darba } \\
\text { vietas izveidi un } \\
\text { jauniešu patstāvīgu } \\
\text { nodarbinātību. } \\
\text { Iesaiste pasākumā } \\
12 \text { mēneši. }\end{array}$ & $\begin{array}{l}\text {-No 18-29 gadiem; } \\
\text {-Nepagūst pilna laika studiju } \\
\text { programmas Augstskolu likuma } \\
\text { izpratnē; } \\
\text {-Iegūta profesionālā vai augstākā } \\
\text { izglītība; } \\
\text {-Regiistrēts bezdarbnieka statusā } \\
\text { vismaz } 1 \text { mēnesi; } \\
\text {-Pēc bezdarbnieka statusa iegūšanas } \\
\text { nav strādāts } 4 \text { mēnešus; } \\
\text {-Pirms bezdarbnieka statusa } \\
\text { iegūšanas nav strādājis vairāk par } \\
12 \text { mēnešiem. }\end{array}$ & $\begin{array}{l}\text {-Pasākumu } \\
\text { neorganizē } \\
\text { mazkvalificētos } \\
\text { un } \\
\text { nekvalificētos } \\
\text { darbos; } \\
\text {-Jaunieši } \\
\text { invalīdi var } \\
\text { saņemt } \\
\text { ergoterapeita } \\
\text { pakalpojumus; }\end{array}$ & $\begin{array}{l}\text {-Vai tiešām darba } \\
\text { devējs nodrošinās } \\
\text { jaunietim darba vietu } \\
\text { arī pēc iesaistes } \\
\text { pasākumā? } \\
\text {-Ar algu, kas valstī } \\
\text { noteikta kā minimālā } \\
\text { (360 EUR mēnesī/ } \\
\text { neto), jaunietim nav } \\
\text { iespējas uzsākt } \\
\text { patstāvīgu dzīvi. }\end{array}$ & $\begin{array}{l}\text {-Veidojot ciešu sadarbību } \\
\text { starp izglītības sektoru un } \\
\text { uzñēmējiem nebūtu valstī } \\
\text { situācija, ka jaunietim } \\
\text { vecumā no } 22-29 \text { gadiem } \\
\text { jāiesaistās rāāās } \\
\text { programmās, jau skolas laikā } \\
\text { jaunietis apgūtu pieredzi } \\
\text { kādā no uzñēmumiem, kas } \\
\text { veicinātu arī vina turpmāko } \\
\text { karjeru. Veicinātu ar̄i } \\
\text { prakses kā formalitātes } \\
\text { izskaušanu. }\end{array}$ \\
\hline
\end{tabular}


1. pielikuma turpinājums/Continuation of Annex 1

1. tabulas turpinājums/ Continuation of Table 1

NVA pasākumi „Jauniešu garantijas” ietvaros/ „Youth Guarantee” measures of State Employment agency

\begin{tabular}{|c|c|c|c|c|c|c|}
\hline $\begin{array}{l}\text { Pārstāvošā } \\
\text { institūcija }\end{array}$ & $\begin{array}{c}\text { „Jauniešu } \\
\text { garantijas" } \\
\text { pasākums }\end{array}$ & Mērḳis & Noteikumi dalībniekiem & Pozitīvais & Negatīvais & Ieteikumi \\
\hline $\begin{array}{l}\text { Nodarbinātības } \\
\text { valsts aǵentūra }\end{array}$ & $\begin{array}{l}\text { Subsidētā } \\
\text { darba vieta } \\
\text { jauniešiem } \\
\text { bezdarbniekiem }\end{array}$ & $\begin{array}{l}\text { Sekmēt jauniešu } \\
\text { iekḷaušanos } \\
\text { sabiedrībā, } \\
\text { konkurētspēju un } \\
\text { iekārtošanos } \\
\text { patstāvīgā darbā, } \\
\text { praktiskā pieredze. }\end{array}$ & 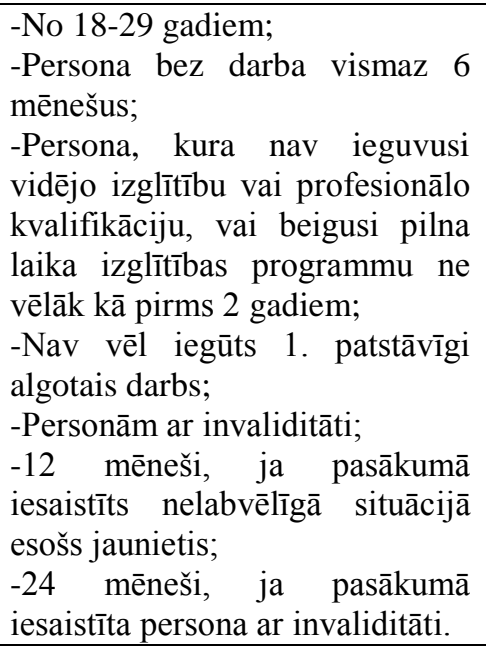 & $\begin{array}{l}\text {-Iegūta darba vieta } \\
\text { uz laiku un } \\
\text { pieredze. }\end{array}$ & $\begin{array}{l}\text {-Nav garantijas, ka pēc } \\
\text { pasākuma jaunietis tiks } \\
\text { paturēts darbā. }\end{array}$ & $\begin{array}{l}\text {-Veicināt arī jauniešu } \\
\text { paturēšanu darbā pēc } \\
\text { iesaistes projektā. }\end{array}$ \\
\hline $\begin{array}{l}\text { Nodarbinātības } \\
\text { Valsts aǵentūra }\end{array}$ & $\begin{array}{l}\text { Darbam } \\
\text { nepieciešamo } \\
\text { iemaņu } \\
\text { attīstība } \\
\text { nevalstiskajā } \\
\text { sektorā }\end{array}$ & $\begin{array}{l}\text { Nav skaidri } \\
\text { formulēts } \\
\text { konkrētajai } \\
\text { programmai }\end{array}$ & 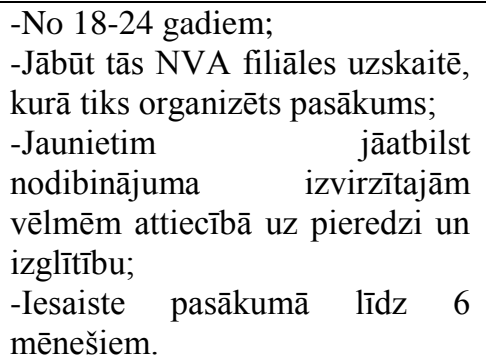 & $\begin{array}{l}\text {-Ikmēneša } \\
\text { stipendija 90,- EUR, } \\
\text { atbilstoši mēnesī } \\
\text { nostrādātajām } \\
\text { dienām; } \\
\text {-Nelaimes gadījumu } \\
\text { apdrošināšana. }\end{array}$ & $\begin{array}{l}\text {-Stipendijas apmērs ir } \\
\text { nemotivējošs. }\end{array}$ & $\begin{array}{l}\text {-Jāizvērtē programmas } \\
\text { efektivitāte un } \\
\text { nepieciešamība. }\end{array}$ \\
\hline
\end{tabular}


1. pielikuma turpinājums/Continuation of Annex 1

1. tabulas turpinājums/ Continuation of Table 1

NVA pasākumi „Jauniešu garantijas” ietvaros/ „Youth Guarantee” measures of State Employment agency

\begin{tabular}{|c|c|c|c|c|c|c|}
\hline $\begin{array}{l}\text { Pārstāvošā } \\
\text { institūcija }\end{array}$ & $\begin{array}{c}\text { „Jauniešu } \\
\text { garantijas" } \\
\text { pasākums }\end{array}$ & Mērķis & $\begin{array}{c}\text { Noteikumi } \\
\text { dalībniekiem }\end{array}$ & Pozitivais & Negatīvais & Ieteikumi \\
\hline $\begin{array}{l}\text { Nodarbinātības } \\
\text { Valsts aǵentūra }\end{array}$ & $\begin{array}{l}\text { Darbam } \\
\text { nepieciešamo } \\
\text { iemaņu attīstība } \\
\text { nevalstiskajā } \\
\text { sektorā } \\
\text { (turpinājums) }\end{array}$ & $\begin{array}{l}\text { Nav skaidri } \\
\text { formulēts } \\
\text { konkrētajai } \\
\text { programmai }\end{array}$ & $\begin{array}{l}\text {-No 18-24 gadiem; } \\
\text {-Jābūt tās NVA filiāles } \\
\text { uzskaitē, kurā tiks } \\
\text { organizēts pasākums; } \\
\text {-Jaunietim jāatbilst } \\
\text { nodibinājuma izvirzītajām } \\
\text { vēlmēm attiecībā uz } \\
\text { pieredzi un izglītību; } \\
\text {-Iesaiste pasākumā līdz } 6 \\
\text { mēnešiem. }\end{array}$ & $\begin{array}{l}\text {-Ikmēneša } \quad \text { stipendija } \\
\text { 90,- EUR, atbilstoši } \\
\text { mēnesī nostrādātajām } \\
\text { dienām; } \\
\text {-Nelaimes gadījumu } \\
\text { apdrošināšana. }\end{array}$ & $\begin{array}{l}\text {-Stipendijas apmērs ir } \\
\text { nemotivējošs. }\end{array}$ & $\begin{array}{l}\text {-Jāizvērtē programmas } \\
\text { efektivitāte un } \\
\text { nepieciešamība. }\end{array}$ \\
\hline $\begin{array}{l}\text { Nodarbinātības } \\
\text { Valsts aǵentūra }\end{array}$ & $\begin{array}{l}\text { Atbalsts } \\
\text { pašnodarbinātības } \\
\text { un } \\
\text { uzṇēmējdarbības } \\
\text { uzsākšanai }\end{array}$ & $\begin{array}{l}\text { Konsultatīvu un } \\
\text { finanšu atbalsta } \\
\text { pasākumu } \\
\text { sniegšana, } \\
\text { komercdarbības vai } \\
\text { pašnodarbinātības } \\
\text { uzsākšanai. }\end{array}$ & $\begin{array}{l}\text {-No 18-29 gadiem; } \\
\text {-Profesionālā vidējā } \\
\text { izglīīiba vai augstākāà } \\
\text { izglītība uzñēmējdarbības, } \\
\text { biznesa vadības vai citā } \\
\text { tām pielīdzināmā jomā vai } \\
\text { jomā, kurā plānots uzsākt } \\
\text { uzṇēmējdarbību. }\end{array}$ & 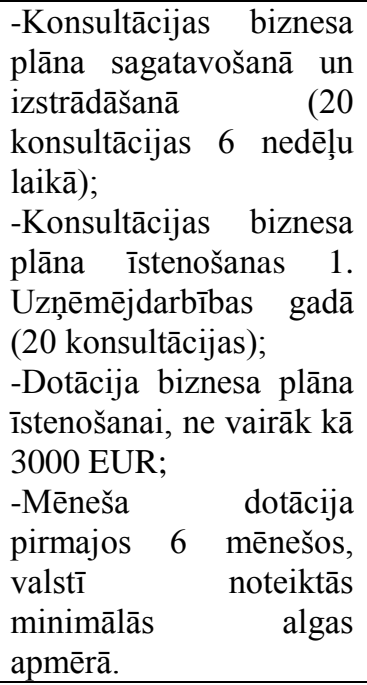 & $\begin{array}{l}\text {-Nav paredzēti } \\
\text { pasākumi atbalstam } \\
\text { uzņēmējdarbības } \\
\text { lejupslīdes gadījumā; } \\
\text { - Savstarpējā jauno } \\
\text { uzņēmēju } \\
\text { komunikācijas } \\
\text { platformas izveide. }\end{array}$ & $\begin{array}{lr}\text {-Būtiski } & \text { veicināt } \\
\text { savstarpējo } & \\
\text { komunikāciju } & \text { starp } \\
\text { jaunajiem } & \text { uzñēmējiem } \\
-\quad \text { sāàda platforma } \\
\text { jāizveido ralstiskā } \\
\text { līmenī. }\end{array}$ \\
\hline
\end{tabular}


1. pielikuma nobeigums/ The ending of Annex 1

1. tabulas nobeigums/ The ending of Table 1

NVA pasākumi „Jauniešu garantijas” ietvaros/ „Youth Guarantee” measures of State Employment agency

\begin{tabular}{|c|c|c|c|c|c|c|}
\hline $\begin{array}{l}\text { Pārstāvošā } \\
\text { institūcija }\end{array}$ & $\begin{array}{c}\text { „Jauniešu } \\
\text { garantijas" } \\
\text { pasākums }\end{array}$ & Mērķis & $\begin{array}{c}\text { Noteikumi } \\
\text { dalībniekiem }\end{array}$ & Pozitīvais & Negatīvais & Ieteikumi \\
\hline $\begin{array}{l}\text { Nodarbinātības } \\
\text { Valsts aǵentūra }\end{array}$ & $\begin{array}{l}\text { Atbalsts } \\
\text { jauniešu } \\
\text { reǵionālajai } \\
\text { mobilitātei }\end{array}$ & $\begin{array}{l}\text { Finansiāls atbalsts } \\
\text { mobilitātei }\end{array}$ & -No 15-29 gadiem; & 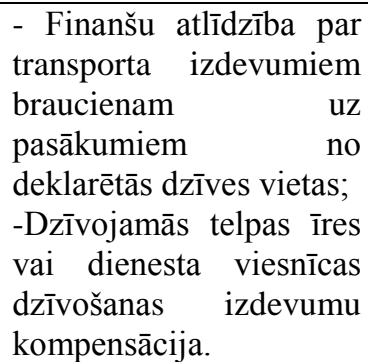 & $\begin{array}{l}\text { - Paredzēta atlīdzība par } \\
\text { izdevumiem transportam } \\
\text { no deklarētās dzīves } \\
\text { vietas, bet mūsdienās } \\
\text { daudzi indivīdi nav } \\
\text { deklarējušies tur, kur, } \\
\text { piemēram, ìrē dzīves } \\
\text { vietu. }\end{array}$ & $\begin{array}{l}\text {-Iekḷaut iespēju saņemt } \\
\text { arī transporta atlīdzību } \\
\text { no esošās dzìves } \\
\text { vietas, ja persona to } \\
\text { var apstiprināt un } \\
\text { pierādīt, bet } \\
\text { personisku iemeslu dēl } \\
\text { nedzivo deklarētajā } \\
\text { dzìves vietā. }\end{array}$ \\
\hline
\end{tabular}

Avots: Autores veidots balstoties uz Nodarbinātības valsts aǵentūras informāciju 
NVA sniegtais atbalsts „Jauniešu garantijas” ietvaros/ „Youth Guaranty” support by State Employment Agency

\begin{tabular}{|c|c|c|c|}
\hline \multirow[t]{2}{*}{$\begin{array}{c}\text { Projekta ,Jauniešu garantija” } \\
\text { pasākumi }\end{array}$} & 2014. gada izpilde & $\begin{array}{l}\text { 2014. gada } \\
\text { izpilde }\end{array}$ & $\begin{array}{l}\text { 2015. gada } \\
\text { plāns }\end{array}$ \\
\hline & Iesaistīto skaits & $\begin{array}{l}\text { Iesaistīto skaits } \\
\text { \% pret kopējo } \\
\text { jauniešu- } \\
\text { bezdarbnieku } \\
\text { skaitu }\end{array}$ & $\begin{array}{l}\text { Iesaistāmo } \\
\text { skaits }\end{array}$ \\
\hline \multicolumn{4}{|l|}{ Apmācību pasākumi } \\
\hline $\begin{array}{l}\text { Neformālās izglītības programmas } \\
\text { (no 15-24 gadu vecumam) }\end{array}$ & 880 & $0.39 \%$ & 798 \\
\hline $\begin{array}{l}\text { Profesionālās izglītības programmas } \\
\text { (no 15-24 gadu vecumam) }\end{array}$ & 1033 & $0.46 \%$ & 1680 \\
\hline $\begin{array}{l}\text { Darbnīcas jauniešiem (no 15-24 gadu } \\
\text { vecumam) }\end{array}$ & 501 & $0.22 \%$ & 858 \\
\hline \multicolumn{4}{|l|}{ Nodarbinātības pasākumi } \\
\hline $\begin{array}{l}\text { Pirmā darba pieredze jaunietim (no } \\
18-29 \text { gadu vecumam) }\end{array}$ & 70 & $0.031 \%$ & 522 \\
\hline $\begin{array}{l}\text { Subsidētā darba vieta jauniešiem } \\
\text { bezdarbniekiem (nelabvēlīgākā } \\
\text { situācijā esoši darbinieki) (no 18-29 } \\
\text { gadu vecumam) }\end{array}$ & 191 & $0.09 \%$ & 273 \\
\hline $\begin{array}{l}\text { Subsidētā darba vieta jauniešiem } \\
\text { bezdarbniekiem (jaunieši } \\
\text { bezdarbnieki ar invaliditāti) (no 18- } \\
29 \text { gadu vecumam) }\end{array}$ & 92 & $0.04 \%$ & 105 \\
\hline $\begin{array}{l}\text { Darbam nepieciešamo ieman̦u } \\
\text { attīstība nevalstiskajā sektorā (no 18- } \\
24 \text { gadu vecumam) }\end{array}$ & 962 & $0.43 \%$ & 1059 \\
\hline \multicolumn{4}{|l|}{ Atbalsta aktivitātes } \\
\hline $\begin{array}{l}\text { Individuāla karjeras konsultācija (no } \\
\text { 15-29 gadu vecumam) }\end{array}$ & 27283 & $12.09 \%$ & 26100 \\
\hline $\begin{array}{l}\text { Konkurētspējas paaugstināšanas } \\
\text { pasākumi (no 15-29 gadu vecumam) }\end{array}$ & 8050 & $3.57 \%$ & 9227 \\
\hline $\begin{array}{l}\text { Atbalsts jauniešu reǵionālajai } \\
\text { mobilitātei (no 15-29 gadu } \\
\text { vecumam) }\end{array}$ & 332 & $0.15 \%$ & 846 \\
\hline $\begin{array}{l}\text { Atbalsts pašnodarbinātības un } \\
\text { uzñēmējdarbības uzsākšanai (no 18- } \\
29 \text { gadu vecumam) }\end{array}$ & 69 & $0.031 \%$ & 59 \\
\hline Kopējais finansējums, EUR & $2056216,-$ & - & $6433001,-$ \\
\hline $\begin{array}{l}\text { Kopā iesaistīti jaunieši } \\
\text { bezdarbnieki }\end{array}$ & 39380 & $17.45 \%$ & 41527 \\
\hline
\end{tabular}

Avots: Labklājības ministrijas dati un autores aprēķini 


\section{Aptauja „Jauniešu iekḷaušanās darba tirgū”/ \\ Questionaire "Youth's inclusion in the labour market”}

Jūs tiekat aicināts/-a piedalīties aptaujā par jauniešu iekḷaušanos darba tirgū. Aptauju veic Latvijas Lauksaimniecības universitātes doktorante Līva Grineviča.

Aptaujas mērķis ir izpētīt jauniešu viedokli par iekḷaušanos darba tirgū. Aptaujas rezultāti tiks izmantoti jauniešu darba tirgus tendenču apzināšanai Latvijā.

Aptaujas aizpildī̌sana pras̄̄s ne vairāk kā 10 minūtes. Aptauja ir konfidenciāla un iegūtie rezultāti tiks izmantoti pētījumā apkopotā veidā.

Izvēlieties vienu vai, ja norādīts- vairākus no piedāvātajiem atbilžu variantiem. Atvērtajā jautājumā lūdzu izteikt person̄̄go viedokli.

\section{Jūsu šĩ brīža statuss:}

Šobrīd mācos/studēju (Pāriet uz jautājumu Nr.3)

skolnieks/students

nestudēju

\section{Esmu strādājošs}

\section{Kādā veidā Jūs atradāt līdzšinējo darbu?}

Г Ar paziṇu, draugu starpniecību (Pāriet uz jautājumu Nr.4);

$\square$ Studiju ietvaros pie darba devēja izgāju praksi un prakses beigās piedāvāja patstāvīgu darbu (Pāriet uz jautājumu Nr.4);



Atradu pats, regulāri sūtot CV uz internetā izvietotiem darba sludinājumiem (Pāriet uz jautājumu Nr.4);

Darba devējs izteica piedāvājumu, atrodot manu CV interneta vietnēs (Pāriet uz jautājumu Nr.4);

Cits

\section{Cik ilgi Jūs esat darba meklējumos?}
1-3 mēneši
3-6 mēneši
6-9 mēneši nestudēju (Pāriet uz jautājumu Nr.3)

3. pielikums/ Annex 3 
3. pielikuma turpinājums/Continuation of Annex 3

Aptauja ,Jauniešu iekḷaušanās darba tirgū"/

Questionaire "Youth's inclusion in the labour market”

4. Lūdzu, novērtējiet, cik lielā mērā dažādi ārēji no Jums neatkarīgi faktori ir līdz šim traucējuši//kavējušsi atrast darbu?

\begin{tabular}{|c|c|c|c|c|c|}
\hline & $\begin{array}{l}\text { Loti traucēja } \\
\qquad(5)\end{array}$ & $\begin{array}{l}\text { Traucēja } \\
\quad(4)\end{array}$ & $\begin{array}{c}\text { Neitrāls } \\
\text { (3) }\end{array}$ & $\begin{array}{l}\text { Gandrīz nav } \\
\text { traucējis } \\
(2)\end{array}$ & $\begin{array}{l}\text { Nemaz nav } \\
\text { traucējis } \\
(1)\end{array}$ \\
\hline $\begin{array}{l}\text { Neapmierina piedāvātā } \\
\text { darba samaksa }\end{array}$ & Г & Г & \ulcorner & Г & $\sqsubset$ \\
\hline $\begin{array}{l}\text { Zināšanu, prasmju trūkums } \\
\text { attiecīgajā jomā }\end{array}$ & Г & 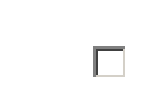 & \ulcorner & Г & $\sqsubset$ \\
\hline $\begin{array}{l}\text { Nav nepieciešamā darba } \\
\text { pieredze }\end{array}$ & $\sqsubset$ & Г & \ulcorner & $\sqsubset$ & $\sqsubset$ \\
\hline Maz brīvu darba vietu & ᄃ & ᄃ & \ulcorner & $\sqsubset$ & ᄃ \\
\hline $\begin{array}{l}\text { Iegūtā/iegūstamā izglītība } \\
\text { neatbilst piedāvātajām darba } \\
\text { vietām }\end{array}$ & ᄃ & Г & \ulcorner & Г & Г \\
\hline Neapmierina darba apstākḷi & Г & Г & \ulcorner & Г & ᄃ \\
\hline $\begin{array}{l}\text { Nav informācijas par darba } \\
\text { piedāvājumiem }\end{array}$ & Г & Г & \ulcorner & $\sqsubset$ & $\sqsubset$ \\
\hline $\begin{array}{l}\text { Slikti attīstīta infrastruktūra } \\
\text { (piem., transports) }\end{array}$ & $\sqsubset$ & $\sqsubset$ & \ulcorner & \ulcorner & $\sqsubset$ \\
\hline Ģimenes apstākḷi & $\sqsubset$ & $\sqsubset$ & \ulcorner & $\sqsubset$ & $\sqsubset$ \\
\hline $\begin{array}{l}\text { Nodarbinātības statuss- } \\
\text { bezdarbnieks }\end{array}$ & Г & \ulcorner & \ulcorner & Г & Г \\
\hline
\end{tabular}

5. Ar kādu attieksmi no darba devēju puses līdz šim sastapāties, izvērtējot Jūsu kandidatūru uz izsludināto vakanci? (Iespējamas vairākas atbildes) līmeña;

Tika pozitīvi vērtēta kandidatūra neatkarīgi no līdzšinējās pieredzes un izglīî̄bas izpildei;

Tika dota iespēja iegūt pieredzi un apgūt nepieciešamās prasmes konkrētā amata pretendentiem;

Tika negatīvi vērtēta konkurētspēja attiecībā pret pieredzes bagātākiem

Г Tika negatīivi vērtēts tas, ka šobrīd studēju;

Г Negatīva attieksme, ietilpstu kādā no bezdarba riskam pakḷautām grupām (ğimenes apstākḷi, pieredzes trūkums, valodu zināšanas utt.); 


\section{3. pielikuma turpinājums/Continuation of Annex 3}

Aptauja ,Jauniešu iekḷaušanās darba tirgū”/

Questionaire ,Youth's inclusion in the labour market”

Г Neitrāla attieksme, ietilpstu kādā no bezdarba riskam paklautām grupām (ğimenes apstākḷi, pieredzes trūkums, valodu zināšanas utt.).

Cits

6. Vai Jūs esat domājis par savas uzṇēmējdarbības uzsākšanu tuvākajā laikā?
Г $\mathrm{Ja}$
Cits
Nē (Pāriet uz jautājumu Nr.8)
Nr.8)
$\square$ Neinteresē (Pāriet uz jautājumu

7. Ja Jūs uzsāktu uzṇēmējdarbību, kurā no tālākminētajām nozarēm Jūs vēlētos darboties?

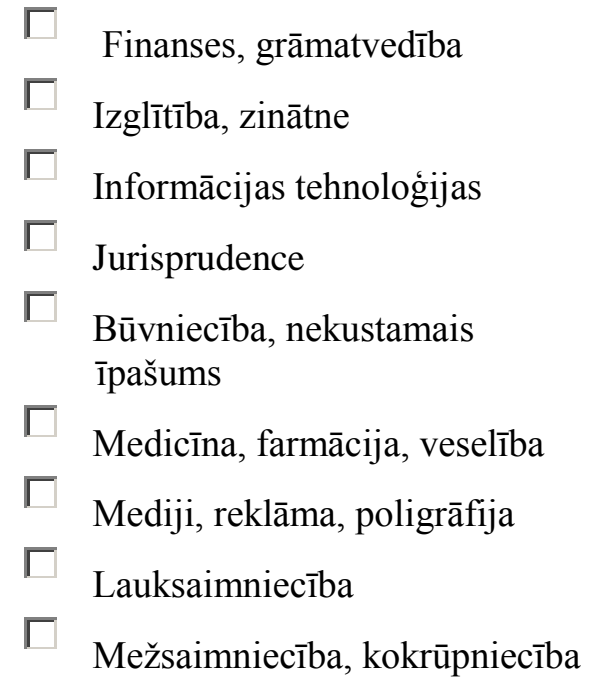

8. Vai esat informēts un iepazinies ar uzṇēmējdarbības uzsākšanas atbalsta programmām?
Јā
「ē (Pāriet uz jautājumu Nr.10)
Neinteresē (Pāriet uz jautājumu

9. Par kuru/kurām no uzṇēmējdarbības atbalsta programmām biznesa uzsākšanai esat bijis informēts? (Iespējamas vairākas atbildes)

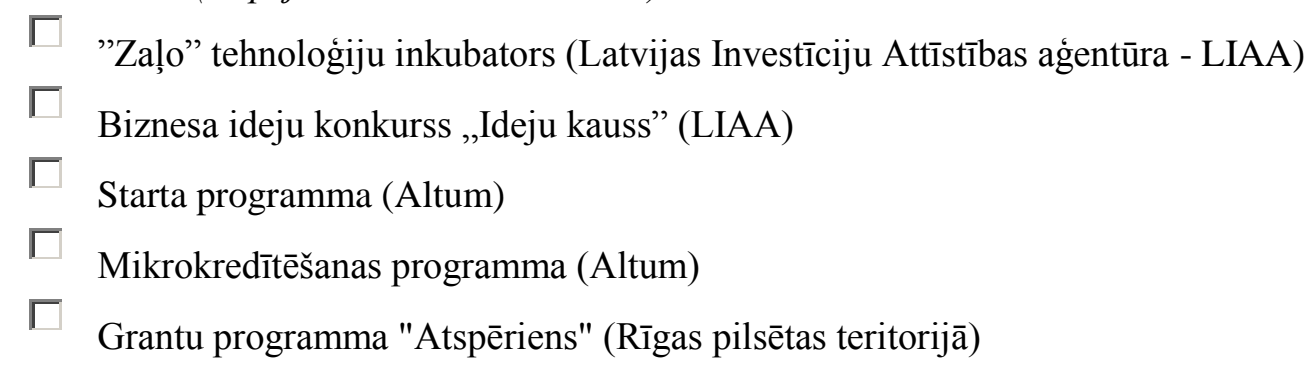


3. pielikuma turpinājums/Continuation of Annex 3

Aptauja ,Jauniešu iekḷaušanās darba tirgū"/

Questionaire ,Youth's inclusion in the labour market”

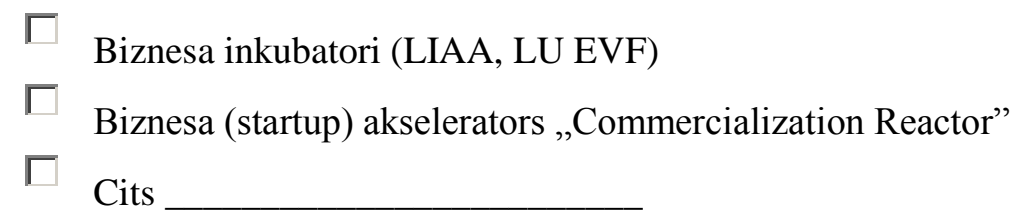

10. Lūdzu, izvērtējiet minēto apgalvojumu svarīgumu, kas, Jūsuprāt, veicinātu uzṇēmējdarbības attīstības iespējas jauniešu vidū!

Biznesa inkubatoru pieejamība ( telpas

Nesvarīgi Mazsvarīgi Svarīgi Loti svarīgi

birojiem, grāmatvedības, lietvedības, administratīvais atbalsts utt.)

Biznesa eñgeḷ piesaiste (finansiāls atbalsts no personām, kurām ieinteresējusi biznesa ideja)

Dalība darba grupās, kurās iespēja izveidot kontaktus ar potenciālajiem partneriem

Finansējuma piesaistes iespējas bez apgrūtinājuma/ ķīlas piesaistes

Izglītojoši kursi jaunajiem uzņēmējiem Eiropas Savienības projektu ietvaros

Mentoru piesaiste (atbalsts, sniedzot praktiskus padomus, idejas uzn̄ēmuma attīstības pirmos mēnešus)

Nodokḷu atvieglojumi jaunajiem uzņēmējiem

Pašvaldību atbalsts jaunajiem uzñēmējiem

Plašāka grantu programmu pieejamība

Prakses iespēju nodrošināšana studiju procesā

Studiju laikā nodrošināta iespēja

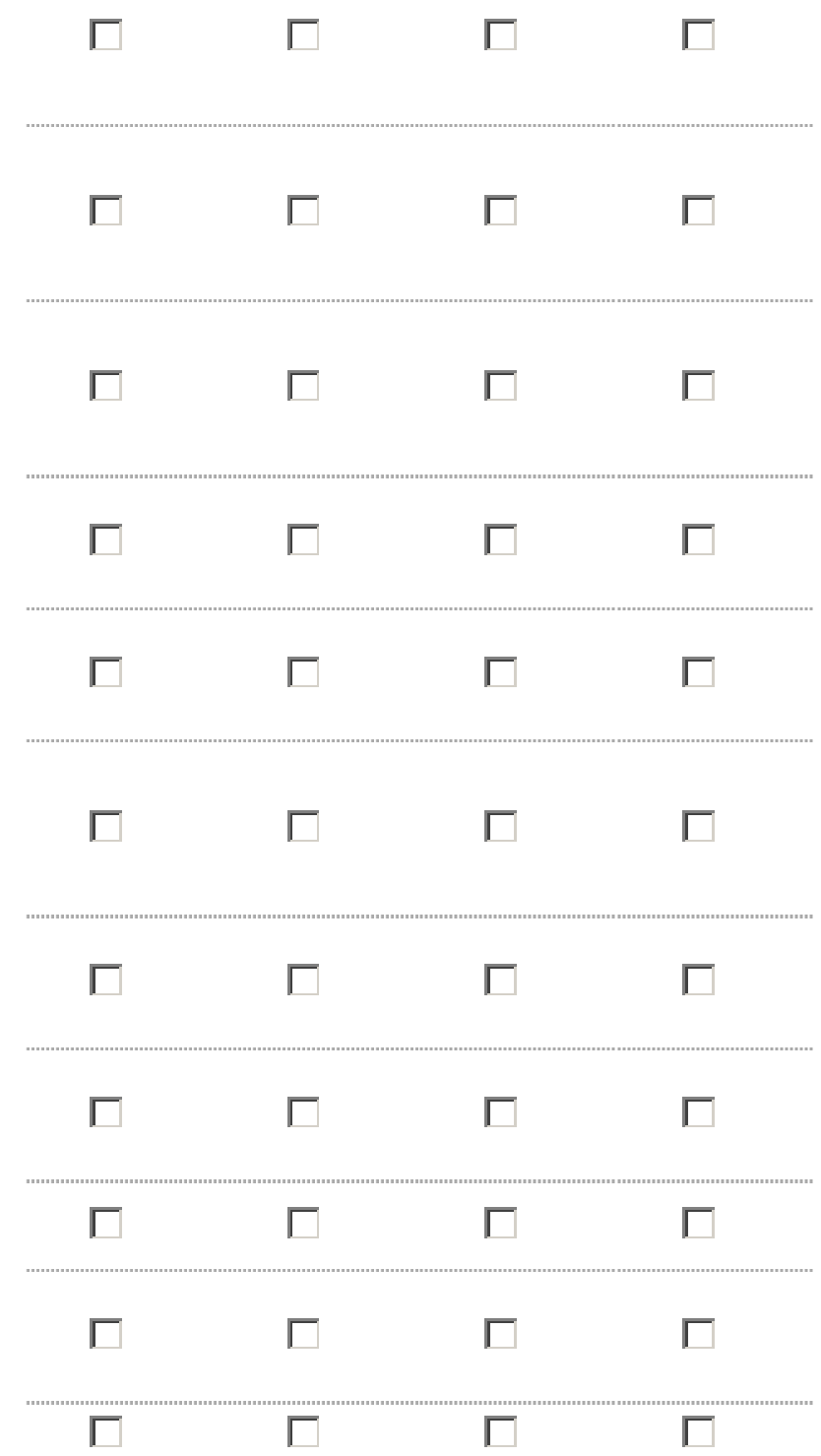


sadarboties ar uzn̦ēmējiem, paplašinot

sadarbības partneru loku

3. pielikuma nobeigums/ The ending of Annex 3

Aptauja ,Jauniešu iekḷaušanās darba tirgū"”

Questionaire „Youth's inclusion in the labour market”

11. Ar kādām metodēm, Jūsuprāt, ir vēl iespējams cīnīties ar jauniešu bezdarbu?

Aptaujas rezultāti netiks izpausti un tiks izmantoti tikai apkopotā veidā.

Lūdzu norādiet informāciju par sevi:

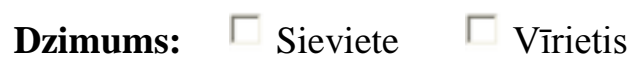

Vecums:

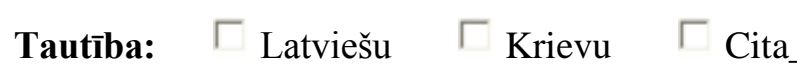

Izglītības līmenis:

$\Gamma$ Pamatskolas

$\Gamma$ Bakalaurs

$\Gamma$ Magistrs

「Vidējā

$\ulcorner$ Augstākā profesionālā

$\Gamma$ Doktors

$\lceil$ Vidējā profesionālā

ГNepabeigta augstākā

$\Gamma$ Cits

Dzīves vieta:

$\Gamma$ Rīga
$\ulcorner$ Pierīga
$\ulcorner$ Daugavpils
$\ulcorner$ Jēkabpils
$\ulcorner$ Jelgava
$\ulcorner$ Jürmala

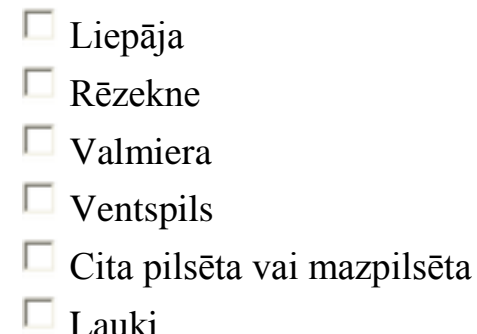

Sīkāka informācija par aptauju pieejama: Līva Griṇeviča,

e -pasts: liva_g2@inbox.lv.

\section{Paldies par atbildēm!}




\section{Uzņēmēju/ institūciju pārstāvju aptauja/ \\ Questionnaire for entrepreneurs/ institutions}

\section{Labdien!}

Latvijas Lauksaimniecības universitātes Reǵionālās ekonomikas 3. kursa studente, Līva Griņeviča, doktora darba ietvaros veic aptauju ar mērḳi noskaidrot nozares ekspertu viedokli par jauniešu iekḷaušanos darba tirgū.

Jūs tiekat aicināts/-a piedalīties aptaujas procesā un sniegt viedokli par zemāk minētajiem jautājumiem.

Aptaujas aizpildīšana prasīs ne vairāk kā 15 minūtes. Iegūtie rezultāti tiks izmantoti tikai doktora darba izstrādei.

1. Kā Jūs vērtējat jaunieša, ar izglìtību zemāku par vidējo vai profesionālo, iespējas ieklauties darba tirgū?

2. Kā Jūs vērtējat jaunieša, kurš šobrīd studē augstākā līmeņa studijās un vēl nav ieguvis augstāko izglītību, iespējas iekļauties darba tirgūu,?

3. Kā Jūs vērtējat Nodarbinātības Valsts aǵentūras istenotos jauniešu mobilitātes pasākumus, kuros ar Eiropas Savienības Fondu atbalstu jaunietim tiek dota iespēja apgūt profesionālās pilnveides kursus?

4. Kā Jūs vērtējat Nodarbinātības Valsts aǵentūras ìstenotos jauniešu mobilitātes pasākumus, kuros ar Eiropas Savienības Fondu atbalstu tiek piesaistīts lìdzfinansējums jauniešu darba algas dal̦ējai segšanai, ar nosacījumu, ka darba devējs nodarbina jaunieti, iesaistoties projektā noteiktu laika periodu?

5. Vai Jūsuprāt atvieglojumi nodokļu jomā spētu ietekmēt darba devēju lēmumu par jaunieša kandidatūras apstiprināšanu uz vakanto vietu attiecībā pret citiem pretendentiem?

5. Kā Jūs vērtējat jauniešu potenciālās iespējas uzsākt uzņēmējdarbību, ņemot vērā mūsdienu ekonomisko situāciju?

6. Vai Jūsuprāt Latvijā pieejamie atbalsta instrumenti uzñēmējdarbības uzsākšanai ir nodrošināti pietiekošā lìmen̄ (mikrokreditēšanas programmas, starta programmas uzņēmējdarbības uzsākšanai, mentoru konsultācijas, biznesa inkubatori, utt.)?

7. Lūdzu, miniet, Jūsuprāt svarīgākos valsts institūciju ìstenojamos pasākumus jauniešu darba tirgus situācijas stabilizēšanai!

\section{Liels paldies par Jūsu veltīto laiku un atsaucību!}


SVID analīze -jauniešu vērtējums par to konkurētspēju darba tirgū Latvijā $(\mathrm{n}=764) /$

SWOT Analysis - Youth assessment for their competitiveness in the labour market in Latvia $(n=764)$

\begin{tabular}{|c|c|c|}
\hline Vide & Stiprās puses & Vājās puses \\
\hline Mikro & $\begin{array}{l}\text {-Vecāku ietekme uz jaunieša nākotni, jau } \\
\text { no bērnības nepieciešams ieaudzināt bērnā } \\
\text { čaklumu, elastību, pieklājīgumu, cieņu utt. } \\
\text { - Jaunieša piederība kādai sabiedrības dalai } \\
\text { ar kopīgām interesēm, piem., iesaistǐšanās } \\
\text { jauniešu organizācijās, brīvprātīgajā darbā } \\
\text { veicina jaunieša interesi par dažādām } \\
\text { jomām un dod pieredzi; } \\
\text {-Jauniešu organizācijām ir iespējams } \\
\text { piesaistīt finansējumu dažādu aktivitāšu } \\
\text { realizēšanai, kā piem., apmācības } \\
\text { braucieni uz ārvalstīm, ārvalstu studentu } \\
\text { pasniegtie valodu kursi, citi kursi un } \\
\text { aktivitātes, kas veicina jaunieša } \\
\text { ieklaušanos sabiedrībā un kontaktu } \\
\text { iegūšanu. }\end{array}$ & $\begin{array}{l}\text {-Jauniešu ilgstošā uzturēšanās pie datora, } \\
\text { neefektīvi izmantojot laiku, pozitīvāk būtu } \\
\text { iesaistīties jauniešu organizācijās un atrasties } \\
\text { sabiedrībā, veicinot savstarpējo } \\
\text { komunikāciju un iekḷaušanos sabiedrībā; } \\
\text {-Jauniešu negatīvā attieksme pret } \\
\text { mazkvalificētu darbu, kas radusies } \\
\text { apkārtējās vides ietekmē, piem., jaunietis } \\
\text { pieder tādai sociālajai jauniešu grupai, kas } \\
\text { izsmej tos, kas veic mazkvalificētus darbus, } \\
\text { līdz ar to jaunietim šādi uzskati ir ieaudzināti } \\
\text { jau no skolas gadiem; } \\
\text {-Sabiedrības uzskati par jauniešu } \\
\text { nevēlēšanos strādāt, kas veicina arī negatīvo } \\
\text { attieksmi no darba devēju puses; } \\
\text {-Jauniešu kā sociālās grupas zemā vērtēšana } \\
\text { no darba devēju puses, kas veicina jauniešu } \\
\text { nespēšanu ieklauties darba tirgū; } \\
\text {-Daudzas „lietas” jauniešu rokās nokl̄ūst } \\
\text { pārāk viegli, bez piepūles, un viņiem rodas } \\
\text { sajūta, ka tā notiek nemitīgi. Jau skolas laikāa } \\
\text { ir jāaudzina jaunā paaudze, kas spēj } \\
\text { uzņemties atbildību par sevi un nodrošināt } \\
\text { darba vietu kaut sev. }\end{array}$ \\
\hline Mezo & $\begin{array}{l}\text {-Jauniešu apzināšanās, ka studiju periodā } \\
\text { darba devēji pārsvarā nebūs ieinteresēti } \\
\text { jaunieti nodarbināt par konkurētspējīgu } \\
\text { atalgojumu - šì apziņa var veicināt } \\
\text { jaunieša cīñas sparu un nepadoties ši laika } \\
\text { perioda radītajam spiedienam, un } \\
\text { samierināties, vismaz uz studiju laiku, ar } \\
\text { zemu atalgojumu; } \\
\text {-Erasmus + ES finansēti projekti, kas } \\
\text { jauniešiem dod iespēju doties pieredzes } \\
\text { apmaiņā uz ārvalstīm. }\end{array}$ & 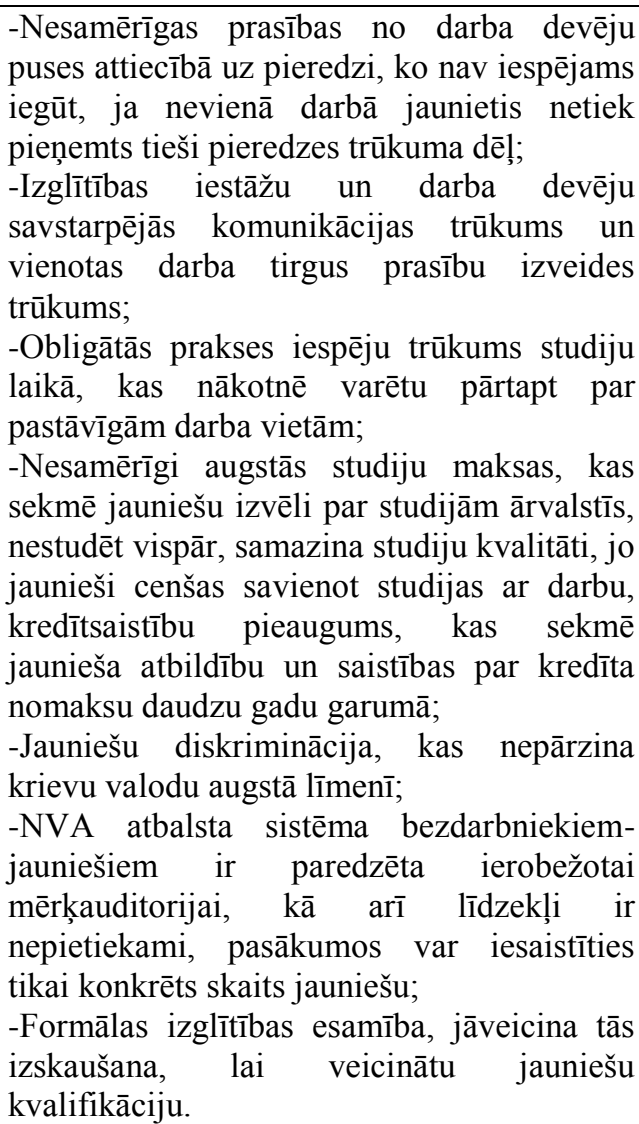 \\
\hline
\end{tabular}


5. pielikuma turpinājums/ Continuation of Annex 5 3. tabulas turpinājums/ Continuation of Table 3

SVID analīze -jauniešu vērtējums par to konkurētspēju darba tirgū Latvijā $(\mathbf{n}=764) /$

SWOT Analysis - Youth assessment for their competitiveness in the labour market in Latvia $(n=764)$

\begin{tabular}{|c|c|c|}
\hline Vide & Stiprās puses & Vājās puses \\
\hline Makro & $\begin{array}{l}\text {-Jauniešu bezdarba problemātika tiek } \\
\text { apskatîta ES politikas plānošanas } \\
\text { dokumentos, kā arī valstiskā līmenī. }\end{array}$ & $\begin{array}{l}\text {-Darba piedāvājumu trūkums atsevišksās } \\
\text { specialitātēs; } \\
\text {-Nekonkurētspējīgs atalgojums jauniešiem } \\
\text { gan par mazkvalificētu darbu veikšanu, gan } \\
\text { kvalificētu darbu veikšanu; } \\
\text {-Neefektīva jauniešu bezdarba mazināšanas } \\
\text { politikas îstenošana, kas nesniedz rezultātu } \\
\text { ilgterminnā, īstenotie instrumenti vērsti } \\
\text { îstermiņa problēmas ,apārstēšanai”, šādu } \\
\text { apgalvojumu sniedz arī nozaru eksperti; } \\
\text {-Par valsts budžeta līdzekļiem tiek apmācīti } \\
\text { jaunieši, kas trūkstošo darba vietu dēl,, dodas } \\
\text { strādāt uz ārvalstīm. }\end{array}$ \\
\hline Vide & Iespējas & Draudi \\
\hline Mikro & $\begin{array}{l}\text {-Jaunietim pašam jādomā par savu } \\
\text { izaugsmi, turpmākās } \\
\text { nodrošināšanu; } \\
\text {-Jaunietim, meklējot darbu, jānorāda uz } \\
\text { savām stiprajām pusēm un individuālajām } \\
\text { vērtībām; } \\
\text {-Jau iepriekšs strādāt ar bērniem, kas nāk no } \\
\text { nelabvēlīgām gimenēm, nodrošinot ar } \\
\text { prakses vietām, dodot iespēju gūt } \\
\text { atalgojumu vai papildus bonusus, piem., } \\
\text { bezmaksas ēdināšana, kopmītnes utt.; }\end{array}$ & $\begin{array}{l}\text {-Jaunieša iekḷaušanās sociālajā riska grupā, } \\
\text { veicinot sabiedrības nabadzības līmeņa } \\
\text { paaugstināšanos; } \\
\text {-Jaunieša nespēšana iekḷauties sabiedrībā, } \\
\text { kas var veicināt dažădu atkarību rašanos, } \\
\text { piem., alkoholisms, atkarība no } \\
\text { narkotiskajām vielām, netiklu darbību } \\
\text { veikšana, noziedzība utt.; } \\
\text {-Ģimenes labklājības līmeņa samazināšanās, } \\
\text { jo vecākiem jāuztur vairāki gimenes locekḷi, } \\
\text { ja jaunietis jau vecumā no 17. gadiem, } \\
\text { vismaz vasaras periodos nespēj atrast darbu, } \\
\text { lai sapelnītu naudu skolas gaitām, nemaz } \\
\text { neapsverot iespēju iekrāt līdzekḷus ar vasaras } \\
\text { darbiem studiju maksai augstskolā. }\end{array}$ \\
\hline Mezo & $\begin{array}{l}\text {-Jāveido ciešāka sadarbība starp izglītības } \\
\text { iestādēm un uzņēmējiem, nodrošinot } \\
\text { vairāk prakses vietas; } \\
\text {-Apmaksātu prakses vietu nodrošināšana; } \\
\text {-Iespēja apgūt un uzlabot valodu, kas } \\
\text { nepieciešama ikdienas darba pienākumu } \\
\text { veikšanai (piem., krievu valoda, angluu } \\
\text { valoda), sadarbībā ar NVA, nevalstiskajām } \\
\text { organizācijām; } \\
\text {-Brīvā laika pavadīšanas iespēju } \\
\text { paplašināšana augstskolām sadarbojoties } \\
\text { ar jauniešu organizācijām, savstarpēji } \\
\text { popularizējot šos pasākumus un veicinot } \\
\text { jauniešu interesi; } \\
\text { - Izglītības sistēmas maiņa - Studiju } \\
\text { programmu kvalitātes izvērtēšana, studiju } \\
\text { programmas padarot praktiskākas; } \\
\text {-Paplašināt apgūstamo arodu veidus } \\
\text { dažādās nozarēs, veicinot nepieciešamo } \\
\text { profesiju apgūšanu; }\end{array}$ & $\begin{array}{l}\text {-Nekonkurētspējīgas izglītības apgūšana kā } \\
\text { drauds turpmākajai integrācijai darba tirgū; } \\
\text {-NVA un nevalstisko organizāciju valodu } \\
\text { kursi notiek salīdzinoši neilgu laika posmu, } \\
\text { līdz ar to ne vienmēr jaunietis pilnvērtīgi } \\
\text { apgūst valodu, it îpaši, ja valodas apmācības } \\
\text { ir pirmajos līmeños; } \\
\text {-Došanās uz ārvalstīm, labāk atalgota darba } \\
\text { meklējumos; } \\
\text {-Izglītības ieguve ārvalstīs, lai pielāgotos } \\
\text { ārvalstu darba tirgum, līdz ar to aizplūst } \\
\text { potenciālie Latvijas augstskolu studenti; } \\
\text {-Ierobežots finansiālo resursu apmērs, lai } \\
\text { varētu nodrošināt lielāku īpatsvaru jauniešu } \\
\text { ar iespēju piedalīties NVA rīkotajos } \\
\text { pasākumos. }\end{array}$ \\
\hline
\end{tabular}


5. pielikuma nobeigums/ The ending of Annex 5 3. tabulas nobeigumss/ The ending of Table 3

SVID analīze -jauniešu vērtējums par to konkurētspēju darba tirgū Latvijā

$$
(\mathbf{n}=764) /
$$

SWOT Analysis - Youth assessment for their competitiveness in the labour market in

\section{Latvia $(n=764)$}

\begin{tabular}{|c|c|c|}
\hline Vide & Iespējas & Draudi \\
\hline Mezo & $\begin{array}{l}\text {-Veicināt darba vietu attīstīšanu, ko } \\
\text { iespējams apvienot ar studijām; } \\
\text {-Konkurētspējīgas izglīīibas pieejamības } \\
\text { veicināšana; } \\
\text {-Sniegt iespēju apmeklēt kursus un } \\
\text { seminārus, kas sniegtu iespēju papildus } \\
\text { apgūt jaunas, iepriekš neapgūtas jomas; } \\
\text {-Budžeta vietu pārdale atbilstoši } \\
\text { tautsaimniecības attīstībai } \\
\text { nepieciešamajām nozarēm. }\end{array}$ & \\
\hline Makro & 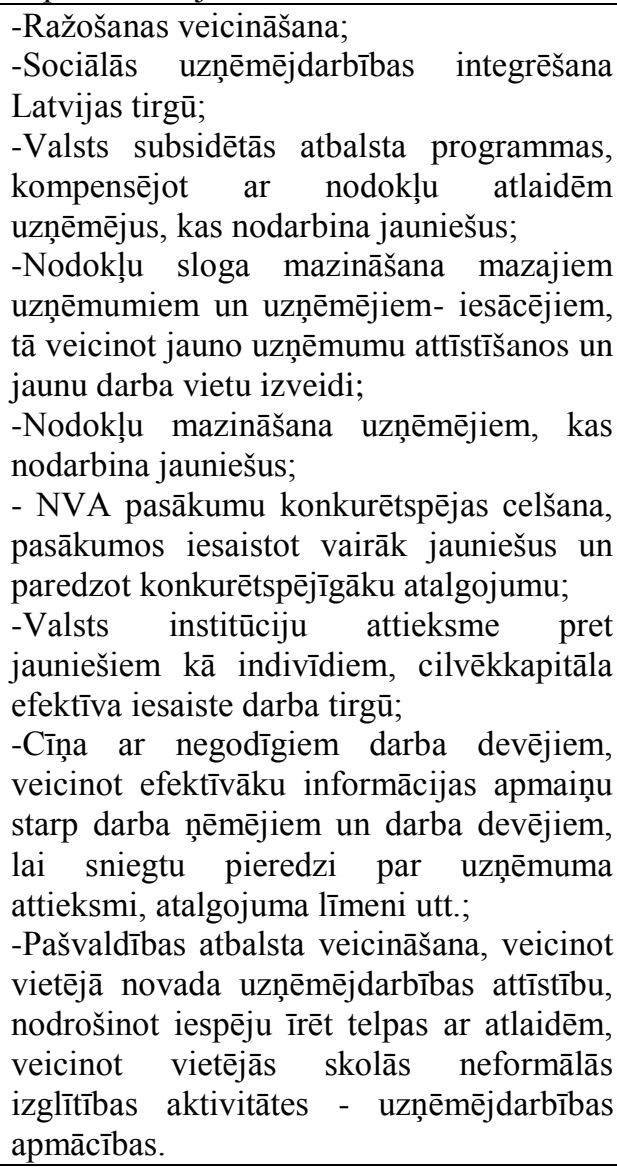 & 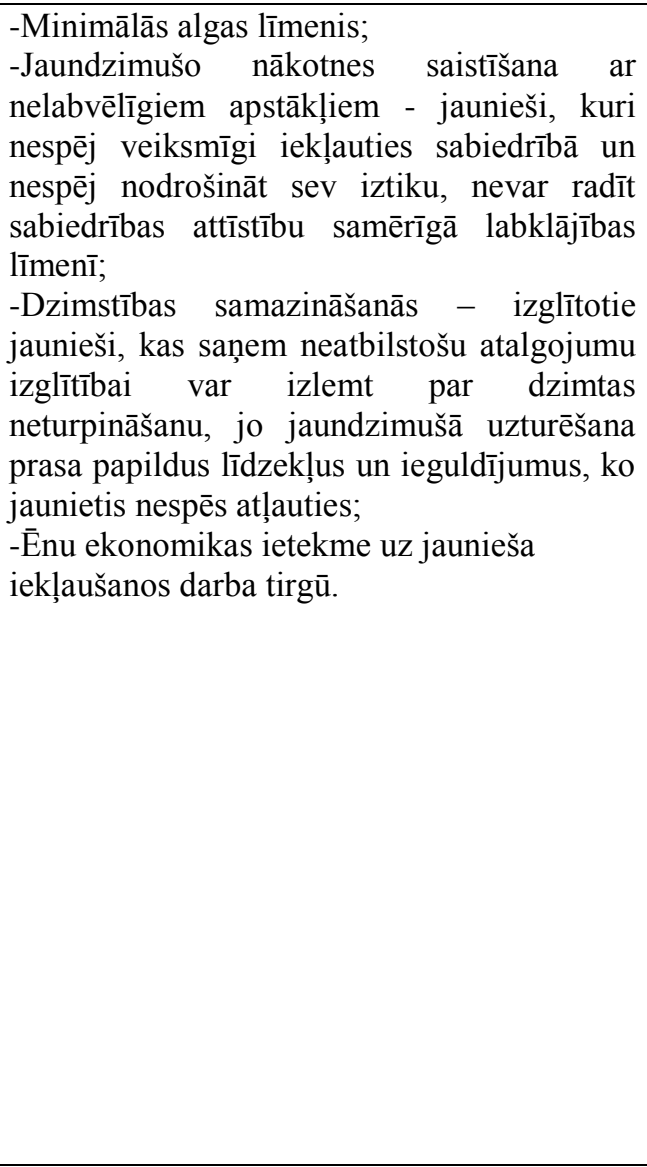 \\
\hline
\end{tabular}

Avots: autores konstrukcija, balstoties uz pētījuma rezultātiem 


\section{Ekspertu aptaujas anketa hierarhiju analīzei/ Questionnaire for eksperts (Hierarchy Analysis)}

\section{Cienījamie eksperti!}

Latvija ārvalstu pētījumos 2030. gadā tiek pozicionēta kā „depresīvais” reǵions, kurā būs nepietiekams iedzīvotāju skaits jauniešu vidū. Līdz ar to Latvija, kā valsts ar uzņēmējdarbības attīstībai draudzīgu vidi nespēs būt konkurētspējīga attiecībā pret citām Eiropas valstīm un investīciju plūsma tiks apdraudēta, kā arī novirzīta uz citiem, konkurētspējīgākiem un demogrāfiskā ziņā attīstītākiem, reǵioniem. Tāpēc ir ļoti aktuāli analizēt jauniešu nodarbinātības tendences un strādāt pie Latvijas ekonomiskās attīstības apstākḷiem atbilstošas sistēmas ieviešanas un realizēšanas, lai veicinātu cilvēkkapitāla iesaisti darba tirgū un samazinātu to aizplūšanu uz ārvalstīm. Būtiski ir vērst uzmanību uz šo jautājumu un rast atbildes uz jautājumiem: Kuru no jauniešu nodarbinātības veicināšanas scenārijiem iespējams realizēt Latvijā tuvākajā laika periodā? Kurš no scenārijiem ir atbilstošākais Latvijas attīstības veicināšanai? Kurš no scenārijiem ir vairāk vērsts uz visu iesaistīto pušu interešu apmierināšanu? Kurš scenārijs nodrošinās valsts ekonomikas attīstību?

Ekspertu izvērtēšanai tiek piedāvāti četri iespējamie scenāriji jauniešu nodarbinātības veicināšanai Latvijā. To vispārējs apraksts ir 2. lpp. Aicinu Jūs izvērtēt piedāvātos scenārijus.

\section{Jūsu viedoklis ir l̦oti vērtīgs!}

Iepriekš pateicoties, Līva Griṇeviča.

\section{Instrukcija}

Tālāk tekstā ir ekspertu tabulu aizpildīšanas instrukcijas. Iespējams, visērtākais veids, kā to izdarīt, ir elektroniski aizpildot Word tabulas. Izpildīto anketu, lūdzu, nosūtīt uz e-pastu (liva_g2@inbox.lv).

Jums būs jāaizpilda simetriskas tabulas (skat. paraugu sarkanā krāsā nākošajā lapā). Katrā tabulas rūtin̄ā tiek savstarpēji salīdzināti divi elementi (kritēriji, scenāriji). Iekrāsotos lodziņus ērtības labad neaizpilda. Ja pirmais elements (kritērijs, scenārijs) ir svarīgāks par otro, tad attiecīgajā rūtiņā ieraksta veselu skaitli no relatīvās svarīguma skalas (1.tabula), bet pretējā gadījumā tiek izmantots apgriezts lielums. Piemēram, parauga tabulā indivīdu intereses ir novērtētas kā būtiski ( 8 pret 1/8) svarīgākas par pašvaldību interesēm. 


\section{6. pielikuma turpinājums/ Continuation of Annex 6 \\ Ekspertu aptaujas anketa (Hierarhiju analīzei)/ \\ Questionnaire for experts (Hierarchy Analysis)}

1. tabula

Relatīiā svarīguma skala

\begin{tabular}{|c|c|c|}
\hline 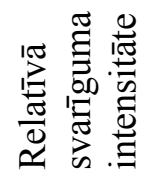 & Definīcija & Paskaidrojums \\
\hline 1 & Vienāds svarīgums & $\begin{array}{l}\text { Divu kritēriju, kritēriju grupu vai alternatīvu } \\
\text { vienāds ieguldījums mērksa sasniegšanā. }\end{array}$ \\
\hline 3 & $\begin{array}{l}\text { Mērens viena pārākums par } \\
\text { otru }\end{array}$ & $\begin{array}{l}\text { Pieredze un spriedumi dod vieglu pārsvaru vienam } \\
\text { kritērijam, kritēriju grupai vai alternatīvai par otru. }\end{array}$ \\
\hline 5 & Būtisks vai stiprs pārākums & $\begin{array}{l}\text { Pieredze un spriedumi dod stipru pārsvaru vienam } \\
\text { kritērijam kritēriju grupai vai alternatīvai par otru. }\end{array}$ \\
\hline 7 & Nozīmīgs pārsvars & $\begin{array}{l}\text { Vienam no kritērijiem, kritēriju grupām vai } \\
\text { alternatīvām tiek dots tik stiprs pārsvars par otru, } \\
\text { ka tas kḷūst praktiski nozīmīgs. }\end{array}$ \\
\hline 9 & Ļoti stiprs pārsvars & $\begin{array}{l}\text { Viena kritērija, kritēriju grupas vai alternatīvas } \\
\text { pārākums par otru apstiprinās visstiprāk. }\end{array}$ \\
\hline $2,4,6,8$ & Starpvērtības & Tiek lietotas kompromisa gadījumos. \\
\hline
\end{tabular}

PARAUGS: Kritēriju grupu salīdzināšana

(attiecība uz jauniešu nodarbinātības veicināšanu Latvijāa)

\begin{tabular}{|l|r|r|r|r|r|r|}
\hline $\begin{array}{c}\text { Jauniešu } \\
\text { nodarbinātības } \\
\text { veicināǎana } \\
\text { Latvijā }\end{array}$ & $\begin{array}{c}\text { Indivīdu } \\
\text { intereses }\end{array}$ & $\begin{array}{c}\text { Izglīīības } \\
\text { iestāžu } \\
\text { intereses }\end{array}$ & $\begin{array}{c}\text { Uzñēmēju } \\
\text { intereses }\end{array}$ & $\begin{array}{c}\text { Pašvald̄̄bu } \\
\text { intereses }\end{array}$ & $\begin{array}{c}\text { Valsts } \\
\text { intereses }\end{array}$ & ES intereses \\
\hline Indivīdu intereses & $\mathbf{1}$ & 7 & 1 & 8 & 6 & 7 \\
\hline $\begin{array}{l}\text { Izglītības iestāžu } \\
\text { intereses }\end{array}$ & $1 / 7$ & $\mathbf{1}$ & & & & \\
\hline Uzn̦ēmēju intereses & 1 & & $\mathbf{1}$ & & & \\
\hline $\begin{array}{l}\text { Pašvaldību } \\
\text { intereses }\end{array}$ & $1 / 8$ & & & $\mathbf{1}$ & & \\
\hline Valsts intereses & $1 / 6$ & & & & & $\mathbf{1}$ \\
\hline ES intereses & $1 / 7$ & & & & & $\mathbf{1}$ \\
\hline
\end{tabular}

Šajā piemērā eksperts indivīdu intereses vērtē kā būtiski svarīgākas (7) par izglīî̄bas iestāžu interesēm (1/7), indivīdu un uzņēmēju intereses ir vērtētas vienādi (1), savukārt indivīdu intereses (8) attiecībā pret pašvaldību interesēm tiek vērtētas kā stipri svarīgākas (1/8), indivīdu intereses (6) attiecībā pret valsts interesēm tiek vērtētas kā pārākas (1/6), arī indivīdu intereses (7) attiecībā pret ES interesēm tiek vērtētas kā nozīmīgi svarīgākas (1/7). Līdzīgi jāaizpilda visas tabulas. Kā redzat, matricas ir simetriskas un elementi simetriskajās rūtin̄ās ir apgriezti. Tāpēc tos aizpildīt NAV nepieciešamības, tas tiks aizpildīts automātiski.

Tālāk mēs raksturosim četrus iespējamos scenārijus jauniešu nodarbinātības veicināšanai Latvijā. 


\section{6. pielikuma turpinājums/ Continuation of Annex 6 \\ Ekspertu aptaujas anketa (Hierarhiju analīzei)/ Questionnaire for experts (Hierarchy Analysis)}

1. scenārijs: jauniešu uznēēējdarb̄̄bas vides atț̄istību veicinošais scenārijs. ES fondu līdzekḷ̆u piesaiste jauniešu pašnodarbinātības un uznēēējdarbības finansēšanai, paredzot speciāla finansiāla un administratīva atbalsta programmas izveidošanu VAS „Latvijas Attīstības finanšu institūcija Altum".

Raksturojums. Nozīmīga ir intereses raisīšana jauniešos par uzņēmējdarbības attīstību un uzṇēmējspēju veicināšanu. Valstiskā līmenī ir jāvērš uzmanība uz finansējuma piesaisti un tā apjomiem start-up uzņēmumiem un pašnodarbinātības uzsākšanai, lai sekmētu jauniešu kḷūšanu par uzņēmējiem Latvijā un nodrošinātu efektīvu valsts resursu izmantošanu.

Nozīmīga ir arī mentoru un biznesa engegeḷu piesaiste, un ieinteresētîbas radīšana par šiem biznesa atbalsta pasākumiem, nodrošinot atgriezenisko saiti, gūstot labumu visām iesaistîtājām pusēm. Piemēram, sadarbībā ar "Altum" valsts reǵionu līmenī jāveido finansējuma piesaistes iespēju nodrošināšana jauniešu uzn̄ēmējdarbības finansēšanai un biznesa atbalsta programmu efektivitātes paaugstināšanai. Mijiedarbojoties šiem procesiem, tiks veidota sekmīga savstarpēja sadarbība vairāku gadu garumā starp jau esošajiem uzṇēmējiem, jaunajiem uzṇēmējiem un valsts reǵionu institūcijām.

2. scenārijs: izglītības iestā̄̌zu un uznēemēju sadarbības scenārijs. Uznēmēju interese par darba tirgū konkurētspējīgu speciālistu sagatavošanu.

Raksturojums. Nozīmīga ir uzṇēmēju sadarbība ar profesionālās un augstākās izglītības iestādēm, lai veicinātu jauniešu iekļaušanos darba tirgū, veicinot profesionālās izglìtības apmācību sistēmas attīstību, kas balstīta darba vidē. Izglītîbas iestādēm sadarbībā ar uzn̄ēmējiem jāveido darba tirgū konkurētspējīgas mācību programmas, kuru ietvaros jauniešiem būtu iespējams iziet praksi attiecīgajā uzņēmumā. Cieša mijiedarbība starp izglīî̄bas un uzṇēmējdarbības sektoru nodrošinātu nozares speciālistu sagatavošanu specifisku darbu veikšanai un ar speciālistiem apgādātu nozares, kurās tie trūkst. Izglīî̄bas institūciju sadarbība ar uzņēmējiem arī ierobežotu intelektuālā kapitāla aizplūšanu no valsts. Nozīmīgi ir par valsts budžeta līdzekḷiem finansētos jauniešus nodarbināt valstī un nepieļaut to izcelılošanu. Neefektīva ir valsts pieškirto budžeta līdzekḷu izmantošana, jo nozares speciālisti pēc studiju absolvēšanas bieži vien dodas studēt un strādāt uz ārvalstīm. Piemēram, medicīnas, informācijas tehnologiiju, inženierzinātņu studentiem, kas studijas apgūst par valsts budžeta līdzekḷiem, vajadzētu 3 gadus pēc studiju beigšanas strādāt Latvijāa, lai, maksājot nodokḷus, atpelnītu valsts izdevumus. Pēc šāda principa sagatavoti speciālisti, kas ir apguvuši studijas par budžeta līdzekḷiem, izgājuši praksi pie darba devēja un ieguvuši iespēju turpināt turpat stažēties, uzlabotu valsts ienākumus no nodokliem.

3. scenārijs: valsts institūciju un uzn̄ēmēju sadarb̄̄bas scenārijs. Atvieglojumi uzñēmējiem, kas nodarbina jauniešus.

Raksturojums. Pozitīvu ietekmi uz jauniešu nodarbinātības veicināšanu dotu nodokḷu atvieglojumi uzñēmējiem, kas nodarbina jauniešus. Tikai nodrošinot veiksmīgu savstarpēju mijiedarbību starp valsti, tās pārvaldītajām institūcijām, finansējuma apjomu un cilvēkkapitālu, ir iespējams uzlabot valsts ekonomisko situāciju nodarbinātības jomā un demogrāfijas jomā. Demogrāfijas joma šī brǐža ekonomiskās situācijas rezultātā Latvijā virzās uz negatīvo pusi, līdz 2014. gadam dzimstība bija mazāka par mirstîbu, darba spējīgie jaunie valsts iedzīvotāji ir spiesti izbraukt ārpus valsts studiju un darba meklējumos, lai spētu nodrošināt pilnvērtīgu dzīvi. Ir jāatrod risinājumi, kā valstī ,noturēt” neaizbraukušos jauniešus.Viens no veidiem, kā veidot pozitīvāku vidi jauniešiem, ir pārskatīt normatīvo aktu ietvaru par nodarbinātības jautājumiem, motivējot darba devējus nodarbināt pēc iespējas vairāk jauniešus un mainīt savu attieksmi pret jauno cilvēku zināšanām un profesionālajām prasmēm (palīdzēt tās attīstīt, ne tikai vēlēties saņemt gatavus profesionāļus, kuru no izglìtības iestādēm).

Pilnīgi noteikti uzsvars ir jāliek uz valsts un reǵionālo institūciju ciešu sadarbību ar darba devējiem, lai virzītu uz zināšanām balstītas ekonomikas attīstību un efektīvu resursu 


\section{6. pielikuma turpinājums/ Continuation of Annex 6 \\ Ekspertu aptaujas anketa (Hierarhiju analīzei)/ Questionnaire for experts (Hierarchy Analysis)}

izmantošanu, it īpaši lauksaimniecībā, rūpniecībā un mežsaimniecībā, kas tiek pozicionēta starp iespējām, kā panākt ekonomikas izaugsmi un cilvēkkapitāla neaizplūšanu uz ārvalstīm. Nozīmīga joma ir arī informācijas tehnoloğijas un inovācijas, kas jauniešiem var pavērt plašas karjeras iespējas. Ne mazāk būtisks priekšnoteikums ir pienācīgs algu līmenis arī gados jauniem cilvēkiem, izvērtējot padarītā darba kvalitāti.

4. scenārijs: ES līdzdalības scenārïjs. ES interese izaugsmes nodrošinā̄̌šanā, veicinot efektīvu ES piešķirtā finansējuma izmantošanu Nodarbinätūbas valsts aǵentūras rīkotajos jauniešu mobilitātes pasākumos.

Raksturojums. Tā kā Latvija ir ES dalībvalsts, nozīmīgu lomu ekonomikas attīstībā ieņem ES fondu finansiālā atbalsta piesaistǐšanas apmēri. ES ir ieinteresēta, lai dalībvalstis spētu palielināt ien̄ēmumus un uzlabotu valsts ekonomisko izaugsmi. Nepieciešams ES struktūrfondu līdzekḷus izmantot efektīvi Nodarbinātības valsts aǵentūras rīkotajos jauniešu mobilitātes pasākumos. Latvijas valsts nevar aţ̦auties šo līdzekḷu neefektīvu un formālu izlietošanu, tie ir efektīvi jāiegulda jauniešu potenciāla attīstīšanā un izmantošanā. Nozīmīgi ir šajos NVA organizētajos pasākumos, kā arī augstskolās vērst jauniešu uzmanību uz uzṇēmējdarbības iespējām un informēt par biznesa atbalsta programmām, finansējuma apmēriem. Lai jaunieši ātrāk iekḷautos darba tirgū, būtisks devums ir tādam NVA mobilitātes pasākumam kā kursiem konkrētās jomās. Izejot krievu valodas, latviešu valodas, projektu vadības u.c. kursus, jaunietis ir uzlabojis zināšanas un paaugstinājis konkurētspēju darba tirgū.

\section{1. uzdevums (1 tabula)}

Pēc izveidotās jauniešu nodarbinātības veicināšanas hierarhijas ekspertiem jāsalīdzina kritêriju grupas atkarība no kopējā mērka - jauniešu nodarbinātības veicināšana Latvijā (ietonēts dzeltenā krāsā), proti, jāizvērtē, kuras iesaistîtās grupas intereses ir nozīmīgākās jauniešu nodarbinātības veicināšanā Latvijas regíonos. Kritēriju grupu salīdzināšanas rezultātus katrs eksperts ieraksta tabulā, kas izveidota matricas formā.

1.1. tabula

Kritēriju grupu salīdzināšana

\begin{tabular}{|c|c|c|c|c|c|c|}
\hline \begin{tabular}{|l} 
Jauniešu \\
nodarbinātības \\
veicināšana \\
Latvijāā \\
\end{tabular} & $\begin{array}{l}\text { Indivīdu } \\
\text { intereses }\end{array}$ & $\begin{array}{l}\text { Izglītīibas } \\
\text { iestāžu } \\
\text { intereses }\end{array}$ & $\begin{array}{l}\text { Uzņēmēju } \\
\text { intereses }\end{array}$ & $\begin{array}{l}\text { Pašvaldību } \\
\text { intereses }\end{array}$ & $\begin{array}{l}\text { Valsts } \\
\text { intereses }\end{array}$ & ES intereses \\
\hline Indivīdu intereses & 1 & & & & & \\
\hline $\begin{array}{l}\text { lzglîtības iestāžu } \\
\text { intereses }\end{array}$ & & 1 & & & & \\
\hline $\begin{array}{l}\text { Uzñēmēju } \\
\text { intereses }\end{array}$ & & & 1 & & & \\
\hline \begin{tabular}{|l} 
Pašvaldību \\
intereses
\end{tabular} & & & & 1 & & \\
\hline Valsts intereses & & & & & 1 & \\
\hline ES intereses & & & & & & 1 \\
\hline
\end{tabular}




\section{6. pielikuma turpinājums/ Continuation of Annex 6 Ekspertu aptaujas anketa (Hierarhiju analīzei)/ Questionnaire for experts (Hierarchy Analysis)}

\section{2. uzdevums (6 tabulas)}

Ekspertiem savstarpēji jāsalīdzina vērtēšanas kritēriji katras kritēriju grupas ietvaros attiecībā pret kopējo mērki (jauniešu nodarbinātības veicināšana Latvijā).

2.1. tabula

Kritēriju grupas “Indivīdu intereses" kritēriju salīdzināšana

\begin{tabular}{|c|c|c|c|c|c|}
\hline Indivīdu intereses & 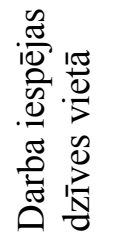 & 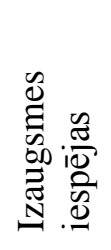 & 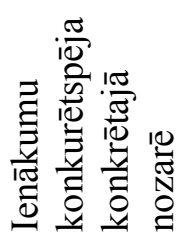 & 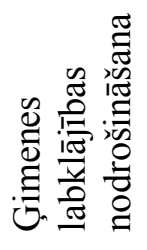 & 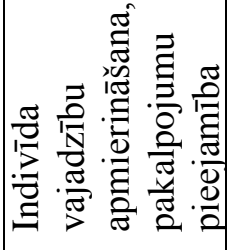 \\
\hline $\begin{array}{l}\text { Darba iespējas } \\
\text { dzīves vietā }\end{array}$ & 1 & & & & \\
\hline Izaugsmes iespējas & & 1 & & & \\
\hline \begin{tabular}{|l|} 
Ienākumu \\
konkurētspēja \\
konkrētajā nozarē
\end{tabular} & & & 1 & & \\
\hline $\begin{array}{l}\text { Ģimenes labklājīibas } \\
\text { nodrošināšana }\end{array}$ & & & & 1 & \\
\hline $\begin{array}{l}\text { Indivīda vajadzību } \\
\text { apmierināšana, } \\
\text { pakalpojumu } \\
\text { pieejamība }\end{array}$ & & & & & 1 \\
\hline
\end{tabular}

2.2. tabula

Kritēriju grupas "Izglìtības iestāžu intereses" kritēriju salīdzināšana

\begin{tabular}{|c|c|c|c|c|c|}
\hline $\begin{array}{l}\text { Izglītības iestāžu } \\
\text { intereses }\end{array}$ & 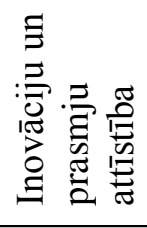 & 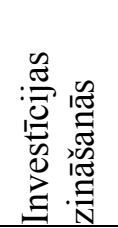 & 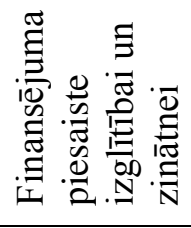 & 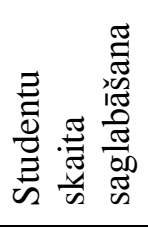 & 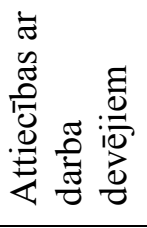 \\
\hline $\begin{array}{l}\text { Zināšanu, inovāciju } \\
\text { un prasmju attīstība }\end{array}$ & 1 & & & & \\
\hline $\begin{array}{l}\text { Investīcijas } \\
\text { zināšanās }\end{array}$ & & 1 & & & \\
\hline \begin{tabular}{|l|} 
Finansējuma \\
piesaiste izglîtīīai \\
un zinātnei
\end{tabular} & & & 1 & & \\
\hline \begin{tabular}{|l|} 
Studentu skaita \\
saglabāšana
\end{tabular} & & & & 1 & \\
\hline $\begin{array}{l}\text { Attiecības ar darba } \\
\text { devējiem }\end{array}$ & & & & & 1 \\
\hline
\end{tabular}




\section{Ekspertu aptaujas anketa (Hierarhiju analīzei)/ \\ 6. pielikuma turpinājums/ Continuation of Annex 6 Questionnaire for experts (Hierarchy Analysis)}

2.3. tabula

Kritēriju grupas “Uzņēmēju intereses” kritēriju salīdzināšana

\begin{tabular}{|c|c|c|c|c|c|}
\hline $\begin{array}{l}\text { Uzņēmējuu } \\
\text { intereses }\end{array}$ & 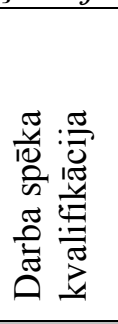 & 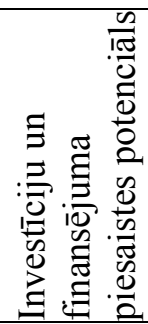 & 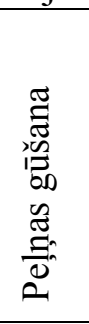 & 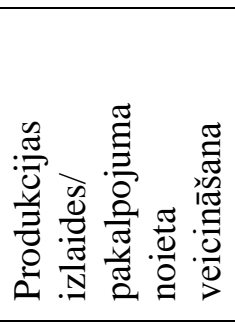 & 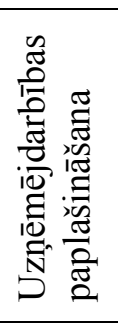 \\
\hline \begin{tabular}{|l} 
Darba spēka \\
kvalifikācija
\end{tabular} & 1 & & & & \\
\hline $\begin{array}{l}\text { Investīciju un } \\
\text { finansējuma } \\
\text { piesaistes } \\
\text { potenciāls } \\
\end{array}$ & & 1 & & & \\
\hline \multicolumn{6}{|l|}{ Peḷņas gūšana } \\
\hline $\begin{array}{l}\text { Produkcijas } \\
\text { izlaides/ } \\
\text { pakalpojuma noieta } \\
\text { veicināšana }\end{array}$ & & & & 1 & \\
\hline $\begin{array}{l}\text { Uzñēmējdarbības } \\
\text { paplašināšana }\end{array}$ & & & & & 1 \\
\hline
\end{tabular}

2.4. tabula

Kritēriju grupas "Pašvaldības intereses" kritēriju salīdzināšana

\begin{tabular}{|c|c|c|c|c|c|}
\hline $\begin{array}{l}\text { Pašvaldības } \\
\text { intereses }\end{array}$ & 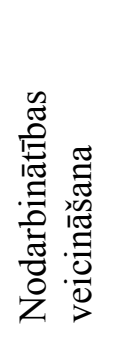 & 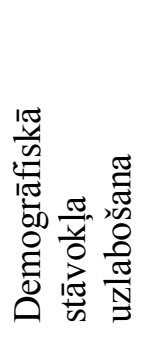 & 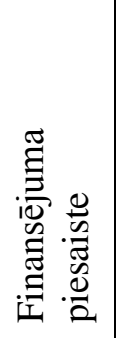 & 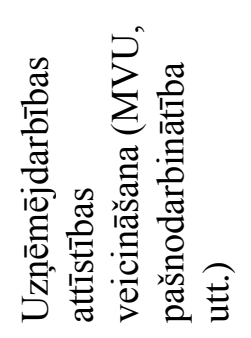 & 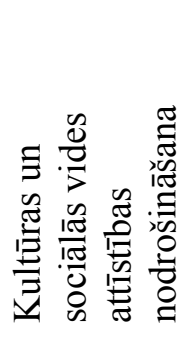 \\
\hline $\begin{array}{l}\text { Nodarbinātības } \\
\text { veicināšana }\end{array}$ & 1 & & & & \\
\hline $\begin{array}{l}\text { Demogrāfiskā } \\
\text { stāvokḷa uzlabošana }\end{array}$ & & 1 & & & \\
\hline $\begin{array}{l}\text { Finansējuma } \\
\text { piesaiste reǵionu } \\
\text { attīstībai }\end{array}$ & & & 1 & & \\
\hline $\begin{array}{l}\text { Uzñēmējdarbības } \\
\text { attīstības veicināšana } \\
\text { (MVU, } \\
\text { pašnodarbinātība utt.) }\end{array}$ & & & & 1 & \\
\hline $\begin{array}{l}\text { Kultūras un sociālās } \\
\text { vides attīistības } \\
\text { nodrošināšana }\end{array}$ & & & & & 1 \\
\hline
\end{tabular}




\section{Ekspertu aptaujas anketa (Hierarhiju analīzei)/ \\ 6. pielikuma turpinājums/ Continuation of Annex 6 Questionnaire for experts (Hierarchy Analysis)}

2.5. tabula

Kritēriju grupas "Valsts intereses" kritēriju salīdzināšana

\begin{tabular}{|c|c|c|c|c|c|}
\hline Valsts intereses & 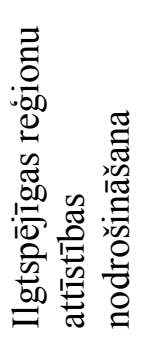 & 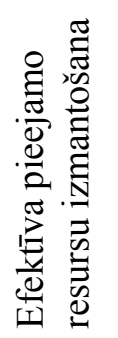 & 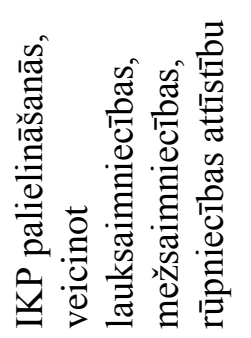 & 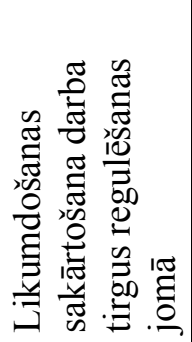 & 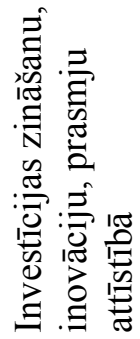 \\
\hline $\begin{array}{l}\text { Ilgtspējīgas reǵionu } \\
\text { attīstības nodrošināšana }\end{array}$ & 1 & & & & \\
\hline $\begin{array}{l}\text { Efektīva pieejamo } \\
\text { resursu izmantošana }\end{array}$ & & 1 & & & \\
\hline $\begin{array}{l}\text { IKP palielināšanās, } \\
\text { veicinot } \\
\text { lauksaimniecības, } \\
\text { mežsaimniecības, } \\
\text { rūpniecības attīstību }\end{array}$ & & & 1 & & \\
\hline $\begin{array}{l}\text { Likumdošanas } \\
\text { sakārtošana darba tirgus } \\
\text { regulēšanas jomā }\end{array}$ & & & & 1 & \\
\hline $\begin{array}{l}\text { Sadarbības veidošana un } \\
\text { uzturēěana ar citām ES } \\
\text { valstīm }\end{array}$ & & & & & 1 \\
\hline
\end{tabular}

2.6. tabula

Kritēriju grupas " $E S$ intereses" kritēriju salīdzināšana

\begin{tabular}{|c|c|c|c|c|c|}
\hline ES intereses & 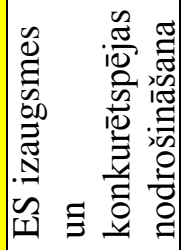 & 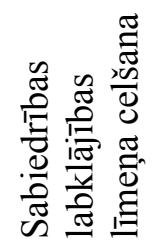 & 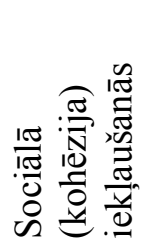 & 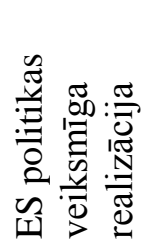 & 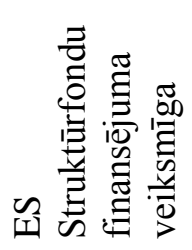 \\
\hline $\begin{array}{l}\text { ES izaugsmes un } \\
\text { konkurētspējas } \\
\text { nodrošināšana }\end{array}$ & 1 & & & & \\
\hline \begin{tabular}{|l|} 
Sabiedrības \\
labklājības līmeņa \\
celšana
\end{tabular} & & 1 & & & \\
\hline $\begin{array}{l}\text { Sociālā kohēzija } \\
\text { (ieklaušanās) }\end{array}$ & & & 1 & & \\
\hline $\begin{array}{l}\text { ES politikas } \\
\text { veiksmīga realizācija }\end{array}$ & & & & 1 & \\
\hline $\begin{array}{l}\text { ES Struktūrfondu } \\
\text { finansējuma } \\
\text { veiksmīga apgūšana }\end{array}$ & & & & & 1 \\
\hline
\end{tabular}




\section{Ekspertu aptaujas anketa (Hierarhiju analīzei)/ Questionnaire for experts (Hierarchy Analysis)}

6. pielikuma turpinājums/ Continuation of Annex 6

3. uzdevums (30 tabulas). Jāizvērtē četri alternatīvie scenāriji jauniešu nodarbinātības veicināšanai Latvijā atkarībā no katra kritērija (6 grupas x 5 kritēriji katrā grupā =30) (ietonēts dzeltenā krāsā).

3.1. tabula. Jauniešu nodarbinātības veicināšanas scenāriju Latvijā

salīdzināšana atkarībā no kritērija „Darba iespējas dzīves vietā ”

\begin{tabular}{|c|c|c|c|c|}
\hline 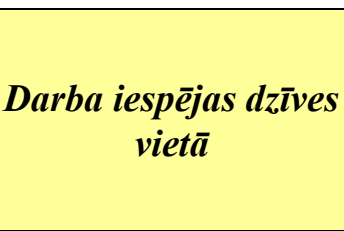 & $\begin{array}{c}\text { Jauniešu } \\
\text { uzñēmējdarbības } \\
\text { vides attīstību } \\
\text { veicinošais } \\
\text { scenārijs }\end{array}$ & $\begin{array}{c}\text { Izglītības iestāžu un } \\
\text { uzņēmēju sadarbības } \\
\text { scenārijs }\end{array}$ & $\begin{array}{l}\text { Valsts institūciju } \\
\text { un uzñēmēju } \\
\text { sadarbības } \\
\text { scenārijs }\end{array}$ & $\begin{array}{c}\text { ES } \\
\text { līdzdalības } \\
\text { scenārijs }\end{array}$ \\
\hline $\begin{array}{l}\text { Jauniešu } \\
\text { uzņēmējdarbības } \\
\text { vides attīstību } \\
\text { veicinošais scenārijs }\end{array}$ & 1 & & & \\
\hline $\begin{array}{l}\text { Izglītības iestāžu un } \\
\text { uzṇēmēju sadarbības } \\
\text { scenārijs }\end{array}$ & & 1 & & \\
\hline $\begin{array}{l}\text { Valsts institūciju un } \\
\text { uzṇēmēju sadarbības } \\
\text { scenārijs }\end{array}$ & & & 1 & \\
\hline $\begin{array}{l}\text { ES līdzdalības } \\
\text { scenārijs }\end{array}$ & & & & 1 \\
\hline
\end{tabular}

Jāizvērtē četri alternatīvie scenāriji jauniešu nodarbinātības veicināšana Latvijā atkarībā no katra kritērija (ietonēts dzeltenā krāsā).

\section{2. tabula}

Jauniešu nodarbinātības veicināšanas scenāriju Latvijā salīdzināšana atkarībā no kritērija „Izaugsmes iespējas”

\begin{tabular}{|c|c|c|c|c|}
\hline Izaugsmes iespējas & $\begin{array}{c}\text { Jauniešu } \\
\text { uzñēmējdarbības } \\
\text { vides attīstību } \\
\text { veicinošais } \\
\text { scenārijs } \\
\end{array}$ & $\begin{array}{c}\text { Izglīīības iestāžu un } \\
\text { uzṇēmēju sadarbības } \\
\text { scenārijs }\end{array}$ & $\begin{array}{l}\text { Valsts institūciju } \\
\text { un uzṇēmēju } \\
\text { sadarbības } \\
\text { scenārijs }\end{array}$ & $\begin{array}{c}\text { ES } \\
\text { līdzdalības } \\
\text { scenārijs }\end{array}$ \\
\hline $\begin{array}{l}\text { Jauniešu } \\
\text { uzņēmējdarbības } \\
\text { vides att̄̄stību } \\
\text { veicinošais scenārijs }\end{array}$ & 1 & & & \\
\hline $\begin{array}{l}\text { Izglītības iestāžu un } \\
\text { uzņēmēju sadarbības } \\
\text { scenārijs }\end{array}$ & & 1 & & \\
\hline $\begin{array}{l}\text { Valsts institūciju un } \\
\text { uzṇēmēju sadarbības } \\
\text { scenārijs }\end{array}$ & & & 1 & \\
\hline $\begin{array}{l}\text { ES līdzdalības } \\
\text { scenārijs }\end{array}$ & & & & 1 \\
\hline
\end{tabular}

Jāizvērtē četri alternatīvie scenāriji jauniešu nodarbinātības veicināšana Latvijā atkarībā no katra kritērija (ietonēts dzeltenā krāsā). 


\section{Ekspertu aptaujas anketa (Hierarhiju analīzei)/ Questionnaire for experts (Hierarchy Analysis)}

6. pielikuma turpinājums/ Continuation of Annex 6

\section{3. tabula}

Jauniešu nodarbinātības veicināšanas scenāriju Latvijā salīdzināšana atkarībā no kritērija „Ienākumu konkurētspēja konkrētajā nozarēe”

\begin{tabular}{|c|c|c|c|c|}
\hline $\begin{array}{c}\text { Ienākumu } \\
\text { konkurētspēja } \\
\text { konkrētajā nozarēe }\end{array}$ & \begin{tabular}{|c|} 
Jauniešu \\
uzñēmējdarbības \\
vides attīstību \\
veicinošais \\
scenārijs \\
\end{tabular} & $\begin{array}{c}\text { Izglīitibas iestāžu un } \\
\text { uzṇēmēju sadarbības } \\
\text { scenārijs }\end{array}$ & $\begin{array}{c}\text { Valsts institūciju } \\
\text { un uzn̄ēmēju } \\
\text { sadarbības } \\
\text { scenārijs }\end{array}$ & $\begin{array}{c}\text { ES } \\
\text { līdzdalības } \\
\text { scenārijs }\end{array}$ \\
\hline $\begin{array}{l}\text { Jauniešu } \\
\text { uzņēmējdarbības } \\
\text { vides attīstību } \\
\text { veicinošais scenārijs }\end{array}$ & 1 & & & \\
\hline $\begin{array}{l}\text { Izglītības iestāžu un } \\
\text { uzṇēmēju sadarbības } \\
\text { scenārijs }\end{array}$ & & 1 & & \\
\hline $\begin{array}{l}\text { Valsts institūciju un } \\
\text { uzñēmēju sadarbības } \\
\text { scenārijs }\end{array}$ & & & 1 & \\
\hline $\begin{array}{l}\text { ES līdzdalības } \\
\text { scenārijs }\end{array}$ & & & & 1 \\
\hline
\end{tabular}

Jāizvērtē četri alternatīvie scenāriji jauniešu nodarbinātības veicināšana Latvijā atkarībā no katra kritērija (ietonēts dzeltenā krāsā).

\section{4. tabula}

Jauniešu nodarbinātības veicināšanas scenāriju Latvijā salīdzināšana atkarībā no kritērija „Ģimenes labklājūbas nodrošināšana”

\begin{tabular}{|c|c|c|c|c|}
\hline $\begin{array}{l}\text { Gimenes labkläjības } \\
\text { nodrošināšsana }\end{array}$ & \begin{tabular}{|c|} 
Jauniešu \\
uzñēmējdarbības \\
vides attīstību \\
veicinošais \\
scenārijs
\end{tabular} & $\begin{array}{c}\text { Izglītības iestāžu un } \\
\text { uzṇēmēju sadarbības } \\
\text { scenārijs }\end{array}$ & \begin{tabular}{|c|} 
Valsts institūciju \\
un uzñēmēju \\
sadarbības \\
scenārijs
\end{tabular} & $\begin{array}{c}\text { ES } \\
\text { līdzdalības } \\
\text { scenārijs }\end{array}$ \\
\hline $\begin{array}{l}\text { Jauniešu } \\
\text { uzñēmējdarbības } \\
\text { vides attīstību } \\
\text { veicinošais scenārijs }\end{array}$ & 1 & & & \\
\hline $\begin{array}{l}\text { Izglītības iestāžu un } \\
\text { uzñēmēju sadarbības } \\
\text { scenārijs }\end{array}$ & & 1 & & \\
\hline $\begin{array}{l}\text { Valsts institūciju un } \\
\text { uzñēmēju sadarbības } \\
\text { scenārijs }\end{array}$ & & & 1 & \\
\hline $\begin{array}{l}\text { ES līdzdalības } \\
\text { scenārijs }\end{array}$ & & & & 1 \\
\hline
\end{tabular}

Jāizvērtē četri alternatīvie scenāriji jauniešu nodarbinātības veicināšana Latvijā atkarībā no katra kritērija (ietonēts dzeltenā krāsā). 


\section{Ekspertu aptaujas anketa (Hierarhiju analīzei)/ \\ 6. pielikuma turpinājums/ Continuation of Annex 6 Questionnaire for experts (Hierarchy Analysis)}

\section{5. tabula}

Jauniešu nodarbinātības veicināšanas scenāriju Latvijā salīdzināšana atkarībā no kritērija „Indivīda vajadzību apmierināšana (pakalpojumu pieejamība)”

\begin{tabular}{|c|c|c|c|c|}
\hline $\begin{array}{c}\text { Indivīda vajadzību } \\
\text { apmierināšana } \\
\text { (pakalpojumu } \\
\text { pieejamība) }\end{array}$ & \begin{tabular}{|c|} 
Jauniešu \\
uzņēmējdarbības \\
vides attīstību \\
veicinošais \\
scenārijs
\end{tabular} & $\begin{array}{c}\text { Izglītîbas iestāžu un } \\
\text { uzṇēmēju sadarbības } \\
\text { scenārijs }\end{array}$ & $\begin{array}{c}\text { Valsts institūciju } \\
\text { un uzñēēēju } \\
\text { sadarbības } \\
\text { scenārijs }\end{array}$ & $\begin{array}{c}\text { ES } \\
\text { līdzdalības } \\
\text { scenārijs }\end{array}$ \\
\hline $\begin{array}{l}\text { Jauniešu } \\
\text { uzñēmējdarbības } \\
\text { vides attīstību } \\
\text { veicinošais scenārijs }\end{array}$ & 1 & & & \\
\hline $\begin{array}{l}\text { Izglītīibas iestāžu un } \\
\text { uzñēmēju sadarbības } \\
\text { scenārijs }\end{array}$ & & 1 & & \\
\hline $\begin{array}{l}\text { Valsts institūciju un } \\
\text { uzņēmēju sadarbības } \\
\text { scenārijs }\end{array}$ & & & 1 & \\
\hline $\begin{array}{l}\text { ES līdzdalības } \\
\text { scenārijs }\end{array}$ & & & & 1 \\
\hline
\end{tabular}

Jāizvērtē četri alternatīvie scenāriji jauniešu nodarbinātības veicināšana Latvijā atkarībā no katra kritērija (ietonēts dzeltenā krāsā).

3.6. tabula

Jauniešu nodarbinātības veicināšanas scenāriju Latvijā salīdzināšana atkarībā no kritērija „Zināšanu, inovāciju un prasmju attīstība”

\begin{tabular}{|c|c|c|c|c|}
\hline $\begin{array}{l}\text { Zināšanu, inovāciju } \\
\text { un prasmju attīstība }\end{array}$ & $\begin{array}{c}\text { Jauniešu } \\
\text { uzñēmējdarbības } \\
\text { vides attīstību } \\
\text { veicinošais } \\
\text { scenārijs }\end{array}$ & $\begin{array}{l}\text { Izglītības iestāžu un } \\
\text { uzņēmēju sadarbības } \\
\text { scenārijs }\end{array}$ & $\begin{array}{l}\text { Valsts institūciju } \\
\text { un uzṇēmēju } \\
\text { sadarbības } \\
\text { scenārijs }\end{array}$ & $\begin{array}{c}\text { ES } \\
\text { līdzdalības } \\
\text { scenārijs }\end{array}$ \\
\hline \begin{tabular}{|l} 
Jauniešu \\
uzņ̄̄mējdarbības \\
vides attīstību \\
veicinošais scenārijs
\end{tabular} & 1 & & & \\
\hline $\begin{array}{l}\text { Izglītības iestāžu un } \\
\text { uzņēmēju sadarbības } \\
\text { scenārijs }\end{array}$ & & 1 & & \\
\hline $\begin{array}{l}\text { Valsts institūciju un } \\
\text { uzņēmēju sadarbības } \\
\text { scenārijs }\end{array}$ & & & 1 & \\
\hline $\begin{array}{l}\text { ES līdzdalības } \\
\text { scenārijs }\end{array}$ & & & & 1 \\
\hline
\end{tabular}

Jāizvērtē četri alternatīvie scenāriji jauniešu nodarbinātības veicināšana Latvijā atkarībā no katra kritērija (ietonēts dzeltenā krāsā). 


\section{Ekspertu aptaujas anketa (Hierarhiju analīzei)/ \\ 6. pielikuma turpinājums/ Continuation of Annex 6 Questionnaire for experts (Hierarchy Analysis)}

\section{7. tabula}

Jauniešu nodarbinātības veicināšanas scenāriju Latvijā salīdzināšana atkarībā no kritērija ,Investīcijas zināšanās,"

\begin{tabular}{|c|c|c|c|c|}
\hline $\begin{array}{c}\text { Investīcijas } \\
\text { zināāanāas }\end{array}$ & \begin{tabular}{|c|} 
Jauniešu \\
uzñēmējdarbības \\
vides attīstību \\
veicinošais \\
scenārijs
\end{tabular} & $\begin{array}{c}\text { Izglīitības iestāžu un } \\
\text { uzṇēmēju sadarbības } \\
\text { scenārijs }\end{array}$ & $\begin{array}{c}\text { Valsts institūciju } \\
\text { un uzñēēēju } \\
\text { sadarbības } \\
\text { scenārijs }\end{array}$ & $\begin{array}{c}\text { ES } \\
\text { līdzdalības } \\
\text { scenārijs }\end{array}$ \\
\hline $\begin{array}{l}\text { Jauniešu } \\
\text { uzṇēmējdarbības } \\
\text { vides attīstību } \\
\text { veicinošais scenārijs }\end{array}$ & 1 & & & \\
\hline $\begin{array}{l}\text { Izglīīibas iestāžu un } \\
\text { uzṇēmēju sadarbības } \\
\text { scenārijs }\end{array}$ & & 1 & & \\
\hline $\begin{array}{l}\text { Valsts institūciju un } \\
\text { uzṇēmēju sadarbības } \\
\text { scenārijs }\end{array}$ & & & 1 & \\
\hline $\begin{array}{l}\text { ES līdzdalības } \\
\text { scenārijs }\end{array}$ & & & & 1 \\
\hline
\end{tabular}

Jāizvērtē četri alternatīvie scenāriji jauniešu nodarbinātības veicināšana Latvijā atkarībā no katra kritērija (ietonēts dzeltenā krāsā).

\section{8. tabula}

Jauniešu nodarbinātības veicināšanas scenāriju Latvijā salīdzināšana atkarībā no kritērija „Zināšanu pārneses nodrošināšana”

\begin{tabular}{|c|c|c|c|c|}
\hline $\begin{array}{c}\text { Zināšanu pārneses } \\
\text { nodrošinā̄̌šana }\end{array}$ & $\begin{array}{c}\text { Jauniešu } \\
\text { uzṇēmējdarbība } \\
\text { s vides attīstību } \\
\text { veicinošais } \\
\text { scenārijs }\end{array}$ & $\begin{array}{c}\text { Izglīīības iestāžu un } \\
\text { uzņēmēju sadarbības } \\
\text { scenārijs }\end{array}$ & $\begin{array}{c}\text { Valsts institūciju } \\
\text { un uzņēēēju } \\
\text { sadarbības } \\
\text { scenārijs }\end{array}$ & $\begin{array}{c}\text { ES } \\
\text { līdzdalības } \\
\text { scenārijs }\end{array}$ \\
\hline $\begin{array}{l}\text { Jauniešu } \\
\text { uzn̄ēmējdarbības } \\
\text { vides attīstību } \\
\text { veicinošais scenārijs }\end{array}$ & 1 & & & \\
\hline $\begin{array}{l}\text { Izglītîbas iestāžu un } \\
\text { uzņēmēju sadarbības } \\
\text { scenārijs }\end{array}$ & & 1 & & \\
\hline $\begin{array}{l}\text { Valsts institūciju un } \\
\text { uzñēmēju sadarbības } \\
\text { scenārijs }\end{array}$ & & & 1 & \\
\hline \begin{tabular}{|l} 
ES līdzdalības \\
scenārijs
\end{tabular} & & & & 1 \\
\hline
\end{tabular}

Jāizvērtē četri alternatīvie scenāriji jauniešu nodarbinātības veicināšana Latvijāa atkarībā no katra kritērija (ietonēts dzeltenā krāsā). 


\section{Ekspertu aptaujas anketa (Hierarhiju analīzei)/ \\ 6. pielikuma turpinājums/ Continuation of Annex 6 Questionnaire for experts (Hierarchy Analysis)}

3.9. tabula

Jauniešu nodarbinātības veicināšanas scenāriju Latvijā salīdzināšana atkarībā no kritērija „Studentu skaita saglabāšana”

\begin{tabular}{|c|c|c|c|c|}
\hline $\begin{array}{l}\text { Studentu skaita } \\
\text { saglabāšana }\end{array}$ & $\begin{array}{c}\text { Jauniešu } \\
\text { uzñēmējdarbības } \\
\text { vides attīstību } \\
\text { veicinošais } \\
\text { scenārijs }\end{array}$ & $\begin{array}{c}\text { Izglītības iestāžu un } \\
\text { uzṇēmēju sadarbības } \\
\text { scenārijs }\end{array}$ & $\begin{array}{l}\text { Valsts institūciju } \\
\text { un uzñēēēju } \\
\text { sadarbības } \\
\text { scenārijs }\end{array}$ & $\begin{array}{c}\text { ES } \\
\text { līdzdalības } \\
\text { scenārijs }\end{array}$ \\
\hline $\begin{array}{l}\text { Jauniešu } \\
\text { uzn̄ēmējdarbības } \\
\text { vides attīstību } \\
\text { veicinošais scenārijs }\end{array}$ & 1 & & & \\
\hline $\begin{array}{l}\text { Izglītîbas iestāžu un } \\
\text { uzņēmēeju sadarbības } \\
\text { scenārijs }\end{array}$ & & 1 & & \\
\hline $\begin{array}{l}\text { Valsts institūciju un } \\
\text { uzn̄ēmēju sadarbības } \\
\text { scenārijs }\end{array}$ & & & 1 & \\
\hline $\begin{array}{l}\text { ES līdzdalības } \\
\text { scenārijs }\end{array}$ & & & & 1 \\
\hline
\end{tabular}

Jāizvērtē četri alternatīvie scenāriji jauniešu nodarbinātības veicināšana Latvijā atkarībā no katra kritērija (ietonēts dzeltenā krāsā).

3.10. tabula

Jauniešu nodarbinātības veicināšanas scenāriju Latvijā salīdzināšana atkarībā no kritērija „Izglītības iestādes attiecības ar darba devējiem”

\begin{tabular}{|c|c|c|c|c|}
\hline $\begin{array}{c}\text { Izglītības iestādes } \\
\text { attiecības ar darba } \\
\text { devējiem }\end{array}$ & $\begin{array}{c}\text { Jauniešu } \\
\text { uzñēmējdarbības } \\
\text { vides attīstību } \\
\text { veicinošais } \\
\text { scenārijs }\end{array}$ & $\begin{array}{c}\text { Izglīīibas iestāžu un } \\
\text { uzṇēmēju sadarbības } \\
\text { scenārijs }\end{array}$ & $\begin{array}{c}\text { Valsts institūciju } \\
\text { un uzñ̄ēēeju } \\
\text { sadarbības } \\
\text { scenārijs }\end{array}$ & $\begin{array}{c}\text { ES } \\
\text { līdzdalības } \\
\text { scenārijs }\end{array}$ \\
\hline $\begin{array}{l}\text { Jauniešu } \\
\text { uzn̄ēmējdarbības } \\
\text { vides attīstību } \\
\text { veicinošais scenārijs }\end{array}$ & 1 & & & \\
\hline $\begin{array}{l}\text { Izglītības iestāžu un } \\
\text { uzñēēēju sadarbības } \\
\text { scenārijs }\end{array}$ & & 1 & & \\
\hline $\begin{array}{l}\text { Valsts institūciju un } \\
\text { uzṇēmēju sadarbības } \\
\text { scenārijs }\end{array}$ & & & 1 & \\
\hline $\begin{array}{l}\text { ES līdzdalības } \\
\text { scenārijs }\end{array}$ & & & & 1 \\
\hline
\end{tabular}

Jāizvērtē četri alternatīvie scenāriji jauniešu nodarbinātības veicināšana Latvijā atkarībā no katra kritērija (ietonēts dzeltenā krāsā). 


\section{Ekspertu aptaujas anketa (Hierarhiju analīzei)/ \\ 6. pielikuma turpinājums/ Continuation of Annex 6 Questionnaire for experts (Hierarchy Analysis)}

\subsection{1.tabula}

Jauniešu nodarbinātības veicināšanas scenāriju Latvijā salīdzināšana atkarībā no kritērija „Darbaspēka kvalifikācija”

\begin{tabular}{|c|c|c|c|c|}
\hline $\begin{array}{l}\text { Darbaspēka } \\
\text { kvalifikācija }\end{array}$ & $\begin{array}{c}\text { Jauniešu } \\
\text { uzn̄ēmējdarbības } \\
\text { vides attīstību } \\
\text { veicinošais } \\
\text { scenārijs }\end{array}$ & $\begin{array}{c}\text { Izglītības iestāžu un } \\
\text { uzṇēmēju sadarbības } \\
\text { scenārijs }\end{array}$ & $\begin{array}{l}\text { Valsts institūciju } \\
\text { un uzn̄ēmēju } \\
\text { sadarbības } \\
\text { scenārijs }\end{array}$ & $\begin{array}{c}\text { ES } \\
\text { līdzdalības } \\
\text { scenārijs }\end{array}$ \\
\hline $\begin{array}{l}\text { Jauniešu } \\
\text { uzņēmējdarbības } \\
\text { vides attīstību } \\
\text { veicinošais scenārijs }\end{array}$ & 1 & & & \\
\hline $\begin{array}{l}\text { Izglītības iestāžu un } \\
\text { uzṇēmēju sadarbības } \\
\text { scenārijs }\end{array}$ & & 1 & & \\
\hline $\begin{array}{l}\text { Valsts institūciju un } \\
\text { uzṇēmēju sadarbības } \\
\text { scenārijs }\end{array}$ & & & 1 & \\
\hline $\begin{array}{l}\text { ES līdzdalības } \\
\text { scenārijs }\end{array}$ & & & & 1 \\
\hline
\end{tabular}

Jāizvērtē četri alternatīvie scenāriji jauniešu nodarbinātības veicināšana Latvijāa atkarībā no katra kritērija (ietonēts dzeltenā krāsā).

\subsection{2. tabula}

Jauniešu nodarbinātības veicināšanas scenāriju Latvijā salīdzināšana atkarībā no kritērija „Investīciju un finansējuma piesaistes potenciāls”

\begin{tabular}{|c|c|c|c|c|}
\hline $\begin{array}{c}\text { Investīciju un } \\
\text { finansējuma } \\
\text { piesaistes potenciāls }\end{array}$ & \begin{tabular}{|c|} 
Jauniešu \\
uzñēmējdarbības \\
vides attīstību \\
veicinošais \\
scenārijs
\end{tabular} & $\begin{array}{l}\text { Izglītības iestāžu un } \\
\text { uzņēmēju sadarbības } \\
\text { scenārijs }\end{array}$ & $\begin{array}{c}\text { Valsts institūciju } \\
\text { un uzñēmēju } \\
\text { sadarbības } \\
\text { scenārijs }\end{array}$ & $\begin{array}{c}\text { ES } \\
\text { līdzdalības } \\
\text { scenārijs }\end{array}$ \\
\hline $\begin{array}{l}\text { Jauniešu } \\
\text { uzņēmējearbābas } \\
\text { vides attīstību } \\
\text { veicinošais scenārijs }\end{array}$ & 1 & & & \\
\hline $\begin{array}{l}\text { Izglītības iestāžu un } \\
\text { uzñēmēju sadarbības } \\
\text { scenārijs }\end{array}$ & & 1 & & \\
\hline $\begin{array}{l}\text { Valsts institūciju un } \\
\text { uzn̦ēmēju sadarbības } \\
\text { scenārijs }\end{array}$ & & & 1 & \\
\hline $\begin{array}{l}\text { ES līdzdalības } \\
\text { scenārijs }\end{array}$ & & & & 1 \\
\hline
\end{tabular}

Jāizvērtē četri alternatīvie scenāriji jauniešu nodarbinātības veicināšana Latvijā atkarībā no katra kritērija (ietonēts dzeltenā krāsā). 


\section{Ekspertu aptaujas anketa (Hierarhiju analīzei)/ \\ 6. pielikuma turpinājums/ Continuation of Annex 6 Questionnaire for experts (Hierarchy Analysis)}

3.13. tabula

Jauniešu nodarbinātības veicināšanas scenāriju Latvijā salīdzināšana atkarībā no kritērija „Peļnas gūšana”

\begin{tabular}{|c|c|c|c|c|}
\hline Peļnas gūšana & $\begin{array}{l}\text { Jauniešu } \\
\text { uzñēmējdarbības } \\
\text { vides attīstību } \\
\text { veicinošais } \\
\text { scenārijs }\end{array}$ & $\begin{array}{l}\text { Izglītības iestāžu un } \\
\text { uzņēmēju sadarbības } \\
\text { scenārijs }\end{array}$ & $\begin{array}{l}\text { Valsts institūciju } \\
\text { un uzñēmēju } \\
\text { sadarbības } \\
\text { scenārijs }\end{array}$ & $\begin{array}{c}\text { ES } \\
\text { līdzdalības } \\
\text { scenārijs }\end{array}$ \\
\hline $\begin{array}{l}\text { Jauniešu } \\
\text { uzņēmējdarbības } \\
\text { vides attīstību } \\
\text { veicinošais scenārijs }\end{array}$ & 1 & & & \\
\hline $\begin{array}{l}\text { Izglītības iestāžu un } \\
\text { uzn̦ēmēju sadarbības } \\
\text { scenārijs }\end{array}$ & & 1 & & \\
\hline $\begin{array}{l}\text { Valsts institūciju un } \\
\text { uzñēmēju sadarbības } \\
\text { scenārijs }\end{array}$ & & & 1 & \\
\hline $\begin{array}{l}\text { ES līdzdalības } \\
\text { scenārijs }\end{array}$ & & & & 1 \\
\hline
\end{tabular}

Jāizvērtē četri alternatīvie scenāriji jauniešu nodarbinātības veicināšana Latvijā atkarībā no katra kritērija (ietonēts dzeltenā krāsā).

3.14. tabula

Jauniešu nodarbinātības veicināšanas scenāriju Latvijā salīdzināšana atkarībā no kritērija „Produkcijas izlaides/ pakalpojuma noieta veicināšana”

\begin{tabular}{|c|c|c|c|c|}
\hline $\begin{array}{c}\text { Produkcijas } \\
\text { izlaides/ } \\
\text { pakalpojuma noieta } \\
\text { veicināšana }\end{array}$ & $\begin{array}{c}\text { Jauniešu } \\
\text { uzñēmējdarbības } \\
\text { vides attīstîbu } \\
\text { veicinošais } \\
\text { scenārijs }\end{array}$ & $\begin{array}{c}\text { Izglītîbas iestāžu un } \\
\text { uzṇēmēju sadarbības } \\
\text { scenārijs }\end{array}$ & $\begin{array}{l}\text { Valsts institūciju } \\
\text { un uzñēēejju } \\
\text { sadarbības } \\
\text { scenārijs }\end{array}$ & $\begin{array}{c}\text { ES } \\
\text { līdzdalības } \\
\text { scenārijs }\end{array}$ \\
\hline $\begin{array}{l}\text { Jauniešu } \\
\text { uzñēmējdarbības } \\
\text { vides attīstību } \\
\text { veicinošais scenārijs }\end{array}$ & 1 & & & \\
\hline $\begin{array}{l}\text { Izglīitības iestāžu un } \\
\text { uzn̄emēju sadarbības } \\
\text { scenārijs }\end{array}$ & & 1 & & \\
\hline $\begin{array}{l}\text { Valsts institūciju un } \\
\text { uzṇēmēju sadarbības } \\
\text { scenārijs }\end{array}$ & & & 1 & \\
\hline $\begin{array}{l}\text { ES līdzdalības } \\
\text { scenārijs }\end{array}$ & & & & 1 \\
\hline
\end{tabular}

Jāizvērtē četri alternatīvie scenāriji jauniešu nodarbinātības veicināšana Latvijā atkarībā no katra kritērija (ietonēts dzeltenā krāsā). 


\section{Ekspertu aptaujas anketa (Hierarhiju analīzei)/ \\ 6. pielikuma turpinājums/ Continuation of Annex 6 Questionnaire for experts (Hierarchy Analysis)}

3.15. tabula

Jauniešu nodarbinātības veicināšanas scenāriju Latvijā salīdzināšana atkarībā no kritērija „Uzñèmējdarbības paplašināšana”

\begin{tabular}{|c|c|c|c|c|}
\hline $\begin{array}{c}\text { Uznēēējdarbības } \\
\text { paplašināšsana }\end{array}$ & $\begin{array}{c}\text { Jauniešu } \\
\text { uzn̄ēmējdarbības } \\
\text { vides attīstību } \\
\text { veicinošais } \\
\text { scenārijs }\end{array}$ & $\begin{array}{c}\text { Izglīīības iestāžu un } \\
\text { uzņē̄ēeju sadarbības } \\
\text { scenārijs }\end{array}$ & $\begin{array}{l}\text { Valsts institūciju } \\
\text { un uzṇēēēju } \\
\text { sadarbības } \\
\text { scenārijs }\end{array}$ & $\begin{array}{c}\text { ES } \\
\text { līdzdalības } \\
\text { scenārijs }\end{array}$ \\
\hline $\begin{array}{l}\text { Jauniešu } \\
\text { uzņēmējdarbības } \\
\text { vides attīstību } \\
\text { veicinošais scenārijs }\end{array}$ & 1 & & & \\
\hline $\begin{array}{l}\text { Izglītīibas iestāžu un } \\
\text { uzņēmēju sadarbības } \\
\text { scenārijs }\end{array}$ & & 1 & & \\
\hline $\begin{array}{l}\text { Valsts institūciju un } \\
\text { uzṇēmēēju sadarbības } \\
\text { scenārijs }\end{array}$ & & & 1 & \\
\hline $\begin{array}{l}\text { ES līdzdalības } \\
\text { scenārijs }\end{array}$ & & & & 1 \\
\hline
\end{tabular}

Jāizvērtē četri alternatīvie scenāriji jauniešu nodarbinātības veicināšana Latvijā atkarībā no katra kritērija (ietonēts dzeltenā krāsā).

\subsection{6. tabula}

Jauniešu nodarbinātības veicināšanas scenāriju Latvijā salīdzināšana atkarībā no kritērija „Nodarbinātības veicināšana”

\begin{tabular}{|c|c|c|c|c|}
\hline $\begin{array}{c}\text { Nodarbinātības } \\
\text { veicināšana }\end{array}$ & \begin{tabular}{|c} 
Jauniešu \\
uzņēmējdarbības \\
vides attīstîbu \\
veicinošais \\
scenārijs
\end{tabular} & $\begin{array}{c}\text { Izglīīības iestāžu un } \\
\text { uzṇēmēju sadarbības } \\
\text { scenārijs }\end{array}$ & $\begin{array}{c}\text { Valsts institūciju } \\
\text { un uzņēmēju } \\
\text { sadarbības } \\
\text { scenārijs }\end{array}$ & $\begin{array}{c}\text { ES } \\
\text { līdzdalības } \\
\text { scenārijs }\end{array}$ \\
\hline $\begin{array}{l}\text { Jauniešu } \\
\text { uzņēmējdarbības } \\
\text { vides attīstîbu } \\
\text { veicinošais scenārijs }\end{array}$ & 1 & & & \\
\hline $\begin{array}{l}\text { Izglītības iestāžu un } \\
\text { uzņēmēju sadarbības } \\
\text { scenārijs }\end{array}$ & & 1 & & \\
\hline $\begin{array}{l}\text { Valsts institūciju un } \\
\text { uzņēmēju sadarbības } \\
\text { scenārijs }\end{array}$ & & & 1 & \\
\hline $\begin{array}{l}\text { ES līdzdalības } \\
\text { scenārijs }\end{array}$ & & & & 1 \\
\hline
\end{tabular}

Jāizvērtē četri alternatīvie scenāriji jauniešu nodarbinātības veicināšana Latvijāa atkarīibā no katra kritērija (ietonēts dzeltenā krāsā). 


\section{Ekspertu aptaujas anketa (Hierarhiju analīzei)/ \\ 6. pielikuma turpinājums/ Continuation of Annex 6 Questionnaire for experts (Hierarchy Analysis)}

3.17. tabula

Jauniešu nodarbinātības veicināšanas scenāriju Latvijā salīdzināšana atkarībā no kritērija „Demogrāfiskā stāvokla uzlabošana”

\begin{tabular}{|c|c|c|c|c|}
\hline $\begin{array}{c}\text { Demogrāfiskā } \\
\text { stâvokla uzlabošana }\end{array}$ & $\begin{array}{c}\text { Jauniešu } \\
\text { uzñēmējdarbības } \\
\text { vides attīstību } \\
\text { veicinošais } \\
\text { scenārijs }\end{array}$ & $\begin{array}{c}\text { Izglītīibas iestāžu un } \\
\text { uzṇēmēju sadarbības } \\
\text { scenārijs }\end{array}$ & $\begin{array}{c}\text { Valsts institūciju } \\
\text { un uzñ̄̄mēju } \\
\text { sadarbības } \\
\text { scenārijs }\end{array}$ & $\begin{array}{c}\text { ES } \\
\text { līdzdalības } \\
\text { scenārijs }\end{array}$ \\
\hline $\begin{array}{l}\text { Jauniešu } \\
\text { uzņēmējdarbības } \\
\text { vides attīstību } \\
\text { veicinošais scenārijs }\end{array}$ & 1 & & & \\
\hline $\begin{array}{l}\text { Izglītīibas iestāžu un } \\
\text { uzņēmēju sadarbības } \\
\text { scenārijs }\end{array}$ & & 1 & & \\
\hline $\begin{array}{l}\text { Valsts institūciju un } \\
\text { uzņēmējeju sadarbības } \\
\text { scenārijs }\end{array}$ & & & 1 & \\
\hline $\begin{array}{l}\text { ES līdzdalības } \\
\text { scenārijs }\end{array}$ & & & & 1 \\
\hline
\end{tabular}

Jāizvērtē četri alternatīvie scenāriji jauniešu nodarbinātības veicināšana Latvijā atkarībā no katra kritērija (ietonēts dzeltenā krāsā).

3.18. tabula

Jauniešu nodarbinātības veicināšanas scenāriju Latvijā salīdzināšana atkarībā no kritērija „Finansējuma piesaiste regionu attīstībai”

\begin{tabular}{|c|c|c|c|c|}
\hline $\begin{array}{c}\text { Finansējuma } \\
\text { piesaiste regionu } \\
\text { attīstībai }\end{array}$ & \begin{tabular}{|c|} 
Jauniešu \\
uzñēmējdarbības \\
vides attīstību \\
veicinošais \\
scenārijs
\end{tabular} & $\begin{array}{c}\text { Izglītīibas iestāžu un } \\
\text { uzṇēmēju sadarbības } \\
\text { scenārijs }\end{array}$ & $\begin{array}{c}\text { Valsts institūciju } \\
\text { un uzñēēēju } \\
\text { sadarbības } \\
\text { scenārijs }\end{array}$ & $\begin{array}{c}\text { ES } \\
\text { līdzdalības } \\
\text { scenārijs }\end{array}$ \\
\hline $\begin{array}{l}\text { Jauniešu } \\
\text { uzñēmējdarbības } \\
\text { vides attīstību } \\
\text { veicinošais scenārijs }\end{array}$ & 1 & & & \\
\hline $\begin{array}{l}\text { Izglīīibas iestāžu un } \\
\text { uzñēmēju sadarbības } \\
\text { scenārijs }\end{array}$ & & 1 & & \\
\hline $\begin{array}{l}\text { Valsts institūciju un } \\
\text { uzṇēmēju sadarbības } \\
\text { scenārijs }\end{array}$ & & & 1 & \\
\hline $\begin{array}{l}\text { ES līdzdalības } \\
\text { scenārijs }\end{array}$ & & & & 1 \\
\hline
\end{tabular}

Jāizvērtē četri alternatīvie scenāriji jauniešu nodarbinātības veicināšana Latvijāa atkarībā no katra kritērija (ietonēts dzeltenā krāsā). 
3.19. tabula

\section{Ekspertu aptaujas anketa (Hierarhiju analīzei)/ Questionnaire for experts (Hierarchy Analysis)}

6. pielikuma turpinājums/ Continuation of Annex 6

Jauniešu nodarbinātības veicināšanas scenāriju Latvijā salīdzināšana atkarībā no kritērija „Uzņēmējdarbības attīstības veicināšana (MVU, pašnodarbinātība utt.)”

\begin{tabular}{|c|c|c|c|c|}
\hline $\begin{array}{c}\text { Uznnēmējdarbības } \\
\text { atțistības } \\
\text { veicināšana (MVU, } \\
\text { pašnodarbinātība } \\
\text { utt.) }\end{array}$ & \begin{tabular}{|c|} 
Jauniešu \\
uzñēmējdarbības \\
vides attīstību \\
veicinošais \\
scenārijs
\end{tabular} & $\begin{array}{c}\text { Izglīīibas iestāžu un } \\
\text { uzṇēmēju sadarbības } \\
\text { scenārijs }\end{array}$ & $\begin{array}{c}\text { Valsts institūciju } \\
\text { un uzñēmēju } \\
\text { sadarbības } \\
\text { scenārijs }\end{array}$ & $\begin{array}{c}\text { ES } \\
\text { līdzdalības } \\
\text { scenārijs }\end{array}$ \\
\hline $\begin{array}{l}\text { Jauniešu } \\
\text { uzn̄ēmējdarbības } \\
\text { vides attīstību } \\
\text { veicinošais scenārijs }\end{array}$ & 1 & & & \\
\hline $\begin{array}{l}\text { Izglīīibas iestāžu un } \\
\text { uzñēmēju sadarbības } \\
\text { scenārijs }\end{array}$ & & 1 & & \\
\hline $\begin{array}{l}\text { Valsts institūciju un } \\
\text { uzñēmēju sadarbības } \\
\text { scenārijs }\end{array}$ & & & 1 & \\
\hline $\begin{array}{l}\text { ES līdzdalības } \\
\text { scenārijs }\end{array}$ & & & & 1 \\
\hline
\end{tabular}

Jāizvērtē četri alternatīvie scenāriji jauniešu nodarbinātības veicināšana Latvijā atkarībā no katra kritērija (ietonēts dzeltenā krāsā).

\subsection{0. tabula}

Jauniešu nodarbinātības veicināšanas scenāriju Latvijā salīdzināšana atkarībā no kritērija „Kultūuras un sociālās vides attīstības nodrošināšana”

\begin{tabular}{|c|c|c|c|c|}
\hline $\begin{array}{c}\text { Kultūras un sociālās } \\
\text { vides attīistības } \\
\text { nodrošināšana }\end{array}$ & $\begin{array}{c}\text { Jauniešu } \\
\text { uzn̄ēmējdarbības } \\
\text { vides attīstību } \\
\text { veicinošais } \\
\text { scenārijs }\end{array}$ & $\begin{array}{l}\text { Izglītīibas iestāžu un } \\
\text { uzņēmēeju sadarbības } \\
\text { scenārijs }\end{array}$ & $\begin{array}{l}\text { Valsts institūciju } \\
\text { un uzņēmēju } \\
\text { sadarbības } \\
\text { scenārijs }\end{array}$ & $\begin{array}{c}\text { ES } \\
\text { līdzdalības } \\
\text { scenārijs }\end{array}$ \\
\hline $\begin{array}{l}\text { Jauniešu } \\
\text { uzn̄ēmējdarbības } \\
\text { vides attīstību } \\
\text { veicinošais scenārijs }\end{array}$ & 1 & & & \\
\hline $\begin{array}{l}\text { Izglīitības iestāžu un } \\
\text { uzñēmēju sadarbības } \\
\text { scenārijs }\end{array}$ & & 1 & & \\
\hline $\begin{array}{l}\text { Valsts institūciju un } \\
\text { uzñēmēju sadarbības } \\
\text { scenārijs }\end{array}$ & & & 1 & \\
\hline $\begin{array}{l}\text { ES līdzdalības } \\
\text { scenārijs }\end{array}$ & & & & 1 \\
\hline
\end{tabular}

Jāizvērtē četri alternatīvie scenāriji jauniešu nodarbinātības veicināšana Latvijā atkarīibā no katra kritērija (ietonēts dzeltenā krāsā). 


\section{Ekspertu aptaujas anketa (Hierarhiju analīzei) / \\ 6. pielikuma turpinājums/ Continuation of Annex 6 Questionnaire for experts (Hierarchy Analysis)}

3.21. tabula

Jauniešu nodarbinātības veicināšanas scenāriju Latvijā salīdzināšana atkarībā no kritērija „Ilgtspējīgas regionu attīstības nodrošināšana”

\begin{tabular}{|c|c|c|c|c|}
\hline $\begin{array}{c}\text { Ilgtspējīgas regionu } \\
\text { attistības } \\
\text { nodrošināšana }\end{array}$ & \begin{tabular}{|c|} 
Jauniešu \\
uzñēmējdarbības \\
vides attīstību \\
veicinošais \\
scenārijs
\end{tabular} & $\begin{array}{c}\text { Izglītīibas iestāžu un } \\
\text { uzņēmēju sadarbības } \\
\text { scenārijs }\end{array}$ & $\begin{array}{c}\text { Valsts institūciju } \\
\text { un uzñ̄ēēeju } \\
\text { sadarbības } \\
\text { scenārijs }\end{array}$ & $\begin{array}{c}\text { ES } \\
\text { līdzdalības } \\
\text { scenārijs }\end{array}$ \\
\hline $\begin{array}{l}\text { Jauniešu } \\
\text { uzñēmējdarbības } \\
\text { vides attīstību } \\
\text { veicinošais scenārijs }\end{array}$ & 1 & & & \\
\hline $\begin{array}{l}\text { Izglīitības iestāžu un } \\
\text { uzñēmēju sadarbības } \\
\text { scenārijs }\end{array}$ & & 1 & & \\
\hline $\begin{array}{l}\text { Valsts institūciju un } \\
\text { uzn̄ēmēju sadarbības } \\
\text { scenārijs }\end{array}$ & & & 1 & \\
\hline $\begin{array}{l}\text { ES līdzdalības } \\
\text { scenārijs }\end{array}$ & & & & 1 \\
\hline
\end{tabular}

Jāizvērtē četri alternatīvie scenāriji jauniešu nodarbinātības veicināšana Latvijā atkarībā no katra kritērija (ietonēts dzeltenā krāsā).

3.22. tabula

Jauniešu nodarbinātības veicināšanas scenāriju Latvijā salīdzināšana atkarībā no kritērija „Efektīva pieejamo resursu izmantošana”

\begin{tabular}{|c|c|c|c|c|}
\hline $\begin{array}{l}\text { Efektīva pieejamo } \\
\text { resursu izmantošana }\end{array}$ & \begin{tabular}{|c|} 
Jauniešu \\
uzñēmējdarbības \\
vides attīstību \\
veicinošais \\
scenārijs
\end{tabular} & $\begin{array}{l}\text { Izglīīibas iestāžu un } \\
\text { uzṇēmēju sadarbības } \\
\text { scenārijs }\end{array}$ & $\begin{array}{l}\text { Valsts institūciju } \\
\text { un uzñēēejuu } \\
\text { sadarbības } \\
\text { scenārijs }\end{array}$ & $\begin{array}{c}\text { ES } \\
\text { līdzdalības } \\
\text { scenārijs }\end{array}$ \\
\hline $\begin{array}{l}\text { Jauniešu } \\
\text { uzñēmējdarbības } \\
\text { vides attīstību } \\
\text { veicinošais scenārijs }\end{array}$ & 1 & & & \\
\hline $\begin{array}{l}\text { Izglītības iestāžu un } \\
\text { uzṇēmēju sadarbības } \\
\text { scenārijs }\end{array}$ & & 1 & & \\
\hline $\begin{array}{l}\text { Valsts institūciju un } \\
\text { uzñēmēju sadarbības } \\
\text { scenārijs }\end{array}$ & & & 1 & \\
\hline $\begin{array}{l}\text { ES līdzdalības } \\
\text { scenārijs }\end{array}$ & & & & 1 \\
\hline
\end{tabular}

Jāizvērtē četri alternatīvie scenāriji jauniešu nodarbinātības veicināšana Latvijā atkarībā no katra kritērija (ietonēts dzeltenā krāsā). 


\section{Ekspertu aptaujas anketa (Hierarhiju analīzei) / Questionnaire for experts (Hierarchy Analysis)}

6. pielikuma turpinājums/ Continuation of Annex 6

3.23. tabula. Jauniešu nodarbinātības veicināšanas scenāriju Latvijā salīdzināšana atkarībā no kritērija „IKP palielināšanās, veicinot lauksaimniecības, mežsaimniecības, rūpniecības attīstību”"

\begin{tabular}{|c|c|c|c|c|}
\hline $\begin{array}{c}\text { IKP palielināšanās, } \\
\text { veicinot } \\
\text { lauksaimniecības, } \\
\text { mežsaimniecības, } \\
\text { rūpniecības attīstību }\end{array}$ & $\begin{array}{c}\text { Jauniešu } \\
\text { uzņēēējdarbības } \\
\text { vides attīstību } \\
\text { veicinošais } \\
\text { scenārijs }\end{array}$ & $\begin{array}{l}\text { Izglītības iestāžu un } \\
\text { uzņēmēju sadarbības } \\
\text { scenārijs }\end{array}$ & $\begin{array}{c}\text { Valsts institūciju } \\
\text { un uzñēmēju } \\
\text { sadarbības } \\
\text { scenārijs }\end{array}$ & $\begin{array}{c}\text { ES } \\
\text { līdzdalības } \\
\text { scenārijs }\end{array}$ \\
\hline $\begin{array}{l}\text { Jauniešu } \\
\text { uzṇēmējdarbības } \\
\text { vides attīstību } \\
\text { veicinošais scenārijs }\end{array}$ & 1 & & & \\
\hline $\begin{array}{l}\text { Izglītības iestāžu un } \\
\text { uzņēmēju sadarbības } \\
\text { scenārijs }\end{array}$ & & 1 & & \\
\hline $\begin{array}{l}\text { Valsts institūciju un } \\
\text { uzn̦ēmēju sadarbības } \\
\text { scenārijs }\end{array}$ & & & 1 & \\
\hline $\begin{array}{l}\text { ES līdzdalības } \\
\text { scenārijs }\end{array}$ & & & & 1 \\
\hline
\end{tabular}

Jāizvērtēe četri alternatīvie scenāriji jauniešu nodarbinātības veicināšana Latvijāa atkarībā no katra kritērija (ietonēts dzeltenā krāsā).

3.24. tabula

Jauniešu nodarbinātības veicināšanas scenāriju Latvijā salīdzināšana atkarībā no kritērija „Likumdošanas sakārtošana darba tirgus regulēšanas jomā",

\begin{tabular}{|c|c|c|c|c|}
\hline $\begin{array}{c}\text { Likumdošanas } \\
\text { sakārtošana darba } \\
\text { tirgus regulēšanas } \\
\text { jomā }\end{array}$ & $\begin{array}{c}\text { Jauniešu } \\
\text { uzņēēējdarbības } \\
\text { vides attīstību } \\
\text { veicinošais } \\
\text { scenārijs }\end{array}$ & $\begin{array}{c}\text { Izglītības iestāžu un } \\
\text { uzņēmēju sadarbības } \\
\text { scenārijs }\end{array}$ & $\begin{array}{l}\text { Valsts institūciju } \\
\text { un uzñēmēju } \\
\text { sadarbības } \\
\text { scenārijs }\end{array}$ & $\begin{array}{c}\text { ES } \\
\text { līdzdalības } \\
\text { scenārijs }\end{array}$ \\
\hline $\begin{array}{l}\text { Jauniešu } \\
\text { uzņ̄ēmējdarbības } \\
\text { vides attīstību } \\
\text { veicinošais scenārijs }\end{array}$ & 1 & & & \\
\hline $\begin{array}{l}\text { Izglītības iestāžu un } \\
\text { uzņēmēju sadarbības } \\
\text { scenārijs }\end{array}$ & & 1 & & \\
\hline $\begin{array}{l}\text { Valsts institūciju un } \\
\text { uzñēmēju sadarbības } \\
\text { scenārijs }\end{array}$ & & & 1 & \\
\hline $\begin{array}{l}\text { ES līdzdalības } \\
\text { scenārijs }\end{array}$ & & & & 1 \\
\hline
\end{tabular}

Jāizvērtē četri alternatīvie scenāriji jauniešu nodarbinātības veicināšana Latvijā atkarībā no katra kritērija (ietonēts dzeltenā krāsā). 


\section{Ekspertu aptaujas anketa (Hierarhiju analīzei) / Questionnaire for experts (Hierarchy Analysis)}

6. pielikuma turpinājums/ Continuation of Annex 6

3.25. tabula

Jauniešu nodarbinātības veicināšanas scenāriju Latvijā salīdzināšana atkarībā no kritērija „Sadarbības veidošana un uzturēšana ar citām ES valstīm”

\begin{tabular}{|c|c|c|c|c|}
\hline $\begin{array}{c}\text { Sadarbības } \\
\text { veidošana un } \\
\text { uzturēšana ar citām } \\
\text { ES valstīm }\end{array}$ & $\begin{array}{c}\text { Jauniešu } \\
\text { uzñēmējdarbības } \\
\text { vides attīstību } \\
\text { veicinošais } \\
\text { scenārijs }\end{array}$ & $\begin{array}{l}\text { Izglītības iestāžu un } \\
\text { uzņēmēju sadarbības } \\
\text { scenārijs }\end{array}$ & $\begin{array}{l}\text { Valsts institūciju } \\
\text { un uzṇēmēju } \\
\text { sadarbības } \\
\text { scenārijs }\end{array}$ & $\begin{array}{c}\text { ES } \\
\text { līdzdalības } \\
\text { scenārijs }\end{array}$ \\
\hline $\begin{array}{l}\text { Jauniešu } \\
\text { uzn̦̄ēmējdarbības } \\
\text { vides attīstību } \\
\text { veicinošais scenārijs }\end{array}$ & 1 & & & \\
\hline $\begin{array}{l}\text { Izglītības iestāžu un } \\
\text { uzņēmēju sadarbības } \\
\text { scenārijs }\end{array}$ & & 1 & & \\
\hline $\begin{array}{l}\text { Valsts institūciju un } \\
\text { uzñēmēju sadarbības } \\
\text { scenārijs }\end{array}$ & & & 1 & \\
\hline $\begin{array}{l}\text { ES līdzdalības } \\
\text { scenārijs }\end{array}$ & & & & 1 \\
\hline
\end{tabular}

Jāizvērtē četri alternatīvie scenāriji jauniešu nodarbinātības veicināšana Latvijāa atkarībā no katra kritērija (ietonēts dzeltenā krāsā).

3.26. tabula

Jauniešu nodarbinātības veicināšanas scenāriju Latvijā salīdzināšana atkarībā no kritērija „Eiropas izaugsmes un konkurētspējas nodrošināšana”

\begin{tabular}{|c|c|c|c|c|}
\hline $\begin{array}{c}\text { Eiropas izaugsmes } \\
\text { un konkurētspējas } \\
\text { nodrošināšsana }\end{array}$ & $\begin{array}{c}\text { Jauniešu } \\
\text { uzn̄ēmējdarbības } \\
\text { vides attîstîbu } \\
\text { veicinošais } \\
\text { scenārijs }\end{array}$ & $\begin{array}{c}\text { Izglīīibas iestāžu un } \\
\text { uzņēmēju sadarbības } \\
\text { scenārijs }\end{array}$ & $\begin{array}{c}\text { Valsts institūciju } \\
\text { un uzñēēēju } \\
\text { sadarbības } \\
\text { scenārijs }\end{array}$ & $\begin{array}{c}\text { ES } \\
\text { līdzdalības } \\
\text { scenārijs }\end{array}$ \\
\hline $\begin{array}{l}\text { Jauniešu } \\
\text { uzñēmējdarbības } \\
\text { vides attīstību } \\
\text { veicinošais scenārijs }\end{array}$ & 1 & & & \\
\hline $\begin{array}{l}\text { Izglītības iestāžu un } \\
\text { uzñēmēju sadarbības } \\
\text { scenārijs }\end{array}$ & & 1 & & \\
\hline $\begin{array}{l}\text { Valsts institūciju un } \\
\text { uzñēmēju sadarbības } \\
\text { scenārijs }\end{array}$ & & & 1 & \\
\hline $\begin{array}{l}\text { ES līdzdalības } \\
\text { scenārijs }\end{array}$ & & & & 1 \\
\hline
\end{tabular}

Jāizvērtē četri alternatīvie scenāriji jauniešu nodarbinātības veicināšana Latvijā atkarībā no katra kritērija (ietonēts dzeltenā krāsā). 


\section{Ekspertu aptaujas anketa (Hierarhiju analīzei) / \\ 6. pielikuma turpinājums/ Continuation of Annex 6 Questionnaire for experts (Hierarchy Analysis)}

3.27. tabula

Jauniešu nodarbinātības veicināšanas scenāriju Latvijā salīdzināšana atkarībā no kritērija „Sabiedrības labklājības līmeņa celšana”

\begin{tabular}{|c|c|c|c|c|}
\hline $\begin{array}{c}\text { Sabiedrības } \\
\text { labklājības līmeņa } \\
\text { celšana }\end{array}$ & \begin{tabular}{|} 
Jauniešu \\
uzñēmējdarbības \\
vides attīstību \\
veicinošais \\
scenārijs
\end{tabular} & $\begin{array}{l}\text { Izglītības iestāžu un } \\
\text { uzņēmēju sadarbības } \\
\text { scenārijs }\end{array}$ & $\begin{array}{l}\text { Valsts institūciju } \\
\text { un uzṇēmēju } \\
\text { sadarbības } \\
\text { scenārijs }\end{array}$ & $\begin{array}{c}\text { ES } \\
\text { līdzdalības } \\
\text { scenārijs }\end{array}$ \\
\hline $\begin{array}{l}\text { Jauniešu } \\
\text { uzn̦̄ēmējdarbības } \\
\text { vides attīstību } \\
\text { veicinošais scenārijs }\end{array}$ & 1 & & & \\
\hline $\begin{array}{l}\text { Izglītības iestāžu un } \\
\text { uzñēmēju sadarbības } \\
\text { scenārijs }\end{array}$ & & 1 & & \\
\hline $\begin{array}{l}\text { Valsts institūciju un } \\
\text { uzn̦ēmēju sadarbības } \\
\text { scenārijs }\end{array}$ & & & 1 & \\
\hline $\begin{array}{l}\text { ES līdzdalības } \\
\text { scenārijs }\end{array}$ & & & & 1 \\
\hline
\end{tabular}

Jāizvērtē četri alternatīvie scenāriji jauniešu nodarbinātības veicināšana Latvijā atkarībā no katra kritērija (ietonēts dzeltenā krāsā).

3.28. tabula

Jauniešu nodarbinātības veicināšanas scenāriju Latvijā salīdzināšana atkarībā no kritērija ,Sociālā kohēzija (ieklaušanās),

\begin{tabular}{|c|c|c|c|c|}
\hline $\begin{array}{c}\text { Sociālā kohēzija } \\
\text { (ieklaušanās) }\end{array}$ & \begin{tabular}{|} 
Jauniešu \\
uzṇēēējdarbības \\
vides attīstību \\
veicinošais \\
scenārijs
\end{tabular} & $\begin{array}{l}\text { Izglītības iestāžu un } \\
\text { uzņēmēju sadarbības } \\
\text { scenārijs }\end{array}$ & $\begin{array}{l}\text { Valsts institūciju } \\
\text { un uzn̄ēmēju } \\
\text { sadarbības } \\
\text { scenārijs }\end{array}$ & $\begin{array}{c}\text { ES } \\
\text { līdzdalības } \\
\text { scenārijs }\end{array}$ \\
\hline $\begin{array}{l}\text { Jauniešu } \\
\text { uzņēmējdarb̄̄ibas } \\
\text { vides attīstību } \\
\text { veicinošais scenārijs }\end{array}$ & 1 & & & \\
\hline $\begin{array}{l}\text { Izglītības iestāžu un } \\
\text { uzņēmēju sadarbības } \\
\text { scenārijs }\end{array}$ & & 1 & & \\
\hline $\begin{array}{l}\text { Valsts institūciju un } \\
\text { uzñēmēju sadarbības } \\
\text { scenārijs }\end{array}$ & & & 1 & \\
\hline $\begin{array}{l}\text { ES līdzdalības } \\
\text { scenārijs }\end{array}$ & & & & 1 \\
\hline
\end{tabular}

Jāizvērtē četri alternatīvie scenāriji jauniešu nodarbinātības veicināšana Latvijā atkarībā no katra kritērija (ietonēts dzeltenā krāsā). 


\section{Ekspertu aptaujas anketa (Hierarhiju analīzei) / Questionnaire for experts (Hierarchy Analysis)}

6. pielikuma nobeigums/ The ending of Annex 6

3.29. tabula

Jauniešu nodarbinātības veicināšanas scenāriju Latvijā salīdzināšana atkarībā no kritērija „ES politikas veiksmīga realizācija”

\begin{tabular}{|c|c|c|c|c|}
\hline $\begin{array}{l}\text { ES politikas } \\
\text { veiksmīga realizācija }\end{array}$ & $\begin{array}{c}\text { Jauniešu } \\
\text { uzñēmējdarbības } \\
\text { vides attīstību } \\
\text { veicinošais } \\
\text { scenārijs }\end{array}$ & $\begin{array}{c}\text { Izglītības iestāžu un } \\
\text { uzṇēmēju sadarbības } \\
\text { scenārijs }\end{array}$ & $\begin{array}{l}\text { Valsts institūciju } \\
\text { un uzñēmēju } \\
\text { sadarbības } \\
\text { scenārijs }\end{array}$ & $\begin{array}{c}\text { ES } \\
\text { līdzdalības } \\
\text { scenārijs }\end{array}$ \\
\hline $\begin{array}{l}\text { Jauniešu } \\
\text { uzņēmējdarbības } \\
\text { vides attīstību } \\
\text { veicinošais scenārijs }\end{array}$ & 1 & & & \\
\hline $\begin{array}{l}\text { Izglītības iestāžu un } \\
\text { uzņēmēju sadarbības } \\
\text { scenārijs }\end{array}$ & & 1 & & \\
\hline $\begin{array}{l}\text { Valsts institūciju un } \\
\text { uzṇēmēju sadarbības } \\
\text { scenārijs }\end{array}$ & & & 1 & \\
\hline $\begin{array}{l}\text { ES līdzdalības } \\
\text { scenārijs }\end{array}$ & & & & 1 \\
\hline
\end{tabular}

Jāizvērtē četri alternatîvie scenāriji jauniešu nodarbinātības veicināšana Latvijāa atkarībā no katra kritērija (ietonēts dzeltenā krāsā).

3.30. tabula

Jauniešu nodarbinātības veicināšanas scenāriju Latvijā salīdzināšana atkarībā no kritērija „ES Struktūrfondu finansējuma veiksmīga apgūšana”

\begin{tabular}{|c|c|c|c|c|}
\hline $\begin{array}{l}\text { ES Struktūrfondu } \\
\text { finansējuma } \\
\text { veiksmīga apgūšsana }\end{array}$ & $\begin{array}{c}\text { Jauniešu } \\
\text { uzñēmējdarbības } \\
\text { vides attīstību } \\
\text { veicinošais } \\
\text { scenārijs } \\
\end{array}$ & $\begin{array}{c}\text { Izglītīibas iestāžu un } \\
\text { uzṇēmēju sadarbības } \\
\text { scenārijs }\end{array}$ & $\begin{array}{l}\text { Valsts institūciju } \\
\text { un uzñēmēju } \\
\text { sadarbības } \\
\text { scenārijs }\end{array}$ & $\begin{array}{c}\text { ES } \\
\text { līdzdalības } \\
\text { scenārijs }\end{array}$ \\
\hline $\begin{array}{l}\text { Jauniešu } \\
\text { uzņēmējdarbības } \\
\text { vides att̄̄stību } \\
\text { veicinošais scenārijs }\end{array}$ & 1 & & & \\
\hline $\begin{array}{l}\text { Izglītīibas iestāžu un } \\
\text { uzņēmēju sadarbības } \\
\text { scenārijs }\end{array}$ & & 1 & & \\
\hline $\begin{array}{l}\text { Valsts institūciju un } \\
\text { uzņēmēju sadarbības } \\
\text { scenārijs }\end{array}$ & & & 1 & \\
\hline $\begin{array}{l}\text { ES līdzdalības } \\
\text { scenārijs }\end{array}$ & & & & 1 \\
\hline
\end{tabular}

Jāizvērtē četri alternatīvie scenāriji jauniešu nodarbinātības veicināšana Latvijāa atkarībā no katra kritērija (ietonēts dzeltenā krāsā). 


\section{Ekspertu aptauja/ Questionnaire for eksperts}

\section{Labdien!}

Latvijas Lauksaimniecības universitātes Reǵionālās ekonomikas 4. kursa studente Līva Griņeviča, doktora darba ietvaros veic aptauju ar mērķi noskaidrot nozares ekspertu viedokli par jauniešu iekḷaušanos darba tirgū Latvijas reǵionos.

Jūs tiekat aicināts/-a piedalīties aptaujas procesā un sniegt Jūsu viedokli uz zemāk minētajiem jautājumiem. Aptaujas aizpildīšana prasīs ne vairāk kā 20 minūtes.

1. Kā Jūs vērtējat jaunieša, ar izglìtību zemāku par vidējo vai profesionālo, iespējas iekļauties darba tirgū? Ja iespējams, lūgums pamatot atbildi.

2. Kā Jūs vērtējat jaunieša, kurš šobrīd studē bakalaura studijās un vēl nav ieguvis augstāko izglītību, iespējas iekļauties darba tirgū? Ja iespējams, lūgums pamatot atbildi.

3. Kā Jūs vērtējat Nodarbinātības Valsts aǵentūras ìstenotos jauniešu mobilitātes pasākumus, kuros ar Eiropas Savienības Fondu atbalstu jaunietim tiek dota iespēja apgūt profesionālās pilnveides kursus, piem., valodas, grāmatvedība, projektu vadība, auto vadītāju kursi utt.? Ja iespējams, lūgums pamatot atbildi.

4. Kā Jūs vērtējat Nodarbinātības Valsts agentūras ìstenotos jauniešu mobilitātes pasākumus, kuros ar Eiropas Savienības Fondu atbalstu tiek piesaistīts līdzfinansējums jauniešu darba algas dal̦ējai segšanai? Ja iespējams, lūgums pamatot atbildi.

5. Vai Jūsuprāt atvieglojumi nodokļu jomā spētu ietekmēt darba devēju lēmumu par jaunieša kandidatūras apstiprināšanu uz vakanto vietu attiecība pret citiem pretendentiem?

6. Kādas Jūsuprāt ir jauniešu potenciālās iespējas uzsākt uzņēmējdarbību, ņemot vērā mūsdienu ekonomisko situāciju?

7. Vai Jūsuprāt Latvijā pieejamie atbalsta instrumenti jauniešu uzn̄ēmējdarbības uzsākšsanai ir nodrošināti pietiekošā līmen̄̄ (mikrokreditēšanas programmas, starta programmas uzņēmējdarbības uzsākšanai, mentoru konsultācijas, biznesa inkubatori, utt.)?

8. Vai Jūsuprāt Lauku atbalsta dienesta izsludinātais projekts „Atbalsts jaunajiem lauksaimniekiem uzñēmējdarbības uzsākšanai” (1. periodā EUR 6’950’466) spēs efektīvi veicināt jauniešu nodarbinātību lauku regionos?

9. Lūdzu, miniet, Jūsuprāt svarīgākos valsts institūciju īstenojamos pasākumus jauniešu darba tirgus situācijas stabilizēěanai R̄̄gā un Latvijas lielākajās pilsētās!

10. Lūdzu, miniet, Jūsuprāt svarīgākos valsts institūciju ìstenojamos pasākumus jauniešu darba tirgus situācijas stabilizēšanai Latvijas lauku reǵionos!

\section{Liels paldies par Jūsu veltīto laiku un atsaucību!}

